
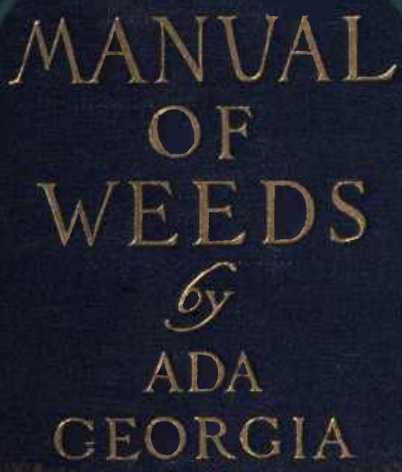


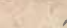





\section{Tbe tRural SDanuals}

Edited By L. H. BAILEY

A MANUAL OF WEEDS 


\section{Tbe Rural SiDanuals}

\section{Edited By L. H. BAILEY}

$*$

Manual of Gardening-Bailey

Manual of Farm Animals - Harper

Farm and Garden Rule-Book - Bailey

Manual of Frutt Insects - Slingerland and

Crosby

Manual of Weeds - Georgia

Manual of Home-MaKing - In preparation

Manual of Cultivated Plants - In preparation 



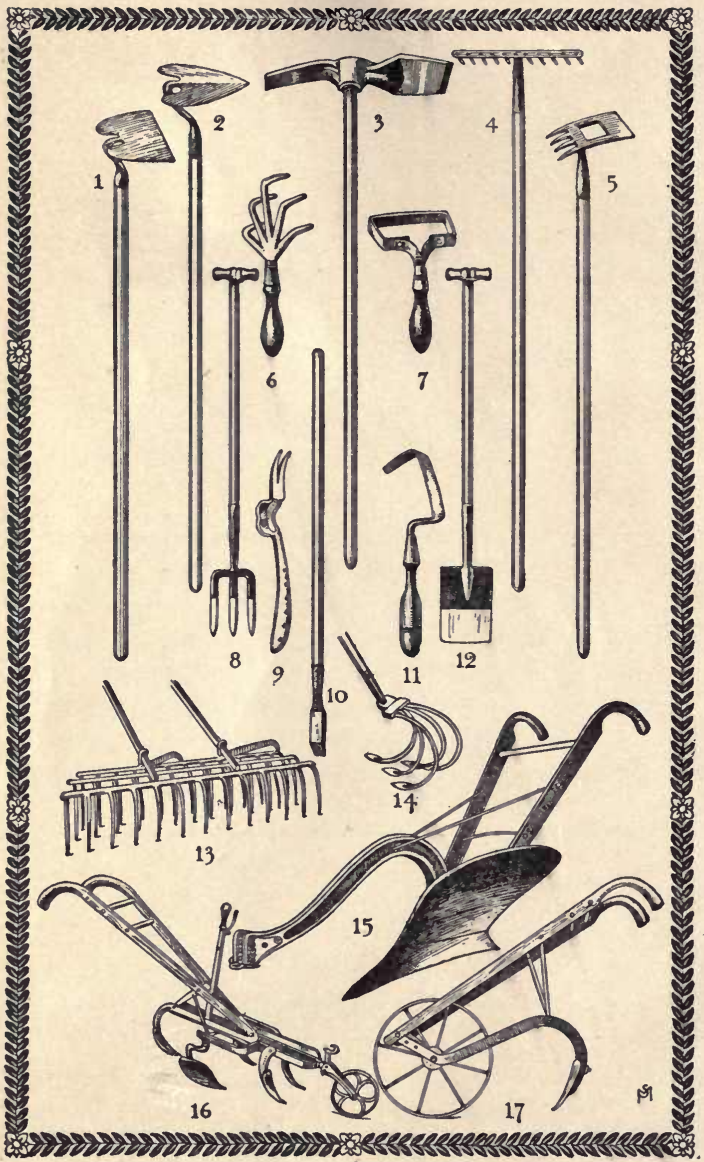

TOOLS FOR DESTROYING WEEDS

1. Broad-bladed Hoe. 2. Warten Pattern Garden Hoe. 3. Grubbing Hoe. 4. Rake. 5. Weeding Hoe. $6,7,11$. Hand Weeders. 8 Spading Fork. 9. Root-digger. 10. Spud. 12. Spade. 13. Weeding Harrow with shafts and teeth adjustable. 14. Cultivating Hoe. 15. Plow. 16. Cultivator, wlth adjustable blades of different gize. 17. Wheel Hoe. 


\section{A MANUAL OF WEEDS}

WITH DESCRIPTIONS OF ALL OF THE MOST PERNICIOUS AND TROUBLESOME PLANTS IN THE UNITED STATES AND CANADA, THEIR HABITS OF GROWTH AND DISTRIBUTION, WITH METHODS OF CONTROL

\section{BY}

\section{ADA E. GEORGIA}

ASSISTANT IN THE FARM COURSE, NEW YORK STATE COLLEGE OF AGRICULTURE, CORNELL UNIVERSITY

WITH 385 ILLUSTRATIONS

BY

F. SCHUYLER MATHEWS

AUTHOR OF "FIRLD BOOK OF AMRRICAN WILD FLOWRR"

सัew 19ork

THE MACMILLAN COMPANY

1916 


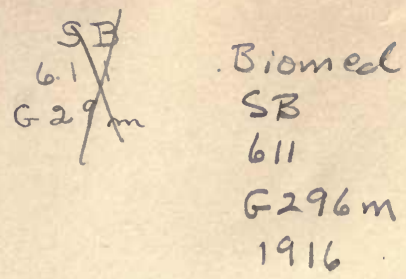

\section{To}

THE REVERED MEMORY OF

\section{JOHN WALTON SPENCER}

MY EMPLOYER, TEACHER, AND FRIEND, TO

WHOSE FIRST SUGGESTION

AND ENCOURAGEMENT THE BEGINNING OF THIS BOOK IS DUE 



\section{TABLE OF CONTENTS}

PREFACE

Preface • * * * * * * * * ix

What is a Weed? . . . . . . . . . . . 1

Financial Loss due to Weeds . . . . . . . 6

Dissemination of WeEDS . . . . . . . . . . 9

Chemical Herbicides . . . . . . . . . . 13

Descriptive List and Means of Control . . . . 17

Bibliography . . . . . . . . . . . . . 559

List of Plants Distinctly Porsonous or Mechanically

Harmful to Animal Life . . . . . . . 563

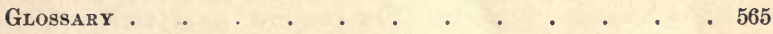

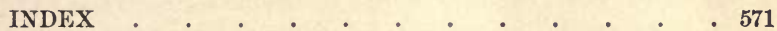





\section{PREFACE}

NATURE is the great farmer. Continually she sows and reaps, making all the forces of the universe her tools and helpers. The sun's rays, wind, rain, frost and snow, insects and birds, animals small and great, even to the humble burrowing worms of the earth, all work mightily for her and a harvest of some kind is absolutely sure. And to the people who must wrest a living from the soil, not only for themselves but for all mankind besides, it must seem that Nature's favorites are the hardy, aggressive, and often useless and harmful plants which they have named weeds.

Yet, when man interferes with the Great Mother's plans and insists that the crops shall be only such as may benefit and enrich himself, she seems to yield a willing obedience, and under his guidance does immensely better work than when uncontrolled. But Dame Nature is an "eye-servant"; only by the sternest determination and the most unrelaxing vigilance can her fellow-worker subdue the earth to his will and fulfill the destiny foreshadowed in that primal blessing, so sadly disguised and misnamed, when the first man was told, "Cursed is the ground for thy sake; in sorrow shalt thou eat of it all the days of thy life ; thorns also and thistles shall it bring forth to thee; and thou shalt eat of the herb of the field." A stern decree. - But the civilization of the peoples of the earth is measured by the forward state of their agriculture; and agriculture in its simplest terms is the compelling of the soil to yield only such products as shall conduce to the welfare of the people who live upon it. It resolves itself into a contest with nature as to what plants shall be permitted to grow, and the discovery of the easiest, surest, and most economical means of securing a victory in the strife.

In agriculture, as in every field of labor, modern invention and discovery have greatly multiplied the power and efficiency of each pair of human hands; but still in this contest with nature and the growing plants, it frequently happens that those hands are 
the only tools which can be used effectively - as the writer knows by many years of hard practical experience, both in garden and in field. Again, some simple expedient of little cost and easy application, may do the work of many hands and increase by many fold the soil's return for the labor. A wider acquaintance with such methods of control seems desirable and therefore the writer has endeavored to bring together, so far as could be learned, the knowledge gained by much study and careful experiment in many different parts of the country by earnest and thoughtful workers. There is a great dearth of books on this most important subject, but such as could be obtained have been diligently studied. The Bibliography on page 559 will indicate the writer's debt in this regard. Many files of agricultural periodicals have been consulted and most grateful acknowledgment is made for assistance received from the publications of the Department of Agriculture at Washington, and to the Agricultural Experiment Station Bulletins of the various states and of the Canadian Provinces.

In nomenclature and order of classification the writer has followed Gray's New Manual of Botany, seventh edition, 1908. For plants outside of the geographic limits included in that book, Coulter and Nelson's New Manual of Rocky Mountain Botany, and W. L. Jepson's Flora of Western Middle California, have been consulted. For range, season of bloom and fruit, and much other very important and necessary information, most invaluable help has been obtained from the New Illustrated Flora of the Northern United States and Canada, by Britton and Brown, and the revised Flora of the Southeastern United States, by Dr. J. K. Small. Statements concerning plants that are poisonous or otherwise harmful to health have been made on authority of publications issued by the United States Department of Agriculture. Dr. L. H. Pammel's Manual of Poisonous Plants has also been a helpful reference. Mention is made of the fact that some weeds are medicinally valuable, and may occasionally be made to pay for the cost of their extermination. The writer's authority for prices and modes of preparation has been the interesting series of bulletins prepared by Miss Alice Henkel, Assistant, Drug-Plant Investigations, at the Bureau of Plant Industry at Washington. 
The writer desires to express most grateful acknowledgment to Professor James G. Needham for helpful suggestions as to the plan of the book and reading of the manuscript; to Professor Karl M. Wiegand for reading, criticism, and amendment of the text while in proof; and to Miss Lela A. Gross of the Editorial Department of the New York State Agricultural College for reading the proof.

The writer has attempted - not very successfully - to make the terms of the descriptive text somewhat less technical and easier for the general reader to understand than that of the botanies; but one who makes even a modest effort in that direction soon realizes the difficulties, for, after all, technical terms are exact, and no paraphrase, however carefully defined, can be made so fit. "Seeds" are often mentioned by that term, because it is the only one used by the seed merchant and the farmer, to whom, also, any capsular fruit is likely to be a "pod." Of the common names given, the writer has in every case selected for a heading the one considered to be in widest and most common use for the plant described.

A few paragraphs of the introductory chapters are rearranged from some lessons about weeds which were furnished by the writer for the Leaflets of the Home Nature-Study Course, while serving as Assistant in the Bureau of Nature-Study at Cornell University. These leaflets, however, are now out of print. To make a book that would be helpful to any one who loves and grows plants, and must combat weeds in order to help them to grow, has been for many years the writer's strongest wish. In the hope that it may be one of the few wishes that "come true," this book is given to the public.

ADA E. GEORGIA.

IthacA, New YoRK, July, 1914. 



\section{tosmesey \\ A MANUAL OF WEEDS}

\section{WHAT IS A WEED?}

A WEED is a plant that is growing where it is desired that something else shall grow. It follows that a plant may be a weed in some places and not in others. Cockle in the wheat fields is most undesirable; New England Asters and Black-eyed Susans are detrimental when growing in the meadow ; but all are graceful and beautiful plants, and, growing in a protected flower garden, would be a feast to color-loving eyes. It is well that most pernicious plants have little beauty to make them desired in the posy beds of the farm home, for, though it is necessary to label some bad weeds as "escapes from cultivation," they are not numerous nor among the most evil of their kind.

Each weed has its own way of winning in its struggle with the farmer's crops and its habits must be learned in order to know how to get the better of it. This can be done only by a study of the life history of the species. According to their nature, different means of extermination must be practiced, always remembering that all living things are tender and die most easily when they are young; and also that in every case the chief end is to prevent reproduction of kind.

Weeds, like all other plants, may be classified according to the length of time they live: as annual, surviving the winter only in the seed; as biennial, storing in fleshy root or broad green leafy rosette the food drawn from the soil and air during the first season, to perfect the fruitage in the second year; and as perennial, surviving through many seasons and springing up to spread abroad their kind and pester the land year after year, unless destroyed "root and branch." Purslane and the common Ragweed are good examples 
of the first class, Burdock and Wild Carrot of the second, and Field Sorrel and Canada Thistle of the third. Some plants that round their life-cycle in a year are known as "winter annuals"; the seeds that have matured during the summer germinating in the fall, making a certain growth before the closing in of winter, and completing their development in the next summer. To this class belong the hated Penny Cress, or Frenchweed, the Corn Cockle, and the Field Gromwell or Wheat-thief. Obviously, the best time to compass their destruction is in the spring, before they can develop fruiting stems. Spring plowing or harrowing is of course in order, but it is with such plants as these that the newer method of killing with a chemical spray, or herbicide, is most successful, particularly when they appear in grain fields. The grains are resistant to injury from the spray, for, being " center growers," they make a swift recovery from the slight harm received on outside sheath-leaves, while the tender, outspread foliage of the weed seedlings is often totally destroyed.

For biennials, also, the one sure means of destruction is prevention of seeding. Where plowing out is impracticable, frequent cutting must be practiced, in the first season spudding out or cutting off the rosettes, or crown leaves, and in the second season mowing off the flowering stems before the formation of seed.

Perennial weeds are by far the hardest to fight, sometimes requiring the cultivation of special hoed crops in order to insure their complete eradication. The plowing and harrowing given to ordinary field crops often only stimulate the growth of these pernicious plants by breaking or cutting the long-lived underground stems and inducing them to send up new shoots. It should be remembered that their food reserves are in fleshy or woody roots, underground stems, bulbs, or tubers, and that the growth above ground never seems to exhaust these hidden stores of nourishment. However, there is a time when they are most vulnerable to attack, and it is just at that stage of growth when flowering stems are nearing full size, but before the formation of seed. They should then be plowed down, or, if too tall for that, first mowed and then plowed under. Any and every plant, even the sturdiest tree, must die if kept deprived of leaves during the growing season; for it is in these green laboratories that the food gathered from soil and air is so changed 
and assimilated as to become available for the making of new plant substance. Without leaf-growth the roots must die.

\section{General principles}

1. Allow no weeds to ripen seeds.

2. Kill while in the seedling stage if possible, for then the weeds die most easily and in the greatest numbers.

3 . Induce autumn germination of the seeds of annuals by surface cultivation of fields after harvest. Many weeds are thus winter-killed before seeds can be produced. Following spring cultivation will rid the ground of a second crop of seedlings and leave the soil comparatively free of this class of plants.

4. Never plow under weeds bearing mature seeds. Burn them. For seeds of many weeds, particularly of some of the most troublesome annuals, have great vitality and may lie dormant in the soil for long periods, to germinate when brought to the surface by future cultivation. It is an old saying that "One year's seeding means seven years' weeding," but it may be much more than that. Mrs. Thaxter wrote that in her Island Garden she destroyed seedlings of Common Dodder every season for twenty years after the first seeding. Professor Beal's experiments demonstrated that the seeds of Charlock and Purslane will germinate after lying for thirty years in the soil, and it is said that the seeds of the Indian Mallow or Butterprint Weed have survived for more than fifty years, dormant but ready.

5. Thoroughly compost all stable manures that are known to contain the seeds of noxious weeds. Some few hard-coated seeds there may be which are able to survive the heat and ferment of the compost heap. Concerning this, the Iowa State Experiment Station, under the direction of Professor L. H. Pammel, has carried out a series of valuable experiments. Collections of various weedseeds were made and placed in gauze bags in the heart of fermenting compost heaps for periods varying from five weeks to six months. The result proved that almost all seeds so treated were thoroughly rotted and their vitality was destroyed. The process is a costly one, in that the fermentation which kills the life-germs in the seeds also deprives the manure of some of its most useful properties, particularly of nitrogen, its most valuable constituent. But to sow 
weed-seeds broadcast, with a fertilizer to help them to grow, is still more expensive. One advantage of feeding hay from clean meadows and bedding the farm animals on straw from clean grain fields, is that stable manure may then be used as fast as it is produced, without loss of much of its fertilizing power from leaching and fermentation or expense from the necessary twice handling.

6. Sow clean seed; as near to perfectly clean as it is possible to make it. A thousand Clover seeds are but a small handful and will not suffice to plant a square rod of ground. If, then, the seeds of Dodder are but one to a thousand in a field of Clover, the crop is in danger of being ruined, and the land of being infested for a number of years with one of the worst of noxious weeds. Could the American farmer once be strongly convinced of the importance of this matter of sowing only the purest seed obtainable, the worst stronghold of the weed-army against which he fights would be conquered. All purchased seeds should be accepted only on a guaranty, and even then should be examined with care. It was undoubtedly by this agency that most of the foreign weeds which harass the land were brought to our shores and it is by this means that most of our home-grown pests are carried about and introduced in sections not before troubled by them. Only the best seed is good enough to plant, and the cheapest brand in the market is by far the most costly. The expense of preparing the land for a crop is equal, but the cost of its cultivation and care is much increased and the returns are greatly lessened where any considerable proportion of the seed sown produces worthless or aggressively pernicious plants.

7. Be on the watch for weeds new to the locality, and never trust to the harmlessness of such strangers. Had a few Dakota farmers been alive to the danger when the first Russian Thistles appeared in their flax-fields, the spread of that most pernicious plant might have been prevented, to the great advantage of large areas of the country. One of the services required by the State from each staff of Experiment Station workers is the identification of weedseeds in samples of seeds submitted and the proportion of such impurities. Unknown plants may also be sent to the Stations for name and statement of qualities, and every farmer has the right of appeal to the Agricultural Department of his State for assistance in such matters. 
8. Call in the aid of grazing animals, particularly sheep. Turning them into mutton and wool is a very profitable way of fighting weeds. In stubbles where a young and succulent growth of such plants usually springs up after harvest, and in old pastures where the more dainty neat cattle have selected the plants that they liked best and left the weeds to seed, sheep may be turned in and by their close cropping so shear down the leaf-growth as to cause many very undesirable plants to be root-smothered to death.

9. Practice rotation of crops. Continued growing of one crop not only exhausts the soil but serves to thoroughly infest it with the weeds that most commonly grow with that crop. Different plants take food from the soil in different amounts and proportions, and a proper rotation must be decided by conditions of soil and climate. It should be a systematic alternation on each field of the three general classes of field crops : grain crops, cultivated crops, and grass crops, including the clovers. The farmer whose scheme of rotation is mainly intent on the improvement of the land and not on his immediate profit, will, in the end, make the most money and have the least difficulty in suppressing the weeds. Any rotation should put much stress upon a cleansing crop, requiring such close care in cultivation as to allow no opportunity for weeds to grow. This has fully as important a place in the series as the crops grown solely for their money value, or as the manurial or feeding crop which is intended to return some of the lost fertility to the soil.

10. More wide-reaching and uniform laws, dealing with the control and eradication of weed plagues, should be in force. Many weeds are in the noxious class because they are so well equipped with the means of spreading their kind over large sections of the country. This quality increases the difficulty and expense of their extermination, and it should interest the entire community as well as the individual. If there are weed-laws already on the statute books, they should be made effective. If there are none, then persistent agitation for the enactment of such laws should be carried on by the persons who are most interested and who would be most benefited by their enforcement; namely, the farmers of the community. 


\section{FINANCIAL LOSS DUE TO WEEDS}

WEEDS cause a direct money loss to the farmer and to the nation. In the first place, the presence of weeds in such abundance as to attract notice, reduces the selling value of the land. A prospective purchaser who sees meadows thickly spangled with Daisies and Buttercups or looks over fields golden-yellow with Mustard, red with Sorrel, or white with the lace-like bloom of Wild Carrot, mentally subtracts the cost of cleaning the soil of these pests when estimating his offering price. And this is as it should be ; for before a profitable crop could be obtained from such ground, much careful thought and expensive labor must go to the subjugation of its enemies; and the cost should very properly be borne by the neglectful husbandman who first allowed his land to be so abused. Rank growth of weeds may indicate fertility of the soil, and often the fitness of the ground for particular crops may be judged by the kinds of weeds found growing thereon; but, nevertheless, buyers are prejudiced and would-be sellers must submit to the embarrassment of debased values when land is infested to any considerable extent by these pernicious plants.

Weeds reduce the crop yield. It is this crop loss that is most considered when estimating the damage suffered from weeds. All living plants must have a certain amount of space for the circulation of air and moisture and to be open to the life-giving warmth and light of the sun. When crowded, even among themselves, they cannot thrive; and if this needed space is to any extent occupied by weeds, the returns from the crop must be correspondingly less. These obnoxious neighbors also steal from the soil a large share of the food and drink belonging to the rightful tenants of the ground. The robbery of soil moisture is one of the chief forms of injury. Weeds are notoriously more resistant to drought, more rapid of growth, more sturdy of habit, and more tenacious of life than the cultivated plants that they "shade down" or "starve out." It 
has been estimated by the United States Department of Agriculture that the average yearly loss due to weeds in the crop and meadow lands of the country is about a dollar an acre.

The presence of weeds not only decreases the yield, but also increases the expense of harvesting a crop. A field betangled with Bindweed or overgrown with the strong woody stems of Kinghead and Thistle enforces extra labor of draft-horses and extra wear of farm machinery, even sometimes compelling the task to be done by hand work - the most expensive form of labor in every occupation. Also, the labor and consequent cost of threshing and cleaning the seed from a weedy and inferior crop is much greater than for a heavier crop that is clean and thrifty.

The market value of the crop is reduced. A report from the Grain Inspection Department of the state of Minnesota shows the average dockage on wheat for two years to be nineteen ounces to the bushel. Minnesota produces yearly more than two hundred million bushels of small grain. A dockage of but one pound to the bushel means a loss of over two hundred million pounds, and if the money value be calculated at no more than a cent a pound it is two million dollars yearly; and this loss is in addition to decrease of yield and increased cost of harvest.

Some weeds serve as host plants for injurious fungi; and rust, smut, and mildew may be transferred from them to the useful crops. For example, the wild Barberry harbors the wheat-rust in one of its stages, and the fungus that causes the "club-root disease" of cabbage finds a host in several weeds of the Mustard Family. Weeds serve too as nurseries and feeding grounds for injurious insects. Wild relatives of the Potato, such as Ground Cherry and Horse Nettle, have been known to harbor the Potato Stalk-borer through the winter when all the ruined stems of the cultivated crop had been carefully burned in order to hinder its appearance another season. Weedy stubbles are often a breeding ground for cut-worms, flea-beetles, and other insect plagues.

Further, much serious loss is caused by a very bad class of weeds, possessed of other and much worse qualities than their mere presence where they are not wanted. Some, like the Death Camas and the Water Hemlock, or Cowbane, are poisonous, and cattle and sheep die from eating their young leaves or juicy tubers; 
even loss of human life is sometimes due to the deadly poison of the Hemlock, through the mistaking of its tuberous roots for harmless artichokes. In the Great Plains Region, horses and cattle are killed or made worthless by the "Loco Weeds." Some wild grasses, such as the Squirrel-tail Grass, or Wild Barley, and the Porcupine Grass, cause injury to the animals that graze on them by the lodgment of their barbed awns in the lining of mouth, throat, and stomach, causing painful inflammation, ulceration, and death. Milk, butter, and cheese are rendered unmarketable by the taint of Wild Onion or Garlic and the bitter Mustards. Cockles "cut the grade" of the wheat and spoil the flour if ground with it. Tickseeds and burs yearly lessen the value of the wool-clip from the farmer's flocks. Altogether, the losses sustained by the American farmer from this cause are greater than he suspects or would believe. A needless loss, too; for there is no weed so vicious that it cannot be subdued, with profit to the owner of the soil, if its habits are well understood and sufficient determination goes to the battle.

But nothing in the world is so bad as to be entirely evil. It is only fair to admit that weeds do sometimes perform useful services to the land. Their presence compels tillage, and the most profitable farming is that which keeps the ground well tilled. They form the greater part of the covering which Nature promptly spreads over soil that the shiftless cultivator has left bare and neglected, keeping it from being blown about by winds, washed away by flood or rain, or baked into a barren desert by the sun. And such a weedblanket, if turned under the ground in preparing it for a better crop, will supply the soil with green manure or humus, which it very much needs. It is not the best type of feeding crop for the land, but it is better than none. It is well that Nature is thus able to redeem the sins of slothful and selfish men, but her processes are too slow. The world grows no larger and its population increases very fast. The surest hope of its continued comfort and prosperity lies in better husbandry. 


\section{DISSEMINATION OF WEEDS}

Most various are the ways and most interesting are the natural mechanical appliances by which plant offspring are helped to leave the place of their birth and "strike out in the world for themselves." All seeds are great travelers; they are carried by wind and water, by wild and domesticated animals, and by birds; they journey by highway and railroad and are parts of steamship cargoes. By far the worst culprit of all, in the distribution of seeds of the kind of plants most adverse to his prosperity, is the farmer himself.

Wind-carried seeds are of many kinds. Some, like the Dandelion, Milkweeds, and Thistles, and the pernicious Orange Hawkweed, are made buoyant by a parachute of fine, downy plumes on which they are lifted and wafted away on even the gentlest breeze. In other cases, like those of Tumbling Mustard and Russian Thistle, the entire plant is broken off at its base or its shallow roots are wrenched from the soil, and it is sent rolling and tumbling along the ground, shaking out its seeds as it goes. Over the wide levels of the prairie states these weeds travel far, but they are not so much to be dreaded in the much-fenced and uneven country of the East. The encrusting of snow in winter makes a smooth surface over which many seeds may be blown abroad that would not otherwise be able to get far away from their parent plant. Some seeds, like the Docks, have corky, membranous wings which not only help to upbear them on the wind but also cause them to float on water. Some plants, like the Oxalis, or Ladies' Sorrel, and the Crane's-bill, are furnished with spring guns which shoot the seeds to some distance.

Many very "pesky" weeds are so because their seeds are gifted by nature with such a marvelous variety of teeth, hooks, and barbs, by which they are able to catch and cling to the fur or wool of animals and to the clothing of passers-by. Burdocks and Cockleburs, Beggarlice, and the Pitchfork Weed, or Devil's Bootjack, are 
a few of the many that are provided with this means of helping themselves to "fresh fields and pastures new."

Birds may undoubtedly be blamed for the appearance of some weeds in new locations, particularly when they are found springing up along telegraph lines or fences. But birds aid the farmer far more as weed destroyers than they do him injury as weed disseminators. Neglected roadsides and lanes; old pastures where the grazing animals have persistently passed by the plants that they did not like; stubbles where weeds have been permitted to spring up and mature seed after harvest; borders of fields and meadows and other waste places of the land, - all are most industriously gleaned throughout the summer, autumn, and winter months by seed-eating birds. Birds have keen appetites and swift digestion. It is safe to say that each Goldfinch, Song Sparrow, or Snow Bunting needs at least a quarter-ounce of food daily to sustain life; and if the number of these feathered benefactors average no more than a dozen to the square mile, in the aggregate the amount of noxious stuff disposed of would reach many tons. The few seeds that are dropped in the culling of these bird meals or that pass uninjured through the digestive tract are of small account when compared to so great a service.

The spreading of stable manure before decomposition is a very common source of weed infestation; and the statement is here repeated that it is better to lose a large part of its fertilizing quality by composting all such material, than to ensure future loss and needless labor by such soil contamination.

One place where weeds are too frequently neglected is on land belonging to the community at large. Along roads, canals, and other public places they are allowed to bloom and mature their seeds, becoming a menace to all near-by property, because "what is everybody's business is nobody's business." The public sees the wisdom and economy of supporting Game Commissioners in every county; and no less wise an outlay would be the appointment of County Weed Commissioners, to whom should be entrusted the supervision, not only of the public domain, but also of individual holdings which, through neglect, might become a menace to the community. The most ignorant and careless cultivator of the land is often the most easy to offend, and complaint and correction, as 
well as instruction in better methods, would be more cordially received from such an accredited officer than from aggrieved neighbors.

But the most prolific source of weed infestation in all parts of the country is in the sale and exchange of commercial seeds and foodstuffs. It is well known that the introduction and subsequent spread in this country of some of its most aggressive and unmanageable land-plagues, as the Orange Hawkweed, the Russian Thistle, and the Penny-cress, or Frenchweed, are due to this agency. In many parts of the country the business is carried on unchecked by inspection or restriction of any kind, and in communities possessed of laws for such regulation these are often inoperative through negligence. This is a state of affairs that works great injustice to both the merchant and the farmer. Itinerant presses are hauled about the country, putting hay and straw into bales convenient for transportation. When shipped away for sale, a hay-bale may contain a large percentage of Ox-eye Daisy, Yarrow, Ragweed, or Wild Carrot, rendering it unpalatable and innutritious to stock and a lasting damage to the fields where the refuse is spread; yet it may bring nearly as good a price as another bale of clean Timothy or Blue Grass. Were the "pressmen" obliged by law to tag every bale according to its quality, growers would be made more heedful of their own shortcomings, and salesmen would be less blamed for a matter over which they have little control.

On both sides of the steel track, long green trails, composed largely of pernicious kinds of growth, have been drawn over the country by the railways, for which they have been called to account and obliged to spend enormous sums yearly in keeping their rights-ofway in order. The cost of weed removal along the railways of the one state of Ohio is placed by Stair at over a half-million of dollars per annum. Yet it is to be remembered that the railways are merely carriers, probably preferring to haul good, rather than bad, merchandise, and having nothing to do with the composition of the cargoes that have leaked and spilled so much vexation to the cultivators along their routes. The farmer who blames the railway for a new pest in his fields may have shipped some that are just as troublesome to other localities.

Many American farmers are very unwise and shortsighted in the 
matter of sowing impure seed. The labor and care required to remove all seeds of an undesirable kind, differing as they do in size, form, and weight, makes both "grain-seed" and "grass-seed" of first quality very expensive; but in the end it is the cheapest of all, and no other should be sown. Its extra cost is never so great as to overbalance the loss from weed-starved crops, requiring extra labor to harvest, to say nothing of infesting the land itself with some long-lived nuisance which it may take years to destroy. If ever a man may be characterized as "penny-wise and pound-foolish" it is the farmer who, from ill-advised motives of present economy, would so wrong his own property and endanger all neighboring possessions. 


\section{CHEMICAL HERBICIDES}

THIs is comparatively a new way of fighting weeds and further experiment is needed for discovery of all its merits. Professor Henry L. Bolley, Botanist at the State Experiment Station of North Dakota, states that "the preliminary field trials at this Station in 1896, were, perhaps, the first experiments of the kind conducted in any country." Soon afterward the discovery was made in France by M. Aimé Girard that Copper sulfate would kill Wild Mustard if applied when the foliage was tender. Since then, in many parts of this country and Canada and in European countries, experimenters have been at work, trying the effects on various plants of different chemicals, seeking to find the reason why the treatment succeeds in some cases and not in others, and to learn how it can be most economically and effectively used. Such experiment has proved the worth of the following chemicals as weed-killers, or herbicides :

Common salt (Sodium chloride). This is the cheapest, handiest, and safest of herbicides, but not the most useful ; for, when applied in sufficiently large amounts to kill a pernicious plant such as the Orange Hawkweed, it may also kill other plant-life and so permeate the soil as to check all agricultural growth for a season. Its destructiveness lies in its power to absorb the moisture in the soil and from the plant tissues, so that they die of thirst; therefore, if it is to be effectual, it should be applied in hot, dry weather. Small areas of Quack Grass and Canada Thistle may sometimes be entirely destroyed by salting freely and then allowing cattle and sheep to bite down the salted herbage, repeating the operation as often as new shoots appear. In places where it is needful to expel all plant growth, salt may be used in the form of hot brine, the solution being so strong as to show forming crystals on its surface.

Copperas, or Green vitriol (Iron sulfate). This chemical, being a by-product of the iron and steel industry, is comparatively cheap, 
costing only about a cent a pound. As an herbicide it should be used as a spray, in a solution of about a hundred pounds to a barrel of water ( 52 gallons), which should be a sufficient amount to spread over about an acre of herbage. A dust spray of this chemical has also been used, but is effective only when the plants are wet with dew. Iron sulfate is particularly useful as a grain-field herbicide, applied in dry, clear weather, when there is no likelihood that rain will wash off the plants before the chemical has done its work. Grains and grasses are very resistant to injury from the spray, partly, no doubt, because their growth is from the center and they quickly recover from such slight harm as may have been done to the outer leaves; also, they are smoother in texture than many of the grain-field pests, such as Corn Cockle, Charlock, and Kinghead, so that the spray does not cling so readily to their slender, blade-like leaves. The spray must be applied before the grain begins to "head" or the weeds to bloom, at a time when both are making the most rapid growth, for then the grain recovers so swiftly as scarcely to receive any check in its growth, and the weeds succumb most readily when they are most green and succulent. In the pea-field also this spray may be used to kill weeds without serious injury to the crop, but not with beans. Clover and alfalfa leaves are blackened, but recover rapidly if the solution has not been too strong.

When successfully carried out, this method of cleaning a field of its undesirable plants pays the farmer very well; for returns from crops that have been relieved from competition with weeds for food and moisture and space to grow, are often half as large again as those from similar fields untreated, and are greatly improved in quality as well as in quantity.

Bluestone, or blue vitriol (Copper sulfate). This well-known fungicide is also a most effective herbicide, if used when the weed foliage is young and tender. The formula for the solution is eight to twelve pounds of Copper sulfate to a barrel of water ( 52 gallons), using fifty to seventy-five gallons per acre. Professor Bolley found twelve pounds of Copper sulfate to be as effective as one hundred pounds of Iron sulfate. Like that chemical, it should be used in clear weather, when the plants are not likely to be rain-washed for at least twenty-four hours, as such a bath would render the work of 
no effect and require that it be done over again. It is necessary that sprays shall be fine, like a fog or a mist, in order to be effectual ; for drops only roll off the leaves as rain would do, and small drops merely make large ones.

Carbolic acid (Phenol). This can be used only on small areas because of its cost. The crude acid may be used in full strength to saturate the soil about the perennial roots of such plants as Milkweed and Canada Thistle. It does not corrode metals and can be used with any sort of can or pump. When diluted with water it needs to be constantly shaken in order to make a good mixture. It is quick in action, but not lasting. The treated plants, if deeply rooted, often recover and send up new shoots.

Caustic soda (Sodium hydrate, or Sodium hydroxide). To be used where one does not mind killing out all plant growth for a season. Better than Carbolic acid for killing Poison Ivy, Spreading Dogbane, or any other woody and deep-rooted plants. Apply in strong solution, preferably in hot, dry weather, and, when the noxious growth is killed, water the bare spots frequently so as to assist the chemical to leach away.

Oil of vitriol (Sulfuric acid). This can be handled only in glass vessels. It is not used as a spray, but is applied directly to individual plants that are particularly hardy and pernicious. Very great care is necessary in its use, as it destroys everything that it touches; if accidentally spilled it may make painful "burns" on the flesh or eat holes in clothing. It is not recommended, as other chemicals are very nearly as effective and are very much less dangerous to handle.

Corrosive sublimate (Bichloride of mercury). Make a solution in proportions of one ounce of the drug to six gallons of water. Though fatal to the weeds, this, too, is not to be recommended for any general use because of its extremely poisonous nature. Its cost is also much greater than less dangerous chemicals.

Kerosene. Crude petroleum. Either of these will kill plants, and the former is usually always at hand in the farm household. They have the merit of being safe to handle, but are relatively more costly than other herbicides. The saturated soil remains sterile longer than with applications of caustic soda or carbolic acid.

Arsenite of soda. This is a very active poison, and extreme care 
must be exercised in its use. Do not inhale the powdered drug when making the solution, or the spray as it is delivered; keep to the windward side while working with it. The formula for the solution is one pound of the drug in three to nine gallons of water. White arsenic is cheaper than Arsenite of soda, but needs to be combined with twice its weight of Sal soda in order to be readily soluble in water; the formula being, one pound of White arsenic, two pounds of Sal soda, three to nine gallons of water. These arsenical compounds are the chief ingredients of all commercial weed-killers, and are used on walks, roadways, tennis courts, and all places where the complete and lasting extirpation of all plant growth is required. 


\section{DESCRIPTIVE LIST AND MEANS OF CONTROL}

\section{COMMON BRAKE, OR BRACKEN}

Ptèris aquilina, L.

Other English names: Eagle Fern, Upland Fern, Turkey-foot Brake. Native. Perennial. Propagates by spores and by rootstocks. Season of leaf-production: Early spring until autumn frosts. Fruiting fronds: Ripe in August.

Range: Throughout the world. In this country most troublesome on the Pacific Coast.

Habitat : Upland fields and pastures, open woods, and thickets.

Every one knows the Bracken under some name, for it is the most widely distributed of all the ferns and its distinctive, very large dull green, threeparted fronds are like no other. Most members of the Fern Family demand shade and moisture, but this one is not so particular. It varies much in size. In the Eastern States it is usually one to three feet tall, but on the Pacific Coast it grows six to eight feet, and on the moors and mountains of Scotland the horns of the "stately stag" are barely to be seen above it. (Fig. 1.)

Its creeping rootstock is black, somewhat less than a half-inch in diameter, often twenty feet or more long, and penetrates the soil deeply. All

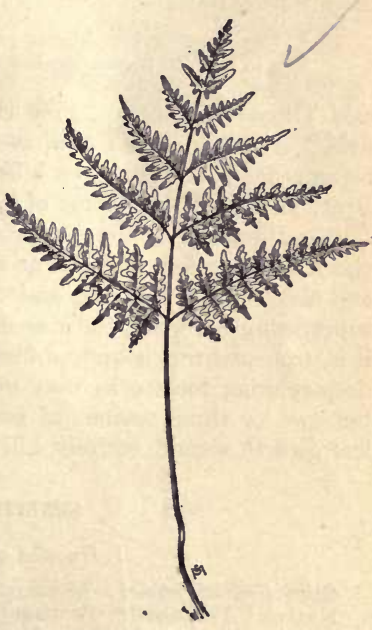

Fig. 1. - Common Brake or Bracken (Pteris aquilina). $\times \frac{1}{8}$. One branch of three-parted frond. 
summer it continues to send up the green, three-parted fronds, each segment of which is in turn twice divided. The uncurled crosiers are gray and softly woolly, and when unrolling they resemble the claw of a large bird, which accounts for its name of Turkey-foot Brake. When ripe the fruiting fronds have a continuous edging of brown sporangia which at first are covered by the reflexed margin of the leaf, but later, as the spores mature, this is pushed away.

Bracken is one of the few ferns for which man has found practical uses. The uncurled crosiers are edible as "greens" cooked like asparagus; the young rootstocks are also used for food and in brewing root beer ; the mature fronds are cut and dried to use as bedding for stock; and in Europe the plant is still often used in thatching roofs.

\section{Means of control}

"In June and in August, as well doth appeere, Is best to mowe Brakes of all times of the Yeere,"

said Thomas Tusser in "Five Hundred Pointes of Good Husbandrie," written in 1557. And the advice still holds good, especially for grasslands and for steep hillsides where tillage is not desirable. Bracken is quite intolerant of lime in the soil, and in such places a liberal dressing of lime, applied just after cutting the fern, is a check to its growth and also an encouragement to that of the grass and clover. But plowing and manuring are the surest means of suppressing the weed, for it resents cultivation. Indeed, hardy as it is, transplanting is quite difficult except when very young. The deep-running rootstocks may not all be destroyed the first year, but two or three seasons of such good tillage as to suppress all leaf growth should entirely kill the weed.

\section{SENSITIVE FERN}

\section{Onoclea sensibilis, L.}

Other English names: Meadow Brake, Polypod Brake.

Native. Perennial. Propagates by spores and by rootstocks.

Season of leaf-production: April till first autumn frost.

Fruiting fronds: Appear in June and July, but do not release spores until the following spring. 
Range: Eastern North America from Newfoundland to Florida and westward to the Mississippi River and in some states west. Habitat: Moist soil ; wet meadows, pastures, fields, and woods.

Ferns are usually associated with woodlands and thickets, and, though this one may be found in such places, it is equally well suited when growing in open ground, provided the soil is not dry. The plant frequents the society of the Field Horsetail and has a bad name with horsemen and sheep-keepers because of such company. But those who have carefully investigated the matter say that the fern is not poisonous, the less noticeable Horsetail being responsible for the mischief generally attributed to it. (Fig. 2).

The plant springs from a creeping rootstock which is about a third of an inch in thickness and grows not far below the surface, branching often and producing new fronds all summer until checked by frost, to which it is very sensitive. It is a rather coarse-looking plant, six inches to three feet high, the whole frond nearly triangular in outline but divided into oblong, lanceshaped, coarsely scalloped segments at the end of a long stipe, or stalk. The leaf is light green and withers quickly when plucked. The fruiting fronds are much shorter than the sterile ones; they are twice pinnate, but the segments, or pinnules, are at first so tightly rolled as to completely hide the sporangia and look like rows of green berries attached to the midrib; later they turn from green to brown, and remain

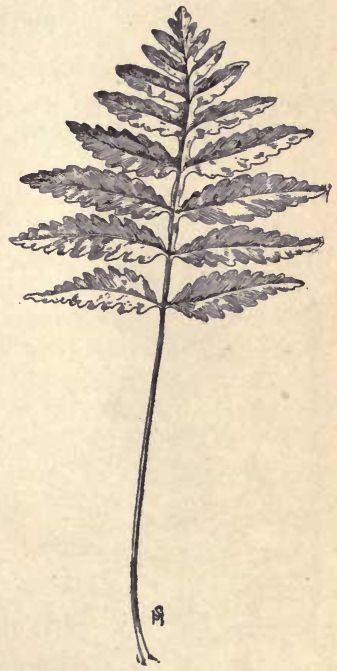

Frg. 2. - Sensitive Fern (Onoclea sensibilis). $\times \frac{1}{3}$. stiffly standing all winter, after the green sterile fronds are withered and gone. Indeed, the fruiting fronds of two or three successive 
seasons may sometimes be found on one plant; but broken and empty, for the spores are cast and germinate in the spring.

\section{Means of control}

Drainage of the ground. The presence of the weed is indicative of unwholesome soil conditions. After drainage, one or two seasons of thorough cultivation will destroy the rather shallow-growing rootstocks and cause the plant to disappear. Distribution of the spores may be prevented by cutting the fronds in the first season, when they are immature.

\section{FIELD HORSETAIL}

Equisètum arvénse, L.

Other English names: Meadow Pine, Green Foxtail Rush, Pinetop, Pine Grass, Snake Grass.

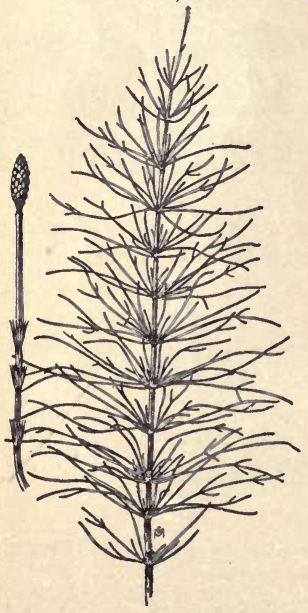

Frg. 3. - Field Horsetail (Equisetum arvense). $\times \frac{3}{8}$.
Native. Perennial. Propagates by spores and by rootstocks bearing small tubers.

Spore-bearing stems appear: April to May.

Sterile stems produced: All summer.

Range: American continent from Greenland to Alaska, southward to Virginia and California.

Habitat: Damp grasslands, moist road embankments.

In early spring one may note large colonies of the fertile stems of these plants, mere cylindrical, light brown, leafless stalks, four to eight inches high, jointed, hollow, and tipped with yellowish, club-shaped, spore-bearing heads. Each joint is ridged and grooved and edged with a brown sheath, notched with eight to a dozen teeth. The joints readily pull apart. These early, fertile plants scatter their spores to the winds and wither and die in a few weeks. But later, from 
the same perennial, creeping, jointed, and branching rootstocks, spring the green, plume-like, sterile stems known as Horsetails (Fig. 3). These are eight inches to more than a foot tall, also hollow and jointed, but having whorls of simple rough branches issuing from the base of each sheath; the branches are usually four-angled, but sometimes have only three sides, and are jointed but not hollow. These green Horsetails are the food-assimilating, starch-making parts of the plant and keep busy all summer, storing the creeping rootstocks with nutriment for the next year's fruiting stems.

The Horsetail is poisonous - most dangerously, sometimes fatally, so to horses, and in a much less degree to sheep, causing in the flocks merely a thin, unthrifty appearance and lack of good condition. Strangely enough, neat cattle seem to be able to digest the weed without injury. The state of Vermont, where horseraising is so great an industry, credits to this plant a loss of some thousands of dollars annually.

\section{Means of control}

Drain, fertilize, and cultivate the ground. The plant thrives best in sandy or gravelly soil that is moist during the early part of the season, or where the soil water approaches near the surface: Drainage, and two or three seasons of good, thorough tillage, will drive it out; for, though the rootstocks are deeper in the ground than ordinary cultivation penetrates, yet they will starve and die if kept deprived of the green, food-assimilating, sterile stems. Plants of waste places should receive attention, to the destruction of both fertile and sterile shoots, as the wind-carried spores may start new infestations.

\section{VIRGINIA BEARD-GRASS}

Andropògon virginicus, $\mathrm{L}$.

Other English names: Broom Sedge. Sedge-grass.

Native. Perennial. Propagates by seeds.

Time of bloom: July to September.

Seed-time: Late August to October.

Range: Massachusetts to Illinois and southward to Florida and

Texas. Most abundant and troublesome in the South.

Habitat: Meadows, pastures; grain, corn, and cotton fields. 
Broom Sedge is a southern weedy grass which is extending its range northward, It grows in thick tufts, the stems attaining a height of three to five feet, very light green when young and turning to a brownish yellow as they ripen, at all times very conspicuous among other grasses. Stems slender, flattened at the base, and sparingly branched above. Sheaths smooth except for a slight hairiness at the edge; leaves six inches to a foot long and less than a quarter-inch wide, with rough edges and upper surface somewhat hairy near the base. The flowering spikes are usually in pairs, sometimes in threes, about an inch long, protruding from smooth spathes which are longer; they are slender and flexuous, the joints and pedicels covered with long, silky hairs. Seeds light yellow, about an eighth of an inch long, oat-like in form, with a tuft of fine hair at the base, and at the tip an awn nearly half an inch in length. These hairy attachments help the seeds to be widely sown by the winds.

\section{Means of control}

In newly infested ground it will pay to grub out the tufts when they are first observed, their light color noticeably contrasting with other grasses. In any case they should be cut while in early bloom, or even before flowering in order to make certain that no seeds may be developed. But if seeds have ripened and fallen, burn over the ground so as to destroy such as are on its surface, and put the field under cultivation in order to kill the roots, following the cultivated crop with clover. In localities where this weed is most aggressive, short rotations, with very thorough tillage, are necessary in order to prevent it from possessing the land.

\section{JOHNSON-GRASS}

Sórghum halepénse, Pers.

(Andropdgon halepénsis, Brot.)

Other English names: Means-grass, Syrian-grass, Aleppo-grass, False Guinea-grass, Egyptian-grass, Moroceo Millet, Arabian Millet, Evergreen Millet.

Introduced. Perennial. Propagates by seeds and by rootstocks.

Time of bloom: Early June to July. 
Seed-time: July to August to September; when cut for hay crop, both blooming and seeding time may be retarded.

Range: Southern part of United States to latitude of Tennessee, westward to California, and along Pacific Coast to Oregon and Washington.

Habitat: Fields, meadows, waste places.

About 1830 there came to Governor Means, of South Carolina, a inessage from the Sultan of Turkey, requesting that an instructor in the art of raising cotton be sent to the Ottoman Empire. Two or three years later, when the instructor returned, he brought with him the seeds of a number of plants that seemed to him to be of economic value, and among them was this grass. An Alabama planter, Colonel William Johnson, while on a visit to South Carolina, became interested in the new plant, obtained a quantity of seed, and raised it extensively on his plantation in the fertile bottom lands of the Alabama River. Since then it has spread over about half of the United States, and but for the fact that it is a tropical plant, likely to be winterkilled where the ground freezes to any depth, it might have possessed the land to a much greater extent. And, once established, it is almost impossible to control it because of its deep-running, branching rootstocks. Added to the difficulty of control is the fact that, like all the Sorghums, the plant occasionally develops a poisonous quality, due to the presence of hydrocyanic acid. Complaints of the deaths of cattle and horses from this cause come mostly from the Pacific Coast, where the growth of the grass on irrigated ground is especially rank. In India, where the plant is much used as fodder for cattle, it has been noted that deaths frequently occur when, because of the failure of rain, plants that have reached a good size become wilted. When a rainfall comes, the poisonous principle disappears; just what condition develops it is not known.

Culms large and stout, about a half-inch thick at base, and ordinarily five or six feet tall but may reach a height of eight or nine feet; pith filled with sugary juice. Sheaths smooth; leaves a foot or more long, about an inch wide, smooth, and flat. Panicles very large and loose, the branches whorled and spreading, naked at base; spikelets in groups of three, the central one sessile and fertile, sometimes bearing an awn, usually bent, the glume purplish, covered 
with fine appressed hair; the two lateral spikelets have pedicels and are staminate or empty. So rapid a grower is the grass that

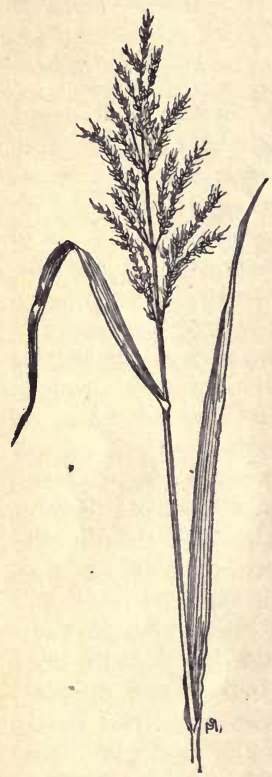

Fig. 4. - Johnson-grass (Sorghum halepense). $\times \frac{1}{8}$. two, three, even four, heavy crops of hay may be harvested yearly, if cut before it blooms; the hay is much relished by all kinds of stock and is very fattening; even the rootstocks are tender and sweet, and hogs eat them eagerly; were it not so aggressive it would be a most valued plant. (Fig. 4.)

\section{Means of control}

With a view toward finding some means of eradication, J. S. Cates, of the Bureau of Plant Industry at Washington, was employed by the Government to make a special study of the plant, and the results of his experiments and conclusions are embodied in Farmers' Bulletin 279 of the U. S. Department of Agriculture. $\mathrm{He}$ states that the rootstocks are of three kinds, which he classifies as primary, secondary, and tertiary.

"Primary rootstocks embrace all the rootstocks alive in the ground at the beginning of the growing season in the spring.

"Secondary rootstocks are those which arise from the primaries, come to the surface and there form crowns, thus producing new plants.

"A tertiary rootstock is one starting later in the season, about flowering time, from the base of the crown of this new plant.

"These tertiary rootstocks, when the ground is soft, and especially when a large top is allowed to develop, grow to a large diameter and penetrate to a great depth, sometimes as much as four feet and normally from fifteen to thirty inches; at other times, when the soil is compact, and especially when the plant above ground is not allowed to develop by reason of mowing or grazing, or both, the tertiary rootstocks grow to but small diameter and run along just under the surface, cropping out at intervals to form new plants. Our observations indicate that 
the primary rootstocks (i.e., those that were in the ground at the beginning of the growing season in spring) all decay in the fall, after the growing season is over. Their strength has been taken up in the formation of secondary rootstocks and above-ground growth. In other words, the old rootstocks do not live over a second winter. Only the new ones (secondaries and tertiaries) do this. Under our classification, secondary and tertiary rootstocks become primary rootstocks at the beginning of the next season after their formation, and they, in their turn, send out secondary growth to reach the surface; the plant formed at the surface then sends out from the base of its crown, about the time it blossoms, the large, deep-burrowing tertiary rootstocks which, in the soft land of the cultivated cotton and corn fields, cause so much mischief the following year. The longer the plants are allowed to stand after blossoming, the larger and deeper these tertiary stems become."

Acting on this study of the rootstock habits of Johnson-grass, Mr. Cates advises the turning of infested land into meadow or pasture and keeping it so persistently mown or grazed as to allow it no opportunity for bloom; then the tertiary growth of rootstocks will be small and near the surface, enabling the farmer to clean out the grass the next year by a little extra care in plowing and cultivating. As a soiling crop the grass may be cut every month from May until November, and this will leave little energy to be given to the formation of the deeper rootstocks.

Professor Killebrew, of the Tennessee Agricultural Experiment Station, says that the way to keep the grass in subjection is to plow the land and allow hogs to pasture on the juicy rootstocks, which they like better than artichokes. Rotation with winter grains, such as oats, barley, or rye, is practiced in many sections, wheat being too late in maturing. The ground is plowed in late summer and as many of the rootstocks are harrowed out as possible; then the grain is sown in early fall and harvested in the spring, before blooming time for the grass, after which three crops of Johnsongrass hay may be cut during the summer.

Professor Spillman, Agrostologist of the Bureau of Plant Industry, believes the best plan to be the sowing of infested land with alfalfa, after harrowing out as many of the rootstocks as possible, early in the fall, in order to allow the alfalfa to get a good start before winter. The next season cut promptly, whenever the grass is tall enough to make a fair crop of hay. This treatment encourages the clover and discourages the grass, which will finally be crowded 
out. Professor Spillman succeeded in cleansing a plot of Johnsongrass in one year, without loss of the use of the ground, by a system of fall plowing, with a turning plow capable of turning every inch of the sod, harrowing thoroughly for the purpose of loosening the soil, and then removing the rootstocks with an implement called a root-digger, or grass-hoe. This method is discussed in detail in Bulletin 72 of the Bureau of Plant Industry.

\section{CRAB-GRASS}

Digitària sanguinàtis, Scop.

(Syntherísma sanguinàlis, Nash.)

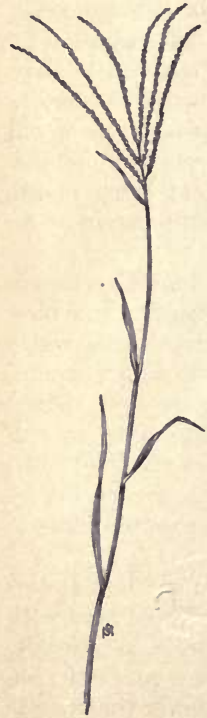

Fig. 5. - Crabgrass (Digitaria sanouinalis). $\times \frac{4}{4}$.
Other English names: Finger Grass, Polish Millet, Purple or Large Crab-grass.

Introduced. Annual. Propagates by seeds and by rooting at the lower joints.

Time of bloom: July to September. Seed-time: August to October.

Range: Throughout the world.

Habitat: Cultivated ground, waste places.

The seeds of this grass must be very longlived, for, though it is never sown, let the ground be cultivated, and as a general thing Crab-grass will be there. In the Southern States this is regarded as a good thing, for the spontaneous growth of the grass in grain fields after harvest often yields a heavy crop of nutritious hay and good pasturage after that. It is in gardens, lawns, and cultivated ground that the plant makes itself a plague, particularly in a moist season. (Fig. 5.)

Culms one to four feet long, decumbent or creeping at base, and putting forth roots wherever the joints are in touch with moist soil. Sheaths and basal part of the blades rough and more or less hairy, the blades three to six inches long and a quarter to a half-inch wide. Spikes usually three to six in number but occasionally as many as ten, two to five inches long, gener- 
ally purplish or reddish brown, arranged in a whorl at the end of the stalk like the fingers of a hand. Spikelets in pairs, one sessile, the other having a minute pedicel. The seeds are very nutritious, and in Germany and Poland they are used for a table viand, cooked in milk, like sago.

Means of control

Nothing but careful hand labor will clean Crab-grass out of a garden or cultivated field; and it needs to be cast into a fire or a compost heap, for an uprooted stem left on the ground promptly takes root again. In lawns the grass must be hand-pulled, for pieces scattered by lawn-mowers are likely to take root and increase the pest. But if the plant is not allowed to develop seed, two or three seasons of careful weeding should clean it from the soil.

\section{SMALL OR SMOOTH CRAB-GRASS}

Digitària humifùsa, Pers. (Syntherisma linedris, Nash.)

Introduced. Annual. Propagates by seeds.

Time of bloom: July to September.

Seed-time: August to October.

Range: Nova Scotia to South Dakota, southward to Florida and Louisiana.

Habitat: Lawns, pastures, and waste places.

Culms six to eighteen inches long, smooth, slender, usually decumbent at base, much branched and spreading. Leaves one to three inches long, very narrow and pointed. Spikes two to four inches long, two to six in number, digitate at the end of the stalk or one or two near the summit, very slender, one-sided. Spikelets usually in pairs, one sessile or nearly so, the other short-pediceled. The whole plant of a reddish color; less troublesome than the preceding species for it does not root at the joints.

Means of control

Cutting so persistently as to prevent seed production. Topdressing and enriching the ground will enable the better grasses and clovers to crowd out the annual weed. 


\section{OLD WITCH GRASS}

\section{Pánicum capillàre, $\mathrm{L}$.}

Other English names: Tumbleweed Grass, Tickle Grass, Witch's Hair.

Native. Annual. Propagates by seeds.

Time of bloom: July to September.

Seed-time: Late August to November.

Range: Nova Scotia to British Columbia, southward to Florida and Mexico.

Habitat: Sandy soil ; fields and waste places.

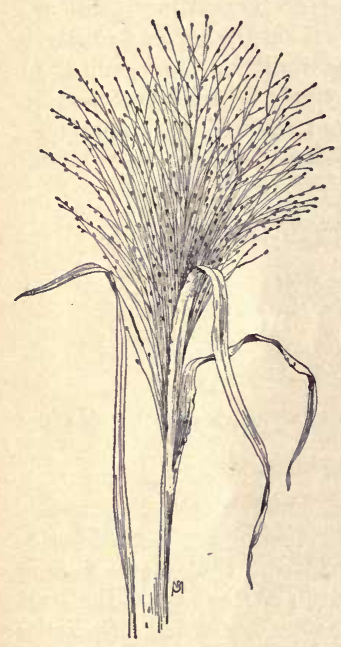

Fra. 6. - Old Witch Grass (Panicum capillare). $\times \frac{1}{6}$.

Culms stout, erect, or with decumbent base, branched and spreading, one to two feet in height. Sheaths very hairy, the blades somewhat less so, the latter a quarter-inch to nearly an inch wide and six inches to a foot long. Panicles very large and spreading, the terminal one often more than a foot long, the branchlets hair-like, the spikelets very small, containing one tiny, shining grayish brown seed. When mature, the branches become very stiff and brittle and the large panicles break away and are driven before the winds for long distances, often piling in thick windrows against fences. In these journeys the seedbearing, hair-like but brittle branchlets are broken from the stalks and the ground over which the tumblers roll is well seeded. In good sod the seed seldom "catches," but on stubbles and cultivated ground the plant is a troublesome weed. (Fig. 6.)

\section{Means of control}

Prevent seed production by mowing, hoe-cutting or hand-pulling while in bloom or before. 


\section{SPROUTING PANIC-GRASS}

Panicum dichotomiflòrum, Michx.

(Pánicum proliferum, Lam.)

Other English names: Sprouting Crab-grass, Knee-grass, Spreading Panicum.

Native. Annual. Propagates by seeds.

Time of bloom: July to September. Seed-time: Late August to November.

Range: Maine to Nebraska, southward to Florida and Texas.

Habitat: Moist, rich soil ; fields and waste places.

A large, coarse grass, the culms stout, flattened, succulent, at first erect, two to three feet high, later becoming decumbent and geniculate, the stalks lengthening, sometimes to six feet, branching, and sending up flowering stalks at all the upper joints. Sheaths loose, smooth, flattened, the ligule a ring of hairs; blades six to eighteen inches long, a quarter-inch to an inch wide, rough on the edges and the central nerve. Panicles large, spreading, six inches to more than a foot in length, the spikelets crowded, brown or purplish, the seeds resembling those of Old Witch but larger. Cattle and horses are fond of the succulent, sweetish stems when young, but it soon becomes hard and innutritious, and nearly worthless as dry forage. (Fig. 7.)

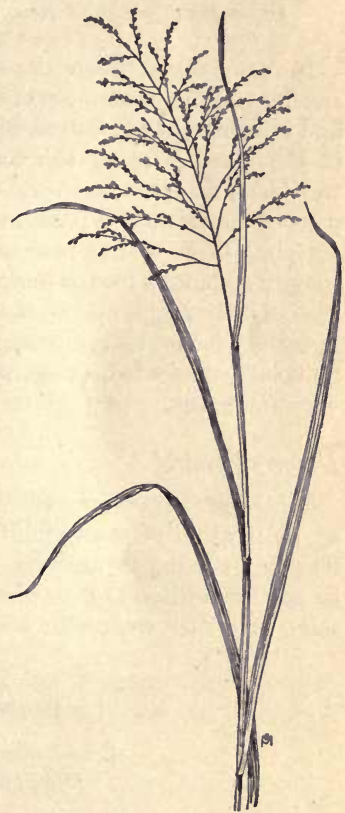

Frg. 7. - Sprouting Panic-grass (Panicum dichotomiflorum), $\times \frac{1}{8}$.

Means of control

Close cutting before seed development. 


\section{SWITCH-GRASS}

\section{Pánicum virgàtum, $\mathrm{L}$.}

Native. Perennial. Propagates by seeds and by rootstocks. Time of bloom: August to September.

Seed-time: September to October.

Range: Maine to Manitoba, southward to Florida and Mexico.

Habitat: Sandy soil ; prairies, in the interior; salt marshes along the coast; banks of streams, low meadows.

In many places where the soil may be in danger of washing, the strong, creeping rootstocks of this grass make it valuable as a binder, and its hard, thickly tufted stalks serve as a check to drifting sands in the marshes along the coast. But as forage it is practically worthless, except when very young, and it is an undesirable occupant of meadows and pastures.

Culms three to five feet tall, smooth, often glaucous. Sheaths smooth; blades a foot or more long, about a half-inch wide, smooth, flat, slightly rough on the margins. Panicles very large, erect, six to twenty inches long, spreading, pyramidal, purple when in bloom. Spikelets one-seeded, ovate, pointed, about a sixth of an inch long, very numerous.

\section{Means of control}

Where practicable the rootstocks may be destroyed most readily by cultivation of the ground for one or two seasons. Early and frequent cutting is necessary in order to secure the forage while in good condition and to prevent the development of seed; at the same time such treatment will starve the rootstocks.

\section{BARNYARD GRASS}

Echinóchloa crus-galli, Beauv.

(Pánicum crus-gálli, L.)

Other English names: Cockspur Grass, Cocksfoot Panicum.

Introduced. Annual. Propagates by seeds.

Time of bloom: July to September.

Seed-time: August to October.

Range: All cultivated regions of the world.

Habitat: Moist, rich soil; gardens, fields, and waste places. 
The Indians of Arizona and Southern California use the seed of this grass for food; cattle are very fond of it when green and succulent; and in some parts of the country, particularly in the flooded river-bottom lands of the Southwest, it yields heavy volunteer crops of hay. But generally it is considered a weed. Its seed is nearly always found with that of other grasses and of clover. (Fig. 8.)

Culms stout, smooth, two to five feet tall. Sheaths compressed, smooth; blades six inches to nearly two feet long, a halfinch to an inch wide, smooth, with a strong central nerve and margins somewhat rough. Panicle large, four inches to a foot or more long, variable, composed of numerous sessile branches, erect or spreading, or the lower ones reflexed. Spikelets one-seeded, nearly sessile, ovate, in three or four irregular, densely crowded rows on one side of the rachis, varying in color from deep purple to pale green, sometimes long-awned, but often without awns, the glumes unequal, sharp-pointed, and bristly-hairy. Seeds about an eighth of an inch long, pointed ovoid, plump.

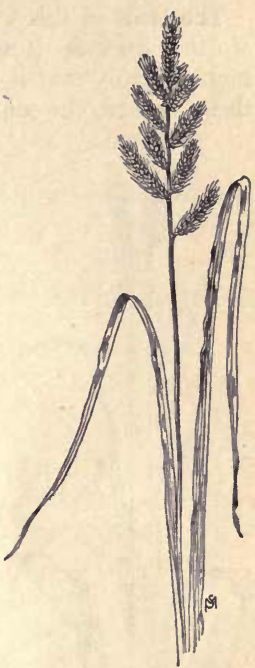

Fig. 8. - Barnyard grass (Echinochloa crusgalli). $\times \frac{1}{b}$.

Means of control

Cutting so frequently that no seed can mature. In cultivated ground the weed is easily kept in subjection by hoe-cutting while small.

\section{YELLOW FOXTAIL GRASS}

Setdria glaúca, Beauv.

Other English names: Pigeon Grass, Pussy Grass, Summer Grass, Wild Millet.

Introduced. Annual. Propagates by seeds.

Time of bloom: July to September.

Seed-time: August to October. 
Range: All cultivated regions of the world.

Habitat: All soils; invades any crop.

The seeds of this weed are among the most frequent impurities of other grass seeds and of clover and grain. It was probably in such company that it came to us from Europe, with the early settlers. Once in the soil, it retains its vitality for years, springing up

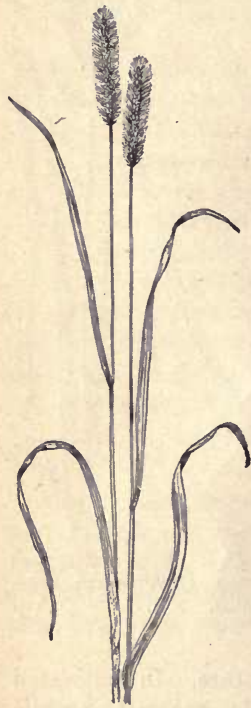

Frg. 9. - Yellow Fortail (Setaria glauca). $\times \frac{1}{4}$. whenever brought near enough to surface warmth and light. Cattle will eat it when young but it soon becomes woody and worthless. Birds and poultry, especially turkeys, are very fond of the seeds, which they strip from the stalks. (Fig. 9.)

Culms branching from the base, growing from fibrous and clustered roots, usually one to four feet tall - though when started late, and pressed for time, Foxtail matures seed when no more than three inches high; stalks compressed at the base, sometimes decumbent. Sheaths loose, compressed, the lower ones often tinged with red; blades three to six inches long, nearly a half-inch wide, flat, smooth, and hanging with a twist. Spikes two to four inches long, the spikelets closely crowded, oneseeded, subtended by an involucral cluster of six to ten upwardly barbed, brownish yellow bristles much longer than the spikelets. Seeds with palea and finely wrinkled lemma both adherent, yellowish brown, long ovoid, about a tenth of an inch in length.

\section{Means of control}

In grain fields, stubbles should be given surface cultivation; or, if the soil is dry enough, burning over will destroy the seeds that have fallen on the ground. In cultivated crops tillage should be continued very late, in order to prevent the development and dis- 
tribution of seed from tardily grown plants. Sheep may be turned in to graze down the aftermath of infested meadows.

\section{BRISTLY FOXTAIL}

Setària verticillàta, Beauv.

Introduced. Annual. Propagates by seeds.

Time of bloom: July to September.

Seed-time: August to October.

Range: Nova Scotia to Ontario, and eastern part of United States to New Jersey and Kentucky.

Habitat: Fields, gardens, and waste places.

Growing in tufts from fibrous roots like the preceding species, but lower and more spreading, the culms ten inches to two feet tall, usually decumbent at base, more or less branched. Leaves two to eight inches long, from a quarter-inch to a half-inch wide, rough on the upper surface. Spikes two to four inches long, the involucral bristles at the base of the one-seeded spikelets being in pairs, stout, and downwardly barbed, standing out almost at right angles to the spike. These downward barbs cause the seeds to adhere to the wool of sheep, which the seeds of other Foxtails do not do.

Like the preceding species, this weed is controlled by preventing seed production.

\section{GREEN FOXTAIL}

Setària víridis, Beauv.

Other English name: Bottle Grass.

Introduced. Annual. Propagates by seeds.

Time of bloom: July to September.

Seed-time: August to October.

Range: Throughout North America except the far North.

Habitat: All soils; invades all crops.

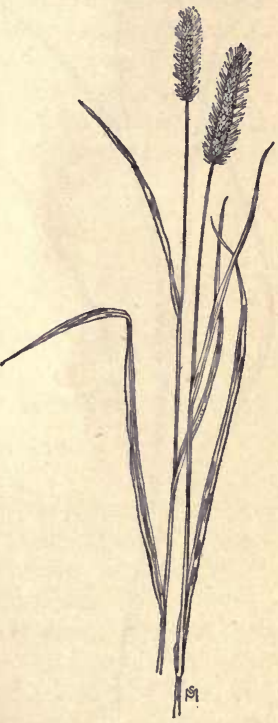

Frg. 10. - Green Foxtail (Setaria viridis). $\times \frac{1}{6}$. 
Culms one to three feet tall, erect, usually simple but sometimes branched, growing in tufts. Sheaths smooth; blades three to ten inches long, one-fourth to one-half inch wide, rough on the margins, dark green. Spikes two to four inches in length, rather thick, the involucral bristles subtending the spikelets being nearly a half-inch long, two to six for each flower, green or sometimes yellowish, barbed upward. Seed similar to that of Yellow Foxtail but slightly smaller, very common in clover seed. Also it seems a worse pest in lawns and gardens than either of its relatives. (Fig. 10.)

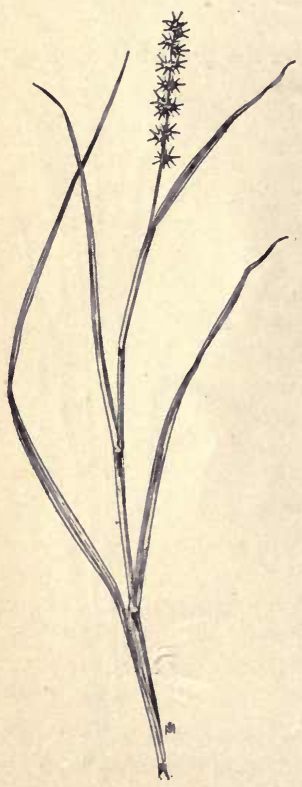

Fig. 11. - Sand-bur (Cenchrus tribuloides). $\times \frac{1}{3}$.

\section{Means of control}

Hoe-cutting or hand-pulling while the tufts are small, in lawns and gardens; surface cultivation or burning over of stubbles after harvest; prevention of seeding in all ways possible.

\section{SAND-BUR}

Cénchrus tribuloides, L.

Other English names: Hedgehog Grass, Bur Grass, Cockspur Bur, Sandspur, Bear Grass.

Native. Annual. Propagates by seeds. Time of bloom: June to August. Seed-time: July to September.

Range: Maine and Ontario to the Dakotas, southward to Florida, Texas, and Southern California; most troublesome in the South.

Habitat: Sandy soil ; shores and waste places.

Usually this grass may be found growing near any place where wool has been stored and cleaned. The burs are said to be more difficult to remove from the fleeces than any others, and a tribulation they must be to the poor beasts in whose hides they rankle. 
Culms ten inches to two feet in length, with many branches, the longer ones spreading and decumbent for part of their length, the shorter ones erect. Sheaths very loose, slightly flattened, smooth but with hairy margins, the ligule conspicuously fringed; blades two to five inches long, smooth, usually flat but sometimes involute. Racemes bearing eight to twenty clusters of two to six flowers, the clusters subtended by ovoid or globular involucres which later enclose the seeds, forming hairy burs about a quarter-inch in diameter, thickly set with stiff, sharp, finely barbed prickles, which are strong enough to penetrate shoe leather. (Fig. 11.)

\section{Means of control}

Small areas about sheep-washing places should be hoe-cut, handpulled, or burned over before the burs ripen. A sandy pasture or meadow infested with the weed should be burned over, cultivated, and fertilized before reseeding to better growths. As a waste-land weed, a whole neighborhood should be interested in its extirpation because of its habit of making any passing animal or person its carrier to a new field.

\section{RICE CUT-GRASS}

Leérsia oryzò̀des, Sw.

Native. Perennial. Propagates by seeds and by rootstocks.

Time of bloom: August to September.

Seed-time: September to October.

Range: Newfoundland to western Ontario, southward to Florida and Texas.

Habitat: Swamps, and along streams and ditches.

A bothersome weed in open ditches, which are frequently clogged by the dense, tangled masses of its interlacing rootstocks. Culms two to four feet long, rather stout, decumbent at base, much branched. Sheaths shorter than the internodes, very rough; blades three to ten inches long, one-fourth to nearly one-half inch wide, very rough, the edges capable of cutting like a knife when drawn through the fingers. Panicle loosely branched, lax and bending, five to eight inches long, the one-seeded spikelets arranged in single rows on the branchlets and overlapping one an- 
other; they have no glumes and the lemma is boat-shaped, sharply keeled, awnless, hard, and bristly, folded over the palea, by strong marginal nerves. (Fig. 12.)

\section{Means of control}

Ditches infested with this weed have to be dug out, and the task should be done before any seed has matured to float downstream in the hairy, boat-like husks.

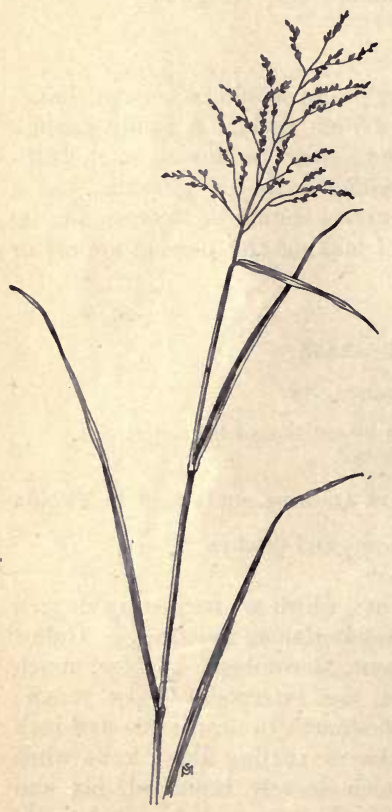

Fig. 12. - Rice Cut-grass (Leersia oryzoides). $\times \frac{1}{3}$.

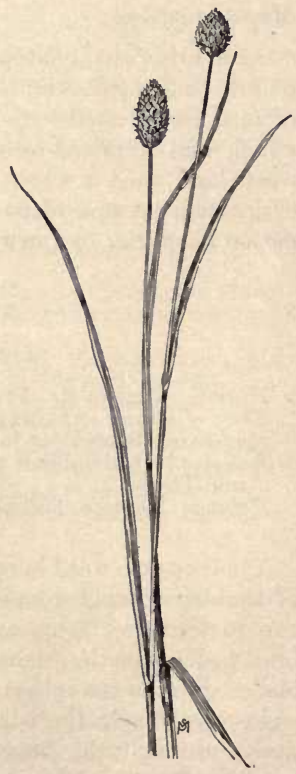

Fig. 13. - Canary-grass (Phalaris canariensis). $\times \frac{1}{4}$. 


\section{CANARY-GRASS}

Phálaris canariénsis, L.

Introduced. Annual. Propagates by seeds.

Time of bloom: July to August.

Seed-time: August to September.

Range: Nova Scotia to Ontario, southward to Virginia.

Habitat: Gardens, roadsides, waste places.

First grown in this country as food for caged birds and for making a flour which is used as sizing in cotton manufacture (weaver's glue), this grass has been spread rather extensively through the accidental mixture of its seeds with better grasses; it is worthless as hay or green forage. (Fig. 13.)

Culms one to three feet tall, erect, usually simple but sometimes branched, smooth. Sheaths shorter than the internodes, rough, loose, the ligules rounded and about one line long; blades three inches to a foot long, nearly a half-inch wide, flat, very rough. Spike a short, dense head, about an inch long and nearly half as thick, the flattened, one-flowered spikelets crowded and overlapping; glumes ovate, keeled, white with green veins. Seeds oblong, smooth, shining, well known as the familiar bird food.

\section{Means of control}

Prevent seed production, and the weed must disappear as soon as all dormant seeds have been stirred to germination and destroyed.

\section{VANILLA-GRASS}

\section{Hieróchloë odoràta, Wahlenb.} (Savastàna odordta, Seribn.)

Other English names: Sweet-grass, Holy-grass, Seneca-grass, Sweet Quack-grass.

Native. Perennial. Propagates by seeds and by rootstocks.

Time of bloom: April to May.

Seed-time: Beginning of June.

Range: Newfoundland to Alaska, southward to Pennsylvania and the shores of the Great Lakes, Colorado, and Oregon. Also native to northern Europe and Ásia.

Habitat: Prairies ; moist meadows. 
The name of "Quack" or "Sweet Quack," which western farmers have given this grass is confusing, for the true Quack-

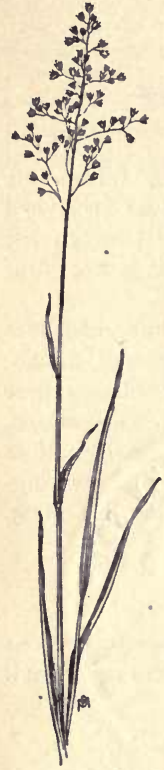

Fig. 14. - Vanilla-grass (Hierochloe odorata). $\times \frac{1}{4}$ grass flowers in June and its matted "couch" of rootstocks is near the surface, while Vanilla-grass flowers in early spring and its rootstocks are deep in the soil. The whole plant has an odor much resembling the Vanilla bean, most lasting if plucked while the plant is in flower. In northern Europe it is strewn before churches, the trampling feet of the congregation causing it to yield its fragrance, and this custom has given it the name of Holy-grass. The Indians of the Northwest make baskets and mats of it; the perfume has a tendency to produce sleep, and pillows are stuffed with it; but as hay or forage it has no value.

Culms one to two feet in height, very slender, erect, simple, smooth. Leaves of the flowering stalks very short, lance-shaped, smooth or only slightly roughened; but after seeding the rootstocks send up many barren stalks with long, flat, rough, and deep green leaves whose task is to assimilate and store food for next season's early bloom. The panicles show when the stalks are but a few inches above the ground and grow with them, unfolding very suddenly; they are pyramidal, two to four inches long, the branchlets spreading and drooping when green but stiffening and becoming erect and wiry as the seeds ripen, the glumes turning golden brown tinged with purple. Spikelets one-seeded. (Fig. 14.)

\section{Means of control}

Summer fallowing, with very deep plowing, which will expose and wither the rootstocks. The ripened grass should first be mowed and burned so as to avoid plowing under the long-lived seeds. Or deep plowing in spring when the grass is in flower, and immediately seeding the ground heavily with some grass of quick growth. 
Shallow plowing or surface cultivation merely stimulates the growth of the grass.

\section{PORCUPINE-GRASS}

Stipa spártea, Trin.

Other English names: Weather Grass, Needle Grass, Auger-seed Grass. In South Dakota it is ealled Wild Oats.

Native. Perennial. Propagates by seeds.

Time of bloom: June to July.

Seed-time: July to August.

Range: Prairies of the Middle Western States from Ohio to the Rocky Mountains, north to Manitoba, British Columbia, and the Saskatchewan region.

Habitat: Dry soil ; wild meadows and pastures.

A large, stout grass, growing in tufts from a matted cluster of fibrous roots. Culms two to four feet tall, simple, erect, smooth. Sheaths long, mostly overlapping, slightly rough; basal blades about half as long as the culm, involute, and tapering to a thread-like point; stem leaves six inches to a foot long, hardly more than a sixth of an inch wide, generally flat but sometimes involute, with long, attenuate points. Panicles long and slim, with erect branches, the base at first often enclosed by the sheath but later much exserted. Spikelets one-seeded, the glumes smooth, very narrow and bristle-pointed, exceeding an inch in length; the lemma tightly enfolding the seed, hard, stiff, brown, its lower part clothed with short rigid hairs, and having a sharppointed beak or callus, and at the tip an awn, sometimes six inches long, rough, stiff, strongly twisted

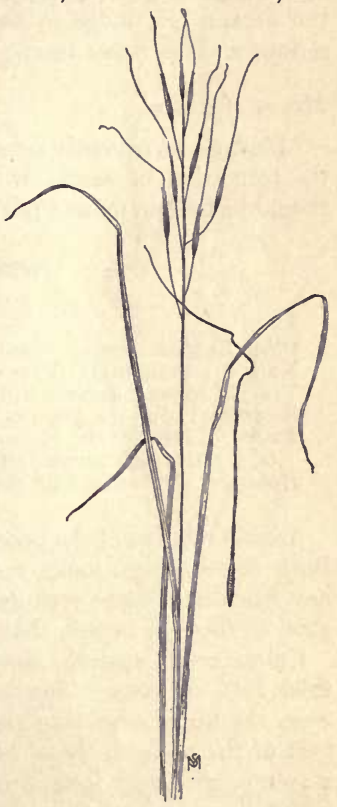

Fia. 15. - Porcupine-grass (Stipa spartea). $\times \$$. 
for half its length, usually with a double bend beyond the straight spiral. (Fig. 15.) This spiral awn relaxes when damp and tightens again when dry, enabling the seed to bore its way into the soil with the sharp beak at its base; but if caught in the wool of a sheep it bores just as readily into the flesh of the animal, the stiff hairs near the base of the seed holding it in place while the awn twists and untwists through days of torment, making sores which injure the quality of the wool and sometimes endanger the creature's life. Hay containing the awns is worse than worthless, for, when eaten by horses, cattle, or sheep, the broken bits lodge in the intestines, causing inflammation so serious as sometimes to end in death.

\section{Means of control}

Mowing so frequently or grazing so closely as entirely to prevent the formation of seed. If the grass is very abundant, the land should be broken up and put to a soiling crop before reseeding.

\section{WESTERN STIPA}

Stipa comàta, Trin. \& Rupr.

Other English names: Needle-grass, Needle-and-thread.

Native. Perennial. Propagates by seed.

Time of bloom: June to July.

Seed-time: July to August.

Range: Plains of the Missouri River, the Rocky Mountain foothills of Northwest Canada, and in New Mexico and California.

Habitat: Dry soil; wild meadows and pastures.

A close relative of the preceding species but not quite so vicious. Both these grasses make excellent forage when young, and good hay when cut before seed development; but there are grasses, as good as these or better, that do not carry such offensive weapons.

Culms erect, smooth, simple, one to two feet tall, growing in thick tufts or mats. Sheaths overlapping, mostly crowded at the base, the upper ones long and loose and often enclosing the lower part of the panicle; basal blades about half as long as the culm, involute, with very long, thread-like tip; stem leaves three to six inches long, broader than the basal ones, involute. Panicle erect, six to ten inches long, somewhat loose and spreading; spikelets 
one-seeded, the glumes exceedingly narrow and tipped with long bristles, the lemma with an acute callus; awn four to eight inches long, rough-hairy and twisted in the lower part, extremely slender, flexible, and thread-like; not harmful when caught in the coats of animals but very objectionable in hay.

Means of control the same as for the preceding species.

\section{POVERTY-GRASS}

Aristiàa dichótoma, Michx.

Other English name: Three-awned Wire-grass.

Native. Annual. Propagates by seeds.

Time of bloom: August to October.

Seed-time: September to November.

Range: Maine to Ontario, southward to Missouri, Oklahoma, Texas, and Florida.

Habitat: Dry upland meadows, pastures, and waste places.

Sterile, sandy, or gravelly soils seem to be preferred by this wiry grass. Stems tufted, six inches to two feet tall, erect, very slender, and usually forking at every joint. Sheaths short, loose, and smooth, with hairy ligules; the blades are one to three inches long, scarcely a tenth of an inch wide, with rough surface and edges involute. Panicles very slender, two to five inches long, the lateral ones often enclosed in the sheaths; spikelets hardly a quarter-inch long, the glumes sharppointed, not quite equal; the lemma hard, convolute, closely enfolding the seed with the palea, and terminated with three awns, of which the lateral ones are short but the central one is about as long as the lemma and is held horizontally with a twist at the base. (Fig. 16.)

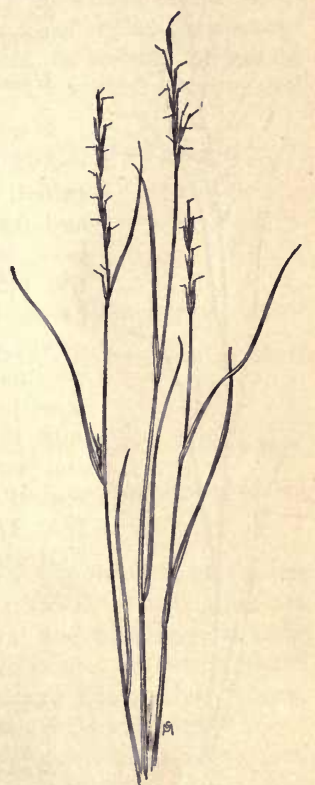

Fig. 16. - Poverty-grass (Aristida dichotoma). $\times$ is. 


\section{Means of control}

Cultivate and enrich the soil by furnishing it with humus to enable it to retain moisture, thus putting it in condition to support grasses or other plants of better quality.

\section{FEW-FLOWERED ARISTIDA}

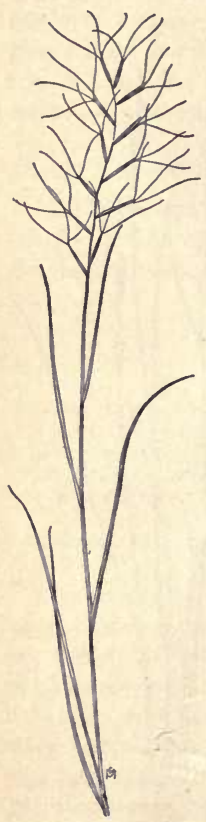

Fic. 17. - Fewflowered Aristida (Aristida oligantha). $\times \frac{1}{6}$.

\section{Aristida oligantha, Michx.}

Native. Annual. Propagates by seeds.

Time of bloom: July to October.

Seed-time: August to November.

Range: New Jersey to Nebraska, southward to Mississippi, Louisiana, and Texas.

Habitat: Dry grasslands, waste places.

A worthless, wiry grass, similar to the preceding, and, like it, partial to sterile soil. Stems tufted, very slender, erect, branched at base, and forked at every joint. Sheaths long and loose, smooth but with minutely hairy ligules, the blades smooth, two to six inches long, hardly an eighth of an inch wide, involute, and extended to a very long, sharp point. Panicle very narrow, and flexuous, bearing only a few, sometimes but two or three spreading spikelets, with the triple awns divergent but ascending, and usually all about equal in length or the central one somewhat exceeding the other two. (Fig. 17.)

Means of control the same as for Povertygrass.

\section{SAND-GRASS}

Aristida fasciculàta, Michx.

Other English name: Three-awned Needle-grass. Native. Annual. Propagates by seeds.

Time of bloom: August to October.

Seed-time: September to November.

Range: Kansas to California, Arizona, New Mexico, and Texas.

Habitat: 'Dry, sterile fields, pastures, and waste places. 
In the hot, arid regions of the Southwest, which are its home, the Sand-grass is not called a weed, for its thin, wiry stems afford some grazing where otherwise there might be none; but when it appears in soils where better forage can be made to flourish, it should be crowded out. Its seeds are often an impurity of western grass seed.

It grows in tufts, from tufted roots, the stems six to eighteen inches tall, many-branched. Leaves three to six inches long, but hardly more than an eighth of an inch wide, pointed and involute. Panicle slender, four to eight inches long, its short, erect branches in fascicles of two to four; the slim spikelets have the glumes onenerved, the first only about half as long as the second, the lemma keeled and hairy, its three awns divergent, the central one extended much beyond the other two.

Means of control the same as for the two preceding grasses.

\section{MEXICAN DROP-SEED}

Muhlenbérgia mexícàna, Trin.

Other English names: Meadow Muhlenbergia, Wood-grass, Knotroot Grass.

Native. Perennial. Propagates by seeds and by ereeping rootstocks.

Time of bloom: August to September.

Seed-time: September to October.

Range: New Brunswick and Ontario to the Dakotas and southward to the Gulf of Mexico.

Habitat: Low ground meadows and pastures, woodlands, and banks of streams.

When growing along the sides of swiftly flowing streams, the strong, creeping, knotted, and scaly rootstocks of this grass are often of much service in binding the soil and preserving it from washing, but it is otherwise of very little value. If cut or grazed while very young, it makes good hay and forage; but it soon becomes hard, wiry, and innutritious, and cattle will not eat it.

Stems smooth, two to three feet high, often branching at the base, usually decumbent and taking root at the lower joints. Leaves four to six inches long, less than a quarter-inch wide, rough to the touch; on the branches they are much smaller and more 
crowded. Flowering panicles terminal on the culms and the many branches, two to six inches long, very slender and compact and usually partly enclosed in the upper sheaths.

Means of control

In fields and meadows, drainage and thorough cultivation of the ground are necessary in order to displace this grass.

\section{NIMBLE WILL, DROP-SEED GRASS}

Muhlenbérgia Schrebèri, J. F. Gmel.

(Muhlenbérgia diffùsa, Schreber.)

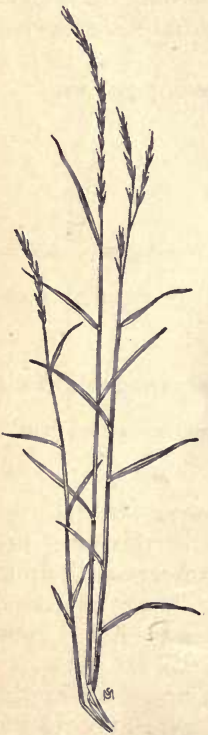

FIG. 18. - Nimble Will (Muhlenbergia Schreberi). $\times \frac{1}{8}$.
Other English name: Wire-grass.

Native. Perennial. Propagates by seeds and by rooting at the joints.

Time of bloom: August to September.

Seed-time: September to October.

Range: From Maine to Minnesota and southward to Kansas, Texas, and Florida.

Habitat: Lawns, pastures, and meadows.

A low, slender, branching, almost creeping grass which grows on dry hills and in woods and shady places about dwellings. When young it is much liked by all kinds of stock, but it soon becomes so dry and wiry that no animal will eat it, and its tough, fibrous, interlacing roots make a sod which is very difficult to break up.

Stems ten inches to two feet long, somewhat flattened, usually prostrate at the base and often rooting at the lower joints, erecting the flowering stalks. Sheaths loose and smooth, the leaves two to four inches long but hardly more than an eighth of an inch wide and rough to the touch. Panicle very slender, two to six inches long, weak and bending; glumes of the spikelet very minute, the lower one often lacking; the lemma is rough, strongly nerved, tipped with an awn, and 
closely enfolds the seed until ripe, when it drops to the ground entire. (Fig. 18.)

Means of control

Where the ground can be cultivated without danger of loss from washing, the sod should be broken up and put to a tilled crop before reseeding with clover or grasses of a better quality.

\section{MARSH FOXTAIL}

Alopecùrus geniculàtus, L:

Other English names: Bent Foxtail, Water Foxtail, False Timothy.

Introduced. Perennial. Propagates by seeds and by taking root at the lower joints.

Time of bloom: June to August.

Seed-time: July to September.

Range: Newfoundland to British Columbia, southward throughout the United States; also in Europe and Asia.

Habitat: Moist meadows, banks of streams, and ditches ; of ten troublesome in damp cultivated ground.

A slender, low-growing grass, with the habit of forming "knees" and rooting at the lower joints; it is said to be nutritious grazing when young and tender, but yields a very small amount of hay to the acre, and the hay is of poor, harsh quality.

Culms eight to eighteen inches tall, smooth, simple or sparingly branched, erect above the decumbent base. Sheaths shorter than the internodes, the upper one usually inflated; leaves rough, two to six inches long and hardly an eighth of an inch wide. Spikes dense, cylindrical, one to three inches long and

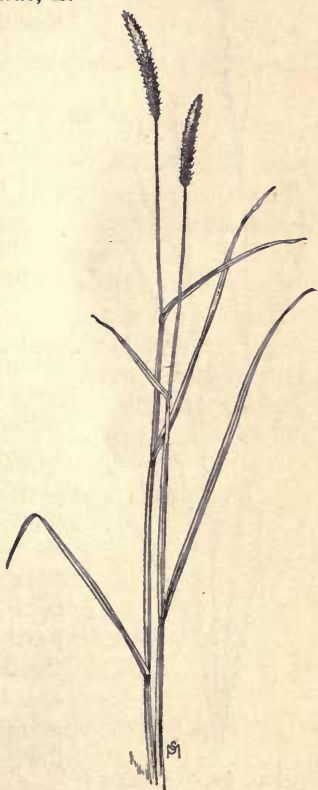

Fig. 19. - Marsh Foxtail (Alopecurus geniculatus). $\times \frac{1}{1}$. 
about a third of an inch in diameter; spikelets one-flowered, flattened, the glumes equal, united at base, obtuse, with hairy keels; the lemma much shorter, obtuse, and smooth, the awn attached slightly below the middle and bent, the portion exserted being usually twice as long as the glumes. (Fig. 19.)

\section{Means of control}

Drain the ground and follow with a season of intensive cultivation and fertilization before reseeding heavily to better and much

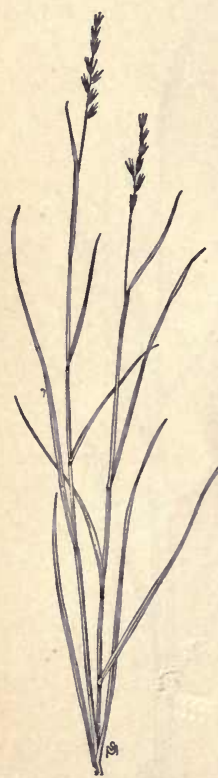

Fic. 20. - Sheathed Rush-grass (Sporobolus vaginiflorus). $\times \frac{1}{6}$. more profitable grasses, such as red-top and timothy.

\section{SHEATHED RUSH-GRASS}

\section{Sporbbolus vaginiflòrus, Wood}

Native. Annual. Propagates by seeds.

Time of bloom: July to August.

Seed-time: August to September.

Range: Maine to South Dakota, southward to Florida and Texas.

Habitat: Dry, sterile fields; waste places.

A thin, dry, and worthless grass which should not be tolerated where anything better can be made to grow. Culms tufted, fifteen to twenty inches tall, slender, smooth, divergent, or sometimes erect. Sheaths about half as long as the internodes, loose and inflated; leaves short, less than an eighth of an inch wide, smooth beneath, rough at base above, involute toward the point, Panicles very numerous, included and partly concealed in all the upper sheaths, the terminal one only being usually exserted, one to two inches long; spikelets thin, the glumes unequal, long-pointed, smooth, the lower one shorter; lemma rough and hairy and exceeded in length by the palea which is very sharp-pointed. The seed is freely 
self-sown as it ripens, the spikelets dropping entire from the axis. (Fig. 20.)

Means of control

Cultivate and fertilize the ground, furnishing humus in order to enable it to retain moisture and support forage of a profitable quality.

\section{SMALL RUSH-GRASS}

Sporóbolus negléctus, Nash.

Native. Annual. Propagates by seeds.

Time of bloom: July to August.

Seed-time: August to Septernber.

Range: New Brunswick to the Dakotas, southward to Virginia and Texas.

Habitat: Sterile and sandy fields; waste places.

Similar to the preceding species, but even smaller and more worthless. Culms tufted, six inches to a foot in height, usually decumbent to the first joint and then erect, smooth, often much branched. Sheaths much inflated, rather more than half the length of the internodes; leaves only about one line wide, smooth below, rough at base above, with very attenuate point. Panicles very slender and almost completely enclosed and hidden in the sheaths, even the terminal one partly so. Spikelet about a tenth of an inch long, the glumes, lemma, and palea all nearly equal, smooth, acute, thin in texture, white and shining; sowing itself when ripe by dropping entire to the ground.

Means of control the same as for the preceding plant.

\section{SMUT-GRASS}

Sporobolus indicus, R. Br.

Other English names: Indian Rush Grass, Indian Drop-seed.

Introduced. Perennial. Propagates by seeds.

Time of bloom: July to September.

Seed-time: August to October.

Range: Virginia to Arkansas, southward to the Gulf of Mexico.

Habitat: Fields, meadows, and waste places.

This grass came from the tropics and is common in all the warmer regions of the world. It is good forage only when very young, the 
stems soon becoming very hard and the slender panicles often overgrown with a black fungus, whence the common name. Cattle will not touch it when other food can be found.

Culms thickly tufted, strong and wiry, two to four feet tall, erect, smooth, simple or occasionally branched. Sheaths but little shorter than the internodes, the ligule a ring of fine, short hairs; leaves six inches to a foot long but less than a quarterinch wide, smooth and flat. Panicle much elongated, slim, spikelike, often half the entire height of the plant. Spikelets about a tenth of an inch long, densely crowded on the erect branchlets of the panicle; they are smooth, shining, the glumes obtuse, very unequal, the lower one shorter and only about half the length of the third scale or lemma, which is acute and exceeds the obtuse palea.

\title{
Means of control
}

Put the land under thorough cultivation for a season in order to destroy the perennial roots before reseeding heavily with grass or clover of good quality.

\section{WILD OATS}

\author{
Avèna fátua, $\mathbf{L}$.
}

Introduced. Annual. Propagates by seeds.

Time of bloom: June to July.

Seed-time: July to August.

Range: All parts of the country, but most abundant and troublesome in the grain-growing sections of the Canadian provinces and in the United States from Minnesota to Oregon and California.

Habitat: All soils; fields of cereal grains, flax, and the large-seeded grasses.

Sowing Wild Oats is proverbially a bad thing to do, but the wide distribution of this weed is almost entirely due to the practice of allowing it to enter the soil with its betters. Once there, it is not an easy task to get it out again. It has a number of bad traits which render it particularly obnoxious in grain fields: it thrives best under the field conditions best suited to the growth of cereals; its seeds ripen irregularly, but usually before those of the grain with which it grows, and drop easily from the stalk as soon as ripe; the seeds have long vitality, and one fouling of the ground will last for several seasons. The plant adapts itself to the widest differ- 
ences of soil and climate, from Dakota flax fields to southern Cali. fornia wheat fields. The stiff and twisted awns are frequently injurious to animals that eat them, causing serious irritation in mouth, nostrils, and digestive tract; also, the hard skins and thick hulls of the seeds sometimes permit of their passing unharmed through the intestines to be sown with the droppings. (Fig. 21.)

Wild Oats look much like the cultivated grain, the culms growing in tufts, two to four feet tall, with long, smooth, green leaves about a half-inch wide, and loose, open seed-panicles six to ten inches long, the spikelets pendulous, the glumes nearly equal, slightly ridged, smooth and pointed. But the lemmas or hulls that enclose the seed are, in the cultivated plant, smooth and thin; those of the Wild Oat are larger, much thicker, covered with stiff, brown hairs, and have a ring of rigid, brown hairs at base; they bear a stiff awn about an inch long, which is both twisted and bent; the awns of the cultivated oat are much shorter and not so stiff. These crooked and bristly awns are able to cling to the wool of sheep and to the insides of grain-sacks, which helps the seeds to find new homes;. when dampened they relax, and twist again when dry, so boring easily into the soil. Wild Oats will germinate and the young

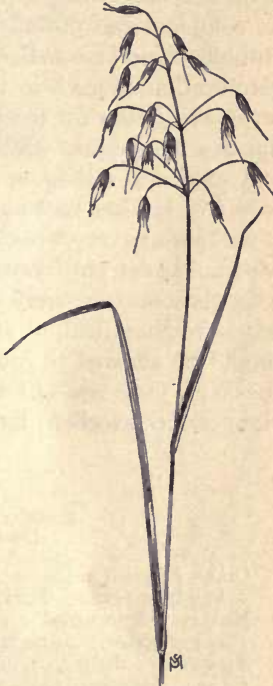

Frg. 21. - Wild Oats (Avena fatua). $\times \frac{1}{6}$. plant force its way to air and sunlight, even when buried four or five inches deep in the ground.

\section{Means of control}

Sow clean seed. No matter what its cost, it cannot be so expensive as the fouling of a whole grain crop, sometimes to such a degree 
as to suffer a dockage in the market of one to fifteen pounds to the bushel. And it is to be remembered that the soil on which such a crop grew is also damaged and below grade while the weed is its tenant. If a field is newly infested and the plants are not too numerous to make the job impracticable, hand-pulling and burning, before the hardening of the seed, is not too great a price to pay for its complete and prompt extermination. But if left until harvest, stubbles should immediately be plowed, very shallow, so as to induce germination of seeds in the soil, the growth being either grazed off or plowed under for humus. In the spring, plow more deeply and put in a hoed crop. Or a crop of sowed corn or rape may be grown and used for soiling or pasturage. Or, if such crops as winter wheat or rye are to be grown, summer-fallow the land, harrowing it well about every week or ten days until time to sow the rye or the wheat. Leave cultivated oats out of the rotation of crops until the wild plants are entirely destroyed. When Wild Oats show themselves in a hay field, no stress of weather nor pressure of other work should be allowed to interfere with the cutting of the crop before the Wild Oats are out of the "dough stage" of the seeds. The plant makes excellent hay when cut green.

\section{WILD OAT-GRASS}

\section{Danthònia spicàta, Beauv.}

Other English names: Poverty-grass, Bonnet-grass, Wire-grass, Wildeat Grass, Turkey-strip, Old Fog.

Native. Perennial. Propagates by seeds.

Time of bloom: June to July.

Seed-time: July to August.

Range: Eastern part of the United States and Canada, westward to the Dakotas, southward to the Gulf of Mexico.

Habitat: Dry, sterile, or rocky soil.

This miserable little grass seems best contented when making some hard, worn-out meadow look shabby and miserable. Its name of "Poverty Grass" fits it well, for its presence seems to be a sure indication of poverty of soil. The grass itself is dry and tasteless, worth nothing either as hay or as pasture.

Roots fibrous and clustered, the hard, smooth, wiry stems nearly naked, most of the short, slim, curly leaves being gathered 
in a tuft at their base, the few on the stems small, stiffly erect, and involute. The hard, thin little seed is covered with a hairy lemma and armed with a bristly, bent, and twisted awn, like that of the real Wild Oat but much smaller. Usually the seeds ripen and fall before the hay is cut, and after this the stems and leaves turn dry and brown and look unsightly. (Fig. 22.)

\section{Means of control}

The presence of the weed is a sign of exhausted fertility, and the best remedy is to enrich and cultivate the ground before reseeding heavily with clover to be plowed under for humus. When the soil is in a condition to retain moisture and support the growth of better plants, the weed will be crowded out.

\section{BERMUDA GRASS}

Cýnodon Dáctylon, Pers.

(Caprìola Dáctylon, Kuntze.)

Other English names: Scutch Grass, Dog's-tooth Grass, Wire Grass.

Introduced. Perennial. Propagates by stolons, or runners which put forth roots at the joints. Rarely by seeds.

Time of bloom: July to August.

Seed-time: August to September. But no seed is produced in the United States except in the most southern parts.

Range: Southern part of the United States, north as far as Maryland, and westward to the Pacific Coast.

Habitat: Fields, meadows, and waste places.

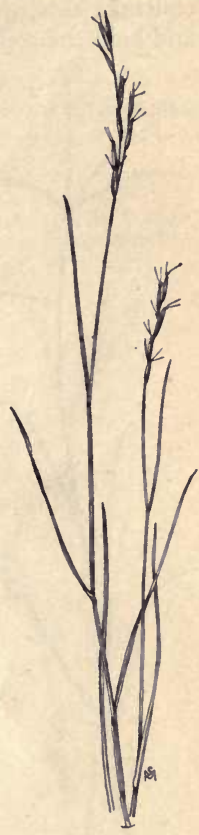

Fig. 22. - Wild Oat-grass (Danthonia spicata). $\times \frac{1}{3}$.

This is a tropical grass, subject to winterkilling north of the altitude of Virginia. It prefers warm, sandy soil, and droughts that kill other grasses harm it not at all. Only in cultivated ground is it a weed, but there its creeping habit of growth makes it a very bad one, extremely hard to destroy, particularly in cotton fields 
and other hoed crops. But it is the most valuable of southern grasses for lawns, meadows, and pastures, and on the levees, road embankments, and stream sides it is the best thing possible to bind and hold the soil in place. For such purpose it is usually started

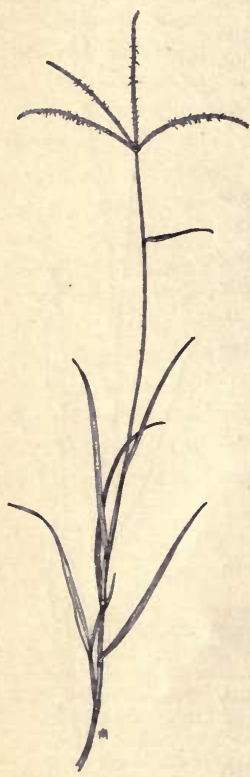

Fig. 23. - Bermuda Grass (Cynodon Dactylon). $\times \frac{1}{2}$. by passing a quantity of the plants through a feed cutter and sowing the pieces, every joint of which will probably strike root and make a new plant. (Fig. 23.)

It is small and low, the stems four inches to a foot tall, slender, slightly flattened, very much branched, becoming stiff and wiry as they mature. Leaves smooth, flat, stiff, light green, only two to four inches in length but very numerous. Sheaths smooth, the ligule a ring of white hairs. The sheaths overlap and are crowded at the base of the stalks and along the stolons. When the flowering stalks do appear, the heads are divided into four or five "fingers" which are shorter and thicker than those of the real finger, or crab, grass (Digitaria).

\section{Means of control}

The plant is a lover of heat and sunlight and will not thrive in the shade. Therefore, when a meadow or a pasture is wanted for a different crop, it can be smothered out by a thick growth of taller plants, such as cow-peas, sorghum, or millet, which will at the same time yield a profitable crop of hay. In latitude where a "cold snap" in winter is sufficiently biting, the roots may be killed by exposing them to freeze, using a good, sharp, turning plow and making the furrow as shallow as possible, for the roots are very near the surface. The hard, wiry, interlacing stems of this grass make tilled crops infested with it very difficult of cultivation, requiring much hand labor with the hoe. But in most localities it leaves no 
seed to infest the soil, and one or two seasons of careful work should conquer it.

\section{GOOSE-GRASS}

Eleusine indica, Gaertn.

Other English names: Yard-grass, Crab-grass, Wire-grass, Crow-foot Grass. Indian Eleusine.

Introduced. Annual. Propagates by seeds.

Time of bloom: June to September.

Seed-time: July to October.

Range: In nearly all parts of North America except the far North. Habitat: Farmyards, roadsides, and waste places; often troublesome in lawns.

A coarse grass that came to us from India and behaves as though domesticated. It grows from clustered, fibrous roots, the culms six inches to two feet long, flattened, decumbent at base, from which there are usually several branches. Sheaths loose, overlapping, compressed, smooth but hairy at the throat; ligule very short and $\mathrm{mi}$ nutely toothed, blades three inches to a foot long, often crowded at the base of the culm, rather thick, pale green. Spikes two to ten, digitate at the end of the stalk or one or two below near the top, one to three inches long; spikelets appressed, three- to five-flowered; glumes unequal, rough-keeled. Seeds black and wrinkled. (Fig. 24.)

\section{Means of control}

In yards and waste places the grass should be hoe-cut or hand-pulled before it develops seeds. In lawns, a few drops of crude carbolic acid squirted into the heart of a tuft with a common machine oil-can will kill it, without defacing the smoothness of the sward as a hoe Frg. 24. - Goose-grass would do.

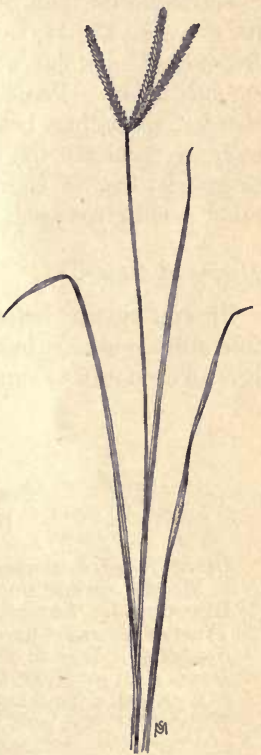

(Eleusine indica). $\times \frac{1}{6}$. 


\section{HAIRY SPEAR-GRASS}

Eragróstis pilòsa, Beauv.

Other English names: Tufted Spear-grass, Slender Meadow-grass. Introduced. Annual. Propagates by seeds.

Time of bloom: July to September.

Seed-time: August to October.

Range: Maine to Minnesota, southward to Florida and Texas.

Habitat: Fields and waste places. Sandy or gravelly soil.

Stems growing in tufts from fibrous roots, six to eighteen inches tall, smooth, slender, erect or decumbent at base, diffusely branched. Sheaths shorter than the internodes, smooth or sometimes sparingly hairy at the throat, the ligule a ring of short hairs; blades one to five inches long, flat, about a tenth of an inch wide, rough above, smooth below. Panicle three to six inches in length, with many slender, spreading branches, having minute tufts of hair in the axils, particularly the lower ones. Spikelets very small, hardly a line wide, five to eighteen-flowered. Seeds often an impurity of other small grass seeds.

\section{Means of control}

Prompt cutting before the formation of seed. This grass makes tolerably good hay, but there is so small a quantity to the acre that it is an economy to supersede it with forage of a better quality.

\section{STINK-GRASS}

Eragróstis megastdchya, Link.

(Eragróstis màjor, Host.)

Other English names: Strong-scented Meadow-grass, Pungent Meadow-grass, Snake-grass, Candy-grass.

Introduced. Annual. Propagates by seeds.

Time of bloom: June to September.

Seed-time: July to October.

Range: In southern Canada and in most parts of the United States. Especially troublesome in the Southwest.

Habitat: Fields and waste places.

A very handsome grass, but offensive to grazing animals both as green forage and as hay. Culms ten inches to three feet high, 
somewhat weak and flaccid, often decumbent at the lower joints, very profusely branched. Sheaths shorter than the internodes, the ligule a ring of short hairs; blades three to ten inches long, a quarter-inch to a halfinch wide, flat. Panicles three to ten inches long, with many spreading branches, densely flowered, grayish green. Spikelets ten- to forty-flowered, the florets closely imbricated, the glumes acute and keeled. Seeds reddish, very small, when ripe dropping readily from the spikelets and seeding the soil for the crop of the next year; a common impurity of timothy and other small grass seeds. (Fig. 25.)

\section{Means of control}

Small areas, in yards, roadsides, and waste places, should be hoe-cut or hand-pulled while the grass is in first bloom. Hay from rankly infested meadows, though not so strong-scented as the green grass, is wiry and weedy, and of such inferior quality that it is most profitable when turned under the ground for the purpose of fertilizing a better crop.

\section{CHESS OR CHEAT}

Bròmus secalìnus, L.

Other English names: Wheat-thief, Williard's Brome Grass.

Introduced. Annual or winter annual. Propagates by seeds.

Time of bloom: June to July.

Seed-time: July to August.

Range: Throughout North America wherever grain is grown.

Habitat: Grain fields, waste places.

Probably the first settler who planted a wheat field in America sowed some seeds of Chess with it and the practice still continues. Some farmers believed that wheat changed into Chess as it grew, but it is needless to say that such a miracle never happened. The 
two plants are not even very closely related, but belong to quite distinct tribes in the Grass Family, and each comes true from its own seed. But Chess seeds, when buried in the soil, retain their vitality for years, and their coming up in a field where clean grain had been sown might be thus accounted for. When sown with

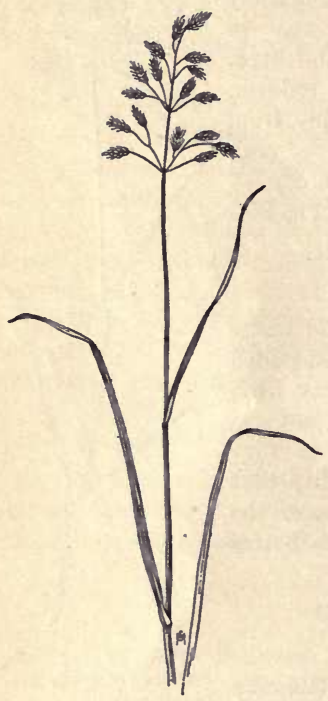

Fig. 26. - Chess or Cheat (Bromus secalinus). $\times \frac{1}{5}$. spring crops it often fails to mature its seeds, and is therefore most frequently found growing with the fallsown crops of rye and winter wheat. Grain containing Chess is somewhat difficult to clean, and if ground with wheat the flour is dark-colored and has a narcotic quality which ruins it commercially. Consequently such wheat is very sharply docked in the market. It is a most prolific weed. Professor Hunt, of Cornell University, sowed one pound of it on onetwentieth of an acre and reaped ninety-nine pounds of seed; and as they are quite small and light, there are nearly as many seeds in a pound as there are wheat kernels in a bushel. (Fig. 26.)

Stems two to three feet tall, erect, smooth, and simple. Sheaths smooth, strongly nerved, shorter than the internodes. Leaves three to ten inches long, slightly hairy above but smooth beneath, and flat. Panicle loose and open, its branches somewhat drooping. Spikelets smooth, containing five to fifteen seeds, about a quarter-inch long, the lemmas adhering like oats, but distinguished from that grain by smaller size and darker color; they are also somewhat thicker and inrolled at the margins; awns, when present, usually short and straight but weak and soft, sometimes more or less flexuose. 


\section{Means of control}

Sow clean seed. Chess is smaller and lighter than wheat, and care in cleaning should remove it. But if it is suspected that a few seeds remain, stir the wheat in a barrel of water just before sowing; the Chess will rise to the top. If the grain is treated with formalin for the purpose of destroying suspected spores of smut, the Chess may be removed at the same time. When the weed makes a first appearance in clean soil, under no circumstances let it be fouled for years by allowing the Chess to ripen and scatter its seeds. Handpulling and burning is worth while in such an instance, even though the quantity be so large as to make the task rather strenuous. Stubbles where seeds have matured should have surface cultivation after harvest, in order to cause them to germinate ; then plow them under, and put no more grain on that land until a hoed crop of some kind needing very thorough tillage has had a place in the rotation.

\section{SOFT CHESS}

\section{Bròmus hordedceus, L.}

Introduced. Annual or winter annual. Propagates by seeds.

Time of bloom: June to July.

Seed-time: July to August.

Range: Nova Scotia to Virginia, and westward to the Mississippi River. Not common, but "becoming frequent."

Habitat: Fields and waste places.

Soft Chess differs from Cheat in being smaller, the culms one to two feet tall, erect, slender, simple. The whole plant is softly hairy, while Cheat is smooth. Panicle erect and rather compact instead of open and drooping, the spikelets having shorter pedicels; these are six- to tenseeded, the glumes covered with soft appressed hairs, the lemma, tipped with an awn about as long as itself, and straight. (Fig. 27.)

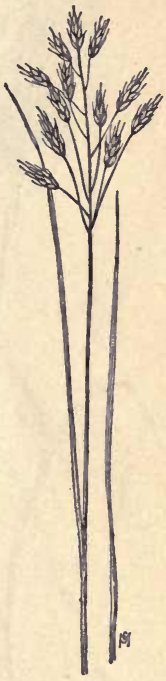

FIG. 27. - Soft

It should be fought in the same manner as the

Chess (Bromus hordeaceus). $\times \frac{1}{2}$. 
common Chess, for if allowed to have its way, it may become as pernicious as that weed.

\section{DOWNY BROME-GRASS}

Bròmus tectorum, L.

Other English names: Slender Chess, Early Chess.

Introduced. Annual or winter annual. Propagates by seeds.

Time of bloom: May to July.

Seed-time: June to August.

Range: Massachusetts to Indiana, Colorado, Washington, Virginia, and Mississippi.

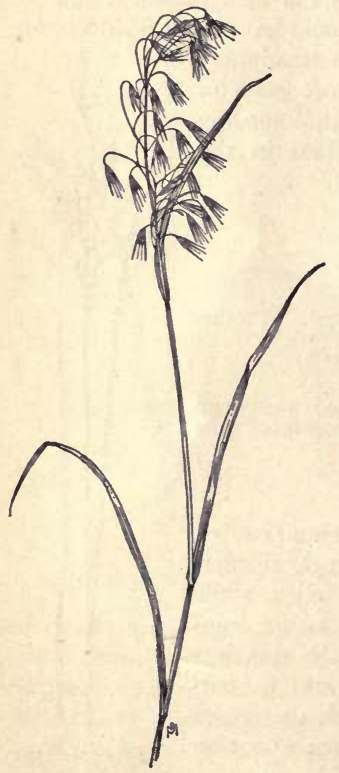

Habitat: Fields and waste places.

The range of this weed has greatly increased of late years. Its early season makes it very objectionable, as its seeds foul the ground before any grain is ripe; the stems also become rough and innutritious very early in the season, so that it is a damage in hay fields as well as among grain. (Fig. 28.)

Culms one to two feet tall, tufted, erect, and very slender. Sheaths and blades softly downy, the latter flat, three to six inches long. The whole plant seems slim and weak, the panicle one-sided, like oats, its branches slender and thread-like, the spikelets pendulous; these are numerous, small, the glumes narrow, rough-hairy; awn straight, longer than the lemma.

\section{Means of control}

Prevent seed production - which

FIG. 28. - Downy Brome-grass (Bromus tectorum). $\times \frac{1}{4}$. means that the grass must be either cut or pulled as early as May. 
Ground largely overgrown with this grass should be put under cultivation and then be reseeded with other and better forage plants.

\section{PERENNIAL RYE-GRASS}

Lòlium perénne, $\mathrm{L}$.

Other English names: Ray-grass, Common Darnel.

Introduced. Perennial. Propagates by seeds.

Time of bloom: June to July.

Seed-time: July to August.

Range: Nearly throughout the northern United States.

Habitat: Fields, meadows, pastures, and roadsides.

The seeds of this grass closely resemble those of the much more expensive and valuable Meadow Fescue and are sometimes used by unscrupulous dealers in substitution or adulteration. It cannot properly be called a weed, though in this country it often proves unenduring and unprofitable, particularly in dry seasons, on light soils. It is a grass that requires moist ground and a cool, moist climate to thrive well, which is the reason it is so highly esteemed in the northern latitudes such as England and Scotland. Experiments at Woburn demonstrated that its nutritive value is very low and its aftermath the lowest of all cultivated grasses. When allowed to seed it is very exhaustive to the soil. (Fig. 29.)

Culm ten to thirty inches tall, erect and smooth. Sheaths shorter than the internodes; leaves flat and smooth, two to five inches long. Spike terminal, three to eight inches long, the spikelets set with the edge to the rachis, the

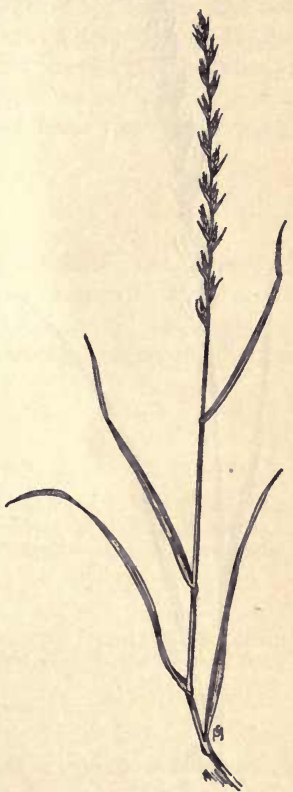

Fic. 29. - Perennial Ryegrass (Lolium perenne). $\times \frac{1}{6}$. 
empty glume at the base slightly shorter than the spikelet, a character which distinguishes it from its annual relative the Poison Darnel, which has the subtending empty glume longer than the spikelet.

\section{Means of control}

Sow clean seed. Prevent the production of seed by early cutting. Though perennial, it is rather short-lived, and if not allowed to seed, may soon be crowded out of the ground by other and more profitable grasses.

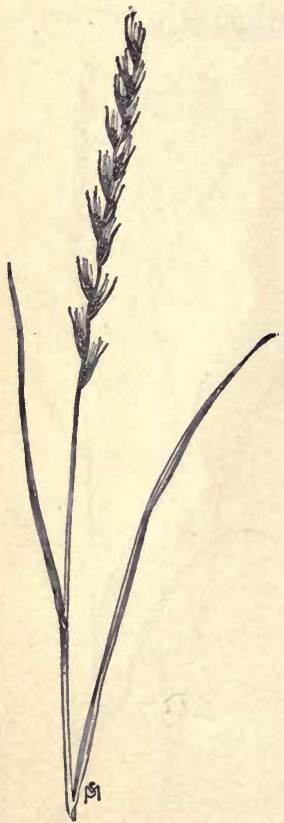

Frg. 30. - Darnel (Lolium temulentum). $\times \frac{1}{4}$.

\section{DARNEL}

\section{Lòlium temuléntum, L.}

Other English names: Poison Darnel, Bearded Darnel, White Darnel, Ivray, Poison Rye-grass, Annual Ray-grass.

Introduced. Annual. Propagates by seeds.

Time of bloom: Late June to July.

Seed-time: July to August.

Range: Locally in most of the United States as far south as Georgia; abundant on the Pacific Coast; occasional in Canada from New Brunswick to Manitoba; very troublesome in Red River Valley.

Habitat: Grain fields and waste places.

Darnel is now said to be poisonous only when diseased, its toxic properties being due to a fungus which has recently been discovered in the tissues under the seed coats. It is reputed to be most dangerous in wet seasons or when grown on wet soil. When ground with wheat, bread made from the flour is likely to cause "eruptions, trembling, and confusion of sight in man and flesh-eating animals"; and if the seeds are malted with barley, the ale or beer "causes intoxication very suddenly"; but the plant is said not to be harmful in any way to grazing animals, and makes 
excellent hay when cut before seeding. Poultry also eat the seeds without any bad effects. (Fig. 30.)

Culms two to four feet tall, simple, erect, smooth. Sheaths overlapping, smooth; blades six inches to a foot long, about a quarter-inch wide, smooth below but somewhat rough above, deep green. Spikes four to eight inches long, the rachis flexuous and grooved on its sides, the spikelets sessile and attached to the rachis with their edges resting in the alternate curves; spikelets five- to seven-flowered, the lemma sometimes awned, sometimes not; the glume at the base of each spikelet equaling or exceeding it in length, looking like a bract in the axil of which the spikelet sits. Seed slender, brown, boat-shaped, with a deep groove on the inner side, appearing somewhat like a slim, hard grain of wheat; the palea is closely adherent to it, making it about as heavy as a kernel of wheat and difficult to separate from that grain when threshed with it.

\section{Means of control}

Sow clean seed. Grain containing Darnel should not be milled but should be fed to cattle or poultry; or the crop should be cut green and used as hay. Darnel-infested land should not again be used for grain until the rotation has included some cultivated crops.

\section{QUACK-GRASS}

Agropỳron rèpens, Beauv.

Other English names: Couch-grass, Wheat-grass, Scutch-grass, Twitch-grass, Quiteh-grass, Dog-grass, Devil's Grass, Whickens. Introduced. Perennial. Propagates by seeds and by creeping, jointed rootstocks.

Time of bloom: June.

Seed-time: July.

Range: The whole of North America except the extreme north. Most injurious in the United States from New England westward to Minnesota.

Habitat: Fields, roadsides, and waste places.

If it were put to a vote, perhaps most farmers would name Quack-grass as the most obnoxious of its tribe; yet it makes good hay and two crops a year of it, is sweet pasture grazing which cattle 
eat greedily, and its matted "couch" of interlacing rootstocks make it an unsurpassed soil-binder in steep gullies or on road embankments where the ground must be guarded against "washouts."

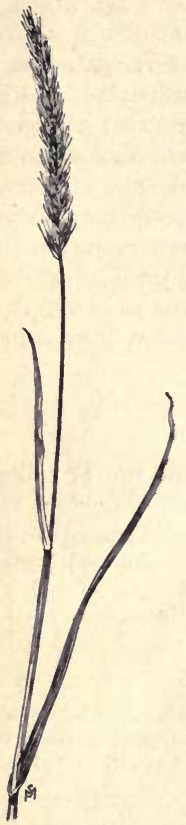

Fir. 31.-Quackgrass (Agropyron repens). $\times \frac{1}{8}$.

But it is its very tenacity of life that makes it such a pest when it gets into cultivated ground. If it could be kept in its place, or were not so hard to kill when it gets out of bounds, it would be a welcome friend.

The mischievous part of the plant is its jointed, branching, underground stem, or rootstock, which is capable of budding a new plant at every joint and taking such entire possession of the soil that other plants growing with it are so crowded and starved as to yield very poor crops or none at all. The same joints from which the buds shoot above ground also send down clusters of fine, fibrous roots which absorb most of the plant-food and moisture. Culms one to three feet tall, with flat, ashy green leaves, smooth beneath but rough above, three inches to a foot long and about a third of an inch wide; sheaths smooth, shorter than the internodes. Fruiting spike erect, three to eight inches long, with spikelets sessile and alternately placed in each notch of the rachis with the broad side turned toward it; each contains three to seven seeds, which are about as long as a grain of wheat but not nearly so plump. Indeed the whole spike looks somewhat like a slender head of wheat, and the grass is a near relative of that noble grain. The glumes of some seeds have a short awn, or beard, and others have none; they do not shell readily, and often the entire spikelet breaks from the stalk. Too often the seed is an impurity of wheat, rye, barley, clover, and other grasses, particularly bromegrass and timothy. Also the plant is often infected with the fungous disease known as "stem rust" of wheat. (Fig. 31.) 


\section{Means of control}

There is no easy way to subdue Quack-grass; but it can be done, and in a single season, without loss of the use of the ground. It must be remembered that the storehouse of the plant is its creeping rootstock, the material for the growth of which comes from the food assimilated by the green leaves, therefore no green leaves must be allowed to develop. Professor Beal, the noted botanist of the Michigan Experiment Station, outlines the following plan, based on long practical use: "If convenient, pasture closely for a whole growing season, which prevents the production of new, thrifty rootstocks, then, if the sod be well turned under deep, rolled and harrowed, much of the grass will be killed at once. Ordinarily I plow late in the fall or very early in the spring, rain or shine, wet or dry, or even in June, and cultivate with a shovel-toothed cultivator every three days till the middle of June or later, if starting the work later. Rarely, if the weather be wet and hot, cultivate every two and a half days. Keep all green leaves from showing themselves. Do not delay to see green leaves. A harrow that does not cut off the stems below the surface of the ground is not efficient." A late crop of corn can be grown on this land and the last spears of the grass killed in its cultivation.

When the grass takes possession of cultivated ground its rootstocks are usually much deeper in the soil than in pastures and meadows. An early fall plowing, with the furrow turned just deep enough to cut the matted rootstocks free from the subsoil (usually about six inches), followed by toothed harrowing to work the soil free from the rootstocks so that they may be raked into piles to be dried and burned or thoroughly rotted in a compost heap, is another good way to fight Quack-grass. Two bouts of such fall plowing and harrowing, raking, and burning, the second a little deeper and crosswise of the first, with early and careful cultivation in the spring, followed by a hoed crop thoroughly tilled until midsummer, will clean out the weed; and the enlarged yield of the crop due to the needful extra cultivation will recompense the increase of care and labor.

Small areas of the pest may be smothered to death by being covered with boards, or spreading thick with manure or straw (not less than a foot deep and well packed down so as to exclude air), or with 
tarred paper pegged down so that the wind cannot stir it. Two or three months of such exclusion from air and sunlight will leave the rootstocks withered and dead.

Quack-grass rootstocks (not the rootlets) are much used in the drug trade. At present this country imports from Europe about a quarter-million pounds of it annually, at a cost of three to seven cents a pound. Since no country grows more Quack-grass than the United States, it would seem needless to go abroad for it. To prepare the plant for market, the smooth, pale yellow rootstocks should be gathered in the spring, carefully washed, and all the fine rootlets and buds removed from the joints, after which the rootstocks may be cut into short pieces on a feed cutter and thoroughly dried.

\section{WILD BARLEY}

Hórdeum jubàtum, L.

Other English names: Squirrel-tail, Flicker-tail, Skunk-tail, Ticklo Grass.

Native. Biennial or winter annual. Propagates by seeds.

Time of bloom. June to August.

Seed-time: July to September.

Range: Labrador to Alaska, southward as far as Maryland, Kansas, and California. Most troublesome in the West.

Habitat: Fields, meadows, pastures, and waste places.

Because of its beauty this plant is sometimes used for ornamental purposes; but it never should be, lest it spread to do injury where it is not wanted. The long, barbed, reddish-golden awns become very brittle when ripe, and break into small bits which work between the teeth and into the jaws of animals that eat the grass, causing such ulcerations and swellings as sometimes to be mistaken for the disease called "Big Jaw" or "Lumpy Jaw" (Actinomycosis) ; they get into the nostrils and into the eyes, sometimes causing blindness; they also work into the tissues of the throat and the alimentary canal, setting up an irritation which may end in ulceration and death. The injury to horses, cattle, and sheep from this cause is great, particularly in the West. (Fig. 32.)

The grass grows in thick tufts from fibrous and clustered roots. Culms ten to thirty inches tall, smooth, erect or sometimes decumbent at the lower joints. Sheaths shorter than the internodes; 
blades two to five inches long, flat, rough, and grayish green; spikes nodding, three to five inches long, the spreading awns making them nearly as broad; spikelets in threes, on opposite sides of the flattened jointed rachis; only the central one produces a seed, the lateral flowers being sterile; glumes equal, rigid, narrow and bristle-pointed, placed at the side of the compressed spikelet which is placed with its back against the spike; the lemma of the fertile flower is armed with a long, sharply barbed awn, and the sterile flowers have three apiece, so that each spikelet has seven awns, all barbed. These rough-awned seeds cling to the hair and the wool of animals, and are carried by the wind, and by the water of irrigating ditches, along which the pest loves to grow - although it adapts itself to almost any soil, even the dry, alkaline regions where few other grasses thrive.

\section{Means of control}

Mowing the grass so early and so frequently as to prevent the formation of the barbed seedheads. If the infestation is new and the plants are not too numerous, hand-pull and destroy them. Large areas may be burned over, killing the plants and any seeds on the surface. Cultivation of the ground will exterminate the weed, care being taken to leave no stragglers along fence rows and ditches.

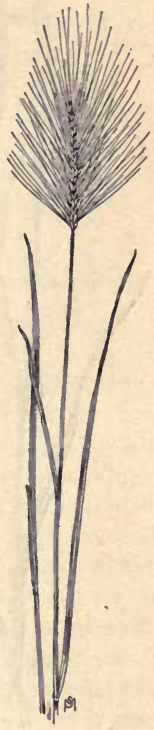

Frg. 32 . Wild Barley or Squirrel-tail (Hordeum jubatum). $\times \frac{1}{4}$.

Hordeum pusillum, Nutt.

\section{LITTLE BARLEY}

Native. Annual. Propagates by seeds.

Time of bloom: Late May to June.

Seed-time: June to July.

Range: Ontario to British Columbia, southward to Arkansas, Texas, and California. On the Atlantic Coast from Virginia to Florida.

Habitat: Plains; has a preference for saline soil. 
Little Barley is not such a dangerous pest as Squirrel-tail-grass, but it makes a similar growth in tufts and crowds out better forage;

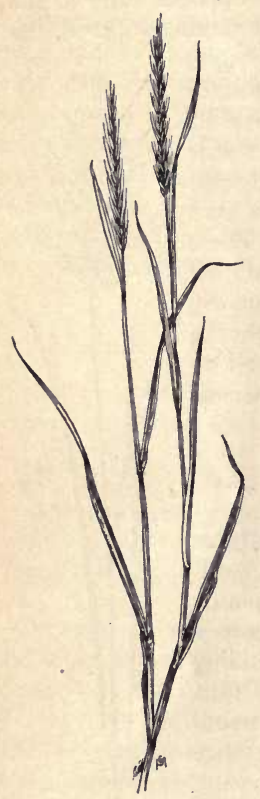

FIG. 33. - Little Barley (Hordeum pusillum). $\times \frac{1}{2}$. also, its early bloom causes it to become dry and worthless just when green food is most needed. (Fig. 33.)

CuIms six to fifteen inches tall, smooth, erect or decumbent at the base. Sheaths loose, smooth, shorter than the internodes, the upper often enclosing the base of the spike; blades one to three inches long, erect, and rough. Spikes erect, one to three inches in length; spikelets clustered in threes, the central one fertile, the lateral pair abortive; glumes of the fertile spikelet dilated above the base and tapering into a slender awn, rough but not barbed, equaling the awned lemma.

Means of control

Early and frequent cutting in order to prevent the development of seed.

\section{WALL BARLEY}

Hordeum murinum, L.

Other English names: Waybent, Barleygrass.

Introduced. Annual. Propagates by seeds.

Time of bloom: June to July.

Seed-time: July to August.

Range: California and Oregon; also in Atlantic States along the coast near seaports.

Habitat: Fields and waste places.

A European relative of the Squirrel-tail-grass, the roughened awns of which are nearly as unpleasant to grazing animals as those of the native plant. Culms six inches to two feet tall, erect or decumbent at base, growing in tufts. Sheaths loose, shorter than the internodes on the long stems, overlapping on the shorter ones, 
the upper ones often inflated and enclosing the base of the spike; blades rough, two to six inches long. Spikes two to four inches in length, the spikelets in threes with lemmas awned, those of the central, fertile flower broader, with hairy margins, the awn nearly an inch long; the lateral ones shorter.

The weed should be suppressed by cutting so frequently as to prevent seed development.

\section{LOW GALINGALE}

\section{Cypèrus diándrus, Torr.}

Native. Annual. Propagates by seeds.

Time of bloom: August to October.

Seed-time: September to November.

Range: New Brunswick to western Ontario and Minnesota, southward to the Carolinas and Kansas.

Habitat: Wet grasslands and along streams, ponds, and ditches.

A meadow overgrown with Galingale is not of much value. This one is not an aggressive weed, merely coming in where the larger, more nutritious grasses have been drowned out. As forage it is nearly worthless. It is a small plant, varying from three inches to a foot in height, most commonly about six inches, with tufted stems or culms, very slender, three-sided, leafy at base, and deep green. Leaves hardly a tenth of an inch wide, smooth; at the summit of the stem are three slim, spreading, involucral leaves, or bracts, subtending the flower-heads; these are a cluster of thin, flattened spikelets, usually about a half-inch long and either sessile on the end of the stem or clustered on the tips of two or three short, unequal rays. Scales ovate, obtuse, one-nerved, green with purplish brown margins or sometimes all brown; stamens two and style two-parted, the cleft tip exserted far beyond the points of the scales. Seeds flattened, oblong lens-shape, dull gray.

\section{Means of control}

Drain the land and put under intensive cultivation for a season in order to cause dormant seeds to germinate and be destroyed; reseed heavily with good grasses or clover. 


\section{NUT-GRASS}

Cypèrus rotuindus, $\mathrm{L}$.

Other English names: Nut Sedge, Coco Sedge, Coco-grass, Hydra Cyperus.

Introduced. Perennial. Propagates by seeds and by tuber-bearing rootstocks.

Time of bloom: July to September.

Seed-time: August to November.

Range: Virginia to Kansas, southward to Florida and Texas.

Habitat: All soils; troublesome in cultivated crops, especially in cotton fields.

This pest is said to have been brought into the United States among some garden plants from the West Indies, nearly a century

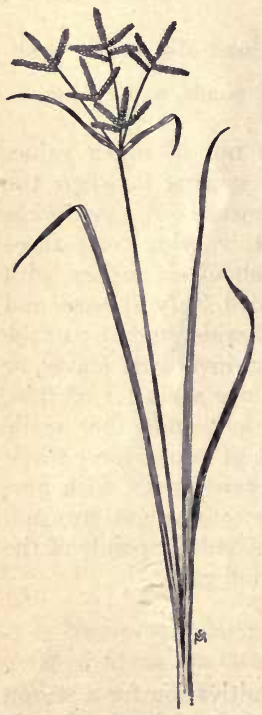

Fro. 34. - Nut-grass ( $\mathrm{C} y$ perus rotundus). $\times \frac{1}{2}$. ago, since when it has spread over a very large part of the country where the climate is propitious to it, extending along the coast as far north as New Jersey. It is very difficult to dislodge, experience having shown that "nothing serves so well to propagate it as to plow and replow, with a view to destroy it," as a planter stated in a letter to Dr. Darlington. The smaller tubers are sometimes shipped, clinging to the roots of garden plants and nursery stock, and the seeds are a common impurity of southern grass and clover seed and baled hay; they are hard-coated and pass unharmed through the digestive tracts of cattle and horses, and such manure, without long composting, is a menace to the land where it is spread. (Fig. 34.)

The fibrous, scaly rootstocks, which are its most mischievous part, are deep-set, first forming by descending from the base of a young plant, to a depth of six inches to a foot or more according to the mellowness of the soil, and there forming the first small, round, potato-like tuber, varying 
from the size of a pea to three-fourths of an inch in diameter; from this center, horizontal cord-like rootstocks are extended in every direction, producing new tubers at intervals of two to ten or more inches, which immediately send up shoots to the surface and begin to throw out their own lateral growths; and so on, indefinitely, provided that the food-producing leafgrowth above is permitted to flourish. The leaves appear first in the spring, three to six inches long, one-eighth to one-fourth inch wide, rather thick, smooth, with mid-vein prominent below and forming a slight channel above. Culm slender, smooth, three-sided, six to eighteen inches tall, leafless except for three or four involucral bracts at its summit, one to four inches long and subtending the umbellate cluster of flowers. Rays of the umbel two or three inches long, spreading, bearing on the upper part four to nine flowering spikes with twelve to forty spikelets; scales closely imbricated, ovate, pointed, dark purplish brown with a green" keel and margin; stamens three and style three-cleft, exserted much beyond the tops of the scales. The many small achenes are oblong, pointed at both ends, three-sided, dull green or brown.

\section{Means of control}

Prevent seed production. Although the weed is very prolific, both above and below ground, the growth of flowering stalks is most exhaustive to the underground tubers, and if such stalks are persistently hoe-cut, before the flowers mature and sow their progeny, the tubers in the soil must gradually yield up their life. Both dormant seeds and tubers should be stimulated to active growth by frequent stirring of the soil in the fore part of the season, but the main battle should come at the time when the plant is expending all its resources, above and below, in the development of seed, which must not be permitted to come to perfection. This intensive, late cultivation should be followed by heavily seeding the ground to some winter crop, such as Rye or Winter Vetch or Japan Clover, to be used for winter grazing which will keep down the Sedge; the crop to be plowed under in the spring for green manure.

Care should be taken that the rootstocks and small tubers are not transported to clean land on farm implements. 


\section{CHUFA}

Cypèrus esculéntus, L.

Other English names: Northern Nut-grass, Yellow Nut-grass, Yellow Galingale.

Introduced. Perennial. Propagates by seeds and by tuber-bearing rootstocks.

Time of bloom: July to September.

Seed-time: August to November.

Range: New Brunswick to Minnesota and Nebraska, southward to

Florida and Texas; also on the Pacific Coast from California to

Alaska. Common in Europe and Asia and in tropical America. Habitat: Moist fields, banks of streams, and ditches.

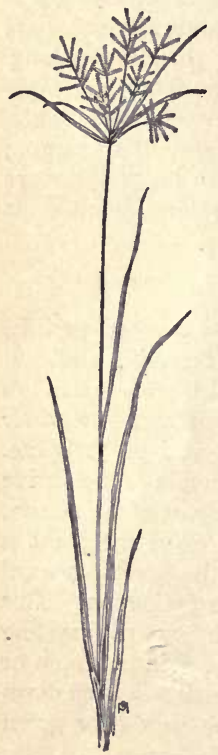

Fig. 35. - Chufa (Cyperus esculentus). $\times$ t.
In the South this plant is frequently cultivated for pasturing and for fattening hogs in autumn, those animals being very fond of its sweet, oily, and fleshy tubers. Unlike those of the preceding species, the tubers are usually clustered very near the parent plant, the scaly rootstocks being shorter and, unless the ground is very soft, not far below the surface. (Fig. 35.)

Culms, stout, fifteen to thirty inches high, three-sided, light yellowish green. Leaves about the same length, one-fourth to onehalf inch wide, with heavy mid-vein and slightly roughened edges. The involucre has three to six leaf-like bracts extending much beyond the rays of the umbel, which are often compound. Spikes straw-colored or pale yellow-brown, the whole plant being conspicuous for its light coloring, plainly visible at a distance among grasses. The scales of the spikelets are oblong-ovate, appressed at the base but loose at the tip, three to five-nerved, with narrow scarious margins. Achenes small, oblong ovoid, three-sided, light yellowish brown. 
Means of control

Drainage of the ground, followed by clean, late-continued hoecultivation which will prevent seed production and gradually starve the underground growth. Hogs may be of assistance in the beginning in cleansing a badly infested plot.

\section{STRAW-COLORED CYPERUS}

Cypèrus strigòsus, $\mathrm{L}$.

Native. Perennial. Propagates by seeds and by tubers.

Time of bloom: July to September.

Seed-time: August to October.

Range: Maine to Ontario, Minnesota, and Nebraska, southward to Florida and Texas.

Habitat: Damp meadows, swamps, and along streams.

This plant is very variable, having dwarf varieties and others with globose heads; but in any form it is a weed, almost worthless as forage, even when young. Ordinarily it grows one to three feet tall, the three-sided culms rather stout, tufted, rising from a cluster of hard, corm-like tubers. Leaves flat and soft, rough-edged, about a quarterinch wide and equaling the stem in length; those forming the involucre are much longer than the rays of the umbel, which are simple or compound, their sheaths terminating in two bristles; spikelets

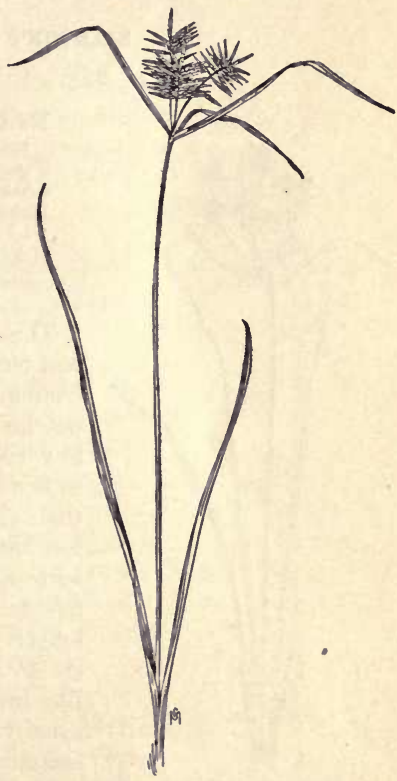

Fic. 36. - Straw-colored Cyperus ( $C y$ perus strigosus). $\times \frac{1}{3}$. 
numerous, flattened, linear, eight to ten-flowered, spreading, in loose oblong or ovoid heads; stamens three; style three-parted, the branched tips exserted; scales straw-colored, oblong lanceshape, strongly nerved, much longer than the slim, three-angled, and pointed achene. (Fig. 36.)

\section{Means of control}

Drainage of the ground, followed by a cultivated crop very thoroughly tilled so as to destroy the tuberous rootstocks. reseeding heavily to red-top or timothy.

\section{BALDWIN'S CYPERUS}

Cypèrus echinàtus, Wood

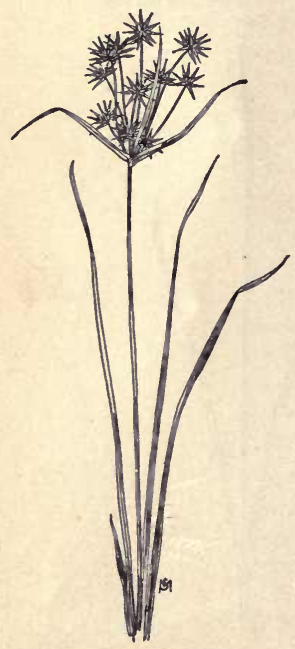

Fig. 37.-Baldwin's Cyperus

(Cyperus echinatus). $\times \frac{1}{3}$.

Native. Perennial. Propagates by seeds and by rootstocks.

Time of bloom: July to September.

Seed-time: August to October.

Range: Virginia to Missouri, southward to Florida and Texas.

Habitat: Dry, sandy soil ; cultivated fields, waste places.

This Cyperus seems to prefer dry and mellow soils, and often makes itself troublesome in strawberry and melon patches. It springs from short cormlike rootstocks, the culms ten inches to two feet high, slender, smooth, longer than the leaves, which are pale green, less than a quarter-inch wide, smooth with rough edges; the involucre has five to ten bracts, most of them much longer than the umbel; the latter has six to twelve unequal ascending rays, the heads globose or slightly oblong, usually about a half-inch in diameter; spikelets twenty to forty, pale green or somewhat yellowish, spreading, lancecylindric or only slightly compressed; 
scales five to eight, narrowly ovate, thin, appressed, striate, with scarious margins; usually the lowest two and the awl-like one at the point of the spikelet are empty. The three-sided, oblong achene is only about half the length of the scale. (Fig. 37.)

\section{Means of control}

Prevent seed production. Persistent, thorough, and late cultivation is necessary in order to hinder the development and dispersal of seeds and to destroy the rootstocks. Partly ripened heads should never be plowed under, but should be removed, either to compost heap or bonfire.

\section{MEADOW RUSH}

Scírpus atróvirens, Muhl.

Other English names: Club Rush, Dark-green Bulrush.

Native. Perennial. Propagates by seeds and by rootstocks.

Time of bloom: June to July.

Seed-time: July to August.

Range: Nova Scotia to the Saskatchewan, southward to Georgia and Missouri.

Habitat: Wet meadows, marshes, and borders of streams.

One of the most widely distributed of its tribe and a bad weed in low grasslands, for it is worthless as fodder, either green or dry. Culms smooth, obtusely triangular, leafy, two to four feet tall. Leaves pale green, a quarter-inch to a half-inch wide, rough-edged, two or three of the upper ones whorled and extending above the flower cluster. Umbels compound, the spikelets densely crowded in capitate clusters of ten to thirty at the ends of the branched rays; scales greenish brown, oblong-ovate, bristle-pointed ; stamens three; style three-parted; perianth composed of six bristles, downwardly

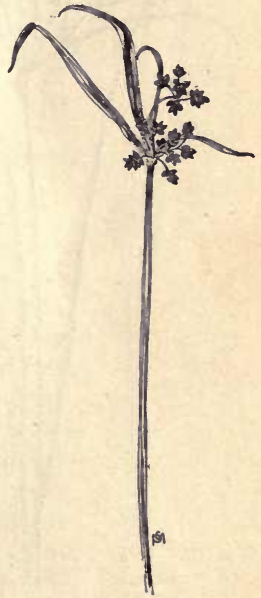

Fro. 38. - Meadow Rush (Scirpus atrovirens). $\times \frac{1}{6}$. 
barbed for most of their length but smooth near the base, equal to or exceeding the achene in length, the latter being oblong, pointed, three-sided, dull brownish yellow. (Fig. 38.)

Means of control

Drainage of the land, followed by a cultivated crop given very thorough tillage throughout the growing season, in order to prevent seed development and to destroy the perennial roots.

\section{SLENDER RUSH}

Júncus ténuis, Willd.

Other English names: Wire-grass, Field Rush, Yard Rush.

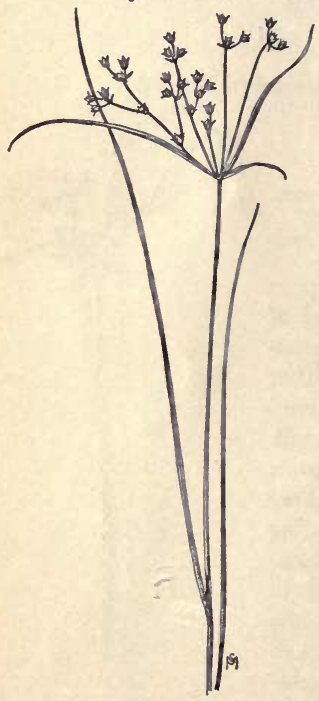

FIG. 39. - Slender Rush (Juncus tenuis). $\times \frac{1}{3}$.

Native. Perennial. Propagates by seeds.

Time of bloom: June to August.

Seed-time: July to September.

Range: Throughout North America and most parts of the world.

Habitat: Lawns, yards, meadows, and pastures.

One usually thinks of marshy, or at least damp, ground in connection with rushes, but the Slender Rush is common everywhere and seems equally content whether the ground be wet or dry. (Fig. 39.)

Stems thickly tufted, eight inches to two feet tall, extremely thin, round, green, wiry, and so elastic that they are always erect, no matter how much trodden upon by the grazing animals, which refuse to eat them. They have a few grassy base leaves which dry and wither away as the wiry, flowering stems develop. Flowers in irregular clusters between two long, flattened, blade-like leaves at the top of the stem; they have six 
sharp-pointed, spreading sepals, a single pistil with style very short, and six stamens with anthers much shorter than their filaments. Later, each six-pointed perianth forms a cup to hold the tawny, ovoid, papery-shelled capsule, filled with small brown seeds which, under the lens, are shown to be delicately ridged and cross-lined.

\section{Means of control}

In lawns and yards the weed is best removed by hand-pulling before seed development. In fields, small areas may be treated by hoe-cutting, but where rankly infested the ground should be cleansed by a rotation of cultivated crops and clover.

\section{COMMON RUSH}

\section{Júncus effùsus, L. and its varieties}

Other English names: Soft Rush, Bog Rush.

Native. Perennial. Propagates by seeds and by rootstocks.

Time of bloom: June to July.

Seed-time: July to August.

Range: Throughout North America.

Habitat: Marshes, wet meadows, and pastures; muck farms. In the South, a pest in rice fields.

In any place where the soil is constantly moist some variety of this rush is likely to be found, and it holds its ground most sturdily. It grows in dense tufts or tussocks from stout branching rootstocks, the leafless stems one to three feet tall, erect but very soft and pliant, round, green, pithy, and about a twelfth of an inch in diameter. Flowers very numerous in dense, spreading cymose clusters which seem to burst from the sides of the stems, the long subtending bracts appearing like continued stems; each individual flower has also just below it a small, ovate, pointed bract; perianth sixpointed, green at first, but soon turning brown; stamens three, with anthers and filaments about

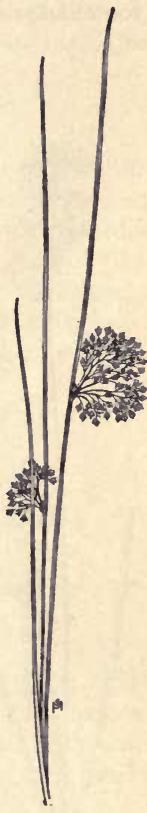

Fra. 40, Common or Soft Rush (Juncus effusus, var. Pylaei). $\times \frac{2}{8}$. 
the same length; style very short. Capsules bluntly oblong, three-celled, filled with fine brown seed, which is widely sown by the wind. (Fig. 40.)

\section{Means of control}

Drainage of the ground, and a season or two of thorough cultivation, are necessary in order to destroy the system of branching rootstocks. For small areas they may be grubbed out.

\section{DEATH CAMAS}

Zygádenus venendsus, S. Wats.

Other English names: Poison Camas, Poison Sego, Hog's Potato, Mystery Grass.

Native. Perennial. Propagates by seeds and by bulbs.

Time of bloom: May to June.

Seed-time: June to July.

Range: South Dakota to British Columbia, southward to Nebraska, Utah, and California.

Habitat: Shallow ravines, sides of foothills, upland pastures.

Western stockmen, particularly the sheep growers of Wyoming and Montana, owe to this plant a loss of many thousands of dollars yearly. All parts of it are poisonous to all grazing animals, but cattle usually reject it because of its bitter taste; horses are even more particular; but sheep feed with little discrimination and are, besides, the stock most commonly kept on the high benchlands and foothills where the plant is most abundant. (Fig 41.)

It springs from an elongated, ovoid, coated bulb, a half-inch or less in thickness, the stems six to twenty inches tall, slender and upright. Leaves very narrow and grass-like, deep green, with roughened margins and mid-

Fig. 41. - Death Camas (Zygadenus venenosus). $\times \frac{1}{3}$. rib, usually partly folded and with sheathing base. Flowers greenish or yellowish white, in 
narrow simple racemes three to sixinches long, each pedicel subtended by a thin, lance-like bract; each blossom is about a half-inch broad, its six perianth segments triangulate ovate or elliptic and narrowing abruptly to a short claw, on the upper side of which is an irregular roundish gland; stamens six. The racemes lengthen as the fruits form and the erect capsules are longer than the segments of the perianth, which are persistent; capsules three-lobed and threecelled, each cavity containing a number of oblong angled seeds. After the fruits mature the plants wither, dying down to the bulbs early in July.

\section{Means of control}

Herding of animals away from the plants while they are in the growing, succulent stage seems to be the only plan practicable on the open range. In more restricted localities the weed may be destroyed by putting the land under cultivation for a time. The bulb is easily and quickly pulled from the ground when it is softened by rains, and for small areas even the expense of removal by hand labor might well be afforded in order to cleanse the soil from such a dangerous plague.

\section{COMMON BUNCH-FLOWER}

Melánthium virginicum, L.

Native. Perennial. Propagates by seeds and by rootstocks.

Time of bloom: June to August.

Seed-time: July to September.

Range: Rhode Island and New York to Minnesota, southward to Georgia and Texas.

Habitat: Wet grasslands, marshes, and borders of streams.

A very pernicious plant, nearly related to the Veratrum. It is specially obnoxious as a weed of wet meadows, for its long, narrow leaves make it much less conspicuous among the grass and hay than its larger and more deadly relative. It is poisonous to all stock, but particularly so to horses.

The stem springs from a large, thick rootstock, and is rather slender, simple, two to four feet or more high, very leafy, and roughish-downy near the top, as is also the flower stalk. Leaves narrow lance-shape to linear, often more than a foot long, a half- 
inch to about an inch wide, the lower ones narrowing to a sheathing base, the upper ones much smaller and sessile. Flowers in a large, dense, terminal, alternately branching, pyramidal panicle, six to eighteen inches long, each pedicel subtended by a small, long-ovate bract; each blossom about a half-inch broad, greenish white or creamy yellow, darkening to brown as they wither. They have no corolla but have six separate clawed sepals, oblong or sometimes heart-shaped or even slightly auricled, and spread flat, the claws bearing the six stamens and usually having at the base of the blades two conspicuous dark glands; some flowers simply staminate, others pistillate, others perfect, may all be found on the same stalk, but usually the lower ones are sterile. Capsules about a halfinch long, three-celled, the persistent styles making them triplepointed, and each cavity contains about ten very flat and broadly winged brown seeds, easily distributed either by wind or by water.

\section{Means of control}

From small areas the perennial rootstocks may be grubbed out; or, when of but one season's growth and before they have penetrated the soil very far, they can be quickly pulled when the ground is soft. Badly infested meadows require to be drained and put under cultivation. In every case, seeding should be prevented by close cutting at the beginning of bloom.

\section{AMERICAN HELLEBORE}

Veratrum viride, Ait.

Other English names: False Hellebore, Swamp Hellebore, Green Hellebore, Indian Poke, Earth Gall, Bugbane, Itch-weed, Duckretter.

Native. Perennial. Propagates by seeds and by thick, fleshy rootstocks.

Time of bloom: May to July.

Seed-time: June to August.

Range: From Quebee to British Columbia and Alaska, southward to Georgia and Tennessee.

Habitat: Wet meadows, swamps, and along streams and ditches.

A large, coarse, and dangerously poisonous plant. Cattle and horses have been killed by cropping the young leaves in the spring; 
the seeds are fatal to poultry, and even human life has been lost through the mistaking of its root for that of some other harmless plant. This fleshy rootstock, however, is medicinally valuable, and when collected after the leaves have died in autumn, carefully cleansed, and dried, it is worth five to ten cents a pound in the drug market. (Fig. 42.)

Leaves appear first in the spring, often as early as March, thrusting up through the wet and sometimes frozen soil like large spearheads; they are at first of a delicate light green color, strongly lengthwise veined and plaited like a fan. When fully unfolded the outer and lower leaves are usually more than a foot long and half as wide, broadly elliptic in shape, pointed at both ends, with sheathing clasp at base; those ascending the stem become successively smaller as they approach the top. Stalk stout, round, grooved, two to six feet tall, without branches except in the large panicle at its summit; stalk, foliage, and panicle are all hairy. Flowers in a dense slenderly pyramidal cluster, six inches to nearly two feet

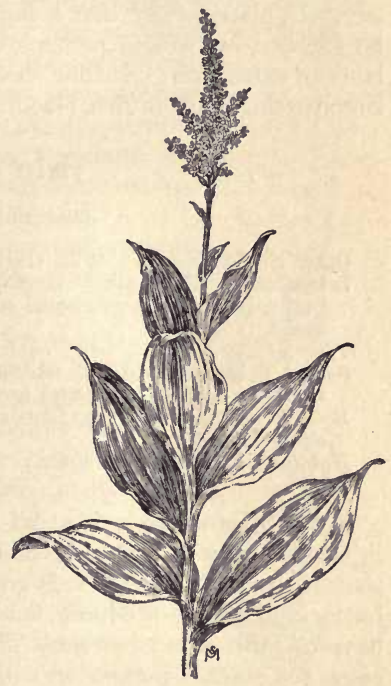

Fig. 42.-American Hellebore (Veratrum viride). $\times \frac{1}{8}$.

long, the pedicels shorter than the bracts at their bases. The blossoms are about a half-inch broad, pale yellowish green, turning brown as they wither, with six spreading, oblong sepals, united at the base and minutely toothed and fringed at the edge; stamens six, shorter than the perianth; styles three, persistent. Staminate, pistillate, and perfect flowers may all be found on the same stalk, but usually the lowermost blossoms are sterile. Capsules nearly an inch long, ovoid, three-lobed, three-celled, and containing many 
large, flat, broadly winged brown seeds which easily sail on the wind or float on water.

\section{Means of control}

For infested meadows, drainage and cultivation is the best remedy. In places where that is impracticable, the rootstocks should be grubbed out - and perhaps sold for sufficient to pay for the labor of extraction. Seeding should in every case be prevented by close cutting while in first bloom.

\section{FIELD GARLIC}

\section{Állium vineàle, $\mathrm{L}$.}

Other English names: Wild Garlic, Crow Garlic, Wild Onion.

Introduced. Perennial. Propagates by secondary underground bulbs, by bulblets produced on the flowering stalk, and rarely by seeds.

Time of bloom: Late May to June.

Seeds: Seldom produced. Aërial bulblets ripen at the same time as winter wheat and rye and are harvested with them.

Range: Massachusetts to South Carolina, westward to the Mississippi River.

Habitat: Prefers sandy loam; fields, meadows, and pastures.

In localities where it is at all common, this is one of the most injurious of weeds and most difficult to destroy. Its presence in pastures where dairy stock is grazing is ruinous to the quality of butter and cheese produced, and any food prepared with garlicflavored milk is unpalatable. The very flesh of animals that have eaten the plant is permeated with its odor and taste. It is also a pest in wheat fields. In the three states of Maryland, Virginia, and Tennessee, where the weed is extremely troublesome, the loss to the wheat crop alone is estimated by a government report to be more than a million dollars annually. The bulblets are about the same size and weight as a grain of wheat, making it impossible to clean them out at harvest time even with the best of sieves and fans. But if infested grain is kept for several months and subjected to freezing cold, the bulblets dry and shrivel, becoming light enough to be fanned out with a good machine. Experiments have been conducted in the seed laboratory at Washington with drying machines 
such as are used at elevators for the drying of commercial grains. It was demonstrated that the specific gravity of the wheat grains was increased by the process and that of the bulblets decreased, enabling the crop to be cleaned and made marketable without loss of time. Flour is spoiled when even a small number of Garlic "kernels" are ground with the wheat. Not only so, but a moist, sticky coating is formed on the rollers that crush the grains, compelling stoppage of the mill so that the machinery may be cleaned. In mills that make stone-ground flour the damage is still greater, for there it is found that the taint can be entirely removed only by redressing the buhrstones. (Fig. 43.)

The plants are one to three feet tall, springing from small, ovoid, membranous-coated bulbs. Leaves slim, deep green, hollow, round in cross section, borne below the middle of the slender flowering stalk, which bears at its top an erect, dense cluster or umbel of small, pinkish purple flowers, sometimes nearly white, each flower having six pointed perianth segments with a stamen inserted at base; pedicels threadlike, often nearly an inch long. Below the flower-head are two papery, pointed bracts which soon fall away. As the flowers wither, their places are taken by aërial bulblets, each about the size of a wheat kernel and tipped with a "whisker," or filament, nearly an inch long. There may be twenty-five or thirty to a hundred bulblets in a seed-head. Lest it should not be enough, the plant works below ground too; secondary bulbs, called "cloves" or "toes," develop at the base of the old bulb, and

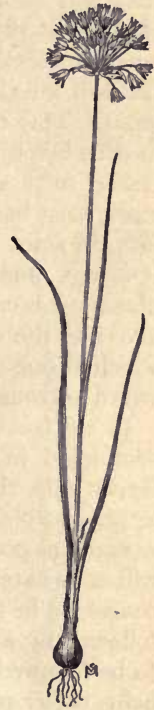

Fra. 43. Field Garlic (Allium vineale). $\times \frac{1}{8}$. in the fall form thick tufts of young plants which remain green all winter, ready to repeat the cycle of growth in the spring. New infestations are usually effected by transportation of the bulblets, and the purchase of strawberry plants from infested localities has been known to start a new "station" by means of the tiny underground bulbs or " cloves." 


\section{Means of control}

Hand-pulling just at flowering time is a good method if the plants are not too numerous to make it impracticable. The ground must be very soft and care must be taken to leave no "cloves" behind that will render the work of no account. Quicker and more effective is the use of crude carbolic acid applied with a common machine oil-can; a few drops on a plant or a small sprinkle on a tuft will kill them all. The acid should be very little, if at all, diluted. This treatment may be given before the grass has started or even before the ground has thawed in the spring, when the green Garlic tufts show plainest. If used during the grazing season, stock must be kept from the fields until rain has washed the poison into the soil. This method seems expensive in time and labor, but it is not more so than the application of Paris green to potato plants; it is certainly the best way of removing the pest from lawns, and was the one used to clean out a very abundant stand of it which at one time impaired the beauty of the eight acres of greensward surrounding the White House at Washington.

In cultivated ground the task of extermination can seldom be completed in one season. When undertaking to destroy Field Garlic with the plow, the work should be done as late in the fall as practicable, the depth of the furrow being so gauged as to bring as many as possible of the bulbs to the surface or near it, where they will alternately freeze and thaw. Some plants will survive, of course, to be fought in the same way with early spring cultivation, followed by a hoed crop, well tilled until midsummer; this in turn to be followed by a crop of clover. Liming and fertilizing the soil helps better plants to crowd out the weed.

In infested pastures, sheep may be induced to keep the Garlic nibbled down by salting a number of tufts from time to time so as to overcome their natural dislike to its taste. If deprived of leaf growth for an entire season, the underground bulbs wither and rot. In some instances success has been attained in mellow soil by loosening it with the plow and turning in hogs to root out and eat the bulbs. It should be remembered that the meat of any animal which has eaten Garlic takes the flavor and is unmarketable. When wanted for that purpose, they must be withdrawn from such grazing and fed for several days on a different diet. 


\section{MEADOW GARLIC}

Állium canadénse, $\mathbf{L}$.

Native. Perennial. Propagates by aërial bulblets, occasionally by seeds.

Time of bloom: May to June.

Seeds: Seldom produced; aërial bulblets ripen in July and August. Range: Maine to Minnesota, southward to the Gulf of Mexico.

Habitat: Moist meadows, pastures, and thickets.

The range of native species of Onion or Garlic is more extensive, but not one of them is so rank in taste and odor, or so difficult to exterminate, as the immigrant Field Garlic. Most of them have a preference for low, moist soil and the shade of thickets, and disappear before drainage and cultivation. This one is most adaptive and therefore most troublesome. Its bulblets are slightly larger than grains of wheat or rye, so that they are not difficult of removal with a sieve of proper-sized mesh. But often the weed is a plague of pasture and meadow, to the detriment of dairy products. (Fig. 44.)

Bulb small, distinguishable from that of the Field Garlic by its coat, which is fibrous and netted instead of a soft, membranous skin, and by the leaves, which rise directly from the bulb instead of being borne part of the way up the flowerstalk, and are flattened in cross section. Flowerstalk eight inches to two feet in height, round, and smooth; umbel large, the flowers pink, sometimes almost white, very numerous. Aërial bulblets ovoid, plump, their capillary appendage sometimes exceeding an inch in length.

Measures for extermination the same as recommended for Field Garlic.

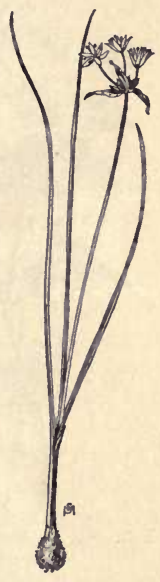

FIG. 44. Meadow Garlic (Allium canadense). $\times \frac{1}{b}$.

\section{SAW BRIER}

Smilax glaúca, Walt.

Other English names: Chain Brier, Prickly Bamboo, False Sarsaparilla.

Native. Perennial. Propagates by seeds and by tubers. 
Time of bloom: May to June.

Seed-time: July to September.

Range: Massachusetts to Kansas, southward to Florida and Texas.

Habitat: Cultivated crops, fields, meadows, waste places.

Most of the Green-briers havea preference for woods and thickets, where they seldom prove very annoying to the farmer, but this one comes out into the open and will invade almost any crop that may be

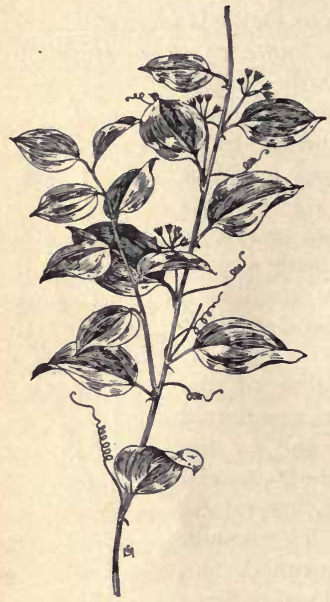

Frg. 45. - Saw Brier (Smilax glauca). $\times \frac{1}{4}$. growing in the dry and mellow soil which it prefers. Birds eat its berries and void the seeds unharmed by digestion, and sometimes the seeds are distributed while still on the dried stalks, in baled hay and straw ; also the long, knotted rootstocks are broken and the tubers scattered by farming tools in ordinary cultivation. (Fig. 45.)

Stem perennial, round, slender, set with scattering, rather stout, slightly curved prickles; but the branches and twigs are angled and unarmed. Leaves broadly ovate, smooth, entire, five-nerved, covered with a bloom on the under side and sometimes above, with short petioles bearing at the base on each side a long tendril ; these tendril-bearing petioles are persistent even when the blades of the leaves fall away in autumn. Flowers in umbels on slender, flattened, axillary peduncles; they are diœcious, yellowish white, very small, with six-parted perianth in two rows of three, soon falling away; the sterile flowers have six stamens, with threadlike filaments inserted on the very base; the fertile flowers have three short and spreading, almost sessile stigmas above a threecelled ovary which develops a small, three-seeded berry, ripening the first year, jet-black and glossy when the glaucous film which covers it is rubbed away. 
Means of control

Put the land to a crop requiring hoe-cultivation; the use of a cultivator only serves to spread the pest by scattering the tubers. Small thickets should be grubbed out, or the tops cut and the roots treated with caustic soda or carbolic acid.

\section{YERBA MANSA}

Anemópsis californica, Hook.

Native. Perennial. Propagates by seeds and by rootstocks.

Time of bloom: May to September.

Seed-time: June to October.

Range: Southern California to Southern Utah, Arizona, and New Mexico.

Habitat: Moist, saline soil ; troublesome in cultivated erops.

The most troublesome part of this plant is its thick, creeping rootstock, which is very acrid, astringent, and strong-scented. Stem scape-like, six inches to two feet tall, with a large, broadly ovate or oblong, clasping leaf just above the middle, in the axil of which is a fascicle of one to three much smaller petioled leaves; root leaves thick, oblong, with rounded apex and heart-shaped base, usually slightly broadened toward the tip, entire, two to eight inches in length, on petioles about as long as the blades, dilated and sheathing at base. Flowers very small, densely crowded on a thickish conical, terminal spike about an inch long, at the base of which is a persistent involucre of six or eight oblong, showy, white bracts about an inch in length, having the appearance of petals and resembling a large white anemone. The true flowers on the spike have no

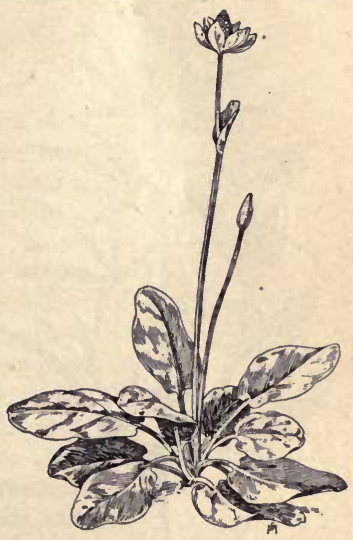

Fic. 46. - Yerba Mansa (Anemopsis californica). $\times \frac{1}{6}$. 
perianth but have six to eight stamens and a one-celled ovary, sunk in the fleshy rachis of the spike and having three or four spreading stigmas; each flower is subtended by a minute white bract. The whole plant has a very pungent, spicy odor. Fruit a berry or capsule, with three to four carpels each containing six to ten very small rounded seeds. (Fig. 46.)

\section{Means of control}

Drainage; followed by intensive hoe-cultivation, alternated with heavy seeding to grass or clover.

\section{HEMP}

\section{Ma Rer eAa}

Cannabis sativa, L.

Introduced. Annual. Propagates by seeds.

Time of bloom: July to September.

Seed-time: August to November.

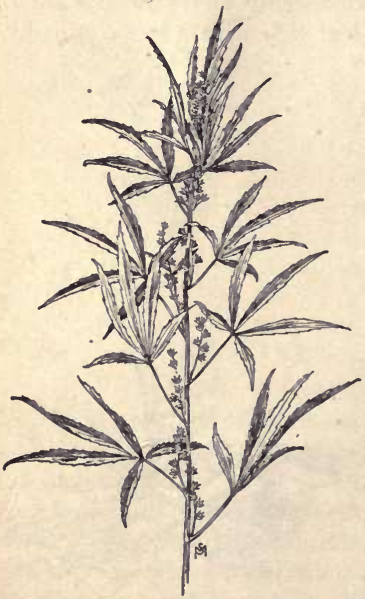

FIG. 47. - Hemp (Cannabis sativa). $\times \frac{1}{8}$.
Range: New Brunswick to Ontario and Minnesota, southward to North Carolina, Tennessee, and Kansas.

Habitat: Barnyards, waste places.

Seeds of hemp are often an impurity of other seeds, notably of oats, particularly if grown in the hemp-raising districts of the country. The writer first saw the plant flourishing finely in a vacant lot behind a city livery stable. (Fig. 47.)

Stem three to ten feet in height, rather stout, erect and holding its branches nearly upright, the inner bark fibrous and extremely tough and strong, the whole plant rough-hairy and strongscented. Leaves compound, with five to seven very slender leaflets, 
attached to their foot-stalk like fingers, all at the same base; leaflets three to six inches in length, a quarter-inch to an inch wide, pointed at both ends, sharply toothed. Flowers diœcious, the sterile ones in axillary, compound panicles, each with five hairy sepals and five drooping stamens; the fertile ones in small, erect, axillary spikes, leafy-bracted, the calyx entire and clasping the ovary. Achene compressed ovoid, about an eighth of an inch long.

\section{Means of control}

Prevent seed development by cutting or pulling while the plant is in early bloom.

\section{TALL, OR SLENDER, NETTLE}

\section{Urìca grácilis, Ait.}

Native. Perennial. Propagates by seeds and by rootstocks.

Time of bloom: June to October.

Seed-time: August until cut off by frost.

Range: Nova Seotia to British Columbia, southward to the Carolinas, Missouri, and Kansas.

Habitat: Rich soils; barnyards, roadsides, waste places.

Stem two to seven feet in height, slender, erect, usually simple, but sometimes with a few ascending branches, hollow and ridged, sparingly set with stinging hairs. Leaves opposite, slender, lanceshaped, rounded at base, three to six inches long, dark green above, paler below, three to five-nerved, sharply saw-toothed, also sparsely set with stinging hairs; petioles slender, more than half as long as the breadth of the leaf. Flowers small, greenish, sometimes diœcious, but more often on the same plant, the staminate ones near the top and the fertile flowers in the axils below, hanging in long, compound clusters; sterile flowers have four sepals, each

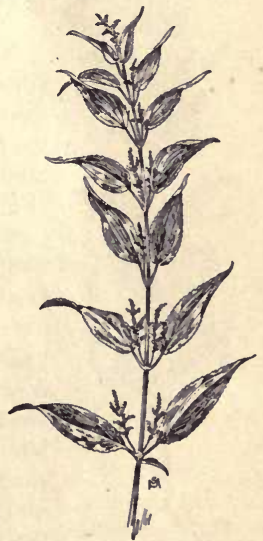

Fig. 48. - Slender Nettle (Urtica gracilis). $\times \frac{t}{6}$. 
with a stamen inserted at base; fertile flowers also have four sepals, the inner pair curving over and persistently enclosing the seed as it matures. Achenes very small, flattened ovoid, numerous. (Fig. 48.)

\section{Means of control}

Close cutting in June and again in August, using dry salt to check recovery. In yards and roadsides the rootstocks should be grubbed out and destroyed. The plants cut or pulled should be dried for a few days and then burned so as to ensure destruction of the seeds.

\section{GREAT, OR STINGING, NETTLE}

Urtica dioica, $\mathbf{L}$.

Introduced. Perennial. Propagates by seeds.

Time of bloom: July to September.

Seed-time: September until cut off by frost.

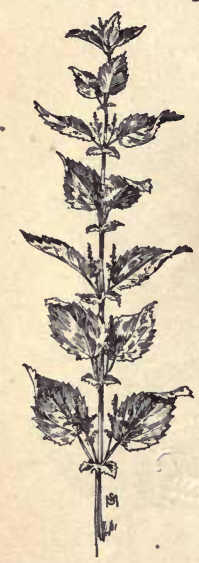

Frg. 49. - Stinging Nettle (Urtica dioica). $\times \frac{1}{6}$.
Range: Nova Scotia to Ontario and Minnesota, southward to South Carolina and Missouri.

Habitat: Waste places and roadsides.

Not a very common plant, which is fortunate, since its stings are so venomous as to cause acute discomfort for a considerable time. It is well to know that dilute alcohol will almost immediately relieve the burning and itching pain. (Fig. 49.)

Stem two to four feet tall, stout, four-ridged, hollow, densely set with fiercely stinging hairs. Leaves long-oval, long-pointed, one to three inches wide and three to six inches long, three to five-nerved, rounded or heart-shaped at base, coarsely but sharply toothed, clothed with the venomous hairs; petioles much shorter than the blades. The flowers are small and greenish, similar to those of the preceding species, growing in large, compound clusters from the axils of the upper leaves, the fertile and the staminate flowers usually on different plants. 
Means of suppression the same as for the Slender Nettle.

Both this plant and the Slender Nettle yield a fiber said to be stronger and finer than that of flax, but no economic use has ever been made of them.

\section{WESTERN NETTLE}

\section{Urtica holosericea, Nutt.}

Native. Perennial. Propagates by seeds.

Time of bloom: August to September.

Seed-time: September to October.

Range: From Utah and the Wasatch Mountains westward throughout California.

Habitat: Waste places, borders of streams.

A larger and stouter plant than either of the common Eastern Nettles, and possessed of vicious stings. Stem erect, unbranched, bristly hairy, frequently attaining to ten feet in height though more commonly four to seven feet tall. Leaves three to six inches long, ovate to lance-shape but obtuse at base, with short, stout petioles and oblong stipules; they are rather thick, hairy on both sides, but especially so on the lower surface. The staminate flowers are in loose, slenderly branching, axillary panicles nearly as long as the leaves ; pistillate panicles much shorter and more crowded, the persistent membranaceous calyx-lobe enfolding the achenes. (Fig. 50.)

\section{Means of control}

Cultivation of the ground for the purpose of destroying the perennial roots; or, small areas may

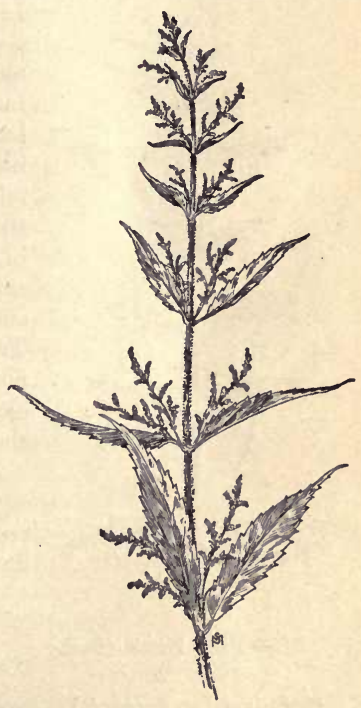

Fir. 50. - Western Nettle (Urtica holosericea). $\times \frac{3}{6}$. 
be grubbed out. When tillage is impracticable, close and persistent cutting will prevent seeding and starve the roots.

\section{FALSE NETTLE}

Boehmèria cylindrica, Willd.

Native. Perennial. Propagates by seeds.

Time of bloom: July to September.

Seed-time: September until cut off by frost.

Range: Quebec and Ontario to Minnesota, southward to Florida and Kansas.

Habitat: Moist soil ; waste places.

Stems six inches to two feet or more in height, erect, round, smooth or sometimes slightly hairy, simple or with few branches.



Frg. 51. - False Nettle (Boehmeria cylindrica). $\times \frac{3}{2}$.
Leaves long ovate to lance-shaped, pointed, three-nerved, sharply toothed, much resembling those of the nettles but without stinging hairs; petioles long, slender, smooth. Flowers may be diœecious or the two kinds intermixed on the same plant, more often the latter, but in either case they are in densely crowded, elongated, axillary spikes, often leafy at the tips; the sterile ones very like those of the True Nettle, but the fertile ones having an urn-shaped persistent calyx enclosing the ovary, and later enfolding the ripened achenes. (Fig. 51.)

Means of control the same as for common Nettles. As they are without stings, small areas may be readily hand-pulled.

\section{PATIENCE DOCK}

Rùmex Patiéntia, L.

Introduced. Perennial. Propagates by seeds.

Time of bloom: June to August.

Seed-time: July to September. 
Range: Newfoundland to Ontario, southward to Pennsylvania, Ohio, and Kansas.

Habitat: Rich soil; farmyards, waste places, roadsides.

A very large species, with a stout and very deep taproot. Stem sometimes attaining to eight or ten feet in height but usually two to six feet tall, stout, erect, grooved, and smooth, simple or sparingly branched. The large basal leaves are sometimes more than two feet in length, oblong lance-shaped, broadening above the base, smooth but with thick ribs and veins and long petioles; stem leaves longpointed and much smaller. Panicle very large and dense, sometimes nearly two feet in length, its branches nearly erect, often with leafy bracts among the whorled flowers. These are small and green with six sepals, six stamens and three styles, the calyx differing from that of the following species in that only one of the three enlarged, heart-shaped, veiny inner sepals or valves has a small tubercle on its back, or sometimes mercly a thickening of the base of its midrib. Pedicels slender with a swollen joint near the base. Fruit an achene, sharply three-angled, about one-eighth of an inch long, smooth, shining, light brown. (Fig. 52.)

Controlled, like the Curled Dock, by

deep cutting or grubbing or by hand- Fig. 52. - Patience Dock pulling when the ground is sufficiently soft.

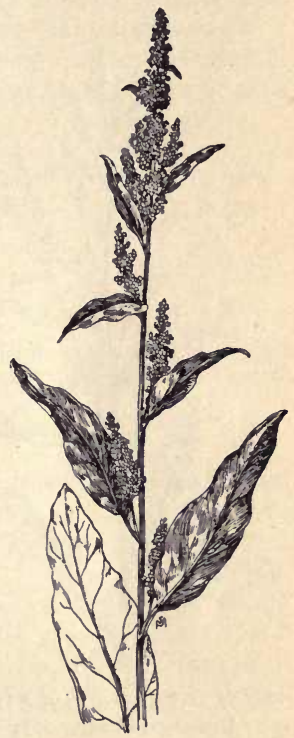
(Rumex Patientia). $\times \frac{1}{12}$.

\section{NARROW-LEAVED DOCK}

Rùmex crispus, L.

Other English names: Yellow Dock, Curled Dock.

Introduced. Perennial. Propagates by seeds.

Time of bloom: June to September. 
Seed-time: July to October.

Range: Throughout the United States and southern British America.

Habitat: Meadows, pastures, farmyards, and waste places.

The root of this plant is spindle-shaped, thick, yellow, often two or three feet long. Stem two to four feet tall, erect, slender, smooth, finely grooved, simple or with a few branches near the top.

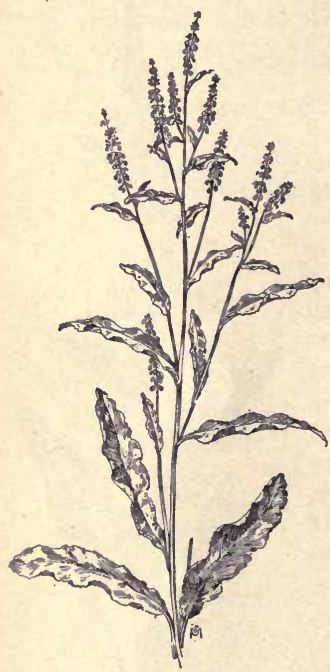

Frg. 53. - Yellow or Curled Dock (Rumex crispus). $\times \frac{1}{3}$. Basal leaves oblong lance-shaped, six inches to more than a foot in length, with margins usually wavycurled; petioles long and stout; upper leaves much smaller, with shorter petioles. Flowers in large, simple or compound racemes, often more than a foot in length, growing in crowded whorls on slender, jointed pedicels; they are small and greenish, without petals, but having six stamens; styles three, with stigmas tufted; calyx of six sepals in double rows of three, the inner ones heart-shaped, beautifully veined, uniting to form valves that enclose the seed, giving it triple wings, which assists its distribution by wind; all three valves have a rather thick, rounded, corky tubercle on the back. Achenes three-sided, plump, with rounded tips, smooth, shining, about one-twelfth of an inch long. Birds are very fond of them and forage on the brown, weatherbeaten panicles all winter. They are a very common impurity of clover and alfalfa seeds; and, though the task of removing them is difficult, it is not so strenuous as grubbing Docks. (Fig. 53.)

Means of control

Prevent seed production. In order to destroy the perennial roots, deep and frequent cutting, with hoe or spud, is necessary 
so that they will be starved of the food assimilated by the leaves. Or when the ground is very soft the roots may be removed entire, by prying with a spade set into the ground vertically by the side of the root and pulling hard at the same time with the other hand.

The roots of all three of the immigrant Docks here described are used in medicine; and the United States annually imports more than a hundred thousand pounds to supply the drug trade, at a cost of about a half-million dollars. If properly cleaned, split lengthwise, and dried, they might be made to pay for the labor of their extraction from the soil.

\section{WILLOW-LEAVED DOCK}

Rùmex mexicdnus, Meisn.

Native. Perennial. Propagates by seeds.

Time of bloom: May to September.

Seed-time: July to November.

Range: Labrador to British Columbia, southward to Maine, Michigan, and Minnesota, and along the Rocky Mountains to central Mexico.

Habitat: Moist, rich soil ; fields, low meadows, waste places.

This weed is tolerant of soil which is somewhat brackish and it often damages the hay crop from the salt-marsh meadows along the Coast. It has also made its way to Europe, where it is regarded with much dislike.

Taproot rather stout, penetrating the soil to a great depth. Stems tufted, slender, ascending, flexuous, grooved, smooth, and pale green, one to three feet tall, usually simple. Leaves narrow, lance-shaped, pointed at both ends, the sides often nearly folded together; petioles rather short. Racemes erect, the whorls very dense; pedicels scarcely exceeding the calyx-lobes, jointed near the base; calyx olive to reddish brown, the valves triangularovate, delicately veined, all tubercled. Achenes dark red, smooth and shining; frequently an impurity of clover and alfalfa seed, so extending the range of a most troublesome weed.

Means of control the same as for Rumex crispus. In well-tilled ground none of these large, deep-rooted weeds attain sufficient size to be very troublesome. 


\section{BROAD-LEAVED DOCK}

Rùmex obtusifòlius, L.

Other English names: Bitter Dock, Butter Dock, Blunt-leaved Dock. Introduced. Perennial. Propagates by seeds.

Time of bloom: June to August.

Seed-time: August to November.

Range: Throughout the United States and southern British America. Habitat: Fields, meadows, pastures, and waste places.

A large, very robust plant, in many localities, the most common of the docks. Stem stout, erect, grooved, simple or with a few branches, somewhat rough, especially near the top. Lower leaves

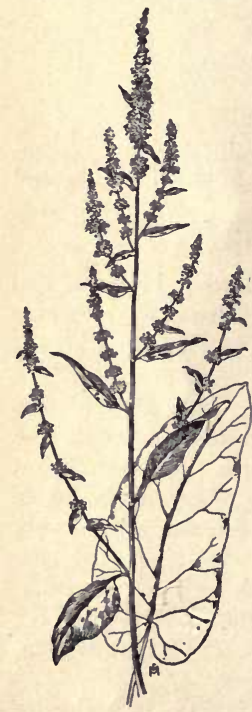

Frg. 54. - Broadleaved Dock (Rumex ob: tusifolius). $\times \frac{1}{8}$. often more than a foot in length and half as broad, oblong, with heart-shaped bases and rounded or bluntly pointed tips, the veins somewhat hairy on the under side; petioles long and thick; stem leaves narrower and more pointed, all petioled. Panicle large and loose, the whorls somewhat distant, often subtended by leafy bracts; pedicels slender, jointed below the middle, longer than the calyx-lobes; the valves, which enclose the fruit, pointedovate, or nearly halberd-shaped, strongly net-veined, sharply toothed at the side, and only one of them bearing a tubercle on the back. Achene dark red, smooth and shining, its three faces concave and its angles faintly margined.

Means of control the same as for Rumex crispus. (Fig. 54.)

\section{TALL SORREL}

Rùmex Acetd̀sa, L.

Other English names: Garden Sorrel, Sour Dock.

Introduced. Perennial. Propagates by seeds and by rootstocks. 
Time of bloom: May to July.

Seed-time: June to August.

Range: Eastern Canada to Vermont, New York, and Pennsylvania; locally south and west.

Habitat: Gardens, fields, roadsides, and waste places.

Usually an escape from gardens where it has been cultivated for "greens," though there are much better pot herbs which are not so unruly. Stems eighteen inches to three feet tall, erect, simple, smooth, slightly grooved. Leaves two to five inches long, arrow-shaped, the auricles at base not spreading; basal leaves on long and slender petioles, those on the stems nearly sessile. Flowers diœcious, the racemes erect, and crowded, or interrupted. Calyx green, the valves winged in fruit, rounded at apex, heart-shaped at base. Achenes dark reddish brown, pointed, three-angled, smooth and shining. (Fig. 55.)

\section{Means of control}

Frequent and close cutting throughout the growing season will prevent seed development and starve the rootstocks. Small areas should be grubbed out and destroyed.

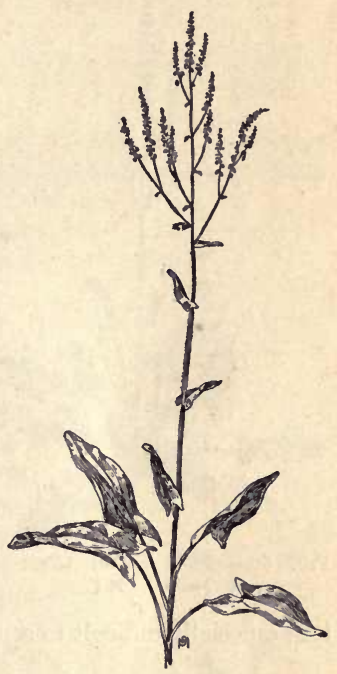

Fig. 55. - Tall Sorrel (Rumex Acetosa). $\times \frac{1}{6}$.

\section{FIELD SORREL}

Rùmex Acetosélla, L.

Other English names: Horse Sorrel, Sheep Sorrel, Redtop Sorrel, Sourweed, Sourgrass.

Introduced. Perennial. Propagates by seeds and by rootstocks.

Time of bloom: May to September.

Seed-time: June to November.

Range: All parts of North America except the extreme North.

Habitat: Rather dry, sandy soil ; fields, meadows, pastures, roadsides, and waste places. 
Rootstocks extensively creeping, branched, yellowish, tough and fibrous, with tufts of feeding rootlets at intervals of a few

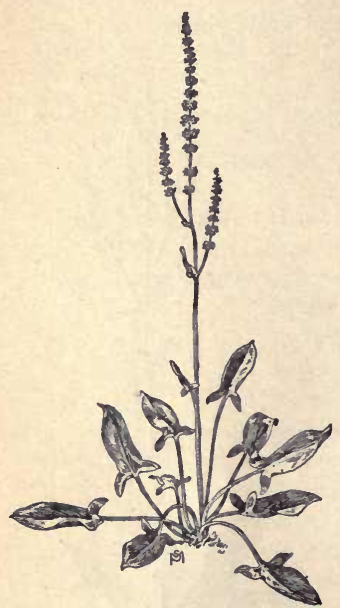

Frg. 56. - Field Sorrel (Rumex Acetosella). $\times \frac{1}{4}$. inches. Stems three inches to a foot or a little more in height, slender, erect or nearly so, usually simple. Leaves halberd-shaped, long-petioled, the basal auricles spreading; stem leaves often without auricles; they are smooth, light green, papillose, filled with an acid juice - which is rather pleasant to taste but very unwholesome, as it is an acid oxalate, which, veterinarians say, is poisonous to horses and sheep. Flowers diœcious, in erect, interrupted, panicled racemes, the staminate ones conspicuously yellow because of the out-thrust, pollenloaded anthers, the fertile ones with reddish calyx-lobes and feathery, crimson stigmas. Achene threeangled, brown, exceeding the calyxlobes. Sorrel seed is a frequent impurity of commercial seeds, particularly of alsike clover, from which it is especially difficult to separate. (Fig. 56.)

\section{Means of control}

Cultivate and enrich the ground, correcting its acid condition with heavy applications of lime. Grain crops infested with Sorrel are so robbed of moisture as to yield very poor returns; they may be helped by a spray of Iron sulfate applied just as the weed comes into bloom; the rootstocks take no harm, but much of the leaf surface is destroyed and seed development prevented for that season. Give surface cultivation, after harvest, exposing the fibrous rootstocks and destroying the leaf-growth, and also stirring dormant seeds into life. Reseed heavily, smothering the weed with strong grasses or clover. 


\section{PROSTRATE KNOTWEED}

Polýgonum aviculdre, $\mathrm{L}$.

Other English names: Doorweed, Knotgrass, Matgrass. Native. Annual or perennial. Propagates by seeds.

Time of bloom: June to October.

Seed-time: July to November.

Range: Nearly everywhere in North America, Europe, and Asia.

Habitat: Cultivated grounds, yards, roadsides, and waste places.

A social, almost domesticated, weed, seeming to thrive best where most trampled and abused, growing in thick mats along hard-beaten farmyard paths, and intruding persistently in lawns and garden borders; it often fringes the stone flags of city sidewalks.

Stems slender, pale green, faintly ridged, usually prostrate, four inches to nearly two feet in length, branching in all directions from the white, woody, rather deeply boring root. Smaller branches come out at many of the numberless "knots," or joints, which are pale under the sheathing stipules. Leaves bluish green, nearly elliptical in shape, sessile or with very short petioles, a quarter-inch to an inch long. Flowers very small, the calyx five-parted, greenish white with pink margins, sitting solitary or in groups of two or three in the leaf axils; stamens usually eight, sometimes fewer; style three-parted. Achenes dull brown, with acute apex and rounded base, three-angled, and minutely ridged. This species and also the one following is often attacked by a white mildew. (Fig. 57.)

Means of control

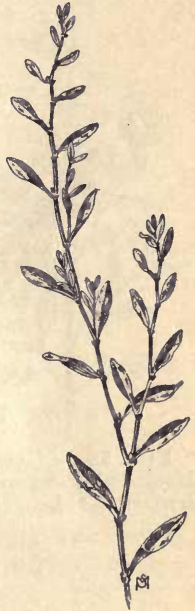

Fig. 57. - Prostrate Knotweed (Polygonum avicu(are). $\times \frac{3}{2}$.

Hoe-cutting or hand-pulling before the first seeds ripen. Dormant seeds will supply later crops to be treated in the same way until the ground is clean. 


\section{ERECT KNOTWEED}

\section{Polýgonum eréctum, L.}

Native. Annual. Propagates by seeds.

Time of bloom: July to September.

Seed-time: August to October.

Range: Ontario to the Northwest Territory, southward to Tennessee and Arkansas.

Habitat: Yards, waysides, and waste places.

A plant resembling the Doorweed and often growing in company with it, but having larger leaves and flowers and standing erect at

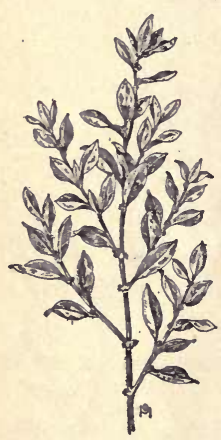

FrG. 58. - Erect Knotweed (Polygonum erectum). $\times \frac{1}{3}$. a height of four inches to a foot or more. Stem slim, round, smooth, yellowish green, with many branches. Leaves broader than those of the Doorweed, one-half inch to an inch long, elliptical, usually obtuse, sessile or with very short petioles; stipules funnel-shaped, paper-white, often torn and ragged. Flowers greenish white, in small axillary clusters, on pedicels usually about as long as the sheathing stipules; stamens five or six. Achenes dull brown, pointed ovoid, enclosed in the persistent calyx-lobes. (Fig. 58.)

Means of control

Prevention of seeding by close cutting or pulling while in early bloom.

\section{BUSHY KNOTWEED}

Polýgonum ramosissimum, Michx.

Native. Annual. Propagates by seeds.

Time of bloom: July to September.

Seed-time: August to October.

Range: Maine to New Jersey on the Atlantic Coast; in the West from Minnesota to the Northwest Territory, California, Arizona, and New Mexico.

Habitat: Sandy, often brackish, soil ; irrigated lands, waste places. 
Stem rigidly upright, sometimes attaining four feet but more of ten six inches to two feet in height, much branched, slender, slightly ridged, and smooth. Leaves yellowish green, smooth, narrow lance-shaped, pointed at both ends, a quarter-inch to an inch long, with very short petioles conspicuously jointed to the collar-like stipules, which are funnel-form, thin, usually cut and torn. Flowers in axillary clusters, greenish with yellow margins; stamens three to six; sepals six, the three inner ones small, the outer ones larger, keeled and curving inward at the summit, persistent, their withered remains enfolding the smooth, shining, three-angled achenes when they mature and fall.

\section{Means of control}

Prevent reproduction by cutting or pulling when in first bloom.

\section{SWAMP SMARTWEED}

\section{Polygonum Muhlengérgii, Wats.}

(Polygonum emérsum, Britton)

Native. Perennial. Propagates by seeds and by rootstocks. Time of bloom: July to September.

Seed-time: August to October.

Range: Ontario to British Columbia, southward to Virginia, Louisiana, and Texas.

Habitat: Muddy or dry soil ; fields, low meadows, swamps.

Although this weed seems to prefer moist soil, it will grow anywhere, even on mountains, varying its form to fit its surroundings. When established in field or meadow its creeping, horizontal rootstocks make it difficult to suppress, as by ordinary cultivation they are likely to be broken and further distributed.

Stems one to three feet long, decumbent or sometimes erect, usually simple, rough with short, appressed hairs, or sometimes smooth and slightly grooved, swollen at the joints. Leaves variable, those in wet places usually smooth, rather broad, and heartshaped at base ; in dry situations narrow, lance-shaped, pointed at base, and covered on both sides with appressed hairs; loose sheathing stipules nearly as long as the petioles. Flowers dark rose- 
color, their peduncles rough-hairy and often glandular, growing in dense spikes, one to four inches long; calyx five-lobed; stamens five, exserted; style two-cleft to about half its length, exserted. Achenes lens-shaped, black, and shining.

\section{Means of control}

Cutting and many times cutting, close to the ground, for the purpose of depriving the rootstocks of all food assimilated by the leaves and preventing seed production. Small areas should be grubbed out.

\section{PENNSYLVANIA SMARTWEED}

\section{Polýgonum pennsylvánicum, L.}

Other English names: Glandular Persicary, Purplehead.

Native. Annual. Propagates by seeds.

Time of bloom: July to Oetober.

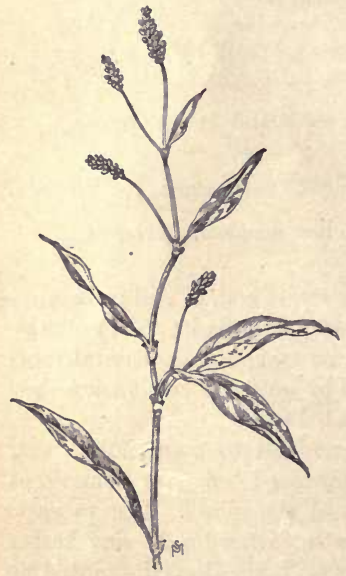

Fig. 59. - Pennsylvania Persicary (Polygonum pennsylvanicum). $\times \frac{1}{4}$.
Seed-time: August to November. Range: Eastern Canada and United States to Minnesota, southward to the Gulf of Mexico. Habitat: Moist soil ; damp grass lands, waste places, and along streams and ditches.

A pest of lowland clover fields, as it ripens its earlier seeds about the time of clover cutting. Stems two to five feet tall, somewhat hard and woody when old, and of rather branching and sprawling habit, the lower part smooth but the topmost leaves and the flowerstalks set with gland-tipped hairs. Leaves two to ten inches long, lance-shaped, with short petioles; sheathing stipules smooth and thin. Flowers in short, crowded, erect spikes, cylindric, often blunt at the end, deep pink; they are frequently affected with a smut or 
fungus which turns the heads into a mass of purple spores, destroying the fruits so that "purplehead" is a benefit from the farmer's point of view. Achenes black, lens-shaped, smooth, and shining. (Fig. 59.)

\section{Means of control}

Cut closely or pull before any seeds have matured. Rankly infested ground should be put under cultivation before being again used for clover or grass. Good drainage is an assistance in subduing this weed, for it likes the soil to be moist.

\section{COMMON SMARTWEED}

\section{Polýgonum Hydrópiper, L.}

Other English names: Water-pepper, Biting Knotweed.

Native. Annual. Propagates by seeds. Time of bloom: June to September. Seed-time: July to November.

Range: Throughout North America. Naturalized in the Eastern States, but indigenous in the Northwest.

Habitat: Low fields and meadows; gardens and barnyards, waste places.

The juice of this plant is exceedingly biting and pungent to the taste and will raise blisters when applied to the skin. It is not insistently a waterweed, as its name implies, but will grow where the soil is only moderately moist.

Stem smooth, erect, slender, with few branches, ten inches to two feet tall, light green or frequently of a reddish color. Leaves narrow lance-shaped, one to four inches long, with short petioles, the surface dotted with glands, the edges entire or slightly wavy, ciliate, the sheathing stipules cylindric and fringed with short bristles. Flowers in slender, $\times \frac{1}{2}$.

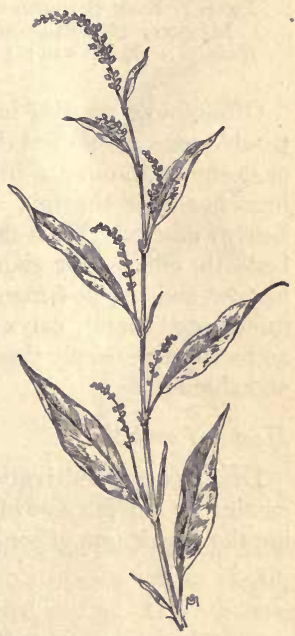

FIG. 60.-Common Smartweed (Polygonum Hydropiper). 
nodding, interrupted racemes ; calyx greenish, also gland-dotted, and as pungent to taste as the leaves; stamens four to six ; style short, two- or three-parted. Achenes minutely ridged, lens-shaped or three-angled approaching to ovoid, dull, reddish brown. (Fig. 60.)

\section{Means of control}

Cultivation of the ground; close cutting or hand-pulling before the earliest flowers ripen seed.

\section{MILD WATER-PEPPER}

Polýgonum hydropiperotdes, Michx.

Native. Perennial. Propagates by seeds.

Time of bloom: June to September.

Seed-time: July to October.

Range: New Brunswick to Minnesota, southward to Florida and Mexico; also in California.

Habitat: Damp soil ; wet meadows, swamps, waste places.

Often found growing in company with the Smartweed, and more troublesome as a weed because perennial. Stems slender, erect or decumbent, one to three feet long, usually simple or with a few branches near the top, smooth or with appressed, bristly hairs. Leaves narrowly lance-shaped, acute, bristly-hairy on the midribs beneath, ciliate, not glandular, and not acrid; sheathing stipules narrow and bristle-fringed. Spikes terminal, erect, narrow, often interrupted below; calyx pink or greenish white, with eight stamens and with style deeply three-parted. Achenes three-angled, smooth, and shining.

\section{Means of control}

Drainage and cultivation where practicable; frequent and close cutting for the purpose of starving the perennial roots and preventing the production of seed. Small areas may be grubbed out.

\section{LADY'S THUMB}

\section{Polýgonum Persicària, L.}

Other English names: Spotted Smartweed, Spotted Knotweed, Red-shanks, Heartwoed, Peach-leaved Persicary. 
Introduced. Annual. Propagates by seeds.

Time of bloom: June to October.

Seed-time: July to November.

Range: Throughout the American Continent except the extreme North, and in most parts of the world.

Habitat: Soil either dry or moist. Invades nearly all crops.

The seeds of this weed form one of the most common impurities of commercial seeds, particularly of red clover. In a bulletin issued by the Agricultural Experiment Station of Nevada, concerning "Clover Seeds and their Impurities," it is stated that of red clover samples submitted for inspection (obtained in all parts of the country), 62.9 per cent contained seeds of Persicaria. (Fig. 61.)

Stems six inches to two feet tall, often red or purplish at base, nearly smooth, erect or sometimes spreading. Leaves lance-shaped, smooth or with fine hair roughening the edges, pointed at both ends and generally blotched near the center with a large brownish spot. It is related that Joseph once hurt his hand while working in his carpenter's shop. Mary wished to make a healing poultice with this plant, but

"She could not find it at her need And so she pinched it for a weed,"

since when its leaves have always borne the mark of the Lady's thumb; the sheathing stipules at their base are fringed with short bristles. Flower-

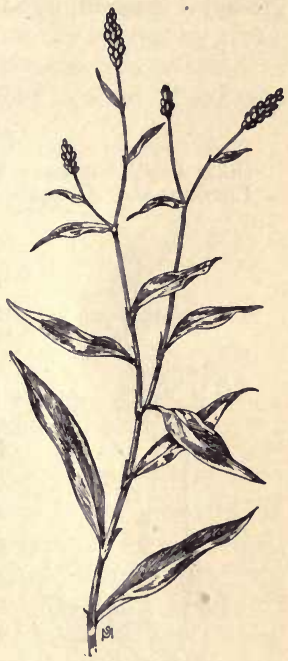

Frg. 61. - Lady's Thumb (Polygonum Persicaria). $\times \frac{1}{4}$. spikes numerous, dense, erect, a half-inch to two inches long; calyx pink or purplish with four or five obtuse lobes, usually six stamens, and a two- or three-parted style. Achenes lensshaped or sometimes three-angled, smooth, shining, jet-black.

In some localities the plant is said to harbor the corn-root aphis, the louse appearing with the first leaves. 


\section{Means of control}

Prevent seed development. Even so expensive a process as hand-pulling is often worth the labor if it hinders so pernicious a weed as this from fouling the ground with its long-lived seeds. In grasslands and grain fields a spray of four-per-cent solution of Copper sulfate will greatly damage the foliage of the weed, checking growth and usually blasting the budding flowers. In cultivated ground it is readily subdued by the necessary tillage.

\section{BLACK BINDWEED}

\section{Polýgonum Convoblvulus, L.}

Other English names: Wild Buckwheat, Knot Bindweed.

Introduced. Annual. Propagates by seeds.

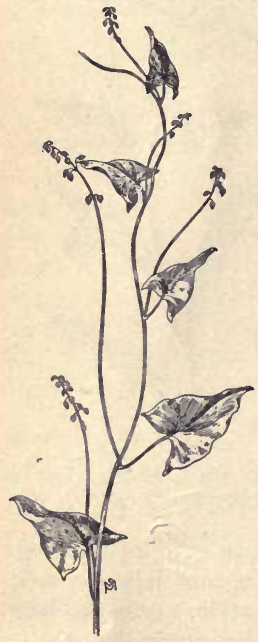

Fig. 62. - Black Bindweed (Polygonum Convolvulus). $\times \frac{1}{1}$.
Time of bloom: June to September.

Seed-time: July until cut off by frost.

Range: Throughout North America except the extreme North.

Habitat: Fields and waste places; invades most erops.

Not very troublesome in ground requiring close tillage, but a special nuisance in grain fields ; climbing over and strangling the rightful growth, robbing it of food and moisture, bending it down by weight of its own fruitage. The seeds have long vitality and begin to ripen and drop into the soil before harvest; are gathered with the grain and often distributed with it; of ten fed to cattle in screenings from the mills, and returned to the soil in stable refuse or in droppings.

Stem slightly angular, roughish, branching, one to three feet long. Leaves halberd-shaped or long-pointed, heartshaped, smooth, dark green, with slender petioles usually not so long as the blades. Flowers in slim, interrupted, axillary ra- 
cemes, or often in small clusters of two to six on the small branches ; they are greenish white, the calyx five-parted, persistent, enfolding the achene, which is black, pointed, three-angled, resembling a small kernel of buckwheat. (Fig. 62.)

\section{Means of control}

Sow clean sced. Before they begin to twine, rake the Bindweed seedlings from the young grain with a weeding harrow. Directly after harvest induce germination of seeds on the ground by giving surface cultivation, the resulting growth being winter-killed or turned under by the plow. Put the ground to a cultivated crop before using it again for grain.

\section{CLIMBING FALSE BUCKWHEAT}

Polýgonum scándens, L. (Tinidria scándens, Small.)

Other English names: Hedge Bindweed, Hedge Buckwheat.

Native. Perennial. Propagates by seeds.

Time of bloom: June to September.

Seed-time: July to October.

Range: Throughout the United States and southern British America.

Habitat: Moist soil ; twining over fences and thickets or trailing on the ground.

A very conspicuous weed, especially when in fruit, capable of spreading itself over a square rod or so of ground, when not finding other support. Stems very slender, pale green, faintly ridged and slightly roughened on the ridges, three to twenty feet in length; several such stems strike off in all directions from the deep-boring, branching, perennial root. Leaves halberd-shaped, the tips and the basal auricles rather long-pointed, smooth but with edges slightly roughened; petioles long and nearly as thick as the stem from which they spring; sheath smooth, oblique, slightly rough on the ridges. Flowers yellowish green, in slender, axillary racemes, interrupted and leafy, two to four inches long; calyx five-parted, the three outer segments winged and decurrent on the pedicels. Achenes small, three-angled, obtuse at both ends, jet black, smooth and shining. They are persistent on the stems until cold weather 
and birds glean them, which accounts for the presence of the weed along fences and thickets. (Fig. 63.)

\section{Means of control}

The best remedy is hand-pulling when the ground is soft, early in the first season's growth, before the root has extensively grown. Otherwise cut the vines from the roots while in early flower, using salt or kerosene on the shorn surfaces. Vines like this are an argument against any more fences than are absolutely necessary.

\section{WINGED PIGWEED}

Cycloloma atriplicifolium, Coult.

Native. Annual. Propagates by seeds.

Time of bloom: July to September.

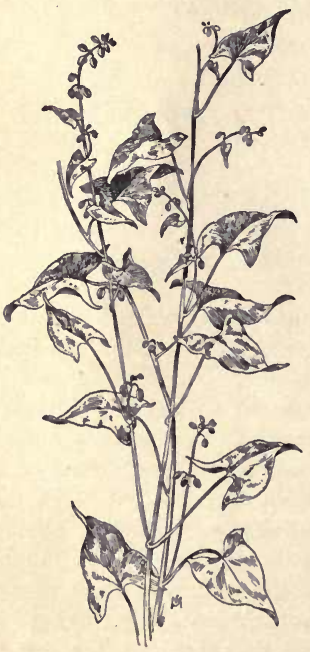

Frg. 63.-Climbing False Buckwheat (Polygonum scandens). $\times \frac{1}{4}$.

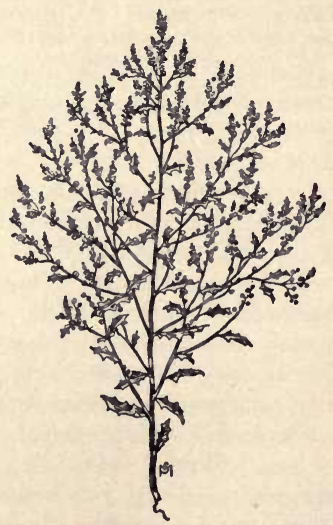

Fra. 64. - Winged Pigweed ( $\mathrm{Cy}$ cloloma atriplicifolium). $\times \frac{1}{6}$. 
Seed-time: Late August to November.

Range: Manitoba to the Northwest Territory, through the Middle West to Arizona.

Habitat: Plains; sandy soil ; fields, waste places.

A low and broadly branching plant, six to twenty inches in height, the stem and branches somewhat striped and angular, with reddish joints, of ten webby-haired when young but soon becoming smooth. Leaves one to three inches long, lance-shaped, with wavy and irregular but sharp teeth, narrowing at base to short, slim petioles; when young they are pale green, but they usually turn dark purple as the plant matures. Flowers in loosely spreading, interrupted panicles, very small, sessile, and scattered unevenly on the spikes; calyx urn-shaped, with five pointed lobes, keeled and curved inward, around the base of which develops a thin, membranous, horizontal wing, or border; stamens five; styles three or occasionally two. Seed flattened and horizontal, crustaceous. (Fig. 64.)

As the plants mature the empurpled leaves fall away, the spreading branches harden and bend their tips inward, the brittle stems part from the roots close to the ground, and after that the plants are tumbleweeds, at the sport of varying winds, seeding the soil over which they roll.

\section{Means of control}

Destroy while young by hoe-cutting or hand-pulling. Maturing plants should be cut and burned. Stragglers of roadsides and waste land should receive attention, for a few tumblers from such sources may seed a wide area.

\section{FIREBALL}

Kòchia Scopdria, Schrad.

Other English name: Mexican Fireweed.

Introduced. Annual. Propagates by seeds.

Time of bloom: July to September.

Seed-time: September to November.

Range: Locally in most of the states; most common in the Middle West.

Habitat: Fields, waste places. 


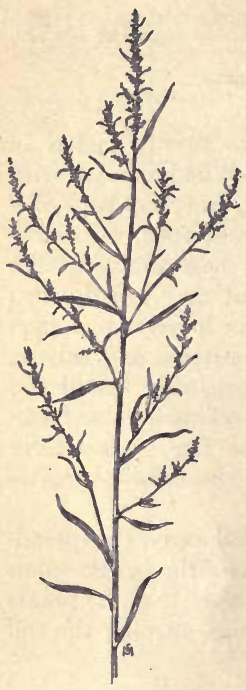

FIG. 65. - Fireball (Kochia Scoparia). $\times \frac{1}{1}$.

Wherever this plant is established as a weed it has usually first been cultivated in gardens for its bright coloring in autumn. It is becoming increasingly common, particularly on the prairies, where the winds carry it far on the unrestricted levels, for its rounded, compact growth makes it a tumbleweed. Its name of "Mexican fireweed" is a misnomer, for it is an immigrant from Europe.

Stem one to three feet in height, very slender, round, pale green, erect and diffusely branching. Leaves very numerous, one to three inches long, pale green, pointed, linear, the upper ones almost thread-like in their narrowness. Flowers sessile in the upper axils, forming short, dense, bracted spikes; calyx five-lobed, each segment bearing a small, triangular wing; seed coat membranaceous. In autumn the dense foliage turns fiery red, but later the plants become brown and unsightly. (Fig. 65.)

Means of control the same as for the Winged Pigweed.

\section{MEXICAN TEA}

Chenopòdium ambrosioides, $\mathrm{L}$.

Other English names: Spanish Tea, Jerusalem Tea, Jesuit Tea, Ambrosia.

Introduced. Annual. Propagates by seeds.

Time of bloom: July to September.

Seed-time: August to Oetober.

Range: Tropical America, northward to Ontario and westward to Pacific Coast.

Habitat: Old pastures, neglected yards, roadsides, and waste places. Most common in the South.

A strong-scented, unpleasant weed, rejected by all grazing animals, even goats. . Stem two to four feet tall, erect, much 
branched, and very leafy. Leaves oblong to lance-shaped, one to three inches long, smooth, wavy-toothed or nearly entire, especially the upper ones, which are pointed at both ends and sessile or with very shórt petioles. Flowers in dense terminal and axillary spikes, intermixed with small leaves; calyx green, its five lobes completely enclosing the small, black, flattened seed.

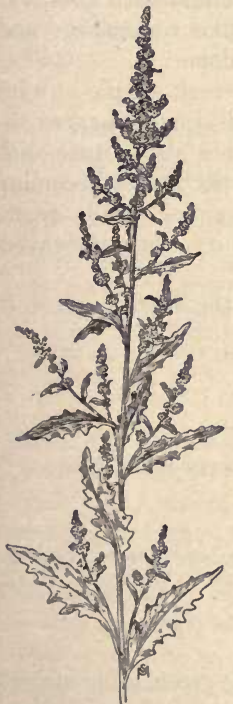

Fig. 67.-- Wormseed (Chenopodium ambrosioides var. anthelminticum). $\times$ ?
(Fig. 66.)

Occupying the same range is a closely related plant, c o $\mathrm{m} \mathrm{mon} \mathrm{y}$ called Wormseed (C. ambrosioides, var. anthelminticum, Gray), differing chiefly in being perennial

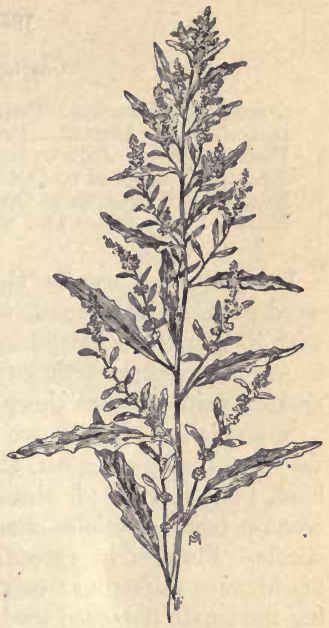

Fig. 66. - Mexican Tea (Chenopodium ambrosioides). $\times \frac{1}{3}$. in latitudes where the ground does not freeze in winter; also, it is a larger, more strongly-scented plant, with more coarsely toothed leaves, two to five inches long and its flowering spikes often lacking the small, entire, sessile leaves that are intermingled with the flowers of Mexican Tea. Both plants are used in medicine as anthelmintics, and the seeds, from which the essential oil is usually distilled, are salable in the drug market for six to eight cents a pound. (Fig. 67.)

Means of control

Close cutting or hand-pulling while in early bloom. 


\section{JERUSALEM OAK}

\section{Chenopòdium Bòtrys, L.}

Other English names: Feather Geranium, Turnpike Geranium. Introduced. Annual. Propagates by seeds.

Time of bloom: July to September.

Seed-time: August to October.

Range: Nova Scotia to Oregon, southward to Georgia and Mexico.

Habitat: Roadsides and waste places.

Its name of Turnpike Geranium indicates the fondness of this weed for the public road, where it is usually an unsightly object, with its glandular, hairy leaves and flowers overlaid with dust. It is strong-scented, with an odor somewhat like turpentine, and grazing animals, even sheep, usually leave it alone.

Stem eight inches to two feet tall, slender, erect, simple or with very few branches, green, glandular-hairy, and viscid. Leaves oblong, pinnately lobed, obtuse at apex, the lobes also obtuse with crenate teeth; petioles slender, short, the upper leaves becoming sessile. Flowers in spreading, cyme-like racemes, small, green, viscid, very numerous; calyx-lobes pointed, hairy, not quite covering the small, flattened seed.

Means of control should be the same as for the Wormseeds.

\section{STRAWBERRY BLITE}

Chenopòdium capitatum, Asch.

Other English names: Blite Mulberry, Strawberry Spinach.

Native. Annual. Propagates by seeds.

Time of bloom: June to August.

Seed-time: July to September.

Range: Nova Scotia to Alaska, southward to New Jersey, Illinois, and Minnesota, and in the Rocky Mountains to Colorado, Utah, and Nevada. Also a native of Europe.

Habitat: Dry soil ; cultivated grounds; waste places.

Stem six inches to two feet high, slender, pale green, often striped with purple, with numerous ascending branches. Leaves triangular or halberd-shaped, one to three inches long, thin, pale green, irregularly and coarsely toothed, not mealy; petioles slender, the lower ones about as long as the blades. Flowers in rounded, 
densely crowded, sessile clusters along the upper part of the stem and branches and in the lower axils; calyx three- to five-parted, becoming pulpy and deep red when ripe, making the clusters look like strawberries. Seed ovoid, slightly flattened, smooth, dull black. (Fig. 68.)

Means of control

Prevent seed production either by hand-pulling or by close cutting while in bloom.

\section{OAK-LEAVED GOOSEFOOT}

Chenopòdium glaùcum, $\mathrm{L}$.

Introduced. Annual. Propagates by seeds.

Time of bloom: June to September.

Seed-time: August to November.

Range: Throughout North America except the far North.

Habitat: Cultivated ground; waste

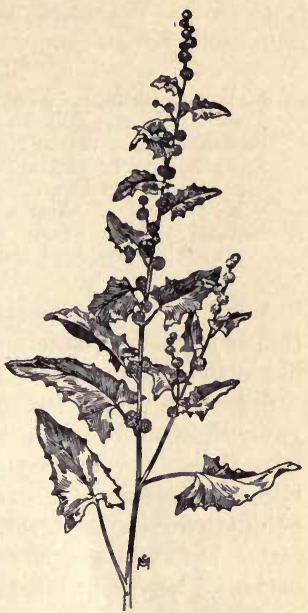

FIG. 68. - Strawberry Blite (Chenopodium capitatum). $\times \frac{1}{2}$. places.

Like the White Goosefoot, this plant has accompanied the European settler to every part of the world. Stem eight to twenty inches high, rather stout, grooved, succulent, with numerous spreading branches, the lowermost often prostrate on the ground, glaucous, often mealy. Leaves oblong to lance-shaped, wavytoothed or partly pinnatifid, the lower ones obtuse at apex and tapering to a slender petiole, the upper ones acute, often entire, sessile or nearly so, pale green above and white-mealy beneath. Flowers in small axillary clusters, usually not so long as the leaves, crowded on short, spreading spikes. Seed dark brown, flattened, sharp-edged, the utricle having its summit not completely covered by the calyx.

Means of control the same as for the Smooth Pigweed. 


\section{MAPLE-LEAVED GOOSEFOOT}

Chenopòdium hýbridum, $L$.

Native. Annual. Propagates by seeds.

Time of bloom: July to September.

Seed-time: August to November.

Range: Quebec to the Northwest Territory and British Columbia, southward to Pennsylvania, Ohio, Kentucky, Kansas, Utah, and New Mexico. Also a native of Europe.

Habitat: Open woods and thickets, farmyards, roadsides, waste places; a frequent tenant of city vacant lots.

A tall and handsome species, differing from others of its kind in that it is fond of shade. It is strong-scented, the odor somewhat like that of Stramonium.

Stem two to five feet or more in height, erect, rather slender, grooved, smooth, green, with many spreading branches. Leaves large, smooth, thin, deep green, not mealy, the lower ones sometimes four inches long, ovate, long-pointed, with one to four large, pointed teeth on each side, the base truncate or rounded, petioles rather long and slender; the upper leaves lance-shaped, usually entire. Flowers in large, loosely spreading, terminal and axillary panicles ; calyx green, its five lobes keeled, rather obtuse, not wholly covering the seed, which is sharp-edged.

\section{Means of control}

Close cutting or pulling before the first flowers mature.

\section{SMOOTH PIGWEED}

Chenopdidium album, $\mathrm{L}$.

Other English names: White Goosefoot, Lamb's Quarters, Fat Hen, Mealweed, Meldweed.

Introduced. Annual. Propagates by seeds.

Time of bloom: June to September.

Seed-time:- August to November.

Range: Throughout the world.

Habitat: Cultivated fields, gardens, waste places.

A succulent, swift-growing weed, which rapidly absorbs the food and moisture needed by the crops among which it intrudes. Pigs and sheep are very fond of it, and when young it makes quite as 
good "greens" as its cultivated relatives, the spinach and the beet; also, it is a frequent host of the insect enemies, mildews, and rusts that injure those plants. (Fig. 69.)

The stem sometimes attains to six feet, but is usually two to four feet tall, stout, erect, ridged and grooved, much branched, often striped with pink or purple, growing from a short, stout main root with many branching rootlets. Leaves rhombicovate or goosefoot-shaped near the base, but become more narrow and lanceshaped as they ascend the stem until those near the top are often nearly linear; smooth and green above but often covered on the under side with a mealy secretion, especially when young, the lower ones irregularly cut and toothed, with petioles of ten as long as the blades. Flowers small, green, crowded on spiked panicles in the axils and at the summit of stem and branches; calyx with five lobes, keeled and enfolding the seed, which is lens-shaped, small and black; these seeds have very long vitality, lying dormant in the soil for years and germinating when brought near the surface by cultivation. Pigweed seeds are nearly always found in dirty grain, and often in clover and grass seed and in alfalfa; though, being lighter, they should be easily removed.

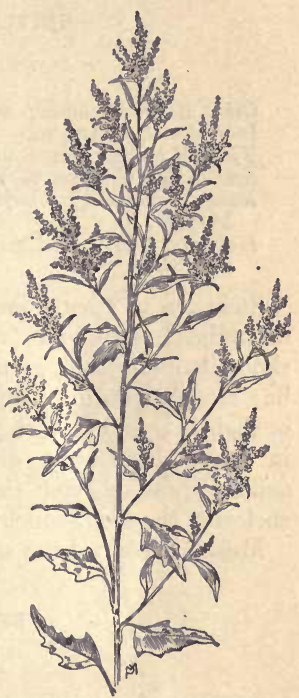

Frg. 69. - Smooth Pigweed (Chenopodium album). $\times \frac{1}{3}$.

\section{Means of control}

In hoed crops the weed is very persistent and cultivation should be continued until late in the season, else the soil will be strewn with late matured seeds. In gardens and other small areas, it should be hoe-cut or hand-pulled while young. When the plant appears in grain fields, it should be harrowed out with one of the small-toothed harrows known as weeders, in the spring, when the grain is but 
a few inches high. Stubbles should be given surface cultivation after harvest for the purpose of stirring into life such seeds as lie on the ground, the young growth to be turned under at the fall plowing, or, it may be grazed off by sheep.

\section{NETTLE-LEAVED GOOSEFOOT \\ Chenopòdium muràle, L.}

Other English names: Sowbane, Swine's Bane.

Introduced. Annual. Propagates by seeds.

Time of bloom: June to September.

Seed-time: August to November.

Range: Maine to British Columbia, southward to Florida and Mexico.

Habitat: Cultivated grounds; waste places.

Stem ten to twenty inches high, leafy to the top, slender, often decumbent, sometimes erect, usually loosely branched. Leaves rhombic-ovate, thin, green on both sides, with large, coarse, wavy but sharply pointed teeth, bases broadly wedge-shaped, truncate, or slightly rounded, with petioles shorter than the blades. Panicles in small, branching, divergent, somewhat corymbose clusters, axillary, and shorter than the leaves; calyx-lobes not wholly enclosing the seed, which is sharp-edged and very flat.

Means of control the same as for Smooth Pigweed.

\section{SPREADING ORACHE}

Átriplex pátula, L.

Introduced. Annual. Propagates by seeds.

Time of bloom: Late July to October.

Seed-time: September to November.

Range: Nova Scotia and Ontario to New Jersey and Ohio; also in northwestern United States and British Columbia, where it is probably native.

Habitat: Sandy soil ; cultivated ground, waste places.

A relative of the Smooth Pigweed and ranking with it in weedy character. Stem one to three feet in length, prostrate or ascending or sometimes erect, diffusely branching, grooved, of ten with reddish stripes. Leaves lance-shaped, one to five inches in length, long- 
pointed, entire or sparingly wavy-toothed, the lower ones with a pointed lobe on each side near the base and with slender petioles; the upper ones becoming nearly linear and sessile. Leaves and stem often scurfy-mealy, especially near the top. Flowers in

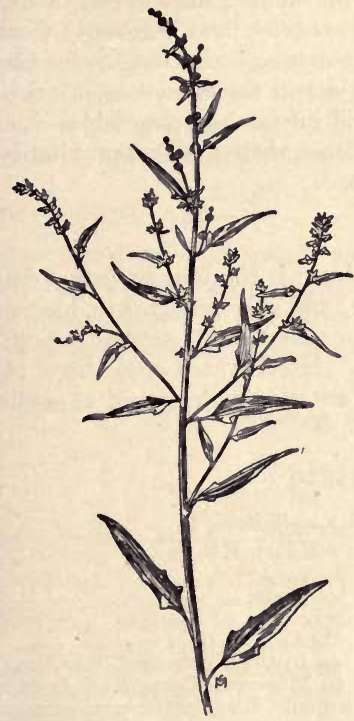

Fro. 70. - Spreading Orache (Atriplex patula). $\times \frac{1}{4}$.

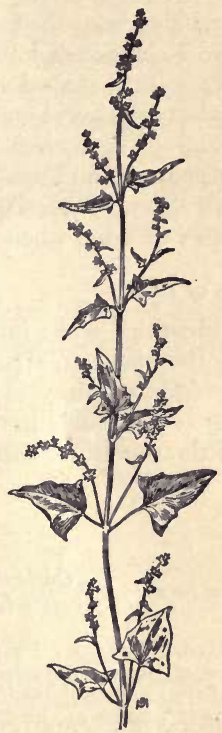

FIG. 71. - Halberdleaved Orache (Atriplex patula, var. hastata). $\times \frac{1}{6}$.

terminal, interrupted, panicled spikes, and also in small clusters in the upper axils, the staminate and pistillate flowers separate or both kinds together; the staminate flower without bracts, the calyx three- to five-parted with as many stamens; fertile flower a naked pistil with two-parted style, placed between two fleshy, triangular 
bracts, which are united at base and often tubercled on their sides. Seed compressed, vertical; often an impurity of other seeds. (Fig. 70.)

The plant is very variable; one of its forms, the Halberd-leaved Orache (A. patula, var. hastata, Gray), is more common than the type, ranging from the Great Lakes across the continent and southward to Nebraska and Utah. It is stouter, more erect, the leaves broadly halberd-shaped and often coarsely and irregularly toothed, particularly the lower ones, the petioles often as long as the blades. (Fig. 71.) These weeds are subject to the mildew so injurious to garden spinach and beets, and will infect those vegetables if growing near them. Like the Goosefoots, their seeds retain vitality for a number of years when in the soil.

\section{Means of control}

Hand-pulling while in early bloom is the best remedy; cutting causes the stems to stool freely, and the new growth hastens to mature fruit, requiring attention a second time; so that prompt uprooting saves trouble in the end. In cultivated crops these plants give little trouble, for there they are usually destroyed as seedlings.

\section{BUGSEED}

Corispérmum hyssopifòlium, $\mathbf{L}$.

(Corispérmum nitidum, Kit.)

Native. Annual. Propagates by seeds.

Time of bloom: July to September.

Seed-time: September to November.

Range: Shores of the Great Lakes to the Northwest Territory and British Columbia, southward to Missouri, Texas, and Arizona.

Habitat: Dry, sandy soil ; grain fields, hoed crops, and grasslands.

This is another of the plants that often become tumbleweeds when mature, which explains why its range extends from the Gulf of Mexico to the Arctic Circle. It is well known also in Europe and Asia.

Stems pale green, succulent and finely hairy when young, but becoming smooth, hard, and faintly ridged with age, often strongly zigzagged, very freely branched, six inches to two feet in length, 
the longer branches spreading and usually decumbent but the shorter ones erect. Lower leaves alternate, narrowly linear but rather thick, with the base somewhat dilated, one-nerved, sessile, spreading, a half-inch to two inches long, tipped with a hard, rigid point (cuspidate); the upper, floral leaves, or bracts, are very different, being thinner, ovate, pointed, little more than a quarterinch long, with dry, scarious margins. In the axils of these reduced leaves are the solitary flowers, hardly an eighth of an inch long; the calyx consists of one delicate sepal, rarely a second one; stamens one to three; styles two. Seed oval, somewhat flattened, with a winged margin, the two persistent styles extended like antennæ, completing its likeness to a small bug.

\section{Means of control}

Prevent seeding by thorough and very late tillage of eultivated crops. Infested meadows should be harvested while the weed is young and succulent. Burn over infested ground where plants have matured, in order to destroy seeds on the surface.

\section{RUSSIAN THISTLE}

Sálsola Kali, L.

Var. tenufolia, G. F. W. Meyer

Other Englis names: Russian Cactus, Russian Tumbleweed, Tumbling Thistle.

Introduced. Annual. Propagates by seeds.

Time of bloom: July to September.

Seed-time: Earliest flowers mature as early as September, later ones elinging to the plant until nearly springtime.

Range: Ontario and Manitoba to Idaho; nearly throughout the Mississippi Valley; in Kansas, Nebraska, and Colorado; locally in Eastern States.

Habitat: Dry soil ; invades most crops; waste places.

A most pernicious weed, which was brought to this country in impure flax seed from Russia not many years ago, but its range is already large and is steadily increasing. Because of its excessive prickliness, the Dakota farmers who first made its acquaintance called it Thistle and Cactus; but it is neither, being a Saltwort and a member of the Goosefoot Family. 
The seedlings are innocent-looking, grass-like shoots, divided into two blades, appearing in April, May, and June. The young stalks are tender and succulent, the young leaves an inch or two long with young branchlets in their axils; at this stage of growth the plant is good forage which cattle and sheep eat greedily. But with the approach of summer weather the plants change their

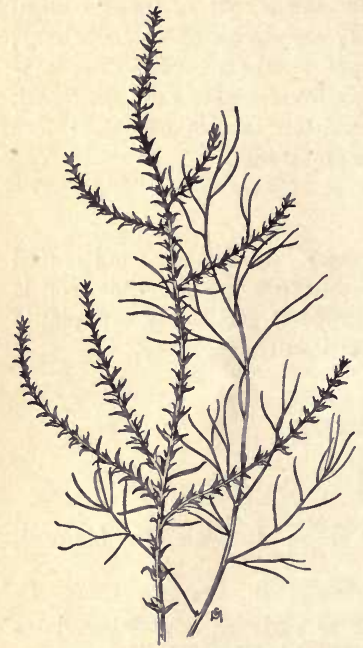

Fig. 72. - Russian Thistle (Salsola Kali, var. tenufolia). $\times \frac{1}{2}$. character : the stem becomes hard and woody, two to three feet high, ridged, and streaked with red lines, diffusely branched and spreading broadly, crowding to death all lesser growth. The first leaves fall away; those of later growth are not more than a half-inch long, mere awl-like spines slightly broadened at base and having on each side a sharp pointed bract which is somewhat shorter. (Fig. 72.) Flowers axillary, sessile, and usually solitary, very small, greenish white or often pink; calyx five-parted, with five stamens and two styles; when mature the calyx-lobes are horizontally winged on the back, forming a papery margin which often helps the seed to be carried before the wind, independent of the tumbling of the parent plant. Seed very small, reddish in color, irregular in shape but somewhat like a flattened top, held in place by fine tufts of coiled hair at the base of the persistent calyx, so that only the ripest will fall when the plant is broken from its hold on the soil and sent tumbling before the wind; but they continue to ripen and shake loose all winter as the weeds are trundled about. According to the size attained, a thrifty plant may bear ten thousand to a hundred thousand seeds, which retain their vitality in the soil for several seasons. 


\section{Means of control}

Sow clean seed. Prevent the production of seed. When the weed is cut close to the ground before seeding, it dies. Young seedlings, six or eight inches high, may be plowed under, a dragchain being used to help pull them beneath the turning furrow. On such land, plowed as late as July, a soiling crop of corn or rape may be grown. In such cultivated crops as potatoes, corn, and beets, tillage should be continued later than is customary. In grain fields, particularly those harvested with a header, the stubbles should be burned over, first being mowed and dried for a few days if the weeds are still green. Entire communities should be concerned in keeping highways, firebreaks, and all waste land clean of the pest.

\section{RUSSIAN PIGWEED}

\section{Áxyris amarantoides, L.}

Introduced. Annual. Propagates by seeds.

Time of bloom: June to July.

Seed-time: July to August.

Range: Manitoba, Minnesota, and the Dakotas.

Habitat: Grain fields, meadows, railway embankments, roadsides, and waste places.

A native of Siberia, first appearing in this country in 1886, in Canada near Winnipeg, Manitoba; since when the plant has spread very rapidly, east, west, and south. It is a coarse, deeply rooted, grossly feeding weed, two to four feet in height, widely branched and very leafy, seriously crowding the crops among which it grows. When young, it somewhat resembles Lamb's Quarters, but, instead of being mealy, the branches and under side of the leaves are clothed with very short, star-shaped hairs. (Fig. 73.)

Stem rather stout, grooved, light-colored, very hard and woody when mature, and injurious to harvesting machines. Leaves alternate, lance-shaped, with short petioles, sparsely toothed or wavy-edged, the upper ones entire. Flowers of two kinds, at first green and inconspicuous, the staminate ones in slender spikes, terminating the many branchlets; the fertile flowers below, thickly 
clustered in the axils; these each produce a single ovoid, flattened seed, about a tenth of an inch long, minutely ridged lengthwise, gray and shining; many seeds have the utricle or papery covering

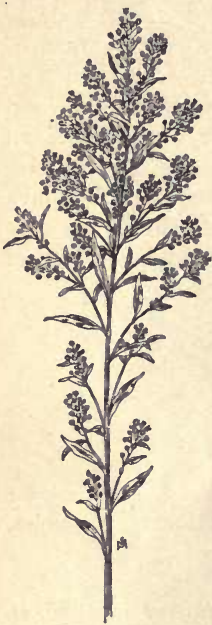

Fra. 73. - Russian Pigweed (Axyris amarantoides). $\times \frac{1}{4}$.

early flower, and shall mature. persistently enfolding them and projecting from the top as a two-lobed wing. When mature, the stems, bracts, and calyx lobes turn white, and the plants are then very conspicuous. They frequently become tumbleweeds, the woody, brittle stems breaking at the base and the whole weed rolling away before the wind, sowing seed as it goes; by this means its range is being very rapidly extended.

\section{Means of control}

In grain fields, large numbers of the young seedlings may be dragged out with a weeding harrow, in the spring, when the crop is but a few inches high; plants that survive this treatment should be hand-pulled later, but before their rank growth injures the crop by absorbing its food and moisture. Meadows infested by the weed should be early cut in order to prevent fouling the soil with the seed. Plants along roadsides and railways and in waste places should be cut while in burned so as to make certain that no seed

\section{ROUGH PIGWEED}

\section{A maranthus retroflexus, $\mathrm{L}$.}

Other English names: Redroot Pigweed, Chinaman's Greens.

Introduced. Annual. Propagates by seeds.

Time of bloom: July to September.

Seed-time: August to November.

Range: Throughout North America except the far North. Native of tropical America and indigenous in the Southwest.

Habitat: Cultivated ground; waste places. 
Like the Smooth Pigweed, this plant is rarely absent from cultivated ground. One reason for its constant recurrence lies in the long vitality of its seeds, which are known to survive in the soil for more than thirty years; they are also a frequent impurity of all commercial seeds.

Stem stout, tough, erect, green, rough-hairy, much branched, occasionally attaining a height of ten feet, but usually one to six feet tall, springing from a long, fleshy, red taproot, befringed with pink or white rootlets. Leaves long ovate or rhombic-ovate, three to six inches in length, dull green, roughhairy, with long petioles and prominent ribs and veins. Flowers on large, dense, terminal and axillary panicles, each subtended by three rigid, prickly bracts; they are very small, greenish, with five sepals and five stamens; stigmas two or three. Each flower produces but one oval, flattened, jet-black, and shining seed which readily falls from its place when ripe. (Fig. 74.)

\section{Means of control}

Prevent seed production. This means that attention must be given to cultivated crops after the horsehoe has ceased its rounds, either hand-pulling or hoe-cutting late

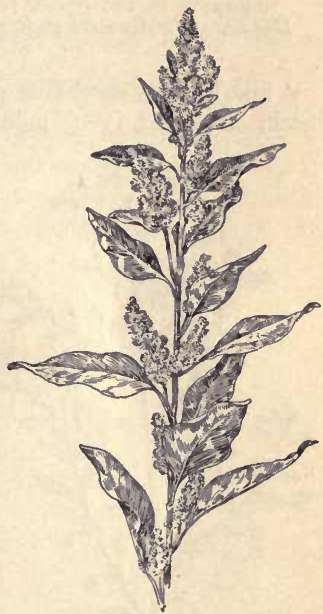

FIG. 74. - Rough Pigweed (Amaranthus retroflexus). $\times \frac{1}{\frac{1}{4}}$. plants which persistently strive to reproduce themselves. If they are nearing maturity, remove the plants from the ground, for seeds will ripen on the stout stalks. In grain fields, seedlings may be dragged out with a weeding harrow in the spring, when the crop is but a few inches tall. Or later, but before the weed blooms or the grain begins to head, spray with Iron or Copper sulfate. 


\section{TUMBLEWEED}

A maranthus grocizans, $\mathrm{L}$. (A maránthus allbus, L.)

Other English names: White Pigweed, Tumbling Pigweed. Native. Annual. Propagates by seeds.

Time of bloom: June to September.

Seed-time: July to October.

Range: Throughout North America except the far North; most common in the plains regions of the West.

Habitat: Cultivated ground ; waste places.

A low, broadly spreading plant, eight to twenty inches high, with thick, succulent, very pale green, almost white stem, diffusely

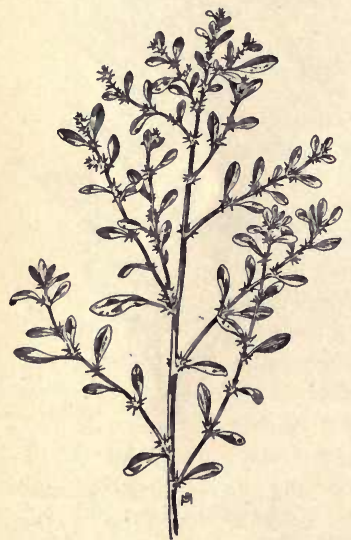

Fig. 75. - Tumbleweed (Amaranthus gracizans). $\times \frac{3}{3}$. branching from the base, and having a shallow, pinkish white root. Leaves smooth, pale green, a halfinch to two inches long, spatulate, with rounded apex, the midvein extended as a minute bristle; petioles slender, paler than the blades. Flowers in small axillary clusters, green, with three membranous sepals and as many stamens, the three subtending bracts much longer, awl-like, sharp, rigid, the lateral ones smaller or sometimes wanting; seed with wrinkled, papery utricle longer than the sepals. When the plants mature the leaves fall away, the hardened stems bend inward, the stalk is uprooted or breaks off at the surface of the ground, and the weed rolls away to scatter the seeds wherever the wind wills. (Fig. 75.)

Means of control

Destroy by hoe-cutting while young; tillage of cultivated crops should be long continued, in order to capture late-ripening plants. 
Odd corners and waste grounds should be well looked after, as many of the largest tumblers come from such places.

\section{PROSTRATE PIGWEED}

Amaránthus blitoides, Wats.

Other English names: Matted Pigweed, Low Amaranth.

Native. Annual. Propagates by seeds.

Time of bloom: June to September.

Seed-time: July to October.

Range: Maine to Minnesota, southward to New Jersey, Texas, and Arizona.

Habitat: Dry soil ; cultivated ground, waste places.

Often growing with the Tumbling Pigweed, and very like it in the shape of its small, spatulate leaves and small, greenish flowers; but its pale green, succulent branches are more slender, slightly ridged, six inches to nearly two feet in length and lie flat on the ground, spreading on all sides from the central root and forming thick mats. Like the other, it crowds out better plants and absorbs much food and moisture from the soil. The bracts subtending the flowers are ovate to lance-shaped, hardly exceeding the sepals; stamens three; utricle smooth, the seed nearly twice as large as those of the Tumbleweed, and for that reason much more difficult to remove from other seeds, particularly clover. (Fig. 76.) This plant and the two preceding species are subject to the white mold which attacks beets, and may also harbor on their roots the small striped beet-feeding beetle (Systena toniata, Say) both in the larval and mature stages.

It requires the same measures for its suppression as does the Tumbleweed.

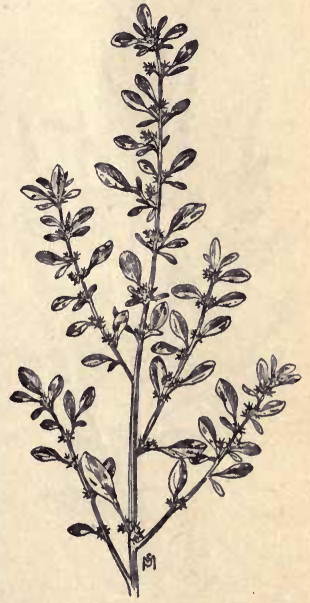

Fig. 76. - Prostrate Pigweed (Amaranthus blitoides). $\times \frac{1}{6}$. 


\section{SPINY AMARANTH}

A marânthus spind̀sus, L.

Other English names: Prickly Careless Weed, Soldier Weed.

Introduced. Annual. Propagates by seeds.

Time of bloom: June to September.

Seed-time: Late July to November.

Range: Massachusetts to Michigan, Illinois, and Kansas, southward to the Gulf of Mexico.

Habitat: Cultivated ground, meadows, lawns, and waste places.

A native of tropical America and a very common and troublesome weed, particularly in the Southern States. Not known north of Mason and Dixon's Line until after the Civil War, when it suddenly appeared in many places - most probably transported in the feed-

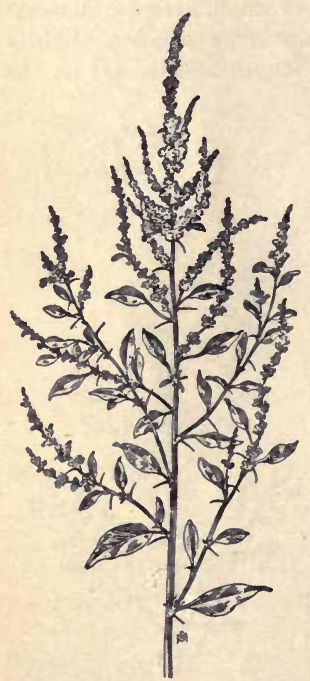

Fro. 77. - Spiny Amaranth (Amaranthus spinosus). $\times \frac{1}{4}$. bags of returning cavalrymen, which is the reason why it is called Soldier Weed, not because of its own weapons.

Stem one to four feet tall, stout, grooved, erect, smooth, branching and bushy, dark green or often purplish red. Leaves one to three inches long, broadly lance-shaped, pointed at both ends, the lower ones with long petioles; at the base of each leaf is a pair of diverging stipular spines, one-fourth to one-half inch long, rigid, keen as awls. Flowers small, greenish, the upper ones mostly staminate, forming long, slender spikes; fertile ones below in the axils, the clusters usually nearly globular; bracts awl-like, about as long as the scarious, sharp-pointed sepals ; stamens five. Seed very small, lens-shaped, smooth, dark, shining brown, imperfectly covered by the utricle; it is too often an impurity of other seeds, and, like all its family, is possessed of long vitality in the soil. (Fig. 77.) 
Means of control

Prevent seed production. In meadows or permanent pastures every stalk should be closely cut or hand-pulled before the flowerspikes develop. Cultivated ground should not be neglected in the latter part of the season, for it is the late-blooming plants that usually seed the soil. Potato and corn land should be plowed or well disked after harvest, and a winter crop sown which will keep down the weed.

\section{WATER HEMP}

\section{Acnida tuberculàta, Moq.}

Native. Annual. Propagates by seeds.

Time of bloom: July to September.

Seed-time: August to October.

Range: Vermont and Massachusetts to Manitoba and the Dakotas, southward to Louisiana and New Mexico.

Habitat: Wet meadows, swamps, and marshes, sides of ditches.

Water Hemp has somewhat the appearance of a large, succulent Amaranth. Stem smooth, erect, sometimes nearly an inch in diameter at the base and attaining ten feet or more in height, but more often three to six feet tall, with many slender, flexuous branches. Leaves two to six inches long, lance-shape approaching to rhombic, entire, smooth but with prominent pinnate veins, and pointed at both ends; petioles slender and shorter than the blades. Flowers diocious, in dense terminal or axillary spikes, sometimes interrupted and leafy, each small and greenish blossom guarded by one to three awl-like bracts. The sterile flowers have five stamens and five sharp-pointed, erect, one-nerved sepals, longer than the rigid bracts; the pistillate flowers are without a calyx and

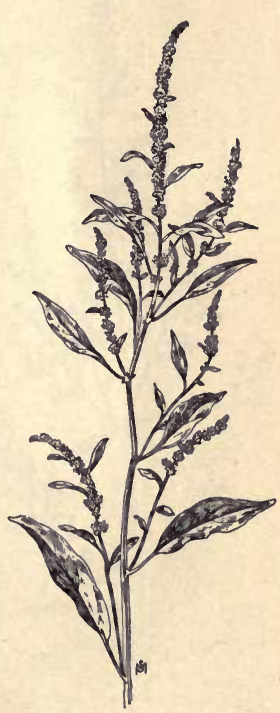

Fig. 78. - Water Hemp (Acnida tuberculata). $\times \frac{1}{2}$. 
have a one-celled, one-seeded ovary with two to five plumelike stigmas. The small, shining seed drops from its place while still enclosed in an egg-shaped, valveless, and tuberculate utricle, which makes it buoyant and easily distributed by wind and water. (Fig. 78.)

\section{Means of control}

Prevention of seed development by close cutting or pulling while in early bloom. Drainage and cultivation of the ground.

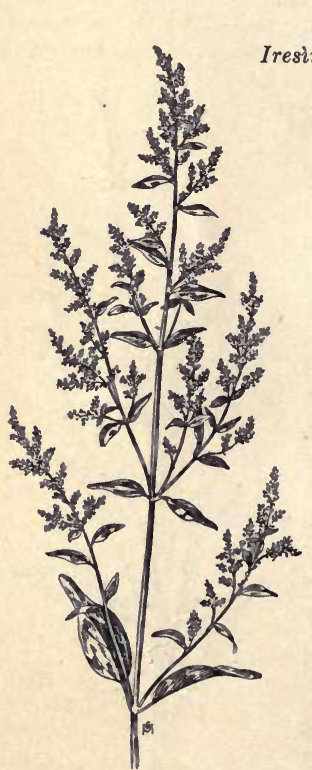

Fro. 79. - Juba's Bush (Iresine paniculata). $\times \frac{1}{4}$.

\section{JUBA'S BUSH}

Iresine paniculdta, Ktze.

Other English name: Blood-leaf.

Introduced. Annual. Propagates by seeds.

Time of bloom: July to September.

Seed-time: August to October.

Range: Ohio to Kansas, and southward to the Gulf of Mexico.

Habitat: Dry fields, meadows, and waste places.

A very conspicuous weed because of its white flowers and the red color which the foliage often assumes. It is a native of tropical America and seems to have a preference for sterile, sandy, or gravelly soils, into which its roots bore deeply, appropriating an undue share of the little food and moisture available.

Stem erect, furrowed, swollen at the nodes, slender, branching, two to five feet in height. Leaves opposite, narrowly ovate, long-pointed, becoming lance-shape near the top, smooth and entire, with short, slender petioles. Flowers in large terminal, branching, nearly leafless panicles, 
the blossoms very small, with silvery white, five-parted calyx, subtended by three dry, white, papery bracts; the pistillate flowers are densely white-woolly at the base and much longer than the bracts. Seed small, nearly globular, with valveless utricle, included in the calyx. (Fig. 79.)

\section{Means of control}

Close cutting or pulling in early summer before any seed has matured. Enrichment and cultivation of the ground, providing humus which will enable the soil to retain moisture and support better plants.

\section{FROELICHIA}

Frœlichia floridàna, Moq.

Native. Annual. Propagates by seeds.

Time of bloom: June to September.

Seed-time: July to November.

Range: Southern Wisconsin and Minnesota to Colorado, southward to Texas and Florida.

Habitat: Dry, sandy soil ; cultivated erops, fields, waste places.

An unpleasant, woolly-hairy plant, closely related to the Rough Pigweed and nearly as troublesome, intruding in all sorts of crops and, by its long flowering season, compelling late tillage.

Stem rather slender, erect, one to three feet tall, with a few ascending branches near the base, or often simple, leafless near the top. Leaves opposite, rather thick, narrowly lance-shaped, sessile, or the lowermost ones somewhat spatulate and tapering to margined petioles, entire, downy on the under side. Flowers very small, perfect, three-bracted, on densely crowded spikes disposed oppositely in branching panicles; calyx densely woolly, tubular, five-toothed at the apex, and has irregular toothed wings

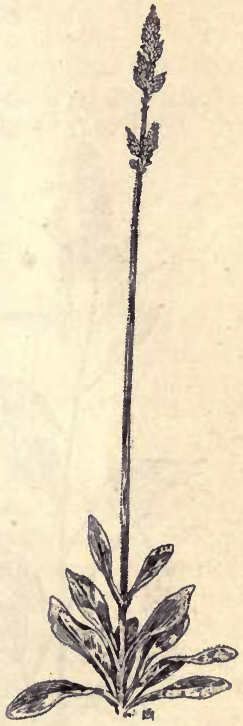

FIG. 80. - Frœlichia (Fralichia floridana). $\times \frac{1}{3}$. 
along its sides; the single seed inside is also enclosed within the tube formed by the united filaments of the five stamens. These woolly and crested seed envelopes are very light and blow easily before the wind. (Fig. 80.)

\section{Means of control}

After the use of the horse-hoe is impracticable, continue the tillage of infested crops in order to prevent the distribution of latematuring seeds. Plants on waste ground should be repeatedly cut in order to prevent contamination of adjacent land.

\section{POKEWEED OR POKEBERRY}

Phytolácca decándra, L.

Other English names: Virginia Poke, Scoke, Garget, Pigeon Berry, Ink Berry, Cancer Jalap, Redweed.

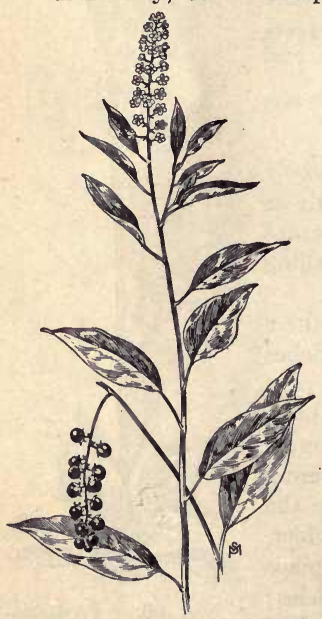

FIG. 81. - Pokeweed (Phytolacca decandra). $\times \frac{1}{6}$.
Native. Perennial. Propagates by seeds.

Time of bloom: July to September. Seed-time: Late August to November.

Range: Maine and Ontario to Minnesota, southward to Florida and Texas.

Habitat: Fence rows, thickets, and waste ground.

A very handsome plant, which has been carried to Europe and naturalized as an ornament in gardens. But when growing uncared for it is a dangerous weed; the root is very poisonous and the berries when eaten cause excessive nausea but are not emetic. Both root and berries are used in medicine, the drug market price for the root being two to five cents a pound and for the berries five cents a pound; the latter being carefully dried on the stems, when fully ripe, and the root collected in 
the fall when well stored with plant substance, cut in transverse slices, and dried.

Stems four to ten feet tall, stout, smooth, usually red or purplish. Leaves oblong lance-shaped, rather thick, smooth, deep green, entire, pointed at both ends, six inches to a foot long, with short petioles; they have an unpleasant odor when bruised. Flowers in terminal racemes, which by the further growth of the plant become lateral and opposite the leaves; calyx white, with five rounded sepals; stamens and styles ten. Fruit in drooping clusters, each blossom producing a juicy, dark purple berry, with ten carpels, each containing a single seed. (Fig. 81.)

\section{Means of control}

Grub out wholly, selling root and fruit to pay for the trouble if possible; or cut off below the crown and apply dry salt, carbolic acid or kerosene to the cut surface of the root.

\section{HEART-LEAVED UMBRELLA-WORT \\ Oxýbaphus nyctagineus, Sweet \\ (Alliònia nyctaginea, Michx.)}

Other English names: Wild Four o'clock. Umbrella Plant.

Native. Perennial. Propagates by seeds.

Time of bloom: May to August.

Seed-time: June to September.

Range: Manitoba to the Northwest Territory, southward to New Mexico, Texas, and Louisiana.

Habitat: Prairies; dry fields and meadows.

A native relative of the garden Four o'clock, and a very persistent weed, having a large, fleshy, deep-boring taproot which makes it a gross feeder and about as hard to dislodge as the Curled Dock. Stem one to three feet tall, angled, smooth or nearly so, branching by repeated forking. Leaves opposite, smooth, entire, two to four inches long, broadly ovate or heart-shaped, and all petioled except the uppermost pairs. Flowers in forking terminal clusters, the peduncles and pedicels all somewhat hairy; subtending each cluster of three to five flowers is a saucer-shaped or umbrellalike involucre, five-lobed, persistent, and enlarging as the flowers 


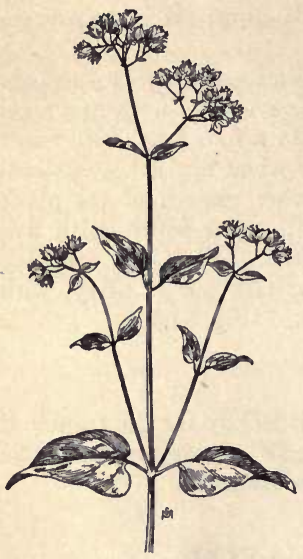

Fia. 82. - Heart-leaved Umbrella-wort (Oxybaphus nyctagineus). $\times \frac{1}{8}$. mature until it becomes nearly an inch broad, thin, and net-veined, acting as a parachute in the distribution of the seeds; each small blossom has a bellshaped five-lobed, red perianth, with three to five stamens and one style, both exserted. Ovary one-celled, the fruit a small, hard, achene-like, narrowly obovoid, ribbed, and hairy nutlet, possessed of long vitality. (Fig. 82.)

\section{Means of control}

Prevent seeding. Cultivation will cleanse infested fields of the perennial roots, but small areas newly contaminated should be hand-pulled when the ground is soft, or should be grubbed out, or cut close to the ground and the fleshy root-crowns treated with salt in order to prevent too swift a recovery.

\section{HAIRY UMBRELLA-WORT}

Oxýbaphus hirsùtus, Sweet

(Alliònia hirsùta, Pursh.)

Native. Perennial. Propagates by seeds.

Time of bloom: July to August.

Seed-time: August to September.

Range: Wisconsin to the Plains of the Saskatchewan, southward to Colorado and Texas. Locally in Ohio, New York, and Connecticut.

Habitat: Prairies; dry fields and meadows.

Even more resistant than the preceding species to summer's drought and winter's freezing. Stem one to three feet tall, erect, angled, ridged, sparingly branched, clothed with glandular jointed hairs, especially at the nodes, which are somewhat swollen. Leaves also hairy, oblong or narrowly lance-shaped, with prominent midvein, entire, sessile, or the lower ones very short-petioled. Flowers 
small, red, similar to the preceding species, but clustered on very short and hairy peduncles and pedicels, giving them a bunched appearance; involucres also hairy. Seed small, ovoid, hairy, with five obtuse ribs.

Means of control the same as for the preceding species.

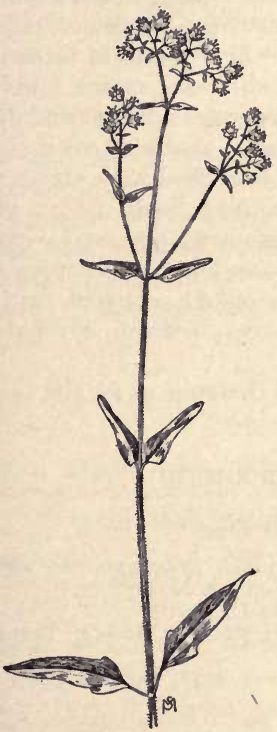

Frg. 83. - Hairy Umbrellawort (Oxybaphus hirsutus). $\times \frac{1}{8}$.

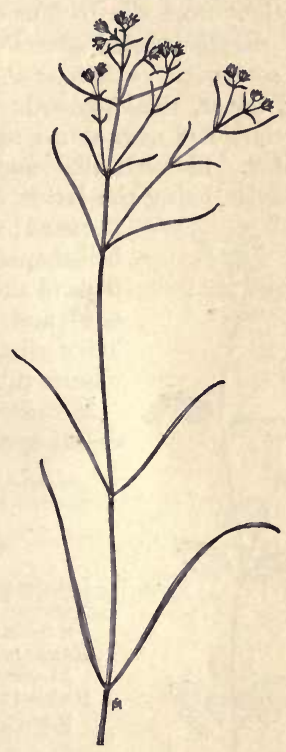

Fig. 84. - Narrow-leaved Umbrella-wort (Oxybaphus linearis). $\times \frac{1}{8}$.

\section{NARROW-LEAVED UMBRELLA-WORT}

Oxýbaphus linedris, Robinson

(Allionia linedris, Pursh.)

Native. Perennial. Propagates by seeds.

Time of bloom: June to August. 
Seed-time: July to September.

Range: Minnesota to Utah, southward to Mexico, Texas, and Missouri to the Carolinas.

Habitat: Prairies; dry, sandy fields and meadows.

Taller than either of the preceding species, the stem varying in height from one to four or more feet, erect, slender, round or only slightly angled near the base, smooth, glaucous, branching, and somewhat swollen at the nodes. Leaves one to three inches long, linear, thick, smooth, one-nerved, sessile or the lower ones short-petioled with obtuse tips, the upper ones distant and acutely pointed. Flower-stalks and involucres sparsely covered with glandular hairs, the latter obtusely five-lobed and about three-

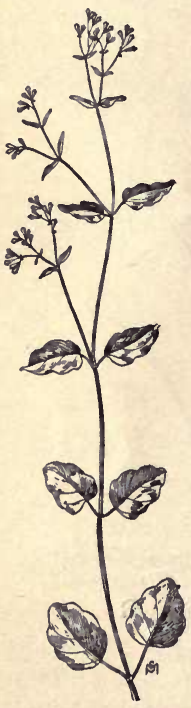

Fig. 85. - Hogweed (Boerhaavia erecta). $\times \frac{1}{3}$. flowered; perianth also finely hairy, purple, bell-shaped, with stamens and style exserted beyond the five obtuse lobes. Seed very small, hard and nut-like, oblong obovoid, with five hairy ribs, the spaces between covered with minute tubercles.

Means of control the same as for the two preceding species.

\section{HOGWEED}

Boerhadvia erécta, L.

Introduced. Annual. Propagates by seeds.

Time of bloom: June to November.

Seed-time: July to December.

Range: South Carolina to Florida, Texas, and Mexico.

Habitat: Cultivated erops, meadows, and waste places.

A native of tropical America now very common in the rich bottom lands of the Southern Seaboard and Gulf States. Stems one to three feet tall, smooth, diffusely branched from the base, spreading wider than its height. Leaves one to three inches long, opposite, ovate or sometimes heart-shaped, rather thick in texture, with slender petioles, scalloped or wavy edges, 
and whitened under-surface specked with minute black dots. Flowers very small, scarcely a twelfth of an inch broad, in clusters of two to six on very slender peduncles; calyx, funnelshaped, five-ribbed and five-lobed, white or purple; stamens five or fewer, exserted. The single seed is about an eighth of an inch long, shaped like a reversed pyramid, the sides strongly fiveridged, the top flat. When in the soil the seed retains its vitality for several years. (Fig. 85.)

\section{Means of control}

In cultivated ground, very thorough and continued tillage in order to prevent the distribution of late-maturing seeds. In meadows the hay should be harvested while the weed is in its first bloom, with repeated cuttings as the plants recover. But rankly infested fields require to be put under cultivation, which should be followed by heavy seeding with clover.

\section{KNAWEL}

\section{Scleránthus ánnuus, L.}

Other English name: German Knot-grass.

Introduced. Annual and winter annual. Propagates by seeds.

Time of bloom: March to October.

Seed-time: May to November.

Range: Eastern United States and Canada, from Quebec and Ontario to Florida. Locally as far inland as Ohio.

Habitat: Gardens, lawns, fields, meadows, and roadsides.

An inconspicuous but persistent little weed, as its season of bloom and fruit is both early and late and the seeds when undisturbed in the soil retain their vitality for several years.

Roots tough and fibrous, sending up a number of slender, light green, fork-branched stems, three to six inches long, usually roughhairy but sometimes smooth, some erect and some prostrate and spreading on all sides.

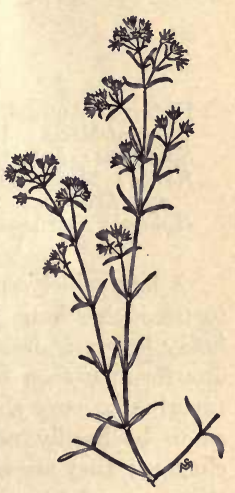

Fig. 86. - Knawel Scleranthus annuus). $\times \frac{3}{2}$. 
Leaves awl-shaped, opposite, with joined bases, and about a half-inch long. In their axils and at the ends of the stems are clustered the numerous minute greenish flowers; these have no petals, but have five or ten stamens, two distinct styles and a deeply cut five-lobed calyx (occasionally four-lobed) with a hardened, cup-like tube which later encloses and persistently holds the solitary seed. These hard seed-coverings - with their points broken off - are sometimes an impurity of grass and clover seeds. (Fig. 86.)

\section{Means of control}

Autumn plants should be destroyed by surface cultivation in early spring. Where such tillage is practicable, persistent hoecutting during the growing season will suppress the weed. In lawns a few drops of carbolic acid, squirted on the crowns with a machine oil-can, destroys the plants with less defacement of the sward than the hoe would make.

\section{FORKED CHICKWEED}

\section{Anýchia polygonoides, Raf.}

Native. Annual. Propagates by seeds.

Time of bloom: June to September.

Seed-time: July to October.

Range: Maine to Minnesota and southward to Florida, Alabama, and Arkansas.

Habitat: Gardens, lawns, fields, roadsides.

A low, widely spreading, nearly prostrate weed, the stems three to ten inches long, branching by many forkings; the whole plant finely hairy, at least when young. Leaves many and crowded, a quarter-inch to a half-inch long, narrowly lance-shape, sessile or tapering to very short petioles. Flowers greenish and so minute as to be hardly noticeable, sitting sessile in the forks in small clusters; they are without petals, but have a five-parted calyx, two stigmas, and two or three, occasionally five, stamens. Each blossom produces but one seed, the small, plump, globose utricle protruding beyond the calyx-lobes. 


\section{Means of control}

Prevent seed development by early and frequent hoe-cutting. Forked Chickweed, like Common Chickweed, may be killed with a spray of Iron sulfate or Copper sulfate if taken just before or during its first bloom, when it is most tender and more or less hairy.

\section{CARPETWEED}

\section{Mollùgo verticillàta, $\mathrm{L}$.}

Other English names: Indian Chickweed, Whorled Chickweed.

Native. Annual. Propagates by seeds.

Time of bloom: May to September.

Seed-time: June to October.

Range: New Brunswick to Ontario and Minnesota, southward to the Gulf of Mexico.

Habitat: Gardens, lawns, fields, roadsides, and waste places.

Like Purslane and Common Chickweed, this plant seems almost domesticated in its liking for cultivated fields and gardens. It is frequent along sandy roadsides, and springs up in the crevices of city pavements and sidewalks.

Stems three inches to a foot long, smooth, prostrate, branching in all directions from the slender root and forming circular mats. Leaves in whorls of five or six, spatulate, sessile, entire, a half-inch to an inch long. Flowers, axillary, very small and without petals but having a five-parted calyx, white inside and green without, three stigmas, and five stamens if they alternate with the sepals or three stamens if they alternate with the three cells of the ovary. Seed cap-

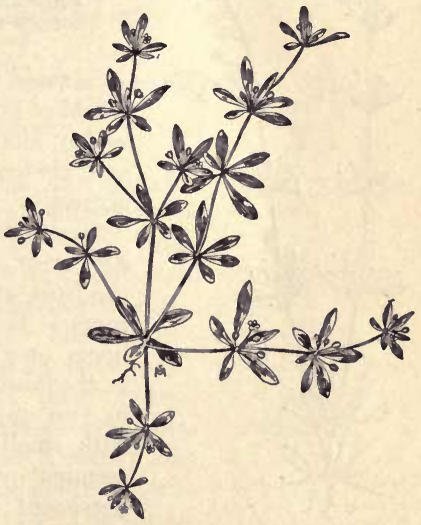

Fig. 87. - Carpetweed (Mollugo verticillata). $\times \frac{1}{3}$. 
sules ovoid, three-celled, and as soon as ripe the partitions break away from the central axes, spilling the many fine, brown, kidneyshaped seeds into the soil. (Fig. 87.)

\section{Means of control}

Prevent seed development by frequent hoe-cutting. After the harvesting of corn, potatoes, or other hoed crops, harrow the ground so as to destroy the later growth of weed seedlings.

\section{SPURRY}

Spérgula arvénsis, L.

Other English names: Corn Spurry, Sandweed, Pickpurse.

Introduced. Annual or winter annual. Propagates by seeds.

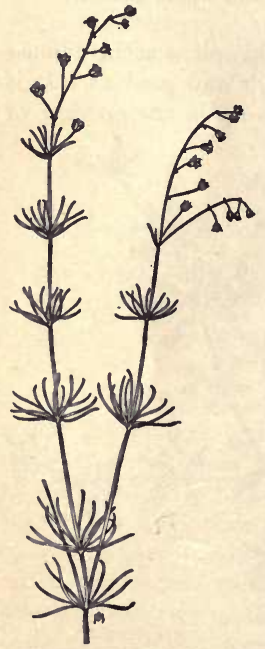

Fre. 88. - Corn Spurry (Spergula arvensis). $\times \frac{1}{4}$.
Time of bloom: June to August.

Seed-time: July to September.

Range: Throughout eastern United States and Canada.

Habitat: Cultivated ground; grain and clover fields. Prefers dry soil, and is sometimes grown on such land as a forage plant for sheep.

So rapid is the growth of this weed that a field of young turnips or carrots may be swiftly smothered by it; young grasses and clovers, too, sometimes find it too aggressive.

Stems six to eighteen inches tall, slender, erect, bright green, branching from the base, growing from slender, branching roots. Leaves one to two inches long, linear or awl-shaped, apparently whorled at the joints of the stem but really growing in two opposite clusters of six to eight, with small stipules between. Flowers in terminal cymes; calyx of five sepals, persistent; petals white and longer than the sepals, open only in sunshine; stamens five or ten; styles five. The thread-like 
pedicels droop as soon as the seed begins to form. Pod or capsule with five valves, which are opposite the sepals. Seeds many, dull black, small, round, flat, sharply margined, roughened with very minute pimples; they are a frequent impurity of grass and clover seed; also they possess long vitality when lying dormant in dry soil. (Fig. 88.)

\section{Means of control}

Prevent seed development. In some cases ground infested with Spurry may profitably be grazed off by sheep while the plants are young. Among crops in which hoe-cutting is impracticable, a fiveper-cent solution of Copper sulfate, applied when the plants are about half-grown or even when they are in first bloom, will prevent the formation of seed. Land fouled with seeds of Spurry should be put to a well-tilled hoed crop before being seeded with grain or clover.

\section{THYME-LEAVED SANDWORT}

Arendria serpyllifòlia, L.

Introduced. Annual. Propagates by seeds.

Time of bloom: May to August.

Seed-time: June to September.

Range: Throughout North America except the far North.

Habitat: Dry soil; waste places.

A very slender, much-branched, and spreading little plant. Not an aggressive weed but merely doing its best to cover dry and sterile soil, that is unsuited to plants of more worth. Stems two to eight inches high, light green, and rough-hairy. Leaves opposite, sessile, ovate, acute, hardly more than a quarter-inch long. Flowers many, very small, white, in leafy, cymose panicles; sepals five, lance-shaped, pointed, bristly on the back, about as long as the petals, which are also five, oblong or obovate. Stamens ten, with lilac anthers. Styles three. The

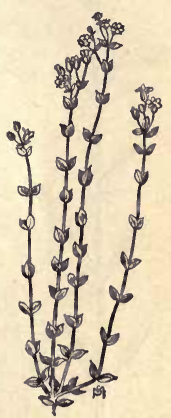

Fig. 89. - Thymeleaved Sandwort (Arenaria serpyllifolia). $\times \frac{1}{3}$. 
capsule is one-celled, shaped like a tiny flask, opening at the top by six outward-curving teeth. Seeds many, very small, compressed, rough. (Fig. 89.)

\section{Means of control}

Ground preferred by Sandwort is not fit to grow much else, until it has been enriched and supplied with humus, which will enable it to retain moisture; better plants will then soon take the place of the weed.

\section{GRASS-LEAVED STITCHWORT}

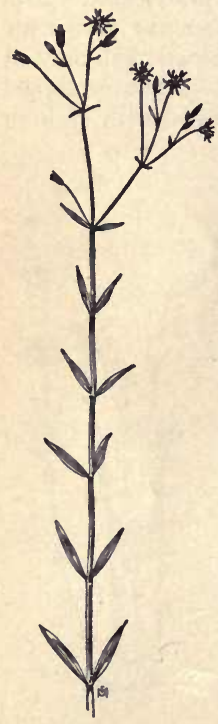

Fig. 90. - GrassJeaved Stitchwort (Stellaria graminea). $\times$ y.
Stelldria graminea, L.

(Alsine graminea, Britton)

Other English names : Lesser Stitchwort, Grassy Starwort.

Introduced. Perennial. Propagates by seeds and by rootstocks.

Time of bloom: May to July.

Seed-time: June to August.

Range: Nova Scotia, Quebec, and Ontario, southward to New Jersey and Pennsylvania.

Habitat: Fields, meadows, and roadsides.

Graceful plants, which are usually found growing in small patches, as the rootstocks send up flowering stalks at intervals of a few inches. Stems two inches to two feet high, slender, weak, four-angled, and roughened on the angles, simple below the flower-cluster. Leaves opposite, narrowly lance-shaped, broadest just above the base, the lower ones smaller than those near the top. Flowers in loose, terminal, many-branching cymes, on very slender, spreading pedicels; sepals narrow and pointed, slightly shorter than the five white petals, which are so deeply cleft as to look like ten, the blossoms being nearly a halfinch broad; stamens usually ten, sometimes fewer; styles usually three, occasionally four or five. Capsules oblong-ovoid, exceeding the 
sepals, opening by twice as many valves as there are styles. Seeds many, minutely roughened. (Fig. 90.)

\section{Means of control}

Close and frequent cutting for the purpose of starving the rootstocks and preventing seed production.

\section{COMMON CHICKWEED}

Stellària mèdia, Cyrill.

(Alsine mèdia, L.)

Other English names: Starwort, Starweed, Winterweed, Birdweed. Introduced. Annual. Propagates by seeds.

Time of bloom: Throughout the year.

Seed-time: Throughout the four seasons.

Range: Throughout the world.

Habitat: Gardens, cultivated fields, lawns, meadows, waste places.

In spite of its frail appearance, this plant is probably the hardiest and the most persistent weed on earth. Its range nears the Arctic Circle, and the writer picked green and thrifty stems, bearing buds, flowers, and seeds, within a yard of a melting snowbank, during a "January thaw" of the present winter. The seed, though small, retains its vitality for many years.

Stems tufted, slender, weak, manybranched, creeping or ascending, with a fringe of hairs down one side. Leaves usually not much more than a half-inch in length, ovate, smooth, entire, the lower ones with hairy petioles, the upper ones sessile, so numerous that the plant often covers the ground like a green mat. Flowers in terminal, leafy cymes or solitary in the axils, on very slender pedicels; each of the five small, snowy petals is cleft down its center, forming a white star, which is set within a larger green one, formed of

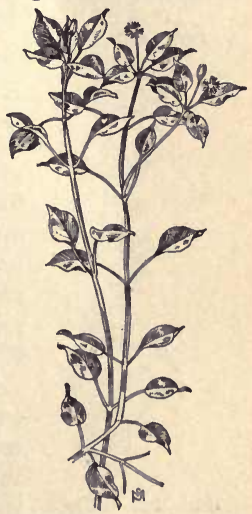

Fig. 91. - Common Chickweed (Stellaria media). $\times \frac{1}{2}$. 
five oblong, pointed hairy sepals, joined at their bases. Stamens three to seven and styles three or four. Capsule ovoid, longer than the calyx and opening at the apex by six or eight teeth, or twice as many as the styles. Seeds very numerous, round, brown, flattened, roughened with rows of small tubercles. (Fig. 91.)

\section{Means of control}

In gardens, constant hoeing or hand-weeding, while the plants are young, is necessary in order to suppress this weed; but among crops that will not be injured by the treatment, such as peas, strawberries, and grain. a spray of Iron sulfate will kill young Chickweed.

\section{FIELD MOUSE-EAR CHICKWEED}

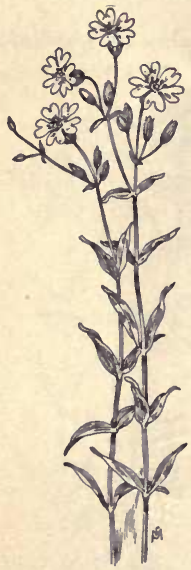

Fic. 92. - Field Mouse-ear Chick. weed (Cerastium arvense). $\times \frac{1}{3}$.
Cerástium arvénse, $\mathrm{L}$.

Native. Perennial. Propagates by seeds and by rootstocks.

Time of bloom: April to July.

Seed-time: May to August.

Range: Labrador to Alaska, southward to Georgia, Missouri, and California.

Habitat: Dry, rocky places, usually on hills in the southern part of its range, but in the North invading pastures and meadows.

A plant which is in many places cultivated for its beauty, the white, starry flowers being more than a half-inch broad, borne in graceful terminal clusters. But its creeping rootstocks make it difficult to keep within bounds, as every joint is capable of forming a new plant.

(Fig. 92.)

Stems densely tufted, erect, slender, downy or sometimes nearly smooth, four to ten inches tall, simple or with few branches. Leaves rather thick, linear oblong to lance-shaped or the lower ones somewhat spatulate. Sepals lanceshaped, the deeply notched white petals more than twice as long. Stamens ten or fewer; 
styles usually five, sometimes four or three. Capsules much exceeding the calyx and containing many small, roughened seeds which are released by the opening of ten pointed teeth at the apex. In the southern part of its range the plant dies down in summer, but makes a second growth in autumn and remains green through the winter.

\section{Means of control}

Where the plant takes possession of grasslands it is best to cleanse the ground with a short rotation of hoed crops. Small areas should be carefully grubbed out, and wayside patches prevented from spreading.

\section{COMMON MOUSE-EAR CHICKWEED}

Cerástium vulgatum, L.

Introduced. Perennial. Propagates by seeds. Time of bloom: May to September.

Seed-time: June to October.

Range: Throughout North America except the extreme North.

Habitat: Fields, meadows, yards, roadsides, and waste places.

Stems tufted, some prostrate, others erect or ascending, six inches to a foot or more in length, dark green, and clammy-hairy. Basal and lower leaves oblong-spatulate, obtuse; upper ones usually oblong, sometimes lanceshaped, a half-inch to an inch long, not at all resembling the ears of a mouse. Flowers in loose cymose clusters, the central one solitary and always the oldest; usually but one flower in a cluster is open at a time; the five white petals are cleft at the tip and are longer than the somewhat obtuse, hairy sepals; styles always five, and stamens ten. Seed capsule slenderly ovoid, faintly ridged, slightly curved upward, opening through ten pointed teeth

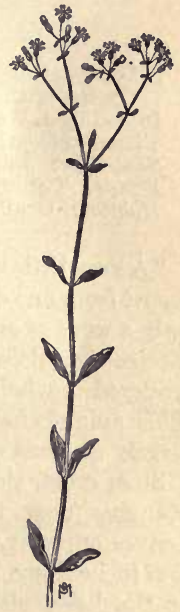

Fig. 93. - Common Mouse-ear Chickweed (Cerastium vulgatum). 
at its summit. Seeds very numerous, brown and rough. (Fig. 93.)

\section{Means of control}

In cultivated ground this weed is not very troublesome, as its spreading, rather shallow-growing roots are readily destroyed by the required tillage. In grain fields its spreading habit makes it obnoxious, as it appropriates more food and moisture than the crop can afford. Here it can be killed when young, or so checked in growth as to prevent seed development, by a spray of Iron sulfate, though it is not so sensitive to that treatment as is the garden Chickweed.

\section{PURPLE COCKLE}

Agrostémma Githàgo, L.

(Lýchnis Githàgo, Scop.)

Other English names: Corn Cockle, Corn Rose, Corn Campion, Crown of the Field, Mullein Pink.

Introduced. Annual and winter annual. Propagates by seeds.

Time of bloom: Late May to July.

Seed-time: July to August.

Range: Throughout the world, wherever grain is grown.

Habitat: Grain fields, roadsides, and waste places.

"A very little Cockle is sufficient to cut the grade," says a market report from one of the wheat-growing states. The plant is particularly a weed of grain fields, and it is there because it is sown there. The seed is poisonous, and when ground with wheat the flour is rendered unwholesome and even dangerous as food. Poultry and other animals have been killed when fed with screenings composed largely of seeds of Cockle. (Fig. 94.)

Stem erect, slender, one to three feet tall, simple or with a few branches near the top, clothed with whitish, appressed hairs. Leaves opposite, a character common to the Pink Family; two to four inches long, lance-shaped to linear, the lowest slightly narrowed at the base, all softly hairy. Flowers terminal on long, hairy peduncles, often an inch and a half broad, with five spreading, reddish purple petals, which are slightly notched at the outer edge and dark-spotted near the claw ; calyx ovoid, hairy, and strongly 
ten-ribbed, with five long, pointed lobes extending beyond the petals; styles five, opposite the petals; stamens ten. Capsule ovoid, one-celled, sometimes exceeding a half-inch in length, and containing twenty-five to forty black or very dark brown seeds, rounded triangular in shape and roughened with rows of short teeth; the size and weight of the seeds make them very difficult to remove from grain among which they are mixed. When in the soil they retain their vitality for several years.

\section{Means of control}

Sow clean seed. When Cockle is first discovered among the grain, hand-pull and destroy the plants before any seed matures. If a field is too rankly infested for handpulling, an application of Copper sulfate or Iron sulfate spray will so injure the tissues of leaf and flower as to prevent the development of seed. Ground where Cockle seed has ripened and been distributed should not be used for grain again until after some cultivated crop has been given a place in the rotation.

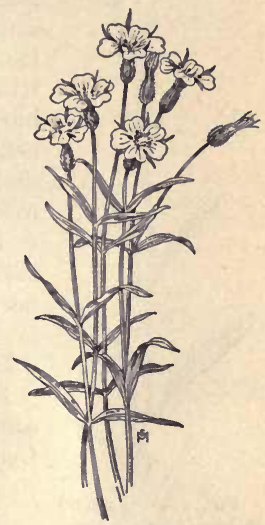

Frg. 94. - Corn Cockle (Agrostemma Githago). $\times \frac{1}{3}$.

\section{RAGGED ROBIN}

Lýchnis Flos-cùculi, L.

Other English names: Meadow Pink, Meadow Campion, Cuckoo Flower.

Introduced. Perennial. Propagates by seeds.

Time of bloom: June to August.

Seed-time: July to September.

Range: New Brunswick to New Jersey, and westward to Ohio.

Habitat: Moist soil; meadows and waste places.

An escape from flower gardens, and a pernicious weed wherever established because of its perennial roots. Its seeds are said to have some of the same poisonous properties as those of its relative the Corn Cockle, but not to so dangerous an extent. (Fig. 95.) 


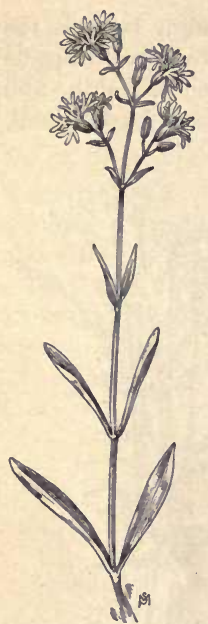

FIG. 95. - Ragged Robin (Lychnis Floscuculi).

Stem one to two feet tall, erect, slender, branching near the top, downy-hairy below, somewhat clammy above. Basal and lower leaves spatulate, tapering to a margined petiole; upper leaves sessile, few, becoming very small as they ascend the stalk. Flowers in loose, spreading panicles; those of plants cultivated in gardens usually pink, white or blue, but those of the wild plant usually magenta-red, nearly an inch broad, each of the five petals divided into four slender lobes, the middle pair of lobes being longest, causing the flower to have a ragged, fringy look; calyx short, tennerved, smooth. Capsule nearly globular, onecelled, many-seeded.

Means of control the same as for the Corn Cockle.

\section{RED CAMPION}

Lýchnis dioica, $\mathrm{L}$.

Introduced. Biennial. Propagates by seeds. Time of bloom: June to September.

Seed-time: July to October.

Range: Nova Scotia, Ontario, New England, and the Middle States.

Habitat: Grain fields, meadows, roadsides, and waste places.

Stems one to two feet tall, erect, clammyhairy particularly just below the swollen joints, branching near the top. Basal leaves oblong, pointed, long-petioled; stem-leaves sessile or the lower ones with short petioles, ovate, acute. Flowers in cymose clusters, each nearly an inch broad, diœcious, without

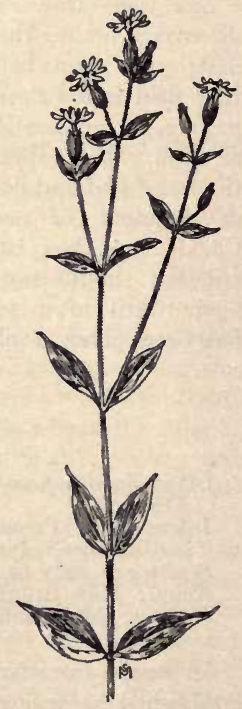

Fig. 96.- - Red Campion (Lychnis dioica). $\times \frac{1}{4}$. 
fragrance, and open in the daytime; petals deeply notched, red, or often nearly white; calyx on staminate plants tubular but on fertile plants becoming nearly globular, the teeth short and acute. Capsules large, one-celled, many-seeded. (Fig. 96.)

Means of control the same as for White Cockle.

\section{WHITE COCKLE}

Lýchnis álba, Mill

(Lýchnis vespertina, Sib.)

Other English names: Evening Lychnis, White Campion.

Introduced. Biennial. Propagates by seeds.

Time of bloom: Late June to September.

Seed-time: August to October.

Range: Eastern and middle United States and Canada.

Habitat: Grain fields, meadows, and waste places.

This plant develops a thick, fleshy root, from which it sends up several slender, branching stems, one to two feet in height, somewhat hairy and viscid. Leaves long ovate to lance-shaped, the lower ones tapering to margined petioles, the upper ones smaller, acute, and sessile. Flowers in loose panicles, usually diœcious, numerous, white or often tinged with pink, fragrant, each about an inch broad, opening in the evening and closing after sunrise the next day; each of the five petals is deeply notched at the outer edge, and at the inner point is a pair of white, scale-like bracts, narrowing the throat of the flower which is fertilized by long-tongued, night-flying moths. Sterile flowers have usually ten stamens. Calyx of the fertile flowers much inflated, crimson-tinged along the hairy ribs. Styles five. Capsules one-

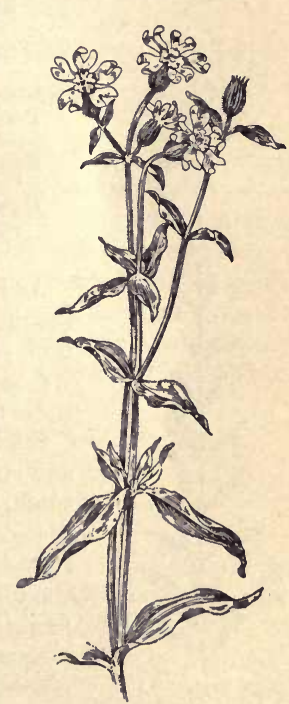

FIs. 97. - White Cockle (Lychnis alba). $\times \frac{1}{3}$. 
celled large, ovoid, with ten inbent valves at the apex which curve outward when ripe and from which the seeds are shaken out as the winds sway the stems; seeds very abundant, small, grayish brown, beaded with fine tubercles; too frequent an impurity among those of grain, grass, and clover. (Fig. 97.)

\section{Means of control}

Prevent seed production by close cutting or hand-pulling at the time of first bloom. Meadows and grain fields where the plants have been permitted to distribute seed should be broken up and given a short rotation of cultivated crops before reseeding.

\section{SLEEPY CATCHFLY}

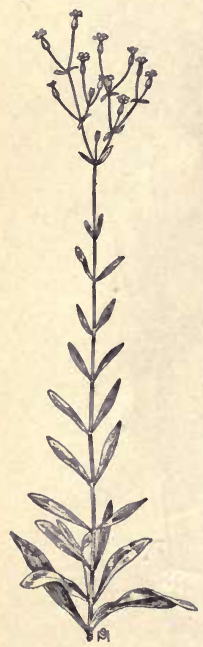

Fig. 98. - Sleepy Catchfly (Silene antirrhina). $\times \frac{1}{3}$.

\section{Silène antirrhina, L.}

Native. Annual. Propagates by seeds.

Time of bloom: June to September.

Seed-time: Late July to Oetober.

Range: Ontario and New England to British Columbia, southward to Florida and Mexico.

Habitat: Dry meadows, waste places, open woods.

An inconspicuous plant because of its habit of keeping its flowers closed except for a very short time each day while the sun shines brightest. Its seeds, however, are often found among those of grass and clover.

Stem eight inches to two feet high, slender and glutinous below the swollen joints. Leaves small, the lower ones about two inches long, spatulate, narrowing to a margined petiole; stem-leaves narrow and sessile, reduced near the top to awl-like bracts. Flowers in a cymose panicle on very slender pedicels, each less than a quarter-inch broad, the five pink petals notched; styles three, rarely four; stamens ten. Capsule ovoid, opening by three or six teeth at the apex, one-celled or imperfectly 
three-celled at base, a characteristic of all the Silenes; the seed is small and dark brown. (Fig. 98.)

\section{Means of control}

Hay should be cut from infested meadows before the seed matures and falls into the soil. It is better that there should be some present loss if thereby the ground is made comparatively clean for the next crop.

\section{FORKED OR HAIRY CATCHFLY}

Silène dichótoma, Ehrh.

Introduced. Annual and winter annual. Propagates by seeds.

Time of bloom: July to September.

Seed-time: August to October.

Range: Eastern United States, Maine to Texas; also on the Pacific Slope.

Habitat: Clover fields, meadows, and waste places.

A special pest in clover fields. Stem erect, hairy, one to three feet tall, branching by forking. Lower leaves petioled, two or three inches long, pointed at both ends, the lowermost tapering to hairy petioles; stem-leaves sessile, becoming mere pointed bracts near the top. Flowers in forking, one-sided spikes, sessile or on very short pedicels; petals five, pale pink or white, deeply cleft; styles three, exserted; stamens ten ; calyx about a half-inch long, five-ribbed, very hairy, short-toothed. Capsule many-seeded, oblong ovoid, opening at apex by three or six teeth.

Means of control the same as for the Sleepy Catchfly.

\section{NIGHT-FLOWERING CATCHFLY}

Silène noctifldra, L.

Other English names: Clammy Cockle, Sticky Cockle.

Introduced. Annual and winter annual. Propagates by seeds.

Time of bloom: June to September.

Seed-time: July to October.

Range: Nova Scotia to Manitoba, southward to Florida and Missouri.

Habitat: Cultivated ground; clover and alfalfa fields, meadows, and waste places. 
First cultivated in gardens because of its fragrance and beauty, but now a widespread pest. Stem one to three feet tall, erect, rather stout, branching, covered with glandular, viscid hairs. Basal and lower leaves three to five inches long, spatulate, narrowing to margined petioles; upper leaves sessile, often uniting

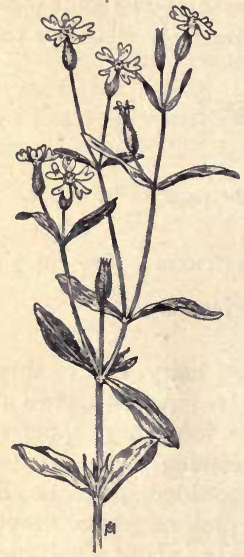

Fig. 99. - Night-flowering Catchfly (Silene noctiflora). $\times \frac{1}{4}$.

well below the crown. Rankly infested fields should be broken up and put under cultivation for a season.

\section{BLADDER CAMPION}

Silène latifolia, Britten and Rendle

(Silène inflata, Sm.)

Other English names: White Bottle, Cow-bell, Bubble Poppy, Spattling, Behen.

Introduced. Perennial. Propagates by seeds and by rootstocks. Time of bloom: Late May to August.

Seed-time: July to October. 
Range: New Brunswick and Ontario southward to New Jersey, Illinois, and Iowa.

Habitat: Moist soil ; fields, meadows, roadsides, and waste places.

A beautiful flower, but also a very pernicious weed. Stems thickly tufted, six inches to two feet in height, pale green, smooth and glaucous; some stems of each tuft are flowerless but bear many leaves that assimilate food for storage in the rootstocks.

Leaves rather thick in texture and glaucous, obiong, pointed, the upper ones often meeting around the stems, the lower ones usually spatulate, narrowing to margined petioles. Flowers in loose, open panicles, on slender pedicels, white, drooping, each blossom about a half-inch broad, the five petals deeply cleft, and ten long stamens out-thrust, tipped with brown anthers; styles three; calyx pale green, very much inflated, beautifully veined, sometimes with pinkish purple, sometimes with markings of deeper green. Capsule broadly ovoid, opening with five recurved teeth. Seed rounded kidneyshaped, brown, roughened with fine tubercles. (Fig. 100.)

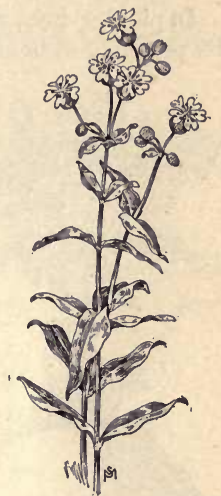

Fig. 100. - Bladder Campion (Silene latifolia). $\times \frac{1}{8}$.

\section{Means of control}

Prevent seed production. Cut the stalks from the roots well below the crowns, with hoe, spud, or broad-bladed cultivator, so frequently that little or no sustenance may be given the creeping rootstocks. If the infested ground is in meadow it should be broken up and put to cultivated crops, well tilled for two or more seasons.

\section{BOUNCING BET}

Sapond̀ria officinàlis, L.

Other English names: Soapwort, Scourwort, Fuller's Herb, Old Maid's Pink, Hedge Pink, Sweet Betty, Wild Sweet William, Lady-by-the-Gate, London Pride. 
Introduced. Perennial. Propagates by seeds and by rootstocks.

Time of bloom: July to September.

Seed-time: Late August to November.

Range: Throughout eastern North America.

Habitat: Along roadsides and railways; in old pastures and on waste ground.

In pioneer days, when the art of soap-making had not approached its present excellence, housewives knew that fine woolens and silks

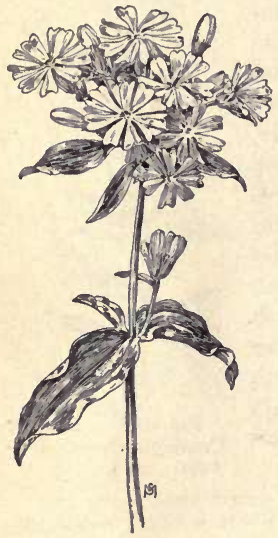

Fig. 101. - Bouncing Bet (Saponaria officinalis). $\times \frac{1}{3}$. could be well cleansed with a slippery, sudsy solution made by bruising the mucilaginous stems and leaves or young rootstocks of this plant in water. For this purpose a patch of it was kept handy, and hence its names Soapwort and Fuller's Herb. The cylindrical roots - not the stolons - are used in medicine, and are worth five to ten cents a pound in the drug market when collected in late autumn or early spring, carefully cleansed, and dried. (Fig. 101.)

Stems in tufts, one to two feet tall, stout and smooth, with swollen joints. Leaves opposite, long ovate, threenerved, pointed, rather thick, smooth, sessile or with short, broad petioles. Flowers pink, usually double, in large, dense, terminal, corymbose clusters; calyx tubular, five-toothed; stamens ten; styles two; Ovary one-celled or sometimes incompletely two- or four-celled. Capsule oblong, conic, opening by four short teeth at apex. Seeds rough, dark slate-color or dull black, shortened kidney-shaped; they contain a poisonous property called saponin, like that which makes dangerous the seeds of the related Cow Cockle and Corn Cockle.

\section{Means of control}

If the patches are small, grubbing out is the best remedy. Caustic soda or hot brine is effectual, but the ground will be barren until 
the chemicals have leached away. Constant cutting of the green tops will finally starve the rootstocks, if continued without cessation for two seasons.

\section{COW COCKLE}

Sapondria Vaccària, L.

Other English names: Cow-herb, Spring Cockle, Pink Cockle, China Cockle.

Introduced. Annual. Propagates by seeds.

Time of bloom: June to July.

Seed-time: July to August.

Range: Ontario to British Columbia, southward to the Gulf of Mexico. Locally very abundant, especially in the wheat-growing parts of the West.

Habitat: Grain and alfalfa fields, waste places.

An immigrant from Europe, where it is said to have been formerly used as a forage plant, the specific name, Vaccaria, having been given in allusion to its value as cow fodder. But it is listed among the "StockPoisoning Plants of Montana," in the bulletin of that name published by the United States Department of Agriculture, and its seeds, like those of Corn Cockle, contain a poisonous property that makes flour unwholesome and dangerous to use when by accident they are ground with wheat. Grain contaminated with these seeds is sharply "cut" in the market. (Fig. 102.)

Stem one to three feet tall, erect, slender, smooth, glaucous, round, and swollen at the joints, many-branched. Leaves long ovate, pointed, smooth and glaucous, opposite and clasping the stem, the pairs sometimes united at base. Flowers in loose corymbose clusters, on rather long, wiry pedicels ; calyx a swelling, five-ribbed vase in two shades of green, the ribs darker and so promi-

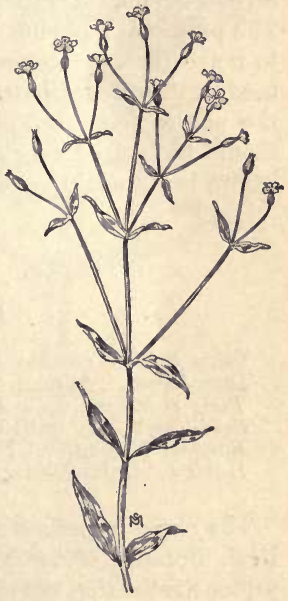

Fig. 102. - Cow Cockle (Saponaria Vaccaria). $\times \frac{1}{4}$. 
nent as to be angled wings; the five petals pink, veined with deeper pink, notched at the outer edge ; stamens ten; styles two. Capsule ovoid, four-toothed, imperfectly two- to four-celled, containing twenty to thirty hard, nearly globular, black seeds, about a tenth of an inch in diameter. These seeds retain their vitality for several years when buried in the soil.

\section{Means of control}

Sow clean seed. A Montana miller stated that the quantity of Cow Cockle seed cleansed yearly from the wheat brought to his mill, and supposed to be already clean, was about a ton. Seed should be made as clean to sow in one's fields as to be eaten in bread. Raking the grain fields with a weeding harrow when the crop is but a few inches high will kill very many of the Cockle seedlings; those not killed by the harrow should be hand-pulled at the time of their earliest bloom, when they show very conspicuously among the grain. The process is a paying one, even though the weeds are so many as to make the task somewhat strenuous, for the food and moisture used in their development is stolen from the rightful crop, which is the poorer for it. Stubbles where the weed has matured seed should be burned over and the ground used for a cultivated crop before being again seeded to grain.

\section{PURSLANE}

\section{Portuláca oleràcea, L.}

Other English names: Pussley, Wild Portulaca, Duckweed.

Introduced. Annual. Propagates by seeds.

Time of bloom: Late June until cut off by frost.

Seed-time: July until killed by frost.

Range: Throughout North America except the northern part. Habitat: Cultivated ground, waste places.

The noted experiments with buried seeds, conducted by W. J. Beal, Botanist of the Michigan Agricultural Experiment Station, demonstrated that the seeds of Purslane will germinate after having lain dormant in the soil for thirty years. Few gardens are without the weed. It is said to harbor both the melon plant louse and 
the corn root louse; also it is sometimes attacked by a white mold, which may make it a menace to better plants.

Stems four inches to more than a foot in length, prostrate, thick, round, smooth, succulent, branching on all sides from the central root and again often forking. Leaves, alternate, obovate or wedgeshaped, with rounded tips, very small, thick, and fleshy, mostly clustered at the ends of the branches. Both stems and leaves often have a reddish tinge. Flowers solitary, sessile, about a quarter-inch broad, opening only in the brightest sunshine; sepals two, broad, pointed, keeled; four to six - mostly five - broadly rounded yellow petals, soon falling away; stamens seven to twelve; style five- or six-parted. Capsule urn-shaped, one-celled, membranous, many-seeded, opening transversely and the top falling off like a lid; when near maturity, the plants can hardly be touched without sowing these seeds by hundreds. The weed is most tenacious of life, often readjusting itself after having been torn up bodily, the fleshy stems, and leaves sustaining it while doing so, if not placed where the feat is impossible. (Fig. 103.)

\section{Means of control}

Killing while in the seedling stage by constant shallow hoeing is the only way of vanquishing this weed. If old enough for seed-

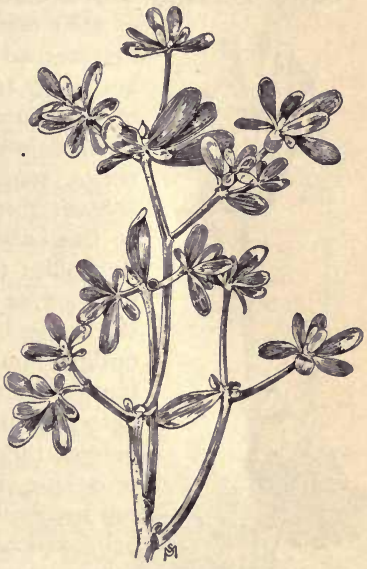

Fia. 103. - Purslane (Portulaca oleracea). $\times \frac{1}{3}$. cones to begin to form, plants should be removed from the soil, for the stems and roots retain life enough to ripen and distribute seed. Pigs are very fond of Purslane, and one of those greedy animals will dispose of a considerable crop. Or the plants may be thrown on a compostheap, wherefermentation will destroy the vitality of the seeds. 


\section{CURSED CROWFOOT}

\section{Ranúnculus sceleràtus, L.}

Other English names: Celery-leaved Crowfoot, Ditch Crowfoot, Bog Buttercup.

Native. Annual. Propagates by seeds.

Time of bloom: May to August.

Seed-time: June to October.

Range: New Brunswick to Minnesota, southward to Florida; also in the Rocky Mountains, Colorado, and Utah. Native to Europe and Asia.

Habitat: Wet meadows, low pastures, along ditches and in bogs.

Cattle ordinarily are careful to reject all Buttercups, because

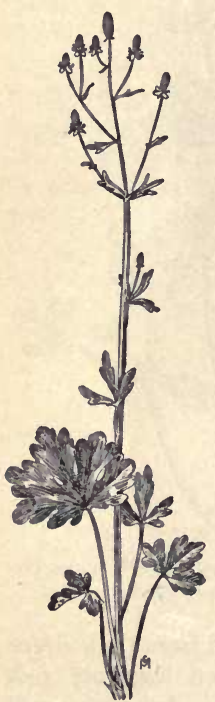

Frg. 104. - Cursed Crowfoot (Ranunculus sceleratus). $\times \frac{1}{8}$. of their acrid and poisonous juices, but when first turned out to grass in the spring they are likely to graze so eagerly as to get some of the young leaves of this one, which causes an inflammation of mouths and digestive tracts, sometimes so severe as to be fatal.

Stem stout, sometimes over an inch thick at the base, smooth, hollow, much-branched, six inches to two feet in height. The alternate leaves are also very smooth and rather thick, the basal ones rounded heart-shape in outline, but deeply three- to five-lobed, bluntly toothed or entire, with long, broad, flattened petioles; stem-leaves also threeparted, but the lobes are more slender, approaching to wedge-shape, those near the top becoming linear. Flowers small, the five pale yellow petals scarcely exceeding the calyx; stamens and styles numerous. Ranunculus fruits are composed of many oneseeded carpels tipped by more or less elongated styles; in this species the heads are oblong, the length nearly thrice the thickness, each one closely set with many minute, short-beaked carpels, each containing one oval, flattened, dull brown seed. 


\section{Means of control}

Cut or pull while in early bloom in order that no seeds shall be allowed to ripen.

\section{SMALL-FLOWERED CROWFOOT}

Ranúnculus abortivus, L.

Other English names: Abortive Buttercup, Kidney-leaved Crowfoot. Native. Biennial. Propagates by seeds.

Time of bloom: Late April to August.

Seed-time: June to September.

Range: Labrador to Manitoba, southward to Florida and Texas.

Habitat: Moist soil ; meadows, lawns, and cultivated ground, particularly strawberry fields.

This plant is readily identified by the great difference between its root leaves and stem-leaves; the basal leaves being thick of texture, bright green, rounded heart-shaped or kidney-shaped, with scalloped edges and long petioles ; the stem-leaves, three- to fiveparted, with wedge-shaped or linear segments, the lowermost with short petioles, those near the top sessile; all are smooth, as is also the stem, which is erect, slender, many-branched, six to eighteen inches tall. Flowers numerous but very small, the pale yellow petals being hardly noticeable and shorter than the reflexed sepals. The small seed-head is globose, the carpels minute, tipped with a mere bristly point. (Fig. 105.)

\section{Means of control}

Better drainage; for this Crowfoot is a plant that demands moisture. Early cutting with hoe or spud in order that no seed may be permitted to develop.

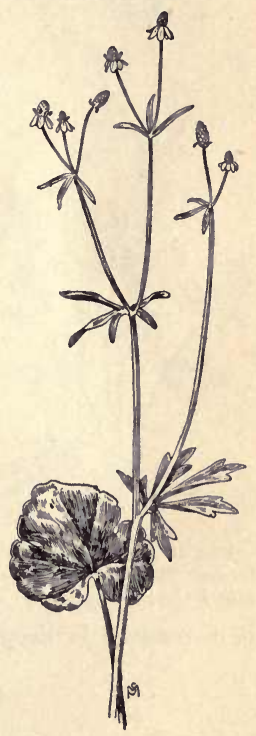

Fig. 105. - Smallflowered Crowfoot ( $R a-$ nunculus abortivus). $\times \frac{1}{3}$. 


\section{EARLY BUTTERCUP}

\section{Ranúnculus fasciculàris, Muhl.}

Other English names: Early Crowfoot, Tufted buttercup.

Native. Perennial. Propagates by seeds.

Time of bloom: April to May.

Seed-time: Late May to July.

Range: New England and Ontario to Manitoba, southward to the

Carolinas, Texas, and Arkansas.

Habitat: Hillsides; upland fields and pastures.

The earliest of the Buttercups ; it springs from a tuft or bundle of roots, which look as though meant to be fibrous but are thickened

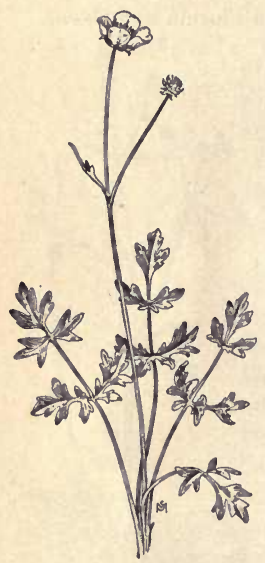

Fig. 106. - Early Buttercup (Ranunculus fascicularis). $\times \frac{1}{3}$. best remedy is deep hoe-cutting in the first days of bloom.

\section{CREEPING BUTTERCUP}

Ranuinculus rèpens, $\mathrm{L}$.

Native and introduced. Perennial. Propagates by seeds and by stolons.

Time of bloom: May to July. 
Seed-time: Late June to August.

Range: Nova Scotia to Virginia. On the Atlantic Coast an immigrant from Europe, but several varieties are native in the West and the South.

Habitat: Moist meadows and pastures, roadsides, waste places.

Where this plant is plentiful it is likely to monopolize a large amount of space; for after the early bloom is past its energies are devoted, for the remainder of the growing season, to throwing out numerous slender runners, one to three feet long, from every joint of which a young plant may take root. The roots are fibrous and tufted; the stem is about a foot high, and hairy, but of ten only slightly so; the runners also are usually hairy at the base, the leaves on veins and petioles. Leaves three-parted, all three segments usually, and the terminal one always, with a footstalk; all irregularly cut and toothed, often blotched with white. Flowers bright golden yellow, nearly an inch broad, the petals obovate, much longer than the spreading sepals. Fruits in globose heads, the achenes flattened and having a thin margin and a stout, bent beak. (Fig. 107.)

\section{Means of control}

Its manner of growth causes the weed

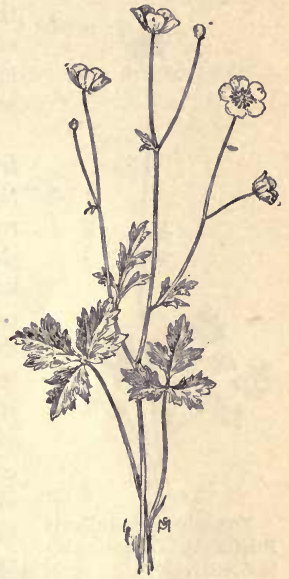

Fra. 107. - Creeping Buttercup (Ranunculus repens). $\times \frac{1}{3}$. to form patches, which, if not too many and too large, may be cleaned out with the hoe, of course before the first seed is developed. Ground too rankly overspread to be so-cleansed should be put under cultivation for a season.

\section{- BULBOUS BUTTERCUP}

Ranúnculus bulbdsus, L.

Introduced. Perennial. Propagates by seeds.

Time of bloom: May to July.

Seed-time: July to Oetober. 
Range: Throughout the United States and southern Canada, but most abundant in the eastern part.

Habitat: Meadows, pastures, roadsides, and waste places.

The range of this weed has of late years greatly increased, mostly by the agency of baled hay. It is one of the most acrid of its tribe, the juices causing blisters when applied to the skin, and cattle cannot eat it in the green state; but drying seems to deprive it of

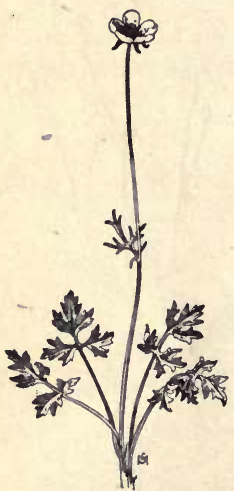

Frg. 108. - Bulbous Buttercup (Ranunculus bulbosus). $\times \frac{1}{4}$. this dangerous quality, and therefore less strenuous endeavor is made for its extermination than is deserved by so noxious a weed.

The bulbous base of this plant is well fringed with long, fibrous, feeding roots. Several stems usually grow from the same root-tuft, six to eighteen inches high, erect, slender, more or less branched, grooved and hairy. Lower leaves long-petioled, threeparted, with the segments again usually three-cleft, sharply toothed, the terminal segment having a somewhat lengthened stalk. Stem-leaves much smaller, less divided and sessile. Flowers bright yellow, so lustrous that they reflect light, about an inch broad, the petals much longer than the hairy, reflexed sepals; the blossoms are often partly double, the peduncles slender and grooved. Head globose, containing many small flattened, short-beaked carpels, so nearly of the size and weight of grass seeds that they are very difficult of separation. (Fig. 108.)

\section{Means of control}

Hand-digging will pay if the infestation is new and the plants not so numerous as to make the task impracticable; but it is worth considerable trouble to save a plot from being fouled by the seeds. Ground too rankly infested to be so cleansed should be broken up, put to cultivated crops, and be given thorough tillage for one or two seasons. 


\section{MEADOW BUTTERCUP}

Ranúnculus dcris, L.

Other English names: Tall Crowfoot, Butter Flower, Blister Flower, Goldeup, Kingeup.

Introduced. Perennial. Propagates by seeds.

Time of bloom: May to September.

Seed-time: June to October.

Range: Throughout the United States and Canada; most common and troublesome at the North.

Habitat: Meadows, pastures, roadsides, and waste places.

The juices of this weed are so acrid as to draw blisters when applied to the skin. Grazing cattle seem to know its character and shun the plant. This irritant quality is dispelled in drying, however, and, though as hay the plant is woody and innutritious, it will not then injure the mouths and intestines of animals that eat it.

Stem two to three feet tall, springing from clustered and fibrous roots, erect, hollow, hairy, branched at top. Basal leaves tufted, three- to seven-parted, the divisions again cleft into several narrow, pointed lobes; petioles long, slender, and hairy; upper leaves short-petioled, distant, usually three-parted. Flowers bright yellow, nearly an inch broad, the five petals broadly obovate, much longer than the spreading calyx. Fruits in small, globose heads, the achenes somewhat compressed, and with shortpointed beaks. (Fig. 109.)

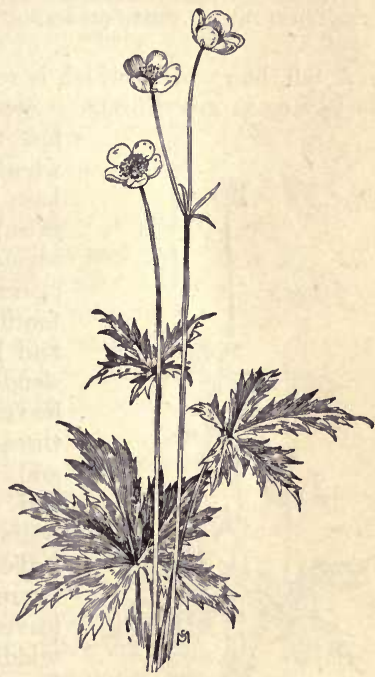

Fig. 109. - Meadow Buttercup (Ranunculus acris). $\times \frac{1}{2}$.

Means of control

Where the plants are few, pulling and hoe-cutting will repay the labor; but grass lands too rankly cursed with Ranunculus should 
be broken up and put to cultivated crops, and well fertilized and tilled for a year or two before being reseeded heavily with clean seed.

\section{THIMBLEWEED}

Anemdne virginidna, $\mathrm{L}$.

Other English names: Tall Anemone, Virginia Anemone.

Native. Perennial. Propagates by seeds.

Time of bloom: June to August.

Seed-time: July to September.

Range: Nova Scotia and Maine to Manitoba and Minnesota, southward to the Carolinas and Kansas.

Habitat: Upland meadows and pastures, borders of woods, and fence rows; waste places.

A tall, hairy plant which is rejected by grazing animals, either as hay or as green forage. Stem two to three feet high, with a

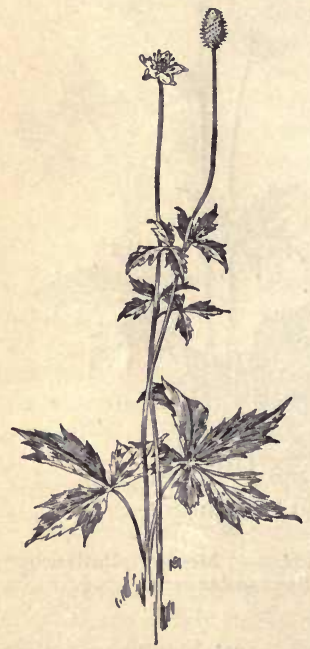

Fig. 110. - Thimbleweed (Anemone virginiana). $\times \frac{1}{4}$. few tufted leaves at its base and a whorl of three involucral leaves at the base of its flower-stalks. Base-leaves broader than long, three-parted, the segments broadly wedge-shaped and again cut into pointed and sharply toothed lobes; they are softly hairy and have prominent veins and long, slender petioles. The three involucral leaves have short petioles and are also three-parted, the lateral segments twice and the middle one thrice divided, and sharply toothed. If the plant bears but one flower, its peduncle is leafless, but usually there are several lateral stalks and these have a twoleaved, short-petioled involucel at the middle. Flowers a half-inch to an inch broad, without petals but having five greenish white sepals surrounding a thick central tuft of many yellow stamens and awl-shaped styles. Seedheads oblong, cylindric, about three- 
fourths of an inch long and half as thick; achenes flattened, pointed by the withered styles, and densely woolly, which makes them easy to be distributed by the wind. (Fig. 110.)

\section{Means of control}

Prevent formation of seed by cutting or pulling while in early bloom. Cultivation of the ground at once destroys the weed.

\section{FIELD LARKSPUR}

\section{Delphinium Consólida, L.}

Other English names: Knight's Spur, Lark-heel. Introduced. Annual. Propagates by seeds. Time of bloom: June to August.

Seed-time: July to September.

Range: New Jersey, Pennsylvania, and Ohio, southward to Florida; locally in the Northern States.

Habitat: Fields, roadsides, and waste places.

A lovely plant, both in leaf and flower, brought to this country to beautify our gardens and growing wild as an "escape." In Europe its leaves are reputed to be poisonous to cattle, particularly when the plant is young and growing rapidly, but in this country it is regarded as far less dangerous than the native perennial Larkspurs so common in the West.

Stems erect, smooth or nearly so, one to two feet in height, the branches spreading at wide angles. Leaves deep green, sessile or with very short petioles, palmately compound, the lobes again divided into numerous linear, cleft segments. Flowers in loose, terminal racemes, blue or violetpurple, sometimes lilac or white; they are very irregular, with five colored sepals, the upper one extending into a long, curved spur at the base; petals two in this species, with base enclosed in the spur of the calyx and united. Fruit a single erect, smooth follicle, tipped with a slender beak

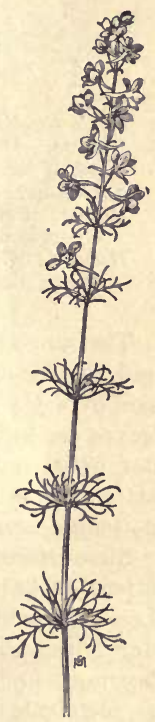

Fig. 111. Field Larkspur (Delphinium Consolida). $\times \frac{1}{3}$. 
formed of the persistent style, and containing many angled, roughened, black seeds, which are sometimes an impurity of grass seeds and grain. (Fig. 111.)

\section{Means of control}

Small areas and plants in grain fields are best destroyed by handpulling at the time of first flowering, when the weed is most conspicuous among surrounding crops. Infested meadows, waste land, and roadsides should be closely cut while the plants are in early bloom, thus preventing reproduction.

\section{DWARF LARKSPUR}

\section{Delphinium tricórne, Michx.}

Other English name: Stagger Weed.

Native. Perennial. Propagates by seeds.

Time of bloom: May to June.

Seed-time: June to July.

Range: Pennsylvania to Minnesota and Nebraska, southward to Georgia and Arkansas.

Habitat: Upland fields, meadows, and pastures, open woods, and waste places.

The range of the Dwarf Larkspur includes much grazing land, and the losses caused by it yearly are very considerable. It is said to be the most dangerous in early spring, when the young green leaves are but a few inches above the ground. Full-grown plants not only contain less of the poisonous properties, but are less attractive as forage, and it is stated that deaths from Larkspur poisoning nearly always occur before the plants are in bloom.

Stem rather stout, simple, nearly smooth, succulent, six to fifteen inches tall, springing from tuberous and clustered roots. Leaves palmate, on long petioles, each of the five lobes again deeply but unequally three- to five-cleft. Panicles loose and open, bearing usually not more than six or eight bright blue flowers about an inch in length; the upper sepal, or spur, is nearly straight and ascending; petals four, the two upper ones yellowish with blue lines, the lower two bearded inside with white hairs. Follicles three or four, widely divergent, each about an inch long, tipped 
with a short beak. The seeds are smooth. As soon as they mature the foliage dies down and the plant seems to be dead. (Fig. 112.)

\section{Means of control}

The perennial roots must be killed and that is most quickly and certainly accomplished by removing them from the soil. The clustering tubers do not lie very deeply beneath the surface and may be readily grubbed out, or even pulled by hand, when the ground is soft. Handlabor is expensive, but the price of a valuable cow would pay the wages of an ordinary farm laborer for a considerable time. Land too rankly infested to be so cleansed should be put under thorough cultivation and then heavily reseeded.

\section{SKY-BLUE LARKSPUR}

Delphinium azùreum, Michx.

(Delphinium caroliniànum, Walt.)

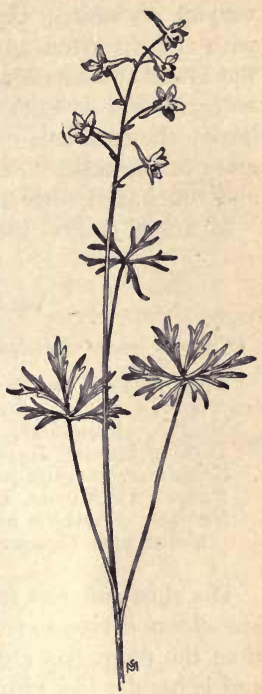

Fig. 112. - Dwarf Larkspur (Delphinium tricorne).

Other English names: Carolina Larkspur, $\times \frac{1}{5}$.

Azure-flowered Larkspur.

Native. Perennial. Propagates by seeds.

Time of bloom: May to July.

Seed-time: July to September.

Range: Virginia, the Carolinas, and Georgia, to Arkansas and Missouri, northward to Minnesota and the Saskatchewan. Habitat: Prairies, fields, and meadows.

A very beautiful species often cultivated in gardens. Stem one to two feet in height, slender, clothed in very fine, ashy-gray hairs. Leaves deeply three- to five-parted, the lobes with very slender, almost linear bases, and each again twice or thrice divided into narrowly linear segments; petioles long and slender, dilated at the base. Racemes terminal, four to eight inches long, the flowers numerous, large, short-pedicelled, deep sky-blue occasionally 
varying to white; the spur is long, and usually lies horizontally with the tip tilted upward; four petals shorter than the sepals, the lower two densely bearded within. Follicles in threes, about an inch long, covered with fine down, and tipped with an awl-like beak; they are held erect or very slightly spreading, their pedicels close to the stalk. Seeds about a tenth of an inch long, angled, and roughened with transverse wrinkles.

Means of control the same as for Dwarf Larkspur.

\section{TALL MOUNTAIN LARKSPUR}

Delphinium glaùcum, $\mathrm{S}$. Wats.

Other English names: Cow Poison, Smooth Larkspur, Large Larkspur.

Native. Perennial. Propagates by seeds.

Time of bloom: June to August.

Seed-time: August to October.

Range: California, Idaho, and Montana, northward to Alaska.

Habitat: Foothills and mountain valley pastures to an altitude of about nine thousand feet.

The chief sufferers from this noxious plant are cattle, since sheep are seldom driven to the mountain pastures before July and by that time the plant has grown too large and coarse for their cropping and is besides less virulent than in its younger stages. It is when the tufted base leaves first appear in April and May that they are most dangerous and also most succulent and tempting to stock. Frequently the danger is increased by the fall of light spring snows, which cover the young grass, and the Larkspur's taller foliage is the only forage showing green above the snow.

Stem four to seven feet tall, stout, simple, ridged, and covered with a white bloom (glaucous). The base leaves which first rise from the thick, woody roots are long-petioled, smooth, glaucous, four to six inches broad, rounded in outline, five- to seven-lobed, the segments rather broad, long-pointed, and deeply cut; the lower stem leaves are smaller, with fewer lobes, becoming simple and lance-shaped as they ascend the stalk. Raceme terminal, long and slender, the flowers numerous, rather small, pale blue or white. Follicles in threes, smooth, erect, tipped with a short beak; the seeds are black. 


\section{Means of control}

Herding cattle away from places where the plant abounds during the spring months, when it is most dangerous. But in some localities it is considered that extermination by digging would be feasible and a paying investment of labor. An instance is given by Chesnut ${ }^{1}$ and Wilcox of a Montana range where forty cattle had died in a single month from eating this plant. "A careful inspection of this range showed that the Tall Larkspur was entirely confined to a few areas of small size. It is believed that it could all be completely exterminated by twenty-five days' work with a weed digger designed for severing the roots at a short distance below the ground. The expense of this labor would not exceed the value of two eattle and this number is much less than the average annual loss from the Tall Larkspur on this range." Similar conditions prevail on many other ranges.

\section{PURPLE LARKSPUR}

\section{Delphinium bicolor, Nutt.}

Other English name: Poison Weed.

Native. Perennial. Propagates by seeds.

Time of bloom: May to August, according to altitude.

Seed-time: July to September.

Range: Colorado and Wyoming to Oregon, northward to Alaska.

Habitat: Hillsides, bench lands, and mountain ranges up to about ten thousand feet.

Very common in most parts of its range and much less restricted in its habitat than the Tall Larkspur, this plant is considered by stockmen even more pernicious. Sheep are most often its victims but other stock also are affected. It is a small plant, six to fifteen inches tall, smooth or only slightly hairy, rather stout for its height, the stem rising from thick, fascicled, deep-set roots. Leaves deeply five- to seven-parted, the segments again divided into nearly linear lobes, which on the lower leaves have rounded tips but above become more slim and pointed. They are succulent and liked by grazing animals only when young, the time when they are most harm-

1 The Stock-poisoning Plants of Montana: A preliminary report. Bulletin No. 26, Division of Botany, U. S. Department of Agriculture. 
ful. Raceme terminal, the flowers few but large, often exceeding an inch in width, the sepals and the spurs of about the same length and of a deep, rich purple; the two upper petals pale yellow or white, and netted over with purple veins. Follicles three, smooth, erect or sometimes recurving. Like the Buttercups, Larkspurs seem to lose much, if not all, of their toxic quality when dried in hay; but, unfortunately, the seeds retain vitality, and, when the hay is baled and sold, are likely to increase the range of a very noxious weed.

\section{Means of control}

In restricted localities and small areas, the perennial roots may be pulled or grubbed out or the land may be put under cultivation and reseeded. But on open ranges, the only practicable way seems to be to guard the animals by herding them away from the weed until it becomes so mature that they will eat other forage in preference.

\section{SMALL LARKSPUR}

\section{Delphinium Ménziesii, DC.}

Native. Perennial. Propagates by seeds.

Time of bloom: April to July, varying with altitude.

Seed-time: June to September.

Range: Northern Colorado to California, and northward to British Columbia.

Habitat: Hillsides and mountain valleys, ascending to about eight thousand feet.

As this plant seldom exceeds a foot in height, stockmen and herders are accustomed to speak of it, and also of Delphinium bicolor, as the "Little Larkspurs," in contradistinction to their neighbor, Delphinium glaucum, which sometimes attains seven feet and is called the "Big Larkspur" or "Large Larkspur." It is generally regarded as less poisonous than $D$. bicolor, although E. V. Wilcox ${ }^{1}$ reports a case on a Montana range where a flock of six hundred sheep were poisoned by it, of which two hundred and fifty died; and the same poisonous alkaloid, called delpho-

1 "Thirty Poisonous Plants of the United States." Farmers' Bulletin No. 86, U. S. Department of Agriculture. 
curarin, has been extracted from both these species. (Fig. 113.)

The plant springs from a cluster of thickish, oblong tubers, fringed with fine feeding rootlets. Stem simple, slender, of ten bent or flexuous, both it and the foliage finely hairy; the lower leaves have long petioles, slightly dilated at base, and are deeply five-parted, the segments again twice or thrice divided; the upper leaves are small, of tenest of three nearly linear segments. Raceme terminal, slender, the flowers few, on long, nearly erect pedicels ; they are large and showy, deep violet-blue, the sepals and the spurs nearly equal in length, bearded outside; the two upper petals are yellowish but are distinguishable from $D$. bicolor because they are not net-veined. Follicles three, widely recurving at maturity, the seeds black and winged on the outer angles.

Means of control the same as for Delphinium bicolor.

\section{WESTERN LARKSPUR}

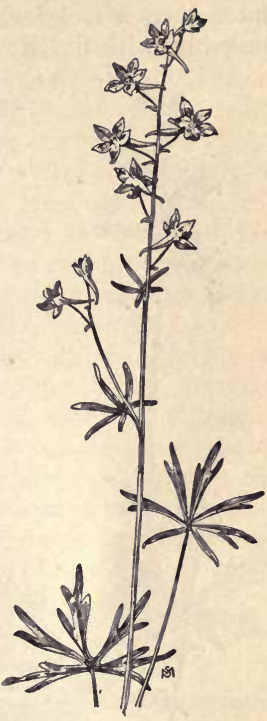

Fig. 113. - Small or Menzies Larkspur (Delphinium Menziesii). $\times \frac{1}{4}$.

\section{Delphinium trollifolium, Gray}

Native. Perennial. Propagates by seeds.

Time of bloom: April to June.

Seed-time: June to August.

Range: Oregon, Washington, Idaho and British Columbia.

Habitat: Moist soil along streams, foothills ; meadows and pastures.

A very beautiful plant but in some localities it bears the unpleasant names of Cow-poison or Cow-killer. Stem two to five feet tall, slender, leafy. Leaves large, three- to seven-parted, often somewhat kidney-shaped at base, the segments wedge-shaped and deeply cut and lobed at the tips. Racemes large and loose, of ten 
more than a foot long in the larger plants; flowers large and deep blue with the two upper petals white; spur and sepals about

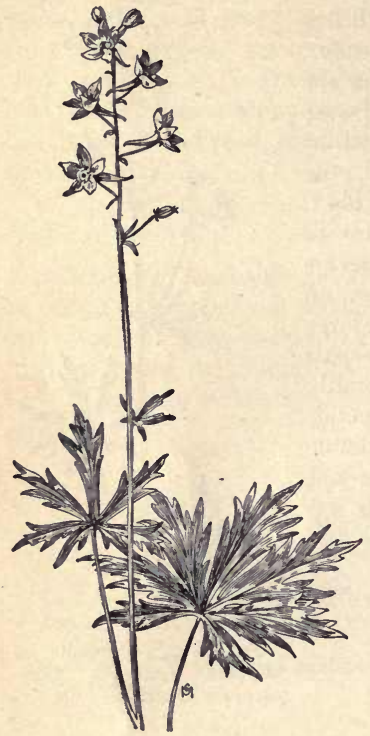

Fig. 114. - Western Larkspur (Delphinium trollifolium). $\times \frac{1}{3}$. equal in length, often threefourths of an inch. Follicles smooth, the seeds with a thin margin or wing at the end. (Fig. 114.)

Means of control the same as for the Purple Larkspur.

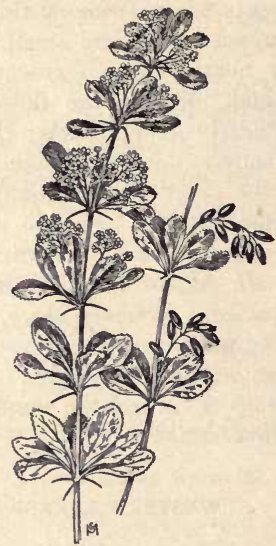

Fia. 115. - Common Barberry (Berberis vulgaris). $\times \frac{1}{4}$.

\section{COMMON BARBERRY}

Bérberis vulgàris, $\mathrm{L}$.

Introduced. Perennial. Propagates by seeds.

Time of bloom: May to June.

Seed-time: Fruit ripe in September, but persistent on the stems until winter.

Range: Eastern and Middle United States.

Habitat: Fence rows, thickets, and waste ground. 
The peasant farmers of Europe, long before science had explained " the reason why," were very certain that wheat fields would be smitten with rust if Barberry bushes grew near by, and insisted on their extirpation. Doctor William Darlington, in his most instructive book on "American Weeds and Useful Plants" published in 1847, sarcastically mentions that "It was formerly a popular belief and one that prevails yet to some extent, that the Barberry possesses the power of blasting grain; the fallacy of this idea has been proved." But popular belief was right, nevertheless, for it is now known that the wheat-rust fungus (Puccinia graminis) passes one stage of its life on the leaves of the Barberry.

The plant is a shrub, four to eight feet high ; leaves alternate or fascicled, one to two inches long, obovate, obtuse, thick, smooth, bristly-toothed, growing in the axils of small, three-forked spines. Flowers in pendulous racemes, yellow, each with six roundish sepals, six petals, upcurved and with two small glands at the base, six stamens, sensitive, springing up against the stigma when touched. Fruit an oblong, scarlet berry; birds eat the fruit and void the seeds in thickets and along the fences, which accounts for the frequency of the plants in such places. (Fig. 115.)

\section{Means of control}

Plants that menace the grain fields should be grubbed out and destroyed, but in the house grounds or the garden borders there is no shrub more graceful and attractive.

\section{GREAT CELANDINE}

\section{Cheliddnium majus, L.}

Other English names: Swallow-wort, Tetterwort, Felonwort, Wartweed, Kill-wart, Devil's Milk.

Introduced. Biennial. Propagates by seeds.

Time of bloom: April to August.

Seed-time: June to September.

Range: Maine to Ontario, southward to Virginia.

Habitat: Farmyards, roadsides, waste places, borders of woods.

Chelidon means a swallow, and it is said that the swallows come with the first opening flower of this plant and go as the last bloom 
fades. When bruised, the weed exudes an orange-colored juice with a disagreeable odor, bitter and acrid, once considered a sure cure for warts, corns, pimples, boils, and "tetters" of every kind, even to the painful felon. It still has good standing in the United States Pharmacopoia, and the drug market pays collectors six to

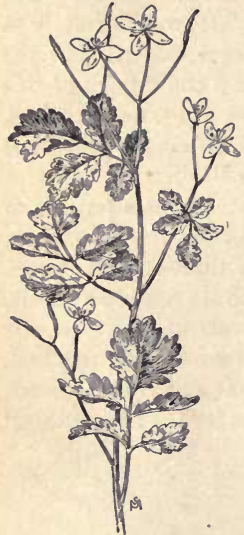

Fig. 116. - Great Celandine (Chelidonium majus). $\times \frac{1}{4}$. eight cents a pound for the herb, pulled entire when in full flower and carefully dried.

Stems one to two feet high, weak, brittle, sparsely hairy, and swollen at the joints. Leaves large, thin, gray-green, once or twice pinnatifid, the segments deeply cut and scallop-toothed; petioles dilated at base and clasping the stem. Flowers in axillary umbellate clusters, the peduncles about as long as the leaves, the pedicels of unequal length; stamens many; style extremely short with two-lobed stigma; sepals two; petals four, bright yellow, arranged crosswise, each blossom about a half-inch broad. Pods smooth, one to two inches long, twovalved, opening at the base; seeds smooth, shining, dark brown, bearing on the side a white crest like a cock's comb. (Fig. 116.)

\section{Means of control}

Destroy first-year leaf-tufts by hoe-cutting; prevent seed production in the second year by cutting the flowering stalks while in early bloom.

\section{FIELD POPPY}

\section{Papàver Rhòas, L.}

Other English names: Corn Poppy, Redweed, Canker Rose. Introduced. Annual. Propagates by seeds.

Time of bloom: June to August.

Seed-time: July to September.

Range: Semi-arid lands of the Southwest, where seed-wheat from 
southern Europe has been sown. Occasional elsewhere but not troublesome as a weed.

Habitat: Grain fields.

This is the pest which for centuries has made the wheat fields of Europe gorgeous with its color, and it is strange that it has not made greater headway in this country. Its seeds are most tenacious of life when in the soil.

Stems one to three feet high, slender, erect, many-branched, set with short, spreading hairs. The whole plant is filled with bitter, milky juices. Leaves all pinnatifid, the lobes lance-shaped, pointed, sharply toothed, the lower ones petioled, the upper ones smaller and sessile. Buds nodding, enclosed in two, or occasionally three, hairy sepals that fall away as the flower unfolds; these are very large, two to four inches broad; petals four to six, broader than long, of thin silken texture, bright scarlet with a dark blotch at the base; stamens many. Capsule top-shaped, the stigmatic disk at its apex usually tenrayed, and with as many cells as rays, filled with very many small, brown seeds. (Fig. 116.)

\section{Means of control}

Sow clean seed. Poppy seed is so very

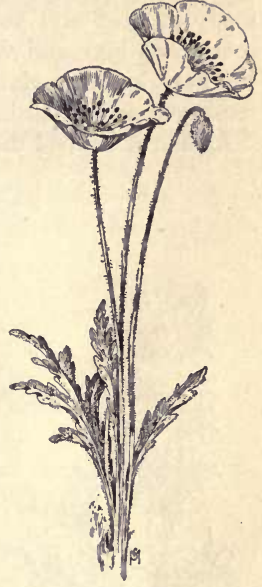

Fra. 117. - Field Poppy (Papaver Rhoeas). $\times \frac{1}{s}$. small that a good fanning mill should be able to remove it completely from all seeds of grass and grain. If the area infested is not too great to make the task impracticable, hand-pull the plants when the first bright bloom appears and burn them. Let none mature seed.

\section{LONG SMOOTH-FRUITED POPPY}

Papdver dùbium, L.

Introduced. Annual. Propagates by seed.

Time of bloom: June to August. 
Seed-time: July to September.

Range: Southern Pennsylvania and Ohio to Virginia, and southward.

Habitat: Cultivated ground and waste places.

Not a troublesome weed in this country, but called Corn Poppy in Europe, where wheat is called corn. It is similar to the preceding species but is taller and more slender, with pinnatifid leaves more finely divided and very hairy. Flowers two inches broad, light scarlet, on long and very bristly petioles. Capsule tapering from the base, smooth, club-shaped, the stigmatic cap at its top six- to ten-rayed and smooth.

Means of control the same as for the Field Poppy.

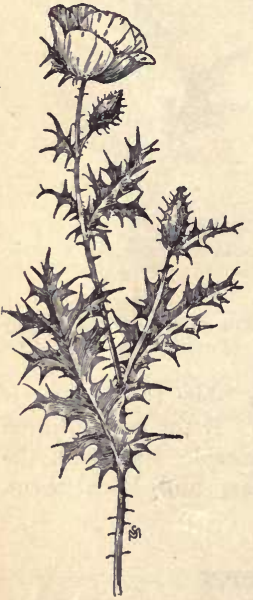

Fis. 118. - Prickly Poppy (Argemone mexicana). $\times \frac{1}{3}$.

\section{PRICKLY POPPY}

Argemòne mexicdna, L.

Other English names: Mexican Poppy, Thistle Poppy, Devil's Fig.

Introduced. Annual or biennial. Propagates by seeds.

Time of bloom: June to September.

Seed-time: August to November.

Range: New Jersey, Ohio, and the Middle Western States, southward to Florida, Texas, Arizona, and southern California. Naturalized throughout the Tropies in Asia, Australia, the South Sea Islands, and Africa.

Habitat: Fields, meadows, waste places.

In some countries this plant is cultivated for the valuable painter's oil expressed from its seeds, but in many parts of the United States it is a very troublesome weed, for, in addition to its exceeding prickliness, it is protected by bitter, yellow juices, said to be poisonous.

Stem one to two feet high, stout, simple or with few branches, usually very prickly but sometimes nearly or quite unarmed. Leaves four to eight inches long and half as wide, glaucous, blotched with white, 
sinuate-pinnatifid, spiny-toothed and more or less prickly on midrib and larger veins, sessile and clasping. Flowers lemonyellow or cream-colored, two or three inches broad, sessile or on very short peduncles; sepals long and prickle-pointed; stamens many with filaments a half-inch or more long. Capsule an inch or more long, ellipsoid, prickly, opening by three to six valves at the top. Seeds small, grayish brown, crested on one side. (Fig. 118.)

\section{Means of control}

Prevent seed production. Pull, hoe-cut, or spud out autumn leaf-tufts; closely and frequently cut flowering stalks while in early bloom. Cultivation of the ground destroys the weed if continued for a sufficient time to stir all dormant seeds into growth.

\section{GRAY BERTEROA}

\section{Berterda incdna, DC.}

Other English name: Hoary Alyssum.

Introduced. Annual and winter annual. Propagates by seeds.

Time of bloom: June to September.

Seed-time: July to October.

Range: Maine to Michigan, southward to New Jersey and Missouri. Habitat: Grain and elover fields, waste places.

This weed came from western Europe but a few years ago, in red clover seed, from which it is very. hard to remove. Wherever established, it has shown itself to be about as prolific and adaptive as Field Pepper grass, and therefore newly entered plants should meet with prompt and severe treatment. (Fig. 119.)

Stem one to two feet tall, slender, with numerous slim branches near the top, gray-green with fine, forking hairs. Basal leaves three or four inches long, spatulate, usually grouped in a small rosette ; stem-leaves alternate, lance-shaped, sessile ; all have entire edges. Flowers in crowded terminal racemes, and, like all the Cruciferæ, have six stamens, four long and two short; four sepals, four petals, arranged in cross-form and situated below the ovary; in this species they are white, minute, the petals cleft at the tip. Pods elliptic and but little compressed silicles, gray-hairy 


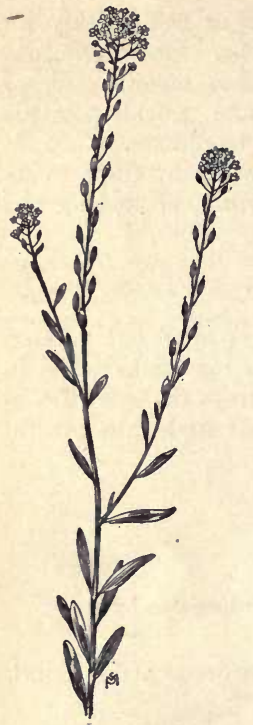

Fig. 119. - Gray Berteroa (Berteroa incana). $\times \frac{1}{3}$.

like the rest of the plant, about a quarterinch long, divided into two cells by a transparent papery partition, which remains on the thread-like pedicel after the seeds have fallen - like an eyeglass in a rim. Each cell contains about a half-dozen flattened brown seeds.

\section{Means of control}

Sow clean seed. Plants newly established in clover field or meadow should be handpulled or cut by themselves and burned, for their seeds not only will foul the ground, but also, if cured with the hay, will be made certain of further distribution. Their hairy surface makes these weeds susceptible to injury from sprays such as Iron or Copper Sulfate applied when buds are developing. Early spring and late autumn cultivation will destroy the seedlings and rosettes.

\section{PENNY CRESS}

Thláspi arvénse, L.

Other English names: Frenchweed, Stinkweed, Stinking Mustard, Bastard Cress, Wild Garlic.

Introduced. Annual and winter annual. Propagates by seeds.

Time of bloom: As soon as snow melts in spring, beginning on autumn plants already budded; spring seedlings bloom later and continue until fall.

Seed-time: Autumn plants ripen seed in early July. Spring seedlings mature fruit in August. Both continue seeding until winter.

Range: Northern and Middle Western United States; in all Canadian provinces, but most abundant in Manitoba and the Northwest Territory.

Habitat: Grainfields, meadows, roadsides and waste places.

This weed is perhaps the most hated enemy of the western farmer, and is considered to have caused greater loss than any other intruder in the grain fields of Minnesota, the Dakotas, and western 
Canada. It is immensely prolific and its seeds have long vitality. Cold does it no harm and chemical sprays that kill other Mustards do not in the least affect it. Other crops cannot crowd it out, for it is the better crowder, seeding in dense timothy sod almost as readily as in a mellow fallow. Blooming "from snow to snow" and constantly developing fruit, it requires and absorbs much of the food and moisture in the soil, starving the accompanying crops almost to worthlessness. T. N. Willing, Chief Weed Inspector of the Northwest Territory, says, "It will pay well to drop all other work and fight this weed when it is first noticed." (Fig. 120.)

Stem six inches to two feet tall, smooth, bright green, often simple but usually branching at the top. Root-leaves long oval, broadest at tip, with long petioles; stem-leaves lance-shaped and clasping with a pair of pointed ears at the base; all leaves coarsely toothed. When bruised, the plant exhales a most disgusting garlicky odor; if it is eaten by milch cows, the dairy products are spoiled. Flowers clear white, very small, in thick, flat terminal clusters; beginning to mature at the bottom of the cluster, they leave behind a long raceme of the fruits, standing out on slender, wiry, upcurved pedicels about as long as themselves. Silicles flat, about three-fourths of an inch across, pale green at first, broadly winged at the

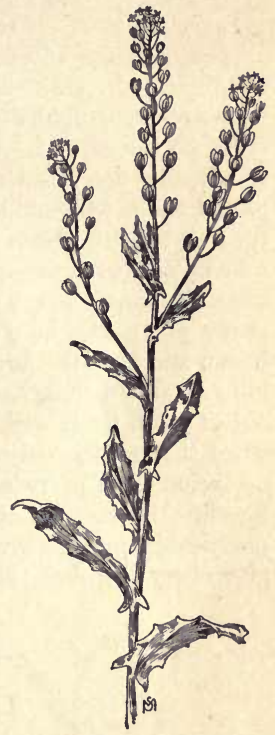

Fia. 120. - Penny Cress (Thlaspi arvense). $\times \frac{3}{b}$. sides, notched at the top, two-celled, the division being across the narrowest part, as in Shepherd's Purse; each side contains two to eight seeds. As the pods ripen they turn to a rusty orange color, making the weed very conspicuous when growing with grain or clover. Seeds deep reddish brown, flattened ovoid, roughened with fine curved ridges about a central groove. 
A very few of these seeds ground by accident with a grist of wheat, ruins the flour, and grain that contains them is very sharply cut in price.

\section{Means of control}

Sow clean seed. If the infestation is new, hand-pull and destroy all plants before any fruits mature, even though the task be very strenuous. In grain fields, if seeds have been allowed to ripen, burn over the stubbles for the purpose of destroying those that have fallen on the ground. Give surface cultivation in order to encourage germination of such seeds as are in the soil, and plow the young plants under while still in the rosette stage of growth. But never turn under any plants bearing developed pods, even though they may be green, for they go on ripening on the stalks, when under the warm soil, quite as well as or better than above it. Autumngrown plants are the most obnoxious, since they come earliest into bloom and fruit the next season, and every effort should be made to kill as many of these as possible. Spring seedlings may be dragged out of grain fields with small-toothed weeding harrows, beginning when the grain is only about three inches high and repeating the operation once or twice afterwards - a treatment which greatly benefits the crop at the same time that it kills the weeds. If practicable, put the ground to a cultivated crop, which should be given very thorough tillage, before the land is used again for grain.

\section{COMMON PEPPERGRASS}

\section{Lepidium virginicum, $\mathrm{L}$.}

Other English names: Tongue Grass, Bird's Pepper.

Native. Annual and winter annual. Propagates by seeds.

Time of bloom: May to September.

Seed-time: Late June to October.

Range: Nova Scotia to Minnesota, southward to Florida, Texas, and Mexico.

Habitat: Grain and clover fields, roadsides, and waste places.

Stem six inches to two feet tall, much branched. The weed sometimes becomes a tumbleweed because of this spreading growth. 
Lower leaves pinnatifid, spatulate in outline, with terminal lobe large and lateral lobes very small; stem-leaves merely toothed, not lobed, the upper ones becoming lance-shaped and often entire. Flowers white, very small, on elongating racemes that are finally six or eight inches in length, closely set with small, round, flattened, two-celled silicles, notched at the outer edge and each containing two reddish yellow seeds. Birds are very fond of these seeds and dispose of large quantities; they are a common impurity among clover seeds.

Means of control the same as for Shepherd's Purse.

(Fig. 121.)

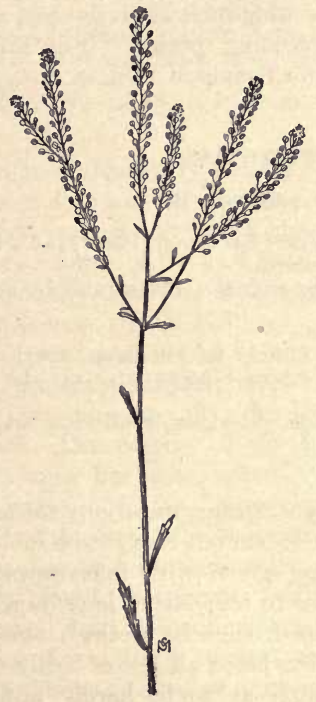

Fra. 121. - Common Peppergrass (Lepidium virginicum). $\times \frac{1}{3}$.

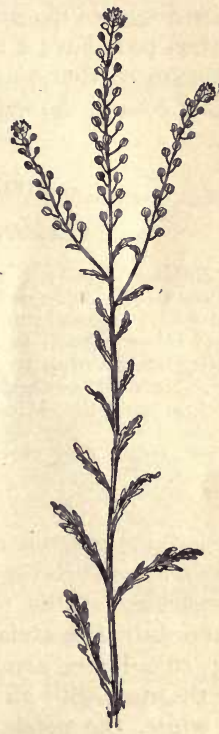

Fig. 122. - Greenflowered Peppergrass (Lepidium apetalum). $\times t$. 


\section{GREEN-FLOWERED PEPPERGRASS}

Lepidium apétalum, Willd.

Introduced. Annual and winter annual. Propagates by seeds.

Time of bloom: May to August.

Seed-time: June to September.

Range: Maine, New York, and Ontario, to the Northwest Territory, California, and Texas.

Habitat: Grain and clover fields, waste places.

Similar to the native plant, but has pinnatifid root-leaves, the stem-leaves are fewer and more slender, and the white petals of the flowers are very minute, sometimes entirely lacking. The rounded and notched pods have a minute wing-margin at the top, slightly more pronounced than in the preceding species. (Fig. 122.)

Means of control the same as for Shepherd's Purse.

\section{FIELD PEPPERGRASS}

Lepidium campéstre, $\mathrm{R}$. Br.

Other English names: Field Cress, Cow Cress, Poor Man's Pepper, Yellow Seed, Mithridate Mustard.

Introduced. Annual and winter annual. Propagates by seed.

Time of bloom: April to July.

Seed-time: Late May to August.

Range: New Brunswick and Ontario to Michigan, southward to Virginia and the Middle Western States; also on the Pacific Coast.

Habitat: Grain and clover fields, meadows, roadsides, and waste places.

A weed whose range is rapidly widening, mostly by the agencies of impure grass and clover seed. Stem ten to eighteen inches tall, erect, branching at the top, gray-green with fine, downy hair. Root-leaves tufted, spatulate, two to four inches long, tapering to petioles; stem-leaves arrow-shaped, slightly toothed, sessile and clasping the stem with an auricled base; all leaves softly downy. Flowers white, the petals so small as to be hardly noticeable. Silicles ovate, rough, concave above, convex below, winged and notched at the tip, the style protruding from the notch. Seeds reddish yellow, very pungent to the taste. 
Means of control

Infested grain fields and meadows should be sprayed with Iron sulfate or Copper sulfate before the first flowers mature. Stubbles should be cultivated after harvest in order to destroy autumn seedlings.

\section{SWINE CRESS}

Corb́opus didymus, Sm.

(Senebiera didyma, Pers.)

Other English names: Lesser Wart Cress, Carpet Cress.

Introduced. Annual or biennial. Propagates by seeds.

Time of bloom: March to June.

Seed-time: Early May to August.

Range: Newfoundland to Florida and Texas, westward to California.

Habitat: Yards, roadsides, waste places.

Grazing cattle usually avoid plants with a disagreeable odor, but they seem to make an exception of the Mustards. The smell of this weed is suggestive of a pigsty, whence its name of Swine Cress; it is occasionally the cause of damaged dairy products. (Fig. 123.)

Stems four inches to a foot in length, prostrate, diffusely branched, hairy, spreading on all sides from the root. Leaves very deeply pinnatifid, some but once, others with the segments also cut; upper ones sessile but those near the base having slender petioles. Flowers white, extremely small, in slender axillary racemes on short, threadlike pedicels. Autumn plants flower earliest, coming into bloom as soon as uncovered

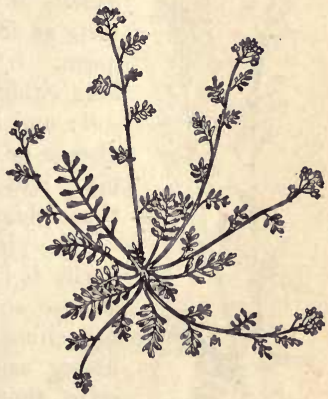

Frg. 123. - Swine Cress (Corono. pus didymus). $\times \frac{1}{3}$.

from winter snows. Silicles small, wrinkled, warty, the two valves separating readily into two ovoid nuthets, each containing one seed. 


\section{Means of control}

Carpet Cress usually grows in patches, which should be hoed out very early in spring before any seeds are developed. Successive crops will probably appear from seeds that have lain dormant in the soil, and these should be given like treatment.

\section{SHEPHERD'S PURSE}

Capsélla Búrsa-pastoris, Medic.

Other English names: Caseweed, St. James' Weed, Mothers' Hearts. Introduced. Annual and winter annual. Propagates by seeds.

Time of bloom: March to November in the northern part of the country. All the year round where not covered with snow for autumn seedlings bloom in winter if not checked by cold and spring seedlings take up the succession in summer.

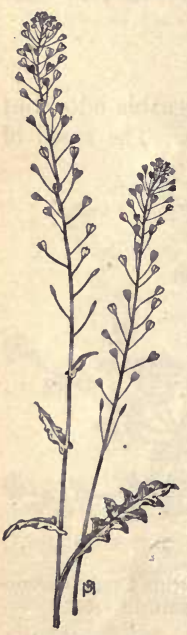

Fig. 124. - Shepherd's Purse (Capsella Bursa-pastoris). $\times \frac{2}{2}$.
Seed-time: April to December.

Range: All cultivated regions of the world.

Habitat: Any soil; invades any crop.

With the exception of Chickweed, this is probably the commonest weed on earth. But usually it is not regarded with so much hostility as are some other plants that really do less harm. It is very prolific and the seeds have long vitality; it absorbs much fertility from the soil ; and it often harbors the club-root fungous disease so ruinous to cabbage, cauliflower, turnips, and radishes, and will infect soil where those plants may be cultivated. (Fig. 124.)

The plant is extremely variable, but ordinarily it has a rather deep taproot with many slender rootlets, and the stem is slender and branching, six to twenty inches high. Base leaves usually pinnatifid and tufted in a rosette, though late spring seedlings often send up a fruiting stalk directly from the root, without the tuft of lower leaves; upper leaves lanceshaped and clasping, with small, pointed auricles at base. Flowers white, minute, terminating a lengthening raceme of triangular, flattened, heart- 
shaped silicles, on fine, wire-like pedicels ; each "Mother's heart" is partitioned across its narrow thickness and each cell contains about ten reddish brown seeds, a thrifty plant of average size producing about two thousand.

\section{Means of control}

In cultivated ground the weed succumbs to the constant tillage required, but such plants as spring up after the cultivator has ceased its rounds should be cut or pulled and should not be allowed to seed the ground. Autumn rosettes should be hoe-cut in spring. In meadows and grain fields the weed may be killed while young with a spray of Iron sulfate or Copper sulfate.

\section{FALSE FLAX}

\section{Camélina sativva, Crantz}

Other English names: Wild Flax, Gold of Pleasure.

Introduced. Annual and winter annual. Propagates by seeds.

Time of bloom: June to August.

Seed-time: July to September.

Range: Ontario to Manitoba, southward to Ohio, Iowa, and South Dakota.

Habitat: Flax and grain fields, clover; waste places.

In Europe this plant is cultivated for the fine oil in its seeds and for mucilage, both of which are similar to the products obtained from flax seed. It was formerly believed that this plant was changed or degenerate flax, like Chess in wheat, and early writers spoke of it as Pseudo Linum, or False Flax. (Fig. 125.)

Stem eighteen inches to three feet tall, erect, slender, smooth, branching near the top. Lower leaves lance-

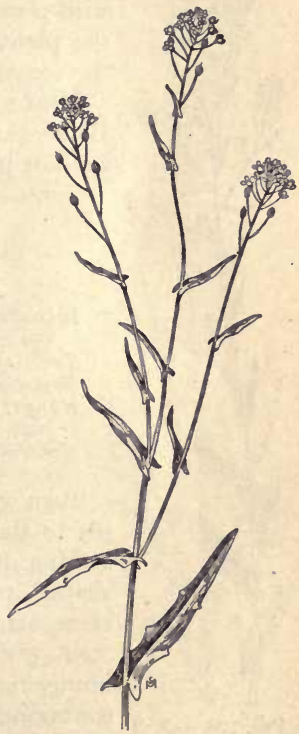

Fro. 125. - False Flax (Camelina sativa). $\times \frac{1}{3}$. 
shaped, the base narrowing to a petiole, entire or very slightly toothed, somewhat hairy, especially those that form the rosettes of autumn plants ; upper leaves smooth, arrow-shaped, clasping the stem by an auricled base. Flowers yellow, very small, in racemose clusters, the pedicels at first fine and threadlike but lengthening and becoming wiry as the pods mature. The latter are pear-shaped, two-celled silicles and resemble a flax boll, though they are not quite so large; slightly flattened, with a marginal ridge, and tipped with the persistent style which splits with the pod. Seeds brownish yellow, about ten to each pod. In the company of this plant is often

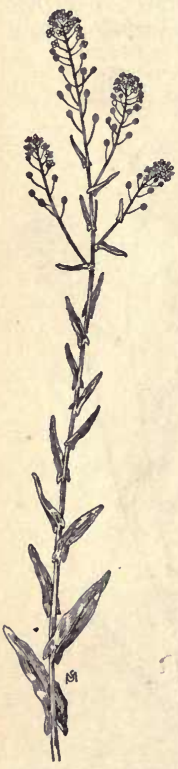

Fig. 126. - Ball Mustard (Neslia paniculata). $\times \frac{1}{2}$. found the Small-Fruited False Flax (Camélina microcárpa, Andrz.), smaller and more slender, with pods not much more than half as large but the plant is said to be even more prolific than the commoner weed.

Means of control similar to those given for Hare's-ear and Indian Mustard, the smooth foliage not being susceptible to injury from spray.

\section{BALL MUSTARD}

Néslia paniculata, Desv.

Introduced. Annual or biennial. Propagates by seeds.

Time of bloom: June to September.

Seed-time: July to October.

Range: Ontario, Manitoba, and British Columbia, Minnesota and the Dakotas.

Habitat: Grain fields and waste places.

Stem one to two feet tall, slender, usually simple to the flowering stalk, finely roughened with forking hairs. Basal leaves oblong to lanceshaped, tapering to a slim petiole; those on the stem arrow-shaped, long-pointed, clasping the stem with auricled base; all clothed with fine, branching hairs. Flowers in a terminal panicle, containing several slender racemes tipped with small clusters of orange-colored blossoms, not more than an eighth of an inch across ; maturing, 
the flowers leave behind a string of bead-like silicles of lesser diameter; as they ripen the tiny balls become netted and pitted, growing smaller yet, until it would take a dozen to measure an inch. Each ball contains one small, yellow seed, which does not "shell" but drops from the plant, pod and all, looking like a speck of dry, brown earth; the seeds are a common impurity of poorly cleaned grain and are overlooked and mistaken for harmless dirt in seed wheat and oats. (Fig. 126.)

Means of control the same as for Field Peppergrass.

\section{WILD RADISH}

Raphanus Raphanistrum, L.

Other English names: Jointed Charlock, White Charlock.

Introduced. Annual or biennial. Propagates by seeds.

Time of bloom: June to September.

Seed-time: July to October.

Range: New Brunswick to Ontario, southward to Rhode Island, Pennsylvania and Ohio. Also in British Columbia.

Habitat: Fields and waste places.

Root slender, not swollen and fleshy like the garden radish. Stem fifteen to thirty inches tall, erect, branching, sparsely set with fine stiff hairs, or of ten entirely smooth. Basal and root leaves deeply pinnatifid, with terminal lobe large, and four to six pairs of lateral lobes, decreasing in size toward the petiole, which is short; upper leaves small and oblong, but all are toothed and scalloped. Flowers about a half-inch broad or sometimes larger, the four spreading petals pale yellow with purple veins, fading to white as they wither; calyx-lobes drawn close together, instead of spreading like those of Wild Mustard. Pods indehiscent siliques one to two inches long, constricted between the seeds, faintly grooved lengthwise but

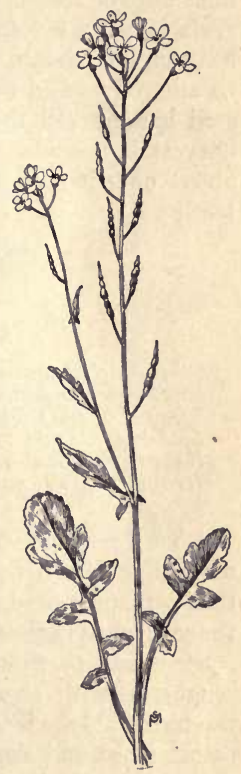

Fic. 127. - Wild Radish (Raphanus $R a$ phanistrum). $\times \frac{1}{3}$. 
without partitions, being stuffed with a spongy substance between the seeds, which are larger than Mustard seed and brown. Because its rather thick-textured leaves are so nearly smooth, this weed is more resistant to injury from sprays than other wild Mustards and it must be fought in other ways. (Fig. 127.)

\section{Means of control}

Cut the tufted leaves of autumn plants from their roots with hoe or spud, the latter tool being preferable in grain fields. Spring seedlings may be raked from the fields with a weeding harrow when the grain is but a few inches tall. Plants that spud, hoe, and harrow have missed, should be hand-pulled in their first bloom rather than be allowed to foul the ground with their long-lived seeds. Where seed has entered the soil, give stubbles surface cultivation after harvest, in order to stimulate germination, and then disk the ground about once in two weeks, so as to kill the weeds while they are tender.

\section{CHARLOCK OR WILD MUSTARD}

Brássica arvénsis, Ktze.

(Brássica sinapistrum, Boiss)

Other English names: Kedluck, Skellick, Herrick, Field Kale.

Introduced. Annual. Propagates by seeds.

Time of bloom: May to September.

Seed-time: June to October.

Range: Throughout North America except the extreme North.

Habitat: Grain and clover fields, meadows, waste places.

A very noxious weed because of its immense productiveness more than fifteen thousand seeds having been taken from a single thrifty plant - and also because of the exceedingly long vitality of the seed when in the soil.

Stem one to three feet tall, erect, branching toward the top, roughened with short, stiff hairs. Lower leaves pinnatifid, with the terminal lobe large, and the few lateral lobes small, the petioles rather stout and short; upper leaves narrowly rhombic, sessile or nearly so; all irregularly toothed and somewhat hairy; small blotches of brownish red show on the stem at the junction with the leaves. Flowers in racemose clusters at the ends of stem and 
branches, bright yellow, fragrant, each about a half-inch broad, the calyx-lobes spreading; they begin to open at the bottom of the cluster, which lengthens as the season advances and the pods form and ripen, so that there may be emptied pods below and forming buds above. Silique, or pod, one to two inches long, round and somewhat constricted between the seeds, veined and ribbed, and tipped with a long, two-edged beak; it may contain three or four to a dozen or more seeds, one of which is usually sticking in the beak when the pod splits. Seeds globular, dark reddish brown, under a lens seen to be delicately pitted. They are a common impurity of grass and clover seeds. (Fig. 128.)

\section{Means of control}

In grain fields seedlings should be harrowed out, with one of the light harrows known as weeders, when the grain is but a few inches tall; or later, but before the grain begins to head, the Mustard may be almost entirely destroyed by the use of Iron sulfate or Copper sulfate spray. Stubbles should be surface-cultivated immediately after harvest in order to stir into growth such seeds as may be lying on the ground; the young plants to be plowed under, or they may be profitably grazed off by sheep. Plants of waste places, fence rows, and roadside should be hand-pulled or closely cut when the flowers are first noticed.

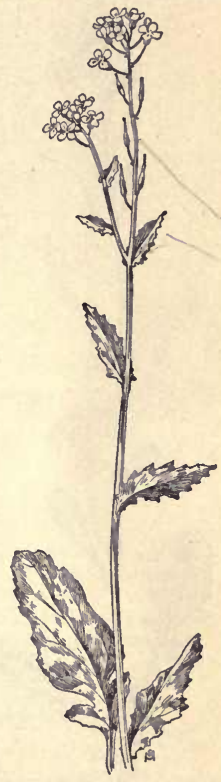

Fig. 128. - Charlock (Brassica arvensis). $\times \frac{1}{3}$.

\section{INDIAN MUSTARD}

\section{Brássica júncea, Cosson}

Introduced. Annual or biennial. Propagates by seeds. Time of bloom: May to July.

Seed-time: June to August.

Range: Ontario to Manitoba, southward to Georgia and Kansas. Habitat: Grain fields, roadsides, and waste places. 
A special pest in grain fields, as its early season of bloom enables it to foul the ground with its seeds before the grain is ready to harvest and the smooth, glaucous foliage renders it impervious to injury from sprays that would not also kill the accompanying crop.

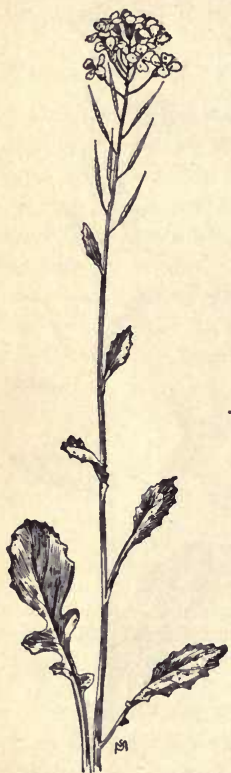

FIg. 129. - Indian Mustard (Brassica juncea). $\times \frac{1}{2}$.

Stem one to four feet tall, erect, rather - stout, with few branches. Lower leaves pinnatifid, with terminal lobe very large, coarsely toothed, and with long petioles; upper leaves oblong, nearly entire, tapering to the base, all light green, rather thick, smooth, and glaucous. Flowers bright yellow, more than a half-inch broad, clustered at the top of racemes, which, before the pods are all formed, often become more than a foot long. Siliques one to two inches long, nearly a third of their length taken by a slim, awl-shaped, empty beak. Seeds globular and brown. (Fig. 129.)

\section{Means of control}

Harrow young seedlings from grain fields with a weeding harrow. Plants that survive the treatment should be hand-pulled while in early bloom. If seeds have matured and fallen, stubbles should be burned over for the purpose of destroying them. Plants of roadsides and waste places should also be pulled or cut before seed is formed.

\section{WHITE MUSTARD \\ Brássica alba, Boiss \\ (Sindpis alba, L.)}

Introduced. Annual or biennial. Propagates by seeds.

Time of bloom: June to August.

Seed-time: July to September.

Range: Locally in most parts of North America except the far North.

Habitat: Cultivated ground, waste places. 
As a weed, this plant is usually the survival of dormant seeds from former cultivation, or an escape, though its seeds are occasionally found with those of other plants.

Stems one to two feet high, branching, covered with stiff, spreading hairs. Lower leaves with slender petioles, deeply pinnatifid, the terminal lobe very large, the lateral lobes small and narrow, all toothed and rough-hairy ; upper leaves less divided, with shorter petioles or the topmost ones sessile. Flowers yellow, more than a halfinch broad, the sepals spreading and much shorter than the petals. Siliques round and very bristly, the beak often longer than the part containing the seeds. Seeds light yellow, smooth, larger than those of Black Mustard, milder in flavor. (Fig. 130.)

Means of control the same as for Charlock and Black Mustard.

BLACK MUSTARD

Brássica nigra, Koch. (Sindpis nigra, L.)

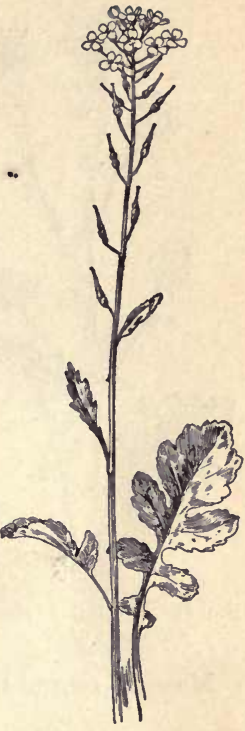

Fra. 130. - White Mustard (Brassica alba), $\times \frac{1}{6}$.

Introduced. Annual or biennial. Propagates by seeds.

Time of bloom: June to September.

Seed-time: July to November.

Range: In most parts of the American Continent except the far North; most abundant on the Pacific Coast.

Habitat: Fields and waste places.

Mustard seeds, both the Black and the White, are used in making a popular condiment, also in medicine, and to express a fine, clear oil which has little or none of the sharp flavor of Mustard. The United States imports these seeds to the amount of over five million pounds annually, at a cost of three to six cents a pound. 


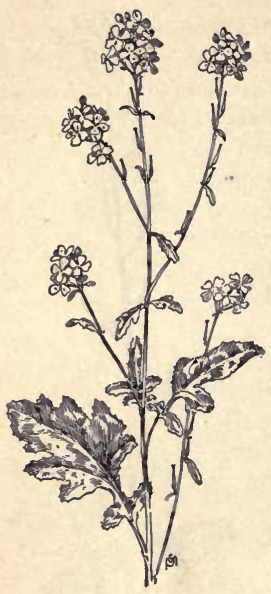

Fig. 131. - Black Mustard

(Brassica nigra).

Means of control the same as for Charlock.

Stems two to seven feet tall, or even more in warm southern soil, branching widely, sometimes hairy near the base but usually smooth above. Lower leaves pinnatifid, with the terminal lobe very large and the several lateral lobes small, toothed all around, with a long, slim petiole ; upper leaves less divided, becoming lance-shaped and nearly sessile at the top. Flowers bright yellow, a little more than a quarter-inch broad. This plant is often confused with Charlock, or Wild Mustard, but the difference between the fruits readily distinguishes them: Charlock has long, knotted or wavy pods, with stout, two-edged beaks, while Black Mustard has short, smooth, four-angled pods, a half-inch to an inch long, with short, slim beaks; and they are held closely pressed to the stalk, making the raceme very slender. Seeds globular, almost black,

very pungent to the taste. (Fig. 131.)

\section{SAND ROCKET}

Diplotáxis muràlis, DC.

Introduced. Annual or biennial. Propagates by seeds.

Time of bloom: June to August.

Seed-time: July to September.

Range: Nova Scotia to New Jersey and Pennsylvania, westward to Michigan.

Habitat: Fields and waste places.

Not a common weed in this country as yet, but Professor Beal reports that wherever found in Michigan, it "thrives and spreads at an alarming pace."

Stem one to two feet high, smooth or sparsely set with bristly hairs, branching from the base, leafy only below. Leaves oblong to 
lance-shaped in outline but deeply and irregularly toothed or somewhat pinnatifid, narrowing to petioles. Flowers in terminal racemes, each about a half-inch broad, golden yellow. Siliques about an inch long, linear, somewhat flattened and almost beakless, erect, on very slender spreading pedicels; the two cells of the pod each contain a double row of small reddish brown, slightly flattened seeds. (Fig. 132.)

\section{Means of control}

Prevent seed production by close cutting or pulling before the first flowers mature.

\section{HARE'S-EAR MUSTARD}

Conringia orientalis, Dumort.

Other English names: Rabbit-ears, Hare's-ear Cabbage, Klinkweed. Introduced. Annual and winter annual. Propagates by seeds.

Time of bloom: Late June to September.

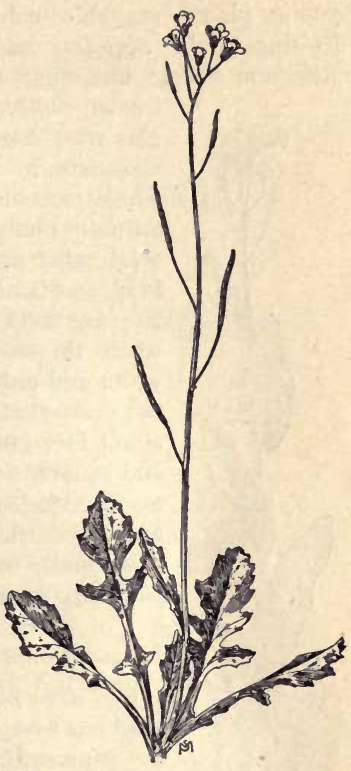

Frg. 132. - Sand Rocket (Diplotaxis muralis). $\times \frac{1}{3}$.

Seed-time: August to October.

Range: Ontario and Manitoba, Minnesota and the Dakotas. Appearing locally in other states and provinces.

Habitat: Grain and flax fields; waste places and along railways.

Brought to this country in flax seed from Europe about 1892, this weed has since spread through all the grain-growing section of the Northwest and bids fair to be still more widely known. Autumn plants send down a main root with many branching rootlets, and form a tuft of thick, smooth leaves, three to six inches long, broadly oval, rounded at tip and tapering toward the base, the edges entire, and the surface covered with a bloom like a cabbage; in fact the 
young plants resemble cabbage. In the second season the fruiting stalk appears, one to four feet tall, slender but stiff and erect, becoming hard as wire when mature; stem leaves oblong, rather thick, also smooth and

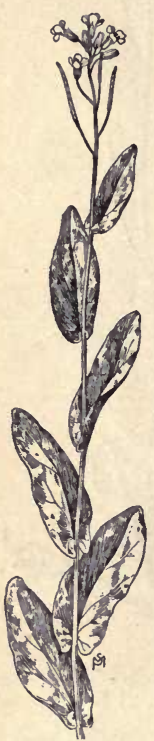

Fig. 133. Hare's-ear Mustard (Conringia orientalis). $\times \frac{3}{3}$. glaucous, shaped like a rabbit's ears and clasping the stem by two rounded auricles at the base. These succulent leaves, particularly on young autumn plants, are crisp and tender and make good salad and greens; they absorb most of the food and moisture of the soil, and the accompanying crop does not usually amount to much where the weed is very plentiful. Flowers creamwhite and only about a quarter-inch broad. But the pods that follow on the elongating stalk are about four inches long when mature, slim, smooth, and square, each one containing about fifty brown seeds, rounded oblong in shape, very mucilaginous when wet, which causes them to stick to the feet of animals, to a boot-sole, or to a wagon wheel, and helps in their distribution. (Fig. 133.)

\section{Means of control}

Sow clean seed. If the infestation is new, hoe or spud out every autumn plant and hand-pull every flowering stalk in its first bloom; and if pods have formed, burn them, lest they ripen on the stalks. The smooth, waxy surface of the plant sheds all liquids like a duck's back and sprays cannot harm it. Drag out spring seedlings with a weeding harrow and disk off the autumn plants. In every case prevent seeding if possible.

\section{GARLIC MUSTARD}

Allid̀ria officinàlis, Andrz.

Other English names: Hedge Garlic, Jack-by-the-hedge, Saucealone.

Introduced. Biennial. Propagates by seeds. 
Time of bloom: May to June.

Seed-time: July to August.

Range: Ontario to Ohio, southward to Virginia.

Habitat: Roadsides, waste places, and about farmyards.

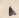

In Europe the leaves of this plant are sometimes used for flavoring food in place of garlic, which they resemble in. odor. In this country the plant occasionally flavors milk and butter through being eaten by milch cows.

Stem one to three feet high, rather stout, smooth, erect, and branching. Leaves broadly oval or heart-shaped, sometimes nearly round, coarsely toothed, smooth or with a slight hairiness on midvein and margins, the lower ones six or more inches broad with long petioles, the upper ones smaller and short-stalked. Flowers in short racemose clusters, white, nearly a half-inch broad. Siliques one to two inches long, stiff and four-angled, slender, with valves keeled and three-nerved. Seeds brown, oblong, and ridged, one row in each cell. (Fig. 134.)

Means of control

Deep cutting of autumn leaf-tufts from the roots with hoe or spud; cutting or hand-pulling the fruiting stalks before the

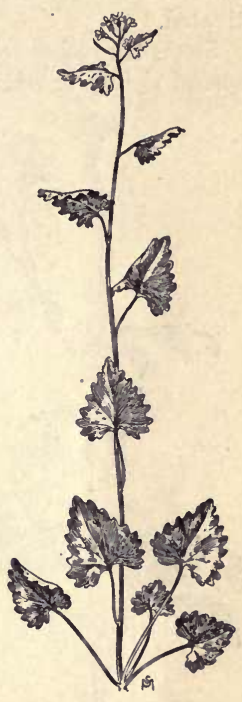

FIG. 134. - Garlic Mustard (Alliaria officinalis). $\times \frac{1}{6}$. first flowers mature.

\section{HEDGE MUSTARD}

Sisýmbrium officinàle, Scop.

Introduced. Annual or biennial. Propagates by seeds.

Time of bloom: May to November.

Seed-time: July to December.

Range: Throughout North America except the extreme North.

Habitat: Fields, roadsides, and waste places. 
Common everywhere; a frequent tenant of vacant city lots ; it is detested by the truck gardener because it harbors the club-root fungus so injurious to cabbage and turnips, and may have fouled the soil with the disease where those plants have never been cultivated.

Stems six inches to three feet tall, erect, slender, with branches spread rigidly at wide angles. Leaves deeply cut and lobed, with

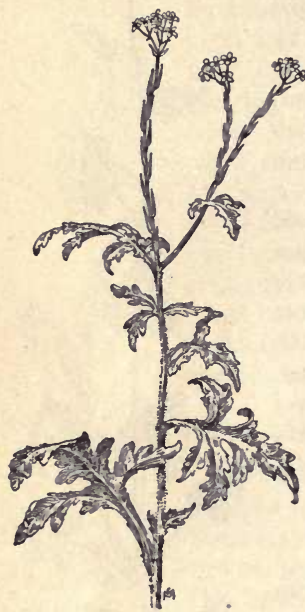

Fie. 135. - Hedge Mustard (Sisymbrium officinale). $\times \frac{1}{3}$. the lower segments usually turned backward. Flowers yellow, about_an eighth of an inch broad, in small, flat clusters at summit of stem and branches, above lengthening rows of pods. These are small, round, slightly hairy, pointed, about a halfinch long, held erect and closely pressed to the stalk. When old both stems and pods often turn to a dirty purple, making the plant look still more weedy and unpleasant. (Fig. 135.)

\section{Means of control}

Prevent seed production. Destroy autumn plants by hoe-cutting before fruiting stalks appear. Hand-pulling while in first bloom is a paying operation, as the plant is a gross feeder during the long season of seed development.

\section{TUMBLING MUSTARD}

Sisýmbrium altissimum, L.

Introduced. Annual or winter annual. Propagates by seeds.

Time of bloom: June to July.

Seed-time: First seed ripe in July. Plants dry and ready for tumbling in September.

Range: All states of the Middle West as far south as Missouri and 
Kansas, northwestward to Washington; all the Canadian provinces from Quebec to Vancouver Island.

Habitat: Grain fields and grasslands, waste places.

A native of Central Europe brought to this country in impure commercial seeds ; by this agency it still travels, and no doubt journeys farther in this way than when wind-driven about the country.

Stem two to four feet high, slender, smooth, and exceedingly branched and bushy. Leaves deeply pinnatifid, the segments nearly linear, toothed or entire, the upper ones reduced to thread-like thinness; when the plant is young the lower leaves are downy and the basal ones lie on the ground in rosette form, but these wither away and the later leaves are smooth. Flowers pale yellow, about a third of an inch across, on elongating racemes that leave behind alternating rows of stiff, diverging, needle-like pods, two to four inches long but hardly: thicker than their short pedicels. Each pod usually contains more than a hundred seeds - the fecundity of the weed is almost incredible. When mature the stems become very brittle, breaking away at

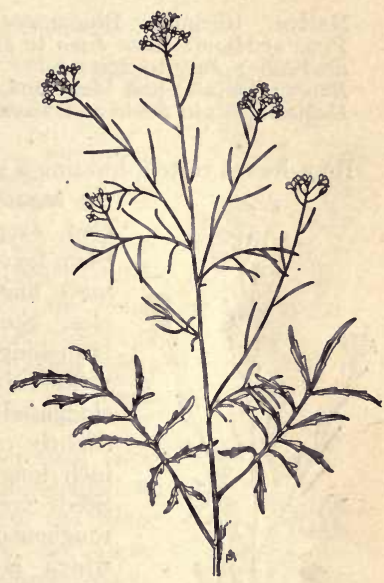

FIG. 136. - Tumbling Mustard (Sisymbrium altissimum). $\times \frac{1}{2}$. the surface of the ground, and the plants are afterward the sport of the winds; on the prairies they often roll for miles, but in fenced and uneven ground they are battered to and fro, seeding the soil the more thickly for such restriction. (Fig. 136.)

Means of control

Sow clean seed. Harrow seedlings out of grain fields in the spring. Harvest infested meadows before the first seeds ripen. Burn over 
stubbles for the purpose of killing the seeds on the ground. The plant gives no trouble in cultivated ground, for there the stroke of a hoe destroys it when young. The smooth foliage is unharmed by sprays.

\section{GREEN TANSY MUSTARD}

Sisymbrium incisum, Engelm.

Var. filipes, Gray

Native. Biennial. Propagates by seeds.

Time of bloom: Late June to July.

Seed-time: July to August.

Range: Ontario and Manitoba, Minnesota and the Dakotas.

Habitat: Grain fields and waste places.

Root-leaves tufted, forming a graceful rosette, deeply pinnatifid,

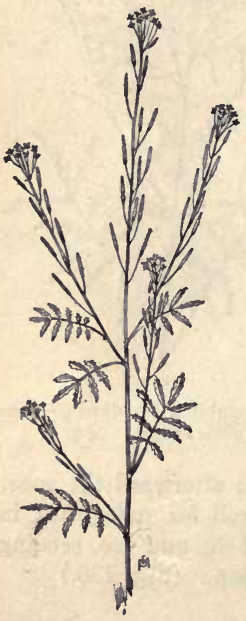

Fig. 137. - Green Tansy Mustard (Sisymbrium incisum, var. filipes). $\times \frac{2}{4}$. the segments again cut and toothed, petioled, deep green, slightly glandular, hairy. Stem leaves also all pinnatifid, but smaller, more finely divided, and with short petioles. Stem two to four feet tall, erect, branching, and finely hairy. Flowers bright yellow, about an eighth of an inch broad, in elongated racemes; pods smooth, narrow, slightly curved, a little more than a halfinch long, on slender, spreading pedicels. Seeds very small, reddish brown, minutely roughened, very mucilaginous when wet, which is an aid to their distribution. (Fig. 137.)

Another nearly related plant with nearly the same range is the Gray Tansy Mustard (S. incisum, var. Hartwegiànum, Watson), differing in that its much divided foliage is densely covered with soft, gray, appressed hairs. The Gray Tansy Mustard is later in flowering and in seed development, the pods being but a quarter-inch long, held nearly erect on short, ascending pedicels, making the racemes very slender. 
Means of control

Harrow autumn rosettes from the crop in the spring, when the grain is but a few inches tall. Spray the young flowering stalks with Iron sulfate or Copper sulfate at the appearance of the first yellow blossoms. Destroy waste-land plants by deep cutting or hand-pulling.

\section{WORMSEED OR TREACLE MUSTARD}

Erýsimum cheiranthoides, L.

Introduced. Annual or winter annual. Propagates by seeds.

Time of bloom: June to August.

Seed-time: July to September.

Range: Newfoundland to Alaska, southward to North Carolina and Tennessee.

Habitat: In fields and along streams.

The foliage and, particularly, the seeds of this weed are very bitter, and when milch cattle eat it the dairy products are much damaged; also its juices are said to be so irritating to mucous surfaces as to bring about serious bowel disorders in stock. Its Greek name means "to draw blisters."

Stem eight inches to two feet tall, slender, and branching. Leaves lance-shaped to linear, entire or sparingly toothed, the lower ones tapering to a short petiole, the upper ones sessile; the whole plant minutely roughened with fine, forking hairs. Flowers about a quarter-inch broad, bright yellow; racemes slender, the siliques four-sided, narrow, smooth, a half-inch to an inch long, held erect on divergent pedicels, making a noticeable elbow between the pod and its stem. Seeds small, reddish yellow, varying in shape from being crowded in the pods but approaching a flattened oval; too often an impurity among clover seeds. (Fig. 138.)

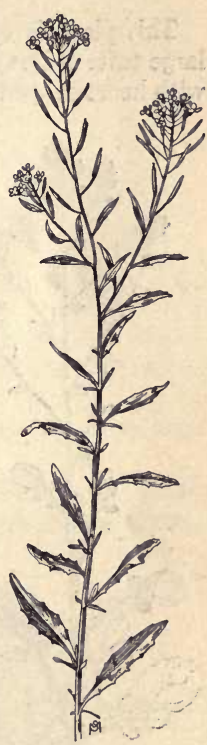

Fig. 138.-Wormseed Mustard (Erysimum cheiranthoides). $\times \frac{1}{4}$.

Means of control the same as for Field Peppergrass. 


\section{WINTER CRESS}

Barbarèa vulgàris, R. Br.

Other English names: Herb Barbara, St. Barbara's Cress, Yellow Rocket, Rocket Cress.

Native. Biennial. Propagates by seeds.

Time of bloom: April to June.

Seed-time: June to August.

Range: Labrador to the Pacific Coast, southward to Virginia and the Middle West. Also native to Europe.

Habitat: Fields, meadows, roadsides, and waste places.

This plant is easily distinguished from other Mustards by the large tufts of lyrate root-leaves, dark green, thick, smooth, shining, with heart-shaped terminal lobes and one to four lateral pairs along

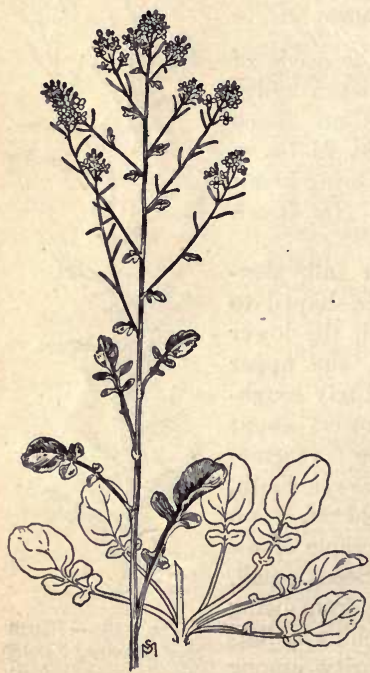

Frg. 139. - Winter Cress (Barbarea vulgaris). $\times \frac{1}{}$. the midribs; these glossy green rosettes are very conspicuous when first appearing from beneath the winter snow; at that season they make excellent greens, and in Europe they are cultivated for use as a potherb. Even on St. Barbara's Day, which is the fourth of December, one may dig away the snow and find the plants green and succulent. Flowering stalks one to two feet tall, with leaves sessile and sometimes clasping. Flowers in open clusters, bright yellow, nearly an inch broad, sweetscented. Siliques about an inch long, obscurely four-sided with valves keeled, the pedicels spreading but the pods nearly erect. Seeds brown, sometimes grayish with a coat of mucilage, flat, finely pitted; they are a common impurity of grass and clover seeds. (Fig. 139.) 
Sheep are fond of Winter Cress and cattle feed on it with as greedy an appetite as on rape or turnips or other cultivated crucifers; for this reason its planting as forage has been advocated, but its weedy habit of never "staying put" should be considered.

\section{Means of control}

Spudding or hoe-cutting the rosettes from the roots in the first year of growth, and closely cutting the flowering stalks while they are in first bloom.

\section{SCURVY GRASS}

Barbarèa vèrna, Asch.

(Barbarèa præ̀cox, Sm.)

Introduced. Perennial. Propagates by seeds.

Time of bloom: April to June.

Seed-time: June to August.

Range: Massachusetts to Virginia, and westward to Missouri.

Habitat: Fields, meadows, and waste places.

Often cultivated for winter salads, frequently escaping and now thoroughly naturalized as a weed. A more slender plant than the preceding species, its root-leaves more finely divided, having five to eight pairs of lateral segments. Flowers smaller and a paler yellow. Pods much longer, sharply four-sided, slightly compressed on short and very thick pedicels. Seeds smaller, more numerous, brown and flattened.

Means of control the same as for Winter Cress. The smooth, glossy surface of these two Mustards renders them impervious to injury from sprays.

\section{BULBOUS CRESS}

\section{Cardámine bulbòsa, B.S.P.}

Other English names: Bitter Cress, Spring Cress.

Native. Perennial. Propagates by seeds and by tuber-bearing rootstocks.

Time of bloom: April to June.

Seed-time: May to July.

Range: Nova Scotia to Minnesota, southward to Florida and Texas.

Habitat: Wet meadows, swamps, sides of streams, and ditehes. 
Although it produces seed in plenty, the worst part of this weed is underground; it springs from a small tuber about the size of a kernel of corn, attached to a slender rootstock on which there are other tubers, all of which will send up new plants during the present or the coming spring. Cows sometimes eat of the plant when first

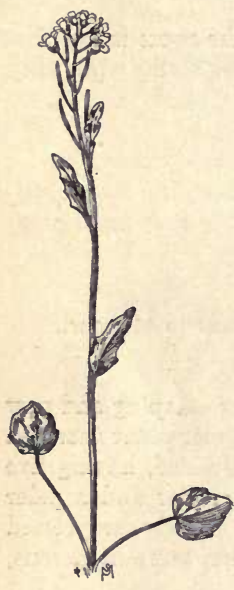

FTG. 140. - Bulbous Cress (Cardamine bul bosa). $\times \frac{2}{2}$. turned out to graze in spring, seeming to relish its pungent, bitter taste, the taint of which is communicated to the milk. (Fig. 140.)

Stem very slender, smooth, six inches to a foot in height. Base leaves about an inch broad, nearly circular or sometimes heartshaped, smooth, entire, with long, slender petioles; those on the stem broadly lanceshaped, sessile, often entire, others slightly toothed. Flowers in rather large, loose clusters at the top of the stalk, white, and about a half-inch broad. Siliques about an inch long, flattened, very slim, tapering at each end, nearly erect.

\section{Means of control}

Cleanse infested grass lands with better drainage, for if they lack moisture the tubers will die. Plants of brooksides and ditches should be cut with hoe or scythe in the spring, if they are likely to come within reach of grazing milch cattle.

\section{CLAMMYWEED}

Polanisia gravèolans, Raf.

Other English names: Clammy Clover, Stinking Clover.

Native. Annual. Propagates by seeds.

Time of bloom: June to August.

Seed-time: Late July to October.

Range: Quebec to the Northwest Territory, southward to Maryland, Tennessee, and Colorado.

Habitat: Sandy or gravelly soil; shores of streams and lakes, road embankments, moist, sandy fields. 
An unpleasant weed, with fetid odor and acrid juices, the whole plant glandular and clammy-hairy, even to its pods. Stem six inches to two feet tall, with slender ascending branches. Leaves alternate, dark green, with three oblong leaflets, tapering to each end, on slender petioles about as long as the central blade. Flowers in the upper axils, forming long, leafy, terminal racemes; corolla of four yellowish white or pinkish petals, notched at the outer edge, with a tassel of many unequal pinkish purple stamens in the center: four purplish pointed sepals, soon falling away. Capsule one to nearly two inches long, erect on spreading pedicels, one-celled, thin, rough, net-veined, crammed with rough, brown seeds. (Fig. 141.)

\section{Means of control}

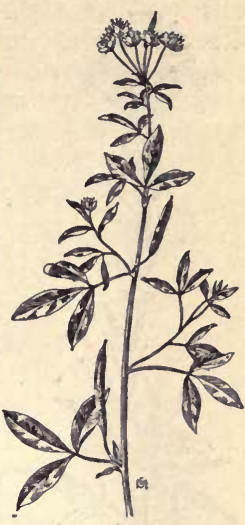

Frg. 141. - Clammyweed (Polanisia graveolans). $\times \frac{1}{6}$.

Close cutting or pulling before the formation of seed.

\section{PINK CLEOME}

Cleòme serrulàta, Pursh.

Other English names: Rocky Mountain Bee-plant, Stinking Clover, Stinkweed.

Native. Annual. Propagates by seeds.

Time of bloom: July to September.

Seed-time: Late August to November.

Range: Minnesota, Iowa, and Missouri, westward to the Rocky Mountains, New Mexico, and Arizona; also in Manitoba and the Northwest Territory:

Habitat: Dry upland prairies and hillsides, waste places.

The foliage of this plant has a very unpleasant odor, which causes it to be rejected by grazing cattle; but the blossoms yield much nectar, which the bees turn into clear honey of fine flavor; therefore bee keepers are its friends, for it blooms at a time when beepasture is not so very plentiful. 


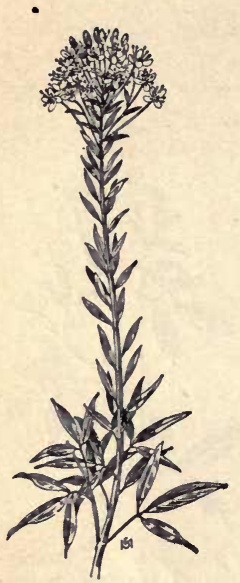

FIg. 142, - Pink Cleome (Cleome serrulata). $\times \frac{1}{3}$.

Stems two to three feet tall, erect, smooth, with a few branches near the top. Leaves alternate, three-parted, or the uppermost simple, the leaflets oblong, veiny, and pointed at each end; leaves near the base have slender petioles, but the upper ones are sessile or very short-petioled. Flowers in terminal racemes, rose-colored, sometimes nearly white, very showy, the four petals being about a half-inch in length and half as broad; sepals four, often persistent; ovary stalked, with a gland at its base ; stamens usually six, occasionally four, inserted above the petals on the stipe of the ovary; pedicels subtended by small, lance-shaped bracts. Pods one-celled, very slender, one to two inches long, pointed at each end, crowded with seeds. (Fig. 142.)

\section{Means of control}

Cut or pull before the earliest flowers have matured any pods.

\section{MOSSY STONECROP}

Sedum àcre, $\mathrm{L}$.

Other English names: Wall Pepper, Biting Orpine, Golden Moss, Creeping Jack, Pricket.

Introduced. Perennial. Propagates by seeds and by rooting at the joints.

Time of bloom: June to August.

Seed-time: July to September.

Range: New Brunswick to Ontario, southward to Virginia and Ohio.

Habitat: Fields and roadsides; cemeteries.

At least one case of severe poisoning has been reported from the eating of this peppery little plant. Stems tufted, spreading on the ground, rather thick and succulent, rooting at the joints, only the flowering branches erect, one to three inches high. Leaves yellow- 
ish green, smooth, fleshy, alternate, sessile, hardly a quarter-inch long, crowded and overlapping on the stalks. Flowers in small terminal cymes, bright golden yellow, each about a half-inch broad; calyx four- or five-lobed; petals four or five, distinct; stamens eight or ten. Follicles four or five, spreading, tipped with the persistent styles. Seeds reddish yellow, very small.

Means of control the same as for Sedum stoloniferum.

\section{LIVE-FOREVER}

Sedum stoloniferum, Gmel.

Introduced. Perennial. Propagates by seeds and by stolons.

Time of bloom: June to July.

Seed-time: August to September.

Range: Nova Scotia, New Brunswick, Maine.

Habitat: Fields and roadsides.

An escape from the flower garden, very hard to suppress when established as a weed. Stems rather thick, spreading on all sides, taking root at the joints and sending up numerous flowering stalks, three to eight inches tall. Leaves opposite, obovate, small, thick, sessile, wedge-shaped at the base, the rounded tip finely scallop-toothed. Flowers in flat, crowded cymes, the blossoms pink, about a half-inch broad, the central and firstopened flowers usually having five pointed petals, most of the others but four. Seeds very small, in four or five pointed spreading follicles which are united at the base; not of ten produced, the plant spreading chiefly by its stoloniferous stems. (Fig. 143.)

\section{Means of control}

Careful hoe-cutting, skinning the patches from the ground and removing to the compost heap or the bonfire; for any bit of stem in contact with moist soil, if it contains a joint, will take root and continue to grow.

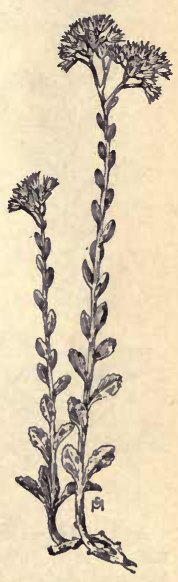

FIG. 143 . Live-forever (Sedum stoloniferum). $\times t$. 


\section{COMMON OPINE OR LIVE-FOREVER}

Sedum purpùreum, Tausch.

(Sedum Telephium, L.)

Other English names: Live-long, Aaron's Rod, Purse Plant, Pudding-bags.

Introduced. Perennial. Propagates by seeds, by tubers, and by rooting at the joints.

Time of bloom: June to September.

Seed-time: August to October.

Range: Quebec to Ontario and Michigan, southward to Maryland. Habitat: Fields, roadsides; waste places.

An escape from gardens, and a most pernicious weed when out of bounds. The tuberous, fleshy, white roots are attached to the

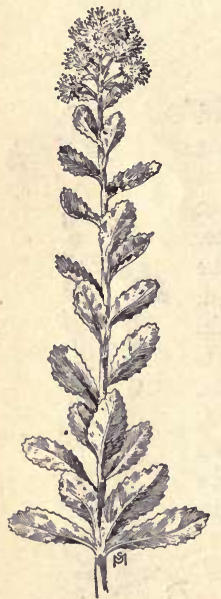

Fro. 144. - Common Orpine or Liveforever (Sedum purpureum). $\times \frac{1}{8}$. stems by small necks, and if even a very little one is broken off it sprouts a stalk and continues to thrive; broken stalks become slips, which put forth roots and form new plants.

Stem six inches to two feet in height, round, stout, smooth, erect, very leafy, often purplish. Leaves alternate, long obovate or the upper ones oval, thick, light green, bluntly toothed, sessile or the lowermost with petioles. By careful lateral pressure with the finger-tips the two surfaces of a leaf may be separated, making a "purse," or "pudding-bag." Flowers purple, in a dense, compound cyme at the summit of the stalk; each blossom about a half-inch broad, with five petals, rather thick, ovate, acute, twice as long as the sepals; stamens ten; carpels five, tipped with a persistent style, very short. Seeds small, seldom produced, the plant spreading almost entirely by its tuberous rootstocks. (Fig. 144.)

\section{Means of control}

Deep cutting in midsummer, salt or carbolic acid being applied to the shorn surfaces. Sheep will graze the plants down, particularly if strewn with a little salt. There is a fungous disease that attacks and kills the 
weed, and diseased plants may be used for the purpose of infection and destruction. The writer once killed a small patch in a cemetery with kerosene oil, but the ground was made sterile and resodding was necessary. Caustic soda would be equally effective and leach away more quickly.

\section{MEADOW-SWEET}

Spirc̀a latifolia, Borkh.

Other English names: Quaker Lady, Meadow Queen.

Native. Perennial. Propagates by seeds.

Time of bloom: June to August.

Seed-time: August to October.

Range: Eastern North America from Newfoundland to Virginia.

Habitat: Rocky pastures, roadsides, and waste places.

A handsome shrub which seems to have a preference for hillside pastures, where it spreads its kind undisturbed by grazing animals, as they dislike its astringent, bitter taste.

Stems two to four feet tall, with smooth, reddish or purplish brown bark, simple or branching near the top. Leaves alternate, thin, smooth, dark green, nearly an inch broad and three times as long, rather coarsely toothed, obtuse, and narrowing somewhat abruptly to a short petiole. Flowers in dense terminal panicles, very small, white or pale pink, with little or no fragrance in spite of the name; calyx short, five-cleft, persistent, nearly smooth; the five petals obovate and equal; stamens many; pistils usually five, superior, alternate with the calyx lobes. The blossoms open from the summit downward, and as the season advances the plume-like clusters begin to turn brown at the top. Seeds minute, in five small, smooth, brown, style-tipped follicles.

(Fig. 145.)

\section{Means of control}

Yearling shoots are easily and quickly hand-

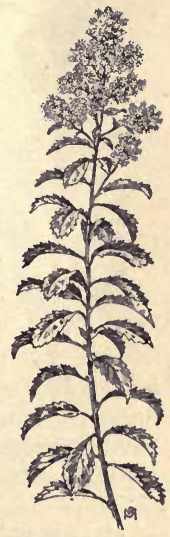

Fig. 145 . Meadow-sweet (Spirca latifolia). $\times \frac{1}{6}$. 
their woody roots into the soil they require to be grubbed out. Seeding may be prevented and root-growth checked by close cutting in the hot "wood-sere" days of July and early August.

\section{WILLOW-LEAVED MEADOW-SWEET}

Spiràa salicifolia, L.

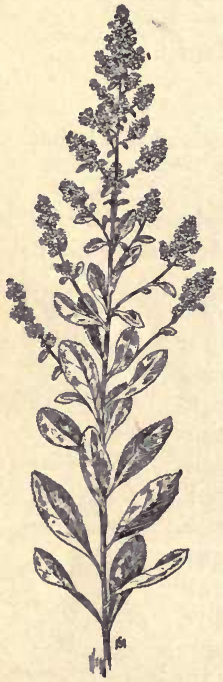

Fig. 146. - Willowleaved Meadow-sweet (Spircea salicifolia). $\times \frac{1}{6}$.

Native. Perennial. Propagates by seeds.

Time of bloom: June to August. Seed-time: August to October.

Range: Newfoundland to the Rocky Mountains, southward to Georgia and Missouri.

Habitat: Moist meadows and swamps.

Stems erect, slender, two to five feet tall, with smooth, yellowish brown bark; these stems are very tough and troublesome to mowing knives and scythes. Leaves firm, light green, smooth, or nearly so, lance-shaped, usually obtuse at apex, finely toothed, tapering at base to a short petiole. Flowers in large terminal panicles somewhat more narrow and pyramidal than in the preceding species, the five white petals of the small blossoms nearly round; pedicels and calyx finely downy. The five tiny follicles smooth, two- to fourseeded. (Fig. 146.)

Means of control the same as for S. latifolia.

\section{HARDHACK}

Spiræ̀a tomenṫsa

Other English names: Steeple-bush, Woolly Meadow-sweet.

Native. Perennial. Propagates by seeds.

Time of bloom: June to August.

Seed-time: August to October.

Range: Nova Scotia to Manitoba, southward to Georgia and Kansas.

Habitat: Moist meadows and swamps. 
Stems erect, two to four feet tall, woody, so hard and brittle as to nick scythe blades and break mowing knives, the bark red and clothed in rusty wool which readily rubs off. Leaves long ovate, unequally toothed, obtuse at apex, the base rounded or abruptly narrowed to a short petiole, smooth and green above but covered underneath with tawny or whitish wool. Flowers in dense terminal racemes, spire-like, deep rose-pink, sometimes a reddish purple, occasionally white. The roundish, pointed follicles are also woolly, filled with minute, brown seeds. (Fig. 147.)

Means of control the same as for Meadow-sweet.

\section{ROUGH CINQUEFOIL}

Potentilla monspeliénsis, L.

Other English names: Tall Five-finger, Norway Cinquefoil.

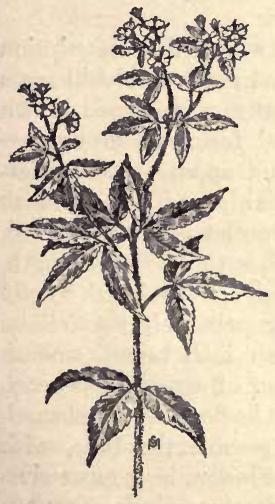

FIg. 148. - Rough Cinquefoil (Potentilla monspeliensis). $\times \frac{1}{3}$.
Native. Annual or biennial. Propagates by seeds.

Time of bloom: June to September.

Seed-time: July to October.

Range: Labrador to Alaska, southward to Georgia, Texas, and Mexico.

Habitat: Dry soil ; fields, meadows, and waste places.

Stem one to three feet tall, stout, erect, rough-hairy, branching near the top, becoming tough and woody with age and changing from green to a dingy reddish purple. Leaves alternate, palmately trifoliate, the leaflets obovate, doubletoothed, tapering to the base, hairy on both sides, the lower leaves petioled, the upper ones sessile or nearly so ; stipules leaf-like, lance-shaped, toothed or entire. Flowers in terminal cymose clusters, 
rather small, the five rounded, pale yellow petals being less than half as long as the hairy, pointed, persistent calyx-lobes which are subtended by bracts still longer; stamens many. After the flower has been fertilized the long calyx-lobes close protectingly over the cone-like heads until the many small achenes have ripened and are ready to be scattered by the swaying of the tall weed in the wind. (Fig. 148.)

\section{Means of control}

Close cutting while in first bloom; cultivation of the ground for one or two seasons.

\section{- SILVERY CINQUEFOIL}

Potentilla argèntea, $\mathrm{L}$.

Native. Perennial. Propagates by seeds.

Time of bloom: May to September.

Seed-time: Late June to November.

Range: Nova Scotia to the Dakotas, southward to Maryland and Kansas. Native also to Europe and Asia.

Habitat: Dry soil ; fields, meadows, and pastures.

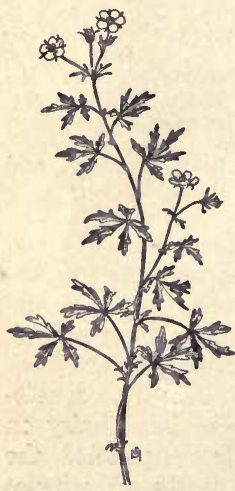

F1G. 149. - Silvery Cinquefoil (Potentilla argentea). $\times \frac{1}{2}$.
The plant from which this description is written was pulled from a sidehill grass lot, on which the grass was burned brown and apparently dead from the drought but the weed did not appear to be suffering. Root deep, hard, and woody, with branching, fibrous rootlets. Stems tufted, spreading, three inches to a foot in length, also coarse and woody, covered with woolly white hair. Leaves palmately five-foliate, usually less than an inch broad, smooth and green above but silver-white beneath with woolly hair; leaflets wedge-shaped, deeply cut, entire toward the base, with margins revolute. Flowers in cymose clusters, terminal on short pedicels, about a quarter-inch broad, the calyx white-woolly, the five rounded petals greenish yellow, 
slightly notched at the edge. Achenes smooth, very small, ripening and falling all summer. (Fig. 149.)

\section{Means of control}

Enrich the soil, furnishing humus which will enable it to retain moisture and support the growth of better plants.

\section{SHRUBBY CINQUEFOIL}

Potentilla fruticòsa, L.

Other English names: Yellow Hardhack, Prairie Weed, Black Brush, Chester Flower.

Native. Perennial. Propagates by seeds.

Time of bloom: May to October.

Seed-time: Seeds remain on the plant until winter, being usually seattered between December and March.

Range: Labrador to Alaska, southward to New Jersey, Illinois, and Minnesota. In the Rocky Mountains to Arizona and in the Sierra Nevadas to California.

Habitat: Dry open ground; meadows and pastures.

A plant which has shown its weedy qualities chiefly in New England and in parts of Colorado, Indiana, and Ohio. It is a shrub, one to five feet tall, branching from the base, making a spreading, compact growth which chokes out all else. Young shoots are clothed in white down, but when mature the stems become hard, woody, and covered with hairy, ragged, grayish brown bark. These old "Hardhack" stems are incredibly tough and turn the edge of the sharpest scythes. Leaves pinnately five- to seven-foliate, the leaflets pointed at both ends, a half-inch to an inch long, entire, with margins slightly revolute, gray-green with silky hairs. Flowers in terminal cymose clusters, numerous, bright yellow, about an inch broad, the five petals nearly round and exceeding the ovate calyx-lobes and the pointed bracts.

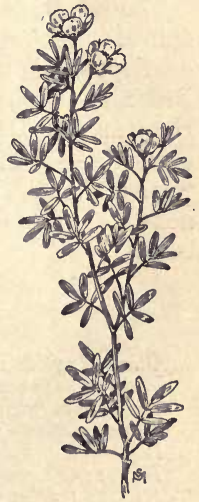

Fig. 150.- Shrubby Cinquefoil $(\mathrm{Po}$ tentilla fruticosa). Achenes twenty or more to a flower, small, $\times \frac{1}{3}$. 
light, hairy-coated, blown far and wide over crusted winter snow. (Fig. 150.)

\section{Means of control}

One way is to cut or burn off the tops before the leaves start in the spring, and then, with a strong team and a heavy plow, turn out the roots, drag them from the soil with a harrow, pile, dry for a few days, and burn. Some of the largest roots will prove too much for the plow and the harrow; such roots must be pulled by a horse with a chain, aided by a man with a crowbar. Or young and comparatively shallow roots may be knocked out of the ground with a pickax while the soil is still frozen. Farmers who have thus reclaimed Cinquefoil fields say that the land is left in excellent condition for crops, being apparently improved rather than exhausted by its weedy occupant. Some of these shrubby lots may not be worth so much expense and labor and should be given back to forest growth, which soon drives out the weed and would, in the end, prove a very profitable investment.

The keeping of Angora goats has been successfully tried, those animals browsing back the twigs and entirely preventing seed development; but there is probably more than enough Black Brush, as the shrub is called in Colorado, to supply all the goats in the country. On the whole, the best means of keeping out this very aggressive weed is not to let it get in; that is, whenever the white, woolly, young shoots appear, hand-pull them promptly, letting none mature to reproduce themselves by thousands and possess the land.

\section{SILVER WEED}

\section{Potentilla Anserina, L.}

Other English names: Goose Grass, Goose Tansy.

Native. Perennial. Propagates by seeds and by many-jointed runners which take root at the nodes.

Time of bloom: May to September.

Seed-time: July to November.

Range: Throughout North Ameriea; also in Europe and Asia.

Habitat: Wet grasslands, banks of streams, lake and sea shores.

All that this plant seems to require is that the ground shall be damp, and, whether the land be the tropic shores of the Gulf of Mexico or an Alaskan or Greenland marsh, it is satisfied. 
The weed springs from a slender taproot, fringed with many thready rootlets. Leaves thickly tufted, spreading, six to eighteen inches long, pinnately compound with seven to twenty-five oblong, tooth-edged leaflets, the larger ones at the tip, decreasing in size inward to the long, grooved petiole, dark green and smooth above but underneath white with fine, silken hairs. Thrust out from among the tufted leaves are a number of jointed runners, one to three feet long, the young plants sitting on the nodes until the parent has pushed them out a convenient distance for striking root and starting an independent growth. Flowers solitary, lifted on slender, erect, axillary peduncles, bright yellow, nearly an inch broad; calyx-lobes acute, silky-hairy; these fold over the seedheads until the smooth, small achenes have ripened, when they reopen and the nodding stems scatter them abroad.

\section{Means of control}

Good drainage is all that is necessary in order to drive out the Silverweed, but in places where that is impracticable the plants should be closely cut in June, before the first seeds fall or any runners have taken root.

\section{COMMON CINQUEFOIL OR FIVE-FINGER}

Potentilla canadénsis, L.

Native. Perennial. Propagates by seeds and by stolons.

Time of bloom: April to August.

Seed-time: June to September.

Range: Maine and Quebec to Minnesota, southward to Georgia and Oklahoma.

Habitat : Dry soil ; fields, meadows, pastures, and waste places.

Stems tufted, spreading, stoloniferous, six inches to two feet long, very slender, the runners thin as wire, often reddish, finely hairy. Leaves palmately five-foliate, the

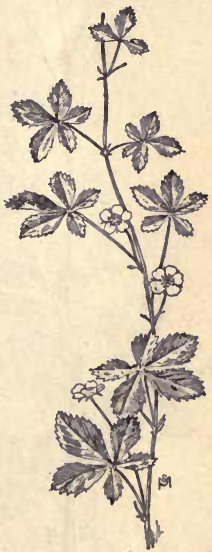

Fig. 151. - Common Five-finger $(\mathrm{Po}$ tentilla canadensis). $\times \frac{1}{3}$ 
above, sparsely hairy beneath, with slender petioles. Flowers solitary in the axils, on long slender, wiry peduncles, golden yellow, about a half-inch broad, the five petals broadly obovate, longer than the pointed calyx-lobes and the narrow bractlets. Achenes small, smooth, scattered by the nodding of the wiry flower-stalks. (Fig. 151.)

\section{Means of control}

Cultivation, liming and manuring the soil, will so stimulate the growth of better plants that the weed will soon be superseded. Clover is the best crop to grow for this purpose.

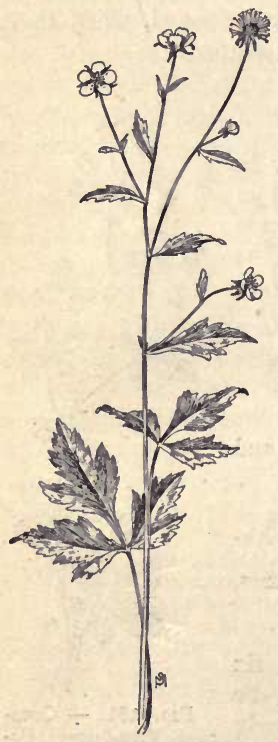

FIG. 152. - White Avens

(Geum canadense). $\times \frac{1}{2}$.

\section{WHITE AVENS}

Gèum canadénse, Jacq.

(Gèum album, Gmel.)

Native. Perennial. Propagates by seeds. Time of bloom: June to August.

Seed-time: July to September.

Range: Nova Scotia to Minnesota, southward to Georgia and Missouri.

Habitat: Fence-rows, woodland borders, thickets along streams.

A frequent weed in brushy pastures where sheep are likely to be foraging and to get their fleeces beset with its bristly, hooked achenes. Stems one to two feet in height, slender, erect, finely hairy or sometimes smooth, branched near the top. Lower and basal leaves long-petioled, pinately three- to fiveparted, the terminal lobe large and broadly ovate, the lateral lobes small and narrow, all sharply toothed; stem leaves with fewer segments and short petioles, the topmost becoming lanceshaped and sessile. Flowers white or pale greenish yellow, about a half-inch 
broad, with five short, rounded petals and pointed, reflexed calyxlobes; stamens many, inserted on a disk at the base of the calyx. Head of fruit nearly globular, the many persistent, jointed styles forming hooks by which the achenes attach themselves to clothing or to the coats of animals for transportation to new homes. (Fig. 152.)

Means of control

Close cutting before the development of seeds.

\section{DEWBERRY}

Rùbus villdsus, Ait.

(Rùbus procúmbens, Muhl.)

Other English names: Running Blackberry, Trailing Bramble.

Native. Perennial. Propagates by seeds.

Time of bloom: Late April to June.

Seed-time: Fruit ripe in June in southern part of its range, in July farther north.

Range: Newfoundland and Ontario to Lake Superior, southward to Virginia and Missouri.

Habitat: Upland fields, meadows, and pastures, fence rows, and waste places.

A variety of this plant, much improved by selection and cultivation, comes to our tables as the delicious "Lucretia Dewberry"; but the wild bramble, sprawling itself over acres of open uplands, is a pestiferous weed. Birds are very fond of the fruits and eat them to repletion, voiding the seeds unharmed, so that prickly young Dewberry shoots get mown with the hay of the meadows and keep turning up in the most unexpected places.

Stems prostrate, shrubby, very prickly, six to ten or more feet in length, with many small erect fruiting

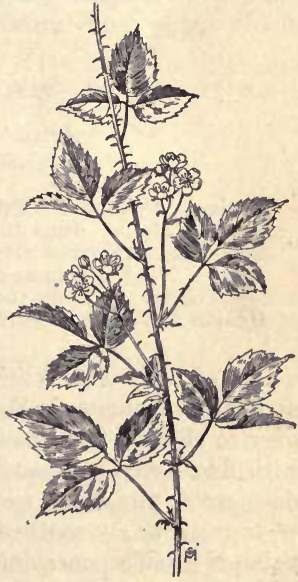

FIG. 153. - Wild Dewberry (Rubus villosus). $\times \frac{1}{6}$. 
branches, six inches to a foot high, all armed with sharp prickles. Leaves pinnately compound, with three to seven long-ovate or rhombic leaflets, on very slender and often prickly petioles, rather thin, prominently veined, finely double-toothed, dark green, taking on a gorgeous red coloring in autumn. Flowers in terminal clusters, or occasionally solitary, about an inch broad, with fiveparted calyx and five obovate, white petals; stamens many; pistils many, closely set on a succulent "core" or torus which elongates as they mature, each becoming a small pulpy drupelet, containing one achene. These drupelets cohere and form the fruit, black, sweet, juicy, often an inch long, dropping readily from the stems when ripe. (Fig. 153.)

\section{Means of control}

The vines should be cut close to the ground, or, better, spudded off below the surface, before the fruit is formed, and then piled and burned. A handful of salt or a little kerosene on the cut surfaces is discouraging to new growth.

\section{TALL HAIRY AGRIMONY}

Agrimònia gryposépala, Wallr.

(Agrimònia hirsùta, Bicknell)

Native. Perennial. Propagates by seeds.

Time of bloom: June to August.

Seed-time: August to October.

Range: Nova Scotia and Maine to Minnesota, southward to North Carolina. Also on the Pacific Coast.

Habitat: Woodland borders, thickets along streams.

One of the many "stickseed" plants that vex the wool-grower, and rather common in the rocky brush-lot pastures usually given over to sheep. Stem two to four feet tall, slender, and covered with fine, spreading hairs. Roots fibrous and clustered. Leaves deep green, pinnatifid, mostly with seven - sometimes five or nine - large, coarsely toothed, oblong to obovate leaflets, and three pairs of smaller ones interposed between them; petioles hairy, with large, coarsely toothed stipules at the base. Flowers in long, slender, spicate racemes, the rachis glandular-hairy, interspersed 
with longer spreading hairs; blossoms less than a half-inch broad, with five small, rounded, yellow petals, many stamens, one pistil with two-parted style, and a hairy, five-lobed calyx, closed after flowering and surrounded with a ring of hooked bristles; these lengthen as the two achenes within mature, forming a small, top-shaped bur with its outer row of hooks deflexed, the inner ones spreading and erect, so that no sheep or woollen garment can touch a spike without attaching most of its fruits. (Fig. 154.)

\section{Means of control}

If flocks are to be kept in their neighborhood the plants should be searched out and closely cut while in first bloom. Or, when the ground is soft, they may be hand-pulled.

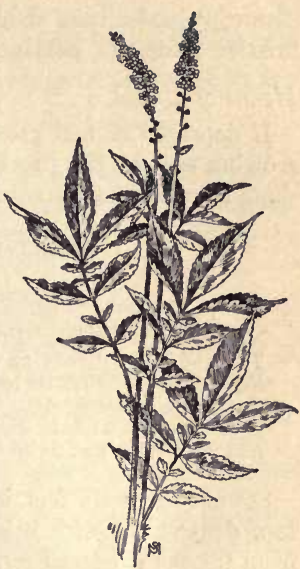

Fig. 154. - Tall Hairy Agrimony (Agrimonia gryposepala). $\times \frac{1}{8}$.

\section{SOFT AGRIMONY}

\section{Agrimonia mollis, Britton}

Native. Perennial. Propagates by seeds and by tubers.

Time of bloom: July to October.

Seed-time: August to November.

Range: Connecticut to Michigan, southward to North Carolina and Kansas.

Habitat: Hillsides, dry woodland borders, and thickets.

Roots tuberous, rather thick and elongated. Stems very slender, two to five feet tall, with slim ascending branches, covered with fine, very soft hair. Leaflets five to nine (mostly seven), with two or three intermediate smaller pairs, oblong to elliptic or obovate, obtuse, rather thick, scallop-toothed, grayish green and very softly hairy on both sides; stipules oblong to lance-shaped, and entire, or sometimes broad and sharply toothed. Racemes long and wandlike, interrupted, the flowers nearly a half-inch broad, bright yellow. 
The top-shaped burs about a quarter-inch long, the ring of hooked bristles ascending nearly in a single row.

\section{Means of control}

If deprived of leaf growth by frequent cutting throughout the growing season, the tubers shrivel and die; in any case no fruits should be allowed to mature in the neighborhood of grazing flocks.

\section{SMALL-FLOWERED AGRIMONY}

Agrimònia parviflòra, Ait.

Native. Perennial. Propagates by seeds.

Time of bloom: July to Oetober.

Seed-time: August to November.

Range: Connecticut to Ontario, Michigan, and Kansas, southward to Georgia and Louisiana.

Habitat: Sandy alluvial soil ; damp meadows, thickets along streams.

Stem two to six feet in height with slender branches near the top, densely set with bristly, brownish hairs, very leafy, growing from fibrous clustered roots. Leaflets nine to nineteen, elliptic to narrow lance-shaped, pointed at both ends, sharply toothed, thin, finely hairy, with many interposed pairs of small leaflets of varying sizes; stipules usually broader than their length, clasping, sharply toothed. Racemes many-flowered, one to two feet long, the blossoms hardly more than a quarter-inch broad, the petals light yellow. Burs small, dilated top-shaped, deflexed on their pedicels, the rows of hooked bristles erect, spreading, and reflexed.

\section{Means of control}

If areas are not too large to make the task impracticable, handpulling the plants before seed development is well worth while. Repeated and close cutting throughout the growing season, depriving the roots of all leaf-growth, will finally suppress the weed.

\section{SWEET BRIER}

Ròsa rubiginòsa, $\mathbf{L}$. (Ròsa eglanteria, Mill.)

Other English names: Eglantine, Sweetleaf Rose.

Introduced. Perennial. Propagates by seeds. 
Time of bloom: June to July.

Seed-time: Hips ripe in September but remain on the bushes until winter.

Range: Nova Scotia to Ontario and Michigan, southward to Virginia and Tennessee.

Habitat: Rocky pastures, along roadsides, and in fields.

Every pure pink blossom and fragrant leaf of this plant seem a protest against its being called a weed. It came to us from Europe, and the pages of Chaucer, Spenser, Shakespeare, are full of its sweetness. But,

"With brambles and bushes in pasture too full, Poore sheepe be in danger and loseth their wull,"

and cattle will not touch it nor even graze very near it, fearing the hooked prickers and apparently not liking its fragrance. (Fig. 155.)

Canes slender, four to eight feet high, brown when old, armed with strong, flattened, hooked, brown prickles; between them the stem may be smooth, or, when young, may be set with fine bristly hairs. Leaves alternate, pinnately compound, with five to seven roundish oval leaflets, rather thick, finely double-toothed, dark green and smooth above, but covered underneath with fine, soft hair and resinous, rust-colored glands that show very plainly under a lens; the broad stipules are also glandular. Flowers pink, not fragrant, usually about two inches broad, the five petals notched into a heart-shape at the outer edge, with a tuft of many yellow stamens in the center; calyx-lobes spreading and much divided, glandular-hairy, as are also the pedicels. Within the calyx-tube is a hollow disk on which the many pistils are set; ovaries hairy, becoming bony achenes. Hips about a half-inch long, ovoid, smooth, orange-red; under the

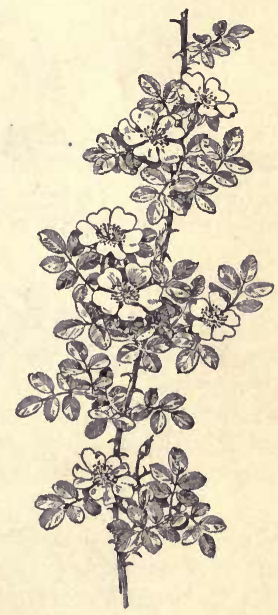

Fig. 155. - Sweet Brier (Rosa rubiginosa). $\times \frac{1}{4}$. 
rather thin skin is a layer of soft pulp, but within they are stuffed with the hard, hairy, straw-colored achenes.

\section{Means of control}

Old bushes require grubbing for their removal. Young ones, while the canes are still green, may be destroyed by repeated cutting and salting, or by treating with a little caustic soda about the roots.

\section{PRAIRIE ROSE}

\section{Ròsa arkansdna, Porter.}

Other English names: Running Brier-rose, Prairie Bramble. Native. Perennial. Propagates by seeds and by rootstocks. Time of bloom: June to July.

Seed-time: Hips ripe in autumn but retained until winter.

Range: Manitoba, Minnesota, and the Dakotas, southward to

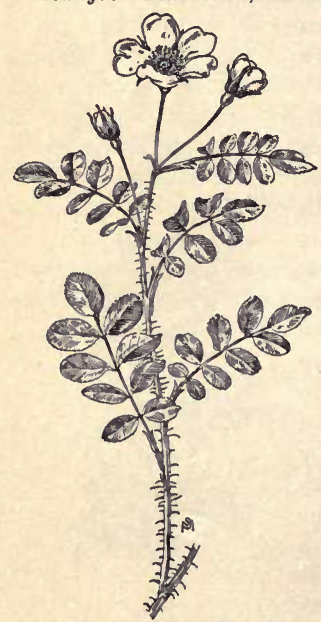

FIG. 156. - Prairie Wild Rose (Rosa arkansana). $\times \frac{1}{2}$. Colorado, New Mexico, and Texas. Habitat: Prairies; fields, meadows, pastures, waste places.

In spite of its beauty this plant is considered a bad weed throughout its range, for, though itself but one or two feet tall, it has long, deep-running, branching, underground stems, which, from the axils of their scales, send up many flowering shoots. It is especially troublesome in grain fields and is now established in a number of eastern localities, the seeds having been an impurity of western oats.

Stem erect, slender, bristling with very thin, fine prickles. Leaflets seven to eleven, obovate, finely and sharply toothed, smooth on both sides, seldom more than an inch long ; stipules long and narrow, sometimes toothed above, and more or less glandular. Flowers pink, large, 
often more than two inches broad, occasionally solitary but usually growing in open corymbose clusters. Hips globular, smooth, about a half-inch in diameter, crammed with hard, hairy achenes. (Fig.156.)

\section{Means of control}

If the plants are young and few, grub out the colonies, securing, if possible, every shred of the rootstocks; in ground rankly infested, cut the stalks from the rootstocks with a very sharp-bladed plow in the hot days of July. New shoots will promptly appear, which, at intervals of not more than two weeks - ten days would be better - must be disked, or cut off with a sharp and broadbladed cultivator, in order to keep leaf growth from feeding the rootstocks. Next season put in a cultivated crop of which the tillage will constantly keep the shoots cut off, and so starve the underground stems.

\section{WILD BLACK CHERRY}

Prùnus serbtina, Ehrh.

Native. Perennial. Propagates by the stones, or pits.

Time of bloom: May to June.

Seed-time: A drupe, ripe in August and September.

Range: Nova Scotia to Florida, westward to the Dakotas and Arizona.

Habitat: Woodlands, and also common along fence rows, roadsides, and waste places.

The Black Cherry is often a large tree and a most valuable one to dealers in fine cabinet-making woods. It has reddish brown twigs, with somewhat bitter, aromatic, inner bark. The leaves are somewhat thick in texture, smooth and shining on the upper side, broadly lance-shape to oblong, taper-pointed, the teeth incurved and short. The flowers are white and grow in elongated terminal racemes; the fruits which follow are purplish black drupes, slightly bitter but pleasant to the taste.

It is not the mature tree that must be placed on the list of noxious plants, but its numerous progeny of young shoots which spring up everywhere about the country. Birds are very fond of the juicy fruits and eat great quantities, voiding the stones along fence rows and telephone lines, with the result that those land- 
marks are often bordered by thickets of Black Cherry sprouts. The leaves of this and kindred plants, under certain conditions, contain a dangerous quantity of hydrocyanic acid, commonly called prussic acid, a most virulent poison. When eaten by cattle and sheep, the complex chemical changes that take place within the animals' stomachs liberate the poison, frequently with fatal effect. The common Choke Cherry (Prùnus virginiàna) also contains prussic acid, but in a less amount than the Black Cherry. Leaves from large trees or old but stunted shrubs are not nearly so dangerous as leaves from young, rapidly growing sprouts. Both fresh and wilted leaves are poisonous, but chemists have demonstrated by experiment that "Leaves wilted in bright sunlight to about 75 per cent of their original weight, or until they begin to appear slightly limp and to lose their gloss, yield the maximum amount of prussic acid." It is stated that a half-pound of Black Cherry leaves is a fatal quantity for a cow to eat, and a much less quantity will kill a sheep.

\section{Means of control}

Yearling Cherry sprouts may be easily and quickly pulled when the ground is soft, leaving no stubs to put forth more leaves. Older, shrubby growths should be closely cut, or, better, grubbed out, before coming into leaf, if they are situated where cattle or sheep are likely to browse them. Often grazing animals will eat litter that is lying on the ground, even though they have not contracted the habit of browsing from standing growth; therefore all the brush cut should be put out of harm's way by piling and burning.

\section{WILD SENNA}

\section{Cássia marilándica, L.}

Other English names: American Senna, Yellow Locust Plant.

Native. Perennial. Propagates by seeds.

Time of bloom: July to August.

Seed-time: September to October.

Range: Now England to Florida, westward to Michigan and Indiana.

Habitat: Moist, open ground; pastures and meadows.

The roots of Wild Senna are spreading, contorted, woody, and black, mostly horizontal, but yet gathering nourishment from the 
depths through a mass of stringy feeding fibers, also black. With such a food reserve, no wonder it is able to send up yearly such a quantity of growth above ground; for each plant is a collection of many woody stalks, three to six feet tall, erect, slender, pale green, round, smooth, or slightly grooved at base; when young, both stems and leaf-stalks may be slightly hairy. Leaves alternate and set rather far apart, pinnately compound, with five to nine pairs of smooth, oblong leaflets, dark green above and paler below, the edges entire and the midvein extending beyond the rounded tip in a bristly point; petioles short, yellow, grooved on the upper side, and having a prominent, club-shaped gland set just above the swollen base. Flowers bright yellow, springing in many loose clusters from the upper axils; calyx-lobes five, very narrow and reflexed; five unequal petals, three close together at the top, the two below larger and spreading; ten yellow stamens with filaments of differing lengths, tipped with brown anthers of differing sizes, the three lowermost ones largest. Pods about three inches long, flat, curved, slightly constricted between the seeds, hairy when young but becoming smooth as they ripen, and turning to a dark reddish brown. Seeds flat, dark brown, usually four to eight in a pod, possessed of very long vitality when in the soil. A Wild Senna plant in bloom has a look of elegance, as though it cared for its own fine appearance. Grazing animals leave it undisturbed, or if scarcity of forage drive them to browse its leaves they suffer from "scours" as it has a strong cathartic action. It is one of the medicinal plants, and its leaflets, stripped from their stalks at flowering time and carefully dried, may be sold in the drug market for six to eight cents a pound.

\section{Means of control}

If the plants are few they may be grubbed out, but if plentiful this would be a task for Hercules. Cutting close to the ground at the time of bloom, repeating the operation as the roots send up more stalks, will finally exhaust their vitality ; but the treatment must be so persistent as to allow no opportunity for storing fresh nutriment. Dry salt on the cut surfaces will help to check new growth; or the plants may be wholly and promptly destroyed by the use of caustic soda or hot brine about the roots, leaving the ground barren for a season. 


\section{COFFEE SENNA}

Cássia occidentàlis, $\mathrm{L}$.

Other English names: Negro Coffee, Magdad Coffe日.

Introduced. Annual. Propagates by seeds.

Time of bloom: July to August.

Seed-time: August to September.

Range: Virginia to Indiana and southward to the Gulf of Mexico.

Habitat: Meadows and pastures, waste places.

Like the Partridge Pea and the Wild Senna, this weed is strongly cathartic, and its young shoots, when harvested with hay greatly

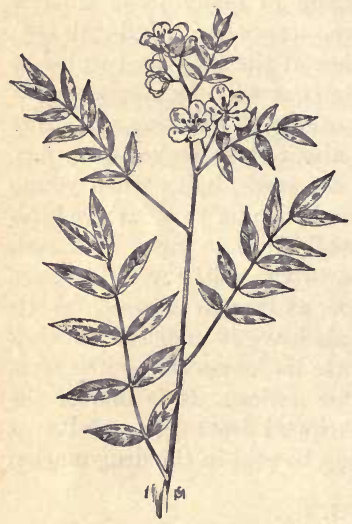

Frg. 157. - Coffee Senna (Cassia occidentalis). $\times \frac{1}{2}$. damage the quality, as animals feeding on it are subject to "scours." The plant is an immigrant from tropical America, and seems to have become acclimated during its slow northward march.

Stems erect, smooth, light green, much branched, and three to six feet tall. Leaves pinnately compound with four to six pairs of smooth, long-pointed, ovate leaflets, one to two inches long; the slender petioles are lighter than the leaflets, and near the base of each is an egg-shaped, brownish yellow gland. Flowers in short, branching, axillary clusters; each blossom about a half-inch broad, with five spreading yellow petals more nearly equal than those of the perennial Wild Senna; ten brown anthers, the upper three of which are dwarfed and imperfect; calyx-lobes oblong, obtuse. Pods smooth and slender, slightly curved, four to six inches long and about a quarter-inch wide, with thickened border; each contains about a dozen small brown seeds, which retain their vitality in the soil for at least two years and probably longer. (Fig. 157.) 


\section{Means of control}

Prevent seed production by early and persistent cutting throughout the growing season, treating the shorn surfaces with salt for the discouragement of new growth. For small areas, newly infested, hand-pulling is a paying process.

\section{PARTRIDGE PEA}

Cassia Chamacrista, L.

Other English name: Large-flowered Sensitive Pea.

Native. Annual. Propagates by seeds.

Time of bloom: July to September.

Seed-time: September to November.

Range: Massachusetts to Minnesota, southward to the Gulf of Mexico.

Habitat: Dry, sandy soil ; fields, meadows, pastures, roadsides, and waste places; most troublesome in the Southwest.

Pastures rankly infested with this weed are nearly useless, for it is strongly cathartic and when eaten in any quantity by cattle and sheep they "scour" very badly ; grazing horses are sickened in the same way and must be relieved by change of forage. Young stalks are often mown and baled with the hay of infested meadows, causing the same trouble when the fodder is used in winter.

The plant is low and spreading, often branching wider than its height of one or two feet. When young the stem may be sparsely hairy, but usually it is smooth and pale green. Leaves pinnately compound, composed of ten to fifteen pairs of small, entire, lanceshaped leaflets each tipped with a sharp bristle; petioles short, with persistent, awl-shaped stipules and having near the base a sessile gland. The leaves are sensitive, and at night "go to sleep" by folding their blades

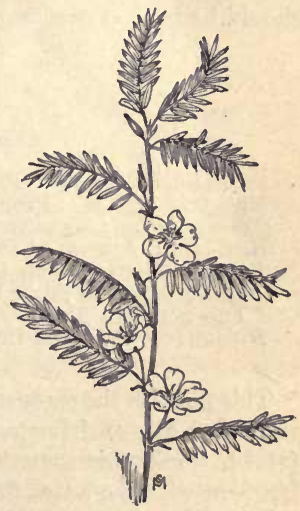

Fig. 158. - Partridge Pea (Cassia Chamaecrista). $\times\left\{\begin{array}{l}\text {. } \\ \text {. }\end{array}\right.$ 
face to face and drooping against the stalk. Flowers large, often more than an inch across, lifted on slender peduncles from the upper axils, singly or in clusters of two or three; they are bright golden yellow, but often two or three of the rounded petals are spotted with purple at the base, and usually six of the anthers are purple and four are yellow. Pods slender, about two inches long, slightly hairy; when ripe, they split apart with a slightly twisting action by which the seeds are thrown a short distance from the parent plant; so that next year, where one weed grew there will be a little patch. (Fig. 158.)

\section{Means of control}

Prevent development of seed. Postpone all other work for a day and cut the Partridge Pea patches on noting the first golden bloom. Repeat the operation with the new growth which follows, and as soon as all dormant seed in the ground has stirred into life and been given like treatment the trouble will be ended. New infestations should be promptly pulled or cut before any seed is formed. Ground on which plants have been allowed to mature and scatter seeds should be burned over in order to destroy them.

\section{RATTLE-BOX}

\section{Crotaldria sagittalis, L.}

Other English names: Rattleweed, Wild Pea.

Native. Annual. Propagates by seeds.

Time of bloom: June to July.

Seed-time: August to October.

Range: Massachusetts to Florida, along the coast; bottom lands of the Missouri River in South Dakota, Iowa, Nebraska, Kansas, and northern Texas.

Habitat: Rich, moist soil ; pastures and meadows.

This plant is the cause of a sickness, called Crotalism by veterinarians and Missouri Bottom Disease by the farmers, which is often fatal to horses and sometimes also to eattle, though deaths are less frequent with the latter than with horses. The poisonous principle is in both leaves and seeds, and is not dissipated by drying but seems to be even more potent in plants that have been harvested with 
hay than in those that are green in the field. Its action is slow, often several weeks intervening before death. If recovery comes it is not complete, the animal being never so well again as before the attack of Crotalism. The weed is a relative of the dreaded Locoweed of the plains, but does not cause the animals to "go plumb crazy," as does that plant. (Fig. 159.)

The plant is small, seldom more than a foot in height, with a much-branched and hairy stem growing from a small, straight root. Leaves alternate, nearly sessile, lance-shaped, one or two inches long, pointed at both ends, entire or slightly wavy, with edges softly hairy; they have curious stipules, shaped like an arrow-head, point down, with the ears sticking up on each side of the leaf and the point decurrent on the stem for a part of its length. Flowers yellow and very small, shaped like peablossoms, that is, with a corolla of five irregular petals, the upper one larger than the others, and enclosing them in the bud; this broad upright petal is called the standard and is usually turned backward; two lateral petals or wings, obliquely spread and outside of the two lower ones which cohere at their edges, forming the keel, which usually encloses the stamens and pistil. In this

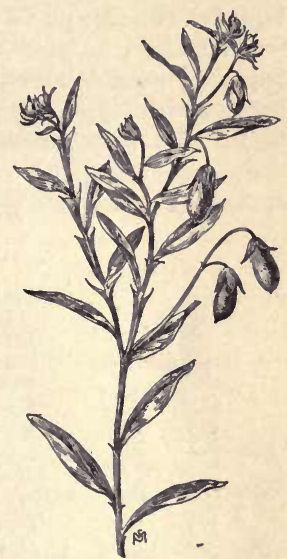

Fig. 159. - Rattlebox (Crotalaria sagittalis). $\times \frac{1}{3}$. species the stamens are ten, one separate and nine of them united into a tube, cleft on its upper side, the anthers of two lengths and sizes, alternating with each other; calyx two-lipped, the two upper lobes broadest, all five long-pointed and softly hairy. The flowers grow in clusters of two or three on slender, axillary peduncles. Pods black, very hard and brittle, about an inch long but swollen much larger than the small, black seeds within, which break from their hold when ripe and rattle about inside the stiff, thin walls. In winter these light pods are blown long distances over the snow, and they can float like a boat on water. 


\section{Means of control}

Let the infested meadows be cleansed by fire, burning them over in August or at the time of maturing seeds, thus destroying all this year's plants and their progeny while not seriously harming the roots of the perennial grasses. If next year some seeds that have lain dormant in the soil spring up, see that the plants are either cut or pulled before seed development. Or, if too numerous for that, repeat the flaming purification. On lands that are not in danger of washing and can safely be put under the plow, a cultivated crop requiring careful hoe-culture should be grown before reseeding heavily with better forage. No annual plant so.dangerous to the health of grazing animals should be allowed to survive.

\section{DYER'S GREENWEED}

\section{Genista tinctòria, L.}

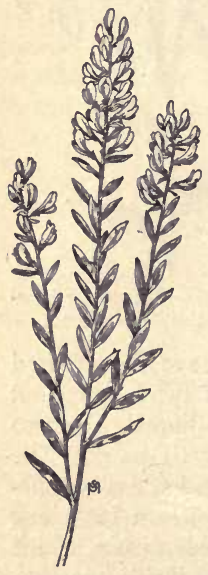

Fia. 160.-Dyer's Greenweed (Genista tinctoria).
Other English names: Woad-waxen, Dyer's Broom, Dyer's Whin, Base Broom, Alleluia.

Introduced. Perennial. Propagates by seeds and by woody, creeping rootstocks.

Time of bloom: June to July.

Seed-time: July to August.

Range: Maine to Massachusetts and eastern New York.

Habitat: Dry uplands.

Time was when the clothing of a New England household was spun, woven, and dyed at home; then the Genista was cultivated as a useful and necessary plant. Used by itself, it colored woolen cloth yellow; combined with Woad (İsatis tinctòria), a blue-dye plant of the Mustard Family, it dyed green. But, its usefulness gone, it was left uncared for and "escaped," becoming so abundant in some localities that dry upland pastures are sometimes yellow in summer with its bloom. Cattle will eat it when other forage is scarce, with the result that its bitter taste is imparted to the dairy products. (Fig. 160.) 
Stems usually not much more than a foot high, hard and woody, branching freely from the base, round, ridged, and without thorns. Leaves alternate, lance-shape to elliptic, sessile, entire, smooth and shining. Flowers in spiked racemes, each flower about a half-inch long, like a golden-yellow pea-blossom, sessile, with a small bract at its base. Pods about an inch long, smooth, and flat, each containing several seeds which are very long-lived.

\section{Means of control}

Frequent and persistent cutting close to the ground, beginning at the first bloom and allowing no leaf-growth throughout the growing season. More than one season of such persistent root-starvation may be required in order to subdue the weed, but, if not permitted to refill its underground storehouses with sustenance, it must succumb.

\section{WILD LUPINE}

Lupinus perénnis, L.

Other English names: Sun Dial, Wild Pea, Old Maid's Bonnets.

Native. Perennial. Propagates by seeds.

Time of bloom: May to June.

Seed-time: Late June to August.

Range: Maine and Ontario to Minnesota, southward to the Gulf of Mexico.

Habitat: Dry, sandy soil; meadows, woodland borders, waste places.

A beautiful plant, often cultivated in eastern gardens. It is very commonly called Sun Dial because the leaves always face that luminary, the leaflets sometimes rotating ninety degrees on their own axes; and at night they take a position as if for sleep, folding downward around the stem. The roots penetrate the soil to a great depth, finding moisture to keep the plant green and flourishing, even in late summer when neighboring plants suffer from drought. (Fig. 161.)

Stems erect, rather stout and succulent, slightly hairy, ten to eighteen inches tall. Leaves lifted on long, slim petioles; palmately compound, with seven to eleven softly downy, sessile leaflets, widest near the tip and tapering to the base, the midrib of 


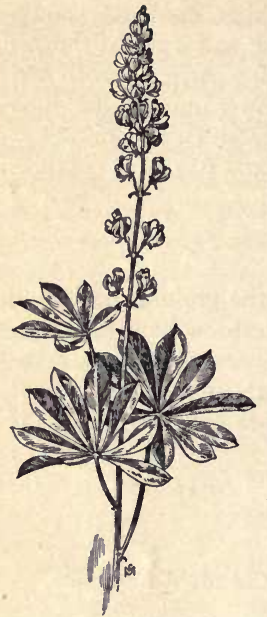

Frg. 161. - Wild Lupine (Lupinus perennis). $\times \frac{1}{3}$.

each extending beyond the tip in a minute, bristly point. Flowers numerous and very showy, on long terminal racemes, the corollas purplish blue, sometimes white; shaped like pea-blossoms, with standard turned backward at the sides, the wings united and enclosing the small, curved keel; stamen tube not cleft, its anthers of two forms; style incurved; calyx twolipped and deeply toothed. Pods broad, flat, very hairy, about an inch and a half long, two-valved, splitting in spiral coils at maturity and flinging to some distance the four or five seeds contained; these have long vitality, often remaining dormant in the soil for many years. The seeds are also said to be very unwholesome for grazing animals, though not so dangerously harmful as those of its western relatives.

Prevent seed development by cutting before the first flowers mature. Hay containing Lupines is wholesome if it contains no ripe seeds. The perennial roots may be destroyed by cultivation of the land, which should be put to a well-fertilized and well-tilled hoed crop before reseeding with clover or grass.

\section{NEBRASKA LUPINE}

Lupinus platténsis, S. Wats.

Native. Perennial. Propagates by seeds and by rootstocks.

Time of bloom: June to July.

Seed-time: July to August.

Range: Nebraska, Wyoming, and the Dakotas.

Habitat: Plains; pastures and meadows.

Lupines furnish western stockmen with much nutritious green forage and good hay. They are especially valuable in the late fall, 
when they remain green and succulent after grasses and other plants have become dry. But observation and experiment have demonstrated that, during the time of seed development, Lupines are very injurious to grazing animals, particularly sheep. Cattle usually reject the seeds, selecting the leafy parts of the plant which seem to contain little, if any, of the poisonous property; but the seeds and pods contain a dangerous quantity of a substance known as lupinotoxin, which causes a disease called lupinosis, the acute form of which may cause death in a few hours, sometimes less than one. Sheep seem to have a preference for the pods, often nibbling them from the plants and leaving the rest. Cornevin states that in 1880 more than fourteen thousand sheep died of this complaint in Germany, where Lupines of several species are much used as forage and for reclaiming sandy soils where clover does not readily "catch."

This is rather a large species, one to nearly two feet tall, the stems erect and branching, covered with fine, appressed, silky hairs which give it a glaucous appearance. Leaves on rather long petioles, the leaflets seven to ten, about two inches in length, short-spatulate, usually obtuse, smooth above but appressed hairy beneath, giving a glaucous appearance. Racemes long and graceful, the flowers large and not crowded on the stalk, pale blue or pur-

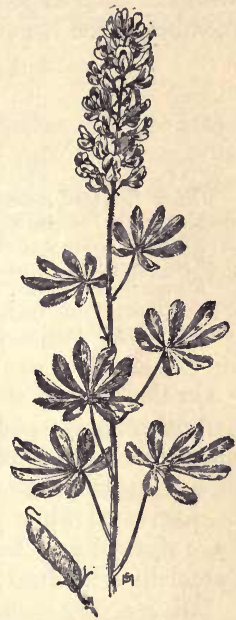

Fig. 162. - Nebraska Lupine (Lupinus plattensis). $\times \frac{1}{4}$. plish, the standard having a conspicuous blotch of darker color. Pods numerous, covered with appressed hairs, two- to five-seeded. (Fig. 162.)

\section{Means of control}

Prevent seed production by cutting while in early bloom or even before flowering. At times even the green fodder becomes dangerous, causing bloat and other symptoms of unwholesomeness. 
In Europe, where stall-feeding of farm animals is more commonly practiced than in this country, it has been found that Lupine fodder is rendered entirely innocuous by steam heating under pressure, which at the same time makes it much more palatable and fattening. Dry heat does not destroy the poison. In many places it would be advisable to put the ground under cultivation with the purpose of replacing these plants by some less dangerous member of the Legume Family.

\section{SILVERY LUPINE}

Lupinus argenteus, Pursh.

Other English names: Blue Pea, Blue Bean.

Native. Perennial. Propagates by seeds.

Time of bloom: July to August.

Seed-time: August to September.

Range: Nebraska and the Dakotas to the plains of the Columbia River, southward to New Mexico and Arizona.

Habitat: Prairies, hillside slopes; wild pastures and meadows.

On the sides of the vast foothills of the Rocky Mountains this and other species of Lupines often completely cover the ground for miles, and when in bloom the wide tracts of blue flowers are visible at a great distance. If the plant is to be used for hay it should be harvested while in bloom, or else very late, after the seeds have ripened and been cast from the pods. The leaves remain succulent until frost.

This is a very variable species but is usually a somewhat shrubby, bushy-branched plant, one to nearly three feet in height, densely covered with fine, silky, appressed hairs. Leaves on slender petioles about as long as the blades, the leaflets five to eight, nearly smooth above but silvery-hairy beneath, linear to lance-shaped and pointed at both ends. Racemes terminal, usually densely flowered, two to five inches long; calyx-lips unequal, the upper one rather broad, two-toothed, the lower one longer and entire ; petals usually purple but sometimes pale blue or cream-colored, the standard and keel sometimes finely hairy. Pods about an inch long, silky-haired, three- to five-seeded.

Means of control should be similar to that of the Nebraska Lupine. 


\section{LOW LUPINE}

\section{Lupinus pusillus, Pursh.}

Other English names: Blue Pea, Low Blue Bean.

Native. Annual. Propagates by seeds.

Time of bloom: April to June.

Seed-time: June to August.

Range: Kansas, Nebraska, and the Dakotas, westward throughout the whole Rocky Mountain region to the Sierra Nevadas, southward to Arizona and Now Mexico.

Habitat: Dry soil; upland pastures and meadows.

A low but rather stout plant, four to eight inches tall, the stems diffusely branched from the base and covered with fine, spreading hairs. Leaves on slim hairy petioles slightly dilated at the base; leaflets five to seven, oblong, sessile, smooth above but hairy underneath, little more than an inch in length and tapering toward the base from slightly wider tips. Racemes terminal, one to three inches long, on very short peduncles, the pea-like flowers closely crowded, small, about a quarter-inch in length, deep blue. Pods about three-fourths of an inch long, densely hairy, tipped with an awl-like beak, usually two-seeded.

Low Lupines furnish an immense amount of good forage in spring and in autumn, but during the season of seed development they are considered dangerously unwholesome for grazing animals, particularly sheep.

\section{Means of control}

As the plant is an annual, the persistent prevention of seed development by frequent close cutting will destroy it. Dormant seeds may furnish a subsequent crop, which should have similar treatment.

\section{RABBIT-FOOT CLOVER}

\section{Trifolium arvénse, $\mathrm{L}$.}

Other English names: Stone Clover, Old-field Clover, Pussy Clover, Hare-foot Clover.

Introduced. Annual. Propagates by seeds.

Time of bloom: May to July.

Seed-time: June to August. 
Range: Throughout eastern North America.

Habitat: Meadows, pastures, grain fields, roadsides, and waste places.

Stone Clover usually grows and is able to thrive on very dry, sandy, and gravelly soils, and it is a pity that it is not a better

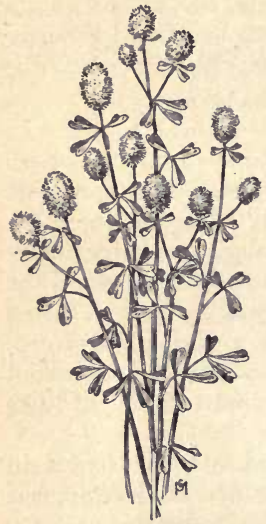

Fra. 163. - Rabbit-foot Clover (Trifolium arvense). $\times \frac{1}{2}$. fodder plant. But its excessive hairiness causes cattle to dislike it and even makes it dangerous, particularly when eaten by horses, as the fuzzy flower-heads sometimes collect into felt-like, compact masses called phytobezoars, or hair-balls, closing the intestines and occasionally causing a very distressful form of death.

Stem six inches to a foot high, erect, slender, much branched, covered with fine, silky, gray hair. Leaves alternate palmately three-foliolate, with short petioles and narrow, awl-shaped stipules; leaflets narrowly oblong or wedge-shaped, about an inch in length, obtuse or often notched at the tips. Flowers in dense, nearly cylindrical heads, a half-inch to an inch long, on slender, terminal peduncles; corolla white or pinkish but hidden by the calyx-lobes, which extend far beyond it in five slender, awl-like points, thickly fringed with silky gray or pale reddish hairs. Pods very tiny, containing one or two seeds which are a frequent impurity of other clover seeds and of grasses and grain.

(Fig. 163.)

\section{Means of control}

Enrich and cultivate the ground, seeding heavily to other and better members of the Clover Family. When Stone Clover is cured with hay, the danger from hair-balls is averted by cutting before the heads are matured. Also such prevention of seeding will cleanse the ground of the weed, if persistently repeated until all dormant seeds have germinated and been thus destroyed. 


\section{YELLOW OR HOP CLOVER}

Trifolium agrdrium, L.

Introduced. Annual. Propagates by seeds.

Time of bloom: June to August.

Seed-time: July to September.

Range: Nova Scotia and Ontario to Michigan and Iowa, southward to Virginia.

Habitat: Meadows, roadsides, and waste places.

Were there no larger and better Clovers, this plant could not be characterized as a weed; but, as it is, the places that it holds might be better occupied, and its seeds are a frequent impurity among those of its larger relatives. Stems smooth, slender, branching, usually erect, six to fifteen inches in height. Leaves light green, on petioles but little longer than the cohering, narrow, lance-shaped stipules; the leaflets all grow from the same point, and are sessile, about a half-inch in length, obovate or oblong, and edged with very minute teeth. Heads axillary on peduncles much longer than the leaves; they are small, oblong, rounded, densely crowded, golden yellow, the flowers having rather narrow, incurled standards and short, blunt keels ; the corollas are persistent and each flower turns downward on the stalk as it is fertilized, finally becoming dry and brown, the withered heads resembling small dried hops. The pods are oneseeded. (Fig. 164.)

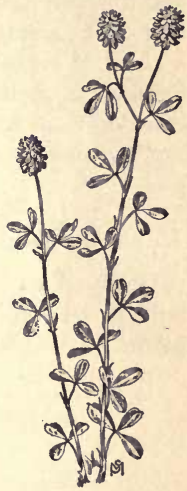

Frg. 164. - Yellow or Hop Clover (Trifolium agrarium). $\times \frac{1}{3}$.

\section{Means of control}

Prevent seed development and distribution by early and frequent cutting. Cultivate and reseed the ground with larger and better forage plants.

\section{LOW HOP CLOVER}

Trifolium procumbens, L.

Introduced. Annual. Propagates by seeds.

Time of bloom: May to September. 
Seed-time: June to October.

Range: Throughout the United States and southern British America. Habitat: Fields, roadsides, and waste places.

Still more weedy and valueless than the preceding species, mature plants in dry and exposed situations sometimes becoming tumble-weeds. Stems many from the same root, slender, finely ridged, hairy, weak and reclining, three to ten inches long. Leaves small with short petioles, and broadly ovate, pointed, cohering stipules; leaflets short, wedge-shaped at base, rounded truncate or notched at the apex, shorter than those of the preceding species, and differing also in having the lateral ones sessile but the terminal one on a distinct foot-stalk. Heads globose, scarcely more than a third of an inch in diameter, and lifted much above the leaves on slender, axillary peduncles; corolla bright yellow, the standard broader than long, spreading, and persistent, becoming reflexed, and turning brown, exceeding and covering the small, one-seeded pod.

\section{Means of control}

Graze off with sheep, so preventing seed development. Put the land under cultivation and reseed heavily with larger and better plants of the Clover Family.

\section{WHITE SWEET-CLOVER}

Melildtus álba, Desv.

Other English names: White Melilot, Tree Clover, Cabul Clover, Bokhara Clover, Honeylotus.

Introduced. Biennial. Propagates by seeds.

Time of bloom: June to October.

Seed-time: August to November.

Range: Throughout North America except the far North.

Habitat: Roadsides and waste places; common about towns.

The Sweet-clovers are natives of Central Asia but came to us from Mediterranean Europe, where for centuries they have been grown for forage and as honey plants. Weeds only when they are permitted to make highways and by-places unsightly with thickets of dying stalks. Their good qualities are many. First, they are 
"soil renovators," partly by reason of their large and deeply penetrating roots, which break up the soil, mellow, aërate, and drain it, and then, by their death and rapid decay, furnish it with humus; also they bear on their roots many tubercles in which live those beneficent, nitrogen-gathering bacteria that make the earth better for their having lived in it. For this reason, Sweet-clover is often used to prepare the ground for the growing of Alfalfa. The hay is nutritious, but cattle do not like its strong odor and will not eat it until they have been "educated to the taste," which is usually done by turning them into the Sweet-clover field early in spring, when no other green forage is available. (Fig. 165.)

Stems three to ten feet tall, round, slender, somewhat woody, many-branched, smooth except the young growing twigs, which are finely hairy. Leaves pinnately three-foliolate, the leaflets oblong to elliptic, obtuse or sometimes even notched at the tip, very finely toothed, the foot-stalk of the middle one bent slightly upward; petioles usually shorter than the blades. Flowers in long, slender, one-sided, axillary racemes, white and very fragrant; corolla about a quarter-inch long, with narrow petals, the standard longer than the wings or the keel. Pods ovoid, wrinkled, net-veined, one- or two-seeded. When in the soil the seeds are said to retain their vitality for fifty years or more; they are sometimes used by unscrupulous dealers for the adulter-

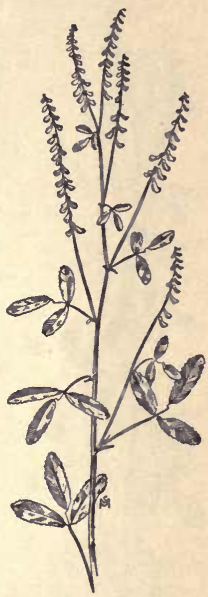

Frg. 165. - White Sweet-clover (Melilotus alba). $\times \frac{1}{3}$. ation of Alfalfa seed, which is somewhat similar in appearance but much more expensive.

\section{Means of control}

Close cutting as soon as the first flowers open; the plants will immediately sprout thick stools of flowering stalks, requiring a second and perhaps a third cutting, but if no seed is allowed to mature and drop into the soil there will be no further trouble, for 
when it has flowered the plant dies. Small areas may be more quickly hand-pulled.

\section{YELLOW SWEET-CLOVER}

Melilòtus officinàlis, L.

Other English names: Yellow Melilot, Hart's Clover, King's Clover,

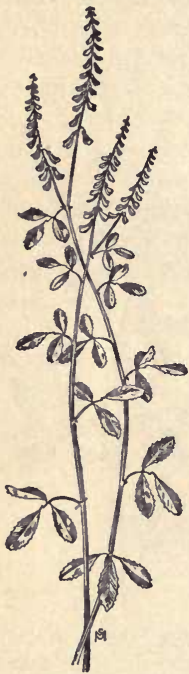

Fig. 166.-Yellow Sweet-clover (Melilotus officinalis). $\times \frac{1}{3}$. Balsam-flowers.

Introduced. Biennial. Propagates by seeds.

Time of bloom: June to October.

Seed-time: August to November.

Range: Throughout North America except the far North.

Habitat: Roadsides and waste places ; common about towns.

A smaller plant than the preceding species with stems two to five feet tall, slender, erect, with many spreading branches, the growing twigs finely hairy. Leaflets oblong-obovate, with rounded tips, edges finely toothed; petioles nearly as long as the blades. Flowers bright yellow, in long, one-sided, axillary racemes, the blossoms slightly larger than those of White Melilot but less fragrant, the standard and wings of nearly equal length; the plant often flowers a week in advance of its white sister and holds in bloom somewhat later, which wins for it the liking of bee-keepers. Pods ovoid, transversely wrinkled, net-veined, often slightly hairy, one- or two-seeded. (Fig. 166.)

Means of control the same as for White Sweet-clover.

\section{BLACK MEDICK}

Medicàgo lupulinna, L.

Other English names: Yellow Trefoil, Hop Medick, None-such, Black-seed Hop Clover.

Introduced. Annual. Propagates by seeds. 
Time of bloom: March to December.

Seed-time: May until snow-covered.

Range: Throughout the world in all temperate regions.

Habitat: Fields, meadows, waste places.

Properly speaking, this plant cannot be called a weed, further than that it is much less valuable for hay and forage than its larger relatives. Also the hulled seeds, though a trifle smaller, bear a strong resemblance to those of its tall perennial sister, the Alfalfa (Medicàgo sativa, L.), and unscrupulous dealers use them to adulterate the expensive Alfalfa seed. Grazing animals eat the plant readily and it makes good pasture. (Fig. 167.)

Stems slender, softly hairy, one to two feet long, procumbent, branching at the base and spreading on all sides, with many shorter branches which are usually ascending. Leaves pinnately three-foliolate, also finely hairy, with rather long petioles, the leaflets obovate, rounded and slightly toothed at the tips, seldom more than a half-inch in length. Flowers only about one line long, bright yellow, in small, oblong, dense heads or spikes about a quarterinch thick and usually about twice as long. Pods thin-skinned, kidney-shaped, net-veined and ridged, slightly twisted, containing one seed, black when ripe.

Means of control

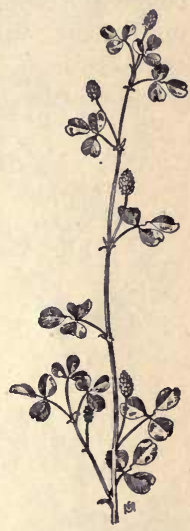

Fig. 167.-Black Medick (Medicago lupulina). $\times \frac{1}{3}$.

Cultivation of the land and reseeding heavily with larger and more valuable members of the Clover Family, which will crowd out any renewal of the Medick from dormant seed.

\section{BUR CLOVER}

Medicdgo hispida, Gaertn.

(Medicàgo denticulàta, Willd.)

Other English names: Toothed Medick, Winter Medick. Introduced. Annual or biennial. Propagates by seeds. 
Time of bloom: May to July.

Seed-time: July to September.

Range: Nova Scotia and Ontario to Florida and Texas. Also on the Pacific coast and in Arizona.

Habitat: Cultivated crops, grain fields, meadows, waste lands.

This plant is often cultivated in the South and West for a cover crop and green manure, and also for winter forage. These purposes it serves very well, particularly if it is used while young, before the approach of the fruiting season causes the stems to become woody and innutritious; but its hooked burs

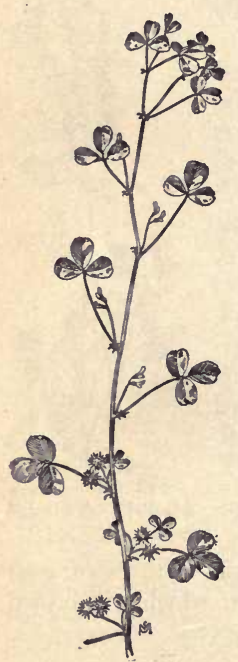

Fig. 168. - Bur Clover (Medicago hispida). $\times \frac{1}{3}$. greatly damage the fleeces of sheep, and the long vitality of its dormant seeds causes the plant to retain possession of the ground when it is desired for other crops. (Fig. 168.)

Stems six inches to two feet long, branched at the base, some prostrate and some ascending, spreading in all directions. Leaves smooth, with obovate or broadly wedge-shaped leaflets, rounded and finely toothed at the tips; petioles slender and variable in length, with toothed stipules. Heads one- to three-flowered, on peduncles shorter than the leaves; the corollas bright yellow and about a quarter-inch long. Pods several-seeded, twisted in a loose spiral of two or three coils, strongly netveined, flattened, with thin keeled edge bordered with a double row of hooked spines.

\section{Means of control}

Burn over the ground where plants have matured seeds in order to destroy the burs on the surface before plowing for other crops, which should be such as will require very thorough tillage. Seed the ground with other and better clovers that will supersede this one. 


\section{BIRD'S-FOOT TREFOIL}

\section{Lòtus corniculatus, L.}

Other English names: Bloom-fell, Ground Honeysuckle, Cat's Clover, Crow-toes, Sheep-foot.

Introduced. Perennial. Propagates by seeds.

Time of bloom: June to September.

Seed-time: July to October.

Range: Waste places and on ballast in New Brunswick and Nova Scotia, about the seaports of Eastern and Middle States.

Habitat: Waste places; in a few instances invading fields.

An emigrant from Europe, where it is a widely distributed and very troublesome weed, native to Asia. It has a long, deep-boring root which renders it very resistant to drought, and a spreading habit. of growth which enables it to crowd out all better plants growing with it. It is not considered poisonous, and has even been cultivated as a forage plant in some localities in the South, but grazing animals suffer from bloat and indigestion when they eat very much of it. (Fig. 169.)

Stems many from the same root, slender, hairy, some erect and others prostrate, four inches to two feet long. Leaves sessile or nearly so, pinnately compound, consisting of five small, oblong leaflets, the basal pair appearing like large stipules, the other three

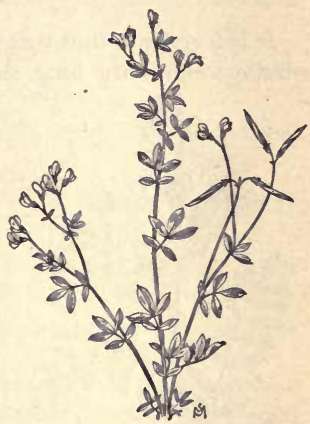

Frg. 169. - Bird's-foot Trefoil (Lotus corniculatus). $\times \frac{1}{3}$. like a trefoil at the end of the stalk, or rachis. Flowers numerous, in showy, umbellate heads lifted on slender peduncles three to six inches long; corolla about a half-inch long, bright yellow, or the standard a coppery red. Pods linear, nearly an inch long, each containing several shining, light brown seeds.

\section{Means of control}

Prevent seed development and starve the roots by close and repeated cuttings from the time of flowering until the end of the 
growing season. Small areas should be hand-pulled or grubbed out while in early bloom.

\section{HOARY PEA}

Tephròsia virginiàna, Pers.

(Crácca virginidna, L.)

Other English names: Wild Sweet Pea, Turkey Pea, Goat's Rue, Catgut, Devil's Shoe-strings.

Native. Perennial. Propagates by seeds and by slender, creeping rootstocks.

Time of bloom: June to July.

Seed-time: August to September.

Range: Ontario to Manitoba, southward to Florida, Texas, and Mexico.

Habitat: Dry upland meadows, pastures, and woodland borders.

It is fortunate that this plant has a preference for dry, sandy, and sterile soil, for the long, slender, and very tough rootstocks, which

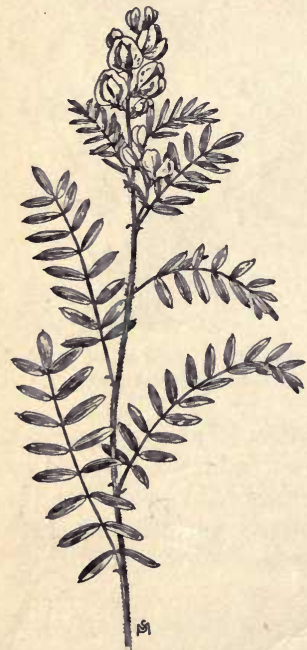

FrG. 170. - Hoary Pea (Tephrosia virginiana). $\times \frac{1}{2}$. have given it the common names of Catgut and Devil's Shoe-strings, cause it to grow in large clumps or patches and make it very difficult to exterminate where it is well established. (Fig. 170.).

Stems erect, tufted, simple, ridged, hard and woody at the base, one to two feet high, leafy to the top. The whole plant is covered with soft, silky, whitish hairs, especially when young, making the foliage ashen-gray or hoary. Leaves alternate, odd-pinnate, with seventeen to twenty-nine narrowly oblong, entire leaflets, about an inch in length, the midrib of each projecting slightly as a minute bristle at the tip. At night the leaves take a position as for slumber, turning on their bases and folding themselves along the stem. Flowers in short, crowded, terminal racemes; each blossom is nearly an inch long, with hairy, five-lobed calyx, 
a rounded, yellowish white standard tinged with purple, a rosy pink keel, and reddish purple wings; the standard is softly hairy on the back. Pods one or two inches in length, flattened, often somewhat curved, densely hairy, and many-seeded. Wild turkeys are said to search for and fatten on the peas, though the plant has the reputation of being poisonous. The Indians used its string-like rootstocks for a vermifuge, and Pammel ${ }^{1}$ states that it was used also for poisoning fish.

\section{Means of control}

Prevent seed production and starve the rootstocks by cutting the stems close to the ground in early summer. Cultivate and enrich the soil.

\section{WOOLLY LOCO-WEED}

Astrágalus mollisimus, Torr.

Other English names: Crazyweed, Purple Loco, Stemmed Loco, Texas Loco.

Native. Perennial. Propagates by seeds.

Time of bloom: April in the southern limit of its range, to June at the northern limit.

Seed-time: June to August.

Range: South Dakota and Wyoming, southward to Texas, New Mexico, and Arizona. Most abundant in Colorado and western Kansas and Nebraska.

Habitat: Open prairies; lower mountain slopes; wild meadows.

The Loco-weed Disease in horses, cattle, and sheep is every year the cause of enormous losses to persons engaged in the business of raising live-stock in many of the Western States. The symptoms indicate much cerebral disturbance and affected animals are commonly said to be crazy. There are a number of plants that cause the disease, all of them Legumes and nearly related; but this and the following species range most widely and are credited with the greatest amount of injury to the stock-raising industry. Horses and sheep are the chief sufferers from the poison, though cattle also are frequently "locoed."

Woolly Loco has a large, tough, woody, deep-boring root, sometimes penetrating to a depth of six or more feet, from the crown of which spring tufts of short, branching stems, a foot or less long, some 
erect and some reclining on the ground for most of their length. The whole plant is densely covered with long, white, silky hair. Leaves alternate, odd pinnate, five to eight inches in length, composed of seventeen to twenty-nine leaflets, pointed-ovate, and about a half-inch long; petioles slender, with membranous pointed-

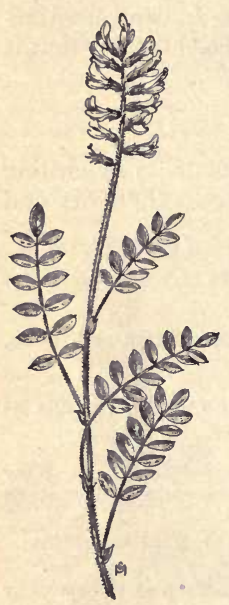

Fia. 171. - Woolly Loco-weed (Astragalus mollisimus). $\times \frac{1}{3}$.

ovate stipules united to their bases. The peduncles spring from the lower axils and are longer than the leaves, so that the short, dense spike of deep purple or violet flowers is held above them; each flower is a little more than a half-inch long, and has a tubular calyx with five nearly equal teeth, an erect, oblong standard, narrow wings, and a blunt keel. Like the rest of the plant, the flower is hairy; the pods, however, are smooth, dry, leathery, about three-fourths of an inch long, slightly incurved, grooved at the sutures, two-celled, each cavity containing a number of seeds, which have very long vitality when in the soil. (Fig. 171.)

\section{Means of control}

During the years 1881 to 1885 the State of Colorado paid a bounty of 21 dollars a ton, dry, "for any Loco or poison weed dug up not less than three inches below the surface of the ground, during the months of May, June, and July." After about two hundred thousand dollars had been spent, the law was repealed. But the experiment proved that if these plants are cut off at the root, well below the crown, when they are in full bloom, they never sprout again, but die. And a man with a sharp spade or a sharp and heavy hoe can destroy the plants very rapidly, cleansing a large extent of ground in a day. Dormant seeds may furnish another crop; but if successive germinations are cut off before developing seed, the ground will be cleansed in the course of two or three seasons at a much less expense than is now suffered in losses of live-stock in a single year. 


\section{STEMLESS LOCO-WEED \\ Oxýtropis Lambérti, Pursh. (Aragállus spicàtus, Rydb.)}

Other English names: Colorado Loco-vetch, White Loco-weed, White Rattleweed.

Native. Perennial. Propagates by seeds.

Time of bloom: April at southern limit of range, August at northern limit.

Seed-time: June to October.

Range: Minnesota to the Saskatchewan and British Columbia, southward to Texas and Mexico.

Habitat: Prairies and foothills; wild pastures and meadows.

This plant not only has a far wider range than the preceding species, but also climbs higher up the mountain sides, being found in Colorado and Montana at an altitude of eight thousand feet. Where they grow in company, however, the Woolly Locoweed is considered the more harmful.

The root is hard, thick, woody, and scaly, boring deeply into the earth; it is crowned with a thick tuft of nearly erect, oddpinnate leaves, about four to eight inches long, with slender petioles and nine to nineteen narrow, lance-shaped leaflets, about an inch in length and covered with fine, silky, whitish hairs; stipules hairy, membranous, lance-shaped, united to the base of the petiole. The peduncles also rise from the crown, eight to twelve inches in height, holding the dense flower-spikes well above the leaves; the flowers are usually white, and where the plant is abundant/large areas appear as though covered with snow; but in some localities, usually in the higher mountain regions, there is 'great variation, some flowers being pink, others yellowish or violet or purple; they are large, more Lioco-weed (Oxytropis than an inch long, slender, with erect, ovate Lamberti). $\times \frac{1}{2}$. 
standard, narrow, oblong wings, and keel tipped with a sharp, projecting point. (Fig. 172.) Pods sessile, imperfectly two-celled, very firm and leathery, densely hairy, long-pointed, and filled with small seeds which loosen and rattle about in the pods as they become dry.

\section{Means of control}

Like the preceding plant, White Loco-weed can be killed by deep cutting from the root, well below the crown - as was demonstrated by a Montana ranchman who lost three hundred lambs out of a herd of two thousand in one season from Loco poisoning; the next year, while the plants were in bloom in May and June he hired two men to dig up the Loco-weeds on an area four miles square, the tools used being heavy, narrow, and very sharp steel hoes; the plants never sprouted again and no further losses from Loco occurred on his ranch.

\section{WILD LIQUORICE}

Glycyrrhiza lepidòta, Pursh.

Other English name: Sweet-root.

Native. Perennial. Propagates by seeds and by rootstocks.

Time of bloom: May to August.

Seed-time: July to October.

Range: Ontario, Manitoba, and Minnesota, to Hudson Bay, westward to British Columbia and Washington, and southward to Missouri, New Mexico, and California.

Habitat: Open prairies; fields, meadows, and pastures.

Its hooked pods make this plant very obnoxious to western woolgrowers, and it is a weed that is exceedingly hard to destroy. The rootstocks are long, thick, creeping, stored with sweet juices, whence it is called Sweet-root, a translation of the Greek generic name. These thick, juicy, deep-lying roots enable it to withstand drought and recover from much cutting and grazing. Stems erect, branching, one to three feet high, usually scurfy with fine scales. Leaves long-petioled, odd-pinnate, with eleven to nineteen oblong, pointed leaflets, entire, bristle-tipped, and specked with minute scales or dots, being scurfy when young and dotted when old. Flowers densely crowded on axillary spikes, shorter than the 
leaves; the corolla, a little less than a half-inch long, yellowish white with narrow standard exceeding the wings and blunt keel. Pods about a half-inch long, two- to sixseeded, brown, bur-like, bristling all over with short, hooked prickles, making fast to almost anything at a touch and widely distributed by animal transportation. (Fig. 173.)

\section{Means of control}

Prevent seed development and distribution by repeated cutting, beginning as soon as the first flowers wither. In

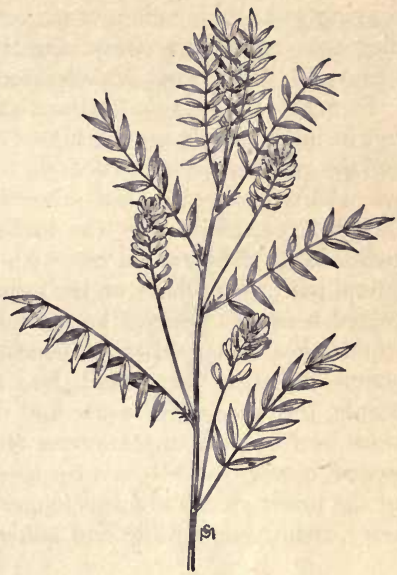
order to kill the perennial Fig. 173. - Wild Liquorice (Glycyrrhiza rootstocks, the land requires lepidota). $\times \frac{1}{3}$.

to be kept under very thorough cultivation for three successive years, giving the weed "no chance to see daylight" throughout each growing season. Increased returns from the crops will repay extra tillage.

\section{HOARY TICK-TREFOIL}

Desmòdium canéscens, DC.

(Meibòmia canéscens, Ktze.)

Other English names: Seed Ticks, Wool Ticks.

Native. Perennial. Propagates by seeds.

Time of bloom: June to September.

Seed-time: August to November.

Range: New England and Ontario to Minnesota and Nebraska, southward to Florida, Louisiana, and Texas.

Habitat: Rich, moist soil; borders of fields and woods, roadsides, and waste places.

To the wool-grower this is one of the most vexatious weeds that grow, for its "ticks" are glutinous as well as bristly-hooked, 
clinging to anything they touch, even a bare hand, and in fleeces they are very adhesive, carrying strands of wool with them when removed. Ticky wool is therefore sharply "cut" in the market.

Stem erect, slightly ridged and grooved, sometimes attaining five feet in height but more often two or three feet tall, smooth below but the growing branches densely set with two kinds of hairs, some very short, fine, and hooked, others longer, spreading, and glutinous. Leaves large, trifoliolate, the leaflets broadly ovate, two to four inches long, the terminal one with a footstalk and larger than the lateral pair, rough-hairy on the upper surface, white-hairy and netveined beneath; petioles hairy and about as long as the leaves; stipules heart-shaped, acute, persistent. Flowers in terminal compound racemes, very small, less than a quarter-inch in length, purple, the standard obovate and the wings attached to the short, blunt keel by a small transverse appendage. Pods four- to sevenseeded, constricted between the seeds above and below but most so on the under side, the joints longer than broad, net-veined, sticky, hairy, readily separating and adhering to anything at a touch.

\section{Means of control}

Close cutting while in early bloom, repeating the treatment as new shoots appear. Cultivation of the ground destroys the perennial roots.

\section{SHOWY TICK-TREFOIL}

Desmòdium canadénse, DC.

(Meibòmia canadénsis, Ktze.)

Native. Perennial. Propagates by seeds.

Time of bloom: July to September.

Seed-time: Late August to November.

Range: New Brunswick to the Saskatchewan, southward to the Carolinas and Oklahoma.

Habitat: Woodland borders and thickets along streams.

Stem two to six feet tall, stout, erect, ridged and grooved, very hairy. Leaflets oblong-ovate, nearly smooth above, finely appressed hairy beneath, obtuse, with numerous nearly straight veins; petioles very short, the uppermost leaves nearly sessile. Flowers in large panicled racemes, densely many-flowered, very showy; 
similar in form to the preceding species but much larger, each blossom more than a half-inch long, bluish purple or sometimes nearly white. Pods three- to five-seeded, slightly curved, the joints roundish triangular, covered with hooked hairs. (Fig. 174.)

Means of control the same as for the Hoary Tick-trefoil.

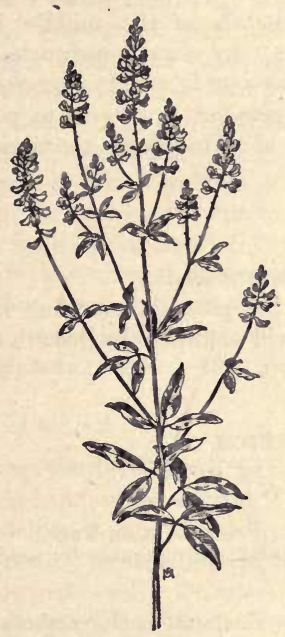

Frg. 174. - Showy Ticktrefoil (Desmodium canadense). $\times \frac{1}{6}$.

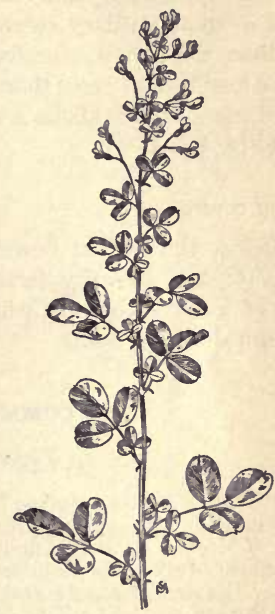

Frg. 175. - Bush Clover (Lespedeza violacea). $\times\}$.

\section{BUSH CLOVER}

\section{Lespedeza viold̀cea, Pers.}

Native. Perennial. Propagates by seeds.

Time of bloom: July to September.

Seed-time: August to October.

Range: New England to Minnesota, southward to Florida, Louisiana, and Kansas.

Habitat: Dry, sterile soil; pastures and thin meadows; thickets and open woods. 
Cattle will eat this plant when it is young if there is no better forage, but it soon becomes hard and innutritious. Stems one to three feet tall, much branched, slender and spreading, sparsely hairy. Leaves few and rather small, pinnately three-foliolate, the leaflets a half-inch to two inches long, thin, oblong or elliptic, bristle-tipped, finely appressed-hairy on the under side; petioles often scarcely longer than the footstalk of the middle leaflet. Flowers in small axillary clusters on very slender peduncles much longer than the leaves; corolla violet-purple, about a quarter-inch long, the keel often longer than the standard. Pod ovate, pointed, flattened, net-veined, about a sixth of an inch long, containing one seed. (Fig. 175.)

\section{'Means of control}

Cut before the earliest flowers mature seeds.

Cultivate and liberally fertilize the ground, reseeding it with clovers of a better quality which will smother the growth of this weed from dormant seeds.

\section{COMMON VETCH}

Vicia sativa, L.

Other English names: Spring Vetch, Pebble Vetch, Tare.

Introduced. Annual or winter annual. Propagates by seeds.

Time of bloom: June to August.

Seed-time: July to September.

Range: Eastern Canada and New England to the Dakotas, and southward to the Gulf of Mexico. Also on the Pacific Coast.

Habitat: Grain fields, meadows, roadsides, waste places.

This is the Vetch most commonly grown as a forage plant, and as a weed it is often a survival of former cultivation by means of selfsown, dormant seeds. Also the seeds are sometimes sown as an impurity with grass and grain seeds, and in such places it makes itself a nuisance by entangling and pulling down the crop, making the harvest difficult. (Fig. 176.)

Stems one to three feet long, simple or branching from the base, hairy when young but later becoming smooth. Leaves pinnately compound, with broad, sharply toothed stipules 
and four to eight pairs of oblong leaflets, slightly notched at their tips and with midrib projecting as a fine, bristly point. Extending from between the terminal pair of leaflets is a long forked tendril. Flowers on short axillary peduncles, usually in pairs, nearly an inch long and rather showy, the corolla being reddish purple or sometimes rosy pink, the standard long obovate and notched at the top, the wings adherent to the curved keel. Pods slender, two to three inches long, hairy when green but becoming smooth, and slightly constricted between the small globular seeds as they ripen.

\section{Means of control}

Prevent the development of seeds by early and close cutting. In grain fields, many of the young

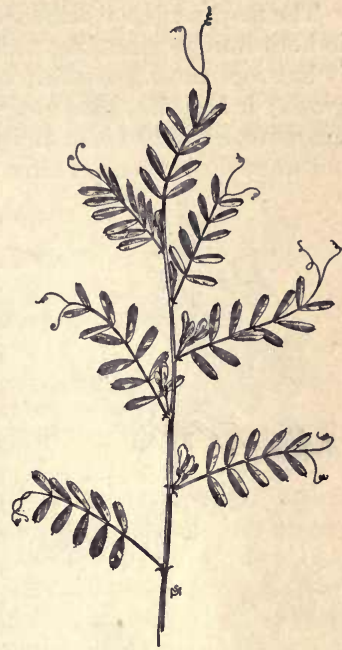

Fig. 176. - Common Vetch (Vicia sativa). $\times \frac{1}{1}$ :

seedlings may be raked out with a weeding harrow when the crop is but a few inches tall. Or, later, but while still in the young and hairy stage, the weed may be destroyed by the use of chemical sprays.

\section{COW VETCH}

\section{Vicia Crácca, L.}

Other English names: Tufted Vetch, Blue Vetch, Bird Veteh, Tine Grass, Titters, Cat Fitch, Cat Peas.

Introduced. Perennial. Propagates by seeds and by rootstocks. Time of bloom: June to August.

Seed-time: July to September.

Range: Newfoundland to British Columbia, southward to New Jersey, Kentucky, Iowa, and Minnesota.

Habitat: Fields, meadows, and waste places. 
The most widely distributed of the Vetches, being very common in both Europe and Asia. Like nearly all of the Legume Family it has root tubercles which cause it to enrich the soil where it grows; it furnishes good forage and good hay, but its tough, creeping rootstocks make it so difficult of removal from places where it is not wanted that it must often be rated as a bad weed. (Fig. 177.)

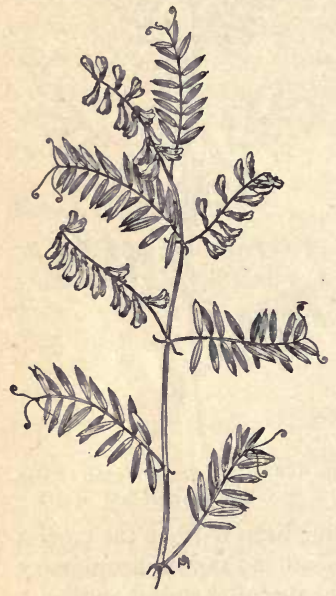

Fis. 177. - Cow Vetch (Vicia Cracca). $\times \frac{1}{4}$.

Stems tufted, slender, angled, branching, two to four feet long, climbing by means of tendrils at the tips of the pinnately compound leaves and forming dense mats, smothering grass or other plants that grow beneath, and entangling and pulling down the crop when growing in a grain field. Leaves sessile or nearly so, composed of eighteen to twentyfour thin, narrowly oblong, entire bristle-tipped leaflets. The whole plant is covered with fine, closepressed hairs and is a soft olive green in color. Flowers numerous, on slender, one-sided axillary racemes about as long as the leaves, the standard and wings of the corollas being narrower than in the preceding species; each blossom is about a half-inch long, violet-blue in color, and hangs reflexed on its stalk. Pods smooth, about an inch in length, and contain five to eight small, dark brown, globular seeds. They are frequently an impurity of grass and clover seeds and are somewhat troublesome to remove.

\section{Means of control}

In grain fields, very many of the seedlings that have not yet begun to cling may be raked out with a weeding harrow in the spring. Infested meadows should be broken up and put to a well-tilled hoed crop such as corn or potatoes, followed by oats and clover. In places where cultivation is not desirable, the rootstocks must be 
starved by close, repeated, and persistent cutting throughout the growing season. Or, as the finely downy foliage is somewhat susceptible to injury from chemical sprays, leaf-growth may be held in check and seeding prevented by this means, but the treatment must be repeated as often as the plants make recovery from the roots.

\section{HAIRY VETCH}

Vicia villosa, Roth.

Other English names: Winter Vetch, Hairy Tare.

Introduced. Annual or biennial. Propagates by seeds.

Time of bloom: May to September.

Seed-time: June to October.

Range: Locally in most parts of the country, but most common in the southern states from Pennsylvania to Georgia.

Habitat: Fields, roadsides, and waste places.

Hairy Vetch is frequently planted for a cover crop or for fodder, and is inclined to persist or to escape to roadsides and waste places. It resembles the Cow Vetch in form and habit, but is covered all over, stems, leaves, and even flower-stalks and pods, with persistent, long, soft hairs. Stems one to three feet long, with short, petioled pinnate leaves having lance-like stipules and twelve to twenty oblong leaflets, which are obtuse or varying to lance-shape or linear. Racemes three to six inches long, many-flowered, with rather short peduncles; the blossoms are violet and white, of ten nearly an inch long - almost twice the length of those of Vicia Cracca - with calyx-lobes bristly hairy on the lower side and the corollas not so slim, with standard and wings somewhat more spreading. The hairy pods contain six or eight small, dark, globular seeds.

\section{Means of control}

Destroy winter plants by hoe-cutting or by surface cultivating of the ground, or they may be grazed off in early spring. Prevent seed development by cutting while in first bloom - and, if abundant, curing for hay. All waste-land and roadside plants should be destroyed. 


\section{EVERLASTING PEA}

Láthyrus latifòlius, L.

Introduced. Perennial. Propagates by seeds.

Time of bloom: July to August.

Seed-time: August to September.

Range: Locally from Ontario to southern New York and Connecticut.

Habitat: Fields, meadows, and waste places.

A showy plant, often cultivated in gardens for its beauty and becoming wild as an "escape." Stem often six feet or more long, smooth, angled, and broadly winged between the joints; the leaves also have winged petioles. Leaflets a single pair, broadly elliptic in shape, rather thick, strongly nerved, one to three inches long and a half-inch to an inch wide; tendrils short, with angled stalks, usually triple-branched; stipules large, lance-shaped, auricled at the base on the outer side. Flowers densely bunched or clustered at the end of a stiff, angled peduncle rising from the axils; they are about the size of Sweet Peas or even larger, but without fragrance, usually rosy pink in color but may be either purple or white. Pods one to three inches long, smooth, and many-seeded. These seeds, like those of the Meadow Pea, contain an alkaloid which makes them most unwholesome food for animals if eaten uncooked, causing a disease called Lathyrism, affecting the nervous and muscular systems and ending in paralysis.

\section{Means of control}

Small areas should be grubbed out when first observed. Rankly infested ground should be put under cultivation of the most thorough kind. Seeding should be prevented by close cutting before the first flowers have matured, as the seeds have long vitality when in the soil.

\section{TUBEROUS WILD PEA}

Láthyrus tuberòsus, L.

Other English names: Wild Sweet Pea, Tuberous Sweet Pea.

Introduced. Perennial. Propagates by seeds and by tuber-bearing rootstocks.

Time of bloom: June to August. 
Seed-time: August to October.

Range: Locally established in Vermont and Ontario.

Habitat: Fields, meadows, and waste places.

This plant bears numerous flowers of charming color and fragrance, and these pleasant traits may blind many eyes to other qualities that fit it to become a very noxious weed. The tough, slender rootstocks bear many small tubers from which new plants are produced, and the plant also fruits abundantly above ground. It grows in dense mats, smothering all other plants that grow with it. Ordinary cultivation only serves to spread it by breaking the rootstocks and scattering the tubers.

Stems smooth, very slender, one to three feet long, with thin leaves and stipules; each pinnate leaf has but two oblong leaflets a little more than an inch long; petioles, slim and wiry, the tendrils hair-like and usually not branched. Racemes on very slender axillary peduncles, three- to six-flowered, Blossoms fragrant, not quite an inch long, with erect standard and obliquely spread rosy pink or reddish purple wings. Pods smooth, with globular, dark seeds, which, as forage, are dangerously unwholesome. (Fig. 178.)

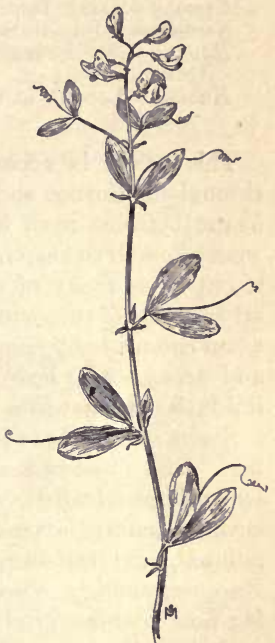

Frg. 178. - Tuberous Wild Pea (Lathyrus tuberosus). $\times \frac{1}{3}$.

\section{Means of control}

Prevent seeding and check the growth of rootstocks by close and persistent cutting throughout the growing season; then plow late in the fall, and in the next spring put the ground to a well-tilled hoed-crop, permitting no leaf-growth to the weed. A second season of such root-starvation may be required, but increased returns from the crops repay the expense of extra tillage. 


\section{MEADOW PEA}

\section{Lathyrus praténsis, L.}

Other English names: Yellow Vetchling, Yellow Tar-fitch, CrawPeas, Mouse-Peas.

Introduced. Perennial. Propagates by seeds.

Time of bloom: June to August.

Seed-time: July to September.

Range: New Brunswick, Maine, Massachusetts, New York, and Ontario.

Habitat: Locally in fields and waste places.

This plant is accounted a worthless and troublesome weed throughout Europe and Russian Asia, and, since the areas where it has established itself in this country are as yet few and small, it would be well to keep it from wider dissemination, or even to stamp it out in as many of these restricted localities as possible. Like other plants of the genus Lathyrus, it is poisonous to grazing animals when eaten in any considerable quantity, especially when seeding; and persons who have eaten the seeds have suffered with violent headache and nausea.

Stems one to three feet long, weak, slender, angled and branching. The pinnate leaves consist of two bright green, narrowly lance-shaped leaflets, smooth and pointed at both ends, a long, curling tendril extending between them; stipules large, longpointed, and leaf-like, auricled at the base on the outer side. Racemes axillary, on peduncles much longer than the leaves, bearing four to nine bright yellow blossoms about a half-inch long with broadly obovate standard and wings nearly equaling it in length. Pods a little more than an inch long, slender, thin, and smooth, containing many small, dark, globular seeds.

\section{Means of control}

Prevent development of seed by cutting repeatedly during the growing season, which will also starve the perennial roots. Small areas should be hand-pulled or grubbed out. Ground too rankly infested to be cleansed by land-labor should be put to some crop requiring very close cultivation. 


\section{TRAILING WILD BEAN}

\section{Strophostỳles hélvola, Britton}

\section{Native. Annual. Propagates by seeds.}

Time of bloom: June to September.

Seed-time: July to October.

Range: Atlantic States from Massachusetts to Florida; along the Great Lakes from Quebec to Minnesota, and southward through the Mississippi Valley to the Gulf of Mexico and Texas.

Habitat: Sandy fields; shores of lakes and streams.

Usually this plant is prostrate, trailing or twining to a length of three to eight feet, branching at the base, and with leaves at somewhat distant intervals; but occasionally it will have a stouter, more leafy stalk, held erect and less than two feet tall; in either form rough, with downward-pointing hairs. The plants are said to be very nutritious and are much liked by grazing cattle, but in cultivated fields they are often rather troublesome.

Leaves pinnately trifoliolate with slender petioles and very small, narrow, pointed stipules; leaflets one to three inches in length, rather long ovate, the lateral ones often obtusely lobed on the outer sides and the terminal one on both sides, or the upper leaves may have entire leaflets and the lower ones be distinctly three-lobed. Flowers axillary, lifted on long, slender peduncles in dense capitate clusters of three to ten pale purple blossoms, fading to a greenish color, the keels curved and slender, the standards rounded and about a half-inch wide. Pods round, slender, sessile, nearly smooth, tipped

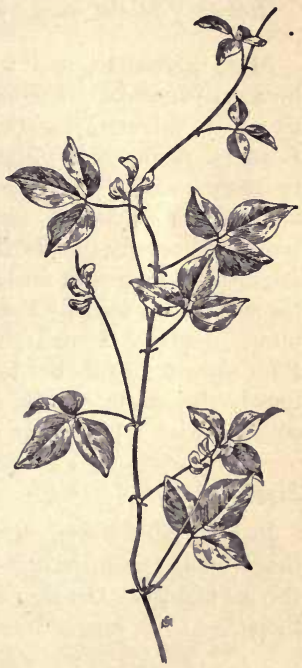

Frg. 179. - Trailing Wild Bean (Strophostylss helvola). $\times \frac{1}{1}$. with the persistent bent style, four- to eight-seeded, the beans downy. (Fig. 179.) 


\section{Means of control}

Prevent seed production by hoe-cutting while small. Dormant seeds often germinate and bloom late, after horse cultivation of crops has ceased. Follow the cultivated crop with heavy seeding to clover or cowpeas.

\section{PINK WILD BEAN}

Strophostỳles umbellàta, Britton

Native. Perennial. Propagates by seeds and by rootstocks.

Time of bloom: July to September.

Seed-time: August to October.

Range: New York to Missouri, southward to Florida and Texas.

Habitat: Moist, sandy soil ; fields and waste places.

More persistent and troublesome than the preceding species, because perennial. Stems often several from the same rootstock, two to five feet in length, very slender, branched, and trailing. Leaflets smaller and thinner in texture than the preceding species, sparsely hairy, long-ovate to oblong, usually somewhat obtuse at apex and rounded at base, entire, or rarely slightly lobed, the petioles generally shorter than the leaflets, with small, lance-shaped stipules. Flowers in umbellate heads on slender peduncles often three times as long as the leaves, with short pedicels, the corollas pink, fading yellowish, the standard about a half-inch broad. Pods one to two inches long, very slender, straight, slightly flattened, the seeds within closely packed, truncate at the ends, covered with a glandular mealiness.

\section{Means of control}

In cultivated fields, close and persistent hoe-cutting throughout the growing season, in order to prevent seed development and starve the rootstocks. Grazing off when in grasslands, particularly with sheep.

\section{SMALL WILD BEAN}

Strophostỳles paucifìra, S. Wats.

Other English names: Few-flowered Wild Bean.

Native. Annual. Propagates by seeds.

Time of bloom: July to September. 
Seed-time: August to October.

Range: Indiana to Minnesota and Nebraska, southward to the Gulf of Mexico.

Habitat: Fields and meadows, banks of streams, waste places.

A small, very slender, low-climbing plant, with stems fifteen to thirty inches long, clothed with fine, downward-turning hairs. Leaflets lance-shaped or oblong to linear, without lobes, obtuse at apex and rounded at base, entire, little more than an inch long and less than a half-inch wide. Heads two- to six-flowered, in capitate clusters, on peduncles much longer than the leaves; corollas pale purple and only about a quarter-inch long. Pods very slender, a little more than an inch in length, flat, and very hairy. Beans purple, very small and flat, at first mealy but later smooth and shining.

Means of control the same as for the Trailing Wild Bean.

\section{YELLOW WOOD SORREL \\ Óxalis stricta, L. \\ (Xanth6xalis stricta, Small)}

Other English names: Upright Wood Sorrel, Sheep Sorrel, Sheep Poison, Sour-grass.

Native. Annual or perennial. Propagates by seeds and by woody rootstocks.

Time of bloom: April to September.

Seed-lime: Late May to October.

Range: Nova Seotia to South Dakota, southward to Florida and Texas.

Habitat: In woods, cultivated ground, roadsides, waste places, even along the curbstones of city streets.

Stems tufted on woody rootstocks, or annual seedlings single, upright or sometimes decumbent, branching at the base, pale green, slender, covered with fine, appressed hairs. Leaves alternate, palmately three-parted, the leaflets about a half-inch long, bright green, smooth, deeply notched at the

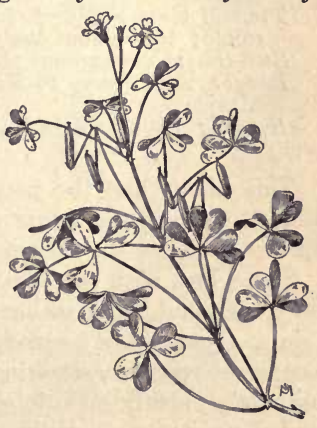

Fig. 180. - Yellow Wood Sorrel (Oxalis stricta). $\times \frac{1}{3}$. 
outer edge, sensitive, drooping against the stalk when plucked; this position they also take at night; petioles long, slender, also finely appressed-hairy. Flowers lemon-yellow, in open cymes of about two to four, on peduncles longer than the leaves, the pedicels slender and divergent, deflexed in fruit. Petals five, withering soon after opening; stamens ten, five long and five short, the filaments united at base; ovary five-celled; five separate styles with terminal stigmas. Capsules large, cylindric, short-pointed, often more than an inch long. Seeds very small, brown, flattened ovoid, covered with transverse wrinkles. (Fig. 180.)

\section{Means of control}

Prevent seed production by deep hoe-cutting or hand-pulling before the first flowers mature.

\section{LADY'S SORREL}

Óxalis corniculàta, $\mathrm{L}$. (Xanthóxalis corniculàta, Small)

Native. Annual or perennial. Propagates by seeds and by stolons.

Time of bloom: March to late October at the northern limits of range; throughout the year where not snow-covered.

Seed-time: Throughout the year.

Range: New Jersey to Kansas, southward to the Gulf States and Mexico.

Habitat: Fields, roadsides, waste places.

This plant, like the preceding one, may be called annual, in that it flowers and fruits during its first year of life; but this species prolongs its existence through its many slender runners.

Stems low, with spreading branches, those at the base creeping on the ground, three inches to a foot or more long, rooting at the joints, those above sparsely covered with fine, spreading hairs. Leaflets deep green, sometimes with a purplish tinge, notched at the outer edge, nearly smooth, often an inch broad. Flowers yellow, in umbellate or cymose clusters, peduncle and pedicels sparingly hairy, the latter not deflexed in fruit. Capsule smaller than that of the 
preceding species, a little more than a half-inch long, faintly fivesided, with tapering point. Seeds compressed ovoid, brown, transversely wrinkled.

Means of control the same as for Wood Sorrel.

\section{SMALL-FLOWERED CRANE'S-BILL}

Gerd̀nium pusillum, Burm. f.

Introduced. Annual or biennial. Propagates by seed.

Time of bloom: May to September.

Seed-time: June to October.

Range: Ontario to British Columbia, southward to North Carolina, Nebraska, and Utah.

Habitat: Cultivated ground, lawns and yards, roadsides, and waste places.

This plant is frequently troublesome in lawns and its seeds are too often an impurity of the mixed grass seeds sold for making such green turf. Its seed capsules open elastically, scattering its progeny for severad feet; lawn-mowers also help in its distribution, and soon the grass begins to be "run out" by the weed, especially when the turf is rather thin and the soil in need of enrichment.

(Fig. 181.)

It has a slender taproot, fringed with thready rootlets. Stem three inches to a foot or more in length, branching from the base, spreading or prostrate, softly hairy. Leaves rounded or kidneyshaped in outline but deeply five- to seven-lobed, the segments toothed at the tips, finely downy-hairy. Flowers in pairs, on short peduncles in the axils or opposite to them, about a quarterinch broad, pinkish purple, the five petals notched at their edges; five sepals, nearly as long as the petals,

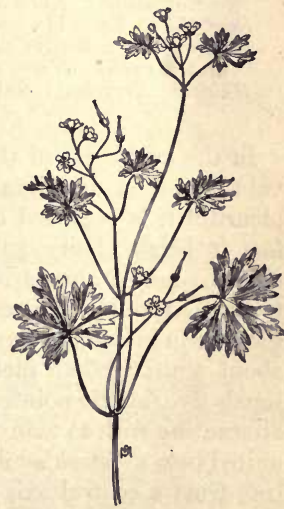

Fig. 181. - Small-flowered Crane's-bill (Geranium pusillum). $\times \frac{1}{2}$. sharp-pointed but without awns; stamens five; the five united, persistent styles form the "crane's-bill," which tips the five- 
celled ovary and splits from the base when ripe. Seeds two in each cavity, very small, smooth, slightly flattened, reddish brown.

\section{Means of control}

Prevent seed development. The best way of ridding a lawn of this intruder is to fill a common machine oil-can with crude carbolic acid and squirt a few drops directly on the crown of the root as soon as the first small, pink blossoms make it noticeable among the grass. Or it may be cut from the root with a knife or a small spud.

\section{ALFILARIA OR FILAREE}

Eròdium cicutàrium, L'Her.

Other English names: Pin Clover, Pin Grass, Pin Weed, Stork'sbill, Heron's-bill.

Introduced. Annual or biennial. Propagates by seeds.

Time of bloom: April to September.

Seed-time: Late May to October.

Range: Nova Scotia to Oregon, southward to New Jersey, Texas, and Mexico. Very abundant on the Pacific eoast.

Habitat: Dry soil ; fields and waste places.

In the arid lands of the West and the Southwest, the Filaree is valued as a pasture plant when young; but where better forage is plentiful it is regarded as a weed. Stems tufted, six inches to a foot in height, hairy, somewhat viscid, reddish, usually branched above. Leaves pinnatifid, the segments again finely cut and toothed, the lower ones with petioles, the upper ones sessile. Flowers in umbellate clusters of two to twelve, pink or light purple, about a third of an inch broad; petals five, with rounded tips; sepals five, bristle-pointed and hairy ; stamen-bearing anthers five, alternating with as many sterile filaments; carpels and styles five, united into a "stork's-bill" one or two inches long, when ripe splitting from a central axis into spirally twisted and bearded awns or beaks with sickle-bent tips; when damp the awns straighten and when dry they recoil, thus being easily caught in the fleeces of sheep, and the seed so distributed. (Fig. 182.)

Occupying about the same range as this plant is a near relative, the Musk Clover, or Musky Alfilaria (Eròdium moschàtum, L'Her.), 
a larger, coarser plant, with less finely divided leaves and somewhat larger flowers. Less valuable as a forage plant, for cattle do not relish its musky odor and taste; sheep, however, do not seem to object to it. Both plants invade grain fields to the disadvantage of the crop.

\section{Means of control}

Prevent seed production. Put the ground under cultivation in order to stir dormant seeds into germination, and give such frequent tillage that no seedlings will be allowed to mature.

\section{GROUND BUR-NUT}

Tríbulus terréstris, L.

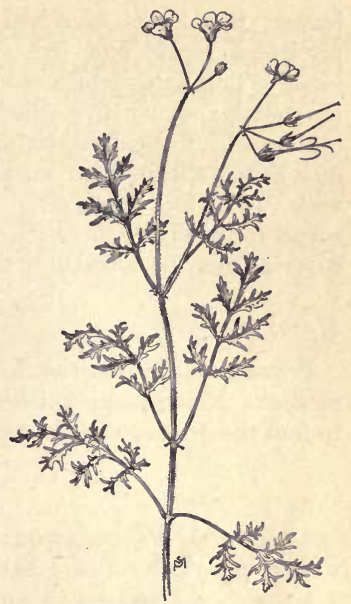

Fic. 182. - Alfilaria or Filaree (Erodium cicutarium). $\times \frac{1}{3}$.

Other English name: Land Caltrop.

Introduced. Annual. Propagates by seeds.

Time of bloom: June to August.

Seed-time: July to September.

Range: Iowa, Illinois, Kansas, and Nebraska; also about Atlantic seaports.

Habitat: Pastures, waste places.

The Caltrop is native to the Mediterranean regions of Europe, and is said to have been brought into its western range in the fleeces worn by imported sheep; and it is a very troublesome weed to wool-growers.

Stems eight inches to nearly three feet long, branching from the base, and often forking above, weak, slender, silky-hairy, some prostrate and others ascending, spreading on all sides. Leaves numerous, also silky-hairy, evenly pinnate, short-petioled, with ten to fourteen small, oblong, sessile leaflets, the pairs frequently unequal in size. Flowers axillary, on peduncles shorter than the 
leaves; they are about a half-inch broad, with five hairy, pointed, persistent sepals and five fan-shaped, rounded, yellow petals, broader than long, which soon fall away; stamens ten, as long as the petals; ovary five-celled and hairy, the styles united in a column with five-ridged stigma. The fruit, or nut, is nearly a halfinch broad, and splits at maturity into five carpels, each one armed with two to four hard, often curved and spreading spines. Each carpel contains several seeds, which, protected by their hard, spiny covering, may lie dormant in the soil for more than one season.

\section{Means of control}

Prevent seed production by close cutting before the first flowers mature. No annual plant can long survive which is not permitted to foul the ground with its future generations.

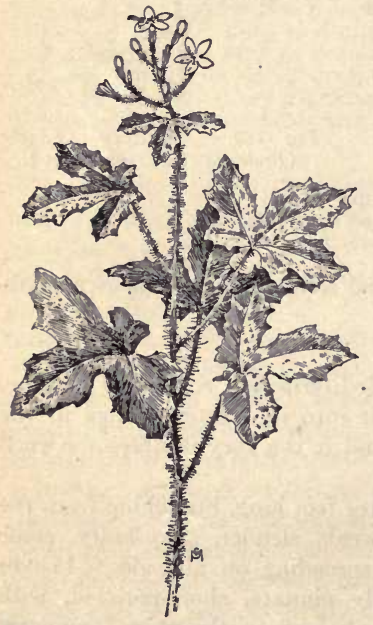

FIG. 183. - Spurge Nettle (Jatropha stimulosa). $\times \frac{1}{3}$.

\section{SPURGE NETTLE}

Jatropha stimulòsa, Michx.

Other English names: Bull Nettle, Tread-softly.

Native. Perennial. Propagates by seeds.

Time of bloom: May to September.

Seed-time: June to November.

Range: Virginia and Tennessee, south and west to Florida, Louisiana, and Texas.

Habitat: Prefers light, sandy soils, but invades nearly all erops.

The tough, woody, branching roots of this plant often penetrate the soil to a depth of three to five feet, taking to themselves what food and moisture is to be found. Herbaceous stems are sent up yearly, one to three feet tall, slender, branching, bright green, 
bristly with stinging hairs, which produce, when in contact with the skin, a much more painful and lasting irritation than do those of the nettle. The leaves are similarly armed; these are two to six inches or more broad, roundish heart-shaped in outline but three- to fivelobed, with prominent veins, wavy-toothed, and with prickly edges and long, bristly petioles. Male and female flowers are separate, the staminate ones usually in terminal clusters, the fertile ones in the axils just below. Calyx of the staminate flower white, fuzzy, the five lobes spread salver-shape, more than a half-inch broad, fragrant; fertile flowers also five-parted but smaller, soon followed by three-celled, three-seeded, wrinkled, and bristly-hairy pods, about three-fourths of an inch long when mature. Seeds obovoid, smooth, nearly a half-inch long, mottled, and caruncled. (Fig. 183.)

\section{Means of control}

Cutting, again and again cutting, throughout the growing season, with a sharp steel hoe or a cultivator with broad and very sharp blades, in order to starve the roots and prevent all seed production.

\section{HOGWORT}

Cròton capitàtus, Michx.

Native. Annual. Propagates by seeds.

Time of bloom: July to September.

Seed-time: August to October.

Range: New Jersey to Iowa, southward to Georgia and Texas.

Habitat: Dry, sandy fields, roadsides, and waste places.

A very common and troublesome weed in the southern part of our area, particularly in the Gulf States. Stem one to two feet in height, erect, branching, densely soft-woolly with star-shaped hairs. Leaves also finely woolly on both sides, silvery green, oblong lance-shape with rounded or heart-shaped base, entire, the larger lower ones with petioles about as long as the blades, those near the top short-petioled. Flowers clustered at the summit of stem and branches; they are monœcious, the sterile ones lifted on a short raceme, at the base of which the fertile ones are crowded 


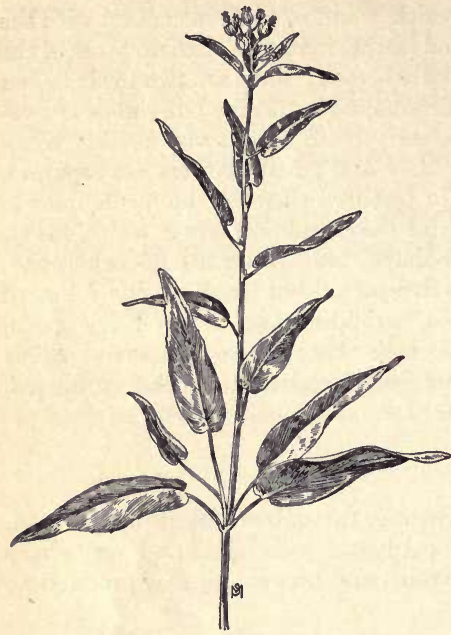

Fig. 184. - Hogwort (Croton capitatus). $\times \frac{1}{2}$.

on very short pedicels; sterile flowers with fiveparted calyx, five spatulate fringed petals alternating with as many glands, usually ten stamens, or sometimes more, with filaments finely bearded below; fertile flowers with seven- to twelve-lobed calyx, no petals, and three styles twice or thrice cleft. Seeds gray or brownish, rounded oblong, with a tiny knob or caruncle at the point; they are often an impurity of southern alfalfa seed. (Fig. 184.)

\section{Means of control}

Prevent seed production. Infested grass crops should even be harvested too early, in order to prevent continued fouling of the ground. Roadsides and waste places should be mown often enough to guard neighboring soil from contamination.

\section{THREE-SEEDED MERCURY \\ Acalỳpha virginica, L.}

Other English names: Wax-balls, Copper-leaf.

Native. Annual. Propagates by seeds.

Time of bloom: June to September.

Seed-time: August to November.

Range: Nova Scotia to Minnesota, southward to Florida and Texas.

Habitat: Rich, moist soil ; a common barnyard weed and a special nuisance in clover fields.

The seeds of this weed, when an impurity in those of clover, are so nearly of the same size and weight that they are almost im- 
possible to remove. Professor Selby, of the Ohio State Experiment Station, wisely remarks that "the time to remove such seeds is before the clover is cut."

Stem six inches to two feet high, erect, somewhat hairy, often purplish or brown. Leaves alternate, two to four inches in length, long ovate, thin, dark green, often turning to a coppery brown, coarsely toothed except near the base. In their axils are the inconspicuous greenish flowers, male and female separate, but growing from the same point, the staminate ones being lifted on a tiny spike, the fertile ones just below, and both supported by a large, leafy, cut-lobed bract, longer than either, usually about a half inch high. Capsules three-celled, each cavity containing one dull reddish brown or gray seed, egg-shaped, and easily crushed between the fingers, which is the reason why they are called Wax-balls. (Fig. 185.)

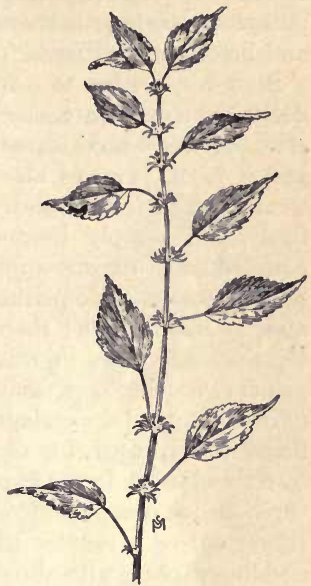

Fig. 185. - Three-seeded Mercury (Acalypha virginica). $\times \frac{1}{1}$.

\section{Means of control}

Pulling or cutting the weeds before any seeds have matured. Land badly fouled by the seeds should be put to a profitable and thoroughly tilled hoed crop for a season.

\section{THYME-LEAVED SPURGE}

\section{Euphórbia serpyllifolia, Pers.}

Native. Annual. Propagates by seeds.

Time of bloom: May to September.

Seed-time: June to Oetober.

Range: Michigan to California, southward to Mexico, Texas, and Florida.

Habitat: Sandy, alluvial soils; fields, gardens, waste places. 
A common, worthless, and prolific little plant, not so much detested as it deserves to be, for it and all its kindred are more or less poisonous, their growth serving merely to impoverish the ground and befoul it with seeds for another generation.

Stem four inches to a foot in length, branching from the base, declining or prostrate, slender, smooth, usually green on the under side but red where exposed to the light, filled with a poisonous milky juice. Leaves also reddish or red-spotted, opposite, less than a half-inch long, obovate or spatulate, obtuse, unequal-sided, finely and sharply toothed for about half their length, shortpetioled, with narrow stipules ending in a fringe of weak bristles. Spurge flowers have neither calyx nor corolla, but are monœcious after an odd fashion; there is a funnel-shaped involucre on a short terminal peduncle, in this case appearing lateral but not really axillary, bearing four small, disk-like glands, each subtended by a narrow, toothed appendage; within the involucre are several male flowers, each consisting of a single stamen on a pedicel subtended by a tiny bract; fertile flower a single three-celled, three-styled, and three-seeded ovary, at first in the bottom of the involucre but soon thrust out on a slender stipe and ripening in the outer air into a nodding capsule with three carpels, each holding one seed; in this species the latter are hardly one-twelfth of an inch long, sharply four-angled, the faces cross-wrinkled and pitted.

Means of control the same as for the ubiquitous Spotted Spurge.

\section{UPRIGHT SPOTTED SPURGE}

Euphórbia Préslii, Guss.

(Euphórbia nùtans, Lag.)

Other English names: Stubble Spurge, Pasture Spurge, Eyebright, Slobber Weed.

Native. Annual. Propagates by seeds.

Time of bloom: May to October.

Seed-time: June to November.

Range: All of North America east of the Rocky Mountains except the extreme north.

Habitat: Dry fields and meadows, old pastures, roadsides, and waste places.

Dry stubbles sometimes seem to redden with young Spurges in a few days after harvest, but usually the stalks were already there 
and it is their rapid stooling after beheading that causes the swift appearance. Its acrid, milky juice is credited with causing "slobbers" in grazing cattle and horses, and another symptom of Spurge poisoning is a wide-staring, glassy brightness of eyes, whence the common names. (Fig. 186.)

It is a graceful plant, with slender, round, wiry, reddish stem, six inches to two feet or more in height, smooth or nearly so, forkbranched and spreading. Leaves narrowly oblong, varying to ovate, or sometimes lance-shape and slightly curved, a half inch to an inch long, often with unequal sides, usually with red margins and a brownish red blotch in the center, finely and sharply toothed, with short petioles and triangular stipules. Flowers on peduncles longer than the petioles, the involucres narrowly obovoid, the four glands subtended by rounded, entire, white or red appendages. Pods smooth, the seeds grayish black, long ovoid, obtusely four-angled, wrinkled and tubercled between. They are nearly always found in clover and grass seed.

Means of control

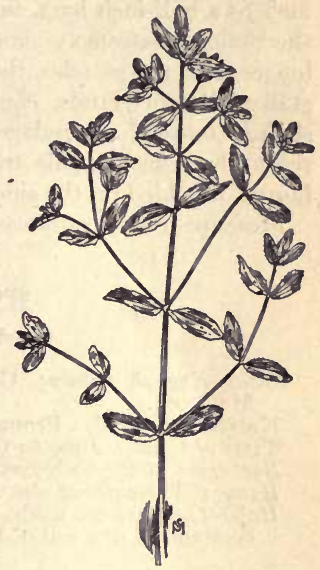
Fra. 186. - Upright Spotted
Spurge (Euphorbia Preslii). $\times \frac{1}{2}$. to kill the stalks and destroy the seeds on the surface of the ground. On cultivated ground, persistently hoe-cut or hand-pull the weed before seed matures. Infested meadows should be put to some well-tilled crop, liberally fertilized, before reseeding heavily to grass or clover.

\section{HAIRY SPURGE}

Euphorbia hirsùta, Wiegand

Native. Annual. Propagates by seeds.

Time of bloom: June to September. 
Seed-time: July to October.

Range: Quebec and Ontario, southward to New Jersey, Pennsylvania, Ohio, and Illinois.

Habitat: Dry, sandy soil ; fields, roadsides, waste places.

A very common, small, and spreading plant, with hairy stems three to ten inches long, branching from the base, zigzagged and forking, nearly prostrate. Leaves oblong-ovate, from a quarterinch to a half-inch long, finely toothed nearly to the oblique base, the petioles extremely short. Flowers on peduncles considerably longer than the petioles, the involucres funnel-shaped, bearing four stalked brown glands, concave at top, and subtended by white, slightly toothed appendages. Pods smooth, with rounded angles; seeds black with a pale transparent coating, sharply four-angled, faintly wrinkled on the sides between.

Measures for its suppression the same as for Spotted Spurge.

\section{SPOTTED SPURGE}

Euphórbia maculata, L.

Other English names: Creeping Spurge, Milk Purslane, Spotted Matweed.

Native. Annual. Propagates by seeds.

Time of bloom: June to October.

Seed-time: July to November.

Range: Throughout the American Continent except the far North. Habitat: Gardens, fields, roadsides. Found in all erops, but most common in dry soil of low fertility.

Of all the Spurges, this one seems the most hardy and adaptable, able to grow anywhere and to endure any hardship; it often appears from the cracks of flags and paving stones in cities, and flourishes while being trodden under foot. From such a place the writer pulled the thrifty specimen from which this description is written. Every part of it, even the root, exudes a poisonous milky juice which will irritate the skin to a red rash or in a short time blister it. Apparently nothing eats the weed, even insects leaving it untouched. (Fig. 187.)

It has rather long, branching, and fibrous roots, with many fine feeding rootlets. Stem round, slender, finely hairy, prostrate, three inches to a foot or more in length, with numerous 
branches extended in all directions, red where exposed to the light but green underneath. Leaves opposite, oblong, from a quarter-inch to nearly an inch in length, short-petioled, very finely toothed, usually with a purplish brown spot near the center; stipules nearly linear, tipped with a fringe of bristles. Flowers on peduncles about as long as the petioles, the involucres bearing four minute, cupshaped glands with narrow red appendages. Pods angled and hairy, with ash-gray, four-angled seeds which are a frequent impurity in the seeds of grass and clover.

\section{Means of control}

In cultivated ground, persistent hoecutting as soon as the first flowers appear. Grasslands badly infested should be put under cultivation, the ground being fertilized well before reseeding heavily to grass or clover.

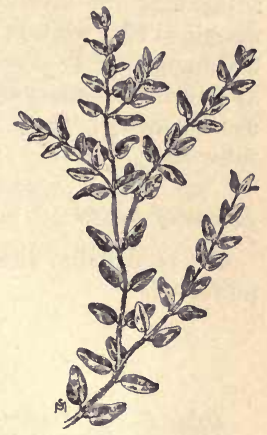

FIG. 187. - Spotted Spurge (Euphorbia maculata). $\times \frac{1}{2}$.

\section{SNOW-ON-THE-MOUNTAIN}

Euphórbia marginàta, Pursh.

Other English name: White-margined Spurge.

Native. Annual. Propagates by seeds.

Time of bloom: May to September.

Seed-time: June to October.

Range: Minnesota to Colorado, southward to Texas, spreading eastward to Ohio; introduced in Eastern States and freely escaping.

Habitat: Dry soil ; fields, pastures, waste places.

The handsomest of our native Spurges, but dangerous to handle, as the copious milky juice when in contact with the skin causes a swelling and eruption similar to that produced by Poison Ivy; persons unacquainted with its quality often pluck it for its beauty and suffer for it. Honey made from its flowers is poisonous and unfit to use, acting as a violent emetic and purge.

Stem rather stout, two to three feet tall, erect, slightly grooved, 
usually hairy. Leaves oblong-ovate, pointed, entire, sessile, those on the stalk few and scattered, with a whorl at the base of the umbel, which has usually three fork-branched rays; the bracts subtending the involucres are large, numerous, whorled, broadly margined with white, very showy ; involucres clustered in the center, bellshaped, softly downy, bearing five glands subtended by white, kidney-shaped appendages. Capsule depressed, with rounded lobes, usually hairy; seeds bluntly ovoid, dark ash-gray, netted, and tubercled.

\section{Means of control}

Cut repeatedly, close to the ground, permitting no seed to be perfected.

\section{FLOWERING SPURGE}

Euphórbia corollata, L.

Other English names: White-flowered Milkweed, Poison Milkweed. Native. Perennial. Propagates by seeds and by rootstocks.

Time of bloom: June to Oetober.

Seed-time: July to November.

Range: Ontario to Minnesota, southward to Kansas, Texas, Louisiana, and Florida.

Habitat: Dry fields, old pastures, waste places.

The deep, perennial rootstocks of this weed make it very difficult to suppress. Grazing animals usually avoid it, seeming to know the quality of its milky sap, which is acrid and strongly emetic.

Stem ten inches to two feet or more in height, bright green, erect, smooth or sometimes slightly hairy, often spotted, unbranched below the flower-cluster. Leaves narrowly oblong to lance-shape, obtuse at apex, smooth, rather thick, entire, one or two inches long, sessile or with very short petioles; those at the base of the unbel whorled, but those on the stem scattering. Rays of the umbel slender, usually five, each again twice or thrice fork-branched, the flowers at the base of the forks being several weeks earlier than the terminal ones; involucres on long peduncles, the five greenish yellow glands at the tip being subtended by large, white, rounded appendages simulating petals. Pod smooth, containing three 
bluntly ovoid, ash-colored seeds, about a twelfth of an inch long, smooth or faintly pitted.

\section{Means of control}

Small areas or scattering plants are most quickly and economically ousted by grubbing up the rootstocks or by treating with a strong herbicide such as hot brine or caustic soda. Infestations too large to make such treatment practicable should be closely and repeatedly cut during the growing season, thus preventing any seed formation and starving the rootstocks, the process being kept up for at least two seasons. Or the land may be put under thorough cultivation, well fertilized, and then seeded to grass or clover.

\section{TOOTHED SPURGE}

Euphórbia dentata, Michx.

Native. Annual. Propagates by seeds. Time of bloom: July to September. Seed-time: August to November.

Range: Pennsylvania to Wyoming, southward to Louisiana, Texas, and Mexico. Habitat: Rich, moist soil ; fields, meadows, waste places.

A robust-looking, grossly feeding weed, transforming into its poisonous foliage much of the fertility needed by its wholesome neighbors. Stem eight to twenty inches high, somewhat woody at base, erect and branching. Leaves two to four inches long, the upper ones opposite but at base alternate, varying in shape from ovate to nearly linear, coarsely toothed, hairy, with prominent veins on the under side, and with hairy petioles. Involucres in clusters at the ends of stem and branches on very short peduncles; they are bellshaped, with five oblong, sharply toothed lobes, bearing usually one or sometimes

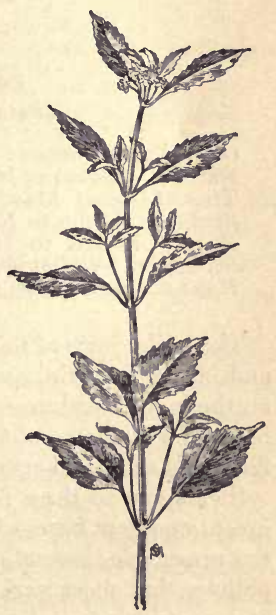

FIG. 188. - Toothed Spurge (Euphorbia dentata). $\times \frac{1}{6}$. 
several short-stalked, yellowish glands without appendages. Capsules smooth, with rounded angles, nearly one-sixth of an inch in diameter. Seeds ashy-gray, obscurely four-angled, bluntly ovoid, the surface tuberculate; they are often an impurity of grass and clover seeds. (Fig. 188.)

\section{Means of control}

Infested meadows should be harvested early, before the first flowers mature seed. The poisonous qualities of the milky juice are volatile and disappear with heat or drying, and such hay is wholesome. In grain fields the seedlings should be harrowed out in the spring, for the spreading habit of growth of the plant will crowd and starve the crop; if practicable, hand-pull the survivors ; if not, burn over the stubble. In cultivated ground tillage should be late in order to prevent the maturing of late-developed seed.

\section{PAINTED LEAF}

Euphórbia heterophýlla, L. (Poinséttia heterophýlla, Small)

Other English names: Cruel Plant, Various-leaved Spurge.

Native. Annual or biennial. Propagates by seeds.

Time of bloom: May to October.

Seed-time: June to November.

Range: Illinois to Montana, southward to Mexico, Texas, and Florida. Widely distributed in tropical America.

Habitat: Dry, sandy soil; fields, waste places.

The milky juice of this plant, like that of all its tribe, will irritate and blister the skin, and, if eaten by stock, will have a like effect on the inner membranes and make the animals very sick; another reason for its name of Cruel Plant is that honey gathered from its flowers is acrid and emetic and unfit for use.

Stems one to three feet tall, erect, smooth or nearly so, bright green, woody at base, with numerous branches, the lower spreading, the upper ones ascending. Leaves alternate and all with slender petioles, but most variable in shape, some being round, or ovate, or lance-shaped, or linear, with edges entire or toothed or wavy, often on the same plant; sometimes the upper leaves are fiddle- 
shaped, and to add to their oddity are blotched with deep red. The involucres are in terminal clusters, each on a peduncle of about its own length, with five much incised, ovate lobes, bearing usually one, occasionally several, cup-shaped glands, which are sessile or nearly so, and without appendages. Seeds nearly globular, roughened with small tubercles.

\section{Means of control}

If not too numerous, the plants are best destroyed by handpulling as soon as observed; or by cutting so closely and frequently that no seed will be allowed to mature.

\section{LEAFY SPURGE}

\section{Euphorbia Ésula, L.}

Other English names: Tithymal, Faitour's Grass.

Introduced. Perennial. Propagates by seeds and by rootstocks. Time of bloom: June to August.

Seed-time: July to October.

Range: Southern Maine to New Jersey, westward to Michigan.

Habitat: Roadsides, waste places.

Not a common weed in this country as yet, and should not be permitted to become so, for its creeping, horizontal rootstocks make it difficult to dislodge when once established; like the Cypress Spurge it grows in patches, smothering all weaker growths in its way.

Stems thickly clustered, ten inches to two feet tall, erect, slender, scaly at base, smooth above, branching near the top. Leaves narrowly oblong to lance-shape, a half-inch to nearly two inches in length, entire, sessile, whorled at the base of the umbel, few and scattering on the stalk. Umbel compound, its many rays forkbranched and bearing numerous opposite, greenish yellow bracts, broadly heart-shaped, with midvein extended in a minute bristle; involucres bell-shaped, nearly sessile, bearing four unappendaged, crescent-shaped brown glands. Capsule smooth, nodding on a long stipe; the seeds drab-gray, oblong, round and smooth, caruncled at base. 


\section{Means of control}

Small areas, newly infested, should be grubbed out or destroyed with hot brine or caustic soda. Where too abundant to make such treatment practicable, close, persistent cutting, in order to starve the roots and prevent all seed development, will finally suppress the weed.

\section{SUN SPURGE}

Euphórbia Helioscdpia, L.

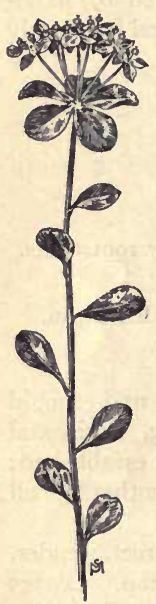

Fra. 189. Sun Spurge (Euphorbia Helioscopia). $\times \frac{1}{2}$.

Other English names : Wartgrass, Wartweed, Sunweed, Little-good, Cat's Milk, Wolf's Milk, Mouse-Milk. Introduced. Annual. Propagates by seeds.

Time of bloom: June to Oetober.

Seed-time: July to November.

Range: Eastern Quebec to Ontario, southward to Pennsylvania, Ohio, and Illinois.

Habitat: Fields, roadsides, and waste places.

An immigrant from Europe, abundant in its range, which is gradually extending. Its milky juice is exceedingly copious, and so acrid that it is used as a caustic to destroy warts. (Fig. 189.)

Stem stout, smooth, eight to fifteen inches tall, often branched from the base. Leaves obovate, rounded at tips, finely toothed, whorled and sessile at the base of the umbel, but those on the stalk scattering and tapered to a short petiole. Umbel compound, the rays usually five, first triply branching and then each branch forked; involucres bell-shaped, with unappendaged, round, stalked glands. Capsule smooth, with rounded lobes; seeds ovoid, reddish brown, the surface netted and pitted like a honeycomb.

Means of control the same as for Spotted Spurge.

\section{CYPRESS SPURGE}

\section{Euphórbia Cyparissias, L.}

Other English name: Quack Salver's Grass.

Introduced. Perennial. Propagates by seeds and by rootstocks. 
Time of bloom: June to September.

Seed-time: July to November.

Range: Eastern part of the United States.

Habitat: Fields, roadsides, waste places; frequent in cemeteries.

An escape from flower gardens and cemeteries, where it should never be given a place, for it is as pervading and uncontrollable as Toad-flax. Its tough, horizontal, creeping rontstocks cause it to grow in dense patches, choking out all other growth. In pastures it is said to be very injurious to grazing cattle, but the writer's observation has been that cattle avoid it.

Stems thickly clustered, six inches to a foot in height, erect, scaly at base, very leafy above, with few branches. Leaves linear, deep green, smooth, those subtending the umbels whorled, those on the stalks alternate, crowded, and sessile. Rays of the umbel very numerous, the flowers subtended by greenish yellow, heartshaped bracts; involucres top-shaped, bearing four crescent-shaped glands without appendages. Pods rounded and granular, with smooth, oblong, ash-gray seeds, caruncled at base. (Fig. 190.)

\section{Means of control}

Close cutting just at blooming time when the rootstocks are most depleted of their stored nutriment, using salt to retard recovery. Small

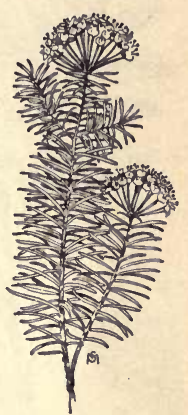

FIG. 190. - Cypress Spurge (Euphorbia Cyparissias). $\times \frac{1}{3}$. areas are most quickly dealt with by grubbing out and destroying the rootstocks.

\section{POISON SUMAC}

\section{Rhuis Vérnix, L.}

Other English names: Swamp Sumac, Poison Dogwood, Poison Ash, Poison Elder, Thunderwood.

Native. Perennial. Propagates by seeds.

Time of bloom: June.

Seed-time: Fruit ripe in late summer but retained until winter.

Range: New England and southern Ontario to Minnesota, southward to Florida and Louisiana.

Habitat: Swamps. 
"Berries white, dread the sight;

Berries red, have no dread,"

used to be repeated in distinguishing the harmless sumaes from their "dreaded" relative, which is a shrub six to twenty feet in height, and hardly to be called a weed, but included here since, because of its beautiful autumnal coloring, it is frequently brought from its

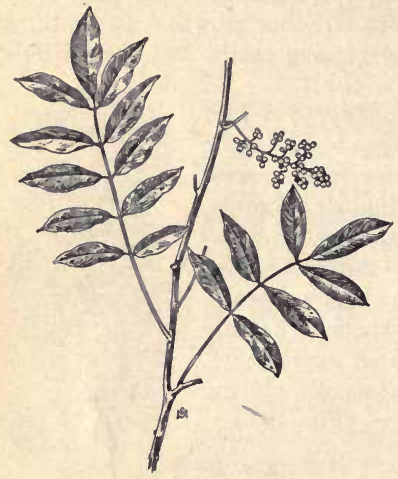

Frg. 191. - Poison Sumac (Rhus Vernix). $\times \frac{1}{3}$.

home in the swamps for house decoration - usually to the ex ceeding great bodily distress of the person who plucked it, for it is even more poisonous than its relative, Poison Ivy. (Fig. 191.)

Leaves pinnately compound, the leaflets seven to thirteen, obovate, smooth, thin, entire, green on both sides, the slender petiole slightly swollen at the base. Flowers in axillary clusters three to eight inches long, very small, greenish white, similar to those of Poison Ivy. Fruit a cluster of greenish white, waxy drupes, each with one hard, ridgy seed within, like

Poison Ivy. Remedies for the effects of its poisonous touch are the same.

\section{POISON IVY}

Rhús Toxicodéndron, $\mathrm{L}$.

(Rhúśs radicans, L.)

Other English names: Poison Oak, Poison Creeper, Three-leaved Ivy, Climath, Black Mercury, Markweed.

Native. Perennial. Propagates by seeds and by rootstocks.

Time of bloom: Late May to July.

Seed-time: Fruits attain full size in August but remain on the stem until late in winter.

Range: Nova Scotia to British Columbia, southward to Florida, Arkansas, and Utah.

Habitat: Roadsides and waste places, fence rows, and borders of woods. 
A very poisonous plant, far too common everywhere, for to many persons the touch of it brings disaster, blotching the skin with burning "water-blisters" and causing the flesh beneath to swell hideously and throb with a pain so intense as to be alarming. Fortunately such an attack leaves no scars and the general health is not injured. Chemical analysis has shown that the poison is a nonvolatile oil, found in all parts of the plant, even the seasoned wood, but especially in the growing leaves. It is insoluble in water, therefore washing the skin after contact merely serves to spread the trouble; but alcohol will at once dissolve and remove it, and, if applied soon enough, will prove the prevention that is better than cure. If too late for that, a little powdered sugar of lead, dissolved in alcohol, will check the eruption and soothe the pain. This remedy is also a poison, and care must be taken to keep it out of eyes and mouth, and of course it should not be used if the vesicles have broken; in such case dilute extract of Grindelia will check their spread and soothe the smart.

The plant is sometimes an erect and bushy shrub, sometimes prostrate and trailing, sometimes a long, woody vine, climbing tall trees by means of aërial

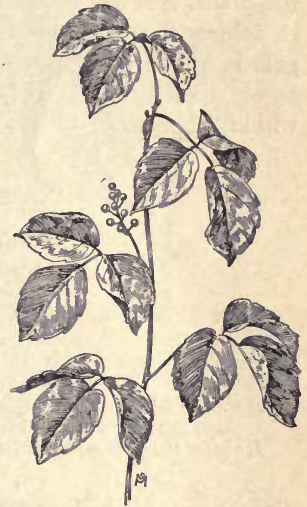

FIg. 192. - Poison Ivy (Rhus Toxicodendron). $\times \frac{1}{4}$. rootlets. Leaves compound, with three leaflets, ovate to rhombic, pointed, usually entire but sometimes scalloped or irregularly few-toothed, the two lateral ones sessile or on very short stalks, the terminal one longer. In form they are somewhat like the leaflets of the Virginia Creeper, or Woodbine (Psédera quinquefòlia), but it should be remembered that those are five in number like the fingers of the hand, and can be safely handled; but "Leaflets three, let it be." Flowers in loose, axillary panicles, small, greenish white, with five-parted calyx, five petals, five stamens and one-celled ovary. Fruit also greenish white, smooth, and waxy, dangling in clusters of about the size of small currants, 
each containing one hard seed. Crows and other birds eat the fruits, apparently without harm, and void them along fences and telephone routes. The pest is increasing throughout the country, for most people are so afraid of it that it is left unmolested to multiply its kind. (Fig. 192.)

\section{Means of control}

Some fortunate persons are quite immune to the bad effects of the plant, and one of these might be hired to grub it out and burn it, taking care that no one inhales the intensely irritant smoke or gets it in the eyes. Or a few drops of sulfuric acid (handle with care), applied every few days to the woody stem near the roots, will kill the plant; or hot brine or caustic soda will destroy it.

\section{INDIAN MALLOW}

Abùtilon Theophrásti, Medic.

(Abùtilon Avicénnœe, Gaertn.)

Other English names: Velvet Leaf, American Jute, Butter Print.

Introduced. Annual. Propagates by seeds.

Time of bloom: July to October.

Seed-time: August to November.

Range: Maine to South Dakota, southward to Florida and Texas. Also on the Pacific Slope.

Habitat: Rich soil ; cultivated ground, farm yards, waste places.

Once established and allowed to mature fruit, this is a most persistent weed, for the seed has been known to survive in the soil for more than fifty years. The inner bark of the plant yields a fine, strong fiber which may be made into twine, rope, or paper, whence the name of American Jute; but this is a misnomer, for the plant is a native of Asia, where it is cultivated for its fiber. (Fig. 193.)

Stem stout, erect, round, softly hairy, three to six feet in height, and branching widely. Leaves alternate, pointed-heart-shaped, three inches to nearly a foot broad, velvety above and below with a dense coat of exceedingly fine, soft hair; petioles slender and nearly as long as the blades. Flowers solitary in the axils, each about a half-inch broad, with five yellow petals and a velvety green, five-lobed calyx, many stamens, united in a ring around 
the several pistils which are also united at the base, but distinct above, projecting beyond the stamens. The compound seed-vessel is much larger than the flower, being about an inch broad, composed of a ring of twelve to fifteen awn-tipped carpels, splitting at the top when ripe and each containing three to nine seeds, which are rounded kidneyshaped, grayish brown, slightly rough, about one-eighth of an inch long. These seeds are shaken from the carpels by winter winds and blown for long distances over crusted snow.

Means of control

Cut or pull the plants while in early bloom. Seedlings that bloom late, even after corn is harvested, Fig. 193. - Indian Mallow may produce enough seed to foul the (Abutilon Theophrasti). $\times \frac{1}{4}$. ground; plants bearing unripe seed-vessels should be burned, as they will ripen on the stalks.

\section{RED FALSE MALLOW}

\section{Malvastrum coccineum, Gray .}

Native. Perennial. Propagates by seeds.

Time of bloom: May to August.

Seed-time: July to Oetober.

Range: Manitoba to British Columbia, southward to Texas and New Mexico.

Habitat: Dry prairies, hillsides; wild pastures.

The Greek name of this weed means Star-mallow, and the whole plant is silvery gray with stiff, star-shaped hairs, which are said to have a bad effect on the digestive tracts of grazing cattle and horses, though sheep seem to take no harm and appear to be very fond of the plant. In some localities it has been suspected of being 
poisonous, but Pammel ${ }^{1}$ states that "there is no evidence to support this view." (Fig. 194.)

Stems two to ten inches in height, growing in tufts from a peren-

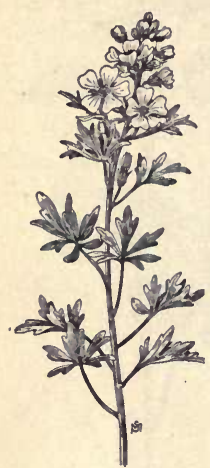

Fig. 194. - Red False Mallow (MaL vastrum coccineum). $\times \frac{1}{3}$. they seem to be unwholesome. nial deep-boring taproot. Alternate leaves but one or two inches long, rounded oval in outline but deeply three- to five-lobed and the segments again incised; lower leaves with slender petioles but those above nearly sessile. Flowers in crowded terminal racemes on each of the numerous stalks, brick red in color, each blossom a half-inch or more across, the five petals often slightly notched at the tips and longer than the pointed calyx-lobes; styles five or more, surrounded by the ring of many united stamens. Carpels, ten to fifteen, rough, netveined, and usually but one-seeded.

\section{Means of control}

Infested pastures should be broken up and reseeded to better forage. Until this is done such weeds can be guarded against only by herding away from them the animals for which

\section{PRICKLY SIDA}

Sida spindsa, L.

Other English names: Thistle Mallow, Spiny Sida.

Introduced. Annual. Propagates by seeds.

Time of bloom: Late May to September.

Seed-time: July to October.

Range: Maine to Michigan, Iowa, and Kansas, southward to Florida and Texas.

Habitat: Dry clay soils; fields, gardens, pastures, and waste places.

An emigrant from tropical America, which is gradually gaining ground to the north and the west. Stems eight to twenty inches

${ }^{1}$ Manual of Poisonous Plants. 
high, erect, much branched, downy-hairy. Leaves alternate, one to two inches long, ovate to lance-shaped, scallop-toothed, downy-hairy, with base rounded or abruptly narrowed to petioles about half as long as the blades; at the base of some of the larger leaves is a small, pointed tubercle, which gives the plant its name though it is hardly long enough or sharp enough to be called a spine. Flowers light yellow, only about a quarter-inch broad, on short axillary peduncles; calyx with five teeth, shorter than the obovoid petals; styles five with undivided stigmas, surrounded by united stamens. Fruit ovoid, containing five carpels, each splitting at the top into two beaks. Seeds triangular, smooth, dark brown. (Fig. 195.)

\section{Means of control}

Deep hoe-cutting while in early bloom. Mowing the plants leaves stubs, which hasten to produce new stalks and require attention a second time; but deep cutting kills.

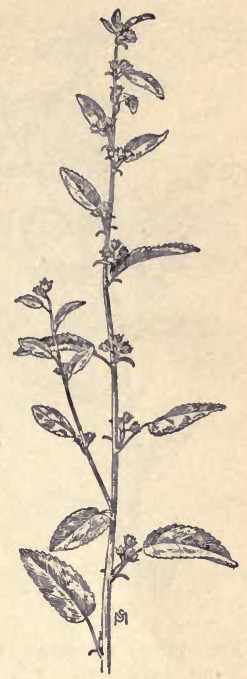

Frg. 195. - Prickly Sida (Sida spinosa). $\times \frac{1}{4}$.

\section{PAROQUET BUR \\ (Sida, acuta, Burm.) \\ (Sida stipulàta, Cav.)}

Native. Annual or perennial. Propagates by seed.

Time of bloom: June to November.

Seed-time: July to December.

Range: The Gulf States from Florida westward.

Habitat : Cultivated crops, pastures, roadsides, and waste places.

Sheep are grown in the South more for mutton than for fleece, but the value of the latter is annually damaged to a large amount by the hooked carpels of this weed, the distribution of which is almost entirely due to animal transportation. 


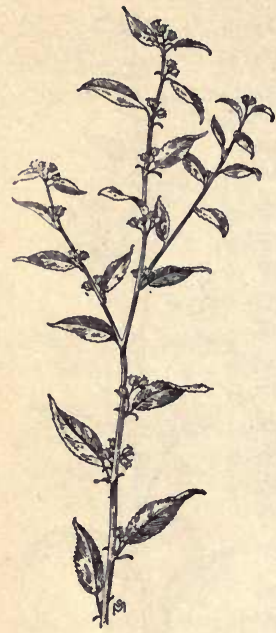

Fig. 196. - Paroquet Bur (Sida acuta). $\times \frac{1}{3}$. other places the weed should be frequently and closely cut throughout the growing season.

\section{COMMON MALLOW}

Malva rotundifolia, $\mathrm{L}$.

Other English names: Dwarf Mallow, Running Mallow, Round Dock, Cheeses, Shirt-button Plant, Maul.

Introduced. Biennial or perennial. Propagated by seeds.

Time of bloom: May to October.

Seed-time: June to November.

Range: Throughout North America except the extreme North. Habitat: Cultivated ground; waste places.

The deep, branching roots of this plant seem to spread nearly as far beneath the soil as its creeping stems spread above it; the latter are six inches to nearly two feet long, round, smooth, branched 
at the base. Leaves rounded or kidney-shaped, on long, slender petioles, heart-shaped at base, five- to nine-ribbed and -lobed, scallop-toothed, with edges often crisped. Flowers pale pink, veined with deeper pink, clustered or single in the axils; calyxlobes five, hairy, ovate, pointed, about half the length of the petals, which are notched at the outer edge; styles many, stigmatic down the inner side, longer than the stamens which are united in a column, the anthers at the summit, the pollen grains very large and white - like pearls when seen through a lens. Carpels as many as styles arranged in a circle, one-seeded; when

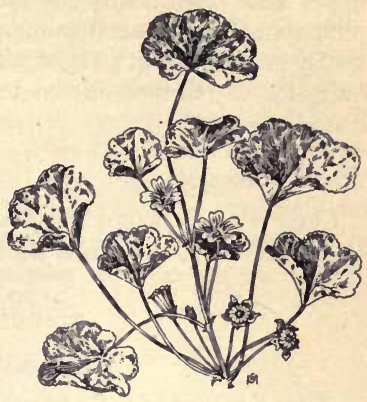

Fig. 197. - Common Mallow (Malva rotundifolia). $\times \frac{1}{2}$.

green they are mucilaginous and sweet - the "cheeses" that children like to eat. (Fig. 197.)

\section{Means of control}

Hand-pulling or deep hoe-cutting before the development of seed.

\section{MUSK MALLOW}

Malva moschdta, $\mathrm{L}$.

Introduced. Perennial. Propagates by seeds.

Time of bloom: June to August.

Seed-time: July to September.

Range: Eastern Canada, New England, and Middle States.

Habitat : Meadows, roadsides, and waste places.

A very handsome plant, an escape from gardens, objectionable in meadows and pastures, for cattle dislike its musky odor and hard, woody stalks and usually leave it to reproduce itself. Stems one to two feet high, slender, clothed with soft hair or sometimes smooth. Base-leaves rounded, with five to nine shallow, scalloptoothed lobes, slender-petioled; stem-leaves deeply five-parted, the 
segments again deeply cut or pinnatifid, very short-petioled. Flowers clustered at the ends of stem and branches and in the upper axils, often nearly two inches broad, pale rose-color or white, pink-veined, the central column of many styles and anthers nearly a half-inch in height; calyx with five short, triangular-ovate, very hairy lobes. Carpels fifteen to twenty, arranged in a circle, also densely hairy.

\section{Means of control}

Close cutting before the development of any seeds, repeating the treatment as the plants send up new shoots from the roots.

\section{BLADDER KETMIA}

\section{Hibiscus Trionum, L.}

Other English names: Flower-of-an-hour, Goodnight-at-noon, Shoofly Plant, Venice Mallow.

Introduced. Annual. Propagates by seeds.

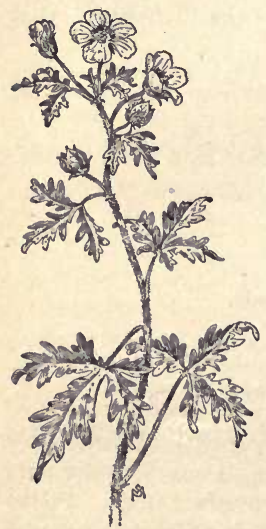

Frg. 198. - Bladder Ketmia (Hibiscus Trionum). $\times \frac{2}{4}$.
Time of bloom: July to September.

Seed-time: August to October.

Range: Nova Scotia to Minnesota, southward to Florida.

Habitat: Cultivated ground, roadsides, waste places.

At one time this weed was much helped in its wide distribution by seedsmen who recommended it as an ornamental plant. But for that purpose its beauty is too evanescent, and in grain field and garden it has proved itself extremely obnoxious because of the long vitality of its seeds; ground once fouled continues to produce plants for years, as cultivation brings the dormant seeds to surface light and warmth. (Fig. 198.)

Stems ten to twenty inches long, branched from the base, slender, rather weak and often reclining, covered with fine, bristly hairs. Leaves broadly heart- 
shaped in outline but deeply three-lobed, the middle lobe much the longest, the segments again cut and toothed. Flowers usually single in the upper axils, about two inches broad, pale sulfur-yellow with a purple center and fine purple veining, the five broad petals of ten tinged with purple on the outer edge; they open only in sunshine and are usually closed before noon; calyx a thin, hairy, five-angled, membranous, and much inflated grsen "bladder," also delicately purple-veined ; ovary fivecelled, the cells usually three-seeded, the styles stigmatic at the summit, the column of stamens long, truncate at the top and bearing anthers below for much of its length. Involucral bracts linear, very hairy. Seeds triangular kidney-shaped, brown, roughened with pimples of lighter shade.

\section{Means of control}

Prevent seed production by hand pulling or hoe-cutting while in first bloom. Ground where seeds have matured should be put to a well-tilled hoed erop.

\section{OKRA OR GUMBO}

Hibiscus esculéntus, L.

Introduced. Annual or perennial. Propagates by seeds.

Time of bloom: July to September.

Seed-time: September until cut off by frost.

Range: Southeastern and Gulf States. An escape from eultivation. Habitat: Fields, roadsides, and waste places.

Okra was brought from Africa in the old slave-trading days. It is cultivated in the South for its mucilaginous green pods, which are used for thickening soups, ketchups, and stews, or cooked whole as a table vegetable; also its ripe seeds are often roasted and used as a substitute for coffee. Although treated as an annual, the plant will live for years if not killed by frost, and therefore it is rather a bad weed when out of bounds.

Stem eighteen inches to three feet high, rather stout, with few branches. Leaves somewhat thick in texture, rounded in outline but five- to seven-lobed, the segments cut about halfway to the base, coarsely toothed, and with petioles about as long as the leaves. 
The whole plant is softly hairy. Flowers two inches or more broad, cream-yellow, with a purplish brown spot at the base of each of the five petals. Fully ripened pods are two to four inches long, nearly three-quarters of an inch thick at base, tapering to a point, and ten-ribbed. The ribs soon become strongly fibrous, and when the fruit is wanted for food, the pods must be picked when about two days old. Seeds dark brown, nearly globular, with a white eye on one side; they retain their vitality for about five years.

\section{Means of control}

Small patches may be hand-pulled or grubbed out. More extensive areas require to be put under cultivation, in order to destroy the perennial roots, and stir dormant seeds into germination.

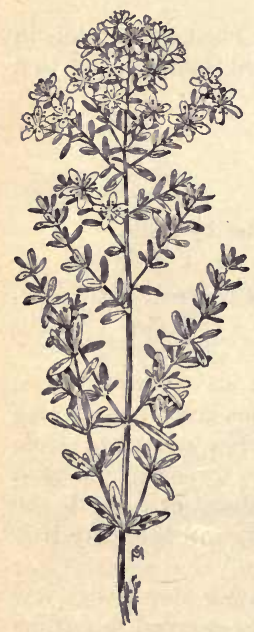

Fig. 199. - Common St. John's-wort (Hypericum perforatum). $\times \frac{2}{3}$.

\section{COMMON ST. JOHN'S-WORT}

\section{Hypericum perfordtum, L.}

Other English names: Herb of St. John, Speckled John.

Introduced. Perennial. Propagates by seeds and by runners from the base of the stem.

Time of bloom: June to September. Seed-time: July to October.

Range: Throughout British America except in the far North, and in all the states except the most southern.

Habitat: Fields, pastures, and waste places.

A most pernicious weed, difficult of suppression. When young its juices are so acrid and blistering that no grazing animal will eat the plant; and when mature or dried in hay, stock reject it because of its woody toughness. (Fig. 199.)

Stem ten to thirty inches tall, erect, slender, much branched, rather stiff, bearing along the sides two opposing ridges which make it two-edged. Leaves opposite, oblong to elliptic, one-half inch to 
an inch long, light green, sessile, .more or less black-dotted and specked all over with pellucid dots. Flowers in terminal cymose clusters, very showy; petals five, golden yellow, nearly a halfinch long, with black-dotted margins; stamens many, separated into three groups, their anthers black-dotted; styles three, divergent; calyx of five lance-shaped, acute sepals, specked with pellucid dots. Capsule ovoid, three-celled, filled with small, rounded, oblong seeds, their surface delicately pitted in rows. Too often an impurity among grass seeds.

\section{Means of control}

The plant is best destroyed by hand-pulling when the soil is sufficiently soft to slacken its hold on the long, woody roots. Or it may be grubbed out, care being taken to leave no stray runners. A meadow or a pasture too rankly infested to be so cleansed should be turned under and put to a well-tilled hoed crop.

\section{SHRUBBY ST. JOHN'S-WORT}

Hypericum prolificum, $\mathrm{L}$.

Native. Perennial. Propagates by seeds.

Time of bloom: July to September.

Seed-time: August to October.

Range: New Jersey to Southern Ontario and Minnesota, southward to Georgia and Arkansas.

Habitat: Dry soil ; sandy fields, rocky upland pastures, waste places.

A very beautiful and ornamental plant, provided it might be restricted to a corner of a flower garden. Stems one to four feet tall, strong and woody, branching near the base, the branches ascending, the branchlets with side-ridges making them two-edged. Leaves two to three inches in length, pellucid dotted, narrowly oblong, obtuse, tapering toward the base, the lower ones with short petioles, those near the top sessile ; in the axils are usually tufts of smaller leaves. Flowers bright yellow, each nearly an inch broad, in terminal and axillary clusters, very numerous; sepals unequal, shorter than the petals; stamens very numerous, 


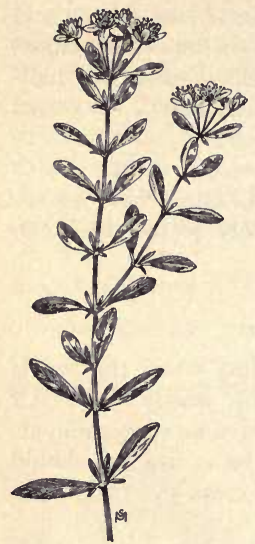

Frg. 200. - Shrubby St. John's-wort (Hypericum prolificum). $\times \frac{1}{4}$.

not separated into clusters; styles three. Capsule long ovoid or conic, three-celled, many-seeded. (Fig. 200.)

\section{Means of control}

The smaller plants may be hand-puiled when the ground is soft, but many of the plants require strenuous work with the grubbing hoe. The St. John's-worts are considered indicative of exhausted soil, and after their removal the ground should be put under cultivation and well fertilized.

\section{DWARF ST. JOHN'S-WORT}

Hyperìcum mùtilum, L.

Native. Annual or perennial. Propagates by seeds.

Time of bloom: July to September.

Seed-time: August to October.

Range: Nova Scotia to Manitoba, southward to Florida and Texas.

Habitat: Damp meadows, pastures, and waste places.

Stem six to eighteen inches long, rather weak and flaccid, decumbent, branching from the base, four-angled, often reddish. Leaves a quarter-inch to an inch long, narrowly ovate to oblong, obtuse, entire, partly clasping, five-nerved, minutely specked with the pellucid dots. Flowers in terminal cymose clusters, each about a quarter-inch broad, bright yellow or light orange, the pedicels subtended by awl-like bracts. Capsules pointed ovoid, about a sixth of an inch long, filled with seed of dust-like smallness. The plants often turn reddish in autumn and their presence is then noted where they had not been suspected.

\section{Means of control}

Cultivate and heavily fertilize the ground; the presence of this plant is considered by many farmers to be an indication that the soil lacks lime. Follow the cultivated crop with clover. 


\section{PASSION-FLOWER}

\section{Passiflòra incarnàta, L.}

Other English names: Passion-vine, May-pop.

Native. Perennial. Propagates by seeds.

Time of bloom: May to August.

Seed-time: July to October.

Range: Virginia to Missouri, southward to Florida and Texas.

Habitat: Dry soil ; troublesome in eultivated erops; waste places.

A handsome climbing vine, with curious and beautiful flowers and edible fruits. Stem smooth, or sometimes finely hairy at the growing tips and twigs, ten to thirty feet in length, the lower and older part becoming somewhat angled and ridged, climbing by means of long, coiling, axillary tendrils. Leaves alternate, three to five inches broad, usually smooth, heart-shaped at base and deeply three-lobed, the lobes pointed and sharply toothed, the slender petiole bearing two glands near the base of the blade. Flowers solitary, axillary, about two inches broad, showy, lifted on jointed pedicels longer than the leaf-stalks, and bearing three leaflike involucral bracts just below the flower; sepals five, united at base; five large white petals inserted on the throat of the calyx and crowned with triple rows of long fringes which are pale purple with a lighter band near the center; the one-celled

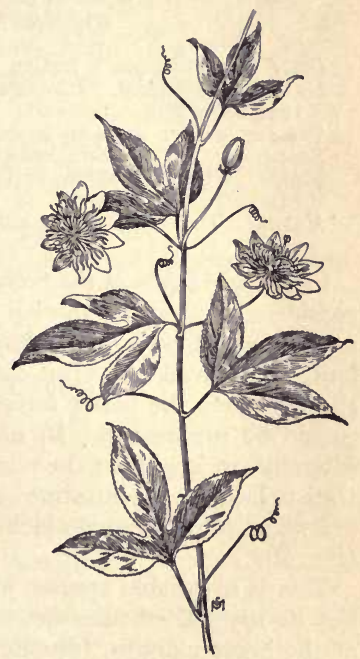

F1G. 201. - Passion-flower (Passiflora incarnata). $\times \frac{1}{2}$. ovary is lifted on a stipe, or foot-stalk, subtended by the five stamens and bears at its top three club-shaped stigmas. Fruit ovoid, about two inches long, smooth, yellow, pulpy, the 
many seeds borne on its inner wall surface in three groups. (Fig. 201.)

\section{Means of control}

Very thorough tillage of cultivated crops, destroying as much as possible of the perennial roots; alternate such cultivation with heavy seeding to cowpeas or clover.

\section{PRICKLY PEAR}

Opuntia Rafinésquii, Engelm.

(Opúntia humifùsa, Raf.)

Other English names: Indian Fig, Old Man's Hands.

Native. Perennial. Propagates by seeds and by the rooting of broken joints.

Time of bloom: June to August.

Seed-time: July to September.

Range: Ohio, Michigan, and Minnesota, southward to Kentucky, Missouri, and Texas.

Habitat: Dry soil; rocky hills and pastures.

In the arid lands of the Southwest, Prickly Pear is hardly to be considered a weed, for there it is singed of its spines and furnishes an emergency food for stock during the season of drought when other forage is unavailable. But cattle prefer grasses to cactus and in ground where the better forage can be made to grow the cactus should be suppressed. If, under stress of hunger, the plant is eaten by stock without the removal of the spines, they often penetrate or lacerate the intestines, or sometimes form interlaced prickly masses or phytobezoars which close the passage and cause death. (Fig. 202.)

This is a variable species, but is usually prostrate and spreading, its roots often tuberous, and all joints are capable of rooting at the lower margins, forming new plants. Joints usually about two to six inches long and two to four inches wide, sometimes twice as large, deep green, thick, fleshy, obovate to rounded, bearing when young a few awl-shaped leaves that soon fall away; in the axil of each leaf is a small rounded elevation, usually somewhat woolly, bearing a cluster of reddish brown bristles and a 
few spines or a single strong one, sometimes none. Flowers yellow, sometimes with a reddish center, nearly three inches broad, the many petals slightly united at base, the stamens very numerous, the style with two- to seven-parted stigma; ovary inferior or below the flower and one-celled. Fruit a thick club-shape, nearly two inches long, not spiny, with a fleshy purplish pulp, edible, with an insipid or slightly acid taste.

\section{Means of control}

Prickly Pear may be killed by burning, as stockmen of the arid lands discovered when removing the spines for the benefit of their cattle, especially if the work is done with a gasoline torch applied to the growing plants. On land capable of supporting better growths cultivation and liberal fertilization of the ground should be the method used for suppression of the prickly

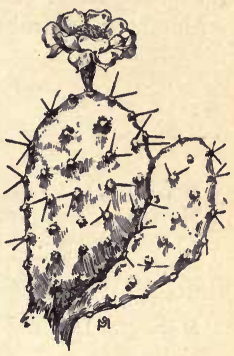

Fig. 202. - Prickly Pear (Opuntia Raphinesquii). $\times \frac{1}{6}$. pest, reseeding heavily with some of the most drought-resistant grasses and clovers.

\section{BRITTLE PRICKLY PEAR}

Opuntia frágilis, Haw.

Native. Perennial. Propagates by seeds and by the rooting of broken joints.

Time of bloom: June to August.

Seed-time: July to September.

Range: Minnesota to British Columbia, southward to Utah, Colorado, and Kansas.

Habitat: Dry soil; prairies, rocky foothills.

Plants rather small, partly prostrate, the joints very numerous and breaking away so readily that they often attach themselves to animals by their many spines and are thus transported to new localities. Joints small, only one or two inches long, roundly ovate or club-like, slightly flattened, the fruit-bearing ones rather more compressed. Leaves small, red, awl-like, soon falling away; the tiny protuberances in the axils white-woolly, bearing a cluster of 
short, grayish-white bristles, becoming stiff and straw-colored as the plants grow old, with usually about four stouter, yellowishbrown spines, a half-inch to an inch long. Flowers pale yellow, nearly two inches broad. Fruit ovate, inedible, prickly, becoming dry at maturity. Seed rather large and thick, with a corky margin.

Means of control the same as for the preceding species.

\section{GLOBE CACTUS}

\section{Mamillària vivipara, Haw.}

Other English names: Ball Cactus, Purple Cactus.

Native. Perennial. Propagates by seeds.

Time of bloom: June to July.

Seed-time: Early in the following summer.

Range: Manitoba to Alberta, southward to Kansas, Colorado, and Utah.

Habitat: Dry soil ; prairies, rocky hillsides, pastures.

When these small spiny plants occur in pasture land, they are most unpleasant weeds, occupying the place of forage too scanty at best. This species usually grows in tufts, forming

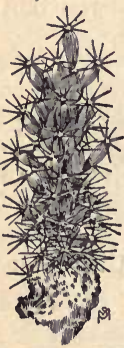

Fig. 203. Ball or Globe Cactus ( $M a$ millaria vivipara). $\times \frac{1}{4}$. large flat masses. Stems two to four inches in diameter, usually depressed globose, covered with fleshy, rather loose, slightly grooved, nearly cylindrical green tubercles, woolly at base, each bearing a central bundle of four to eight reddish brown spines, a half-inch or more long, erect or somewhat spreading, surrounded by fifteen to twenty smaller, radiating, grayish-white spines in a single row. Flowers solitary, growing from small cavities at the base of the tubercles, funnel-shaped, nearly two inches long and about as wide when fully open (which is only for a few hours in bright sunlight) with fringed sepals and narrow, lance-shaped petals, deep purple; stamens very numerous and style divided into threadlike, stigmatic branches; ovary inferior, one-celled. Fruit a little more than a half-inch long, ovoid, pale green, juicy; seed about a twelfth of an inch long, obovoid, slightly curved, light brown, the surface finely pitted.

(Fig. 203.) 


\section{Means of control}

Small areas may be removed by deep cutting from the roots with a stout hoe or spud, before the maturing of the fruit. Turning the sod with a plow at once destroys the plants.

\section{MISSOURI CACTUS}

Mamillària missouriénsis, Sweet

Other English names: Nipple Cactus, Bird's-nest Cactus.

Native. Perennial. Propagates by seeds.

Time of bloom: May to June.

Seed-time: The following spring.

Range: South Dakota to Kansas and Texas.

Habitat: Dry soil; prairies, rocky foothills.

Like the preceding species, this plant is a nuisance in pastures. It is small, the stems often but one or two inches high, simple or sometimes clustered in patches, the tubercles on its surface less than a half-inch long, slightly grooved, rather loose, arranged in spiral rows. Spines ten to twenty, nearly a half-inch long, gray and bristly, radiating about a central, stouter, hairy spine, or the latter may be lacking. Flowers reddish yellow, nearly an inch long and of about the same width when fully expanded in bright sunlight, the petals acute and bristle-tipped. Fruit red, nearly globular, about the size of a pea. Seed black and finely pitted.

Means of control the same as for Globe Cactus.

\section{CLAMMY CUPHEA}

Cùphea petiolàta, Koehne

(Parsónia petiolàta, Rusby)

Other English names: Clammy Loosestrife, Blue Waxweed, Tarweed, Red-stem, Sticky-stem.

Native. Annual. Propagates by seeds.

Time of bloom: July to October.

Seed-time: August to November.

Range: Rhode Island to Ontario, Illinois, and Kansas, southward to Georgia and Louisiana. Most common in the South.

Habitat: Dry fields, meadows, pastures, roadsides, and waste land.

An unpleasant, viscidly hairy, and homely weed, much too common in some localities. Cattle will not eat it and its deep-boring 
roots absorb a large amount of the food and moisture needed by better plants.

Stem six to eighteen inches in height, round, red, branching, thickly set with sticky hairs to which small dead or dying insects are often seen adhering. Leaves opposite, long ovate, rough, entire, viscid, especially on midribs and veins, and tapering abruptly to short sticky-hairy petioles. Flowers on very short peduncles, not rising directly from the axils but from the side of the stem between the opposite leaf-stalks; they are less than a half-inch broad, bluish purple, with six very unequal petals, a tubular sixtoothed, twelve-ribbed calyx, swollen at base on the upper side, and often ruddy-colored like the stem; stamens eleven or sometimes twelve; style slender with two-lobed stigma; ovary unequally two-celled, with a curved gland at its base. The capsule bursts lengthwise and the seeds protrude from its side while still immature and attached to one side of the placenta; they ripen while exposed to the open air and then drop off into the soil, where they are said to retain their vitality for several years.

\section{Means of control}

Prevent seed development by closely cutting or uprooting the plants while in their first bloom.

\section{SEED-BOX}

Ludvigia alternifolia, $\mathrm{L}$.

Other English name: Rattle-box.

Native. Perennial. Propagates by seeds.

Time of bloom: June to September.

Seed-time: July to October.

Range: New Hampshire to Ontario and Michigan, southward to Florida, Kansas, and Texas.

Habitat: Swamps, low meadows, banks of streams, and ditches.

Roots fascicled, spindle-shaped, rather thick and fleshy. Stems two to three feet tall, erect, round, smooth, with a strong bark and many branches. Leaves alternate, entire, with marginal veins, smooth or nearly so, pointed at both ends, two to four inches in length, sessile or with very short petioles. Flowers solitary in 
the axils on very short peduncles; they are nearly an inch broad, with four light yellow, rounded petals, between which show the four-pointed, spreading, leaf-like lobes of the calyx, about as long. When plucked, the petals almost always fall away; stamens four, inserted with the petals; ovary four-celled. Capsules smooth, square, with winged angles and rounded base, about a quarter-inch high; the seeds become loose and rattle about in them when the plant is shaken. These seed-vessels readily float on water and are often blown far on crusted snow. (Fig. 204.)

\section{Means of control}

Drainage of the ground, followed by a cultivated crop, very thoroughly tilled. Or starvation of the perennial roots by close and frequent cutting throughout the growing season.

\section{WATER PURSLANE}

Ludvigia paluistris, Ell.

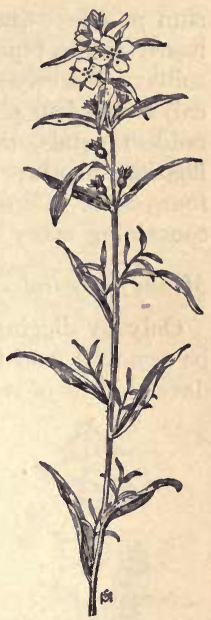

Fra. 204. - Seedbox (Ludvigia alternifolia). $\times \frac{1}{\text {. }}$.

\section{(Isnárdia palústris, L.)}

Other English names: Ditch Purslane, Marsh Purslane, False Loosestrife.

Introduced. Perennial. Propagates by seeds and by rooting at the joints.

Time of bloom: June to October.

Seed-time: July to November.

Range: Nova Scotia to Manitoba and Oregon, southward to Florida, Louisiana, California, and Mexico.

Habitat: Swamps, wet meadows; clogs ditehes.

A small, prostrate, often floating weed, whose habit of putting forth fibrous roots at its joints makes it frequently a pest to the muck farmer.

Stems smooth, succulent, much branched at the base, often ruddy-colored, four to fifteen inches long. Leaves opposite, ovate or spatulate, a half-inch to an inch long, narrowing to a short, 
slim petiole; when growing in mucky ground, they are smaller, nearly sessile, blunt-pointed, and reddish. Flowers axillary, sessile, solitary, scarcely a tenth of an inch broad; they have a top-shaped calyx with four pointed triangular lobes, and sometimes four small reddish petals, though these are often wanting, particularly in floating plants; stamens four and stigma four-parted; ovary four-celled. Capsule four-sided and four-celled, flat at the top, containing many very fine, wrinkled, brown seeds.

\section{Means of control}

Only by digging or hand-pulling can this obnoxious little plant be removed, and the work needs to be done early, before the first development of seed.

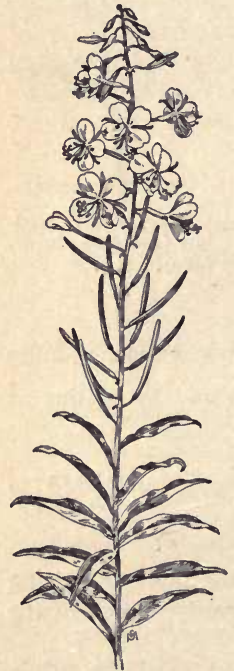

Fig. 205. - Great Willow-herb (Epilobium angustifolium), $\times \frac{\frac{1}{4}}{4}$.

\section{GREAT WILLOW-HERB}

Epildbium angustifòlium, L. (Chamœnèrion angustifòlium, Scop.)

Other English names: Fireweed, Spiked Willow-herb.

Native. Perennial. Propagates by seeds.

Time of bloom: July to August.

Seed-time: August to September.

Range: Labrador to Alaska, southward to North Carolina and Kansas, in the Rocky Mountains to Arizona, and on the Pacific Coast to California.

Habitat: Low grounds and thickets; land that has been newly cleared or burnt over.

Stem two to six or more feet in height, somewhat woody, rather stout, erect, simple or branched from the base, usually reddish, smooth or sometimes finely hairy above. Leaves alternate, narrow lance-shaped, thin, entire or minutely toothed, pale beneath, with very short petioles and pinnate veins united in marginal loops. Flowers in large terminal racemes, purple, magenta, pink, or sometimes white, very showy; petals four, rounded and entire, with twice as many stamens and an elongated pink style with four- 
parted white stigma; ovary below the calyx-tube and four-celled. The plant is good bee pasture, generous of both pollen and nectar. Capsules two inches or more long, obscurely four-sided, reddish brown, velvety-hairy when young, many-seeded, opening at the summit. Seeds small and brown, tufted with white hair finer than thistle-down, by which they are widely wind-sown. (Fig. 205.)

\section{Means of control}

Close cutting or hand-pulling before the development of seeds; destruction of the perennial roots by cultivation of the ground.

\section{COMMON EVENING PRIMROSE}

Enothèra biénnis, L.

(Ónagra biénnis, Scop.)

Other English names: Field Primrose, Tree Primrose, Fever Plant, Night Willow-herb.

Native. Biennial. Propagates by seeds.

Time of bloom: June to September.

Seed-time: August to November.

Range: Labrador to Florida, westward to the Rocky Mountains.

Habitat: Dry soil; fields, meadows, roadsides, waste places.

The long, stout taproot of this plant is used in Germany as a table vegetable, like parsnips, and its young crown leaves are blanched and used for salad. It is also medicinally valuable. Collectors receive about five cents a pound for the plants pulled entire in mid-flowering time and dried in the shade.

Stem two to six or more feet tall, rather stout, usually simple, more or less hairy. Root leaves lance-shaped, three to six inches long, the surface dark green, rough-hairy, slightly toothed, tapering to a petiole; stem leaves much smaller, alternate and sessile. Flowers in terminal leafy-bracted spikes, sessile, the calyx-tube sometimes two inches long, its four lobes reflexed and falling away; stamens eight, inserted on the top of the calyx-tube; style with deeply four-cleft stigma; ovary below the long calyxtube, itself much elongated and four-celled; the four broad, sulfuryellow petals are rolled in the bud, and at the falling of twilight their unfolding is so swiftly accomplished that one may "see her 


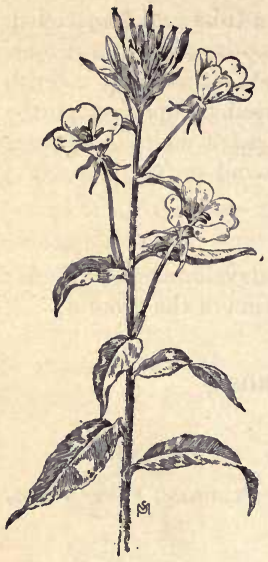

Frg. 206. - Evening Primrose (Enothera biennis). $\times \frac{1}{2}$. doff her soft green hood and blossom with a silken burst of sound." Sweet odors pour from the pale yellow cups and attract the night-flying moths, which fertilize the flowers, and in the morning sunlight the blossoms droop and wither. Capsules an inch or more long, four-celled, slightly hairy, splitting at the top into a slender, vase-like shape; they sway on the tall stalks all winter and birds destroy many of the seeds in their foraging. (Fig. 206.)

\section{Means of control}

Cutting crown leaves from the roots with spud or hoe in the first season; close cutting of flowering stalks while in early bloom; plants with capsules formed should be cut and burned, as they ripen on the stalks.

\section{SUNDROPS}

Enothèra fruticòsa, L. (Kneiffia fruticòsa, Raimann)

Other English names: Day Primrose, Perennial Primrose.

Native. Perennial. Propagated by seeds.

Time of bloom: June to August.

Seed-time: August to October.

Range: Nova Scotia to Minnesota, southward to Georgia and 'Louisiana.

Habitat: Dry soil ; fields, meadows, and waste places.

Stems rather slender, one to three feet tall, usually branched, finely hairy or sometimes smooth. Leaves alternate, oblong to lance-shaped, with few and shallow teeth, somewhat hairy, the lower ones with petioles, those on the stem sessile, the upper ones nearly linear. Flowers in terminal, leafy-bracted spikes, the blossoms sometimes nearly two inches broad, the petals notched at the 
outer edge, lustrous golden yellow, open in the daytime; tube of the calyx much longer than the ovary, its lobes narrowly lanceshaped and spreading. Capsules about a half-inch long, fourangled, and having four small wings projecting from the top, the base often narrowed abruptly to a short foot-stalk.

\section{Means of control}

Starvation of the perennial roots by frequent, successive, close cuttings. In cultivated ground the plants are destroyed by the required tillage.

\section{BIENNIAL GAURA}

\section{Gaúra biénnis, L.}

Native. Biennial. Propagates by seeds. Time of bloom: July to September. Seed-time: August to October.

Range: Quebec and Ontario to Minnesota, southward to Georgia, Mississippi, Arkansas, and Nebraska.

Habitat: Fields, meadows, pastures, roadsides, and waste lands.

The winter rosettes and deep-boring taproot of this plant resemble those of the Evening Primrose, to which it is a near relative. Flowering-stalks, which appear in the second year, are two to five feet tall, erect, much branched, and covered with finely downy hairs, hard and woody when mature, and very troublesome to harvesting machinery. Leaves alternate, lance-shaped, pointed at both ends, sparsely toothed or wavyedged, smooth above but finely hairy beneath, sessile, two to four inches long. Flowers sessile on slender terminal spikes, the succession of bloom beginning at the base of the spike with hairy buds above; each blossom is nearly a half-inch across, with four cream-white petals, turning

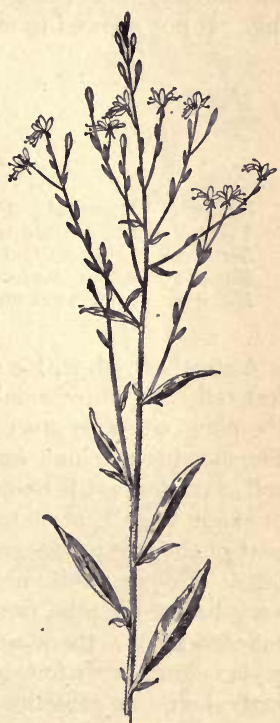

Fra. 207. - Biennial Gaura (Gaura biennis), $\times\{$. 
pink as they wither, four long-pointed, reflexed calyx-lobes, usually eight stamens, drooping like a tassel, and a long, declining style with four-parted stigma; ovary at the base of the long calyx-tube, one-celled. Fruits nut-like, four-ribbed, pointed at both ends, finely downy, and nearly a half-inch long. (Fig. 207.)

\section{Means of control}

Leaf-tufts of autumn plants should be spudded off or destroyed by deep hoe-cutting. Plants that have survived to the second season should have flowering-stalks closely cut in their first bloom, the shorn surfaces being treated with salt in order to prevent stooling. If not allowed to mature seed the weed is readily suppressed.

\section{WOOLLY GAURA}

Gaúra villòsa, Torr.

Native. Perennial. Propagates by seeds.

Time of bloom: June to September.

Seed-time: July to October.

Range: Prairies, Kansas to Arkansas and Texas.

Habitat: Cultivated crops, grain fields, meadows, pastures.

A sturdy weed, with a stout, woody, branching stem, one to three feet tall, very objectionable in pasture or meadow, for cattle reject the plant either as green forage or as hay and it dulls and breaks the mowing-machine knives. The whole plant is covered with soft, fuzzy, grayish hairs. Leaves alternate and sessile, but vary in shape from lanceolate to sometimes nearly linear at the upper part of the plant, to wavy-toothed or even pinnatifid ones near the base. Flowers white or pinkish, nearly an inch across, the calyx very hairy, its tube funnel-shaped above the ovary, with linear, reflexed lobes; the stamens are shorter than the petals, but the style is long, with four-parted stigma. The nut-like fruit is sparingly hairy or sometimes smooth, four-ribbed, tapering to both base and apex but narrowing most abruptly to the short, slender pedicel. 
Means of control

Prevent reproduction and spreading by cutting the flowering stalks before any fruit has matured. In order to destroy the perennial roots it is necessary to put the land under cultivation.

\section{SANICLE OR BLACK SNAKEROOT}

Sanicula canadénsis, L.

Native. Perennial. Propagates by seeds.

Time of bloom: June to August.

Seed-time: August to October.

Range: Massachusetts to Nebraska, southward to Florida and Texas.

Habitat: Shrubby upland pastures, thickets, open woods.

Sanicle is a shade lover and would hardly be included in this weed list were it not that its hooked and prickly carpels are so detrimental to the fleeces of sheep. The plant has bitter juices which protect it from their nibbling jaws and it is left to reproduce itself unharmed.

Stem rather stout, eighteen inches to three feet tall, erect, round, grooved, smooth, with forking, leafy branches. Leaves palmately compound, three- to five-parted, the segments narrowly obovate to lance-shaped, smooth, sharply and irregularly toothed, often cutlobed; those at the base have long petioles but the stem leaves become smaller and nearly sessile as they near the top; involucral leaves small and lance-shaped. Flowers greenish white, with perfect and staminate flowers intermixed in small, compact, globular umbels, not much more than a halfinch broad. In this species the styles

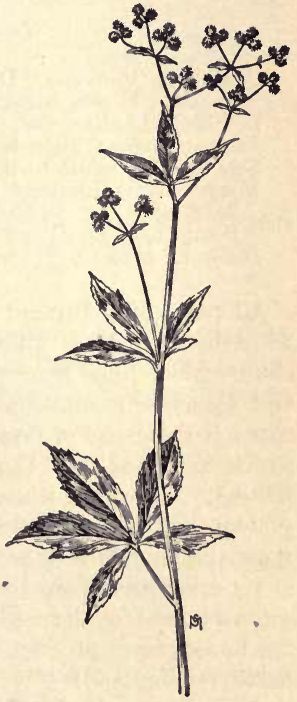

Fig. 208. - Sanicle (Sanicula canadensis). $\times \frac{1}{3}$. 
are shorter than the bristles on the carpels. These are in pairs, forming tiny, ovoid burs, bristling with prickly hooks, there being several of the burs in a cluster, ready at a touch from woolen garments or a sheep's fleece to "catch on for a ride." (Fig. 208.)

$S$. marilandica, differing in that the styles are much longer than the bristles and recurved, is equally common and has a more extensive range from Newfoundland to Georgia and westward to the Rocky Mountains.

\section{Means of control}

Prevent the formation of seed by close cutting or pulling when in first bloom.

\section{POISON HEMLOCK}

\section{Conium maculdtum, $\mathbf{L}$.}

Other English names: Deadly Hemlock, Spotted Cowbane, Spotted Parsley, Poison Stinkweed, Wode Whistle, Herb of St. Bennet. Introduced. Biennial. Propagates by seeds.

Time of bloom: June to July.

Seed-time: August to September.

Range: Now England and Middle Atlantic States, westward to Michigan and Indiana, southward to Virginia. Also in California and Louisiana.

Habitat: Moist soil ; waste places.

All parts of this plant are exceedingly poisonous. Every year domestic animals are killed by eating its young leaves in the spring, children have died from mistaking its seeds for fennel or caraway, and the close resemblance of its leaves to those of parsley sometimes is the cause of fatal poisoning. This is said to be the herb which furnished the "Cup of death" given to Socrates in Ancient Athens. The plant is used in medicine for diseases of the nervous system, and to supply the demands of the drug trade about thirty thousand pounds of its seeds and fifteen to twenty thousand pounds of its dried leaves are annually imported, at a cost of about three cents a pound for the seeds and four cents for the leaves. Probably the home-grown product would be as readily purchased if properly cured. (Fig. 209.)

According to the fertility of the soil, the height of the plant varies from two to five feet. Stem smooth, erect, much branched, hollow, 
often purple-spotted. Leaves pinnate and thrice divided, the segments finely cut and toothed. Flower clusters terminal, in large, open, compound umbels, composed of many small umbellets of tiny white flowers, five-petaled, the large umbel and its parts subtended by small, narrow bracts. Fruit consisting of two dry, seedlike carpels, cohering by their inner face, grayish brown when ripe, about one-eighth of an inch long, ovoid, flattened at the side, prominently ribbed, and having on the flattened surface a deep, narrow groove. The whole plant has a very disagreeable "mousy" odor, especially when bruised.

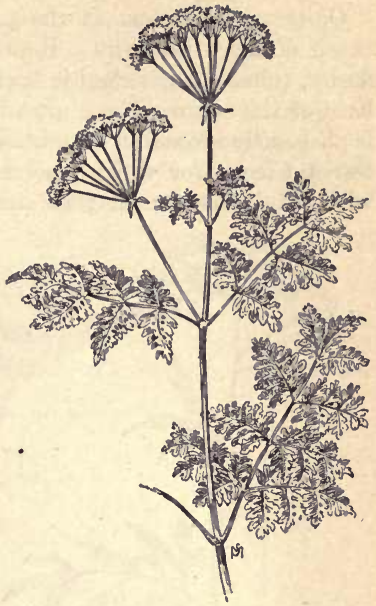

Frg. 209. - Poison Hemlock (Conium maculatum). $\times \frac{3}{4}$.

\section{Means of control}

Grub it out, "root and branch," and destroy it. So dangerous a neighbor should never be allowed on any farm land, and in particular the roads of the countryside should be free from its presence.

\section{WATER HEMLOCK}

Cicùta maculata, L.

Other English names: Spotted Cowbane, Beaver Poison, Musquash Root, Muskrat Weed, Death-of-man, Children's Bane.

Native. Perennial. Propagates by seeds.

Time of bloom: June to August.

Seed-time: August to October.

Range: Newfoundland to Manitoba, southward to Florida and New Mexico.

Habitat: Low grounds; wet meadows, marshy places, sides of ditches, and ponds. 
Quite as poisonous as the preceding plant and probably the cause of more fatalities. Roots two to four inches long, thick, fleshy, tuberous, bunched in a cluster (fasciculated) at the swollen base of the stem. These are especially dangerous, for their taste is pleasantly aromatic, somewhat like that of its harmless relative, Sweet Cicely, for which they are sometimes mistaken, generally with fatal results; or they may be mistaken for artichokes or

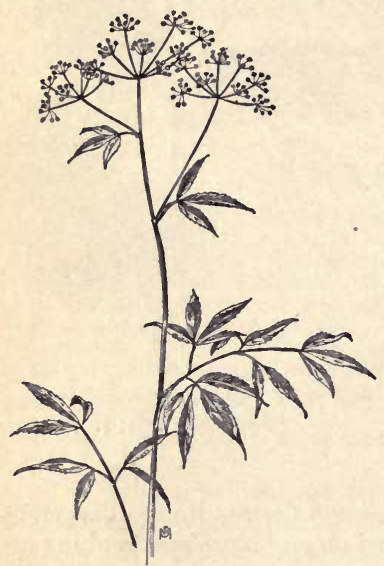

FIG. 210. - Water Hemlock (Cicuta maculata). $\times \frac{1}{4}$. parsnips in the early spring. At this season the roots are frequently forced out of the earth by washing or freezing, or cattle and sheep, biting at the young shoots, pull them easily from the wet soil. One of the fascicled roots will kill a cow, and a much smaller portion, when eaten by a person, is sufficient to bring a swift and distressful death, unless medical aid is immediately at hand. (Fig. 210.)

Stems stout, smooth, hollow, two to six feet tall, streaked with brown and purple, the color more pronounced at the junction of stem and branches. Leaves pinnately twice or thrice divided, the segments lanceshaped, thin, sharply and rather coarsely toothed, the veins terminating in the notches instead of at the points. Umbels open and spreading, without involucres, the pedicels in the umbellets unequal in length, giving the clusters an uneven appearance; like all the Parsley Family, the flowers are very small, five-petaled with five stamens inserted on the disk that crowns the two-celled and two-seeded ovary. In this species the petals are white. Carpels about an eighth of an inch long, ovoid, smooth, each one striped on the convex side with five corky ribs and four brown oil-tubes and on the flat side with two wide corky stripes and two oil-tubes. 
Means of control

Grub out and destroy the plants, allowing no seeds to ripen and fall into the soil to perpetuate so deadly a menace to the safety of the children and the domestic animals of the neighborhood. Or the plant is easily pulled, roots and all, in the spring when the ground is soft and the young shoots first appear.

\section{FOOL'S PARSLEY}

\section{Ëthùsa Cynd̀pium, L.}

Other English names: False Parsley, Dog's Parsley, Dog Poison, Fool's Cicely.

Introduced. Annual. Propagates by seods.

Time of bloom: June to August.

Seed-time: August to October.

Range: Nova Seotia to Virginia, westward to the Mississippi River.

Habitat: Fields and waste places.

Fool's Parsley is acridly poisonous; its Greek name means " to burn," which indicates the sort of agony that its victims feel.

Root spindle-shaped like a radish, three to six inches long. Stem one to two feet tall, slender, smooth, branching by forking. Leaves very dark green, smooth, shining, twice or thrice ternately divided, the segments again finely cleft; they look very like those of the true Parsley, but, when crushed, have a disagreeable, fetid odor; the upper ones are nearly sessile, the short petioles much dilated at the base. Flowers white, unpleasantly scented, the large umbel without an involucre, but the umbellets having involucels of long, narrow, downward-turned bracts. The flowers of true parsley are yellow.

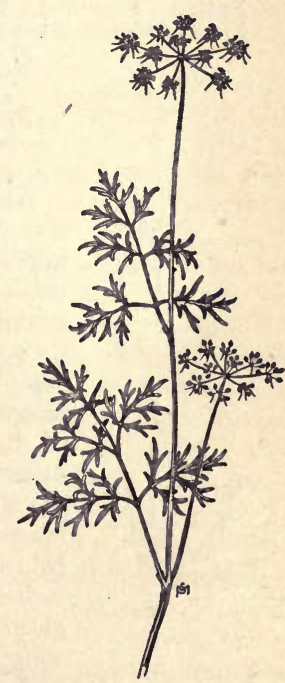

FIG. 211. - Fool's Parsley (Ethusa Cynapium). $\times \mathfrak{l}$. 
United carpels ovoid, nearly as broad as long, each of the two having five sharply keeled ridges. These seeds may remain dormant in the soil for several years and should never be permitted to sow themselves. (Fig. 211.)

\section{Means of control}

If the infestation is new, hand-pull as soon as discovered and destroy it. Being annual, it is necessary only to prevent seed development in order to suppress the weed.

\section{MEADOW PARSNIP}

Tháspium aúreum, Nutt.

Native. Perennial. Propagates by seeds.

Time of bloom: June to July.

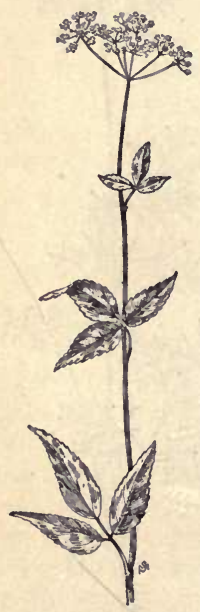

Fra. 212.-Meadow Parsnip (Thaspium aureum). $\times \frac{1}{2}$.
Seed-time: August to September.

Range: New York to the Carolinas, westward to Arkansas and Nebraska.

Habitat: Moist meadows, waste places, open woodlands.

When it first appears in the spring, the young shoots of this plant sometimes give an unpleasant flavor to dairy products; later the cattle reject it, though it seems to be not so noxious as other members of its tribe.

Stems smooth, one to two feet high, with few branches. Base leaves heart-shaped, smooth, sharply toothed, long-petioled; those of the stem three-parted - sometimes twice ternate - the lateral leaflets sessile or nearly so, the terminal one stalked, long ovate to lance-shaped, finely toothed. Flowers deep golden yellow, the compound umbel about two inches broad. Carpels small, ovoid or nearly globose, smooth, the ribs standing out like wings. (Fig. 212.)

Ranging nearly with this plant is a close relative, the Hairy-Jointed Meadow Parsnip 
(Tháspium barbinòde), also yellow-flowered, but larger, its ternately compound leaves broader and more coarsely toothed, and having tiny tufts of fine hair at each joint.

\section{Means of control}

Frequent close cutting before seed development, using dry salt in order to retard new growth.

\section{WILD PARSNIP}

Pastind̀ca satìva, L.

Other English names: Field Parsnip, Madnep, Tank. Introduced. Biennial. Propagates by seeds.

Time of bloom: June to August.

Seed-time: August to October.

Range: All parts of the United States and Canada.

Habitat: Roadsides and waste places.

"Pastus" means food, and, as its name indicates, this is the garden Parsnip, long ago "gone to the bad," for its thick, white, fleshy root is no longer a food but a poison, even after it has been cooked - a fact which is every year demonstrated by several deaths.

Crown leaves of the first year large, often eighteen inches in length, with long, flattened, and grooved petioles: pinnate, the segments thin, sessile, ovate, coarsely and sharply toothed, often cut-lobed. Fruiting stem two to four feet tall, hollow, grooved, smooth, its leaves much smaller and clasping. Umbel compound, without involucre or involucels, the flowers very many, small, and yellow. Carpels nearly one fourth of an inch long, broadly oval, much flattened, surrounded by a thin, corky ridge which helps them to float on water or to be carried by the wind. This weed, like the Wild Carrot, serves as host to the fungus which is so injurious to celery, and will infect that plant when it grows near it.

Means of control

Hand-pulling when the ground is soft in spring. Spudding or hoe-cutting the root leaves from their crowns, an operation best 
performed in late autumn or early spring. Plants that survive to send up flowering stalks should be cut while in bloom.

\section{COW PARSNIP}

\section{Heraclèum lanàtum, Michx.}

Other English names: Woolly Parsnip, Masterwort.

Native. Perennial. Propagates by seeds.

Time of bloom: June to July.

Seed-time: August to September.

Range: Labrador to Alaska, southward to North Carolina, Missouri, Utah, and California.

Habitat: Moist ground; waste places, sides of ponds, ditches, and streams.

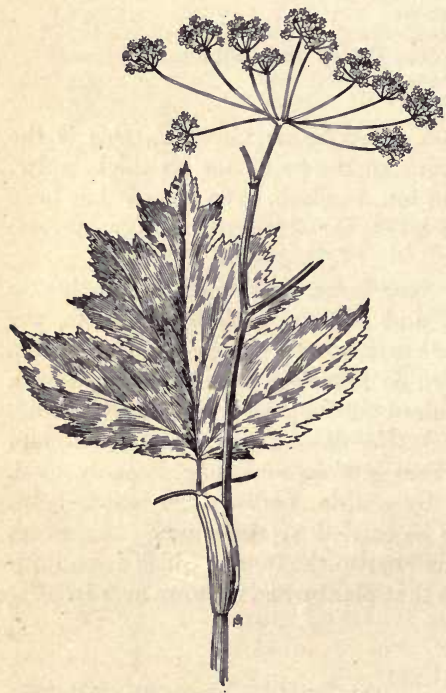

Fra. 213. - Cow Parsnip (Heracleum lanatum). $\times \frac{1}{2}$.
One of the largest of umbellifers, well named for Hercules, the giant. The huge, fleshy root sends up a stalk four to eight feet tall, sometimes two inches thick at base, deeply ridged and grooved, and wrapped in matted white hair. Leaves large, ternately compound, the segments broadly ovate, sharply toothed, and cutlobed, stalked, somewhat thin for their size, densely covered on the under side with a network of white, woolly hair ; petiolesstout, much inflated, and clasping at base. The whole plant has a disagreeable odor, especially when bruised, and the juice is extremely acrid; that of the root, when applied to the skin, will quickly draw 
blisters. Flowers white, occasionally purplish, the flattened compound umbel sometimes a foot broad ; individual flowers often more than a quarter-inch broad, particularly the enlarged outer ones, with the five petals notched at the outer edge; involucre deciduous. Carpels obovate, nearly a half-inch long, flattened, with winged margin and notched apex, the oil-tubes extending only part way down the sides. The weed is dangerous to cattle, when growing about their drinking places, at the time of starting shoots in spring ; later they avoid it. (Fig. 213.)

\section{Means of control}

The plant is persistent because of its large root, which needs to be grubbed out or deeply cut and treated with dry salt or kerosene.

\section{WILD CARROT}

\section{Daúcus Caròta, L.}

Other English names: Queen Anne's Lace, Bird's Nest Weed, Devil's Plague.

Introduced. Biennial. Propagates by seeds.

Time of bloom: June to September.

Seed-time: August to December.

Range: Throughout North America except the far North.

Habitat: All soils; meadows, pastures, roadsides, and waste places.

This plant is said to be the progenitor of the cultivated carrot, but its long, tapering root has none of the succulent sweetness which careful selection and cultivation has given to its descendants; on the contrary, it is filled with woody fibers, acrid to taste and said to be poisonous. Only a crown of green leaves is produced the first season; these are twice or thrice pinnate, the segments lance-shaped and toothed, giving the plant a fine, feathery appearance; petioles long, slender, swollen at base, grooved on the upper side; the leaves are rough-hairy, have an unpleasant odor when bruised, and their acrid juices protect them from grazing animals. Flower-stalks appear the second year, one to three feet tall, erect, slender, branching, bristly with stiff hairs, bearing few, sessile, and clasping leaves; flowers clustered, in large, flat, compound umbels, white, except that there is usually one in the center 
of each umbel which is dark purple; rays of the umbel crowded, the inner ones shorter than the outer rows, all subtended by a whorl

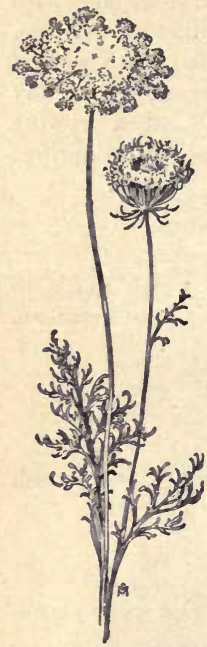

of green, finely cut, involucral bracts. As the fruits mature the outer rows of pedicels bend inward, making the umbel concave and forming the "bird's nest." Carpels thickly set with weak spines along the secondary ribs, forming a small, oblong, gray-brown bur which is light in weight and may be carried far by the wind or drifted with snow; these seeds have long vitality and one seeding may pester the soil for several years. The plant is frequently infested by the leaf-spot fungus, Cercospora apii, which is very injurious to Celery. (Fig. 214.)

\section{Means of control}

Hoe-cutting or spudding the leaf-crowns from the roots during the first season, and closely cutting, or, better, hand-pulling, the flowering stalks of the second year. In grain fields the latter method is the only way to fight the weed effectively, for it is resistant to sprays that would not also destroy the accompanying crop.

Frg. 214. - Wild In cultivated ground the plant gives little Carrot (Daucus Carota). $\times \frac{1}{4}$.

trouble, for there it may be uprooted with hoe or cultivator in its first season - a process which at once destroys it.

\section{NARROW-LEAVED LAUREL}

Kálmia angustifòlia, L.

Other English names: Dwarf Laurel, Sheep Laurel, Sheep Poison, Lambkill, Calfkill, Wicky.

Native. Perennial. Propagates by seeds.

Time of bloom: June to July.

Seed-time: Ripe in September, but often persistent on the shrub until winter.

Range: From Newfoundland to Hudson Bay and southward to Georgia.

Habitat: Hillsides, pastures, and bogs. 
Much loss is eredited to this poisonous little plant when flocks are turned out to pasture in the spring. It does most damage when small, for animals are most likely to eat it when the shoots are young and tender and but a few inches above the ground. Children also have been poisoned by mistaking its first little pinkish leaves for young wintergreens (Gaulthèria procúmbens).

It is a shrub, six inches to nearly three feet tall, slender, with a few nearly erect branches and round, smooth twigs. Leaves evergreen, thick, smooth, entire-edged, pointed at both ends, dark green above, light green below, an inch to two inches long and a quarter-inch to a half-inch wide, with short petioles - about a third of an inch; they grow in opposing pairs or in whorls of three. Flowers beautiful, clustered on the sides of the twigs at the base of the season's new growth; they are small, fivelobed, saucer-shaped, bright pink or crimson in color, a little more than a quarter-inch broad, with thread-like pedicels a half-inch to an inch long. Each small saucer has around its sides tiny pockets into which the ten red anthers are tucked, the filaments of the stamens being bent like a spring. When these are touched by the tongues of foraging insects - or with a needle - the anthers are released with a snap, flinging out the pollen. Capsule five-celled, globose, about an eighth of an inch in diameter,

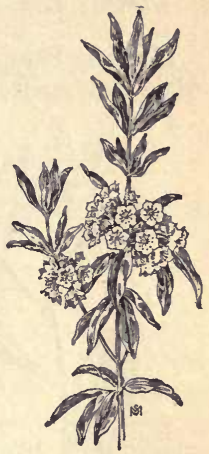

Fig. 215. - Narrow-leaved Laurel (Kalmia angustifolia). $\times \frac{1}{8}$. with the thread-like, persistent style thrust out from a deep dimple in its apex. Seeds very small, round, and slightly flattened. (Fig. 215.)

\section{Means of contrcl}

Grub out or hand-pull the plants in the spring, when the soil is soft. Animals do not often eat the old shrubs, but those are the ones that bloom and fruit and bring on the dangerous young shoots. Cutting the plants causes them to sprout from the roots, unless prevented by the use of a strong herbicide such as caustic soda. 


\section{STAGGER-BUSH}

Lyònia mariàna, D. Don.

(Pieris mariàna, B. and H.)

Other English names: Maryland Andromeda, Calfkill, Sheepkill.

Native. Perennial. Propagated by seeds.

Time of bloom: May to June.

Seed-time: August to September.

Range: Rhode Island to Florida on the Atlantic slope; also in Tennessee and Arkansas.

Habitat: Low, moist soil ; wet meadows and pastures.

Like the Sheep Laurel, this poisonous plant does most harm while very small; for, though cattle and sheep sometimes browse,

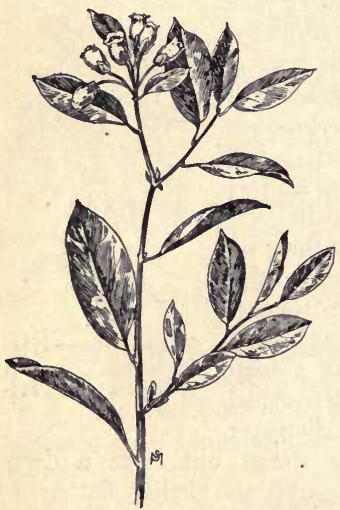

Fig. 216. - Stagger-bush (Lyonia mariana). $\times \frac{1}{2}$. they prefer to graze, and it is usually the young, green shoots which spring up in damp, sandy pastures that are eaten by sheep and calves and cause them to stagger dizzily about, with slavering mouths and labored breathing, until they fall and die. (Fig. 216.)

Stems one to four feet tall, with slender branches held nearly upright; the bark of old wood is specked with black dots. Leaves alternate, oblong, smooth and glossy above but sparingly hairy on the heavy veins and the midrib below, the under surface blackdotted, two or three inches in length, pointed at both ends, with short petioles and entire edges, the margins slightly revolute; they cling to the twigs until very late in the season, but are not evergreen. The flowers grow on the leafless wood of the preceding year's growth and are clustered just above the scars of last year's leaves; they are white or faintly rosy nodding bells, with bulging bases and slightly constricted throats, a little larger than lilies of the valley, which they somewhat resemble in form. The calyx is 
five-lobed and the bell-like corolla has five recurved teeth; stamens ten, included; style columnar and ovary five-celled. Capsule pointed-ovoid, five-angled, and five-celled, filled with many clubshaped seeds, none of which should be allowed to sow themselves and bring on the deadly young shoots.

Measures for control the same as for Sheep Laurel.

\section{SCARLET PIMPERNEL}

\section{Anagallis arvénsis, $\mathrm{L}$.}

Other English names: Red Chickweed, Poison Chickweed, Wink-apeep, Shepherd's Clock, Poor Man's Weather Glass, Poisonweed (on the Pacific coast).

Introduced. Annual. Propagates by seeds.

Time of bloom: May to September.

Seed-time: June to October.

Range: Newfoundland to Vancouver Island and southward to Florida and Texas. Most abundant on the Pacific Coast and also in the Atlantic States.

Habitat: Gardens, lawns, fields, meadows, pastures, waste places.

Like the Chickweed, this plant has accompanied the European emigrant to every part of the world, its seeds mingled with those of better plants. Where abundant it is not only a troublesome weed, but also dangerous, for it is poisonous, all parts of it having "pronounced diuretic and narcotic properties," and it is said to be especially injurious to horses, sometimes fatally so. When growing in pastures cattle usually reject it and it is left to reproduce itself.

Stems six to eighteen inches long, smooth, four-angled, weak, and slender, some prostrate and some ascending, branched and spreading. Leaves opposite or sometimes in whorls of three, or those near the top sometimes alternate, a quarter inch to a halfinch long, ovate, entire, sessile or slightly clasping, black-dotted on the under side. Flowers lifted on very slender, almost hairlike, axillary peduncles; the calyx has five narrow, keeled, and pointed lobes, united at base and persistent; corolla usually bright scarlet but sometimes salmon-color, occasionally white, about a third of an inch broad, wheel-shaped, five-lobed, with each lobe minutely fringed at the tip with fine, glandular hairs; 


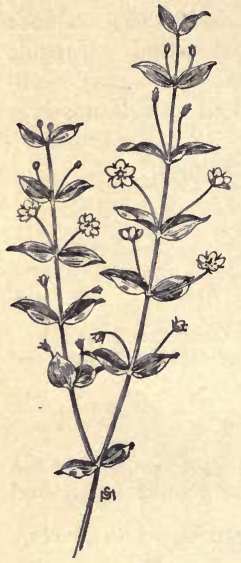

FIG. 217. - Scarlet Pimpernel (Anagallis arvensis). $\times \frac{1}{2}$. thick patches should be burned over for the purpose of destroying seeds on the surface before breaking the ground.

\section{SPREADING DOGBANE}

A pócynum androsamifòlium, L.

Other English names: Wandering Milkweed, Milk Ipecac, Honeybloom, Bitter-root.

Native. Perennial. Propagates by seeds and by rootstocks.

Time of bloom: June to August.

Seed-time: August to October.

Range: Anticosti to British Columbia, southward to Georgia, Nebraska, and Arizona.

Habitat: Fields, roadsides, and thickets ; frequently troublesome in vineyards.

A poisonous weed, but very graceful and attractive, growing usually in patches or colonies because of its extensive creeping, 
horizontal rootstocks, from which new plants are sent up at short intervals. All parts of the plant, even the rootstocks, are filled with an acrid, milky juice. (Fig. 218.)

Stems somewhat shrubby, one to three feet tall, smooth, very slender, branching at wide angles, reddish on the upper side where exposed to the sunlight, green beneath. Leaves opposite, ovate to oblong, entire, smooth and dark green above, somewhat hairy and paler beneath, acutely tipped, rounded or blunt-pointed at base, with short, often reddish petioles. Flowers in terminal and axillary cymose clusters, the corollas nodding, bell-shaped, with five recurving lobes, pale pink, marked with lines of deeper pink, fragrant; stamens five, inserted on the base of the corolla and alternating with five small triangular appendages below the throat and opposite the lobes. Ovaries two, distinct and free from the calyx forming twin follicles, round, slender, four or more inches long, smooth, curved, stuffed with many thin, flat, brown seeds tipped with tufts

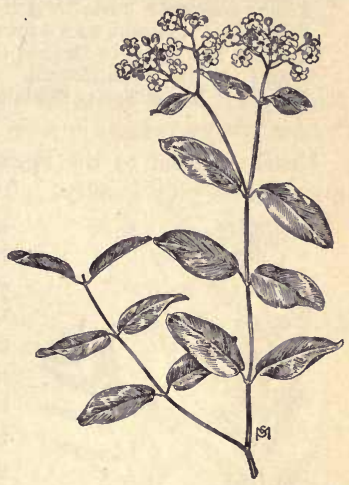

Fig. 218. - Spreading Dogbane (A pocynum androscemifolium). $\times \frac{1}{4}$. of fine white floss, by which the wind is enabled to give them wide distribution.

\section{Means of control}

When colonies of the weed appear near house grounds or barn yards, they should be killed at once by the use of strong, hot brine or caustic soda. In field, pasture, or fence row, the spud or the scythe should be frequently used, beginning with the first bloom and repeating as new shoots appear, dry salt being used for the purpose of checking new growth. Rankly infested ground is most easily cleansed by breaking it up, exposing the rootstocks during hot summer weather. 


\section{BLACK INDIAN HEMP}

Apócynum cannabinum, L.

Other English names: American Hemp, Indian Physic, Choctaw Root, Bowman's Root, Amy Root, Dropsy Root, Rheumatism weed.

Native. Perennial. Propagates by seeds.

Time of bloom: June to August.

Seed-time: August to October.

Range: Anticosti to British Columbia, southward to Florida, Texas, and southern California.

Habitat: Moist soil; fields and thickets.

Nearly related to the Spreading Dogbane, quite as obnoxious, but lacking its beauty. This plant is valuable medicinally,

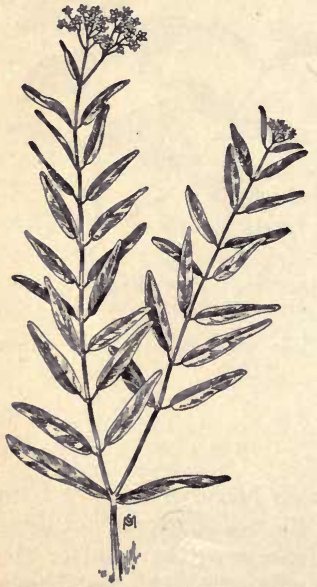

Fig. 219. - Black Indian Hemp (A pocynum cannabinum). $\times \frac{1}{4}$.

to those of the Spreading Dogbane. (Fig. 219.)

Means of control the same as for the preceding species. is made of it. and the roots, gathered in autumn, cleaned, and dried, bring eight to ten cents a pound in the drug market; the inner bark yields a fine and very strong fiber, but no commercial use

Root deep, vertical, branching. Stems one to five feet tall, smooth, erect, with ascending branches. Leaves two to four inches in length, oblong, pointed at both ends or sometimes rounded at base, entire, pale green, smooth above, occasionally somewhat hairy beneath, those on the main stem having distinct petioles, those on the branches often nearly sessile. Flowers terminal (sometimes axillary) in rather dense cymes, held erect; calyx with five lobes, nearly as long as the tube of the very small, five-lobed; greenish white corolla. Pods in pairs, similar 


\section{BUTTERFLY WEED}

Asclepias tuberòsa, L.

Other English names: Orange Milkweed, Orange root, White Root, Pleurisy Root, Wind Root, Swallow-wort.

Native. Perennial. Propagates by seeds.

Time of bloom: June to August.

Seed-time: August to October.

Range: Ontario to Minnesota, southward to Florida, Texas, and Arizona.

Habitat: Dry fields and pastures.

The most showy of the Milkweeds. Where abundant, the plant may be made to pay for the cost of its suppression by the sale of its white, tuberous roots, which are valuable medicinally and bring six to ten cents a pound in the drug market; they should be collected in autumn, when well stored with sustenance for the winter.

Stems several from the clustered tubers, one to two feet high, erect, branched at the top, round, and very hairy; they lack the milky juice so characteristic of the family. Leaves alternate, oblong to lanceshaped, acute or sometimes obtuse at apex, entire, hairy on both sides, sessile or with very short petioles. Flowers in large flat-topped umbels terminating stem and branches, brilliant orange in color; butterflies of many kinds are nearly always hovering about them; the five lower segments of the corolla are reflexed

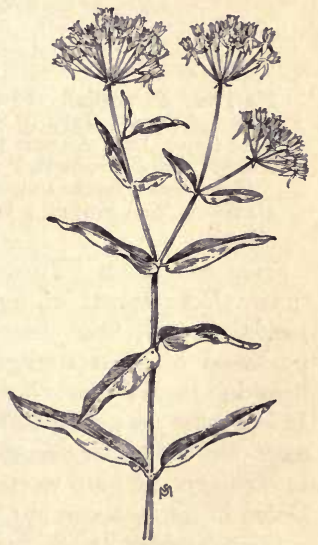

Fig. 220. - Butterfly Weed (Asclepias tuberosa). $\times \frac{1}{4}$. and the crown above it has five small, spreading hoods, each of which has within it a slender, incurving horn. Stamens five, inserted on the base of the corolla, the filaments forming a tube which incloses the pistil, the anthers adherent to the stigma; ovaries two, with very short styles connected at the summit by 
the disk-like stigma. The fruits are twin follicles, three to five inches long, gray-hairy, pointed at both ends, their pedicels so bent as to hold them nearly erect. Seeds flat, margined, brown, bearing a coma or tuft of long, silky hairs. (Fig. 220.)

\section{Means of control}

Persistently deprive the tuberous roots of green growth above ground and they will at length wither and die. Begin cutting before the first flowers mature, and repeat as often as new shoots put forth. Dry salt applied to the shorn surfaces will check new growth.

\section{SWAMP MILKWEED}

Asclepias incarnàta, L.

Native. Perennial. Propagates by seeds.

Time of bloom: July to September.

Seed-time: Late August to October.

Range: New Brunswick to the Northwest Territory, southward to Tennessee, Louisiana, and Kansas.

Habitat: Wet ground; low meadows, swamps, and along ditches.

In a report on "Fiber Investigations" made by the United States Department of Agriculture, it is stated that this plant yields a tough fiber, finer than that of hemp, soft, glossy, and possessed of great strength. Binder twine made of it stood a breaking test of ninety-five to a hundred and twenty-five pounds. It is a pity that the plant is not utilized so as to make valuable many a profitless swamp or marsh. Its hard, knotty roots are used in medicine, and are worth three or four cents a pound when collected in late autumn and carefully dried.

Stems slender, two to five feet tall, round, smooth, often reddish, sometimes simple but usually branching above, leafy to the summit. Leaves opposite, oblong-lance-shaped, smooth, long-pointed, usually obtuse at base, with rather short petioles. Flowers rosy purple, in flattened umbels, the pedicels finely hairy; the hoods of the crown erect and slim, the pointed horns within being as sharp as needles and longer than the hoods. Follicles slender, pointed at both ends, and held erect. 


\section{Means of control}

Drainage of the ground is the first step toward the destruction of Swamp Milkweed, after which it needs to be kept closely cut throughout the growing season in order to starve the perennial roots.

\section{SHOWY MILKWEED}

Asclèpias specidsa, Torr.

Native. Perennial. Propagates by seeds.

Time of bloom: June to August.

Seed-time: August to October.

Range: Minnesota to British Columbia, southward to Arkansas, Utah, and California.

Habitat: Moist soil; wet meadows and along streams.

Plants of this species are sometimes smooth, but usually they are finely white-woolly all over, even to the flowers, of which the calyx is densely so. Stems simple, stout, one to two and a half feet tall. Leaves opposite, thick, broadly ovate to heart-shaped, grayish green, with large veins and short, stout petioles. Umbels many-flowered, the corollas greenish purple, the pedicels and the stout peduncle softly hairy. Follicles plump, three or four inches long, covered with soft, spinous processes, and also densely whitewoolly, held erect or slightly spreading on recurved pedicels.

\section{Means of control}

Drainage of the ground. Uprooting with grubbing-hoe or plow, or such close and persistent cutting as to rob the perennial roots of all sustenance.

\section{COMMON MILKWEED}

Asclèpias syriaca, $\mathrm{L}$.

Other English names: Silkweed, Cottonweed.

Native. Perennial. Propagates by seeds and by rootstocks.

Time of bloom: June to August.

Seed-time: August to October.

Range: New Brunswick to the Northwest Territory, southward to Georgia, Missouri, and Kansas.

Habitat: Fields, pastures, roadsides, and waste places. 
The horizontal creeping rootstock which makes this plant such a noxious weed is often six or eight feet long, wrinkled, cylindrical, white inside, with a grayish brown bark, warty with the scars of former stems. It is medicinally valuable, and, when collected in autumn, cleaned, transversely sliced and dried, is worth six to eight cents a pound in the drug market. Grazing cattle dislike the bitter, milky juice and the weed is a pest in pastures. When young, the

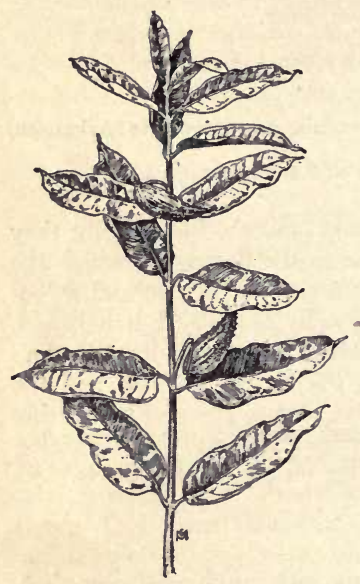

Fia. 221. - Common Milkweed (Asclepias syriaca). $\times \frac{1}{4}$. crisp, succulent shoots make an excellent "dish of greens," cooked like asparagus. (Fig. 221.)

Stem stout, two to five feet tall, softly downy when young but growing smooth with age, erect, and usually simple. Leaves arranged in opposing pairs on alternate sides of the stalk, oblong to elliptic, smooth above, finely downy below, entire, the nerves extending from the strong midrib uniting themselves by a bordering thread before reaching the margin; petioles stout, very short. Umbels terminal and lateral, dense, the flowers dull purple to pinkish, fragrant. Follicles three or four inches long, downy, and covered with soft, spinous projections. Seeds very many, brown, flat, their tufts of fine silken hair long and thick. Should they fall on water, Milkweed seeds can float, as well as fly, for each has a corky margin which makes of it a raft.

\section{Means of control}

Cutting and many times cutting, throughout the growing season, depriving the rootstocks of all sustenance if possible. Plants should not be allowed to form fruit before cutting, for the pods ripen on the stalks. 


\section{CLIMBING MILKWEED}

Gonólobus laèvis, Michx.

(Ampélanus albidus, Britton)

(Enslénia álbida, Nutt.)

Other English names: Angle-pod, Sand Vine, White Swallow-wort. Native. Perennial. Propagates by seeds.

Time of bloom: June to August.

Seed-time: August to October.

Range: Pennsylvania to Kansas, southward to Florida and Texas. Habitat: Fence rows and thickets, waste places; also troublesome in cultivated ground.

Vines such as this furnish a good argument against too many fences, as it is practically impossible to clean out the weed without removing its support. Stems eight to twelve or more feet long, slender, twining, smooth or minutely hairy in lines, filled with milky juice. Leaves three to five inches long, opposite, thin, heart-shaped, long-pointed, smooth, entire, with long petioles. Flowers in axillary cymose clusters, very small, bell-shaped, fivelobed, cream-white, fragrant; stamens five, the filaments united into a short tube; stigma slightly two-lobed; peduncles rather stout, not so long as the leaves, pedicels thread-like, longer than the flowers. Follicles three to five inches long, erect, smooth, wing-angled. Seeds flat, brown, tufted with silken hair.

\section{Means of control}

The weed is a persistent one and frequent and deep cutting is necessary in order to keep it in check, beginning when it is in early bloom and repeating as new shoots put forth. Dry salt or a few drops of carbolic acid will help in retarding new growth.

\section{BLACK SWALLOW-WORT}

Cynánchum nigrum, Pers. (Vincetoxicum nigrum, Moench)

Introduced. Perennial. Propagates by seeds. Time of bloom: June to September. Seed-time: August to October.

Range: Massachusetts to Michigan, Pennsylvania, and Ohio. Habitat: Old fields, fence rows, thickets, and waste places. 


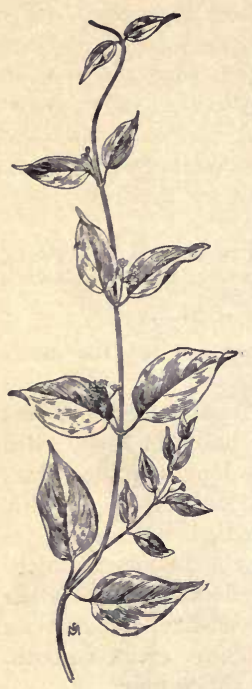

Fig. 222. - Black Swallow-wort (Cynanchum nigrum). $\times \frac{1}{6}$.
This plant, like the preceding one, is often called Climbing Milkweed; the milky juices are poisonous. It is an immigrant from Europe, first planted in gardens for its beauty; but the silken-winged seeds made an easy escape and now the weed is a frequent nuisance in ground not under cultivation. (Fig. 222.)

Stems twining, slender, three to six feet long, slightly hairy, often brownish red where exposed to the light. Leaves opposite, long-ovate, thin, dark green, smooth, entire, pointed at tip and rounded at base, with prominent, sometimes reddish, veins and short petioles. Flowers in axillary cymose clusters, small, saucer-shaped, the five spreading lobes somewhat twisted, hairy within, deep purple; peduncles shorter than the leaves. Follicles about two inches long, pointed at both ends, smooth. Seeds flat, brown, tipped with silken floss.

Means of control the same as for the preceding species. It is more pernicious, and requires persistent treatment.

\section{WILD SWEET POTATO VINE}

Ipomòa panduràta, G. F! W. Mey.

Other English names: Man-of-the-Earth, Mecha-Meck.

Native. Perennial. Propagates by seeds.

Time of bloom: May to September.

Seed-time: Late June to Oetober.

Range: Eastern Canada and New England to Michigan and Kansas, southward to Florida and Texas.

Habitat: Dry soil ; thickets and waste places.

The very large fleshy roots of this plant are edible and sweet, and are buried very deep in the ground below the reach of frost; 
they are sometimes more than two feet long, and so thick as to attain a weight of over thirty pounds. Several stout, smooth stems spring from the same root, trailing or twining for a length of three to twelve feet. Leaves alternate, deep green, heartshaped, long pointed, sometimes drawn in at the sides to a fiddleshape, two to six inches long, with slender petioles often longer than the blades. Flowers like those of the morning glory, the corollas funnel-shaped, two to three inches long, white, with five pinkish purple stripes, often several on one stalk, which lengthens very much as the seed ripens; stamens five, inserted low down on the tube of the corolla and alternating with its lobes; ovary two celled, with entire or two-lobed stigma. Capsules globular, twocelled, containing two to four seeds, which have fine wool all around the margins. (Fig. 223.)

\section{Means of control}

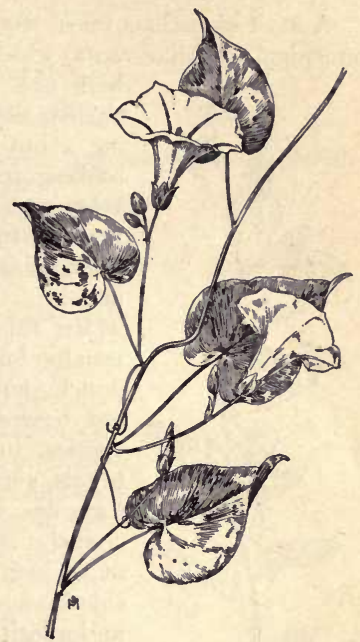

Except to satisfy hunger it would not pay to dig for these deeply

Fic. 223. - Wild Sweet Potato Vine (Ipomea pandurata). $\times \frac{1}{2}$. buried roots. Repeated deep cutting of the stems, putting a handful of salt or a few spoonfuls of crude carbolic acid on the shorn surfaces, will finally subdue the weed.

\section{FIELD BINDWEED}

\section{Convolvulus arvénsis, L.}

Other English names: European Bindweed, Small-flowered MorningGlory, Cow-bind, Bell-bind.

Introduced. Perennial. Propagates by seeds and by horizontal roots that bud new plants. 
Time of bloom: June throughout the summer.

Seed-time: August until cut off by frost.

Range: Nova Scotia to Manitoba, southward to Virginia, Missouri, and Kansas.

Habitat: Rich soil; fields, meadows, and waste places.

A most obnoxious weed, spreading chiefly by means of its long, creeping, cord-like roots, which at any part of their length may bud new plants. Stems smooth, slightly

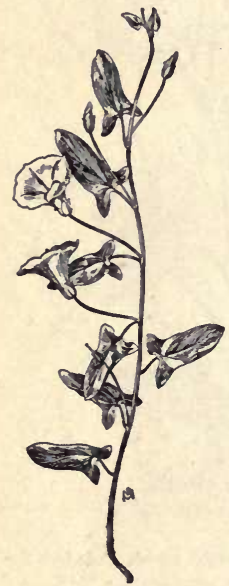

Fig. 224.-Field Means of control

Bindweed (Convolvulus arvensis). $\times \frac{1}{3}$. angled, slender, one to three feet long, twining about and over any plant within reach, robbing it of air and light while the roots below are starving it of food and moisture. Leaves alternate, halberd-shaped, with backward-pointing lobes at the base, on slender petioles. Flowers pink, sometimes nearly white, funnel-shaped, about an inch across, usually but one or two on each slender peduncle, but occasionally three or four; calyx not bracted at the base as in the following species, but there are two small scale-like bracts, some distance below, on the peduncle. Capsules globular, two-celled, usually fourseeded. Seeds dark brown, about one-eighth of an inch long, pear-shaped, rough, with one side flat and the other rounded; too frequently an impurity of other seeds. (Fig. 224.)

Sow clean seed. Put the ground under clean cultivation for two years; the infested land should be deeply plowed and as many as possible of the whip-cord roots harrowed out or raked out and destroyed, or they may be fed to pigs; but each bit left in the soil will start new growth and tillage must be so frequent and so thorough that no green leaves are permitted to feed these roots. Where it is practicable to grow alfalfa, this crop tends to smother the Bindweed with its thick cover and the frequent cutting checks leaf growth of the weed and prevents seeding. Or infested land may 
be broken up with the plow and hogs may be turned in - with snouts in working order - for the purpose of turning out and eating the succulent roots, of which they are very fond. Sheep pasturing on infested ground will also keep leaf-growth down and will starve the underground growth.

\section{HEDGE BINDWEED}

Convólvulus sèpium, L.

Other English names: Great Bindweed, Bracted Bindweed, Hedge Lily, Rutland Beauty, Devil's Vine.

Native. Perennial. Propagates by seeds and by rootstocks.

Time of bloom: June to August.

Seed-time: Late July to October.

Range: Nova Scotia to Minnesota, southward to the Carolinas, Missouri, and Nebraska,

Habitat: Cultivated ground, fence rows, thickets, waste places.

Nearly as obnoxious as the smaller Field Bindweed, and about as hard to control; its rootstocks, however, are larger and not so brittle; the trailing or twining stems are three to ten feet or more in length. Leaves smooth, long, triangular halberd-shaped, the basal lobes diverging and truncate; petioles slender, usually shorter than the blades. Flowers solitary, about two inches long, the corollas flaring funnelshaped, pink, with white stripes, or clear white, lifted on slender axillary four-angled peduncles, often five or six inches in length. Just below the flower and overlapping and concealing its five-lobed calyx is a pair of large, heart-shaped bracts, which are persistent and enfold the fruit. Capsule globular and may contain four seeds, but often only two or three are fertile; the seeds are angular kidney-shaped, about an eighth of an inch long, dark brown. They retain vitality for several years. 225.)

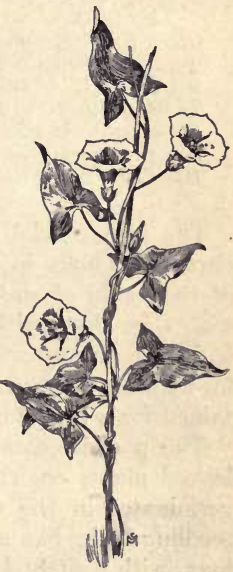
(Fig. Fig. 225 . - Hedge sepium). $\times \frac{1}{3}$. 


\section{Means of control}

Persistently starve the rootstocks by the frequent close cutting of the stems. This weed is an argument against any more fences than are an absolute necessity. It loves the mellow soil of a cornfield and, though it may be well fought until the corn crop attains full stature, too often the later growth is neglected; after the "ears begin to fill" the pest is permitted to mature seed as well as to make sufficient leaf-growth to restock the pernicious underground storehouses with food for another year. There can be no such relaxing of the struggle if the weed is to be suppressed; it must be cut and again cut until the corn is laid by. Other measures, such as are advised for Field Bindweed, may also be used for this plant.

\section{CLOVER DODDER}

\section{Cúscuta Epithymum, Murr.}

Other English names: Love-vine, Strangle Weed, Hairweed, Devil's Hair, Devil's Gut, Hellbind.

Introduced. Annual. Propagates by seeds.

Time of bloom: June to September.

Seed-time: August to October.

Range: Locally in most of the states.

Habitat: Wherever the clovers or alfalfa are extensively grown.

The farmer who sees his newly seeded clover or alfalfa field partly or wholly in the grip of this parasite gets a realizing sense of the value of clean seed. For the Dodder is there because it was sown there with the crop. If the plant is allowed to ripen fruit, the ground will be made foul and unfitted for similar crops for at least eight years, the dormant vitality of the seed being retained for a period of five to seven years.

The parasite awakens late - nearly a month after the greenleaved plants on which it must depend have started growth; it germinates in the soil but draws from it no sustenance. The seedling looks like a bit of yellowish red hair, two to four inches long, with a slight knob, or swelling, at one end, swaving pliantly about, searching for a host plant to which it may attach itself. If no such plant is within reach the seedling falls to the ground and 
dies; if there is such a plant, the parasite quickly twines about it, develops tiny, wart-like suckers at the point of contact, breaks connection with the earth, and thereafter "sponges its living," drawing from the host plant the food assimilated by the green leaves for its own growth. Consequently the Dodder needs no leaves and has none, the whole plant being a mere coarse, yellowish red thread, branching very freely and the branches behaving as did the original filament, reaching out for living support, embracing it, and then of ten parting from the main stalk and becoming separate plants; so that the growth from a single seed may cover a considerable extent of ground, binding the herbage into a tangled mass and sucking out its life. The parasite itself dies at the point where its growth started, when its hosts are killed, but the many spreading branches continue their existence. Even a broken bit of stalk, dropped where it can seize on a host, promptly takes hold and starts a new center. (Fig. 226.)

The small flowers are whitish or faintly tinged with pink, sessile, massed in dense clusters; calyx five-lobed or occasionally only four-lobed, acute; corolla lobes spreading, bell-shaped, with

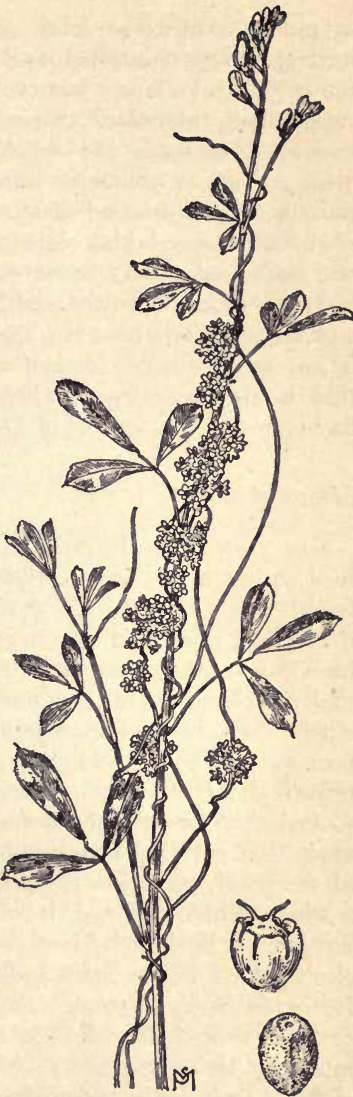

Fig. 226. - Clover Dodder (Cuscuta Epithymum). $\times \frac{1}{3}$. Capsule and seed very much enlarged. 
as many stamens as lobes set between their points and exserted; ovary two-celled and style two-parted. Scales within the corolla tube large, incurved, and toothed all round. Capsules small, globular, two-celled, four-seeded, but often , only two or three seeds are developed. Seeds very small, rounded, oval, grayish or yellowish brown; they are the most dangerous, the most to be dreaded of all the impurities of clover seeds. No seed should ever be harvested from a Dodder-infested clover field and such seed should be unsalable at any price. Neither should such a crop be harvested and fed as hay, for the seeds, uninjured and viable, often pass the digestive tracts of animals, and may be spread on other fields in the manure, not to speak of the seeds that would be scattered wherever the hay was handled. Baled hay is one of the sources of Dodder distribution.

\section{Means of control}

Sow clean seed. Infestation is often in patches where a single seed or but a few have germinated. In such a case, cut the infested plants close to the ground, before any seeds have ripened if possible, pile them on the spot where they grew, let them dry for a day or two, cover with straw, shavings, or some light rubbish, soak with kerosene oil, and burn, being careful to get every thread, cutting beyond the apparent limit of damage. Then stir the surface soil of the patch lightly with rake or hoe, making a small trench about the edge, cover a couple of inches deep with oilsoaked chaff or rubbish, and again burn, in order to destroy any seeds that may have matured and fallen to the soil. Or the soil of the patch may be well sprinkled with crude carbolic acid. If a whole field is infested, it will be best to plow the crop under; but it must be done before the seeds ripen, indeed before they form, else the land will be made unfit for occupation by clover or alfalfa for seven or eight years. Or, the field may be pastured off by cattle or sheep before the seed ripens; but in that case the animals must not be moved about, for bits of stalks may adhere in the clefts of their hoofs, or unsuspected seeds may be in the droppings. If seeds have been allowed to mature, the crop should be mowed, dried, and burned on the spot, for Dodder-infested crops should 
not be carried about because of the danger of infection. Cultivated crops should then be grown for some years before the land is again used for clover or alfalfa.

Spraying with Arsenite of soda has been found in some cases to be satisfactory, a solution of one pound of the poison to ten gallons of water being used. The clover and the alfalfa were also much injured, seemingly killed by the treatment, but recovered and made new growth from the roots after having been relieved from the strangler's grip. A twenty-per-cent solution of Iron sulfate has also been found to be effective on alfalfa fields, killing the parasite and apparently destroying the crop; but, as with the arsenical treatment, new growth sprang from the roots.

\section{FLAX DODDER}

\section{Cúscuta Epilinum, Weihe}

Introduced. Annual. Propagates by seeds.

Time of bloom: June to August.

Seed-time: Late August to October.

Range: Wyoming, Idaho, the Dakotas, and other states where flax is cultivated.

Habitat: Flax and alfalfa fields.

The coiling stems of this species have somewhat less of the reddish tinge that characterizes the Clover Dodder. The flowers are yellowish white, and the tube of the small, five-lobed corolla does not spread like a bell but is often slightly constricted just below the lobes like the mouth of a vase; stamens included; scales short and broad, notched at apex and toothed only partway down the sides. The seeds are very much smaller than the flax seeds, of course, and might very readily be removed from them if it were not for a habit that this Dodder has of dropping seeds in pairs, which cohere, making them nearly as heavy as those of the flax, though of different shape. But seed from Dodder-infested flax fields, if intended for sowing, should be rejected at any price, and even when intended for linseed-oil manufacture, flax-seed should be very carefully cleansed from all contamination of Dodder-seed.

Means of control the same as for Clover Dodder. 


\section{FIELD DODDER}

Cúscuta arvénsis, Beyrich

Native. Annual. Propagates by seeds.

Time of bloom: July to September.

Seed-time: August to October.

Range: New York to the Northwest-Territory, southward to Florida and Texas; also in California.

Habitat: Open situations; appears to dislike shade.

This is the most injurious species east of the Mississippi Valley, for it is not at all particular on what it feeds. One single plant has been recorded as spreading over and drawing nourishment from eight different species at once. Almost any herbaceous plant will do, but it likes the clovers best; and it likes to climb to the top of its host plant and spread a tangled mass of threads there, like a carpet; therefore it is more conspicuous than the lower-growing Clover Dodder and can sooner be detected in a field.

The strangling stems are pale yellow, very slender. Flowers in dense roundish clusters; calyx-lobes broad, obtuse; corolla-lobes pointed, the points inflexed and the scales within the tube of the corolla much fringed; stamens not exserted; capsules globular. Seeds nearly double the size of those of Clover Dodder, and in consequence very much harder to separate from clover sced. For this reason it is often called "Large-seeded Dodder," but this name is applied also to the PretTy Dodder (Cuiscuta indecòra, Choisy), which is more common to the western United States.

Means of control the same as for Clover Dodder.

\section{COMMON DODDER}

\section{Cúscuta Gronòvii, Willd.}

Other English names: Wild Dodder, Onion Dodder.

Native. Annual. Propagates by seeds.

Time of bloom: July to September.

Seed-time: August to October.

Range: Nova Scotia to Manitoba, southward to the Gulf of Mexico. Habitat: Moist shady places; low grounds, meadows, waste places.

This species is probably the most widely known of its tribe. Like the Field Dodder, it seems indifferent as to its hosts and, 
"Like a living skein enlacing,

Coiling, climbing, turning, chasing,"

will embrace anything from a tall New England aster to an onion, or even some shrubby plants, such as the willows, and it is a high climber.

Stems deep yellow to orange, rather coarse. Flowers very numerous, in dense clusters; corolla bell-shaped, waxen white, and its five lobes, as well as those of the calyx, rounded instead of pointed, the scales within the tubes thickly fringed at summit, more sparingly at the sides; stamens exserted. Capsules globose or short-pointed ovoid. Seeds comparatively rather large. (Fig. 227.)

Wherever the Common Dodder attacks cultivated plants, both it and they should be treated with scythe and fire before any seed ripens.

\section{SKUNKWEED}

Navarrètia squarròsa, H. and A.

(Gília squarrdsa, H. and A.)

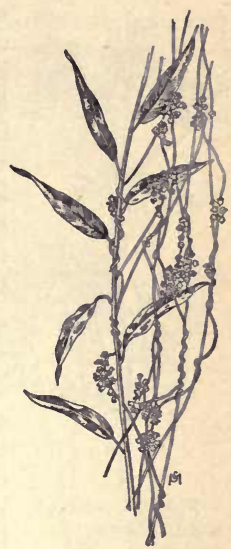

Fig. 227. - Common Dodder (Cuscuta Gronovii). $\times \frac{1}{2}$.

Other English names: Stinkweed, Pepperweed, Sticky Gilia.

Native. Annual or biennial. Propagates by seeds.

Time of bloom: May to July.

Seed-time: June to September.

Range: Washington, California, and Nevada.

Habitat: Grain fields, meadows, and vineyards.

A troublesome and most disagreeable weed, viscidly glandular and unpleasant to touch, very bitter to the taste, and emitting a strong, fetid odor. Hay and grain among which it grows are damaged by contact with it, for the offensive smell of its sticky secretions is persistent and cattle reject not only the weed but also the hay that has been cured in touch with it.

Stem eight to fourteen inches tall, erect, rigid, branching from the base, often of a ruddy or a brownish hue, and covered with glandular hairs. Leaves alternate, once or twice pinnatifid, the 
segments lance-shaped and again cut or toothed, sticky-hairy, the upper leaves and bracts often spinescent. Flowers blue, about

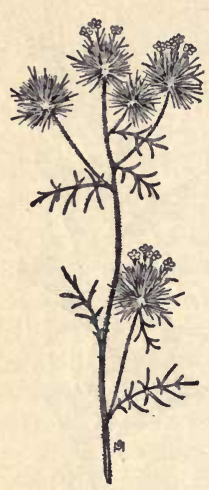

Fic.228. - Skunkweed (Navarretia squarrosa). $\times \frac{1}{3}$. an eighth of an inch broad, in dense, axillary clusters; corolla funnel-form, with five spreading lobes and five included stamens; the calyx has five spine-tipped, viscidly hairy lobes as long as the corolla tube. Capsule three-celled and three-valved with eight to twelve seeds in each cell. Seeds very small, and when wet are mucilaginous, which helps them to be carried about on farming tools and to adhere to the feet of animals. (Fig. 228.)

\title{
Means of control
}

Put the land under cultivation with a hoed crop. In pastures, meadows, and waste places the plants should be closely and repeatedly cut during the growing season, entirely preventing seed development. Burn over rankly infested ground where the plants have matured, thus destroying the seeds on the surface. The seed is said to be short-lived, and if the plant is not allowed to reproduce itself it must soon be suppressed.

\section{NYCTELEA}

\author{
Ellisia Nyctèlea, L. \\ (Macrocàlyx Nyctèlea, Kuntze.)
}

Native. Annual. Propagates by seeds.

Time of bloom: April to June.

Seed-time: May to July.

Range: New Jersey to Minnesota and the Saskatchewan, southward to Virginia, Missouri, Nebraska, and Colorado.

Habitat: Grain fields, meadows, waste places.

Although this plant ranges nearly across the Continent, it is most troublesome as a weed in the wheat-growing country of the Northwest, where it appears early in spring, makes a rapid growth 
which absorbs much of the food and moisture needed by the crop, matures its fruit, and dies down early in July.

Stem four inches to a foot high, slender, and diffusely branched. Leaves two to four inches long, with slender petioles, the upper ones alternate, the lower ones usually opposite; all are pinnately divided, but the segments of the upper ones are usually entire, those of the lower ones toothed or lobed. The whole plant is finely rough-hairy and has a rank, disagreeable odor. Flowers solitary on slender peduncles, from the forks or opposite the leaves; occasionally the later ones are in one-sided clusters of two or three. They have a calyx of five-pointed lobes and a fivelobed, nearly cylindrical, white or bluish corolla, with five included stamens and two styles, united at the base. Calyx and corolla of about the same length (a little more than a quarter-inch) when the flower first opens; but as the fruit forms the calyx enlarges and spreads widely,

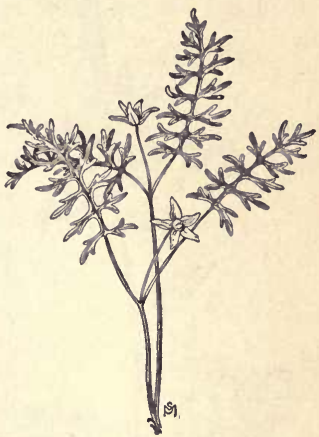

Fig. 229, - Field Nyctelea (Ellisia Nyctelea). $\times \frac{1}{4}$.

becoming a five-pointed star-shape, nearly an inch broad, with a small globose two-celled capsule in the center usually containing four seeds. (Fig. 229.)

\section{Means of control}

In grain fields the seedlings should be dragged out with a weeding harrow in the spring, when the crop is but a few inches high. Short rotations with cultivated crops will most easily keep the weed in subjection.

\section{INDIAN HELIOTROPE}

\section{Heliotrdpium indicum, L.}

Introduced. Annual. Propagates by seeds. Time of bloom: May to September.

Seed-time: July to November. 
Range: Virginia to Ohio and Illinois, southward to Florida and Texas.

Habitat: Fields and waste places.

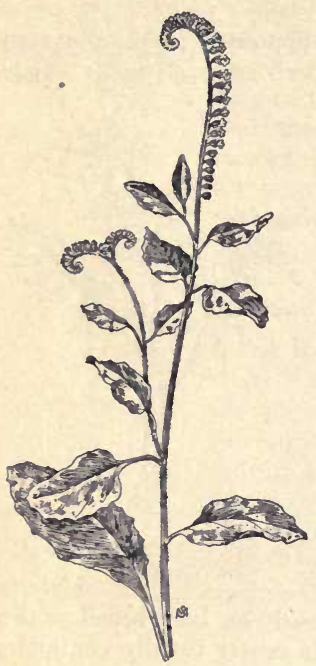

Frg. 230. - Indian Heliotrope (Heliotropium indicum).

A coarse, many-branched, and very hairy plant, untouched by grazing animals, robbing neighboring plants of much food and moisture. Stems one to three feet high, rather stout. Leaves alternate, broadly ovate to heart-shaped, three to six inches long and nearly as wide, with wavy edges and short, slightly margined petioles. Flowers in long, terminal, bractless, partly coiled spikes, which straighten as the blossoms open from the base upward; the season of bloom is so long that ripe seeds are falling from the bases of the spikes before the buds cease to unfold at the summit; corolla salver-form, violet-blue, very small, the tube longer than the hairy calyx; stamens five, included, the anthers nearly sessile. Fruit splitting into two closed carpels, ribbed on the back, each usually containing two seeds or nutlets. (Fig. 230.)

\section{Means of control}

Prevent seed production by early, frequent, and persistent cutting.

\section{HOUND'S TONGUE}

Cynoglossum officindle, $\mathrm{L}$.

Other English names: Dog Bur, Dog's Tongue, Woolmat. Introduced. Biennial. Propagates by seeds. 
Time of bloom: June to August.

Seed-time: July to September.

Range: Quebec to Minnesota, southward to Georgia and Kansas.

Habitat: Fields, pastures, waste places.

A worthless weed anywhere, but a special pest in pastures, its downy-hairy leaves having a disagreeable odor and a nauseous taste and the burs being among the worst that beset the fleeces of sheep.

Root rather thick, deep-boring, black, crowned the first year with tufted, dull green leaves, six inches to a foot in length, oblong, pointed - shaped somewhat like a hound's tongue - with long, channeled petioles; stem-leaves much smaller, and sessile or clasping by rounded or heart-shaped bases. Flowering stalk one to three feet tall, stout, leafy, branching near the top. Racemes terminal, simple or branching, lengthening as the flowers mature; the latter reddish purple, the corolla funnel-form, five-lobed, less than a half-inch broad, with five included stamens, a single style and deeply fourlobed ovary. The hairy calyx enlarges as the burs mature; these are comprised of four pointed obovoid, compressed, nutlets, each about a quarter-inch long, covered with short, barbed prickles, and

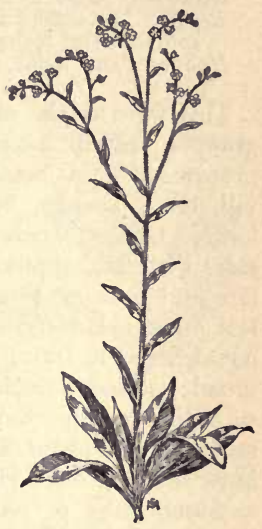

FIG. 231. - Hound's Tongue (Cynoglossum officinale). $\times \frac{1}{8}$. forming a small pyramid with the withered style for its peak, to which they are attached so slightly that a touch from a passing animal or a garment will detach and carry them away. (Fig. 231.)

\section{Means of control}

Deep cutting of the crown leaves, with spud or hoe, in late fall or early spring. Fruiting stalks should be cut close to the ground before the first flowers mature. 


\section{BLOE BUR}

Láppula echinàta, Gilibert

(Echinospérmum Láppula, Lehm.)

Other English names: European Stickseeds, Sheep Bur, Burseed, Burweed, Bur Forget-me-not.

Introduced. Annual or winter annual. Propagates by seeds.

Time of bloom: June to August.

Seed-time: July to September.

Range: Nova Scotia to British Columbia, southward to Virginia, Indiana, and Nebraska. Also in Texas. Locally in other states. Habitat: Dry fields, pastures, roadsides, waste places.

This weed is the cause of much annoyance and loss to woolgrowers. Sheep have carried it into many new localities, its presence in Texas being due to that agency. Stem one to two feet tall, erect, slender, branching at the top, gray with appressed hairs. Leaves narrow oblong to linear, entire, covered on both sides with fine, appressed, white hairs, sessile or the lowest spatulate and tapering to short petioles. Flowers in terminal more or less one-sided, leafy-bracted racemes; the pedicels short, stout, not deflexed in fruit; corolla blue, hardly an eighth of an inch broad; stamens included; calyx five-pointed, enlarging and spreading as the burs mature; these are formed of the four nutlets, each about an eighth of an inch long, angled on the inner side, the other side rounded and having around the margin a double row of short spines tipped with star-shaped hooks. These spines break off readily, but the fruit can still be identified, when among other seeds, by its angles and the smooth space on the rounded side.

\section{Means of control}

Late fall plowing for the purpose of destroying autumn plants. Pull or cut all flowering stalks before the first seeds ripen.

\section{VIRGINIA STICKSEED}

Láppula virginidna, Greene

Other English names: Beggar's Lice, Beggar's Ticks. Native. Biennial. Propagates by seeds. 
Time of bloom: June to August.

Seed time: July to September.

Range: New Brunswick to western Ontario and Minnesota, southward to the Gulf of Mexico.

Habitat: Upland brushy pastures, thickets, borders of woods.

Sheep are the animals most likely to be grazing where this weed grows, and it is most damaging to their fleeces. Stems slender, two to four feet tall, branching at the top into a widely divergent panicle. The root-leaves are roundish ovate to heart-shaped, with long, slender petioles; these die away before the coming of the fruiting stalk in the second year; stem-leaves oblong-ovate to oval, pointed at base and tip, the lower ones petioled, the upper ones sessile, softly hairy on both sides. Racemes long, very slender, swung out almost horizontally; corolla bluish or nearly white, minute, its five lobes spread salver-form, the five stamens included in its tube. Burs globose, the four nutlets covered on margin and back with fine, barbed prickles. (Fig. 232.)

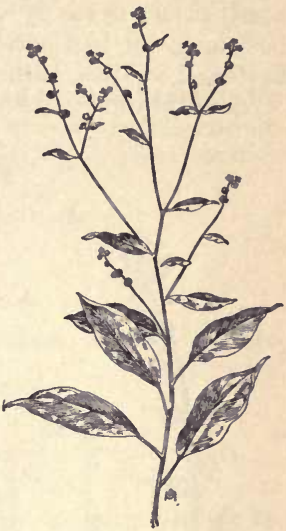

FIG. 232. - Virginia Stickseed (Lappula virginiana). $\times 1$.

Means of control the same as for Lappula echinata.

\section{MANY-FLOWERED STICKSEED}

\section{Lápula floribúnda, Greene}

Other English names: Western Sheep-bur, Western Stickseed, Largeflowered Stickseed.

Native. Biennial or perennial. Propagates by seeds.

Time of bloom: June to August.

Seed time: July to September.

Range: Ontario and Minnesota to the Saskatchewan and British Columbia, southward to New Mexico and California.

Habitat: Plains, upland pastures.

Stems two to five feet tall, stout, erect, branching into a large panicle at top. Leaves rough-hairy on both sides, oblong to 
narrow lance-shaped, two to four inches long, the lower ones tapering to margined petioles, the upper ones sessile. Racemes long, ascending, many-flowered, usually in pairs; corolla blue, more than a quarter-inch broad, the five lobes spreading; pedicels nearly as long as the flower, reflexed in fruit. Burs about a quarterinch long, the four nutlets keeled, margined with a single row of flattened, awl-like, barbed prickles.

Means of control the same as for Lappula echinata.

\section{YELLOW BURWEED}

Amsinckia intermèdia, F. and $\mathbf{M}$.

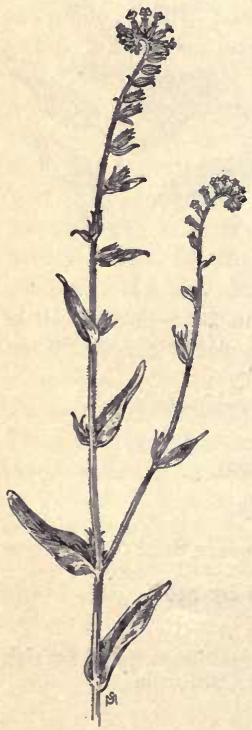

FIG. 233. - Yellow Burweed (Amsinckia intermedia). $\times$ i.
Other English names: Yellow Tarweed, Fireweed, Yellow Forget-me-not.

Native. Annual. Propagates by seeds. Time of bloom: May to July.

Seed-time: June to August.

Range: Pacific Coast.

Habitat: Grain fields, meadows, pastures, and vineyards.

An unpleasant, hairy weed, with sticky, bristly burs which make it a pest to California wool-growers. Stem erect, clothed with stiff white bristles, one to three feet high, with spreading branches. Leaves rather thick, lance-shaped to linear, entire, and thickly covered with fine, bristly hairs much shorter than those on the stem. Flowers in crowded, terminal, leafy-bracted racemes which lengthen as the succession of bloom approaches the summit; when developed, the racemes may be five to ten inches long, peduncled, and have usually matured seeds at the base before the latest buds are unfolded. Corolla orange-yellow, about a quarter-inch broad, its five lobes spread salver-form, and the tube enclosed for about half its length in a bristly calyx with very narrow, 
pointed lobes. The stiff bristles on the calyx enable it to cling to clothing and the coats of animals, particularly sheep, and the seeds which it encloses are largely so distributed. These are four incurved nutlets, keeled on the back, rough, wrinkled, and about a tenth of an inch long. (Fig. 233.)

\section{Means of control}

When grain is but a few inches high and the soil is moist, the weed-seedlings should be raked out of it with a weeding harrow. Badly infested meadows should be cleansed by a short rotation containing a well-tilled hoed crop.

\section{COMFREY}

Symphytum officindle, $\mathrm{L}$.

Other English names: Healing-herb, Knit-back, Backwort, Bruisewort, Slippery-root, Asses' Ears.

Introduced. Perennial. Propagates by seeds.

Time of bloom: June to August.

Seed-time: August to October.

Range: Newfoundland to Minnesota, southward to Maryland.

Habitat: Moist meadows, along ditches, and in waste places.

Comfrey was brought to this country by the early settlers because of its healing virtues, and is an escape from the "Garden of Simples." The root is spindle-shaped, thick, fleshy, mucilaginous, covered with thin, black bark; it is still valued medicinally, and, when collected in late autumn, sliced lengthwise, and dried, is worth six to eight cents a pound in the drug market. (Fig. 234.)

Stems one to three feet high, branching, hairy. Lower leaves long ovate to lance-shaped, thick, rough, net-veined, hairy on both sides, narrowing at base to margined petioles; upper leaves decurrent on the stem in long, wedge-shaped wings. Flowers in curving terminal racemes, yellowish white, sometimes light purple; corolla a little more than a half-inch long, the tube somewhat dilated, the throat crested below the lobes which are very short and spreading; five stamens inserted on the tube and included; calyx with five lance-shaped segments, acute, rough, hairy. Nutlets about one-sixth of an inch long, ovoid, brown, shining, nearly smooth, the base concave and toothed. 


\section{Means of control}

Deep cutting, well below the crown, before the first flowers mature. Dormant seeds may furnish a young crop, but these plants are easily pulled while the taproot is small.

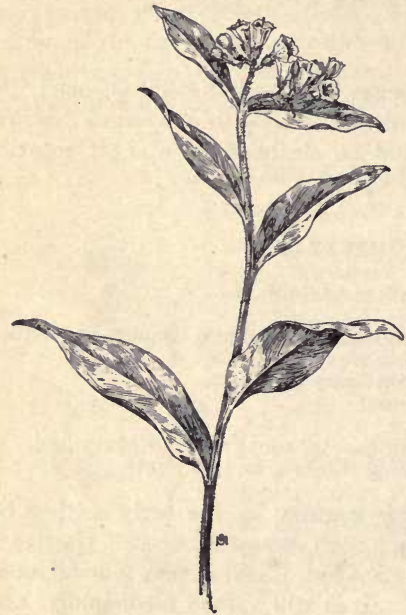

Frg. 234. - Comfrey (Symphytum officinale). $\times \frac{1}{4}$.

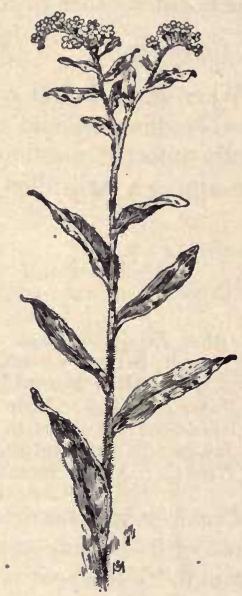

FIG. 235. - Small Bugloss (Lycopsis arvensis). $\times \frac{1}{2}$.

\section{SMALL BUGLOSS}

Lycópsis arvénsis, L.

Introduced. Annual. Propagates by seeds.

Time of bloom: June to September.

Seed-time: August to November.

Range: Quebec to western Ontario and Minnesota, southward to Virginia.

Habitat: Dry or sandy soil ; fields and waste places.

Stems six to eighteen inches high, slender, bristly-hairy, manybranched, the branches procumbent. Leaves one to two inches 
long, narrow oblong to lance-shaped, obtuse, slightly wavy-edged, bristly-hairy, sessile or the lower ones narrowing to short, margined petioles. Flowers in terminal, leafy-bracted, curving racemes, numerous, crowded, the corolla-tubes curved, less than a quarterinch long, with five spreading lobes, pale blue; the five included stamens inserted on the tube, the throat closed with bristly scales; calyx-lobes, acute, nearly as long as the corolla-tube. The four tiny nutlets rough-wrinkled, erect, with concave base.

(Fig. 235.)

\section{Means of control}

Prompt cutting at the beginning of bloom, preventing all seed production.

\section{WHEAT-THIEF}

\section{Lithospérmum arvénse, L.}

Other English names: Stoneseed, Field Gromwell, Corn Gromwell, Redroot, Pigeonweed, Bastard Alkanet.

Introduced. Annual or biennial. Propagates by seeds.

Time of bloom: Early May to August.

Seed time: July to September.

Range: Quebec to Ontario and Michigan, southward to Georgia and Kansas.

Habitat: Grain and elover fields, meadows, waste places.

An early immigrant from Europe, probably coming with the first seed-wheat. Once in the soil it was safe to stay, for the hard seeds retain their vitality for many years. Root red, thickish, rather deep, fringed with spreading, fibrous rootlets. Stem six to eighteen inches high, slender, branching, finely hairy. Alternate leaves a half-inch to two inches long, linear to lance-shaped, light green, entire, sessile or the lowest with short petioles, hairy on both sides. Flowers sessile or very nearly so in the upper axils; corolla cream-white, funnel-form, five-lobed, about a quarter-inch long, scarcely exceeding the hairy calyx, and having five stamens included in its tube. The spikes at first appear crowded but become distant with the succession of bloom, which is so long that ripe nutlets are dropping from the base while buds are yet developing at the top; the earlier fruits fall before the accompanying crop is ready for harvest. Nutlets about a tenth of an inch long, dull 


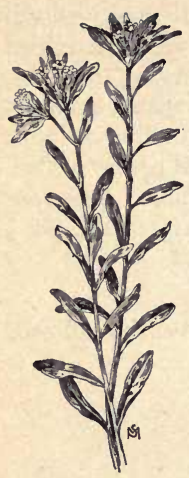

FIG. 236 . Wheat-thief (Lithospermum arvense). $\times \frac{1}{2}$.

brownish gray, wrinkled, pitted, and hard as stone, whence one of the common names; they are a common impurity of poorly cleaned wheat and rye, and also of timothy and alsike clover. (Fig. 236.)

\section{Means of control}

Sow clean seed. Where the appearance is new and the areas small enough to permit of hand-pulling, that operation pays because it saves the soil from befoulment. Spray infested grain fields with Iron sulfate or Copper sulfate when the first blossoms appear. Burn over stubbles for the purpose of destroying seeds on the surface. Drop winter wheat and rye from the rotation until a cultivated crop has been grown on the land for the purpose of stirring dormant seeds into growth.

\section{COMMON GROMWELL}

\section{Lithospérmum officindle, $\mathrm{L}$.}

Other English names: Pearl Plant, Graymile, Littlewale.

Introduced. Perennial. Propagates by seeds.

Time of bloom: May to August.

Seed-time: July to September.

Range: Quebec to Minnesota, southward to New Jersey.

Habitat: Fields, pastures, roadsides, and waste places.

Cattle refuse to eat these rough-hairy plants, though people are said to have used the leaves as a substitute for tea in Revolutionary times. Root deep-boring, pinkish white, spindle-shaped. Stems one to three feet high, erect, much branched, and leafy to the summit. Leaves broadly lance-shaped, pointed at both ends, rough-hairy above, downy underneath, entire, and sessile. Flowers cream-colored or greenish white, very small, on very short pedicels in the upper axils; corolla funnel-form, five-lobed, with five hairy crests in the throat; calyx rough-hairy, with narrow, 
acute segments, nearly as long as the corolla. The four nutlets each about an eighth of an inch long, ovoid, smooth, shining, pearl-white.

\section{Means of control}

Deep cutting while in first bloom. If the root is merely shaved at the surface it sprouts again, but when cut well below the crown it dies. Badly infested ground is best treated by putting to a well-tilled hoed crop.

\section{HOARY PUCCOON}

\section{Lithospérmum canéscens, Lehm.}

Other English names: Paint Plant, Gray Gromwell.

Native. Perennial. Propagates by seeds.

Time of bloom: April to June.

Seed time: June to August.

Range: Ontario to the Northwest Territory, southward to Virginia, Alabama, and Arizona.

Habitat: Dry soil; prairies; fields, meadows, pastures, waste places.

The thick, deep-boring, red root of this plant yields a red stain or dye; the Indians used it for decorating their naked bodies, before battle or on ceremonial occasions, and they called all plants from which they obtained such juices Puccoon. In grain fields it is even more obnoxious than the Wheat-thief, because it is perennial, and its hard, pearl-like seeds are possessed of exceedingly long vitality.

Stems six to fifteen inches high, simple or branched at the top, covered with fine, grayish, appressed hairs, particularly when young. Leaves one-half inch to nearly two inches in length, oblong to linear, obtuse, appressed hairy above, downy beneath, entire, sessile. Flowers sessile in the upper axils, the ends of the branches forming dense spikes, usually curved; corolla about a half-inch long, deep orange, the five lobes spread salver-form, the tube of a lighter yellow and longer than the hairy calyx. Nutlets about an eighth of an inch long, ovoid, pointed, keeled, smooth, and lustrous pearl-white.

Means of control the same as for the Common Gromwell. 


\section{VIPER'S BUGLOSS}

Èchium vulgàre, L.

Other English names: Blueweed, Blue Devil, Blue Thistle, Viper's Herb, Snake Flower.

Introduced. Biennial. Propagates by seeds.

Time of bloom: June to September.

Seed-time: August to November.

Range: New Brunswick to Ontario and Nebraska, southward to Georgia.

Habitat: Fields, meadows, pastures, waste places.

In Australia this weed is known as "Paterson's Curse," from the settler who unwittingly introduced it, and it is "proclaimed"

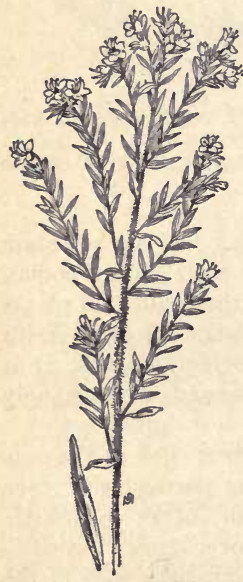

Fig. 237. - Viper's Bugloss (Echium vulgare). $\times \frac{3}{4}$. stamens are unequal, the longer ones exserted and all have red anthers. Nutlets small, three-angled, wrinkled, of very long vitality, and too of ten an impurity among other seeds. 


\section{Means of control}

In meadows and pastures, spudding or hoe-cutting first-year leaf tufts from their roots in autumn or early spring. Overlooked plants that produce flowering stalks the next season should be cut close to the ground before any seed matures. Cultivation of the ground destroys the weed if no seeds are in the soil.

\section{EUROPEAN VERVAIN}

Verbèna officinàlis, L.

Other English names: Holy herb, Herb-of-the-Cross, Simpler's Joy, Enchanter's Plant.

Introduced. Annual. P Propagates by seeds.

Time of bloom: June to September.

Seed-time: July to November.

Range: New England and Middle Atlantic States, southward to Florida and Texas. Also on the Pacific Coast.

Habitat: Fields, roadsides, and waste places.

An escape from gardens that has become a troublesome weed in many places. Stem one to three feet tall, smooth, four-sided, slender, branched and spreading. Leaves opposite, oblong lanceshaped in outline but pinnatifid, the lower ones tapering to margined petioles; upper ones becoming nearly or quite entire and sessile. Flowers purple, very small, on slender, bracted, threadlike spikes often four or five inches long; corollas tubular, the five lobes spreading salver-form; stamens four, in two pairs of unequal length, included ; calyx five-toothed, enclosing the fruit, which, as in all the Vervains, splits into four very small, hard nutlets.

\section{Means of control}

Prevent seed production by close cutting or pulling while the plant is in early bloom.

\section{WHITE VERVAIN}

Verbèna urticafdlia, L.

Other English name: Nettle-leaved Vervain.

Native. Perennial. Propagates by seeds.

Time of bloom: June to September. 
Seed-time: August to November.

Range: New Brunswick to Minnesota, southward to Florida and Texas.

Habitat: Fields, meadows, roadsides, and waste places.

Seeds of this plant are said to retain their vitality for several years, and they are too often an impurity of poorly cleaned clover and grass seed. Stem three to five feet in height, slender, foursided, finely rough-hairy or sometimes smooth, with ascending branches. Leaves opposite, thin, oblong ovate, long-pointed, coarsely toothed, with short, grooved petioles; they are often splotched or covered with a white mildew fungus, which makes the weed most unsightly and a menace to better plants. Spikes loosely panicled, very long, slender, numerous, set very sparsely with tiny, white flowers, of which only a few are open at a time and these are hardly noticeable. Nutlets soon fall after ripening.

\section{Means of control}

Small areas may be grubbed out or hand-pulled when the ground is soft; but land badly infested with this weed should be put under cultivation for a short rotation, in order that its perennial roots and dormant seeds may be cleaned from the soil.

\section{BLUE VERVAIN}

\section{Verbèna hastdta, L.}

Cither English names: Wild Hyssop, Simpler's Joy.

Native. Perennial. Propagates by seeds.

Time of bloom: June to September.

Seed-time: August to November.

Range: Nova Scotia to British Columbia, southward to Florida and New Mexico.

Habitat: Moist meadows, fields, and waste places.

A conspicuous plant because of the deep violet color of its panicled spikes of flowers. Stem three to seven feet tall, erect, square, finely rough-hairy, coarsely grooved, and branching near the top. Leaves oblong lance-shaped, long-pointed, the lower ones often halberd-shaped at base, finely rough-hairy, doubletoothed, darker above than below, with heavy veins and short, 
grooved petioles. Spikes numerous, very slender, the small, five-lobed, tubular flowers sometimes scattered along their length but usually grouped in a short circlet with a green stretch of buds above and another of growing and ripening fruits below. The small, brown nutlets usually drop from the stalk, calyx and all, without separating. They are a frequent impurity in clover and grass seeds.

Means of control the same as for White Vervain.

\section{LARGE-BRACTED VERVAIN}

Verbèna bractedsa, Michx.

Native. Annual or perennial. Propagates by seeds.

Time of bloom: May to July.

Seed-time: June to August.

Range: Minnesota to British Columbia, southward to Georgia, Florida, Texas, and California.

Habitat: Plains and prairies; grasslands, waste places.

Stems numerously branched from the base, some prostrate and some ascending, very slender, four-sided, rough-hairy, six to fifteen inches long. Leaves broadly wedge-shaped in outline but pinnatifid, the lobes cut and toothed, the basal pair spreading and narrowing abruptly to short, margined petioles. Spikes single, the blossoms being scattered somewhat remotely along each spike and having the hairy bracts subtending the flowers very long and stiff, the lower ones pinnatifid, nearly concealing the small, purplish blue corollas. Each plant produces many of the little nutlets which foul the soil worse than other species because of their earlier maturity. Seed-bearing plants are often transported in baled hay, and the weed has of recent years been thus introduced in a number of widely separated localities in the northeastern part of the country.

Means of control the same as for $V$. stricta. 


\section{HOARY VERVAIN}

\section{Verbèna stricta, Vent.}

Other English names: Woolly Vervain, Mullen-leaved Vervain. Native. Perennial. Propagates by seeds.

Time of bloom: June to September.

Seed-time: August to November.

Range: Ontario to Minnesota and Wyoming, southward to Tennessee, Texas, and New Mexico.

Habitat: Dry plains and prairies.

The range of this plant is increasing, mostly by the agencies of impure seed and baled hay. Stem ten to thirty inches tall, rather stout, obtusely four-angled, erect, simple or with a few branches above. Leaves ovate, pointed or sometimes obtuse, doubletoothed, sessile or the lower ones with short petioles; the whole plant clothed with fine, white-woolly hair. Spikes very dense, rather stout, usually solitary but sometimes several in a panicle, becoming six inches to a foot in length when fruiting; corolla purple, large for a Vervain, being more than a quarter-inch long and the five spreading lobes about as broad. Its dense flowering habit makes the plant very productive.

\section{Means of control}

Only by a short rotation of cultivated crops is it practicable to rid the ground of the perennial roots and the dormant seeds of this weed.

\section{CREEPING BUGLEWEED}

Ájuga réptans, L.

Other English names: Carpenter's Herb, Sicklewort, Brown Bugle. Introduced. Perennial. Propagates by seeds and by stolons. Time of bloom: May to July.

Seed-time: June to August.

Range: Eastern Canada and New England to southern New York. Habitat: Fields and waste places.

This plant is a member of the Mint Family which have in common the characteristics of square stems, opposite leaves, corollas more or less two-lipped, stamens four in unequal pairs, 
or sometimes only two, and a deeply four-lobed ovary, which in fruit forms four tiny nutlets or achenes surrounding the base of a single style in the bottom of a persistent calyx. (Fig. 239.)

Stems rather stout, smooth or only slightly hairy, six inches to a foot in height. Root-leaves tufted, obovate, rounded at apex, scallop-toothed, tapering to margined petioles; stem-leaves sessile or nearly so, rounded or a short oval, becoming entire near the top. Thrust out from the tufted basal leaves are numerous slender stolons, a foot or more long, which take root and form new plants, causing the weed to grow in patches. Flowers, pale blue or white, in axillary clusters, sessile, very small; the upper lip of the corolla very short and cleft, the lower one three-lobed and spreading; calyx five-toothed. Nutlets roughened, and very small.

\section{Means of control}

Scattered colonies of the plant should be hoed out and removed from the soil, for if left

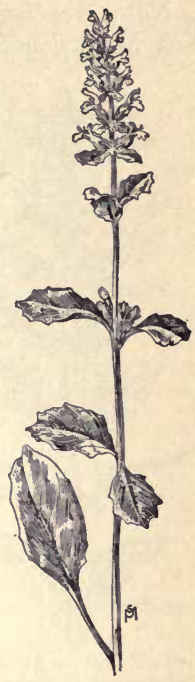

FIG. $239 .-$ Creeping Bugleweed (Ajuga reptans). on moist ground it will take root again. Cultivation of the soil destroys the weed, and badly infested ground should be so treated.

\section{AMERICAN GERMANDER}

Teùcrium canadénse, $\mathrm{L}$.

Other English name: Wood Sage.

Native. Perennial. Propagates by seeds.

Time of bloom: June to September.

Seed-time: August to November.

Range: New England to Nebraska, southward to Georgia and Texas.

Habitat: Moist grasslands, roadsides, fencerows, banks of streams, and waste places. 
Not a woodland plant in spite of its name. Stem one to three feet high, slender, erect, simple or with few branches, covered

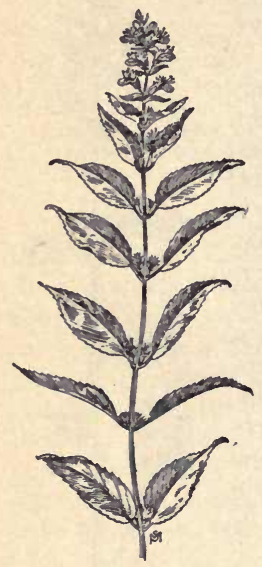

Frg. 240. - American Germander (Teucrium canadense). $\times \frac{1}{2}$. with fine, appressed hairs. Leaves longovate to lance-shaped, green above, appressed gray-hairy beneath, sharply toothed, narrowing to short petioles. Flowers in long, crowded racemes, six inches to a foot in length, making the plant conspicuous when growing in meadows; calyx densely velvety-hairy, five-toothed; corolla pink or rose-purple, the lower lip with one large, rounded spreading lobe and two small pointed ones; upper lip deeply cleft, the exserted stamens and style thrust out between its lobes; the blossoms are often nearly an inch long, in whorls of six or more, on very short pedicels, subtended by leafy bracts about as long as the calyx. Nutlets obovoid and rough. (Fig. 240.)

\section{Means of control}

If the infestation is new, grub out or hand-pull the plants when the ground is soft, before the first flowers mature; or cut closely and repeatedly during the growing season, so as to starve the roots and prevent seed production.

\section{BLUE CURLS}

\section{Trichostèma dichotomum, $\mathbf{L}$.}

Other English name: Bastard Pennyroyal.

Native. Annual. Propagates by seeds.

Time of bloom: July to Oetober.

Seed-time: August to November.

Range: Maine to Kentucky, Florida, and Texas.

Habitat: Dry soil ; fields and waste places.

Stem six to eighteen inches high, slender, stiff, obtusely fourangled, much branched, finely hairy, and viscid. Leaves oblong 
to lance-shaped, pointed at both ends, finely clammy-hairy on both sides, entire, with very short petioles. Panicles loosely spreading, the flowers single or in pairs on forking branchlets, subtended by paired bracts; the flowers are blue, sometimes pink or white, their most noticeable feature being the four very long, upcurving, violet stamens, thrust far out beyond the corolla more than as long again; in the bud they are spirally coiled and both the common name and the "book-name" have reference to their remarkable appearance; corolla tube very slender, its lower lobe oblong and declined; calyx unequal, with three long and two short lobes, and when the withered corolla falls the four small, roughened, ovoid nutlets are in plain sight. (Fig. 241.)

\section{Means of control}

Enrich the land; when cultivated and supplied with humus, which will enable the soil to retain moisture, the droughtloving weed will disappear.

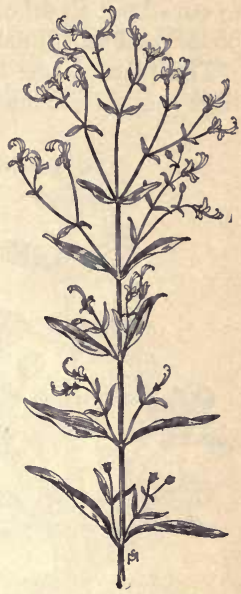

FIG. 241. - Blue Curls (Trichostema dichotomum). $\times \frac{1}{3}$.

\section{HOREHOUND}

Marrùbium vulgàre, $\mathrm{L}$.

Other English names: Marrube, Houndsbene, Marvel.

Introduced. Perennial. Propagates by seeds.

Time of bloom: June to September.

Seed-time: August to November.

Range: Maine and Ontario to South Carolina, Tennessee, and Texas.

British Columbia to California.

Habitat: Dry soil ; upland fields and pastures.

A most troublesome weed where sheep are kept, for the long points of the calyx-lobes harden into hooked spines which catch in the fleeces to the detriment of the latter and which also help 
to distribute the seed. In this way many of the mountain pastures of the Pacific Coast have been so overrun with this weed as to crowd out all other growth. The taste is biting and persistently bitter, and no animal will eat the herb.

The plant is used in medicine as a cough remedy and more than a quarter-million pounds of the dried herb are annually im-

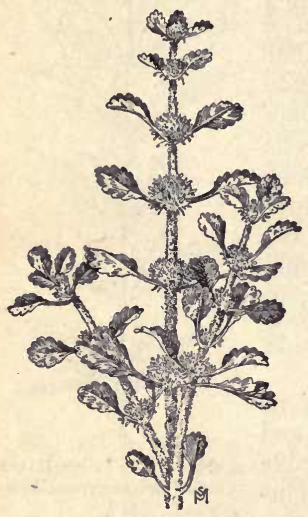

Frg. 242. - Common Horehound (Marrubium vulgare). $\times \frac{1}{4}$.

ported from Europe. The parts used are the leaves and the flowering tops, collected just before the buds open and quickly dried in the shade. The price is two or three cents a pound.

Stem one to two feet high, stout, erect, square, white-woolly, branching and bushy. Leaves opposite, broadly oval or rounded, with scalloped edges, wrinkled and rough-hairy above, whitewoolly below, with large veins and short, stout petioles. Flowers nearly white, in dense axillary whorls, the upper lip of the small, tubular corolla notched, the lower one three-lobed and spreading; stamens included; calyx white-woolly, with ten awl-like, recurved teeth, the alternate ones shorter. Nutlets ovoid and smooth. (Fig. 242.)

\section{Means of control}

Frequent and close cutting before seed development; or, if the colonies are not too large, removal by hoe-cutting. If the ground is fit for cultivated crops, the necessary tillage promptly destroys the weed.

\section{CATNIP OR CATMINT}

Nepeta Catdria, L.

Introduced. Perennial. Propagates by seeds.

Time of bloom: June to September.

Seed-time: July to November. 
Range: New Brunswick and Quebec to Minnesota, southward to Georgia and Kansas.

Habitat: Roadsides, neglected farmyards, waste places.

This herb was formerly much used as a tonic and home remedy for disordered nerves. It is still quoted in the drug market at three to eight cents a pound, the leaves and the flowering tops being the parts used, collected when in full flower.

Stem one to three feet high, erect, rather stout, square, downy-hairy, and much branched. Leaves opposite, ovate or oblong heart-shaped, light green above, downy beneath, deeply scallop-toothed, with slender petioles. Flowers in terminal spikes one to four inches long, subtended by small, narrow bracts; corolla pale lilac or white, with pale purple dots, the tube dilated in the throat and the broad middle lobe of the lower lip finely scalloped; the stamens ascending under the upper lip, the lower pair the shorter; calyx downy, five-toothed, persistent, containing the four nutlets, which are ovoid, slightly flattened, smooth, and brown. (Fig. 243.)

\section{Means of control}

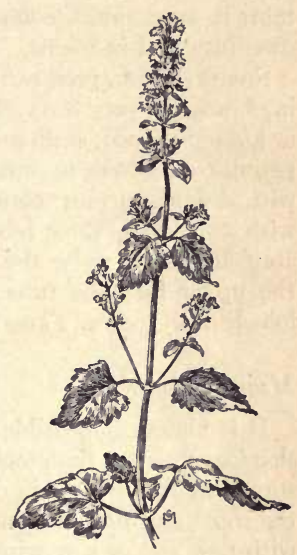

FIG. 243. - Catnip or Catmint (Nepeta Cataria). $\times \frac{1}{\text {. }}$

Cats are very fond of the plant and a few stalks grown for the family pet may be welcome; but patches of the weed about farmyards make a slovenly appearance and should be grubbed out. Roadside and waste-land growth should be cut when beginning to bloom.

\section{GROUND IVY}

\section{Nepeta hederdcea, Trevisan}

Other English names: Field Balm, Gill-over-the-Ground, Gill-ale, Ale-hoof, Cat's Foot.

Introduced. Perennial. Propagates by seeds and by rootstocks. 
Time of bloom: April to July.

Seed-time: Late May to August.

Range: Newfoundland to Ontario and Minnesota, southward to Georgia and Kansas.

Habitat: Moist or shady soil ; lawns and yards, waste places.

In old days, before the hop took its place, this plant was used for flavoring and clarifying the home-brewed ale. Like the Plantain, it seems almost domesticated and is a familiar weed about dwellings and in towns.

Stems slender, prostrate, and creeping, with many small, ascending branches, very leafy, three to five inches high. Leaves rounded or kidney-shaped, scallop-toothed, green on both sides, with slender petioles. Flowers in small axillary clusters, pale purple, spotted with deeper purple; corolla about a half-inch long, its upper lip with two lobes, three lobes in the lower lip, the upper pair of stamens nearly twice the length of the lower ones, rising against the upper lip; the tube more than twice the length of the fivelobed, hairy calyx. The four small nutlets ovoid and brown.

\section{Means of control}

It is almost impossible to dig out this weed and get all of the slender, creeping rootstocks. If the infested ground is a lawn the surest method is to skin off the rather shallow layer that contains the roots and probably also a good supply of the seeds, and relay with new sod or sow with clean seed.

\section{HEAL-ALL}

Prunèlla vulgàris, L.

Other English names: Self-heal, Hock-heal, Heart-of-the-Earth, Carpenter's Herb, Sicklewort.

Native. Perennial. Propagates by seeds and by rooting at the nodes.

Time of bloom: May to October.

Seed-time: June to November.

Range: Nearly all parts of the world. Native to Europe and Asia. Habitat: Fields, lawns and yards, open woods, and waste places.

A frequent pest in lawns, stooling out when beheaded by the 
lawn-mower and sometimes taking complete possession of the sward. It adapts itself to circumstances, fruiting when not more than two inches high or sometimes attaining to more than a foot, the square, grooved stem sometimes erect or ascending, or often prostrate. Leaves long ovate, approaching to lance-shaped, obtuse, entire or with shallow scalloped edges, usually smooth or sometimes sparsely hairy, narrowing to short petioles. Flowers in densely packed terminal and axillary spikes, clustered in threes in the axils of membranaceous, veined, and hairy bracts; the blossoms are in various shades of purple, some very deep in color, others so pale as to be nearly white; corolla tubular, with a lengthened upper lip which is arched into a hood, into which the longer of the two pairs of stamens ascend; the lower lip three-lobed and spreading; calyx also two-lipped, closed in fruit, the upper lip truncate or with three short teeth, the lower one twocleft and pointed. Seeds four small, ovoid nutlets, which are ripening and dropping all summer. (Fig. 244.)

\section{Means of control}

In fields the weed may be killed by frequent hoe-cutting. While treating

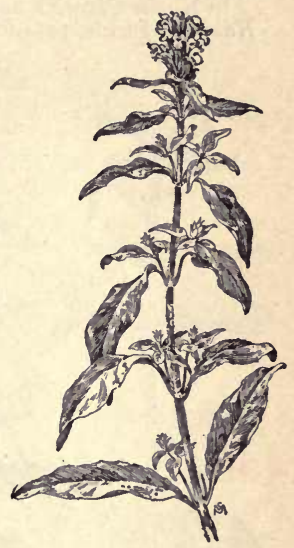

Fig. 244. - Heal-all (Prunella vulgaris). $\times \frac{1}{4}$. a border with Iron sulfate in order to kill Chickweed, the writer discovered that the Heal-all succumbed quite as readily to its blight, the leaves blackening and falling off, while the buds ceased to grow and in a few days rotted; without leaf-growth the roots cannot survive, and therefore Prunella can be driven from the lawns by repeated sprayings without injury to the grass. The solution used was somewhat strong - about eight per cent - but grasses readily recover from much stronger "doses" of this chemical; and the beauty of the sward can afford to endure temporary injury for the sake of relief from such company. 


\section{HEMP NETTLE}

Galeopsis Tetrdhit, L.

Other English names: Dog Nettle, Bee Nettle, Stinging Nettle, Wild Hemp, Bastard Hemp.

Introduced. Annual. Propagates by seeds.

Time of bloom: June to August.

Seed-time: August to October.

Range: Newfoundland to British Columbia and Alaska, southward to North Carolina and Michigan.

Habitat: Fields, pastures, roadsides, and waste places.

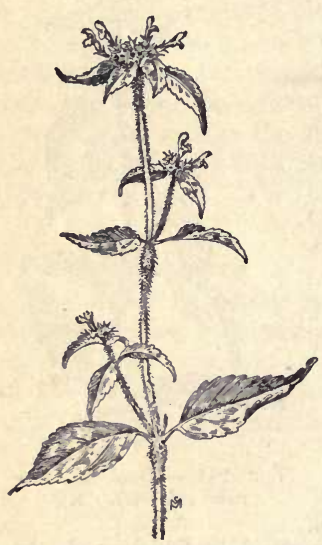

Fig. 245. - Hemp Nettle (Galeopsis Tetrahit). $\times \frac{1}{3}$.

Grazing cattle shun this weed, and gloves are needed in handling it when full-grown. Stem one to three feet tall, stout, four-sided, swollen below the joints, much branched and spreading, bristling with prickly hairs. The opposite leaves are ovate, longpointed, coarsely toothed, bristlyhairy on both sides, and with bristly petioles. Flowers in a dense, short, leafy-bracted terminal spike and in axillary clusters; corolla nearly an inch long, pink or pale purple, with a stiff, concave entire upper lip, longer than the lower one, which has three lobes; the tube is about twice the length of the bristly calyx, which has five long, nearly equal awl-like points. Seeds four small, flattened, ovoid nutlets. (Fig. 245.)

\section{Means of control}

Prevent reproduction by close cutting while young. If nearing maturity when cut the weed should be removed from the ground, as the large, swollen stems contain enough nutriment to ripen the seed. 


\section{HENBIT}

Ldmium amplexicaúle, $\mathrm{L}$.

Other English names: Dead Nettle, Blind Nettle, Bee Nettle.

Introduced. Annual or biennial. Propagates by seeds.

Time of bloom: April to October.

Seed-time: May to November.

Range: New Brunswick to Ontario and Minnesota, southward to Florida and Arkansas.

Habitat: Cultivated ground, waste places.

This weed flourishes best in cool weather, dying down in the heat of midsummer but recovering in autumn and maturing a late crop of seeds; autumn seedlings develop fruit very early in the spring, so that the soil is fouled with two abundant sowings each year. Stems six to eighteen inches long, slender, square, branching from the base and also from the lower axils, weak and spreading on the ground. Leaves opposite, rounded, deeply scallop-toothed, sparsely hairy, the lower ones with short petioles, the upper ones sessile and clasping. Flowers in small axillary and terminal clusters; calyx hairy, with five erect, awllike teeth: corolla-tube slender, with the rpper lip erect, entire, and bearded, dark red, the lower one three-lobed, white, spotted with purple; stamens ascending against the upper lip, the anterior

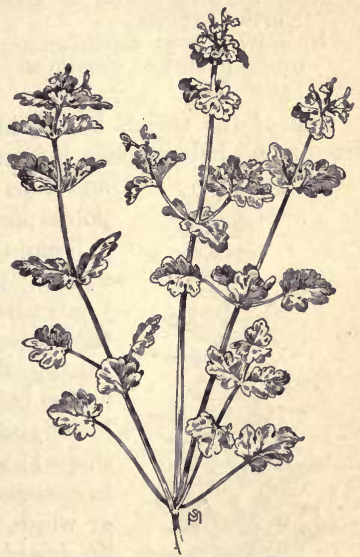

Frg: 246. - Henbit (Lamium amplexicaule). $\times \frac{1}{\text {. }}$. pair the longer. The flowers contain much nectar and honeybees are frequent visitors. Seeds four long, ovoid nutlets, dark brown, specked with white dots. These seeds are long-lived and tillage should begin early and be continued late, in order to prevent their development and distribution. (Fig. 246.) 


\section{Means of control}

For small areas destruction of seedlings by hoe-cutting in autumn or early spring; in fields thorough cultivation followed by heavy seeding with clover, which will crowd out the weed.

\section{MOTHERWORT}

\section{Leonùrus Cardìaca, L.}

Other English names: Lion's-tail, Lion's-ear; Cowthwort.

Introduced. Perennial. Propagates by seeds.

Time of bloom: June to September.

Seed-time: August to November.

Range: Nova Seotia to Minnesota and Nebraska, southward to North Carolina.

Habitat: About dwellings and in barnyards; on roadsides; a frequent tenant of vacant city lots.

One of the social, half-domesticated weeds, seldom found far from men's habitations; it is medicinally valuable, the dried leaves

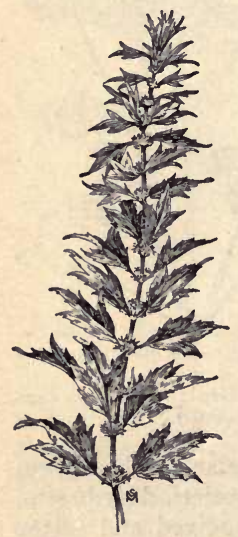

Fio. 247. - Motherwort (Leonurus Cardi$a c a) . \quad \times \frac{1}{2}$. and tops being worth three to five cents a pound in the drug market.

Stem two to five feet tall, rather stout, square, with a few ascending branches. Leaves dark green, thin, finely rough-hairy; the lower ones rounded, palmately lobed, usually five-pointed, often three or four inches broad; higher up they become threelobed and near the top they are often lanceshaped; all with slender petioles. Flowers in crowded axillary whorls, pink, pale purple, or white, the corolla with its curving upper lip bearded outside, the lower one threelobed and purple-dotted ; stamens ascending against the upper lip, the lower pair the longer. Calyx hairy, with five awl-like points which become hard and rigid; each contains four small, brown, three-angled nutlets with blunt or truncate apex tipped with fine, short, bristly hairs. (Fig. 247.) 
Means of control

Deep cutting with hoe:or spud before any seed has matured, using dry salt on the shorn surfaces for the purpose of checking new growth.

\section{HEDGE NETTLE}

Stàchys paluistris, L.

Other English names: Roughweed, Marsh Woundwort, Clown's Heal, Lead Nettle.

Native. Perennial. Propagates by seeds.

Time of bloom: June to September.

Seed-time: August to November.

Range: Newfoundland to the Northwest Territory, southward to New York, Michigan, and Illinois; in the Rocky Mountains to New Mexico. Also native to Europe and Asia.

Habitat: Damp grasslands and borders of streams.

A coarse weed, the stem one to four feet tall, stout, erect, square, the angles bristling with stiff, downwardpointing hairs. Because of its prickly hairiness and unpleasant taste cattle refuse to eat the plant either green or cured in hay. Leaves thick, oblong to lance-shaped, rounded or heartshaped at the base, rough-hairy, coarsely saw-toothed, sessile or with very short petioles. Flowers in terminal interrupted spikes, in whorls of six to ten with small leafy bracts below; calyx bristly-hairy, its awllike teeth more than half as long as the tube of the corolla, which is more than a half-inch in length, the lips pink or pale purple, spotted with deeper purple; the upper lip concave and bearded outside, the unequal



Fra. 248. - Hedge Nettle (Stachys palustris). $\times \frac{1}{3}$. 
stamens ascending against it, the lower lip three-lobed and spreading. Seeds small, ovoid nutlets. (Fig. 248.)

\section{Means of control}

Drainage of the ground; prevention of seed development by close cutting early in the season. Cultivation of the soil at once destroys the perennial roots.

\section{AMERICAN PENNYROYAL}

Hededma pulegioides, Pers.

Other English names: Mock Pennyroyal, Squaw Mint, Stinking Balm, Mosquito Plant, Tickweed.

Native. Annual. Propagates by seeds.

Time of bloom: July to September.

Seed-time: August to October.

Range: Cape Breton Island to Ontario and Minnesota, southward to Florida and Nebraska.

Habitat: Thin meadows, upland pastures, and in open woods about old stumps.

The oil distilled from this herb is much used in making the "mosquito dopes" which hunters and fishermen and many other

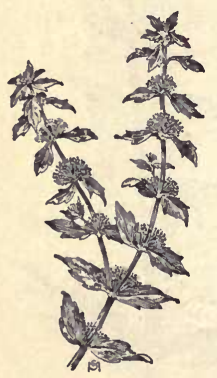

Fig. 249. - American Pennyroyal ( $\mathrm{He}$ deoma pulegioides). $\times \frac{1}{3}$. persons are obliged to use in localities where mosquitoes are a plague; the plant is also used medicinally and the leaves and flowering tops, collected in full bloom and dried, are worth one to three cents a pound. In taste and odor the plant is very like the true Pennyroyal, which is European.

Stem erect, square, very slender, softly hairy, much branched, six inches to a foot in height. Leaves a half-inch to an inch long, thin, oblong-ovate, sparingly toothed, obtuse at apex, and narrowed to short petioles. Flowers in small axillary clusters, on short, hairy peduncles; calyx hairy, the three upper teeth triangular, the two lower ones awl-shaped; corolla lavender or pinkish, about a quarter-inch 
long, the upper lip merely notched but the lower one three-lobed and spreading; perfect stamens two, rising against the upper lip, with two rudimentary ones below. The four nutlets within the persistent calyx, very small. (Fig. 249.)

Means of control

Meadows infested with the plant should be cut before the seeds develop. Cultivation and enrichment of the soil, where practicable, soon enables better plants to crowd out the weed.

\section{CALAMINT OR WILD BASIL}

Saturèja vulgàris, Fritsch

(Clinopddium vulgàre, L.)

Other English names: Field Basil, Stone Basil, Horse Thyme, Basilweed.

Native. Perennial. Propagates by seeds and by stolons.

Time of bloom: June to August.

Seed-time: August to October.

Range: Nova Scotia to Manitoba, southward to West Virginia, and in the Rocky Mountains to Colorado.

Habitat: Alluvial banks, brushy upland pastures, and borders of woods.

Not even sheep care to eat Calamint, and if the plant had not such a preference for partial shade its stoloniferous habit would make it a bad weed. Stems erect, slim, square, hairy, ten to twenty inches tall, usually with a few branches but often simple. Leaves also hairy, variable in shape but mostly a longpointed oval, sometimes toothed, sometimes entire or wavy-edged, the upper ones sessile, the lower ones having short petioles. Flowers in dense axillary and terminal clusters, the latter nearly globular; the subtending bracts bristly-hairy

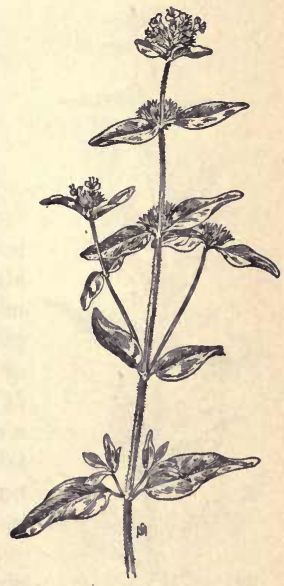

Fro. 250. - Calamint or Wild Basil (Satureja vulgaris). $\times \frac{1}{8}$. 
and as long as the calyx, which is also hairy; corolla lavender, pink, or whitish, its tube not much exceeding the calyx-teeth, the upper lip entire or only slightly notched, the lower lip three-lobed and spreading; stamens four, ascending, the longer pair exserted. Seeds four small, ovoid, smooth nutlets. (Fig. 250.)

\section{Means of control}

Deep hoe-cutting, before seeds are developed or stolons take root.

\section{BUGLEWEED}

Lycdpus virginicus, L.

Other English names: Water Horehound, Ditch Horehound, Virginia Horehound, Buglewort, Paul's Betony.

Native. Perennial. Propagates by seeds and by stolons.

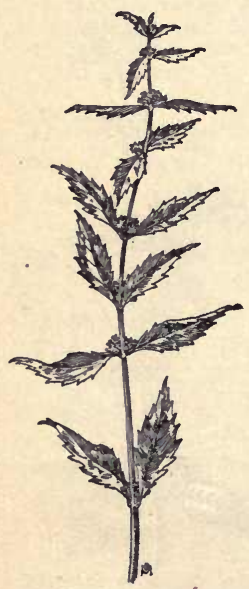

Fig. 251. - Bügleweed (Lycopus virginicus). $\times \frac{2}{6}$.
Time of bloom: July to September.

Seed-time: August to November.

Range: Labrador to British Columbia, southward to Florida, Alabama, and Missouri.

Habitat: Wet meadows, banks of streams ; of ten clogs ditches.

A common weed, of which the most troublesome part is the long, thread-like, leafy, interlacing runners, reaching out in all directions from the parent, sending up new plants and making tangled mats. The plant is used in medicine and brings three or four cents a pound in the drug market. It would be some satisfaction, in clearing out a ditch, to make the weed itself pay for the labor. For this purpose the herb must be pulled entire while in full flower, and dried in the shade.

Stems six inches to two feet high, slender, obtusely four-sided, usually somewhat hairy. Leaves dark green or tinged with purple, long ovate, firm, coarsely toothed, pointed 
at both ends, those near the base tapering to short petioles, the upper ones sessile. Flowers in dense axillary clusters, pale purple to white, the lobes of the calyx nearly equal, the corolla-tube cylindric to funnel-form, with four flaring lobes, suggesting the reason why the plant is named Bugleweed; perfect stamens two, the posterior pair being rudimentary. Seeds four small nutlets, three-angled, longer than the calyx-lobes, in plain view when mature. (Fig. 251.)

\section{Means of control}

In fields, frequent cutting, close to the ground, while in early flower; or, better, hand-pulling, which often takes runners and all. In ditches the weed must be grubbed out or hand-pulled.

\section{PEPPERMINT}

Méntha piperita, $\mathbf{L}$.

Other English names: Lamb Mint, Brandy Mint.

Introduced. Perennial. Propagates by seeds and by rootstocks.

Time of bloom: June to September.

Seed-time: August to November.

Range: Nova Scotia to Ontario and Minnesota, southward to Florida and Tennessee.

Habitat: Prefers moist soil, but will grow anywhere.

Some thousands of acres in this country, particularly in the states of New York, Indiana, and Michigan, are very profitably given to the cultivation of this plant for the distillation of its oil, which is used in flavoring confectionery, in cordials and cosmeties, and also medicinally. But beyond the bounds of cultivation the plant is a troublesome weed. A bed of it in the herb garden is difficult of restriction within proper limits, as the long, underground suckers are continually thrusting up new plants where they are not wanted.

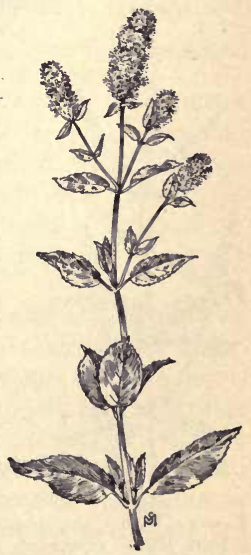

FIG. 252. - Peppermint (Mentha piperita). $\times \frac{1}{3}$. 
Stems one to three feet tall, often tinged with reddish purple, smooth, square, erect and branching. Leaves dark green, lanceshaped, about half as wide as long, sharply toothed, smooth on both sides except that the veins beneath are slightly hairy, pointed at tip, rounded or narrowed at base to a short petiole. Flowers in terminal spikes, obtuse at tip, densely whorled or sometimes interrupted, purple, rather showy; calyx smooth at base but with nearly equal hairy teeth; corolla with upper lip entire and lower lip three-lobed; the four stamens, equal, erect and included; style two-cleft at summit. Nutlets four in each calyx, ovoid and smooth. (Fig. 252.)

\section{Means of control}

A peppermint patch is about as difficult to clean out as is one of Quack Grass, for the rootstocks must all be removed from the soil or starved to death. In the one case, this means very diligent use of grubbing hoe and rake; in the other, such close and frequent cutting as to allow no green leaves to

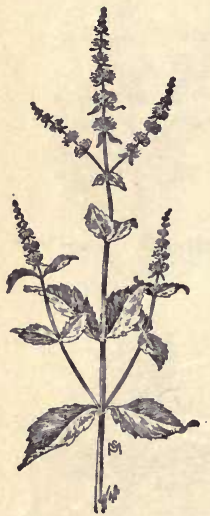

Frg. 253. - Spearmint (Mentha spicata). $\times \frac{1}{2}$. appear throughout the growing season.

\section{SPEARMINT}

Méntha spicàta, L.

Other English names: Lamb Mint, Mackerel Mint, Garden Mint, Our Lady's Mint, Sage of Bethlehem.

Introduced. Perennial. Propagates by seeds and by stolons.

Time of bloom: June to September.

Seed-time: August to November.

Range: Nova Scotia to Ontario and Minnesota, southward to Florida and Kansas.

Habitat: Moist ground ; fields and waste places.

Like the preceding species this mint is cultivated for the distillation of its oil, which has a milder flavor and action than that of Peppermint. Stems ten to twenty inches high, nearly smooth, erect, square, branching. Leaves lanceshaped, unequally toothed, the surface some- 
what puckered and wrinkled, sessile or with very short petioles. Flowers pale purple, in terminal, narrow, pointed, usually interrupted spikes, the subtending bracts long-pointed and conspicuous; calyx-teeth equal, smooth or only slightly hairy and nearly as long as the tube of the corolla which is smooth with upper lip entire or sometimes slightly notched, the lower lip with three rounded lobes; stamens all four of the same length, erect, included. (Fig. 253.)

Means of control the same as for Peppermint.

\section{BITTERSWEET NIGHTSHADE}

Sold̀num Dulcamàra, L.

Other English names: Woody Nightshade, Blue Bindweed, Felonwort, Poison Berry.

Introduced. Perennial. Propagates by seeds.

Time of bloom: May to September.

Seed-time: First fruits ripe in August but late clusters of ten cling to the vine until winter.

Range: New Brunswick to Minnesota, southward to Georgia and Kansas.

Habitat: Moist banks, fence rows, thickets, and around dwellings.

The fruits of this plant are not dangerously poisonous, but are sufficiently so to bring on unpleasant sensations of nausea and cramp, particularly if the seeds are well ripened. Birds eat the fruits, however, without, any apparent harmful effect, and void the seeds along fences and about house grounds and hedges, and the plants spring up where young children might find the berries and be tempted to eat them.

Stem slender, two to ten feet in length, round and smooth, or slightly hairy when young. Leaves alternate, thin, dark green, entire, with slim, grooved petioles, the lower ones ovate to heartshaped, the upper ones halberd-shaped or with two lateral ear-like lobes at the base which often become separate leaflets. Flowers in small cymose clusters, on short, slender peduncles springing from the side of the stem between the leaves; corolla violet-blue or purple, wheel-shaped, with five pointed lobes; stamens five, inserted on the throat of the corolla, the anthers uniting in a cone around the style; ovary two-celled; calyx-lobes short and obtuse, per- 
sistent at the base of the fruit, which is an ovoid pulpy berry, at first green, then bright orange, and finally ruby-red, the thin skin so transparent as to reveal the yellow seeds within. A single vine may exhibit all stages of coloring, from violet flowers to green and ripe fruit.

\section{Means of control}

Young plants may be hand-pulled when the ground is soft; older roots must be grubbed out. Or the shrub may be killed by pouring hot brine or caustic soda about the roots.

\section{COMMON, OR BLACK, NIGHTSHADE}

Solànum nigrum, L.

Other English names: Deadly Nightshade, Duscle, Poison Berry, Hound's Berry, Stubble Berry.

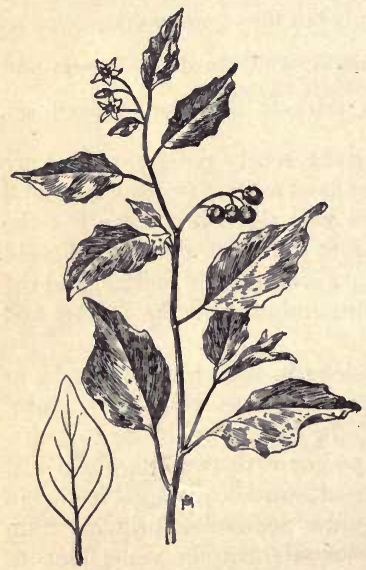

Fig. 254. - Black Nightshade (Solanum nigrum). $\times \frac{1}{3}$.
Native. Annual. Propagates by seeds.

Time of bloom: July to October.

Seed-time: Berries ripe in late August, but frequently are still maturing when plants are winterkilled.

Range: Nova Scotia to the Northwest Territory, southward to Florida and Texas.

Habitat: Cultivated ground, old fields, waste places.

The poisonous qualities of this plant are said to vary much with the conditions of its growth, the more dangerous having more of the characteristic musky odor. Some housewives boldly make pies of the fruit - occasionally with unpleasant consequences. Children have been poisoned by it, also calves, sheep, goats, and swine, but "fortunately few cases are fatal,",

${ }^{1}$ Thirty Poisonous Plants, by V. K. Chesnut, U. S. Dept. of Agriculture. 
though the illness caused by eating its ripe fruit is one of excessive nausea. (Fig. 254.)

Stem one to two feet high, round, slender, with spreading branches, when old often showing a purple tinge at the joints. Leaves alternate, long ovate, with slim, grooved petioles, thin, dark green, entire or sometimes wavy-edged, often bitten full of tiny holes by a small flea-beetle which infests the plant and makes it a menace to its relative, the potato. Flowers white, in small, umbellate clusters of three to ten on drooping peduncles springing from the side of the stem; corolla wheel-shaped, five-lobed, about a quarter-inch broad; stamens five, with filaments slightly hairy and obtuse anthers united in a cone around the style; calyxlobes much shorter, obtuse, spreading, persistent at the base of the berry, which is black, globular, smooth, a little more than a quarter-inch in diameter.

\section{Means of control}

Being annual the plants are readily destroyed by pulling or close cutting before the first fruits mature. If near maturity throw the plants on the compost heap, where fermentation will destroy the vitality of the seed; or burn them.

\section{HORSE NETTLE \\ Soldnum carolinénse, $\mathrm{L}$.}

Other English names: Sand Brier, Bull Nettle, Bull Thistle, Apple of Sodom, Tread-soft.

Native. Perennial. Propagates by seeds and by rootstocks.

Time of bloom: May to September.

Seed-time: July to November.

Range: Massachusetts, Connecticut, and southern Ontario, to Iowa and Kansas, southward to Florida and Texas.

Habitat: Meadows, pastures, and cultivated ground; invddes all crops.

A near relative of the potato and one of the worst weeds native to this country; southern in its origin but rapidly making its way northward and westward through the agencies of impure clover seed and baled hay. The deep-seated rootstocks are most tenacious of life; an Indiana farmer states that they "will live ten years 
under a heap of sawdust and grow as soon as the dust is removed." Sheep are the only grazing animals that will touch the plant, and they merely nibble off the fruits; the seeds are widely scattered

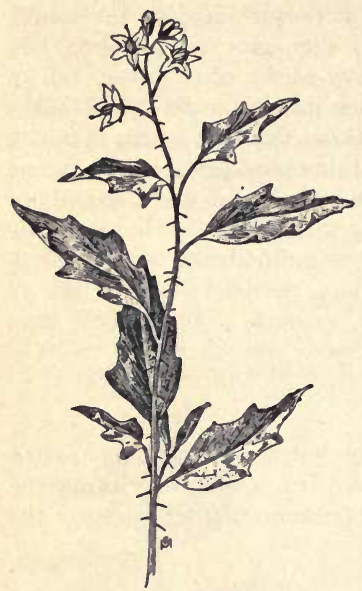

Frg. 255. - Horse Nettle (Solanum carolinense). $\times \frac{1}{8}$. in their droppings and many a productive acre is thus practically ruined. (Fig. 255.)

Stem six inches to two feet tall, erect, loosely branched, roughened with short, stiff, star-shaped hairs, and beset with sharp, awl-shaped, yellow spines. Alternate leaves two to five inches in length, oblong to ovate in outline, irregularly and coarsely wavy-toothed, or sinuatepinnatifid, covered with star-shaped hairs, veins and midrib prickly on both sides as are also the petioles. Flowers in open cymose clusters on prickly peduncles which spring from the side of the stem between the leaves, at first appearing terminal but becoming lateral as the stem lengthens; corolla pale violet or bluish white, five-lobed ; stamens with anthers equal and tapering toward the summit; calyx-lobes hairy, rather short, acute, persistent at the base of the fruit, which is an orange-colored berry, smooth, globular, about three-fourths of an inch in diameter, full of juicy pulp and flattened, straw-colored seeds.

\section{Means of control}

If the infestation is new and the area not too large, the plants may be killed outright by the use of hot brine, caustic soda, or kerosene which usually destroys all accompanying growths or, if pains are taken to apply the herbicide directly about the roots of the weeds, the neighboring plants may not be greatly damaged. If possible, all seed development should be prevented, which 
means early, deep, and frequent cutting with hoe or spud; salt on the cut surfaces will retard new growth and will also induce stock to bite off young shoots. In order to destroy the rootstocks short rotations are necessary, alternating cultivated crops, to which are given such thorough tillage that no green leaves are allowed to appear on the weeds, with such crops as rye, clover, and vetch, which will choke and smother the Nettle, supply late pasturage, and then be plowed under to furnish humus for another cultivated crop, well tilled. Two or three seasons of continuous effort are required in order to suppress the weed, but the labor is well repaid by the deliverance of the soil from such a pest.

\section{WHITE HORSE NETTLE}

Solànum eloagnifòlium, Cav.

Other English names: Prickly Nightshade, Silver-leaved Nightshade, Blue-top, Trompillo.

Native. Perennial. Propagates by seeds and by rootstocks.

Time of bloom: May to September.

Seed-time: July to November.

Range: Missouri and Kansas to Texas and Arizona.

Habitat: Plains and prairies; meadows, pastures, cultivated grounds; invades all crops.

Stems one to three feet high, slender, branching, silver-white with a dense, scurf-like covering of fine, many-rayed hairs, and beset with slender, very sharp prickles, or these are often lacking. Leaves oblong to lance-shaped, obtuse, wavy-edged or entire, covered with fine, star-shaped, white hairs, and narrowed abruptly at the base to short, prickly petioles. Flowers in cymose clusters, appearing terminal but soon becoming lateral, between the leaf axils; corolla violet or light

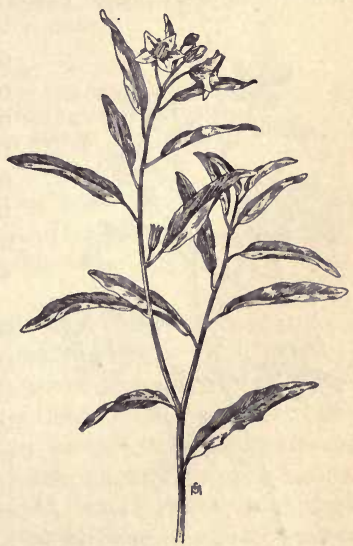

FIG. 256. - White Horse Nettle (Solanum eloagnifolium). $\times \frac{1}{4}$. 
blue, five-lobed, nearly an inch broad; the five stamens with equal tapering anthers, similar to the preceding species; calyxlobes narrow lance-shaped, acute, hairy. Fruit a globular, yellow berry, about a half-inch in diameter. (Fig. 256.)

Means of control the same as for the preceding species.

\section{BUFFALO BUR}

\section{Soldnum rostràtum, Dunal.}

Other English names: Beaked Nightshade, Sand Bur, Colorado Bur, Texas Thistle, Mexican Thistle.

Native. Annual. Propagates by seeds.

Time of bloom: May to September.

Seed-time: July to November.

Range: South Dakota to Tennessee, Mississippi, Texas, and Mexico. Locally in the Eastern States.

Habitat: Plains and prairies, foothills ; meadows, pastures, cultivated ground, waste places.

This is one of the weeds frequently transported in baled hay, and its appearance in eastern localities has usually been first in

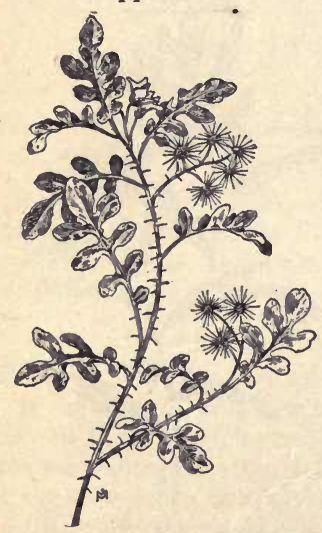

Fig. 257. - Buffalo Bur (Solanum rostratum). $\times \frac{1}{1}$. vacant lots near city livery stables and on near-by farms where such stable refuse has been purchased for manuring the land. Also the burs are distributed in the wool of sheep, as they formerly were in the matted coats of the buffalo herds, the plants being always abundant about the "buffalo wallows." (Fig. 257.)

Stem one to two feet high, much branched, covered with yellowish, starshaped hairs, and densely set with slender, awl-like, yellow spines. Leaves long oval in outline but once or twice pinnatifid, the segments often not opposite and very irregular in size, but the terminal one being usually largest, covered with rayed hairs, the midribs and the petioles prickly. Flowers in 
open racemose clusters, on prickly peduncles from the side of the stem, the corolla wheel-shaped, nearly an inch broad, golden yellow, its five lobes slightly irregular, the stamens and the style declined; the lowest of the five stamens much longer than the others and with an incurved beak; calyx densely prickly, becoming the bur that encloses the fruit. The plant frequently becomes a tumbleweed, distributing its burs as it rolls before the winds.

\section{Means of control}

Prevent seed production. Being annual the weed can readily be suppressed if it is persistently cut or pulled while in early flower. Other tasks may well be postponed for a day or two in order to rid the ground of so undesirable a tenant.

\section{MEXICAN - GROUND CHERRY}

\section{Phýsalis ixocárpa, Brotero}

Other English names: Strawberry Tomato, Tomatillo.

Introduced. Annual. Propagates by seeds.

Time of bloom: July to September.

Seed-time: Late August to November.

Range: Southern and Southwestern States; cultivated for its fruit, and freely escaping. Local farther north.

Habitat: Rich soil ; fields and waste places.

The fruit of this plant has a pleasant flavor, either in the fresh state or when used in catsups and sauces; birds also like the fruit and void the seeds unharmed, and in this and other ways the plant of ten becomes a troublesome weed.

Stem one to nearly three feet in length, much branched, at first erect but later drooped and spreading, woody at base, angled, smooth except for sparse hairiness on growing branchlets. Leaves long-ovate, pointed, coarsely wavy-toothed or entire, the base wedge-shaped and tapering to a slender petiole. Flowers solitary, springing from the side of the stem slightly above the axils; corolla bell-shaped, five-lobed, about a half-inch broad, yellow with purplish throat; stamens five, erect, with anthers separate; calyx at first short and spreading, but as the fruit begins to form it 2 B 
elongates, becomes thin and much inflated, ten-ribbed, netted with purple veins, quite enclosing the two-celled, globular berry, the five triangular teeth meeting at the tip; often the envelope is ruptured by the swelling fruit, or "cherry," which is purplish red, nearly an inch in diameter, with a sweet and somewhat sticky pulp, in which many flattened, yellowish brown seeds are embedded.

\section{Means of control}

Prevent seed development by closely cutting or pulling the plants while in early bloom.

\section{LOW HAIRY GROUND CHERRY}

\section{Phýsalis pubéscens, $\mathbf{L}$.}

Other English names: Bladder Cherry, Dwarf Cape Gooseberry, Husk Tomato, Strawberry Tomato.

Native. Annual. Propagates by seeds.

Time of bloom: July to September.

Seed-time: Late August to November.

Range: Pennsylvania to California, southward to Florida and Mexico.

Habitat: Sandy soils; fields, meadows, pastures, waste places.

Frequently cultivated at the North, but in the Southern States often obnoxiously plentiful as a weed. Stem slender, angled, hairy, decumbent at base, widely branching, seldom rising more than a foot above the ground but of ten extending for a yard or more in all directions. Leaves thin, long ovate, pointed, wavy-edged or entire, rounded or abruptly narrowed at base, the veins and petioles usually hairy. Flowers less than a half-inch broad, pale yellow with brown-spotted throat, the five-lobed calyx at first short and hairy but becoming thin, membranous, and nearly smooth as it enlarges and envelops the growing fruit; the more prominent ribs form a ring of small knobs around its peduncle. The berry within is yellow, about a half-inch in diameter, not sticky like that of the Tomatillo, but more pleasant to the taste, being slightly acid.

Means of control the same as for the preceding species. 


\section{VIRGINIA GROUND CHERRY}

Phýsalis virginiàna, Mill.

Native. Perennial. Propagates by seeds and by rootstocks.

Time of bloom: July to September.

Seed-time: Late August to November.

Range: New York to Manitoba, southward to Florida and Louisiana.

Habitat: Rich soil; fields, meadows, waste places.

This plant is very variable, but is in all its forms a bad weed because of its fleshy, creeping rootstock. Stem eighteen inches to three feet tall, slightly angled, fork-branched, covered with appressed hairs or sometimes nearly smooth or in some forms somewhat glandular. Leaves long-ovate to lance-shaped, tapering at both ends, usually with a few roundish, irregular teeth on each side but often entire, rather thin, light green. Flowers more than a half-inch broad, the corolla sulfur-yellow with purplish brown spots, the stamens erect with deep yellow anthers; the calyx at first hairy but as it enlarges becoming nearly smooth, pyramidalovoid, five-angled, and deeply sunken around the peduncle. Fruit reddish, about a half-inch in diameter.

Means of control the same as for Prairie Ground Cherry.

\section{PRAIRIE GROUND CHERRY}

Phýsalis lanceolàta, Michx.

Native. Perennial. Propagates by seeds and by rootstocks.

Time of bloom: July to September.

Seed-time: Late August to November.

Range: Illinois to Wyoming and New Mexico, southeastward to the Carolinas.

Habitat: Dry soil ; fields, meadows, pastures, waste places.

Its deep, running rootstocks make this weed much more pernicious than its annual relatives, for the ground cannot be rid of its presence until these are killed. Stem one to two feet tall, sparsely set with flat hairs, slightly angled, and at first upright but later diffusely branched and spreading on the ground. Leaves broadly lance-shaped to spatulate, usually obtuse, tapering to the petiole, entire or rarely wavy-edged. Flowers dull yellow with brownish 
centers, each about a half-inch broad, on peduncles about as long as themselves; calyx at first hairy but when inflated almost smooth,

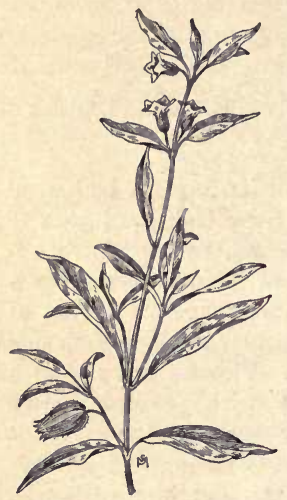

Fia. 258.-Prairie Ground Cherry (Physalis lanceolata). $\times \frac{1}{4}$. nearly ovoid in shape, not sunken around the stem, its ten ribs showing merely as lines on the surface. Berry reddish yellow, about a half-inch in diameter. (Fig. 258.)

\section{Means of control}

Starve the rootstocks by persistently depriving them of leaf-growth, beginning with the first bloom; retarding new growth by the use of salt or a few drops of kerosene on the shorn surfaces. In cultivated crops tillage should be continued much later than is usual, for it is generally the late green foliage that assimilates the food which restocks the underground storehouses. Small areas may be killed outright by more liberal applications of kerosene, caustic soda or hot brine, making the ground barren for a season; or the rootstocks may be grubbed out.

\section{APPLE OF PERU}

Nicándra Physalddes, Pers.

Introduced. Annual. Propagates by seeds.

Time of bloom: July to September.

Seed-time: Late August to November.

Range: Nova Scotia to Ontario, and southward to Florida.

Habitat: Fields, roadsides, and waste places.

Brought to this country to be cultivated for ornament in gardens, but naturalized as a weed in many localities, particularly in the southern part of its range.

Stem rather stout, smooth, angled, two to five feet tall, erect and branching. Leaves long-ovate, rather thin, three to eight 
inches long and half as wide, obtuse, coarsely toothed on the outer half but entire where they taper abruptly to the short, grooved petiole. Flowers solitary on terminal and axillary peduncles, large, the corollas bellshaped, pale blue or sometimes white with purple throats, nearly two inches in length, the lips scarcely at all lobed and flaring to about the same in width; stamens five, inserted on the corolla near its base, the filaments short, dilated and hairy at base; style slender with three to fiveparted stigma and ovary with three to five - mostly five cells; calyx at first small, composed of five joined segments, blunt arrowshaped, with conspicuous, backwardturned, acute auricles at base ; these are beautifully netveined, and enlarge so greatly

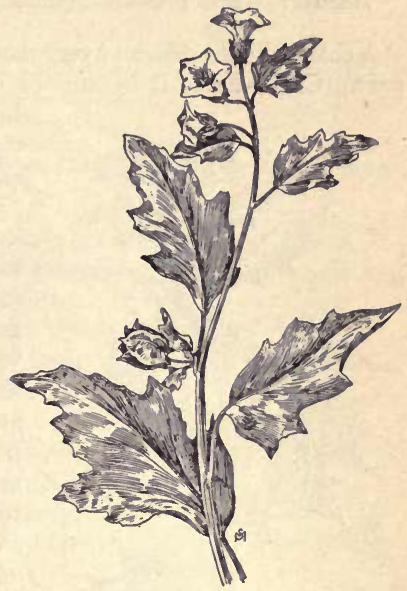

FIG. 259. - Apple of Peru (Nicandra Physalodes). $\times \frac{1}{6}$.

as to quite enfold and conceal the fruit, which is a dry-seeded, inedible berry, about a half-inch in diameter. (Fig. 259.)

\section{Means of control}

Prevent seed formation by close cutting or hand-pulling while the plant is in early bloom.

\section{BLACK HENBANE}

Hyoscỳamus niger, $\mathbf{L}$.

Other English names: Fetid Nightshade, Insane Root, Hog's Bean. Introduced. Annual or biennial. Propagates by seeds.

Time of bloom: June to September.

Seed-time: July to October, 
Range: Nova Scotia and Eastern Quebec to Ontario, New York, and Michigan; also in Idaho and on the Pacific Coast. Locally about Atlantic seaports and in Iowa, Utah, and Montana.

Habitat: Waste places. Prefers rich soil.

A coarse, ill-scented, and very dangerous weed, poisonous in every part. Cattle avoid it because of its harsh texture and evil odor,

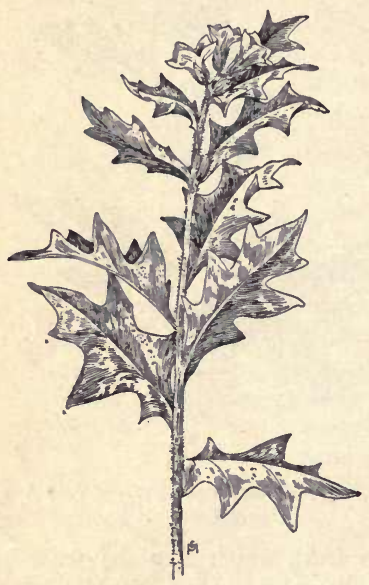

Fig. 260. - Black Henbane (Hyoscyamus niger). $\times \frac{1}{6}$.

but poultry die from eating its ripe seeds and hogs are killed by eating its fleshy roots.

Stem stout, one to three feet in height, clothed with viscid hairs. Leaves dark green, three to six or more inches long, with irregular pointed lobes, wavy edges, and viscid-hairy midribs; they are alternate, the upper ones sessile and clasping, but the lower ones petioled and drooping on the ground. Flowers in a short, onesided cluster at the top of the plant and solitary in the leaf angles; they are funnel-shaped, somewhat unequally five-lobed, nearly two inches broad, the corolla greenish yellow with throat and lobes netted with purple veins; stamens five, exserted and declined; calyx urn-shaped, with five pointed lobes and five ribs; it enlarges to enclose the oblong capsule, which is about a half-inch long, two-celled and opens transversely around the top, the latter falling off like a lid, spilling the numerous seeds. These are kidney-shaped, brown, with a strongly netted surface. (Fig. 260.)

\section{Means of control}

Grub out and destroy the plants as soon as discovered, allowing no seed to mature. 


\section{JAMESTOWN OR JIMSON WEED}

\section{Datùra Stramonium, L.}

Other English names: Jamestown Lily, Thorn Apple, Mad Apple, Devil's Apple, Devil's Trumpet, Dewtry, Stinkwort, Stinkweed. Introduced. Annual. Propagates by seeds.

Time of bloom: June to September.

Seed-time: September to December.

Range: Nova Scotia to Minnesota, southward to Florida and Texas. Habitat: Fields and waste places.

A coarse, ill-scented, dangerously poisonous plant, much too common; children have been poisoned by eating its seeds and taking its flowers into their mouths. Although cattle will not touch the plant when green, they have been poisoned by the young leaves when cured in hay.

Stem one to five feet tall, stout, smooth, or slightly hairy when young, pale green, branching by forking. Leaves alternate, three to eight inches long, pointed oval in outline but irregularly cut and toothed, dark green above, lighter below, thin, smooth, with large veins and stout petioles. Flowers solitary on short peduncles in the forks of the branches, the corolla white, trumpet-shaped, sometimes four inches long, the five-lobed mouth of

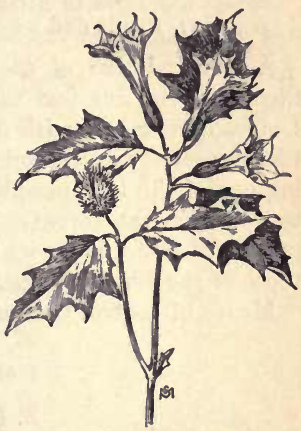

FIG. 261. - Jamestown or Jimson Weed (Datura Stramonium). $\times \frac{1}{6}$.

the trumpet flaring to a width of about two inches; five stamens included, their filaments inserted a little below the middle of the corolla tube; calyx five-lobed and ridged, enclosing the tube for nearly half its length. Capsule about two inches long when mature, ovoid, prickly, incompletely four-celled, opening at the top; seeds many, dark brown, wrinkled, and flat. (Fig. 261.)

Both leaves and seeds of Stramonium are used in medicine. About one hundred and fifty thousand pounds of the dried leaves are imported yearly at a cost of two to eight cents a pound, and 
more than ten thousand pounds of the seeds, costing three to seven cents a pound.

Means of control

Pull or closely cut the plants before the ripening of the earliest capsules.

\section{PURPLE THORNAPPLE}

Datùra Tátula, L.

Introduced. Annual. Propagates by seeds.

Time of bloom: May to September.

Seed-time: August to November.

Range: Ontario to Minnesota, southward to Florida and Texas.

Habitat: Fields and waste places.

A near relative of the Jimson Weed and equally poisonous. Stems one to five feet tall, fork-branched, smooth, deep purple. Leaves dark green, with purple veins and petiole, more hairy than the preceding species, long ovate, and coarsely toothed. The flaring lips of the trumpet-like corollas are violet or lavender, paling to white in the throat. The prickly capsule or "apple" is also purple, the thorns on its surface a little longer and stouter than those of the Jimson Weed. Seeds similar in appearance.

Means of control the same as for the Jimson Weed.

\section{HAIRY THORNAPPLE}

\section{Datùra Mètel, L.}

Introduced. Annual. Propagates by seeds.

Time of bloom: July to September.

Seed-time: September to December.

Range: New England to Florida, westward to Ohio.

Habitat: Roadsides and waste places.

Escaped from gardens, where it was cultivated for its beauty, but a dangerous stray in the highways. Stems four to eight feet tall, stout, much branched, finely glandular-hairy. Leaves four to ten inches long, broadly ovate, acute, inequilateral, entire or sometimes slightly wavy-edged, covered with fine, glandular hairs which give the surface a soft, velvety look. Flowers white, the trumpet-shaped corolla often six or seven inches long, the flar- 
ing lips three or four inches across; calyx tubular, five-lobed, smooth, and glandular-hairy. "Apple" globular, about an inch and a half in diameter, both hairy and prickly. This plant is quite as poisonous as the two preceding species and should be as promptly suppressed when out of the bounds of cultivation.

\section{MULLEIN}

Verbascum Thapsus, L.

Other English names: Velvet Dock, Feltwort, Blanket-leaf, Hedge Taper, Candle-wick, Jacob's Staff.

Introduced. Biennial. Propagates by seeds.

Time of bloom: June to September.

Seed-time: August to November.

Range: Nova Scotia to Minnesota, southward to Florida and Kansas.

Habitat: Old fields, pastures, and waste places.

Gray states that the generic name of this plant is corrupted from Barbascum, "the bearded"- certainly most fitting for a plant so densely hairy in all its parts. (Fig. 262.)

Stem two to seven feet tall, stout, erect, simple or with one or two upright branches near the top. Root-leaves tufted, spreading on the ground in a large, thick rosette; oblong, light green, thick, densely woolly with branched and interlacing hairs, tapering to the base, four inches to a foot or more in length, the larger ones with petioles. No grazing animal will touch these felt-like leaves, and hibernating insects find them a safe winter shelter. Upper leaves narrower and more pointed, alternate, their bases of ten decurrent on the stem to the axils of the leaf below, making the stem four-winged. Flowers sessile on long, dense, cylindrical spikes; calyx with five pointed lobes, very woolly; corolla yellow, with five unequal, rounded lobes, spread flat, open for but a

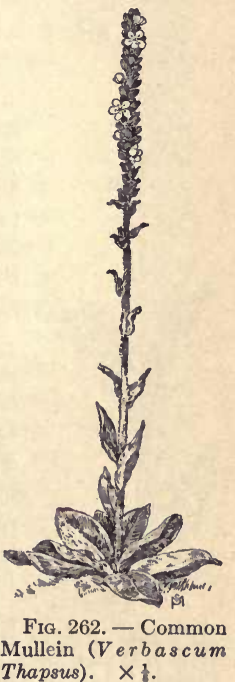


day; five stamens, with white filaments, the three upper ones shorter and bearded, with smaller anthers than those of the longer lower ones. Capsule nearly a quarter-inch high, globular, twocelled, downy, filled with many fine, brown seeds.

\section{Means of control}

Spudding or hoe-cutting of autumn rosettes; pulling or close cutting of flower-stalks before seed development.

\section{MOTH MULLEIN}

\section{Verbáscum Blattària, L.}

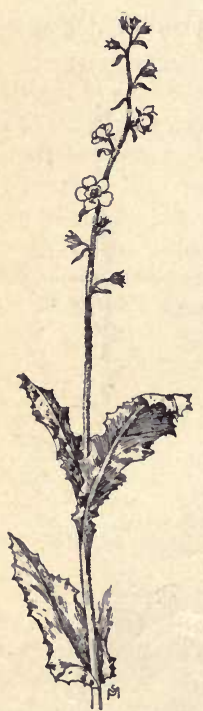

Fig. 263. - Moth Mullein (Verbascum Blattaria). $\times \frac{1}{4}$.
Introduced. Biennial. Propagates by seeds.

Time of bloom: June to October.

Seed-time: July to November.

Range: Quebec to Minnesota, southward to Florida and Kansas.

Habitat: Clover fields, meadows, pastures, and waste places.

A more pernicious weed than the preceding species, its invasion of grasslands causing the seeds to become mixed with those of timothy and other grasses, from which they are difficult to remove. The leaves are said to repel the cockroach (Blatta), whence the specific name; but the writer has not found the reputation merited.

Stem two to five feet high, round, slender, simple or occasionally branched, smooth or sparsely set with glandular hairs near the top. Lower leaves oblong, sometimes pinnatifid, smooth, dark green, veiny, double-toothed, three inches to nearly a foot in length, tapering to petioles; seldom present at flowering time ; upper leaves alternate, pointed and partly clasping. Flowers in long, open racemes, on spreading pedicels nearly an inch long, with small, pointed bracts at the base; corolla about an inch broad, the five lobes unsymmetrical, creamy-white or 
pale yellow, the upper one brownish on the back; stamens of unequal lengths, the filaments bearded with purple hairs. Capsules globose, longer than the calyx, many-seeded. (Fig. 263.)

Means of control the same as for Common Mullein.

\section{YELLOW TOAD-FLAX}

\section{Lindria vulgàris, Hill}

Other English names: Butter-and-Eggs. Wild Snap-dragon, Flaxweed, Impudent Lawyer, Ranstead.

Introduced. Perennial. Propagates by seeds and by rootstocks.

Time of bloom: June to October.

Seed-time: August to November.

Range: Nova Scotia to Manitoba, southward to Georgia and Nebraska.

Habitat: Fields, pastures, roadsides, and waste places.

A weed very difficult to suppress because of its deep, running rootstocks. Cattle dislike its taste and odor, and in pastures it is left to reproduce itself unmolested; seed-bearing plants are frequently transported in baled hay.

Stems several from the same root, erect, smooth, very slender, one to two feet tall, simple or with few branches. Leaves alternate, pale green, linear, entire, pointed at both ends, sessile, crowded on the stalks. Flowers in dense racemes, the earliest clusters terminal, later bloom springing from the axils; corolla yellow, irregular, about an inch long, spurred at the base, two-lipped, the upper one two-lobed and erect, the throat nearly closed and yellow-bearded within, the bulging palate deep orange above spreading lower lips; stamens four, in unequal pairs, included; the flowers have an unpleasant odor. Capsules two celled, ovoid, each containing fifty to sixty flattened, rough, wingmargined seeds. (Fig. 264.)

Means of control

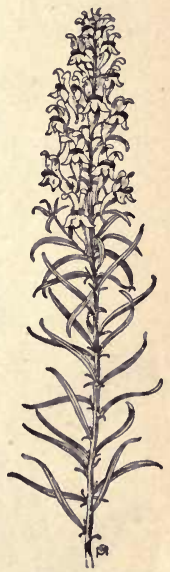

FIG. 264 . Yellow Toad-flax (Linaria vulgaris). $\times \frac{1}{6}$.

If the area infested is small, use one of the strong herbicides, such as hot brine or caustic soda, which will kill all other plant 
growth as well but will leave the ground clean when the chemical has leached away. Do not use a cultivator in ground befouled with Toad-flax; it only serves to spread the weed; hoe and hand-labor are more effective. If the plants are kept persistently and deeply cut throughout the growing season, the underground stems will finally starve to death.

\section{MARYLAND FIGWORT}

Scrophuldria marilándica, $\mathrm{L}$.

Other English names: Pilewort, Heal-all.

Native. Perennial. Propagates by seeds.

Time of bloom: July to September.

Seed-time: August to October.

Range: Massachusetts to South Carolina, Kansas, and Louisiana. Habitat: Lowland meadows, fence rows, and borders of woods.

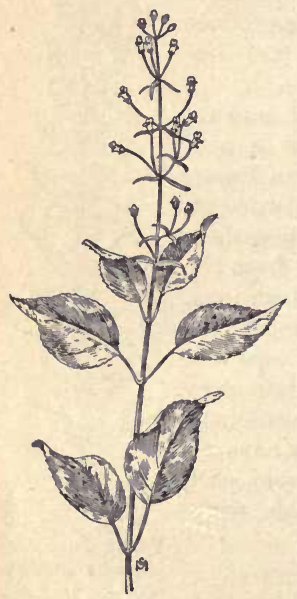

Fig. 265. - Maryland Figwort. (Schrophularia marilandica). $\times \frac{1}{8}$.
The knotted roots of this plant have long been reputed a cure for scrofula, piles, and other diseases, and are salable in the drug-market. The time for collecting is in autumn, when the summer's growth has stored the roots for winter's sustenance.

Stem erect, slender, four-angled, smooth except for the glandular hairs on its flower stalks, usually much branched, of ten purplish red in color, three to eight feet tall. Leaves three inches to a foot in length, opposite, dark green, ovate, long-pointed, saw-toothed, with prominent veins and long, slender petioles. Flowers in long, open, leafless panicles at the summit of the stem and the branches; corolla about a quarter-inch long, dull green outside, glossy purple within, with spreading lower lip and upper one erect, two pairs of fertile stamens of unequal length and a sterile 
fifth one, reduced to a purple scale on the roof of the corolla tube; calyx five-cleft, with rounded lobes. Capsule ovoid, thin, papery, two-celled, opening at the top. Seeds many, small, rough, dull brown. (Fig. 265.)

S. leporélla, Bicknell, is a closely related plant, differing in having more coarsely toothed leaves, and flowers with corolla more contracted at the throat, the sterile stamen greenish yellow; it is even more frequent on hillsides and brushy pasture. Range from Connecticut to Minnesota, southward to Nebraska and North Carolina.

\section{Means of control}

The roots may be killed by persistent cutting, aided by salt or carbolic acid on the cut surfaces. Or they may be grubbed out or pulled when the ground is soft, and perhaps sold for enough to pay for the trouble of their extraction.

\section{FOXGLOVE BEARD-TONGUE}

Pentstèmon lavigàtus, Ait. Var. Digitalis, Gray

Native. Perennial. Propagates by seeds.

Time of bloom: May to July.

Seed-time: June to August.

Range: New York to Illinois, southward to Virginia and Arkansas. Locally in the Northeastern States.

Habitat: Meadows, pastures, and waste places.

An unwholesome and bitter weed which has been introduced in many new localities by means of baled hay and as an impurity of grain and grass seed. Cattle reject it when green, but will eat it as hay, when it is injurious to the flavor of dairy products.

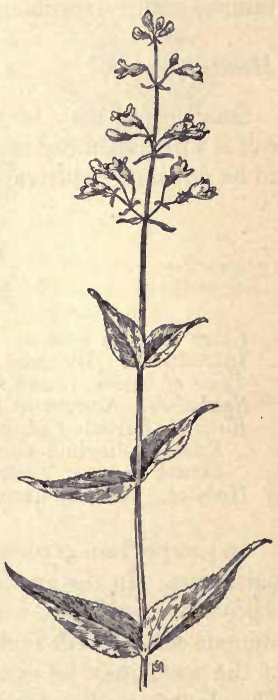

FIG. 266. - Foxglove Beard-tongue (Pentstemon locvigatus var. Digitalis). 
Stem rather stout, two to four feet tall, simple or branched from the base, often ruddy-colored, smooth except for the flower-stalks which are set with glandular hairs. Leaves opposite, light green, firm and glossy, long ovate to lance-shape, the upper ones sessile with clasping bases and the lower ones tapering to margined petioles. Panicle slender, many-flowered, terminal, the corolla about an inch long, whitish, tinged with reddish purple, the tube much dilated just behind the throat, which is open and not hairy; the five lobes are spreading and pointed, two on the upper lip, three on the lower ; four stamens are fertile with purple anthers, and the sterile filament, or "tongue," is bearded only on its upper side; calyxsegments lance-shaped, acute. Capsule ovoid, two-celled, containing many irregular, angled seeds. (Fig. 266.)

\section{Means of control}

Small areas may be destroyed by digging or pulling when the soil is soft, but meadows badly infested with Beard-tongue require to be put under cultivation for a season.

\section{PURPLE FOXGLOVE}

Digitàlis purpùrea, $\mathrm{L}$.

Other English names: Lady-fingers, Pop-dock, Scotch Mercury. Introduced. Biennial. Propagates by seeds.

Time of bloom: June to August.

Seed-time: August to October.

Range: British Columbia, Washington and Oregon; also in the East in Virginia and West Virginia and in Cape Breton Island; casual in New York and New Brunswick.

Habitat: Meadows and pastures, roadsides, waste places.

An escape from gardens, and a very grave one, for the plant is very poisonous. In the green state, cattle usually leave it untouched to reproduce itself, but when cured in hay it becomes a danger to animals served with such fodder; also there is risk that the range of the weed may be extended by its transportation in baled hay. The plant is medicinal and about forty thousand to sixty thousand pounds of its dried leaves are annually imported from Europe at a cost of six to eight cents a pound. They should be collected in mid- 
flowering season of the second year of growth, dried with great care and be put up in close boxes, safe from moisture.

Stems stout, erect, round or slightly angled near the top, leafy and downy-hairy, two to five feet high, appearing in the second year of growth. Leaves of the first year all basal, forming a dense rosette, spreading flat on the ground; long-ovate, rather thick, finely toothed, tapering to petioles ; the upper surface dull green and somewhat wrinkled, the under side softly hairy and netted with prominent veins; the later stem leaves are smaller, alternate and sessile or nearly so. Flowers in slender, terminal, one-sided racemes, sometimes a foot in length; corolla a swollen pale purple tube, nearly two inches long, drooping on a short pedicel, five-lobed, the lower lobe finely white-hairy within, the throat crimson-spotted; stamens four, in two unequal pairs, included in the corolla. Capsule two-celled, ovoid, rather large, containing many rough, brown seeds. 267.)

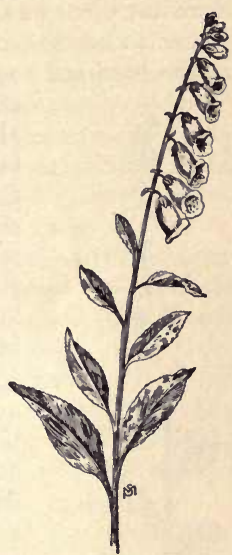
Fig. 267. - Purple
(Fig. Foxglove (Digitalis purpurea). $\times 4$.

\section{Means of control}

Deep hoe-cutting of base-leaves from the roots; close cutting of flower-stalks before the development of any seeds.

\section{COMMON SPEEDẄWLL}

Verónica officinàlis, L.

Other English names: Fluellin, Ground-hele,-Paul's Betony, Upland Speedwell.

Native. Perennial. Propagates by seeds and by stolons.

Time of bloom: May to August.

Seed-time: July to October.

Range: Nova Seotia to Ontario and Michigan, southward to the Carolinas and Tennessee. Also native to Europe and Asia.

Habitat: Dry hillsides and open woods ; pastures, lawns, and waste places. 
A frequent weed of upland pastures; its stoloniferous habit causes it to form patches or colonies, crowding out the larger and more nutritious forage plants.

Stems three to ten inches long, softly hairy, usually decumbent at the base and rooting at the lower joints, the flowering stalks erect. Leaves opposite, or the upper ones alternate, obovate to elliptical, a half-inch to an inch long, obtuse, softly hairy on both sides, finely toothed, the lower ones narrowing to short, margined petioles. Flowers in slender, spike-like racemes densely crowded on very short pedicels; corolla four-parted, the lower lobe less than half as large as the others, pale blue or whitish, marked with dark blue or violet lines, the whole flower only about a quarter-inch broad. Stamens two, one on each side of the upper lobe of the corolla, exserted; one slender style with stigma single; calyx with four narrow pointed lobes, longer than the pedicel. Capsule heart-shaped, two-celled, about an eighth of an inch broad, filled with fine, yellow, flattened seeds. (Fig. 268.)

This Speedwell is a medicinal herb, and its leaves and flowering tops, collected when the plant is in full bloom and carefully dried, are FIG. 268. - Com- worth three to five cents a pound.

mon Speedwell ( $V e-$ ronica officinalis). $\times \frac{3}{3}$.

\section{Means of ccntrol}

In lawns and yards, hoe-cutting and reseeding; in fields, cultivation of the ground; crowding out with clover.

\section{THYME-LEAVED SPEEDWELL}

Verónica serpyllifolia, L.

Native and introduced. Perennial. Propagates by seeds and by rooting at the joints.

Time of bloom: April to October. 
Seed-time: Late May until snow-covered.

Range: Labrador to Alaska, southward to the Gulf of Mexico.

Habitat: Moist grass lands, waste places.

One of the commonest of pasture weeds the world over, but so small and inconspicuous that it is hardly noticed until it monopolizes much of the ground. Often called "Creeping Speedwell" because it lies so close to the earth, rooting at nearly every joint and erecting only its flowering stalks. Much trampling from the sharp hoofs of cattle and sheep does it no harm, for, though cut all to bits, the fragments take root and continue to grow.

Stems two to ten inches long, smooth or only slightly hairy, branching on all sides from the root. Lower leaves opposite, ovate, rounded, nearly smooth, with short petioles; those on the erect part of the stems alternate, sessile, narrow, becoming mere lanceshaped bracts in the axils of which sit the tiny flowers; these are similar to the preceding species in structure, pale blue or white, striped with darker color, and less than a quarter-inch broad. Capsules broadly heart-shaped, nearly as large as the flowers, containing many yellow, flattened seeds as fine as dust.

Means of control the same as for the Common Speedwell.

\section{PURSLANE SPEEDWELL}

Verónica peregrina, L.

Other English names: Neckweed, Winter Purslane.

Native. Annual. Propagates by seeds.

Time of bloom: April until frost.

Seed-time: Late May until snow-covered.

Range: Nova Scotia to British Columbia, southward to the Gulf of Mexico.

Habitat: Gardens, cultivated fields, grasslands, roadsides, and waste places.

This plant was named "neckweed" when it and other members of its family were considered good remedies for the scrofulous sores that of ten appeared on the neck; "Winter Purslane" because the abundant seed sown by the plants of the previous summer springs so suddenly into life at the disappearance of the winter's snow. 


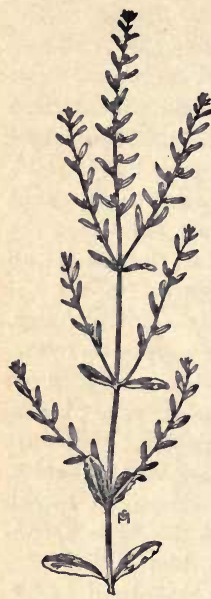

Fig. 269. - Purslane Speedwell ( $\mathrm{Ve}$ ronica peregrina). $\times \frac{1}{2}$.

Stem erect, smooth except for a few glandular hairs, three inches to a foot high, usually branched but may be simple. Lower leaves opposite, rather thick, long ovate or oblong, obtuse, sharply toothed, with short petioles; upper ones alternate, sessile, entire, narrowly oblong to linear, less than a half-inch in length. Flowers like the two preceding species in structure, solitary and nearly sessile in the axils, very pale blue or white, not more than a tenth of an inch broad, followed by a rounded and notched capsule larger than the flower and stuffed with many very fine yellow seeds, which are ripening and dropping into the soil all summer. (Fig. 269.)

\section{Means of control}

In cultivated ground tillage should be continued later than is usual, for, if not, lategrown plants will mature enough seed to keep the ground foul. Grasslands badly infested should be put under cultivation for one or two seasons before reseeding. Cattle eat the plant readily, but it is a poor substitute for good grass or clover.

\section{CORN SPEEDWELL}

\section{Verónica arvénsis, $\mathrm{L}$.}

Introduced. Annual. Propagates by seeds.

Time of bloom: Late March to September.

Seed-time: May to November.

Range: Nova Scotia to Ontario and Minnesota, southward to Florida, Texas, and Kansas.

Habitat: Cultivated ground, waste places.

This plant frequently begins to flower when less than three inches high, at which time the stem is erect and simple; later it branches diffusely from the axils, becoming a rather spreading plant, six to eight inches tall. Lower leaves opposite, petioled, 
ovate, obtuse at both ends, scallop-toothed; upper ones alternate, sessile, lance-shaped, and entire; stem and foliage softly hairy. Flowers axillary, hardly an eighth of an inch broad, pale blue or white, on very short pedicels. Capsules heart-shaped, larger than the flowers, filled with yellow, minute seeds which are ripened and distributed all summer.

Means of control the same as for Purslane Speedwell.

\section{FIELD SPEEDWELL}

Verónica agréstis, L.

Other English names: Germander Chickweed, Winter Weed, Garden Speedwell.

Introduced. Annual. Propagates by seeds.

Time of bloom: May to September.

Seed-time: June to October.

Range: Nova Scotia to Georgia and Texas.

Habitat: Fields, gardens, and waste places.

Stems very slender, three to eight inches long, branching from the base, spreading, procumbent, with smaller branches ascending. Leaves broadly ovate, obtuse at tips, rounded or heart-shaped at base, scallop-toothed, the lower ones opposite and petioled, the upper ones alternate and sessile; the whole plant clothed with fine, soft hair. Flowers axillary and single, on very slender, hairy peduncles longer than the leaves; calyx-lobes hairy and larger than the corolla, which is pale blue and about a quarter-inch broad. Capsule heart-shaped, thickened, much broader than long, fewseeded.

Means of control the same as for Purslane Speedwell.

\section{BRANCHED BROOM-RAPE}

Orobánche ramòsa, $\mathrm{L}$.

Other English names: Hemp Broom-rape, Tobacco Broom-rape.

Introduced. Annual. Propagates by seeds.

Time of bloom: June to August.

Seed-time: July to September.

Range: Illinois, Kentucky, Tennessee, North Carolina, and New Jersey.

Habitat: Hemp and tobacco fields; parasitic on tomatoes in New Jersey truck gardens. 
Broom-rapes are parasites, or robber plants, living directly on their neighbors by attaching strong haustoria, or suckers, to their roots, penetrating the tissues, and absorbing the food materials gathered and assimilated by the host plants for their own development. This species was brought to this country in imported hemp and tobacco seed, and in like manner its range here is being extended.

A Broom-rape seedling appears like a mere light-colored, nearly transparent thread, without root or any green part, having power to push its way into the soil but not to draw any sustenance from it. If a suitable host is not found soon after germinating, it shrivels and dies; but if the downward-boring tip comes in contact with the host adapted to it, in this case a plant of tobacco or hemp, it develops a club-shaped attachment covered with little pegs, or suckers, which penetrate and seem to become a part of the host plant's root, from which thereafter its life is drawn. At the point of juncture a bud is formed and a stem arises, six to fifteen inches tall, rather fleshy at base, dividing into several slender branches, the whole plant brownish yellow in color, with a few scattered scales instead of leaves. The flowers are in spikes terminating the branches, sessile or on very short pedicels, subtended by three or fewer small, scale-like bracts; each blossom has a persistent, fourlobed calyx and an irregular, two-lipped corolla about a half-inch long, with yellow tube and pale bluish lips, the upper one two-cleft, the lower one more spreading and three-parted; four stamens, inserted on the tube and included; ovary one-celled, the style very long, with two-lipped stigma. Capsule bluntly ovoid, one-celled, two-valved, containing an immense number of the most minute seeds, which are widely sown by the winds and, though so small, are very long-lived, having been known to survive in the soil for as many as thirteen years.

\section{Means of control}

If the infestation is new, it will pay to pull or grub out and destroy the stalks as fast as they attain to flowering size, in order to prevent any development and distribution of seed. Burn all stems of tobacco or hemp from infested fields and cultivate some other crops on that ground for several seasons. 


\section{CLOVER BROOM-RAPE}

\section{Orobanche minor, J. E. Smith}

Other English names: Lesser Broom-rape, Chokeweed, Herb-bane, Clover Devil, Devil's Root, Hellroot.

Introduced. Annual. Propagates by seeds.

Time of bloom: May to July.

Seed-time: June to August.

Range: New Jersey southward to North Carolina; locally in a few places in interior states.

Habitat: Clover fields.

This pest, like the preceding species, was brought to this country with the seeds of its host plant. The parasite is larger than the plant on which it feeds, and its presence in any abundance means ruin to the crop.

Stem brownish yellow, rather stout, softly downy, six to eighteen inches in height, without branches; the scales near the base are numerous and overlapping, oblong-ovate in shape; those above are smaller, more distant, and acute. Flower-spike three to six inches long, rather loose, each blossom subtended by one or two lance-shaped bracts nearly as long as itself ; calyx cleft to the base above and below, the divisions twoparted, with long, awl-like points ; corolla about a halfinch in length, with pale brownish yellow tube and lips purple-tinged or lilac, the upper one incurved and notched, the lower with three spreading, rounded lobes. Capsule about a quarter-inch long, crammed with abundant dust-like seeds, which, if allowed to ripen, are sown far and wide by the winds and which, in spite of their small size, have long vitality when in the soil. (Fig. 270.)

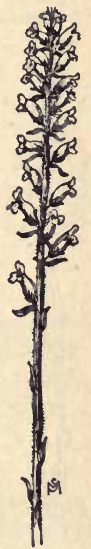

Fig. 270 . - Clover Broom-rape (Orobanche minor). $\times \frac{1}{3}$.

Permit no seed to form. Stalks, with the host plants, should be pulled as fast as they begin to bloom, and be piled with straw or other litter, soaked with oil, and burned. Under no circumstances should clover seed or hay from infested fields be offered in market; such material should be used up on 
the ground. The crop is best used by turning under for green manure, before the parasite matures seed, and clover should be left out of rotation on that ground for several years.

\section{LOUISIANA BROOM-RAPE}

Orobanche ludoviciàna, Nutt. (Myzorrhiza ludoviciàna, Rydb.)

Native. Annual. Propagates by seeds.

Time of bloom: June to August.

Seed-time: July to September.

Range: Illinois to the Saskatchewan, southward to California, Arizona, and Texas.

Habitat: Parasitic on several wild plants, but has also attacked tobaceo.

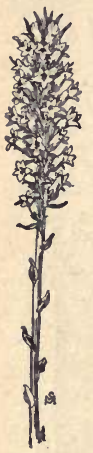

FIG. 271.

- Louisiana

Broom-rape

(Orobanche ludoviciana). $\times \frac{1}{8}$.

This native Broom-rape has a wider range than either of its immigrant relatives, but it is only in localities suited to the growing of tobacco that it has shown itself to be harmful to plants of any value.

Stems solitary or clustered, sometimes simple but usually branched, three inches to a foot in height, rather stout, the stalk and the scales covered with minute, glandular hairs. Scales lance-shaped, numerous. Flowers in dense terminal spikes, each subtended by one or two bracts; calyx viscidly glandular, its five lobes acute and nearly as long as the tube of the corolla: the latter is purplish, slightly curved, and constricted above the ovary; upper lip two-parted, lower one with three lobes, pointed and entire. Capsule ovoid-oblong, two-valved, full of very fine seed. (Fig. 271.)

\section{Means of control}

If the ground is newly infested, the persistent hoecutting of the parasites from the roots of their hosts before any seed can be perfected, piling and burning them with oil-soaked straw or other litter, will be well invested labor. After the crop is harvested and cured, the stalks should be burned. Plant no more tobacco on the infested ground for several seasons. 


\section{COMMON, OR BROAD-LEAVED, PLANTAIN}

Plantdgo màjor, L.

Other English names: Greater Plantain, Dooryard Plantain, Birdseed Plantain, Waybread.

Introduced. Perennial. Propagates by seeds.

Time of bloom: May to September.

Seed-time: July to October.

Range: Throughout North America except the extreme North. Habitat: Yards and lawns, roadsides, and waste places.

A very persistent intruder in yards and lawns, no doubt because of the long vitality of its seeds. Leaves all basal, long ovate, entire, obtuse, rounded at base, with five to seven prominent lengthwise veins that all draw together into a thick, channeled petiole; the outer row of the spreading tuft lies close to the ground, conserving moisture for the clustered, fibrous roots and choking out grass or other plant growth. Flowers on slender, cylindrical blunt spikes, three inches to a foot or more in length, densely crowded, the corollas four-lobed, with four stamens inserted on the throat, and a single style which protrudes from the bud, its stigma withered before its own anthers are ripe, thus insuring cross-fertilization; calyx four-parted, persistent, subtended by a small bract; ovary two-celled. Capsule a small urn or pyxis, the top

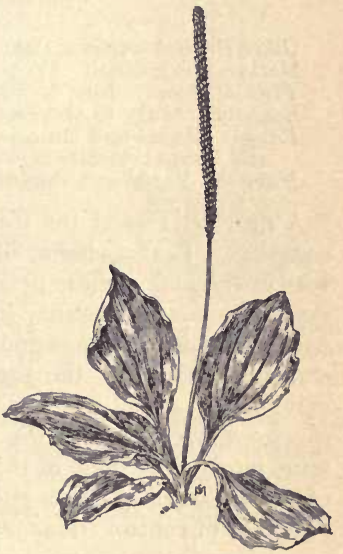

Fig. 272. - Broad-leaved Plantain (Plantago major). $\times \frac{1}{6}$. separating transversely at about the middle; each contains five to sixteen seeds. When wet these seeds develop a coat of mucilage which helps in their distribution; they are a frequent impurity of other seeds, particularly of alsike clover. (Fig. 272.) 


\section{Means of control}

In lawns these weeds can be destroyed without much defacement of the sward by treating them with carbolic acid. Stab each plant in the center, down to the fibrous cluster of roots, with a stout dibble or skewer stick, and squirt in a few drops of the acid with a common machine oil-can. Or the plants may be cut out with a spud. The best time for either operation is in dry weather, just before the spikes appear. In cultivated crops Plantains are not very troublesome, as the needed tillage destroys them.

\section{RED-STEM PLANTAIN \\ Plantàgo Rugèlii, Dene.}

Other English names: Pale Plantain, Rugel's Plantain.

Native. Perennial. Propagates by seeds.

Time of bloom: June to September.

Seed-time: July to October.

Range: Maine and Ontario to North Dakota, southward to Florida and Texas; locally established farther west.

Habitat: Yards and shaded lawns, open woods, and waste places.

A near relative of the Common Plantain, often growing in its company. Leaves similar in form but larger, thinner, pale green, with rather long, slender petioles, crimson at the base. Spikes very slender, sometimes twenty inches in length, not crowded, tapering to a thin point at the summit, and crimson at the base. Flowers similar to those of the preceding species but larger, the green calyx-lobes sharply keeled. Capsule oblong, nearly cylindric, the pyxis opening near the base, within the calyx; seeds four to nine, larger than those of the Common Plantain and more difficult of separation from clover and grass seed.

Means of control the same as for the Common Plantain.

\section{NARROW-LEAVED PLANTAIN}

\section{Plantdgo lanceoldta, $\mathrm{L}$.}

Other English names: Rib Grass, Ribwort, Ripple Grass, English Plantain, Black Plantain, Buckhorn.

Introduced. Perennial. Propagates by seeds.

Time of bloom: April to October.

Seed-time: May to November. 
Range: New Brunswick to the Northwest Territory and Alaska, southward to Florida and Kansas.

Habitat: Grasslands.

A much more pernicious weed than its broad-leaved relatives; they seem to prefer yard and roadside, but this species overruns meadows and pastures. Cattle feed on the plant without any apparent dislike, though it is stringy and somewhat bitter and detracts from the quality of the dairy products. (Fig. 273.)

Rootstock short and thick, with many branching rootlets. Leaves thickly tufted, oblong-lance-shaped, thick, entire, hairy on both sides with small tufts of brownish hair at the base, three- to seven-ribbed, tapering to margined petioles. Scape very slender, strong and wiry, five-grooved, hairy; the spike at its summit is at first capitate and very dense, but lengthens with the procession of bloom, becoming cylindric and more than an inch long; calyx-lobes and subtending bracts greenish brown, scarious. Capsule longer than the calyx, slightly narrowed upward, the pyxis opening at about the middle and containing but

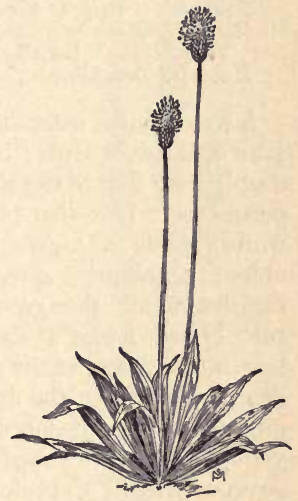

FIG. 273. - Narrow-leaved Plantain (Plantago lanceolata). $\times\{$.

two seeds, grooved on the inner face. An average plant will produce about a thousand seeds; these are a very common impurity of grass and clover seeds. When wet, the seeds are very mucilaginous, a quality which aids their distribution.

\section{Means of control}

Sow clean seed. Small areas in lawn or yard may be treated with carbolic acid after piercing each plant to the root with a skewer or pointed stick; or the weeds may be killed by deep cutting with hoe or spud. But rankly infested meadows and pastures should be plowed under, and a well-tilled hoed crop inserted in the rotation before reseeding. 


\section{HOARY PLAINTAIN}

Plantàgo mèdia, L.

Other English names: Gray Ribwort, Gray Buckhorn, Woolly Plantain, Sweet-flowered Plantain.

Introduced. Perennial. Propagates by seeds.

Time of bloom: May to September.

Seed-time: June to October.

Range: Maine to western Ontario, southward to Rhode Island and

New York. Locally established in many of the Western States. Habitat: Grasslands; yards and waste places.

A weed that is extending its range very rapidly by the agency of grass and clover seeds ; its rootstock is thicker and penetrates more deeply than that of the Rib Grass, and it is in other ways even more pernicious. Like that plant, its leaves are hairy, but the hairs are white, giving it a gray or hoary appearance; they are broadly oblong or elliptic, spreading near the ground in rosette form, smothering all other growth; petioles margined, rather short, with tufts of brown hair at the base. Scapes slender, one to two feet in length, the spikes at the summit one to three inches long, cylindric, densely flowered; the flowers are rather showy, with green scarious-margined calyx-lobes, four parted white corolla and four large, yellowish anthers dangling on purple filaments; also they are sweet-scented. Capsule oblong, obtuse, two- to four-seeded, the seeds concave on the face.

Means of control the same as for Rib Grass.

\section{LARGE-BRACTED PLANTAIN}

Plantàgo aristàta, Michx.

Other Engish names: Western Buckhorn, Bristly Buckhorn, Western Ripple Grass.

Native. Annual and winter annual. Propagates by seeds.

Time of bloom: May to October.

Seed-time: June to November.

Range: Ontario to British Columbia and Alaska, southward to Louisiana, Texas, and New Mexico. Locally established in most of the Eastern States and becoming frequent.

Habitat: Grass and clover fields.

More prolific than any of the foregoing species, an average plant producing about three thousand seeds. The rapid widening of its 
range in recent years is due almost entirely to transportation in baled hay and to the impurity of commercial seeds, especially those of the red and alsike clovers.

Leaves densely tufted, linear, long and grass-like, dark green, softly hairy, three-nerved, with short, margined petioles, growing from a somewhat thickened root which bores straight downward into the soil for several inches. Scapes erect, eight to fifteen inches high, exceeding the leaves; spikes densely flowered, cylindric, two to six inches in length; the bracts, which subtend the flowers, are a half-inch to an inch long, ascending, softly hairy. Capsules oblong-ovoid, each containing two seeds, which are nearly black but appear gray from a coat of dried mucilage, boat-shaped and hollowed on the flattened inner face; they have also a transverse ring around the outer surface at the point of opening of the pyxis, the seeds falling away with the cover, which is winged with the persistent papery corolla, enabling the seeds to be carried a short distance by the wind, so that in the second season after its introduction the plant is usually found covering the ground in dense colonies, choking out nearly all other growth. Also the long

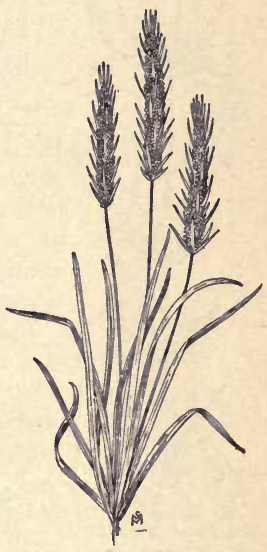

FIG. 274 . - Largebracted Plantain (Plantago aristata). $\times \frac{1}{5}$. vitality of the seeds makes the weed a very persistent one when the ground has been once befouled. (Fig. 274.)

\section{Means of control}

The plant is so grass-like that it is not noticeable until the flower-spikes appear and these should immediately be cut in order to prevent the ripening of any seed. If the infestation is new and the area not too great, hand-pulling and burning is the best remedy. But land badly seeded will require a series of cultivated crops in order to cleanse it. 


\section{SANDWORT PLANTAIN}

Plantàgo arend̀ia, W. and $\mathrm{K}$.

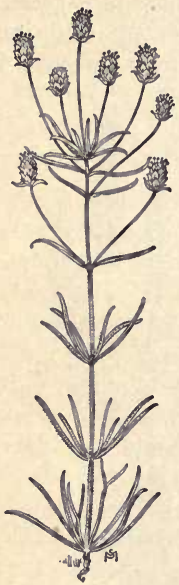

FIG. 275 . Sandwort Plantain (Plantago arenaria). $\times \frac{1}{2}$.

Other English names: Whorled Plantain, Sandwort.

Introduced. Perennial. Propagates by seeds.

Time of bloom: All summer.

Seed-time: Until bloom is checked by frost.

Range: Local in several states of the Middle West.

Habitat: Grasslands.

This is the most lately imported member of the Plantain Family, brought to this country in clover seed from Central Europe. It is not yet sufficiently well known to predict its character as a weed, but, judging it by the qualities of nearly related plants, its prompt destruction wherever noticed may be strongly recommended.

Stem six to fifteen inches tall, at first simple but later diffusely branched, hairy, and somewhat viscid. Leaves opposite or whorled, linear, entire, sessile, one to three inches long. Spikes numerous, on slender axillary peduncles somewhat longer than the leaves; small and bluntly oblong. Capsule contains but one seed, which is dark brown, canoe-shaped, and grooved on one side. (Fig. 275.)

\section{BLUE FIELD MADDER}

Sherárdia arvénsis, L.

Other English names: Spurwort, Herb Sherard.

Introduced. Annual. Propagates by seeds.

Time of bloom: June to July.

Seed-time: July to August.

Range: Nova Scotia to Ontario and Michigan, southward to New Jersey and Ohio.

Habitat: Clover fields and meadows.

An immigrant from Europe, brought to this country in impure clover seed and increasing its range by the same agency. The fleshy 
roots, though much inferior to the true Madder, are sometimes used for the production of a red dye.

Stems numerous, tufted, three to ten inches long, some erect and some spreading on the ground, very slender, square, and rough-hairy on the angles. Leaves about a half-inch long, narrow, rough-edged, sharppointed, sessile, and whorled in fours, fives, or sixes. Flowers very small, in dense terminal clusters or heads, surrounded by an involucral whorl of spiny-pointed, leaf-like bracts; they are blue (sometimes pink), the corollas funnel-shaped, with four or five spreading lobes, and as many stamens as lobes, inserted on the tube, the anthers exserted; style twoparted at summit. Ovary below the flower, two-celled and two-seeded, forming twin carpels which are indehiscent and crowned by the persistent, rough-hairy, four- to six-lobed calyx. (Fig. 276.)

Means of control

Clover fields and meadows infested with this weed should be mowed very early, before the formation of seed. Being annual, it can

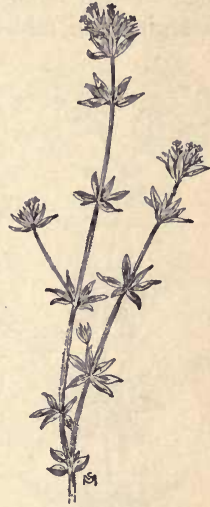

Fig. 276. - Blue Field Madder (Sherardia arvensis). $\times \frac{1}{3}$. thus be driven out in a year or two, if seeds are not allowed to foul the ground.

\section{GOOSE-GRASS, OR CLEAVERS}

Galium Aparine, L.

Other English names: Scratch Grass, Grip Grass, Cling Rascal, Catchweed, Hedgeburs, Sweethearts.

Native. Annual. Propagates by seeds.

Time of bloom: May to September.

Seed-time: July to November.

Range: New Brunswick to Alaska, southward to Florida and Texas. Habitat: Rich soil; fence rows and thickets.

A worthless weed, and sometimes a serious pest to the woolgrower, who finds the quality of his fleeces cheapened by its tiny burs. 
Stems many-branched, ridged, and square, two to five feet long, very slender and too weak to support themselves, so that they clamber over other plants, clinging by means of backward-turning prickles on the stem angles. Leaves in whorls of sixes or eights, one to two inches long, narrowly spatulate, bristle-pointed, the margins and midribs rough with short, stiff hairs. Flowers very

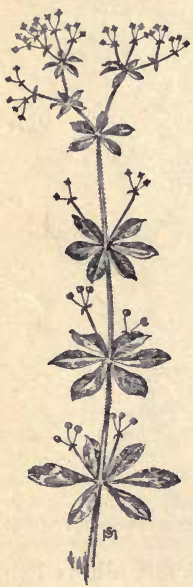

FIG. 277 . Goose-grass or Cleavers (Galium Aparine). small, usually in groups of two to four in the upper axils. Corollas four-lobed, white, with four stamens inserted on the tube and two styles. Fruits small, twinned globular burs about an eighth of an inch broad, covered with short, hooked bristles. (Fig. 277.)

\section{Means of control}

Since the plant is an annual, if Galium thickets are cleaned out in the spring before the first burs form, the ground must soon be rid of their presence.

\section{ROUGH BEDSTRAW}

Gdlium aspréllum, Michx.

Native. Perennial. Propagates by seeds.

Time of bloom: June to August.

Seed-time: July to September.

Range: Newfoundland to Ontario, Minnesota, and Nebraska, southward to Missouri and the Carolinas.

Habitat: Alluvial ground; fence rows, thickets along streams.

A vexation to the wool-grower in the autumn, when the vines have matured and become brittle; broken bits of the square, hooked stems work into and cling to the fleeces of the sheep, often transporting whole clusters of the seeds to new ground, from which the plants are difficult to dislodge because of their perennial roots.

Stems two to six feet long, branching from the base, weak and reclining on bushes and other plants, clinging by means of downward-curving bristles on the stem angles. Leaves usually about an inch long, whorled in fives or sixes or occasionally in fours, oblong- 
spatulate, bristle-pointed, the margins and midribs also bristly with short, stiff hairs. Flowers similar to the preceding species in structure, white, minute but very numerous, in open cymose clusters at the ends of the many branches and in the upper axils. The twin fruits are smooth.

\section{Means of control}

Hand-pull the vines when in first bloom. If the patches are not too numerous, it will pay to grub out the roots and save further trouble.

\section{SMOOTH BUTTONWEED}

Spermacòce glàbra, Michx.

Native. Perennial. Propagates by seeds. Time of bloom: June to September.

Seed-time: August to October.

Range: Ohio to Illinois, southward to Florida, Arkansas, and Texas.

Habitat: Wet meadows, banks of streams, and ditches.

Stem ten to twenty inches tall, rather stout, smooth, four-sided, sometimes simple and erect or often diffusely branched, the branches spreading, the lower ones decumbent. Leaves one to three inches long, opposite, their bases connected by bristly, membranous stipules, entire, elliptic, pointed at each end, with smooth surface but rough edges. Flowers in dense terminal and axillary whorled clusters, the corollas funnelform, four-lobed, white, less than a quarter-

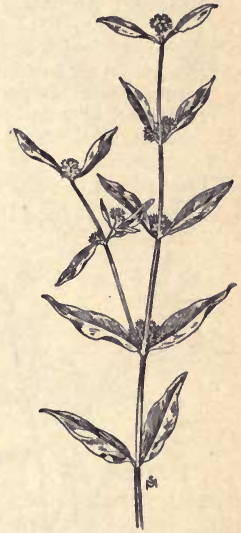

Fig. 278. - Smooth Buttonweed (Spermacoce glabra). $\times \frac{1}{2}$. inch long; stamens four, inserted on the tube; style two-cleft; calyx also four-lobed, its acute teeth persistently crowning the fruit, which is two-celled; when ripe the carpels separate, one carrying with it the partition, leaving the other bare on the inner face. Seeds small, hard, black, oblong to wedge-shaped, rounded on the back, with flat inner face ; too often an impurity of southern grass and clover seed. (Fig. 278.) 


\section{Means of control}

Sow clean seed. Harvest infested meadows before the flowers mature, particularly if the hay is intended for market. Ground badly fouled with the weed should be put under cultivation for the purpose of destroying its perennial roots. Good drainage is a discouragement to the growth of this plant, for it prefers the soil damp.

\section{ROUGH BUTTONWEED}

Diòdia tères, Walt.

Native. Annual. Propagates by seeds.

Time of bloom: July to September.

Seed-time: August to October.

Range: Connecticut to Missouri, southward to Florida, Texas, and New Mexico.

Habitat: Dry soil ; cultivated ground, grain and clover fields, roadsides, and waste places.

This plant is very resistant to drought, having a slender taproot, often nearly a foot long, fringed with fine feeding rootlets. Stems

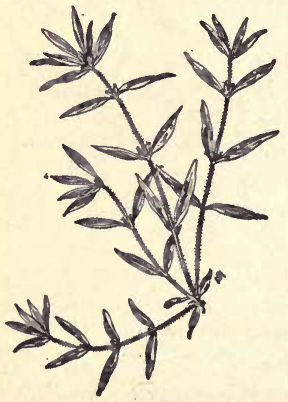

Frc. 279. - Rough Buttonweed (Diodia teres). $\times \frac{1}{4}$. several from the same root, four inches to two feet in length, ascending or sometimes prostrate, usually rough-hairy. Leaves opposite, lance-shaped to linear, rough-hairy on both sides, acute, rigid, sessile, the margins revolute in dry weather. Flowers usually solitary in the axils, the corolla funnel-form, five-lobed, about a quarter-inch long, pale purple; stamens four, with anthers exserted; style with two-parted stigma. Fruit small, obovoid or top-shaped, about onesixth of an inch long, hard and roughhairy, crowned with the four persistent calyx-teeth; it has two or occasionally three cells, and when ripe usually splits into two closed carpels. These seeds are a frequent impurity of southern grain and clover seed; and the weed is most undesirable company for those crops, as it absorbs much of the soil fertility. (Fig. 279.) 


\section{Means of control}

Mow infested meadows before the development of seed; enrich the soil for the encouragement of the clover, aiding it to crowd out the intruder. As soon as the crop is removed from corn and potato ground, sow with winter annuals. Follow grain with a crop requiring frequent and late-continued hoe-culture.

\section{HORSE GENTIAN}

Triósteum perfoliàtum, L.

Other English names: Feverwort, Wild Ipecac, Wild Coffee, Tinker's Weed. Native. Perennial. Propagates by seeds.

Time of bloom: May to June.

Seed-time: August to October.

Range: Massachusetts to Minnesota and Nebraska, southward to Alabama and Kansas.

Habitat: Rich soil; borders of fields, thickets, open woods.

A plant formerly in high esteem for its medicinal qualities, but now merely a weed. Stem two to four feet tall, erect, simple, softly hairy, and somewhat viscid. Leaves three to eight inches in length, opposite, joined at the base, ovate, pointed, entire, softly hairy, tapering to margined, connate petioles. Flowers axillary, sessile,

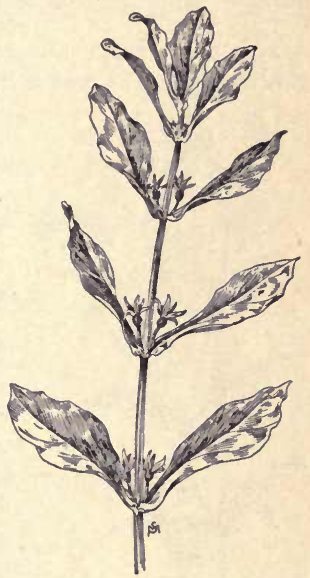

Fig. 280. - Horse Gentian (Triosteum perfoliatum). $\times \frac{1}{2}$. single or clustered, brownish purple; corolla tubular, more than a half-inch long, with five unequal lobes, five stamens inserted on the tube, with bearded filaments and included anthers; style usually three-parted; calyx-lobes very narrow, long-pointed, persistent. Ovary three-celled, the fruit an orange-red drupe, nearly a half-inch long, containing three bony nutlets. (Fig. 280.)

Means of control

Close cutting below the crown before any fruits mature. 


\section{CORN SALAD}

Valerianélla Locústa, Betcke.

Other English names: Lamb's Lettuce, Milk Grass.

Introduced. Annual or winter annual. Propagates by seeds.

Time of bloom: April to July.

Seed-time: June to September.

Range: Maine to Ontario, and southward to Virginia.

Habilat: Old fields, meadows, and waste places.

This plant is an immigrant from Europe and an escape from gardens, where it was cultivated for salads and greens under the

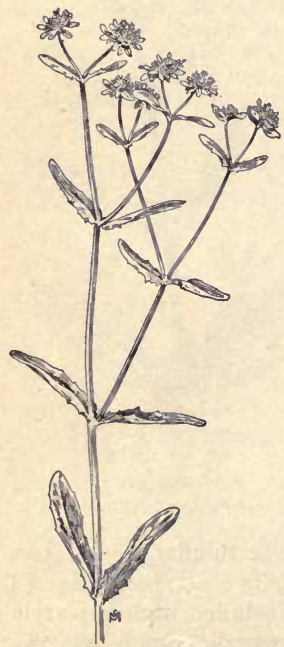

Fig. 281. - Corn Salad ( $V a$ lerianella Locusta). names of Fetticus, Veticost, and White Potherb. It is very hardy, enduring cold so well that in mild climates or mild winters it can be gathered and used throughout that season, a quality that helps it to survive many hardships as a weed. (Fig. 281.)

Stems six inches to a foot high, branching by repeated forking. Leaves opposite, pale green, succulent, tender, the lower ones growing in a tuft about the base of the stalk, blunt-pointed or rounded at the tips, tapering toward the base; stem-leaves sessile, smaller, and more pointed. Flowers very tiny, growing in small, flat clusters hardly a half-inch broad; the corollas pale blue or violet, funnel form, with five spreading unequal lobes; stamens usually three, and style with three-lobed stigma. Seeds very small, contained in a threecelled capsule of which two cells are always empty. Another species, six to eighteen inches tall with white flowers, known as the BEAKed CoRn SALAd (Valerianélla radiàta, Dufr.), ranges from Massachusetts to Minnesota and southward to Texas and Florida, infesting low meadows and other moist soils. Cattle 
eat these weeds readily, but they are less nutritious than grasses and do not make good hay. The seeds are said to retain their vitality for about five years when buried in the soil.

\section{Means of control}

Prevent production of seed by early and frequent cutting. Where practicable, put the ground under cultivation for a season in order to stir dormant seeds into life and destroy them with the needed tillage.

\section{TEASEL}

Dipsacus sylvéstris, Huds.

Other English names: Card Thistle, Water Thistle, Gipsy Combs.

Introduced. Biennial. Propagates by seeds.

Time of bloom: July to September.

Seed-time: August to October.

Range: Maine and Ontario to Virginia, westward to Michigan.

Habitat: Pastures, roadsides, fence rows, and waste places.

Stems stout, erect, strongly ridged, branching, beset with spines, three to six feet tall, springing from a stout taproot often more than a foot long with many feeding rootlets. Root-leaves of the previous year's growth tufted in a broad and very flat rosette, oblong to lance-shaped, obtuse, tapering at the base, scalloptoothed, the surface wrinkled and deep green except the veins and midrib, which are nearly white and beset with spines;

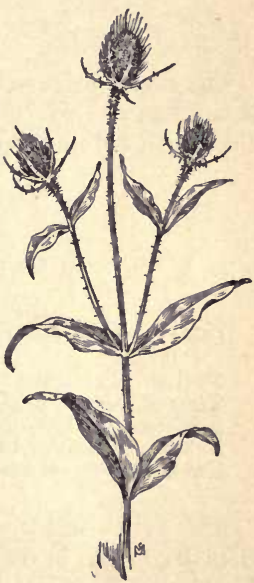

Fic. 282. - Wild Teasel (Dipsacus sylvestris). $\times \frac{1}{3}$. stem-leaves opposite and often united at the base, forming cups which retain water, the rigid midribs spiny on the under side. Flowers in large, dense, solitary heads, sometimes nearly four inches long and two inches in thickness, protected by long, upcurving, spiny involucral bracts and lifted on long, spiny peduncles, terminal and axillary ; corollas lilac or pinkish purple, tubular, four-lobed, 
fragrant, each subtended by a chaffy bract tapering to an awn longer than the flower; stamens four, inserted on the tube of the corolla ; ovary inferior, one-celled. Some flower communities progress in their bloom from the base upward, others from the top downward; but Teasels girdle the middle of the heads with the first flowers and proceed both ways, though the last flowers of September are likely to be as round as clover-heads and produce all their blossoms at once with an air which says, "Time's up ! All out !" Fruit a hard, wedge-shaped, square, black, grooved achene, about a quarter-inch long. (Fig. 282.)

\section{Means of control}

Cut first-year rosettes from the roots with sharp hoe or spud, in autumn or early spring. Flowering stalks should be pulled or closely cut before the earliest heads ripen seed.

\section{WILD GOURD}

Cucúrbita fatidissima, H. B. K.

(Cucúrbita perénnis, Gray)

Other English names: Missouri Gourd, Calabazilla, Fetid Wild Pumpkin.

Native. Perennial. Propagates by seeds.

Time of bloom: April to July.

Seed-time: July to November.

Range: Nebraska to California, southward to Texas and Mexico.

Habitat: Dry or sandy soil; fields and waste places.

Root yellow inside, carrot-like, very thick and fleshy, often more than six inches in diameter and sometimes exceeding five feet in length. Stem stout, angled, ridged, rough-hairy, many-branched, fifteen to twenty-five feet long, trailing and rooting at the joints or climbing by means of branching tendrils. Leaves alternate, rather thick, four inches to a foot in length, ovate-triangular, long-pointed, usually truncate at base or sometimes heart-shaped, rough above, gray-hairy beneath, sharply toothed, with rough-hairy petioles less than half as long as the blades. The whole plant has a disagreeable, fetid odor, especially when bruised. Flowers solitary in the axils and unisexual; calyx five-lobed, ridged, and bristly; corolla 
bright yellow, bell-shaped, three or four inches long and nearly as broad, deeply five-lobed with pointed and recurving tips, ridged, veined, and bearded inside and out; sterile flowers have three stamens, two of which have two-celled anthers, the other onecelled; fertile flowers have one pistil, with short, thick style and three-lobed stigmas. Ovary three celled, the fruit globose or broadly ovoid, about three inches in diameter, with a hard, smooth rind, yellow or pale green variegated with yellow, the pulp within fibrous and very bitter, the seeds numerous, oval, flattened, and lying horizontally in the triple cells.

\section{Means of control}

These troublesome plants are most readily and certainly destroyed by strong hot brine, caustic soda, or carbolic acid, applied to the crown of the huge, fleshy root.

\section{STAR CUCUMBER}

Sicyos angulàtus, L.

Other English names: Nimble Kate, One-seeded Bur Cucumber.

Native. Annual. Propagates by seeds.

Time of bloom: July to September.

Seed-time: August to October.

Range: Quebec to Minnesota, southward to Florida and Texas.

Habitat: Moist, rich soil ; banks of streams, fence rows, thickets, waste places.

A vine of amazingly rapid growth; Dr. Coulter mentions one that climbed up a neighboring tree to a distance of sixty-three feet. Sometimes, on bottom lands which have been flooded, many seeds lie dormant until the ground is put under cultivation, when they suddenly spring to life, binding corn or tobacco rows or other vegetation into tangled thickets.

Stem pale green, slender but very tough and fibrous, angled, more or less viscidly hairy. Leaves very large (the lower ones sometimes ten inches across), alternate, thin, rough on both sides, heart-shaped at base, five-nerved and five-pointed, finely and sharply toothed, with rather short, hairy petioles; opposite each leaf is a three- to five-parted and spirally curled tendril, on a much 


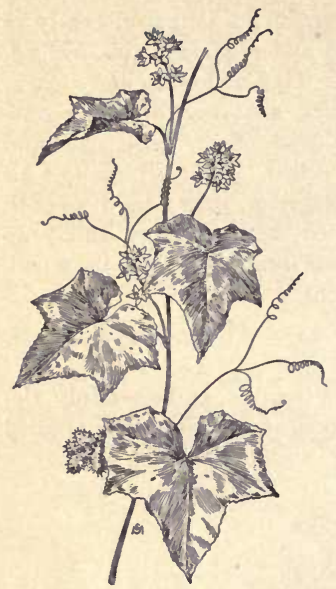

Fig. 283. - Star Cucumber (Sicyos angulatus). $\times \frac{1}{6}$.

longer petiole. Flowers monœcious, the staminate ones in small racemes on long, slender, axillary peduncles ; calyx cup-shaped, five-toothed; corolla with five lobes united at base, white striped with green; the three stamens united and the anthers cohering in a small, club-like mass; below, but in the same axils, are the smaller pistillate flowers, in rounded clusters on much shorter peduncles. Ovary one-celled, the style short and slender with three stigmas; fruits in clusters of three to ten, each containing a single seed, ovoid, covered with prickly, barbed bristles; the arrangement of the clusters is often star-shaped. (Fig. 283.)

\section{Means of control}

When the weed invades a field, or in any place where its growth is harmful, the roots should be cut from the stem or jerked from the soil, leaving the vines to relax and wither, for it is useless to try to untangle the clinging tendrils.

\section{CLIMBING WILD CUCUMBER}

Echinocýstis lobàta, T. \& G.

(Micrámpelis lobàta, Greene)

Other English names: Wild Balsam Apple, Mock Apple, Fourseeded Bur Cucumber.

Native. Annual. Propagates by seeds.

Time of bloom: July to September.

Seed-time: August to October.

Range: Nova Scotia to the Saskatchewan, southward to Georgia and Colorado.

Habitat: Rich soil; fence rows, thickets, and along streams.

A rapid climber, often cultivated as a quick shade for an arbor or as a cover for some eyesore of fence or building. Stem fifteen 
to thirty feet long, angular, grooved, smooth except for a few hairs at the joints. Leaves alternate thin, pale green, slightly rough on both sides with five triangular, pointed lobes or occasionally three- or seven-lobed, with slim, rather short petioles; opposite each leaf a three-forked tendril with a much longer footstalk. Flowers of two kinds, the staminate ones in long compound axillary racemes, the corollas deeply five- to six-parted, star-shaped, white, and fragrant; stamens three, with cohering anthers; below, in the same axil, are the inconspicuous pistillate flowers, usually solitary, but sometimes in twos or threes; ovary twocelled, with slender style and broad, hemispheric stigma. Fruit ovoid, nearly two inches long, covered with weak spines, two-celled, each cavity containing two rough-coated seeds nearly an inch in length; these seeds are discharged somewhat

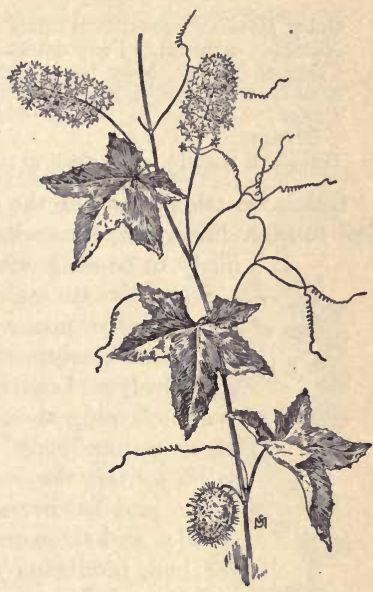

Fia. 284. - Climbing Wild Cucumber (Echinocystis lobata). $\times \frac{1}{6}$. forcibly by the sudden bursting of the "apple" at the top. (Fig. 284.)

\section{Means of control}

The plant is seldom a nuisance except when spreading in home grounds. There the pistillate flowers should be nipped out before maturity - unless one prefers to pull cucumber seedlings from several outlying yards of ground for several seasons. Occasionally it may be found, like the preceding species, invading bottom land corn and tobacco fields. There it should receive the same treatment as recommended for Nimble Kate, of course before the first of the prickly "balsam apples" approach maturity. 


\section{VENUS'S LOOKING-GLASS}

Speculària perfoliàta, A. DC.

(Legoùzia perfoliàta, Britton)

Other English name: Clasping Bell-flower.

Native. Annual. Propagates by seeds.

Time of bloom: May to August.

Seed-time: June to September.

Range: Ontario to British Columbia, southward to Florida and Mexico.

Habitat: Sterile open ground; thin meadows, upland pastures.

Grazing cattle do not like the taste of this plant, and it is usually left to reproduce itself, even where good forage is scarce - as it is

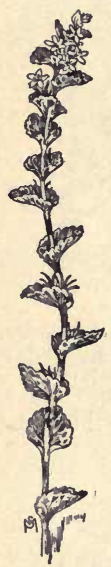

Fig. 285.

- Venus's

Lookingglass (Specularia perfoliata). $\times \frac{2}{3}$. likely to be on ground preferred by the weed.

Stem six to eighteen inches long, slender, weak and usually prostrate, with rough-hairy angles or sometimes smooth, simple or branching near the base, very leafy. Leaves alternate, rounded or broadly ovate, clasping the stem by a heart-shaped base, the edges rather finely toothed. Flowers sessile in the axils, solitary or sometimes in twos or threes; the lower and earlier ones are rudimentary, without corolla, and these never open but are self-fertilized in the bud, producing much seed which is often ripened and sown before the upper flowers expand their fivelobed, violet-blue corollas, which are also fertile; stamens five with thin, flattened filaments, shorter than the anthers; style with three-lobed stigma. Capsule oblong or narrowly top-shaped, three-celled, splitting below the middle. Seed brown, lens-shaped, often an impurity of clover and grass seed. (Fig. 285.)

\section{Means of control}

Enrich the ground by liming, manuring, and furnishing it with humus, which will enable it to retain moisture and support the growth of better plants. Hand-pulling of small and newly infested areas is a paying operation but the work must be done before the development of the inconspicuous early flowers. 


\section{CREEPING BELLFLOWER}

Campanula rapunculotdes, $\mathrm{L}$

Introduced. Perennial. Propagates by seeds and by rootstocks. Time of bloom: July to August.

Seed-time: August to September.

Range: New Brunswick to Ontario, southward to Pennsylvania and Ohio.

Habitat: Fields and roadsides.

An escape from gardens. The plant does all its "creeping" underground by means of slender, horizontal rootstocks. Above ground it sends up numerous stems one to three feet tall, rather stout, smooth or sometimes finely hairy, simple or with one or two branches near the top. Leaves alternate, long-pointed ovate, heart-shaped at base, irregularly toothed, the lower ones with petioles, the upper ones sessile, diminishing in size as they ascend the stalk. Flowers in a slender, one-sided, bracted raceme, each corolla a large, five-pointed, nodding, purple bell, an inch or more long, the "clapper" being its long, white style with three-cleft, curving stigma; stamens five, alternate with the corolla lobes. The flowers unfold from the base upward, leaving behind a string of globular, three-celled smooth capsules, opening by three valves at the base. Seeds small and very numerous. (Fig. 286.)

\section{Means of control}

The plant forms spreading patches, which, if not too large, may be grubbed out, care being taken to get every shred of the rootstocks; or the latter may be starved by close and repeated cuttings throughout the growing season, salt being used on the shorn surfaces in order to check new growth.

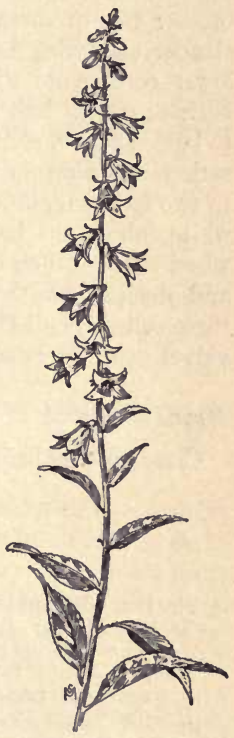

FIG. 286. - Creeping Bellflower (Campanula rapunculoides). $\times\{$. 


\section{TALL BELLFLOWER}

Campánula americàna, $\mathrm{L}$.

Native. Annual or biennial. Propagates by seeds.

Time of bloom: June to August.

Seed-time: August to September.

Range: New Brunswick to South Dakota, southward to Georgia, Arkansas, and Kansas.

Habitat: Moist, rich soil ; woodland borders, thickets along streams, damp grasslands.

One of the most stately and handsome of our wild flowers, a weed only when it enters the meadows and pastures. Stem erect, slender, finely grooved, sometimes attaining six feet in height but oftener two or three feet tall, usually simple but sometimes with slender ascending branches. Leaves large, thin, dark green, the lower ones ovate with rounded or abruptly narrowed bases and petioles nearly half as long as the blades, the upper ones oblong to lance-shaped, short-petioled or sessile ; all toothed and pointed, rather drooping on the stalk. Flowers in terminal racemes one to two feet long, interrupted and leafy ; corolla pale blue or almost white, about an inch broad, the five deep lobes spread nearly wheel-shaped, their edges slightly wavy; style very much exserted and declined, with its three-cleft tip curved upward. Capsule three-celled, slenderly top-shaped, smooth, erect, sessile, opening by valves near the summit.

Means of control

Close cutting before the earliest flowers mature.

\section{GREAT LOBELIA}

Lobèlia syphilítica, L.

Native. Perennial. Propagated by seeds and by short offsets. Time of bloom: July to October.

Seed-lime: August to November.

Range: Maine and Ontario to South Dakota and Colorado, southward to Georgia and Louisiana.

Habitat: Swamps, wet meadows, and along streams and ditches.

Like all its family, the juices of this plant are acrid and poisonous. Stem one to three feet tall, rather stout, slightly angled, 
usually without branches. Leaves large, alternate, thin, dark green, oblong, pointed at both ends, somewhat hairy, irregularly and rather finely toothed, sessile except the lowermost. Flowers in narrow, crowded, leafy, bracted racemes sometimes six inches or more in length, deep blue or occasionally white; corolla nearly an inch long, the tube cleft to the base on the upper side, the two lobes of its upper lip acute but the three lower ones longer and somewhat obtuse; stamens five, united into a tube around the style, with three of the anthers larger than the other two; calyx hairy, with narrow, long-pointed lobes, the sinuses with large, deflexed auricles. The many-seeded, two-celled capsules float easily on water.

\section{Means of control}

Hand-pulling or grubbing from pastures and meadows. Drainage will usually expel the plant from the soil, for it demands moisture.

\section{INDIAN TOBACCO}

Lobèlia inflàta, L.

Other English names: Wild Tobaceo, Asthma Weed, Bladder-pod, Gag-root, Pukeweed, Emetic Root.

Native. Annual. Propagates by seeds.

Time of bloom: July to November.

Seed-time: August until the ground is snow-covered.

Range: Labrador to the Northwest Territory, southward to Georgia, Arkansas, and Nebraska.

Habitat: Dry soil; meadows, pastures, and grain fields.

A very poisonous plant, and medicinally valuable; collectors receive twenty cents a pound for the seeds and three to eight cents a pound for dried leaves and tops. Grazing animals seem to know the quality of its acrid, milky juices, and usually leave the weed untouched; but sometimes its young shoots are eaten and cause a sickness known as "slobbers." The writer knows, from the foolhardy experiments of childhood, that the chewing of a single green "bladdcr-pod" will constrict the muscles of the throat and bring on most unpleasant throes of nausea. (Fig. 287.)

Stem six inches to two feet high, rather stout, with many short 


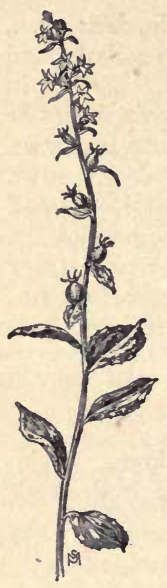

FIG. 287.Indian Tobacco (Lobelia inflata). $\times \frac{1}{3}$.

and slender branches held nearly erect, the whole plant finely rough-hairy. Leaves alternate, thin, light green, long oval, with blunt, irregular teeth, the lower ones narrowed to short petioles, the upper ones much smaller and sessile. Flowers in spike-like bracted racemes, similar in structure to the preceding species, but much smaller, the corollas less than a half-inch long and pale blue; capsule much inflated, containing many small dark brown seeds.

\section{Means of control}

Hand-pulling in pastures and meadows. Surface cultivation of stubbles after harvest. Improvement of the soil by liming, manuring, and cultivation, which will enable better plants to smother the weed.

\section{TALL IRONWEED OR FLAT-TOP}

Vernonia altissima, Nutt.

(Verndnia gigantè, Britton)

(Verndnia máxima, Small)

Native. Perennial. Propagates by seeds.

Time of bloom: July to September.

Seed-time: September to November.

Range: New York to Michigan and Illinois, southward to Missouri, Louisiana, and Alabama.

Habitat: Prairies; meadows, pastures, and roadsides.

This great weed is the despair of the prairie farmer, who sees it take possession of his rich soil, appropriating most of the food and moisture and crowding out the grasses; the plant is rejected by all grazing animals, even sheep.

Stem four to ten feet tall, erect, strong and woody, branching near the top, springing from roots like thick, fibrous cords, forming a huge tassel at the base of the stalk and penetrating in all directions. Leaves alternate, narrow lance-shaped, thin, dark green, pointed at both ends, finely toothed, sessile, usually smooth on 
both sides. Heads in large, rather loose, terminal cymose clusters, deep reddish purple; florets all perfect and fertile with tubular, five-lobed corollas; stamens five, united in a tube about the cleft-tipped style, a characteristic of all composites; involucre top-shaped, purple-tinged, its bracts imbricated in several series, closely appressed. Achenes bristly ribbed, with a double pappus, the outer row of short, very stiff, scalelike bristles, the inner row much longer, of many fine, rough hairs. (Fig. 288.)

\section{Means of control}

In cultivated crops the perennial roots are destroyed by the plow and the following tillage, but in land where there is danger of washing, or which for other reasons is not desired to be put under cultivation, the grubbing-hoe or the scythe must be persistently used. Cut closely in

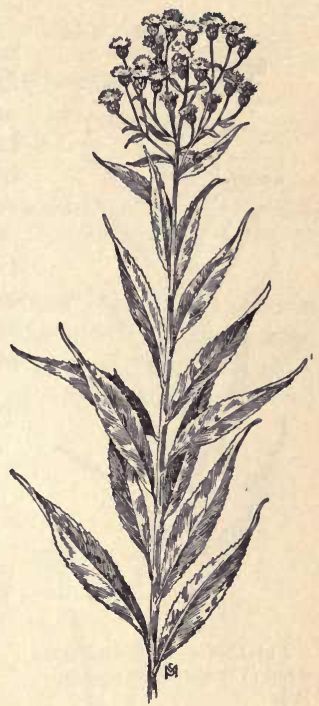

Fig. 288. - Tall Ironweed (Vernonia altissima). $\times 1 \frac{13}{6}$. May, repeating in June, and again in August and September, thus preventing all seed development and exhausting the roots of all sustenance supplied by the leaf-growth.

\section{WESTERN IRONWEED}

Verndnia fasciculàta, Michx.

Native. Perennial. Propagates by seeds.

Time of bloom: July to September.

Seed-time: September to November.

Range: Ohio to South Dakota, southward to New Mexico and Texas.

Habitat: Prairies, hillsides, woodland borders, meadows, pastures, roadsides, and waste places. 


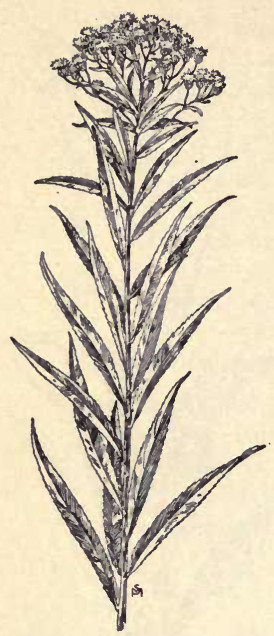

Fig. 289. - Western Ironweed (Vernonia fasciculata). $\times \frac{2}{4}$. Habitat: Dry prairies; meadows and pastures, roadsides, and waste places.

Stems two to six feet tall, erect, smooth, usually simple. Leaves alternate, narrow lance-shaped to linear, numerous, ascending, sometimes finely hairy on the upper surface but smooth beneath, sessile, finely toothed. Heads very many, rather small, in a compact cymose cluster, each containing about twenty florets, deep reddish purple; involucre bell-shaped, its bracts closely appressed. Achenes smooth, the pappus purple-tinged. (Fig.289.)

Means of control the same as for Tall Ironweed.

\section{ILLINOIS IRONWEED}

Vernònia illinoénsis, Gleason

Native. Perennial. Propagates by seeds.

Time of bloom: July to September.

Seed-time: September to November.

Range: Ontario to Minnesota, south-

Stem three to six or more feet tall, rather stout, somewhat rough. Leaves large, oblong lance-shaped, finely woolly-hairy above and rough to the touch beneath, sharply toothed. Heads in a densely crowded cymose cluster, many of them sessile or on very short pedicels, rather large, each containing about forty reddish purple florets; involucre bell-shaped, its bracts purpletinged, obtuse, closely appressed. Achenes slightly rough-ribbed, the pappus purplish brown. Both pollen and nectar are plentifully supplied by all the Ironweeds, and bumblebees and many species of butterflies are attracted by the flowers, thus assuring their thorough cross-fertilization.

Means of control the same as for Tall Ironweed. 


\section{WOOLLY ELEPHANT'S FOOT}

Elephátopus tomentòsus, L.

Other English names: Tobacco Weed, Devil's Grandmother.

Native. Perennial. Propagates by seeds.

Time of bloom: June to August.

Seed-time: August to October.

Range: Virginia to Arkansas, and southward to the Gulf of Mexico. Habitat: Rich moist soils; woodlands ; tobacco, corn, and cotton fields.

This weed is fond of shade and makes itself a special nuisance in tobacco fields, where the tall plants overshadow it, while its broad, basal, tufted leaves and deep roots absorb much of the soil's fertility and are difficult to remove without injury to the crop, of which the larger, lower leaves are the most valuable part, and must be guarded asmuch aspossibleagainst any mutilation. (Fig. 290.)

Stem erect, rigid, hairy, one to two feet high, simple or with a few forking branches. Lower leaves four to ten inches long, two to four inches wide, and spread flat on the ground; they are broadly obovate, bluntpointed, tapering to the base, heavily veined, scallop-toothed, and softly woolly-hairy all over. Simple stems are usually leafless, but where forked there is a small, sessile, lance-shaped leaf. Heads two- to five-flowered, the florets all alike, fertile, tubular, fivelobed but deeply cleft on the inner side, pale purple. Below each head are three heart-shaped, large, leaf-like, and hairy bracts. Achenes oblong, ten-ridged, with a pappus of stiff, slender bristles.

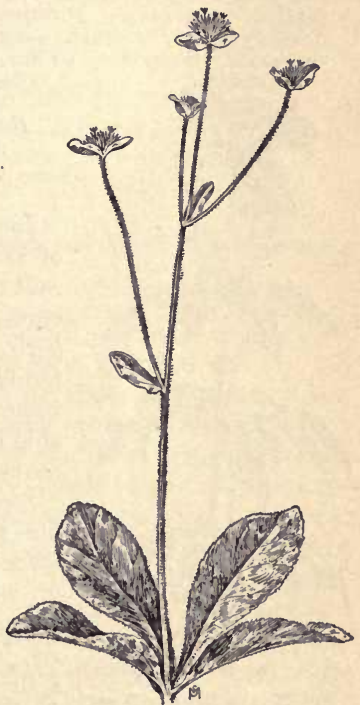

FiG. 290.-Hairy Elephant's Foot (Elephantopus tomentosus). $\times \frac{1}{4}$. 


\section{Means of control}

In crops where thorough and late cultivation may be practiced, this weed is not difficult of suppression; but in tobacco fields, where care must be exercised in order to keep the large lower leaves of the crop uninjured, late tillage is a danger, and handpulling is the only practicable way of destroying late-blooming plants before the development of seed.

\section{JOE-PYE WEED}

Eupatòrium purpùreum, L.

Other English names: Trumpetweed, Feverweed, Purple Boneset, Queen-of-the-Meadow, Gravel-root, Kidney-root.

Native. Perennial. Propagates by seeds.

Time of bloom: August to September.

Seed-time: September to November.

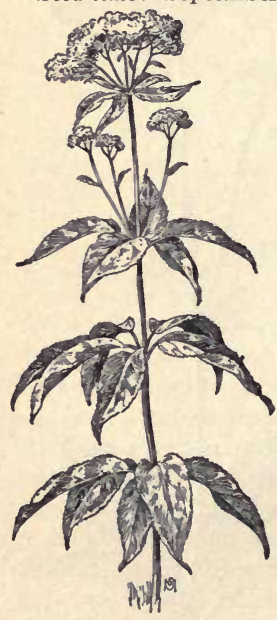

Fig. 291. - Joe-Pye Weed (Eupatorium purpureum). $\times \frac{1}{6}$.
Range: New Brunswick to Manitoba, southward to Florida and Texas.

Habitat: Damp meadows, moist woods and thickets, sides of streams and ditches.

Joe Pye was an Indian "herb doctor" of early days in New England, who is said to have performed many marvelous cures, mostly with decoctions of this herb. However that may be, its woody, fibrous, blackish roots, gathered in autumn and carefully dried, are still salable in the drug market for two to four cents a pound.

Stem round, smooth or sometimes finely grooved, slender for its height of three to ten feet, usually purple, simple or with a few branches at the top. Leaves arranged in whorls of three to six, long-ovate, thin, smooth except for a slight hairiness of the veins beneath, finely scallop-toothed, tapering to short, slim petioles. Heads small, in rather 
long, round-topped, corymbose clusters, pinkish purple, fragrant; the florets all tubular and perfect. Achenes very small, black, angled, with a funnel-shaped pappus of fine, bristly hairs. The plant is often accompanied by a nearly related variety, the Spotted Joe-pye Weed (E. maculàtum, L.), differing in that it has rough-hairy leaves and stem, green and more or less spotted with purple; heads similar, but with broader, flatter cluster and the root also is medicinally valuable. (Fig. 291.)

\section{Means of control}

Only grubbing out bodily or repeated deep cutting throughout the growing season will rid grasslands of this weed. Plants on waste grounds and in thickets should also be prevented from seed production.

\section{THOROUGHWORT}

\section{Eupatòrium perfolidtum, L.}

Other English names: Boneset, Agueweed, Feverwort, Crosswort, Sweating Plant, Vegetable Antimony.

Native. Perennial. Propagates by seeds.

Time of bloom: July to September.

Seed-time: September to November.

Range: New Brunswick to Manitoba and North Dakota, southward to Florida and Texas.

Habilat: Wet meadows, swamps, sides of streams, and ditches.

A near relative of Joe-Pye Weed, and also used in medicine, the parts desired being the flowering tops, gathered when in full bloom, and the leaves, stripped from the stalks and quickly dried, for which collectors receive three to eight cents a pound.

Stem two to five feet tall, rather stout, hairy, branching at the top. Leaves deep green, long-pointed, opposite, and united at the base, seeming like a single leaf through which the stem has grown, downy beneath, somewhat wrinkled, prominently veined, finely scallop-toothed. Heads very small, in rather compact corymbose clusters, dull white or very rarely blue, the florets all perfect and fertile; as they mature, the lengthening and expanding hairy parachutes of the achenes make the clusters appear like fleecy tufts of wool.

Means of control the same as for Joe-Pye Weed. 


\section{WHITE SNAKEROOT}

Eupatorium urticafolium, Reichard

(Eupatorium ageratoides, L. f.)

Other English names: White Sanicle, Indian Sanicle, Nettle-leaved Sanicle, Deerwort Boneset.

Native. Perennial. Propagates by seeds.

Time of bloom: July to October.

Seed-time: August to November.

Range: New Brunswick to Ontario and Nebraska, southward to Georgia, Louisiana, and Oklahoma.

Habitat: Open woods, thickets along streams.

This plant was long suspected of causing in grazing animals a peculiar disease, called "Trembles" from the muscular tremors always noted as a symptom; in turn, if a person ate the milk or the butter or the meat from an animal so affected, a disorder known as "Milk Sickness" resulted, which was often fatal and is said to have caused the death of the mother of Abraham Lincoln. But in 1908, on a sudden outbreak of this disease in Illinois, the Department of Poisonous Plant Investigations at Washington ${ }^{1}$ was asked to look into the matter, and the power for injury of White Snakeroot was thoroughly tested on several species of animals; and finally, convinced of its harmlessness, the chemist experimented on himself, with no bad effects. So the plant stands acquitted. Still, some residents of affected localities say, "When Snakeroot is cleaned out, so are Trembles and Milk Sickness," which is certainly a good thing, and better plants take its place.

Stem very slender, much branched, smooth or nearly so, one to four feet tall. Leaves opposite, broadly ovate, pointed, large, thin, smooth, coarsely and sharply toothed, three-nerved, with long, slender petioles. Heads in large, compound, corymbose clusters, snowy white, each about a quarter-inch broad, the florets tubular, five-lobed; the rather long-pointed lobes of the corollas and elongated style branches give the flowers a soft, fringy appearance, somewhat like the garden Ageratum.

Means of suppression the same as for Joe-Pye Weed. bles.'

${ }^{1}$ The Supposed Relationship of White Snakeroot to Milk Sickness or "Trem-

Bull. No. 121, Bureau of Plant Industry, U. S. Dept. of Agriculture. 


\section{MIST FLOWER}

\section{Eupatòrium calestinum, L.}

Native. Perennial. Propagates by seeds.

Time of bloom: August to October.

Seed-time: September to November.

Range: New Jersey to Illinois and Kansas, southward to Florida and Texas.

Habitat: Rich soil ; moist meadows and thickets.

Stems one to three feet tall, finely appressed-hairy, branching at the top. Leaves opposite, triangular ovate, truncate or heartshaped at base, coarsely and bluntly toothed, with prominent veins and rather short petioles. Heads in rather compact corymbose clusters, each less than a quarter-inch across but very numerous, light blue or violet, the florets five-lobed and perfect. Achenes oblong, five-angled, the pappus a single funnel-formed row of tawny bristles.

Means of control the same as for Joe-Pye Weed.

\section{FALSE BONESET}

Kùhnia eupatorioìdes, L.

Other English name: Plume-seed.

Native. Perennial. Propagates by seeds.

Time of bloom: August to September.

Seed-time: September to October.

Range: New Jersey to Ohio, and southward to Florida and Texas. Habitat: Dry meadows and pastures, roadsides, and waste places.

Patches of this weed are very conspicuous in autumn because of the showy, plumose heads of seed. Stem two to three feet tall, springing from a large, deep-boring root, erect, finely hairy, resinous, branching at the top. Leaves alternate, specked with resinous dots, those near the base lance-shaped, sparingly toothed, three-nerved, and short-petioled, becoming gradually linear, entire, and sessile as they ascend the stalk. Florets all perfect, the corollas very slender and deeply five-toothed, white or creamcolored, the heads very numerous, in loosely clustered terminal panicles. Achenes oblong, small, brown, ten-ribbed, attached to a 


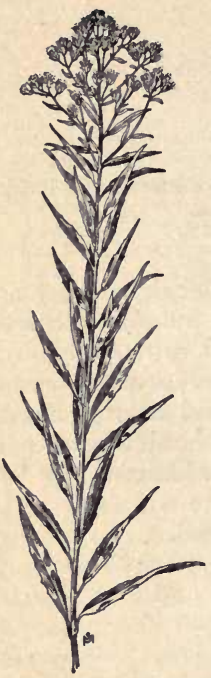

Fig. 292. - F alse Boneset (Kuhnia eupatorioides). $\times \frac{1}{\text { s. }}$. pappus of numerous long and very plumy hairs, yellowish to nearly white. (Fig. 292.)

A near relative of the preceding plant, the Prairie False Boneset (Kùhnia glutinòsa, Ell.) ranges from Illinois to the Dakotas and southward to Alabama and Texas. It is similar in habit and in season of bloom and fruitage, but is taller and stouter, more hairy, and has foliage somewhat viscid or sticky as well as resinous. Its pappus plumes are tawny brown.

\section{Means of control}

Prevent seed formation by cutting when in first bloom. Cultivation of the soil will kill the perennial roots, but, where that is not desirable, frequent hoe-cutting and salting will starve them. Or the plants may be hand-pulled when the ground is soft, the single taproot making the process easy.

\section{BROAD-LEAVED GUM PLANT}

Grindelia squarròsa, Dunal

Other English names: Gumweed, Scaly Grindelia.

Native. Perennial. Propagates by seeds.

Time of bloom: June to September.

Seed-time: July to October.

Range: Illinois and Minnesota to the Saskatchewan, southward to Texas and Mexico, and westward to California.

Habitat: Meadows, grain fields, waste places, and roadsides.

This weed was formerly common only on the western prairies, but unrestricted exchange of commercial seeds has carried it into many of the Eastern States as an impurity of grass seeds and grain. It is very persistent when established in meadow lands and is a serious injury to the crop. The leaves and flowering tops of the weed are official in the United States Pharmacopœia, and, if collected when the flowers are just coming into full bloom and 
quickly dried, are worth in the drug market five to ten cents a pound.

Stem and branches somewhat reddish, smooth, erect, freely branching, ten inches to two feet high. Leaves alternate, oblong or the lower ones spatulate, blunt-pointed, sessile, more or less clasping at the base, spinescently toothed. Heads terminal, solitary, about an inch broad, resinously viscid; bracts of the involucre imbricated in several rows, awl-tipped, green, spreading, and recurved; the outer row of strap-shaped or ray florets are pistillate and fertile, disk florets perfect. Achenes light-colored, short,thick, slightly flattened and curved, obscurely four-sided, marked with lengthwise lines or ribs; pappus consists of two or three barbed awns. (Fig. 293.)

\section{Means of control}

Sow clean seed. Prevent reproduction by cutting before any seed has ripened. Where the infestation is new and areas are small, grubbing out or hand-pulling of the perennial roots is well worth the labor; but rankly infested fields require to be put under cultivation.

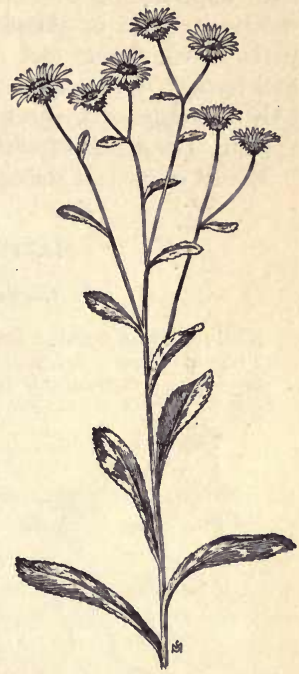

FI 293 . - Broad-leaved Gum-plant (Grindelia squarrosa). $\times \frac{1}{4}$.

\section{NARROW-LEAVED GUM PLANT}

Grindèlia lanceolàta, Nutt.

Native. Perennial. Propagates by seeds.

Time of bloom: July to August.

Seed-time: August to September.

Range: Tennessee, Missouri, and Kansas, southward to Louisiana and Texas.

Habitat: Meadows, fields, and waste places. 
A more slender plant than the preceding, erect, smooth, manybranched, one to two feet tall. Leaves narrow lance-shaped or the lowermost ones slashed into narrow, pointed lobes, the upper ones approaching to linear, but all acute at the apex, sharply toothed, sessile or clasping. Heads about an inch broad, with perfect disk florets and numerous narrow yellow rays, pistillate and fertile; bracts of the involucre very slender and awl-shaped, only the outer row spreading and the inner ones erect; achenes smooth, two-toothed, with a pappus of one or two awns.

Means of control the same as for the Broad-leaved Gum Plant.

\section{MARYLAND GOLDEN ASTER}

Chrysópsis mariàna, Nutt.

Native. Perennial. Propagates by seeds.

Time of bloom: August to September.

Seed-time: September to October.

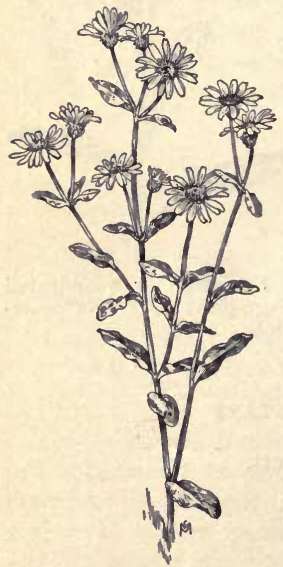

Fig. 294.-Maryland Golden Aster (Chrysopsis mariana). $\times \frac{1}{3}$.
Range: Southern New York and Pennsylvania, southward to Florida and Louisiana.

Habitat: Dry, rather sterile fields, meadows, and pastures.

A very handsome, conspicuous plant with numerous golden flower-heads, often an inch broad, upheld in terminal, branching, flat-topped clusters. Cattle refuse to eat the plant, whether as green forage or cured with hay.

Stem stout, one to two feet in height, set with silky hairs when young, but nearly smooth when old. Leaves alternate entire, oblong to lance-shape, or those near the base spatulate and narrowed to a petiole, the upper ones sessile, all silken-hairy when young but becoming smooth with age. Heads in corymbose clusters on viscid, glandular peduncles, and the pointed involucral bracts also are sticky-hairy; rays six- 
teen to twenty in number, pistillate and fertile; disk florets perfect. Achenes ovoid, flattened, hairy, with a double pappus, the inner row of long hairs, the outer one of short and chafflike bristles. (Fig. 294.)

\section{Means of control}

Prevent seed development and distribution by early cutting of infested grasslands. Destroy the perennial roots by cultivation of the soil, which should be so enriched as to be enabled to support plants of a better quality.

\section{HAIRY GOLDEN ASTER}

Chrysópsis villòsa, Nutt.

Native. Perennial. Propagates by seeds.

Time of bloom: July to September.

Seed-time: August to October.

Range: Wisconsin to Manitoba, and southward to Kentucky, Kansas, Louisiana, and Texas.

Habitat: Grain fields, meadows, and pastures.

A near relative of the preceding plant and even more pernicious because blooming earlier. It is taller, stouter, with fewer but larger blossoms, the heads solitary at the ends of the many branches and more than an inch broad. Stem two to three feet tall, stiff, woody, rough, and gray with close-pressed hairs which are persistent. Leaves narrowly oblong, obtuse at apex, the upper ones rounded at base and sessile, the lower ones narrowing to a petiole; they are hoary with stiff, appressed hairs, the larger, lower ones with bristly, fringed bases. Bracts of the involucre awl-shaped and very hairy. Achenes three- to five-ribbed, the outer row of the double pappus very spreading and bristly.

Means of control should be the same as for the preceding plant.

\section{GRAY GOLDENROD}

Solidàgo nemordlis, Ait.

Other English names: Field Goldenrod, Low Goldenrod, Dyer's Weed. Native. Perennial. Propagates by seeds.

Time of bloom: Late July to November. 
Seed-time: September to December.

Range: Quebee to the Northwest Territory, southward to Florida, Texas, and Arizona.

Habitat: Dry soil ; old fields, meadows, pastures, roadsides, and waste places.

Probably the commonest of the Goldenrods and one of the most beautiful. Stem six inches to two feet high, simple, clothed with fine,

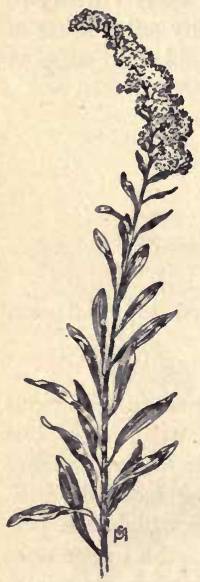

FIG. 295. - Gray Goldenrod (Solidago nemoralis). $\times \frac{1}{4}$. grayish hair. Alternate leaves also roughened with fine, ashy-gray hairs, the lower ones spatulate, scallop-toothed, tapering to petioles, often with fascicles of small leaves in their axils; the upper leaves very much smaller, entire, acute, and sessile. Panicle large, spreading, recurved, usually one-sided, densely manyheaded, brilliant golden yellow, each tiny head having five to nine rays which, as in all the Goldenrods, are pistillate; the disk florets are also yellow and perfect. Achenes very small, hairy, with a fine, bristly pappus. (Fig. 295.)

\section{Means of control}

Cultivate and liberally fertilize the ground. The plant has a preference for dry and sterile soil, and is readily crowded out when the ground is furnished with humus which enables it to retain moisture and support the growth of better plants. Roadside and waste land plants should be prevented from seed production by repeated close cutting.

\section{SOFT OR HOARY GOLDENROD}

Soliddgo mollis, Bart1.

Native. Perennial. Propagates by seeds and by stolons.

Time of bloom: July to September.

Seed-time: September to November.

Range: Manitoba and Minnesota to the Northwest Territory, southward to Texas and Mexico.

Habitat: Dry hills and plains; meadows and pastures. 
Its stoloniferous habit causes this weed to form dense patches, choking out all intervening growth. Stems usually tufted, from a thick, woody root, six inches to a foot high, stout, rigid, clothed with soft, velvety gray hair. Leaves alternate, thick, firm, also velvety-hairy, the lower ones spatulate, three-nerved, wavy-edged, tapering to petioles; the upper ones much smaller, acute, entire, and sessile. Panicles rather narrow and racemose, the branchlets held nearly erect, making the cluster compact and not one-sided; heads small, very bright yellow. Achenes downy-hairy, with fine, bristly pappus.

Means of control the same as for Gray Goldenrod.

\section{CANADA GOLDENROD}

Solidd̀go canadénsis, L.

Other English names: Tall Yellow-weed, Tall Goldenrod.

Native. Perennial. Propagates by seeds and by rootstocks.

Time of bloom: Late July to October.

Seed-time: September to November.

Range: Newfoundland and New Brunswick to the Northwest Territory and British Columbia, southward to Florida and Arizona.

Habitat: Thickets and rich, open soil; meadows and fence rows.

In good soil this stately plant often attains eight or more feet in height, but is oftener three to six feet tall, rather slender, usually simple, hairy toward the top but becoming smooth below. Leaves alternate, narrow lance-shaped, thin, three-nerved, finely toothed, smooth above but finely hairy beneath, especially on the veins, pointed at both ends, the lower ones tapering to petioles, the upper ones becoming smaller, nearly entire and sessile. Panicle large, broadly pyramidal, the racemes recurved and

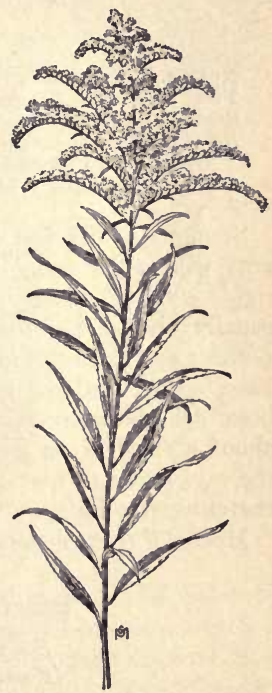

Frg. 296. - Canada Goldenrod (Solidago canadensis). $\times\}$. 
one-sided, densely crowded, the heads small and rather dull yellow, with nine to fifteen rays, the pedicels hairy. Achenes smooth or very slightly hairy, with fine, bristly pappus. (Fig. 296.)

\section{Means of control}

Prevent the development and distribution of the plumed seeds by close cutting while in early bloom. Its creeping, underground stems make this plant more difficult of suppression than others of its kindred, but fall plowing and exposure of the rootstocks to sundrying and freezing will destroy them. Small areas should be grubbed out for the protection of neighboring ground.

\section{STIFF, OR HARD-LEAVED, GOLDENROD}

\section{Soliddgo rigida, L.}

Native. Perennial. Propagates by seeds.

Time of bloom: August to October.

Seed-time: September to November.

Range: Ontario to the Northwest Territory, southward to Georgia, Texas, and Colorado.

Habitat: Dry soil ; hills and plains ; meadows and pastures.

Stem one to five feet tall, stout, rigid, simple or branched above, gray with a fine rough-hairiness. Leaves oblong to ovate, thick, rigid, with prominent feather-veins, rough-hairy on both sides, usually obtuse, the lowermost sometimes a foot long with stiff petioles and slightly toothed, the upper ones short, rounded at the base, entire, and sessile. Panicle very large and showy, corymbose, densely many-headed, the heads very large for Goldenrod, about a third of an inch high, containing thirty or more florets, the rays seven to ten, spreading; bracts of the involucre obtuse, the outer row hairy. Achenes smooth, with fine bristly pappus. Means of control the same as for Gray Goldenrod.

\section{NARROW-LEAVED GOLDENROD}

Solidàgo graminifòlia, Salisb.

(Euthàmia graminifòlia, Nutt.)

Other English names: Fragrant Goldenrod, Bushy Goldenrod, Creeping Yellow-weed.

Native. Perennial. Propagates by seeds and by rootstocks. 
Time of bloom: Late July to October.

Seed-time: September to November.

Range: New Brunswick to the Northwest Territory, southward to Florida, Missouri, and Nebraska.

Habitat: Rich, moist soil; damp fields and meadows, sides of streams and ditehes.

A beautiful plant but a bad weed, usually growing in large patches, formed by means of its long, creeping rootstocks. Stem erect, two to four feet tall, slightly angled and ridged, much branched and bushy. Leaves alternate, lance-shaped to linear, one to four inches long but only a quarterinch wide or less, three- to five-nerved, minutely rough-hairy on the edges and on the under side of the nerves, pointed at both ends, entire, sessile. Heads in many dense, corymbose, small clusters at the ends of the short, leafy branches, forming altogether a large, flat-topped cluster; the heads are large for Goldenrod, about a quarter-inch high, deep yellow, fragrant, with many more rays than disk-florets, both kinds fertile; bracts of the involucre oblong and somewhat viscid. Achenes broadest at the top, downy-hairy, with fine, bristly pappus. The Goldenrods frequently serve as hosts for several species of mildew and rust, which makes them still more undesirable as neighbors to plants of better quality. (Fig. 297.)

\section{Means of control}

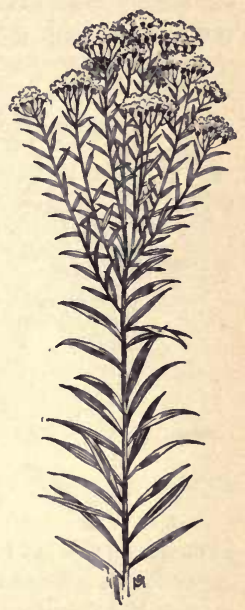

Fig. 297. - Narrowleaved Goldenrod (Solidago graminifolia). $\times \frac{1}{2}$.

The creeping rootstocks are horizontal and not far below the surface, and may be destroyed by shallow fall plowing, which exposes them to alternate freezing and thawing and to shrivel in sun and wind. Better drainage helps in keeping the ground free from new invasion. Of course all flowering stalks should be cut when the plants are in first bloom, in order to prevent seed development. 


\section{BUSHY ASTER}

\section{Boltònia asteroides, L'Her.}

Native. Perennial. Propagates by seeds.

Time of bloom: Late July to October.

Seed-time: September to November.

Range: New Jersey to Minnesota, southward to Florida, Louisiana, and Nebraska.

Habitat: Moist soil ; low meadows, banks of streams, and ditches.

The common name of this plant fits it well, for it has

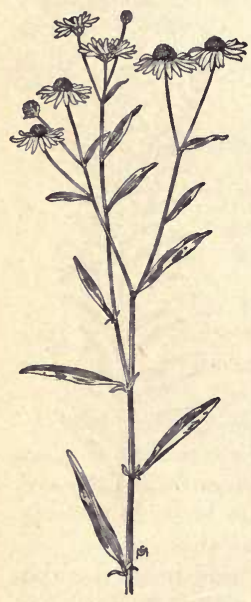

Fig. 298. - Bushy Aster (Boltonia asteroides). $\times \frac{1}{3}$. all the appearance of a big and bushy Aster and is nearly akin to that Family. Stem two to six feet tall, stout, smooth, pale green, much branched, and very leafy. Leaves alternate, the lower ones oblong to lance-shaped or slightly broadened above the middle, thick, smooth, entire, pointed, sessile, often turned edgewise; upper leaves much smaller, acute, and nearly linear. Heads numerous, in loosely branched corymbose clusters, each about a half-inch broad, with many narrow pistillate, and fertile rays, white, pale pink, or purplish, mostly the last. Disk rounded and yellow, the florets perfect and fertile. Achenes flattened, obovate or heart-shaped, winged on the margin, and, instead of an Aster's hairy pappus, are crowned with several short, prickly scales and two to four bristly awns about as long as the achene. (Fig. 298.)

\section{Means of control}

Ground infested with this weed indicates a need of better drainage. Prevent seed production by close cutting while in early bloom. Cultivation of the soil destroys the perennial roots. 


\section{WOODY ASTER}

\section{Xylorhiza Párryi, Gray}

Native. Perennial. Propagates by seeds.

Time of bloom: Late May to June.

Seed-time: June to early July.

Range: Western Wyoming, Colorado, and adjacent Utah.

Habitat: Alkaline clay soil; range pastures.

A most pernicious plant, because of its extremely poisonous properties. A bulletin of the State Experiment Station of Wyoming is authority for the statement that, in the sheep-raising industry alone, that commonwealth suffers a yearly loss of more than three million dollars, the greater part of which is due to poisonous plants on the pasture ranges, this weed being considered by many stockmen the most noxious of all, since at least 90 per cent of the animals affected die.

Roots thick, strong, woody, branching more or less just at the surface of the ground; from these branching, woody crowns



Fig. 299. - Woody Aster (Xylorhiza Parryi). $\times \frac{1}{4}$. rise tufts of short branches, four to eight inches in height, forming a dense, crowded stool. Leaves alternate, one to two inches long, spatulate-linear, sessile, entire, light green, somewhat hoary with a thin, soft woolly-hairiness; usually they are spotted with a brown fungus. Heads solitary, terminating the numerous young branches, an inch or more broad, with many white rays and yellow disks; bracts of the involucre oblong lance-shaped, keeled below, longpointed, covered with ashy-gray hair. Achenes white-hairy, with a bristly, yellowish pappus. When green and growing, the whole plant gives off an unpleasant odor and has a bitter taste. After the flowers mature the plant withers and dries, becoming yellowish brown in color and losing its noxious qualities, as thereafter the 
sheep feed freely on the dried herbage without apparent harm. (Fig. 299.)

\section{Means of control}

Herding the animals away from localities where the plants are abundant, during the noxious season of green leafage and bloom, seems to be the only practicable plan under existing conditions. But it would seem that so tremendous an injury to so important an industry should be a matter of interest to the entire community, better met by concerted communal action than by individual effort, and that yearly a large portion of the land cursed by such deadly herbage might be redeemed from it, supplanting its bane with wholesome growth, if merely salt-bushes.

\section{NEW ENGLAND ASTER}

\section{Áster nòvœ-ángliae, L.}

Native. Perennial. Propagates by seeds.

Time of bloom: August to October.

Seed-time: September to November.

Range: Quebec to the Northwest Territory, southward to the Carolinas, Alabama, Missouri, Kansas, and Colorado.

Habitat: Moist soil ; fields, meadows, roadsides, waste places.

One of the handsomest of its family, cultivated in Europe for its beauty, escaped, and locally naturalized there. In spite of its name the plant is more common in the meadows and thickets of the Middle Western States than in New England.

Stem two to eight feet tall, branching at the top, and the branchlets glandular-viscid, rather stout, erect, often of a reddish color and covered with fine, bristly hairs. Leaves alternate, lanceshaped, deep green, entire, acute, rather thin, softly hairy, clasping the stem by an auriculate base. Heads numerous, clustered at the summit of stem and branches; each nearly two inches broad, with orange-yellow disk changing to reddish brown with age, and forty to sixty long, narrow rays, which are usually deep violetpurple, rarely white, occasionally red or pink; as in all the asters the rays are pistillate and fertile, the disk-florets perfect; bracts 
of the involucre nearly equal, green, linear, spreading, very soft and lax, glandular hairy. Achenes bristly-hairy, with a thick tuft of tawny, brown pappus about three times their length.

\section{Means of control}

Close and repeated cutting for the purpose of starving the perennial roots and preventing seed development. The plant is at once destroyed by cultivation of the ground.

\section{HEART-LEAVED ASTER \\ Áster cordifòlius, L.}

Native. Perennial. Propagates by seeds.

Time of bloom: August to October.

Seed-time: September to November.

Range: New Brunswick to Minnesota, southward to Georgia and Missouri.

Habitat: Woodland borders, fields, and roadsides, fence rows, and thickets.

Stem one to four feet tall, erect, slender, round, and smooth. Leaves thin, finely rough, hairy, sharply toothed, heart-shaped to broadly ovate, long-pointed, the lower ones often five or six inches long and nearly as broad, with slender petioles; the upper ones much smaller, ovate to lance-shaped, short-petioled or sessile. Heads very numerous, in profuse panicled clusters at the ends of stem and branches, each about a half-inch broad, the rays light violet-blue; involucre top-shaped, its bracts appressed and tipped with short, obtuse, green points. Achenes very small, with whitish pappus.

Means of control the same as for New England Aster.

\section{SMOOTH ASTER}

Áster laèvis, L.

Native. Perennial. Propagates by seeds.

Time of bloom: August to October.

Sced-time: September to November.

Range: Maine and Ontario to North Dakota, southward to Georgia, Louisiana, and Kansas.

Habitat: Dry or stony soil ; fields, pastures, roadsides. 


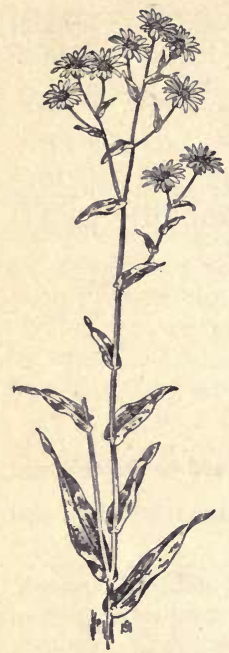

Fig. 300. - Smooth Aster (Aster loevis). $\times \frac{1}{2}$.

Stem two to four feet high, rather stout, smooth and polished or often glaucous, simple or branched at the top. Leaves light green, rather thick in texture, one to four inches long, smooth and shining or covered with a bloom, entire or minutely toothed, oblong and pointed, the upper ones sessile and clasping the stem with auricled or heartshaped base, the lower ones tapering to margined petioles which are partly clasping. Heads numerous, in slender open panicles, each about an inch broad, the rays deep violet-blue, sometimes purple; involucre bell-shaped, its bracts imbricated in several rows, smooth, acute, rigid, green-tipped. Achenes smooth, with a tawny pappus. (Fig. 300.)

\section{Means of control}

Enrich the ground and enable it to support plants of more worth. A cultivated crop, heavily fertilized and well tilled, followed by a clean seeding of clover or grass, will drive out this and many other weeds.

\section{WHITE HEATH ASTER}

\section{Áster ericoides, L.}

Other English names: Steelweed, Frostweed, White Rosemary, Serubbush.

Native. Perennial. Propagates by seeds.

Time of bloom: August to October.

Seed-time: September to December.

Range: Maine to Ontario and Wisconsin, southward to Virginia and Kentucky.

Habitat: Dry soil ; meadows, roadsides, and waste places.

Meadows and pastures infested with this weed are in a bad condition, for as green forage it is worthless, and the hard, woody 
stems that have given it the name of Steelweed dull or break the mowing knives and "cut the grade" of hay that is intended for market.

Stem one to three feet high, smooth or nearly so, diffusely branched, spreading and bushy. Leaves rather thick and rigid, the lower ones spatulate, one to three inches long, tapering to a slightly margined petiole, sometimes sparingly toothed; the upper ones narrow lance-shaped, sessile, entire, becoming linear and awllike as they near the summit. Heads very numerous, racemose along the upper side of the spreading branches; they are hardly a half-inch broad, with fifteen to twenty-five white or pinkish rays; bracts of the involucre rather thick and awl-like, greentipped. The blossoms secrete nectar of a fine, limpid quality, and the plant is a favorite with bee-keepers. Achenes small, gray, finely hairy, the pappus white; they are widely wind-distributed. (Fig. 301.)

Westward to Minnesota and Missouri, this plant gives place to a near relative, the Hairy Heath Aster (Áster ericoides var. pilòsus, Porter), very like it in appearance and habits except that the hard stems and the small, pointed leaves are clothed all over with fine, soft hair.

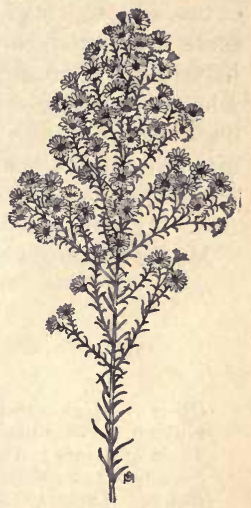

Fig. 301. - Heath Aster (Aster ericoides). $\times \frac{1}{4}$.

\section{Means of control}

Cultivation of the ground, fertilizing heavily and tilling very thoroughly before reseeding with clover and grasses. Sheep will eat the weed while it is young and will do good service in keeping it down in pastures.

\section{MANY-FLOWERED ASTER}

\section{Áster multiflòrus, Ait.}

Other English names: White Wreath Aster, Fall Flower.

Native. Perennial. Propagates by seeds. 
Time of bloom: August to November.

Seed-time: September to December.

Range: Maine to Ontario to the Northwest Territory and British Columbia, southward to Georgia, Texas, and Arizona.

Habitat: Dry, open soil ; fields, meadows, roadsides, and waste places.

Stem one to six feet tall, very slender, strict, hard and woody, with many slender, spreading branches, pale with a close, minute hairiness. Leaves light green, oblong to linear, spreading, rigid, entire, obtuse, rough-edged, sessile or clasping at the base, hardly more than an inch long, those on the branches much smaller, being mere roughened, awl-like bracts. Heads very many, hardly a half-inch broad, with white rays, in densely crowded, long, rather one-sided, racemose clusters, so closely set along the branches as often to conceal them and really form "white wreaths"; involucre top-shaped, its bracts appressed with spreading and recurved green tips. Achenes hairy, with tawny pappus.

Means of control the same as for the Smooth Aster.

\section{TRADESCANT'S ASTER}

\section{Áster Tradescánti, L.}

Other English names: Michaelmas Daisy, Farewell Summer.

Native. Perennial. Propagates by seeds.

Time of bloom: August to October.

Seed-time: September to November.

Range: Ontario to the Northwest Territory, southward to Virginia, Illinois, and Missouri.

Habitat: Damp fields and meadows, borders of swamps.

Stem two to five feet tall, nearly smooth, slender, brownish, with many ascending, paniculate branches. Leaves narrow lanceshaped to linear, three to six inches in length, long-pointed, thin, smooth, sessile and entire or the lower ones toothed along the middle of each side and tapering to petioles. Heads in large, very numerous raceme-like panicles, smaller than related species or rather more than a half-inch broad, the many narrow rays white or very pale purple; involucre broadly top-shaped, its bracts closely imbricated, linear, acute, green-tipped. Achenes minutely hairy, with a white pappus.

Means of control the same as for the Purple-stemmed Aster. 


\section{WILLOW-LEAVED ASTER}

\section{Áster salicifolius, Ait.}

Native. Perennial. Propagates by seeds.

Time of bloom: August to October.

Seed-time: September to November.

Range: Maine and Ontario to Montana, southward to Florida, Missouri, and Texas.

Habitat: Moist soil ; meadows, pastures, waste places.

Stem slender, two to five feet tall, smooth or the upper and younger parts finely hairy. Leaves firm, two to four inches long, somewhat rough-hairy, especially on the margins, narrow lanceshaped, with few and very short fine teeth along the sides or more often entire, pointed at both ends, sessile or slightly clasping or the lowermost ones tapering to petioles. Heads in loose, leafy panicles, each nearly an inch broad; with many violet or pale purple or sometimes nearly white rays; involucre top-shaped, its bracts nearly linear, closely appressed, acute and green-tipped. Achenes finely hairy with white pappus.

Means of control the same as for Purple-stemmed Aster.

\section{PURPLE-STEMMED ASTER}

\section{Áster puniceus, L.}

Other English names: Early Purple Aster, Red-stalk, Ruddy-stem, Swan Weed, Meadow Scabish, Cocash.

Native. Perennial. Propagates by seeds.

Time of bloom: July to November.

Seed-time: August to December.

Range: Newfoundland to Manitoba, southward to Virginia, Ohio, and Illinois.

Habitat: Moist fields and meadows, banks of streams, swamps.

Stem three to seven feet tall, stout, grooved, erect, reddish purple, bristly with short, stiff hairs, branching near the top. Leaves three to six inches long and an inch or more wide, oblong to lance-shaped, long-pointed, rough above, bristly on midrib below, toothed along the sides, clasping the stem with an auriculate base. Heads in loosely branched panicles, on 


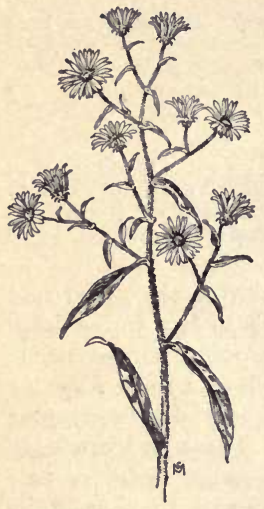

Fia. 302.-Purplestemmed Aster (Aster puniceus). $\times \frac{1}{3}$.

rather short pedicels, each about an inch broad, with light yellow disk and many pale purple or lilac rays; bracts of the involucre usually in two rows, linear, smooth, green, spreading. Achenes hairy, the long, tufted pappus nearly white. This weed is in bloom so early that flowering stems are often cut with hay, and seeds ripen on the stalks. (Fig. 302.)

\section{Means of control}

Deprive the plant of its loved moisture by better drainage. Prevent seed production and starve the perennial roots by frequent close cutting, and so fertilize, cultivate, and improve the ground that better plants will supersede the weed.

\section{ROBIN'S PLANTAIN}

Erígeron pulchéllus, Michx.

Other English names: Blue Spring Daisy, Poor Robin, Rose Petty. Native. Perennial. Propagates by seeds and off-sets.

Time of bloom: April to June.

Seed-time: May to July.

Range: Nova Scotia to Ontario and Minnesota, southward to Florida and Louisiana.

Habitat: Hillsides, woodland borders, moist banks.

Stems slender, simple, softly hairy, ten to twenty inches tall. Base-leaves tufted, spatulate or long obovate, obtuse, softly hairy on both sides, with a few shallow teeth, and tapering to shortmargined petioles; stem-leaves small, distant, narrow-ovate to lance-shaped, sessile or partly clasping, usually entire. Heads few, in a terminal cluster, each an inch or more broad, with many narrow purple rays varying from pale lilac to deep violet; disk broad and flat, greenish yellow, its florets perfect. Achenes flattened, nearly smooth, with pappus of a single row of fine hairs. 
Means of control

This weed is at once suppressed by cultivation of the ground; but where that is not practicable or desirable, the plant may be destroyed by hoe-cutting below the crown.

\section{PHILADELPHIA FLEABANE}

Erígeron philadélphicus, L.

Other English names: Skevish, Lowground Fleabane.

Native. Perennial. Propagates by seeds, stolons, and off-sets. Time of bloom: May to August.

Seed-time: June to September.

Range: Throughout North America except the far North.

Habitat: Alluvial soil ; fields, meadows, and thickets.

Often spoken of as the "common" Fleabane, but not usually an abundant weed, for it has decided preferences, growing only on moist ground and liking partial shade.

Stems one to three feet high, single or in tufts of two or three, slender, leafy, softly hairy. Lower leaves spatulate to long-obovate, obtuse, coarsely toothed, narrowing to short-margined petioles; stem-leaves more narrow and pointed, often entire, clasping by a heart-shaped base. Heads in a corymbose terminal cluster, each nearly an inch broad, with greenish yellow disks and innumerable thin, fringy rays, pale pink or pinkish purple, sometimes nearly white. Achenes hairy, with pappus of one funnel-formed row of fine hair. These seeds are a common impurity of grass and clover seeds, though, being small and light, they should be readily removed. (Fig. 303.)

Controlled by drainage and cultivation of the ground.

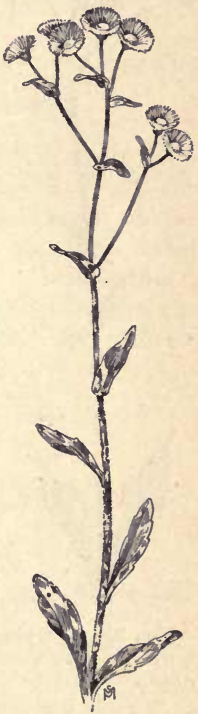

FIG. 303. - Philadelphia Fleabane (Erigeron philadelphicus). $\times \frac{1}{6}$. 


\section{WHITE-TOP.}

\section{Erigeron annuus, L.}

Other English names: Tall Whiteweed, Daisy Fleabane, Sweet Scabious.

Native. Annual or winter annual. Propagates by seeds.

Time of bloom: May to November.

Seed-time: June to December.

Range: Nova Scotia to Alaska, southward to Georgia and Missouri. Habitat: Fields, meadows, roadsides, waste places.

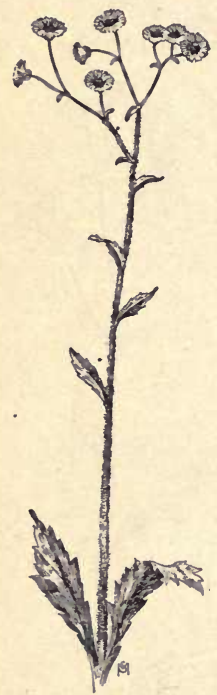

Fig. 304. - Whitetop (Erigeron annuus). $\times \frac{1}{6}$.

A special pest of grass and clover fields, the earlier flowers maturing and dropping seeds into the soil before the accompanying crop is ready to harvest, thus assuring a continuity of its unwelcome presence. Seedbearing plants are transported in baled hay and the seeds are a common impurity of grass seeds.

Stem two to five feet tall, erect, stiff, somewhat ridged, sparsely covered with spreading hairs, much branched at the top. Leaves thin, coarsely and sharply toothed, the lower ones long-ovate, tapering into margined petioles, the upper ones lance-shaped, acute, toothed only along the sides, sessile or with very short petioles, those on the branches still smaller and usually entire. Heads very numerous, in many corymbose clusters, on short pedicels, about a half-inch broad, the many narrow rays white or faintly tinged with purple; bracts of the involucre bristlyhairy and nearly linear. Achenes very small, light-colored, flattened, slightly hairy. Pappus double, the inner row of fine bristly hairs, the outer row of short slender scales. (Fig. 304.)

Means of control

If the infestation is new and the weed not so abundant as to make the task impracticable, it will pay to hand-pull and remove 
the plants at the appearance of its first bloom, rather than that the ground should be fouled for as long as it is kept in clover or grass. Sheep prefer White-top to good hay. After the crop is harvested, turn in the flock and they will graze down the tufts of winter crownleaves. Fields rankly infested are best treated by plowing under for winter wheat or a cultivated crop, to be followed by a clean reseeding.

\section{SLENDER WHITE-TOP}

Erigeron ramòsus, BSP.

Native. Annual or winter annual. Propagates by seeds.

Time of bloom: May to November.

Seed-time: June to December.

Range: Nova Seotia to the Northwest Territory, southward to Florida, Louisiana, and Texas.

Habitat: Fields, meadows, roadsides, and waste places.

Similar to the preceding species and often growing in its company, but smaller, the slender stem one to three feet tall, the clothing hairs appressed instead of spreading. Basal leaves oblong to spatulate, toothed, and narrowed to petioles, the stem leaves lance-shaped to linear, mostly entire, and sessile. Heads smaller, with even thinner and more thread-like white rays; bracts of the involucre nearly linear, scarious-margined, acute. Achenes resemble those of the preceding species.

Means of control the same as for Tall White-top.

\section{CANADA FLEABANE}

Erigeron canadénsis, L.

(Léptilon canadénse, Britton)

Other English names: Horseweed, Bitterweed, Prideweed, Mare'stail, Blood-stanch.

Native. Annual and winter annual. Propagates by seeds.

Time of bloom: June to October.

Seed-time: July to November.

Range: Throughout North America except the extreme North.

Habitat: Grain fields, meadows, pastures, and waste places.

From this plant is distilled the volatile oil of fleabane, used in making "mosquito dope" for the use of persons who have occa- 
sion to go where mosquitoes are troublesome; it is also used in medicine, and the dried plants are quoted at five to six cents a pound in the drug market; its juices are resinous and bitter, and grazing animals will not touch the weed. The hands should be protected when pulling or collecting the plants, for the oily' and acrid juices are sometimes very irritating to the skin, producing an eruption which resembles that caused by the touch of Poison Ivy.

In good soil the stem may attain to a height of ten feet, and, again, it will adapt itself to hard conditions and bloom when less

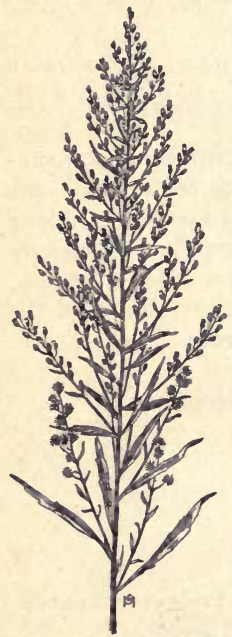

Fig. 305. - Canada Fleabane (Erigeron canadensis). $\times \frac{1}{4}$. than six inches tall; it is erect, finely grooved, bristly with short hairs, simple or branching from the base; when cut it stools freely, hastening to develop new fruiting branches. Lower leaves spatulate or sometimes cut-lobed, tapering to petioles; upper ones usually entire, lance-shaped to linear, finely hairy, much crowded on the stalks. Heads in panicled clusters, very small and very numerous, each about a sixth of an inch broad, with smooth, cylindric involucre, nearly concealing the very small, white rays. Seeds many and small, with yellowish brown pappus. (Fig. 305.)

\section{Means of control}

Where not too abundant to make the task impracticable, hand-pull the weeds and remove them from the ground, for the woody stalks contain enough nutriment to mature the first-opened flowers. Burn over stubbles on infested grain fields for the purpose of destroying the seeds on the ground. Meadows badly "run to Horseweed" should be put to a well-tilled hoed crop before reseeding. Plants of roadside and waste places should be pulled or cut in early bloom or before, for the protection of adjacent property. 


\section{COTTON ROSE}

\section{Gifola germánica, Dumort}

Other English names: Herba Impia, Childing Cudweed, Downyweed, Owl's Crown, Hoarwort.

Introduced. Annual. Propagates by seeds.

Time of bloom: June to September.

Seed-time: August to November.

Range: Atlantic States, New York to Georgia.

Habitat: Dry fields and pastures.

Its oddity tempts one to take a few plants to the home flower garden when first seeing a patch of this weed. Stems five to fifteen inches high, simple or branching from the base, the whole plant grayish white with soft woolly hair. Leaves alternate and crowded thick on the stem, lance-shaped, sessile, acute, erect, less than an inch long. At the top of the stalk is bunched a dense cluster of white-woolly discoid flower-heads, from among which rise several short, leafy branches, like the stalk below but more slender, and these in turn may have a bunch of woolly flower-heads and more leafy branches terminated by more woolly blossoms. For this odd habit of bloom it is called Childing Cudweed, and the early botanists named it Herba Impia because the children so undutifully exalted themselves above their mother. (Fig. 306.)

\section{Means of control}

The lowest cluster of flower-heads ripens first, and in order to keep them from reproduction the plants must be cut as soon as these appear, before any "children" overtop them.

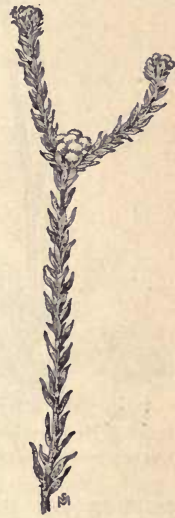

FIG. 306 . Cotton Rose $(G i$ fola germanica). $\times \frac{1}{3}$.

\section{PLANTAIN-LEAVED EVERLASTING}

Antennària plantaginifolia, Richards

Other English names: Early or Spring Everlasting, Mouse-ear Everlasting, White Plantain, Ladies' Tobacco, Pussy-toes.

Native.'Perennial. Propagates by seeds and by stolons. 
Time of bloom: Late March to June.

Seed-time: June to July.

Range: Labrador to Nebraska, southward to Georgia and Texas.

Habitat: Dry soil ; open woods, upland pastures.

These plants have diœcious flowers and their stoloniferous habit causes them to form broad, dense patches, the fertile and sterile groups commonly distinct but very neighborly. Root-

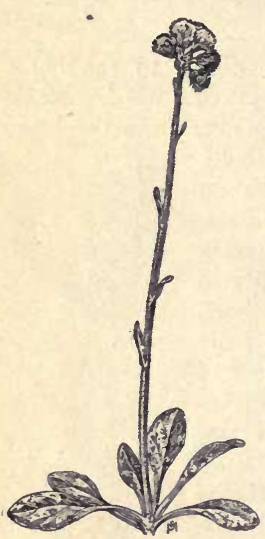

Fig. 307. - Plantainleaved Everlasting (Antennaria plantaginifolia). $\times \frac{1}{3}$.

leaves tufted in a small rosette, obovate to spatulate, obtuse, three-ribbed, tapering to petioles, softly white-woolly on both sides but more so beneath; leaves of old plants sometimes become smooth on the upper surface; stem-leaves few, small, and sessile. Stems at first very short but often lengthening to a height of six inches or a foot, the fertile plants being much the taller. Heads in small corymbose clusters, each head less than a quarter-inch broad, the pistillate ones showing two-cleft, crimson styles and when in fruit having the more copious pappus; bracts of the involucre dry and scarious, those of the fertile heads purplish brown at base, with narrow white tips, those of the staminate heads with broad white petal-like tips. After fruiting, the plants spend their energies for the remainder of the growing season in sending out runners with young plants at the tips, which take root and extend the size of the patches. Cattle leave the plant unmolested, and in dry fields and pastures it sometimes "runs out" much of the grass. (Fig. 307.)

\section{Means of control}

Disk-harrow, fertilize and reseed the hilly pastures in the fall, first removing the thickest patches of the weed by hoe-cutting. Cultivation and rotation with clover is the best remedy for ground not so hilly as to be in danger of washing. 


\section{FIELD CAT'S-FOOT}

Antennària neglécta, Greene

Native. Perennial. Propagates by seeds and by stolons.

Time of bloom: April to June.

Seed-time: June to July.

Range: New Brunswick to Wisconsin and Iowa, southward to Virginia and Kansas.

Habitat: Fields, meadows, pastures, and waste places.

A smaller plant than the preceding, but with much longer and more slender stolons. Root-leaves about two inches long, tufted in small rosettes, narrow spatulate or wedge-shaped, obtuse, onenerved, smooth above, white-woolly beneath, entire, sessile; stem-leaves linear, very small. Stems of staminate plants four to eight inches high, the fertile ones often nearly a foot in height when mature. Heads in racemose clusters, similar in structure to those of the preceding species. (Fig. 308.)

In some localities the Smaller Cat'sfoot, $A$. neodioica, is even more common, forming large matted patches. Its range extends from the North Atlantic States westward to the Dakotas and it has also found its way to Northern Fig. 308. - Field Cat's-foot Europe.

Means of control the same as for the Plantain-leaved Everlasting.

SWEET, OR COMMON, EVERLASTING

Gnaphàlium polycèphalum, Michx.

(Gnaphdlium obtusifolium, L.)

Other English names: Old Field Balsam, Sweet White Balsam, Balsam Posy, Fragrant Everlasting, Many-headed Everlasting, Chafeweed.

Native. Annual or winter annual. Propagates by seeds. 
Time of bloom: July to September.

Seed-time: September to November.

Range: Nova Scotia to Manitoba, and southward to Florida and Texas.



FIG. 309 . Sweet Everlasting (Gnaphalium polycephalum). $\times \frac{1}{4}$.

Habitat: Old fields and pastures, open woods.

Although grazing cattle pass it by and it usurps the place of plants that they do like, yet it would be one country pleasure lost to us if this weed were entirely gone from the old fields and "brushlot" pastures which it frequents. Its fragrance is one of the most delightful of outdoor odors and it is very lasting.

Stem softly woolly, one to three feet tall, simple or branched at the top. Leaves alternate, oblong, very narrow, pointed, sessile, tapering toward the base, dark green and smooth above but densely white-woolly beneath, the margins slightly wavy. Heads very numerous, several panicled clusters growing on a plant. Each head is oblong, few-flowered, with pistillate florets in the outer rows, those in the center perfect; involucral bracts appressed, white and papery, sometimes tinged with brown, blunt-pointed, the outer row woolly at the base. Seeds smooth and very small, the pappus tawny yellow. (Fig. 309.)

\section{Means of control ${ }^{\circ}$}

Hand-pulling or close cutting while in early bloom will prevent seed development. Hoe-cutting of winter rosettes.

\section{CLAMMY EVERLASTING}

\section{Gnaphàlium decúrrens, Ives}

Other English names: Clammy Balsamweed, Clammy Cudweed, Winged Cudweed.

Native. Annual or biennial. Propagates by seeds.

Time of bloom: July to September.

Seed-time: September to October. 
Range: Quebee to British Columbia, southward to Pennsylvania, Ohio, Michigan, and Minnesota and in the Rocky Mountains to Arizona.

Habitat: Upland pastures, clearings, open woods.

At first sight and smell this might be mistaken for Sweet Everlasting, but on handling it the white, woolly stem is found to be glandular and slightly sticky. Leaves sharp-pointed, slightly broader than those of the preceding plant, smooth above, whitewoolly below, sessile, with a decurrent base. Heads a little shorter and thicker, fragrant, closely clustered; their involucral scales are cream-white to pale brownish yellow, pointed oval in shape, the outer row woolly at their bases.

For its extermination the same measures are necessary as for Sweet Everlasting.

\section{LOW CUDWEED}

Gnaphàlium uliginòsum, L.

Other English names: Marsh Cudweed, Wartwort, Mouse-ear.

Native. Annual. Propagates by seeds.

Time of bloom: July to September.

Seed-time: September to November.

Range: Newfoundland to the Saskatchewan, southward to the states bordering on the Great Lakes.

Habitat: Low meadows, sides of streams and ditches, roadsides, and waste places.

Although this plant loves moisture and is a common weed of flooded ground, it can adapt itself to very different conditions; the writer found the specimen from which this description is written thriving in the dry ground of a vacant city lot. (Fig. 310.)

Stem two to six inches tall, with many branches, the lower ones spreading on the ground, making it much broader than its height. The plant is covered all over, stems and leaves, with close-pressed, white wool. Leaves sessile, spatulate to lance-shaped, narrow, pointed, and but one or two inches long. Flower-heads white,

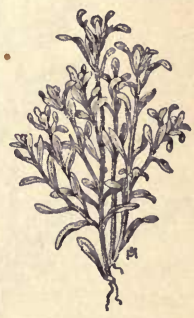

Fie. 310. - Low Cudweed (Gnaphalium uliginosum). very small, in close-packed terminal clusters sur- $\times \frac{1}{2}$. 
rounded by leafy, whlte-woolly bracts. Involucral scales oblong, the outer ones bluntly rounded and woolly, the inner rows acute, dry and scarious, yellowish white. Its very low, spreading habit of growth and dense white-woolliness would make it a pretty border plant in the flower garden if its ambitions in regard to bloom and fruitage were kept nipped in the bud.

\section{Means of control}

Hoe-cutting or hand-pulling while in early bloom, making certain that no seed has developed.

\section{ELECAMPANE \\ Ínula Helènium, L.}

Other English names: Horseheal, Horse Elder, Seabwort, Elf Dock, Velvet Dock, Yellow Starwort.

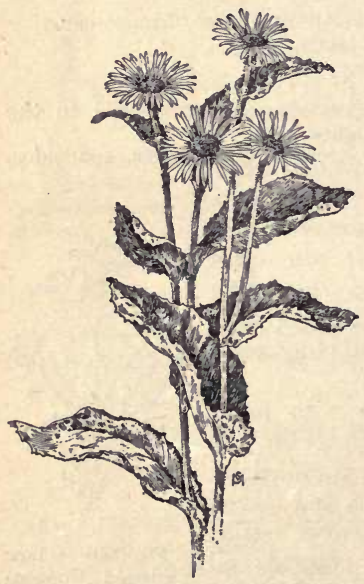

FIG. 311. - Elecampane (Inula Helenium). $\times \frac{1}{\text {. }}$.
Introduced. Perennial. Propagates by seeds.

Time of bloom: July to September.

Seed-iime: August to October.

Range: Nova Seotia to Minnesota, southward to North Carolina and Missouri.

Habitat: Old fields, pastures, roadsides, barnyards, and waste places.

In former days a small patch of this plant was often kept by country people for the relief of asthmatic horses, "to help the heaves" - the thick, fleshy, mucilaginous, yellow taproot being the part used; it is still valued medicinally and collectors receive three to five cents a pound for it, collected in the autumn of the second year of growth, sliced, and dried. 
The plant sends up in the first year only a clump of large leaves, long ovate, light green, the upper surface rough but the under surface downy-hairy, sometimes two feet in length and six or eight inches wide, with stout, hairy petioles. Fruiting stalks appear in the second year, three to six feet tall, stout, hairy, simple or sometimes branched, the leaves alternate, sessile and clasping. Heads terminal, solitary or few, two to four inches broad, on stout, hairy peduncles; rays yellow, numerous, linear, pistillate; diskflorets perfect and fertile; bracts of the involucre triple-rowed, the outer ones broad and leafy. Achenes brown, smooth, four-angled, with a pappus of bristly hairs. (Fig. 311.)

\section{Means of control}

Deep cutting with sharp spud or hoe, dry salt or carbolic acid being applied to the shorn root.

\section{COMPASS PLANT}

\section{Silphium lacinidtum, L.}

Other English names: Pilotweed, Polar Plant, Turpentine Weed, Rosinweed.

Native. Perennial. Propagates by seeds.

Time of bloom: July to September.

Seed-time: August to October.

Range: Michigan to the Dakotas, southward to Alabama, Louisiana, and Texas.

Habitat: Prairies; fields, meadows, and pastures.

Many a traveler of the pioneer, roadless days of "going west" found this plant a very serviceable compass, for its large leaves are held nearly erect with their edges directed north and south. It is a vigorous, grossly feeding weed, with large, thick, deepboring roots which yearly send up huge tufts of stout stems, four to twelve feet tall, bristly-rough, and sticky with resinous juices. Leaves alternate, a foot or more long, also bristly-rough on both sides, oblong, pinnately divided, the segments narrow, pointed, sometimes cut-lobed or pinnatifid, rarely entire; petioles long, rather stout, with dilated and clasping base. Heads three to five inches broad and very showy, sessile or with very short peduncle. 


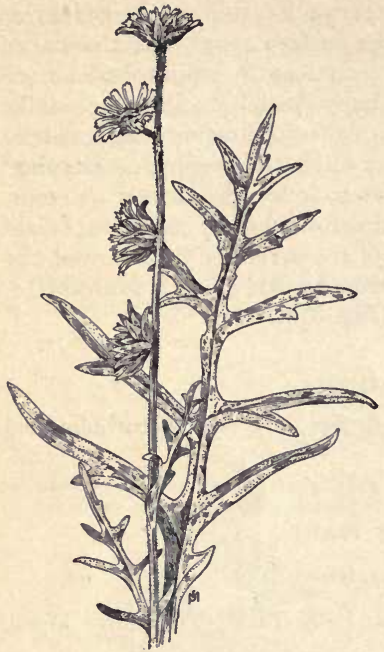

Frg. 312. - Compass Plant (Silphium lacinialum). $\times \frac{1}{8}$.

on the long, naked stalks near their summits; the many rays long, yellow, notched at their tips, pistillate and fertile ; disk-florets orange-yellow, perfect but sterile ; bracts of the involucre narrowly ovate with long, stiff points spreading nearly as wide as the rays. The achenes, being the fruit of the ray florets, are in rings around the outer edge of the heads, each about a halfinch long, brown, flat, oval, and broadly winged, deeply notched at the top, without pappus. (Fig. 312.)

Means of control

Cultivation of the ground is the best method of suppression; but if not desirable to break up the meadows where the plant is most troublesome, it should be cut deeply, below the crown, with a sharp hoe or spud, before the first flowers mature, the roots being salted so as to check new growth.

\section{PRAIRIE DOCK \\ Silphium terebinthindceum, Jacq.}

Other English names: Rosin Plant, Prairie Burdock.

Native. Perennial. Propagates by seeds.

Time of bloom: July to September.

Seed-time: August to October.

Range: Ontario and Ohio to Minnesota, southward to Georgia and Louisiana.

Habitat: Prairies and dry woods, meadows, and pastures.

Terebinthine is the ancient word for turpentine, and the resinous juice of this and the preceding weed accounts for one of their 
common names. Stem stout, four to ten feet tall, smooth or nearly so, branching at the top into a loose and sprawling panicle. Leaves alternate, mostly basal, a foot or more in length and about six inches wide, thick and leathery, rough on both sides but especially so beneath, heart-shaped at base and pointed at tip, sharply toothed, with long, stout, grooved petioles. Heads numerous, two or three inches broad, with many long, yellow rays which are pistillate and fertile; disk-florets perfect but sterile; involucre hemispheric, its bracts erect, obtuse, and smooth. Achenes oblong, flat, narrowly winged, slightly notched at the top, and two-toothed.

\section{Means of control}

Turning out the perennial roots with a plow in the fall is the surest method of destruction; but as it is most frequently a weed of permanent grasslands, deep cutting with sharp hoe or spud, just before the blooming season, is the next best remedy, using a handful of salt on the cut surface of the roots in order to retard their recovery.

\section{CUP PLANT}

\section{Sílphium perfoliàtum, L.}

Other English names: Indian Cup, Ragged Cup.

Native. Perennial. Propagates by seeds.

Time of bloom: July to September.

Seed-time: August to October.

Range: Ontario to the Dakotas, southward to Louisiana and Texas.

Habitat: Prairies; meadows, pastures, and waste places.

A large, stout weed with square, pale green stems, often more than an inch in thickness at the base, four to eight feet tall, growing from thick, perennial roots in great tufts, or thickets. Leaves opposite, large, broadly oval, pointed, coarsely toothed, the upper ones united at their bases and forming rather deep cups which retain dew and rain. Lower leaves very large and abruptly narrowed to winged petioles, which are also joined at base; for their size the leaves are rather thin, and are of a sandpaper roughness on both sides. Flower-heads few because of the curious progression of bloom; the first one grows from the center of a cup, 


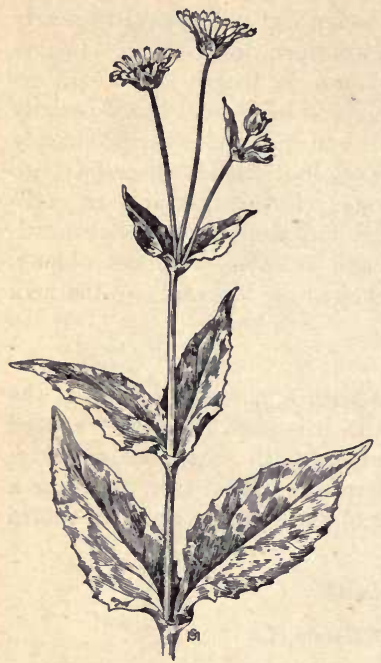

Fra. 313. - Cup Plant (Silphium perfoliatum). $\times \frac{1}{8}$. while on each side of it springs a stalk, taller than itself, bearing a leaf-cup, which in turn will have a central head and two more cup-bearing stalks; these will fork again, and yet again, the series being sometimes "four stories high," as an observant child remarked. Each head resembles a small sunflower, two or three inches broad, with twenty to thirty narrow, yellow rays, pistillate and fertile; the disk-florets are sterile; involucral bracts in triple rows, broadly ovate, and conspicuous. Achenes encircle the outer edge of the head, as only the rays form fruit; they are oval, broad, brown, flat, notched at apex, winged on each side, with a pappus of two awn-like teeth.

The same methods of extermination should be used as for the Compass Plant. (Fig. 313.)

\section{ROUGH MARSH ELDER}

Iva ciliàta, Willd.

Native. Annual. Propagates by seed.

Time of bloom: August to October.

Seed-time: September to November.

Range: Illinois to Nebraska, and southward to Louisiana, Texas, and New Mexico.

Habitat: Meadows and fields, sides of streams, and waste places.

A coarse, unsightly weed, bristly with rough hairs, two to seven feet in height, the erect stem usually simple but sometimes branched and often mottled with different shades of green. Leaves opposite, 
broadly ovate, pointed, three-nerved, coarsely and irregularly toothed, narrowed abruptly to bristly petioles. Heads in dense terminal and axillary spikes, subtended by narrowly lance-shaped, spreading, very hairy bracts, much longer than the greenish heads, which are scarcely an eighth of an inch in diameter. Involucre hairy, its bracts three to five, distinct or sometimes united at base; central florets staminate; fertile florets, marginal, three to five. Achenes about an eighth of an inch long, without pappus, similar to those of Poverty Weed but ribbed on the face. They are to be guarded against in alfalfa seed from the Southwest. (Fig. 314.)

\section{Means of control}

Prevent seed production. Meadows infested with this weed should be harvested early, before the plants have matured. Its bristly and woody stems are rejected by cattle as fodder, and if the plants are not extremely numerous it would pay to remove them by hand-pulling from a good stand of al-

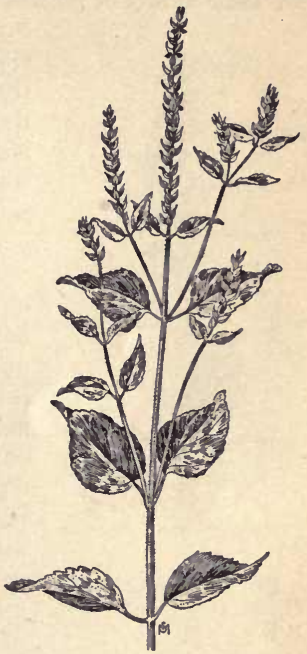

FIG. 314. - Rough Marsh Elder (Iva ciliata). $\times \frac{1}{6}$. falfa. Plants along ditches and streams should be destroyed by hoe-cutting or mowing while young.

\section{HIGHWATER SHRUB \\ İva xanthifolia, Nutt.}

Other English names: False Ragweed, False Sunflower, Red River Weed, Halfbreed Weed, Burweed Marsh Elder.

Native. Annual. Propagates by seeds.

Time of bloom: Late July to September.

Seed-time: September to November.

Range: Michigan and Manitoba to the Northwest Territory, southward to Nebraska, New Mexico, Colorado, and Utah.

Habitat: Grain fields, meadows, cultivated crops, waste places. 
Before flowering, this coarse weed somewhat resembles the Great Ragweed (Ambròsia trifida), for the young plants have nearly the same habits of growth and leaf outlines; but as soon as they

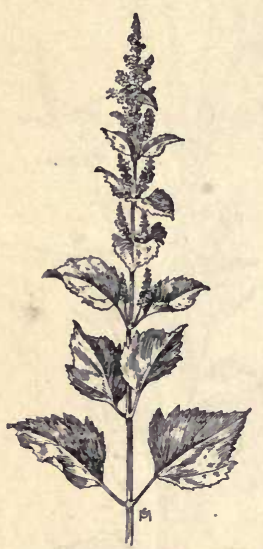

FIG. 315. - Highwater Shrub (Iva xanthifolia). $\times \frac{1}{6}$.

mature the likeness disappears. Stem stout, woody, and shrub-like, much branched, three to eight feet tall. The lower part of the plant is smooth, but the upper leaves and branches are somewhat roughened with minute hairs. Leaves mostly opposite, broadly ovate, coarsely and very irregularly toothed, roughish above, threenerved, narrowed abruptly to a stiff petiole; the lowermost ones are sometimes heart-shaped, six inches or more long and nearly as wide. Heads small and greenish, in large terminal panicles and lesser axillary clusters, sessile and closely crowded on the branchlets; they are scarcely an eighth of an inch broad, the disk-florets perfect but sterile; surrounding these are usually five fertile pistillate-flowers, with very short tubes or none at all. Achenes usually five in each head, about an eighth of an inch long, ovoid, slightly flattened, varying in color from light brown to nearly black, without pappus. They are sometimes found as an impurity in alfalfa seed. (Fig. 315.)

\section{Means of control}

The required tillage of cultivated crops serves to keep the weed in subjection. In grain fields many of the young seedlings may be dragged out with a weeding harrow in the spring, when the grain is but a few inches tall. The slightly roughened surface of its upper foliage makes this weed susceptible to injury from chemical spray, and, if treated in time with Iron sulfate or Copper sulfate, all seed development may be prevented. Waste-land plants should be cut, piled, and burned before any seed has ripened. 


\section{POVERTY WEED}

\section{İva axillàris, Pursh.}

Other English name: Small-flowered Marsh Elder.

Native. Perennial. Propagates by seeds and by rootstocks.

Time of bloom: June to August.

Seed-time: July to September.

Range: Manitoba to British Columbia, southward to Nebraska,

New Mexico, and California.

Habitat: Cultivated erops, grain fields, meadows, and waste places.

A very pernicious weed, difficult to suppress because of its extensive system of tough, woody rootstocks which send up many fruiting stalks, causing it to form dense patches, crowding and starving all other growth. It intrudes in most crops and thrives almost anywhere, but seems to have a preference for soil that is alkaline. The whole plant has a rank, unpleasant odor, causing it to be disliked by grazing animals.

Stems six inches to nearly two feet high, erect, diffusely branched and very leafy. Leaves narrowly oblong or obovate, a half-inch to two inches long, somewhat thick and fleshy, rough-hairy, three-nerved, entire and sessile; the lower ones opposite, those near the top alternate. Heads inconspicuous, solitary, axillary, and drooping, the central florets sterile; bracts of the involucre united into a five-lobed cup, surrounding the fertile pistillate florets which are usually four or five in number. Achenes ovoid, flattened, sometimes keeled on one side, varying in color from green to almost black; they have no pappus. (Fig. 316.)

\section{Means of control}

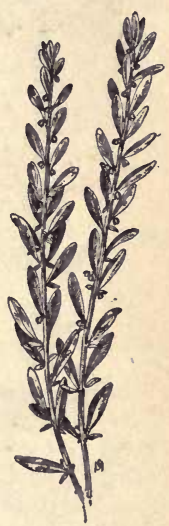

FIG. $316 .-$ Poverty Weed (Iva axillaris). $\times \frac{1}{6}$.

Prevent all seed production by repeated close cuttings throughout the growing season. The rootstocks must be starved to death after the manner of Horse Nettle or Perennial Sow Thistle, by short rotations with cultivated crops well fertilized and so well tilled that no leaf-growth is permitted to store the weed's underground 
stems with sustenance. Alternate with such crops as clover and rye, which may be cut often for soiling or may be plowed under to furnish green manure for another well-tilled hoed crop.

\section{GREAT OR GIANT RAGWEED}

Ambròsia trifida, $\mathbf{L}$.

Other English names: Tall Ambrosia, Kinghead, Crownweed, Wild Hemp, Big Bitterweed, Horseweed, Horse Cane.

Native. Annual. Propagates by seeds.

Time of bloom: July to September.

Seed-time: August to November.

Range: Nova Scotia to Florida, westward to the Northwest Territory, Nebraska, Colorado, and Arkansas.

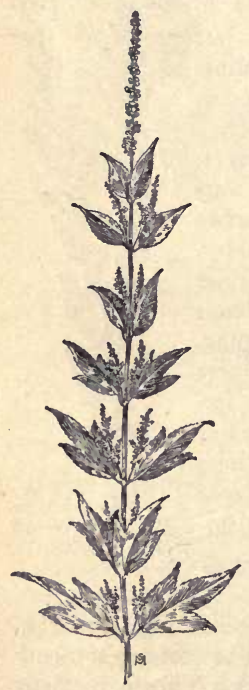

FIG. 317. - Giant Ragweed (Ambrosia trifida). $\times \frac{1}{8}$.

Habitat: Moist, rich soil ; fields and waste places.

A huge, coarse plant, occupying so much room and feeding so grossly that crops growing with it are crowded and starved to death. Its usual height is four to ten feet, but on very fertile river bottom-lands it attains to twelve and even fifteen feet.

Stem stout, tough, woody, widely branched and rough with bristly hairs. Leaves also rough-hairy and varying greatly in shape, often more than a foot long, mostly threeparted, but some may have five lobes and yet others may be ovate or lance-shaped; usually they are coarsely toothed but the smaller upper ones are often entire; all are opposite, three-nerved, the petioles stout and margined. Sterile heads in racemes six inches to a foot in length, their involucres threeribbed on the outer side with scalloped margins. Fertile involucres clustered in the axils of the upper leaves. These form a fruit a quarter-inch or more long, brown, obovoid, five- or six-ribbed, with a conic beak at apex surrounded by five or six 
shorter spines like the points of a crown; whence its names of Kinghead and Crownweed. These spines, or tubercles, give much trouble in cleaning it from other seeds, as they catch in the screens; also they contain air spaces, which enable the fruits to float on water and in winter to be blown far over crusted snow. (Fig. 317.)

\section{Means of control}

When young'and tender, Great Ragweed succumbs readily to the blighting touch of chemical sprays. But if allowed to approach maturity it pays to hand-pull the weed, for the stout, woody stalks so dull and break the blades of mowers and reapers, cause so much waste of binding twine, and are so clogging to the feed-way of threshing machines, that the earlier handwork is really an economy. In cultivated crops the plant gives little trouble, being killed there while young.

\section{COMMON RAGWEED}

A mbròsia artemisiijòlia, L.

Other English names: Roman Wormwood, Bitterweed, Wild Tansy, Hayweed, Hogweed, Carrotweed, Stammerwort.

Native. Annual. Propagates by seed.

Time of bloom: July to September.

Seed-time: August to November.

Range: United States and Canada from Nova Scotia to British Columbia, southward to Florida and Texas.

Habitat: Dry soil ; cultivated ground, meadows, waste places.

One of the most common of weeds, intruding almost everywhere; it is a pest in meadows and pastures, for, though cattle do not relish its bitter juices, they will sometimes eat it when better forage is scarce and, as a consequence, yield bitter milk with a bad odor. After the removal of a grain crop this plant nearly always springs up in the stubble. When in bloom its abundant pollen is said to cause "hay fever," and it is dreaded and avoided by persons subject to the disease.

Ragweed has rather deep, branching roots, from which the stem rises one to five feet, erect, finely hairy, and branching freely. Leaves alternate, two to four inches long, thin, deep green above, paler beneath, twice pinnatifid, giving the plant an open, feathery 
appearance. Flowers of two kinds, the staminate heads in crowded spike-like recemes at the summit of the plant and in its upper axils; the involucres top-shaped, formed of five to twelve united bracts, and containing six to twenty small, greenish flowers. Below, in the axils, concealed by clustering bracts, are the fertile involucres, each one containing a single flower, the elongated

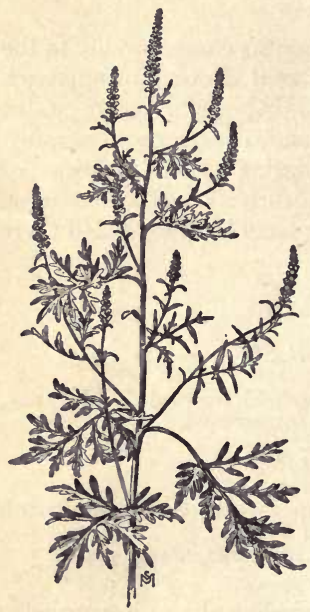

Fig. 318. - Common Ragweed (Ambrosia artemisiifolia). $\times \frac{1}{6}$. branches of its style protruding from the closed and pointed crown; when mature these involucres form hard achene-like fruits, about an eighth of an inch long, ovoid, with a beaked crown, surrounded by four to six spiny points. Once in the soil, they survive for years, springing up when opportunity offers; they are a common impurity of grain and grass seed and are also distributed in baled hay. (Fig. 318.)

\section{Means of control}

The thin, softly hairy, and widespread foliage of young Ragweed is very susceptible to injury from chemical sprays, and an application of Copper sulfate or Iron sulfate will kill the plants in multitudes without injury to the grass or grain among which they are growing. In clover fields the crop is slightly injured but recovers from the roots, which the weed-seedlings seldom do. Infested clover fields that are not treated should be cut early before the flowering of the weed, as its pollen is extremely bitter and "cuts the quality" of the hay even more than its dried young stalks. Stubbles should have surface cultivation directly after harvest so as to encourage germination of seeds in the soil, when the young plants may be killed with the harrow, or they may be plowed under for humus. In cultivated ground tillage should 
be continued late, as it is the plants that bloom and fruit after cultivation has ceased which are most certain to foul the soil.

\section{PERENNIAL RAGWEED}

Ambrosia psilostdchya, DC.

Native. Perennial. Propagates by seeds and by rootstocks.

Time of bloom: June to September.

Seed-time: July to October.

Range: Illinois to the Northwest Territory, southward to Texas, Mexico, and California.

Habitat: Rich prairie soil ; invades all crops.

This is a much harder weed to combat than its annual relatives, for one must have a care in cultivation not to break up and spread abroad the creeping rootstocks and thus increase the plague.

The plant looks very like the smaller Ragweed, but is stouter and grows two to six feet high. Leaves once or twice pinnatifid, with lobes usually acute, thick and bristly instead of thin and soft. Male flowers very abundant, on numerous long racemes, the involucres deeply cup-shaped; fertile flowers mostly solitary, the small, brown achenelike fruits obovoid, hairy, short-pointed, with fewer tubercles than the preceding species or sometimes none at all; they are often found in grass and clover seed and in baled hay. (Fig. 319.)

\section{Means of control}

Newly infested areas, if not so large as to make the method impracticable, should have prompt treatment with a strong herbicide - caustic soda or hot

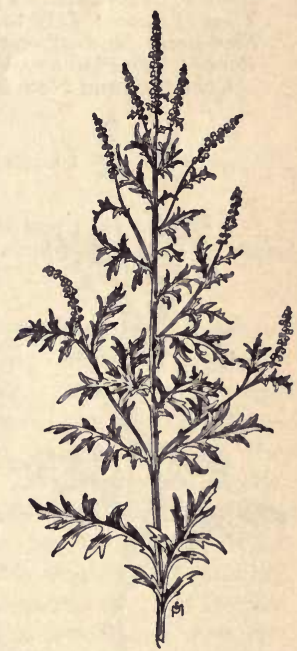

Fig. 319. - Perennial Ragweed (Ambrosia psilostachya). $\times$. 
brine - the soil being cleaned of all plant-growth for a season rather than allow the pest to gain a foothold. Large areas can be finally suppressed by putting the ground under cultivation, plowing deeply during very dry weather, and exposing the rootstocks as much as possible; after this summer fallowing put in a hoed crop, and give such persistent and careful tillage as to kill surviving rootstocks by depriving them of leaf growth.

\section{WHITE-LEAVED FRANSERIA}

Fransèria discolor, Nutt.)

(Gaertnèria discolor, Kuntze.)

Other English names: Bur Ragweed, Creeping Ragweed.

Native. Perennial. Propagates by seeds and by rootstocks.

Time of bloom: July to September.

Seed-time: September to November.

Range: The Plains region west of the Missouri River, to Wyoming, Colorado, and New Mexico.

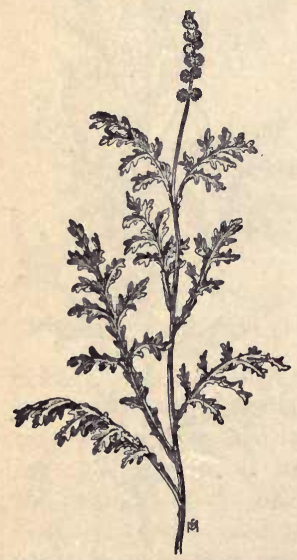

Fra. 320. - White-leaved Franseria (Franseria discolor). $\times \frac{1}{6}$.

Habitat: Dry soil ; prairies; meadows and pastures, cultivated fields, waste places.

A near relative of the Common Ragweed, but much more pernicious because of its creeping rootstocks. Stems twelve to eighteen inches tall, much branched, and spreading, hoary with white hairs. Leaves alternate, smooth and green above but densely whitewoolly beneath, coarsely toothed, long and bipinnate, the lobes narrow and very irregular, separated by narrow, winged segments, the petiole similarly winged. Flowers of two kinds, the sterile ones in narrow terminal racemes, the heads, about one-sixth of an inch long, on very short pedicels; the fertile heads in the axils below, singly or in small clusters; the involucre forms a tiny bur, about a sixth of an inch long, 
softly hairy, and bearing several small, sharp prickles. These burs are often distributed in the wool of sheep, and the weed is a most vexatious one to owners of flocks.

(Fig. 320.)

\section{Means of control}

Like all weeds that keep a reserve supply of food in underground storage, these are very hard to kill. They must be cut close to the ground in early summer, while in their first bloom, and again in September, in order to make certain that no seed shall be matured. If persistently deprived of the sustenance supplied by leaf-growth the rootstocks must finally be starved to death. Large areas are best subdued by deep plowing and exposure of rootstocks in hot weather as recommended for Perennial Ragweed.

\section{WOOLLY FRANSERIA}

Fransèria tomentosa, Gray

(Gaertnèria tomentosa, Kuntze)

Native. Perennial. Propagates by seeds and by rootstocks.

Time of bloom: July to September.

Seed-time: September to November.

Range: Montana, southward to Colorado and Kansas.

Habitat: Moist, rich soil ; cultivated ground, meadows, pastures, and waste places.

Similar to the preceding plant, the two often growing in company. It is larger, the stems usually one to three feet tall, erect, branching from the base, covered with fine, white-woolly hair. Leaves softly woolly on both sides or silky and ashy above, pinnately three- to seven-lobed, with segments lance-shaped, usually toothed, the middle, or terminal, lobe much the largest. Sterile racemes usually solitary, two to four inches long, the heads crowded and a little larger than $F$. discolor. Fertile involucres usually solitary in the upper axils, about a quarter-inch long, softly woolly, and set with very sharp spines, which are finely hooked at the very tip so that sheep and other animals catch them at a touch and they are even more readily and extensively distributed than the preceding species.

Means of control the same as for the preceding plant. 


\section{SPINY CLOTBUR}

Xánthium spinòsum, L.

Other English names: Spiny cocklebur, Thorny Burweed, Daggerweed, Dagger Cocklebur, Bathurst Bur.

Introduced. Annual. Propagates by seeds.

Time of bloom: July to September.

Seed-time: September to November.

Range: Ontario to Florida, westward to Illinois, Missouri, and Texas. Also abundant on the Pacific Coast.

Habitat: Warm, moist soil ; invades almost any crop.

A very pernicious weed which came to us from tropical America. It is sometimes cultivated for theodd appearance of its white-veined,

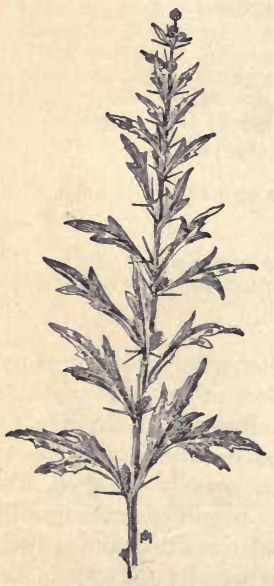

Fig. 321. - Spiny Clotbur (Xanthium spinosum). $\times \frac{1}{4}$.

inch long. Flowers of two linds, the staminate ones in short terminal spikes, the heads very small and greenish, like the Ragweed. Fertile flowers in the axils below, consisting of a 
pistil with its cleft style slightly exserted from a hairy and spiny involucre which later becomes a bur about a halfinch long, with two straight beaks at apex and a covering of short, smooth, hooked spines. The burs are two-celled, each cavity containing a thick-coated, dark brown, flattened seed.

\section{Means of control}

In pastures and meadows the plants should be watched for and cut off in May or June with a sharp hoe or spud ; some will be overlooked, to appear conspicuously later, bristling with spines and burs; these should be cut, piled to dry for a few days, and burned. In cultivated ground tillage should be continued late in order to prevent the development of seed from late-blooming flowers.

\section{CLOTBUR}

Xanthium canadénse, Mill.

Other English names: Cocklebur, Sheepbur, Buttonbur, Ditchbur, Hedgehog Burweed.

Native. Annual. Propagates by seeds.

Time of bloom: July to September.

Seed-time: September to November.

Range: Nova Seotia to the Northwest Territory, southward to Texas and Mexico. Abundant on the Pacific Coast.

Habitat: Rieh, moist soil ; eultivated erops, barnyards, roadsides, and waste places.

A huge, coarse plant, one to four feet tall, branched, and widely spreading, its rough, thick, angled stem often reddish and spotted with brown. Leaves also bristly rough on both sides, alternate, large, broadly oval to heart-shaped, with toothed edges, strongly three-nerved and of ten three-lobed, with long, rigid petioles, of ten reddish like the stem and contrasting with the dark green of the leaf surface. The sterile heads are clustered at the ends of the branches, small, greenish, and inconspicuous, resembling those of Ragweed; below, in the axils, the fertile heads are densely clustered; these are thick, green, oblong, densely hairy, and spiny involucres, from which is thrust a style with two-parted stigma; these involucres develop into burs nearly an inch long, with a 
pair of strong, hooked beaks at the tip and a covering of hooked spines which enable them to cling to a garment or to the coats of animals for a ride to new homes. Each bur contains two "seeds," or achenes, oblong, flat, slightly ridged, with a tough, black coat,

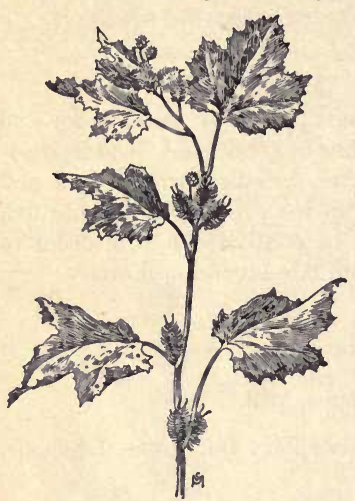

Fre. 322. - Clotbur (X anthium canadense). $\times \frac{2}{3}$. or skin. It is believed that one of the pair germinates the first season and the other the next, thus assuring a two-years' crop for one sowing. But the entire bur is also known to lie dormant in the soil for several years. Several other species of Clotbur are common and all are about as obnoxious as this one but none ranges so widely as $X$. canadense. (Fig. 322.)

\section{Means of control}

Hoe-cutting while the plants are small; or, if not too numerous, hand-pulling before the burs are formed. Put infested corn land to a grain crop, followed by clover or grass, the harvesting of any of which beheads the weed before it has attained to much size or developed the burs. In its tender youth (three to eight inches in height) Clotbur can be killed by a spray of Iron sulfate or Copper sulfate. Plants on waste land or roadside which have been allowed to mature their burs should be cut and burned.

\section{BLACK-EYED SUSAN}

Rudbéckia hirta, L.

Other English names: Yellow Daisy, Golden Jerusalem, Darkeyhead, Nigger-head, Ox-eye Daisy.

Native. Biennial. Propagates by seed.

Time of bloom: June to October.

Seed-time: July to November.

Range: United States and Canadian Provinces east of the Rocky Mountains.

Habitat: Prairies; meadows and pastures, waste places. 
A plant once known only on western prairies, but now common in eastern fields, the wide and rapid distribution having been accomplished by impure commercial seeds and baled hay, of which the refuse is spread on the fields.

Stems one to three feet tall, simple or branching near the base, rather stout, bristly hairy. Leaves alternate, oblong, two to six inches in length, thick, hairy, pointed at both ends, entire, or slightly wavy-toothed, the lower ones spatulate, three-nerved and with grooved petioles, those on the stalks sessile and clasping. Heads two to four inches broad, solitary on long hairy peduncles, the rounded disk brownish purple, its florets perfect and fertile, the long sterile rays brilliant orange. Bracts of the involucre in two or three rows, spreading, rough and hairy. Achenes black or very dark brown, about an eighth of an inch long, narrow, four-angled and without a pappus. (Fig. 323.)

\section{Means of control}

Being biennial, this weed is readily suppressed by pulling or close cutting before its seeds develop. But care must be taken that it is not continually reintroduced in poorly cleaned seed.

\section{PURPLE CONE-FLOWER}

\section{Braunèria purpùrea, Britton}

Other English names: Red Sunflower, Black Sampson.

Native. Perennial. Propagates by seeds.

Time of bloom: July to October.

Seed-time: August to November.

Range: Virginia to Missouri, southward to the Carolinas, Alabama, and Louisiana. Locally in the Northern States from New York to Michigan.

Habitat: Meadows, fence rows, and waste places. 


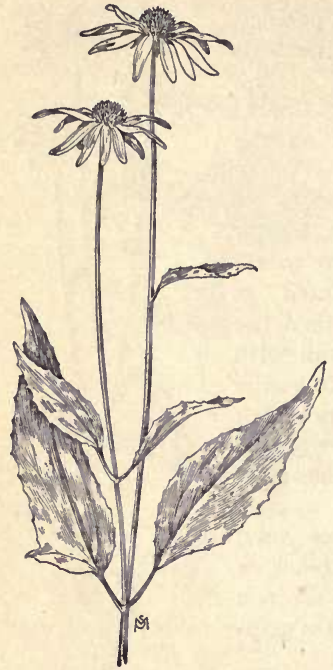

Fig. 324. - Purple Cone-flower

(Brauneria purpurea). $\times \frac{1}{4}$.
The range of this weed is being rapidly extended by the agency of baled hay and grass seeds. It is a handsome plant, two to four feet tall, with slender, rough-hairy stem, usually without branches. Leaves dark green, three to eight inches in length, alternate or the lower ones opposite, lance-shaped, hairy, longpointed, the lower ones five-ribbed, toothed, and petioled, the upper ones entire and sessile. Heads large, solitary, with a conical disk having deep purple, tubular, perfect, and fertile florets surrounded by twelve to twenty large, drooping rays which are pistillate but sterile; these are dull magenta-red, about two inches long, notched at their tips. Bracts of the involucre imbricated in three to five rows, rather soft and lax, nearly linear, and finely hairy. Achenes short and thick, the pappus a toothed crown. (Fig. 324.)

\section{Means of control}

If the infestation is new and the area not too large, it will pay to rid the soil of the perennial roots by hand-pulling the plants before the development of seed. Rankly infested ground requires to be put under cultivation.

\section{PRAIRIE CONE-FLOWER}

Lepachys columnàris, T. \& G.

(Ratíbida columnàris, D. Don.)

Other English names: Long-headed Cone-flower, Cone-headed Daisy.

Native. Perennial. Propagates by seeds.

Time of bloom: May to August. 
Seeed-time: June to September.

Range: Minnesota to the Northwest Territory, southward to Texas and Arizona. Also in Tennessee and locally in the Eastern States.

Habitat: Meadows, roadsides, and waste land.

Like its relatives, the Black-eyed Susan and Purple Cone-flower, this plant has been introduced in a number of widely separated localities by the agency of western baled hay and grass seeds. Stem one to nearly three feet tall, branching from the base, slender and beset with stiff, bristly hairs. Leaves alternate, dark green, thick, rough-hairy, strongly ribbed, pinnately divided into narrow, long-pointed segments; those on the stem are sessile or have very short petioles; those at the base have long, slender petioles and fewer segments; occasionally some are undivided and oblong. The heads have an elongated, cone-shaped, or nearly cylindrical disk, often more than an inch in length, set with grayish brown florets, perfect and fertile, the corollas five-lobed but with very short tubes; rays neutral, four to ten in number, large and drooping, yellow with a brownish purple base or wholly of the darker color. Achenes short and flattened, with

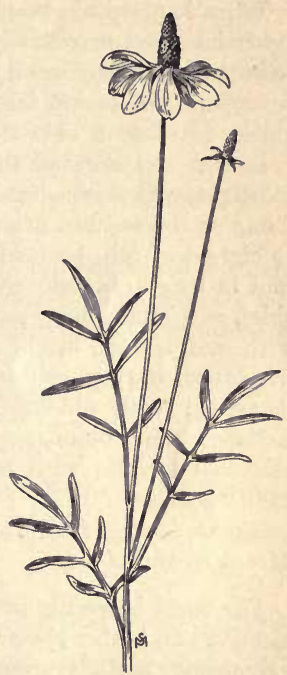

Fig. 325. - Prairie Coneflower (Lepachys columnaris). $\times \frac{1}{4}$.

winged margins, and a pappus of one or two awl-like teeth.

(Fig. 325.)

Means of control should be the same as for the Purple Coneflower.

\section{COMMON SUNFLOWER}

Heliánthus annuus, L.

Native. Annual. Propagates by seeds.

Time of bloom: July to September. 
Seed-time: August to October.

Range: Minnesota to the Northwest Territory, and southward to Missouri and Texas. Locally in the Eastern States.

Habitat: Meadows, waste places, fence rows, roadsides.

When kept within bounds this is a useful plant, which for many years has been extensively cultivated both in this country and in Europe. A fine, clear oil is expressed from its seeds, which are also a very nutritious and fattening food for poultry, horses, and other stock. Its leaves also are considered good fodder.

In rich soil some of the cultivated forms attain to fifteen feet in height, with flower-heads a foot or more across. But in its native home on the western prairies the stout, rough stem is usually three to eight feet tall, branching at the top. Leaves three inches to a foot in length, broadly oval, pointed, three-ribbed, rough on both sides, with stout, hairy petioles. Heads three to six inches broad, with many large, bright yellow, sterile rays ; disk-florets tubular, five-lobed, dark purple or brown, perfect, and fertile. Involucre depressed with oblong, rough-hairy, and sharp-pointed bracts. Achenes large, oblong, nearly smooth, grayish brown with white marginal stripes, with a deciduous pappus of two to four thin chaffy scales.

\section{Means of control}

The weed is readily subdued by cultivation of the soil ; but in meadows and other ground where tillage is not practicable, seed development should be prevented by cutting or pulling the plants while in their first bloom. Plants growing along roadsides, banks of streams, and waste places should have like treatment.

\section{STIFF SUNFLOWER}

Helianthus scaberrimus, Ell.

Native. Perennial. Propagates by seeds.

Time of bloom: August to September.

Seed-time: September to October.

Range: Michigan to the Saskatchewan, and southward to Illinois, Colorado, and Texas.

Habitat: Meadows, waste places, borders of streams. 
Stems rough, stout, woody, three to eight feet in height, simple or with a few branches at the top. Leaves three to six inches long, lance-shaped, pointed at both ends, thick and leathery, rigid, rough on both sides, with sharp but shallow teeth or sometimes entire, and are mostly sessile, only the lowermost ones narrowing to a short, rigid petiole. Heads few, usually solitary at the ends of stem and branches, two to four inches broad, with twenty to twenty-five light yellow sterile rays; the fertile disk-florets are purplish brown. Achenes oblong, hairy, crowned with two broad scales and often with several small, sharp-pointed awns.

\section{Means of control}

Most readily suppressed by cultivation of the soil, which destroys the perennial roots; or by frequent and close cutting during the growing season, which starves the roots and prevents seed development.

\section{JERUSALEM ARTICHOKE}

\section{Helianthus tuberòsus, L.}

Other English names: Tuberous Sunflower, Earth Apple, Girasole, Canada Potato.

Native. Perennial. Propagates by seeds and by short, tuberbearing rootstocks.

Time of bloom: August to September.

Seed-time: September to October.

Range: New Brunswick and Ontario to the Northwest Territory, southward to Georgia and Arkansas.

Habitat: Hummocks in swamps ; meadows, fields, roadsides, and waste places.

Long before the white men came to America the Indians were rudely cultivating this native plant for its edible tubers, which are fleshy and sweet and afford very nourishing food for man and beast. And so persistent is it when once established that some of the aboriginal patches are said to be still productive. The plant will grow almost anywhere, but it thrives best and the tubers grow largest in moist and mellow soil. Stems stout, erect, rough-hairy, four to twelve feet tall and branching at the top. Leaves four to eight inches long, ovate, pointed, thick, firm, three-nerved, sawtoothed, rough on the upper side, finely hairy beneath, tapering 
abruptly to a hairy petiole; the lower ones opposite (sometimes in whorls of three), the upper ones alternate. Heads about three inches broad, with twelve to twenty bright yellow sterile rays. Disk-florets perfect and fertile, tubular, five-lobed, and lighter

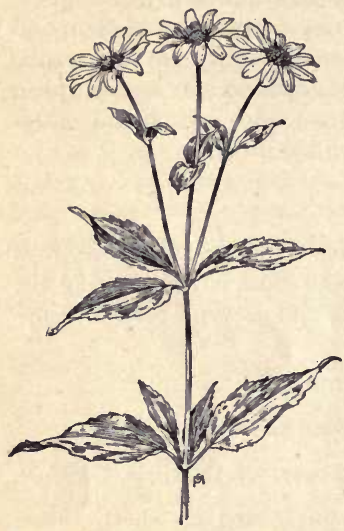

Fig. 326. - Jerusalem Artichoke (Helianthus tuberosus). $\times \frac{1}{6}$. yellow than the rays. Involucre hemispheric, its spreading bracts lance-shaped, sharp-pointed, and hairy. Achenes wedge-shaped, four-sided, hairy on the angles, crowned with a pair of awl-shaped scales or awns which quickly fall away. (Fig. 326.)

\section{Means of control}

Artichokes are very fattening, and a profitable way of clearing the ground of their presence is by turning in hogs to pasture - with untrammeled snouts - in the autumn, when the tubers are most crisp and succulent. Or the rootstocks may be starved by close and persistent cutting of the stalks in early summer, when their stored sustenance is most nearly depleted, allowing no new growth of leaves for replenishment. Dry salt on the shorn surfaces is an effective aid in checking new growth.

\section{WINGED IRONWEED}

Actinómeris alternifòlia, DC.

(Verbesina alternifolia, Brit.)

Other English names: Yellow Ironweed, Wingstem.

Native. Perennial. Propagates by seeds.

Time of bloom: August to September.

Seed-time: September to October.

Range: New York and New Jersey to Ontario, Iowa, and Kansas, southward to Florida and Louisiana.

Habitat: Meadows and pastures, roadsides, and waste places. 
A tall, unsightly weed, growing almost anywhere but with a preference for rich, moist, bottom-lands and borders of streams. Stem three to nine feet in height, hairy, erect, branching near the top, winged by the decurrent leaf-bases, very hard and woody when mature and therefore troublesome to harvesting machines. Leaves four inches to a foot long, lance-shaped, feather-veined, saw-toothed, usually rough on both sides, pointed at both ends, the upper ones mostly extending downward on the stem. Heads numerous in large, corymbose terminal clusters ; they have two to ten drooping, pale yellow neutral rays of irregular size (occasionally none at all), and a darker yellow, globose disk, containing about thirty fertile florets. Bracts of the involucre spreading or deflexed, oneto three-rowed. Achenes broadly wedge-shaped, flattened, and winged with a pappus of two diverging awns.

\section{Means of control}

The deep perennial roots are most effectively dealt with by thorough cultivation of the ground; where that is impracticable, they may be starved by close cutting in May and June, and again in August and September, salt being used on the shorn surfaces in order to retard recovery. Small areas may be grubbed out or handpulled when the ground is soft.

\section{SUNFLOWER CROWNBEARD}

\section{Verbesina helianthoides, Michx.}

Native. Perennial. Propagates by seeds.

Time of bloom: June to July.

Seed-time: July to August.

Range: Ohio to Iowa, southward to Georgia and Texas.

Habitat : Dry fields, meadows, and waste places.

Another pernicious Composite, which, like Black-eyed Susan, is broadening its range by the agencies of commercial seeds and baled hay. Stem, stout, simple, hairy, two to four feet tall, widely fourwinged by the decurrent bases of the alternate leaves; these are two to four inches long, narrowly ovate, rough above but softly hairy on the under sides, saw-toothed, and sessile. Heads few in a cluster or solitary, two or three inches broad, with conical disk 
and eight to fifteen yellow neutral or sometimes pistillate but sterile rays ; involucre hemispheric, about a half-inch high, its bracts closely appressed, lance-shaped, and gray-hairy. Achenes flattened, rough-hairy, with winged border and pappus of two divergent awns.

\section{Means of control}

Prevent seed development and distribution by close cutting while in first bloom. Rankly infested ground should be put under cultivation in order to destroy the perennial roots, but small areas may profitably be hand-pulled or grubbed out.

\section{GOLDEN CROWNBEARD}

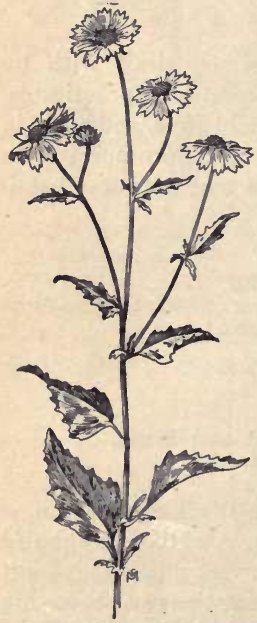

FIG. 327 - Golden Crownbeard (Verbesina encelioides). $\times \frac{1}{4}$.
Verbesina enceliotdes, B. \& H. (Ximenèsia encelioides, Cav.)

Native. Annual. Propagates by seeds.

Time of bloom: June to August.

Seed-time: July to September.

Range: Montana southward to Arizona and Texas, to Florida.

Habitat: Fields, meadows, and waste places.

A very common weed in its range, which is rapidly extending, the plant having appeared locally as far east as Maine. It intrudes in nearly all crops, appropriating an injurious amount of the soil fertility.

Stem one to two feet tall, much branched and densely hairy. Leaves alternate, ovate, abruptly narrowed or heart-shaped at base, irregularly but sharply toothed, the upper surface green, but beneath pale with a covering of ashy-gray hairs; petioles usually winged and often having a spreading, auricular appendage at base. Heads numerous, one to two inches 
broad, with twelve to fifteen pistillate and fertile bright golden rays, three-toothed at tips; disk florets perfect and fertile, brownish yellow; involucre about one-half inch high with lance-shaped, spreading, hairy bracts. Achenes of the disk florets narrowly obovate, flattened, hairy, broadly winged, with a pappus of two needle-like awns; those of the rays thickened, roughwrinkled and usually without awns or wings. (Fig. 327.)

\section{Means of control}

Prevent seed production. In grain fields the weed seedlings may be harrowed out in spring when the crop is but a few inches above the ground. Plants which survive this treatment may profitably be hand-pulled, the increased returns paying for the labor. Grasslands should be harvested before the first flowers mature, and all waste places receive attention.

\section{LANCE-LEAVED TICKSEED}

Coreópsis lanceolata, $\mathbf{L}$.

Native. Perennial. Propagates by seeds. Time of bloom: May to August.

Seed-time: June to September.

Range: Western Ontario to Virginia and Florida. Locally in the Eastern States.

Habitat: Meadows, fence rows, roadsides, and thickets.

A plant often cultivated because of the showy beauty of its flowers, and freely escaping. Stem one to two feet in height, branching from the lower part, smooth, or slightly downy near the base. Leaves opposite, two to six inches long, lance-shaped or the lowest spatulate, tapering to petioles which partly clasp the stem; upper ones sessile, all entire, with rough edges. Heads solitary, about two inches broad, on slen-

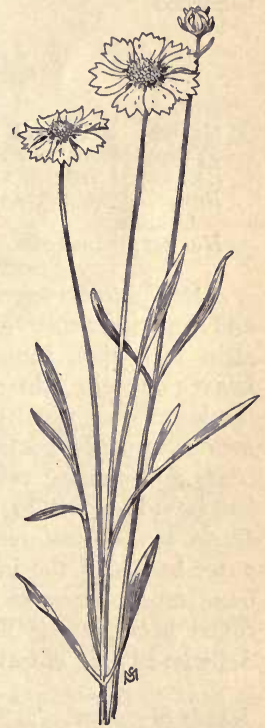

Fig. 328 . - Lanceleaved Tickseed (Coreopsis lanceolata). $\times \frac{3}{3}$. 
der, naked peduncles often a foot in length; disk florets perfect, fertile, the five-lobed corollas purplish brown; rays six to ten, neutral, bright yellow, broadest at apex, and threelobed with the middle lobe notched. Involucre hemispheric, its . bracts in two rows, the outer ones narrower than the inner and not so long. Achenes rounded oblong, broadly winged, crowned with two short teeth. (Fig. 328.)

\section{Means of control}

Prevention of seeding by repeated cutting, which will also finally starve the roots. Cultivation of the soil at once destroys the weed.

\section{TALL TICKSEED}

Coreópsis tripteris, $\mathrm{L}$.

Native. Perennial. Propagates by seeds.

Time of bloom: July to October.

Seed-time: August to November.

Range: Pennsylvania to Wisconsin, southward to Florida and Louisiana.

Habitat: Meadows, fence rows, open woods, and thickets.

A tall, graceful species, common in Southern and Western States and sometimes cultivated and escaping in the East. Stem three to eight feet high, round, smooth, slender, branching at the top. Leaves opposite, three to six inches or more in length, thick, firm, the lower ones usually three-parted with entire, lance-shaped segments ; upper leaves undivided, lance-shaped, entire, all with rough edges and pinnate veins. Heads very many, about an inch and a half broad, on slender peduncles, in open corymbose clusters; rays six to ten, obtuse, entire, bright golden yellow; disks brownish; outer bracts of the involucre linear, obtuse, spreading, united at base, much narrower than the ovate, pointed, inner ones; when rolled between the fingers the heads exhale the odor of anise. Achenes oblong elliptic, narrowly winged, and without a pappus.

\section{Means of control}

Prevention of seeding and starvation of the roots by persistent cutting. Hand-pulling or grubbing out the roots. 


\section{BEGGAR-TICKS}

Bidens fronddsa, $\mathrm{L}$.

Other English names: Bur Marigold, Stick-tight, Devil's Bootjack, Pitchfork Weed.

Native. Annual. Propagates by seed.

Time of bloom: July to September.

Seed-time: August to October.

Range: Throughout United States and southern British America.

Habitat: Moist soil ; gardens, fields, pastures, roadsides, and waste places.

All the Bidens are most annoying weeds and this one is perhaps the most so because it is everywhere. Stem two to five feet high, erect, smooth or nearly so, often purplish in color, with spreading branches. Leaves opposite, usually smooth, the lower ones generally five-lobed with terminal segments long-pointed and often again divided; upper ones three-parted or sometimes lance-shaped, all sharply toothed; petioles slender, and grooved on the upper side. Heads numerous, about a half-inch long, on slender peduncles; involucre double, with an outer row of five to eight leafy and spreading bracts, spatulate, with edges hairy at base, much exceeding the heads in length; the inner row short, with scarious margins; rays, when present, yellow, very small and inconspicuous, sterile; disk-florets tubular, orange-yellow, five-toothed, perfect, and fertile. Achenes wedge-shaped, black, flat,

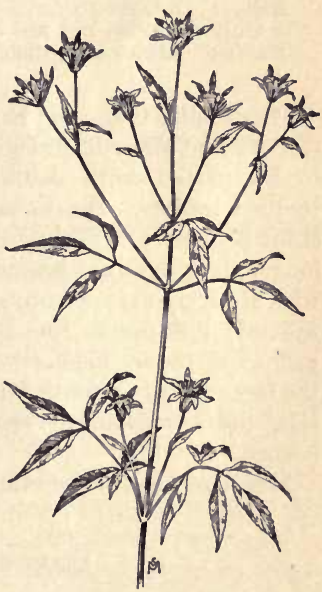

Fig. 329. - Beggar-ticks (Bidens frondosa). $\times \frac{1}{4}$. ridged down the center of each face, the apex bearing two diverging, downwardly barbed awns, which enable them to attach themselves to clothing and to the coats of animals, particularly sheep, and so ensure a wide distribution.

(Fig. 329.) 


\section{Means of control}

Prevent seed production by mowing, hoe-cutting, or hand-pulling the pests while in first bloom or earlier. Cultivation of the soil destroys it and good drainage is a discouragement to this weed, for it prefers the ground damp.

\section{BIG BEGGAR-TICK}

\section{Bidens vulgdta, Greene}

Native. Annual. Propagates by seeds.

Time of bloom: August to October.

Seed-time: September to November.

Range: Ontario to British Columbia, southward throughout the United States, but not common in the eastern part.

Habitat: Moist soil ; fields, waste places.

Much taller than the preceding plant, sometimes attaining eight feet or more, smooth, and much branched. Leaves pinnately threeto five-parted, with slender petioles and long-pointed, coarsely toothed leaflets. Heads large, often an inch or more broad, on stout peduncles; involucre of ten to sixteen outer bracts, usually longer than the disk, bristle-edged, unequal; the inner row short, with abruptly narrowed tips ; rays when present, pale yellow, small, neutral; disk-florets funnel-form, four- to five-toothed, also pale yellow. Achenes oblong wedge-shaped, brown or olive, very flat, the faces usually smooth but sometimes roughened with fine tubercles, the awns and the upper part of the achenes downwardly barbed.

Means of control the same as for the preceding species.

\section{LEAFY-BRACTED TICKSEED}

Bidens comòsa, Wiegand

Native. Annual. Propagates by seeds.

Time of bloom: August to October.

Seed-time: September to November.

Range: Maine to Minnesota, southward to Colorado, Georgia, and Louisiana.

Habitat: Moist rich soil ; fields, banks of streams, waste places. 
Stem one to three feet high, stout, erect, smooth, pale green, with short, stout branches. Leaves light green, lance-shaped, regularly toothed, pointed at both ends, with winged petioles or the upper ones sessile. Heads large, on short, stout peduncles, the outer bracts of the involucre six to eight, lance-shaped, large, and leaflike, often toothed, erect, their height sometimes two to five times exceeding the disk; rays wanting; disk-florets funnel-shaped, four-lobed, pale yellow. Achenes brown or olive, nearly a halfinch in length, flat, smooth or nearly so, three-awned, the outer ones nearly three-fourths as long as the achene, the central one usually shorter, and all barbed downward.

Control of the weed depends on allowing none of the plants to mature their fruits.

\section{SWAMP BEGGAR-TICKS}

\section{Bidens connàta, Muhl.}

Other English names: Purple-stemmed Stickseed, Harvest Lice.

Native. Annual. Propagates by seeds.

Time of bloom: August to October.

Seed-time: September to November.

Range: New England to Minnesota, southward to the Carolinas and Missouri.

Habitat: Wet meadows and fields, banks of streams, and ditches.

This native American has established itself in Europe, where it is very cordially disliked. Stem one to six feet or more tall, erect, smooth, purple, branching freely. Leaves deep green, usually undivided or some of the lower ones three-cleft, narrowly lanceshaped, coarsely toothed, with long, slender petioles. Heads about a half-inch broad, numerous, on short, slender peduncles, the outer bracts of the involucre few, obtuse, entire, extending not far above the head; rays usually wanting, but, when present, golden yellow; disk florets orange-yellow, five-lobed. Achenes dark brown, rather thick, wedge-shaped, tubercled, four-angled, fourawned, or the outer row flattened on one side and three-awned, the sides of achene and awns downwardly barbed.

\section{Means of control}

Drainage and cultivation of the ground; prevention of seeding by frequent, close cutting. 


\title{
NODDING BUR MARIGOLD
}

\author{
Bìdens cérnua, $\mathbf{L}$.
}

Other English names: Double-tooth, Water Agrimony.

Native. Annual. Propagates by seeds.

Time of bloom: July to October.

Seed-time: August to November.

Range: Nova Scotia to British Columbia, southward to the Carolinas, Missouri, and California; also in Europe and Asia.

Habitat: Marshy meadows, swamps, and along streams.

This species, usually in company with the similar, but larger, Brook Sunflower (Bidens laèvis, B.S.P.), often covers acres of

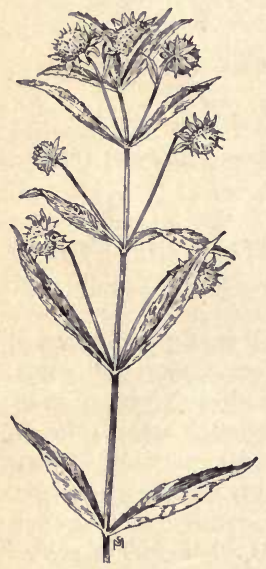

Fig. 330. - Nodding Bur Marigold (Bidens cernua). $\times \frac{1}{4}$. tached to clothing and the coats of animals than those of the preceding species. (Fig. 330.)

' The same measures for suppression are necessary as for the Swamp Beggar-tick. 


\section{SPANISH NEEDLES}

Bidens bipinnàta, L.

Native. Annual. Propagates by seeds.

Time of bloom: July to October.

Seed-time: August to November.

Range: Rhode Island to Nebraska and Arizona, southward to Florida and Mexico. Also in Europe and Asia.

Habitat: Gardens, fields, roadsides, and waste places.

Satisfied if the soil is only moderately moist, this weed often makes itself troublesome in fields of Indian corn and other cultivated crops, maturing seeds after the horsehoe culture has ceased. Stems slender with many spreading branches, one to five feet tall, erect, smooth, and foursided. Leaves pinnately twice or thrice divided, the segments broadly lanceshaped, deeply cut and toothed, opposite or the uppermost sometimes alternate; petioles slender and grooved. Heads usually numerous, on long, ridged, and angular peduncles; outer bracts of the involucre linear, shorter than the inner ones which are broader and acutely pointed; rays small and few, pale yellow with dark veins; disk-florets yellow and five-lobed. Achenes brown, nearly three-fourths of an inch long, slim, spindle-shaped, four-angled, usually tipped with four rather short, awllike, diverging awns, barbed downward. (Fig. 331.)

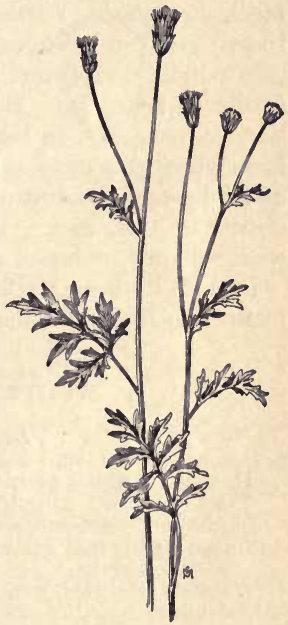

Frg. 331. - Spanish Needles (Bidens bipinnata). $\times \frac{1}{4}$.

\section{Means of control}

Prevent seed production, continuing the tillage of cultivated crops late or hand-pulling the late-flowering remnant of the weed growth. All waste-land plants should be cut several times during the growing season. 


\section{TICKSEED SUNFLOWER}

\section{Bìdens trichospérma, Britton}

Native. Annual or biennial. Propagates by seeds. Time of bloom: August to October.

Seed-time: September to November.

Range: Massachusetts to Georgia, and inland to Kentucky and Illinois.

Habitat: Marshy meadows and swamps, banks of streams, and often in drier situations, along roadsides and in waste places.

Stem smooth, obscurely four-sided, two to five feet in height, much branched. Leaves pinnately three- to seven-lobed, with short, grooved petioles, the segments narrowly lance-shaped, pointed, and sharply toothed; uppermost ones sometimes undivided, sessile or nearly so. Heads many, about two inches broad, on slender peduncles, in loose, corymbose clusters ; involucre nearly hemispheric, the outer bracts linear to spatulate, extending scarcely at all beyond the broader inner ones; rays about an inch long, obtuse at tips, entire, bright golden yellow. Achenes narrowly wedge-shaped, crowned with two short, stout, three-angled awns.

Despite its beauty, the weed should be destroyed in the same manner as Bidens frondosa.

\section{WESTERN TICKSEED SUNFLOWER}

Bidens aristdsa, Britton

Native. Annual or biennial. Propagates by seed.

Time of bloom: August to October.

Seed-time: September to November.

Range: Ohio and Michigan to Minnesota, southward to Mississippi and Louisiana.

Habitat: Prairies, moist meadows, swamps, banks of streams, and ditches.

Stem one to three feet tall, slender, and much branched. Leaves pinnately five- to seven-lobed, the segments slenderly lance-shaped, pointed at both ends, sharply cut and toothed, slender-petioled, softly hairy on the under side; upper leaves with fewer lobes on very short petioles, or lance-shaped and sessile. Heads numerous, one to two inches broad, on slender peduncles, in loose, open 
clusters; outer bracts of the involucre eight to ten, linear or spatulate, not exceeding the inner row; rays six to ten, broad, obtuse, bright golden yellow. Achenes obovoid, flat, rough-hairy, tipped with two (occasionally four) slender, diverging awns, sometimes as long as the achene itself or sometimes reduced to short teeth; the barbs on the awns and on the sides of the achenes are on some directed downward, on others upward. (Fig. 332.)

Means of suppression the same as for Bidens frondosa.

\section{TARWEED}

Mddia sativa, Molina

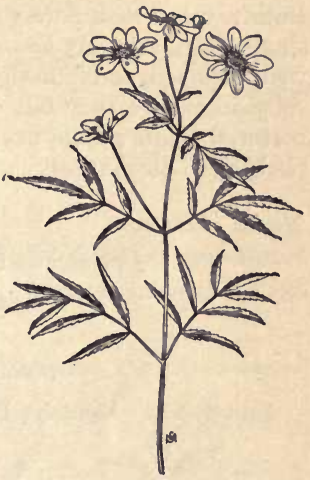

Fia. 332.-Western Tickseed Sunflower (Bidens aristosa). $\times \frac{1}{2}$.

Introduced. Annual. Propagates by seeds.

Time of bloom: May to October.

Seed-time: June to November.

Range: Pacific Coast from California to Washington.

Habitat: Fields, roadsides, and waste places.

A most unpleasant weed, covered with a viscid, ill-scented excretion which injures everything that it touches, from the crops among which it is harvested to the clothing of passers-by. None of the native Tarweeds are so offensive as this, which is an immigrant from Chile. A remarkably sweet and limpid oil is expressed from the seeds, good for table use and particularly valuable for a lubricant, as it does not readily congeal ; in order to obtain this oil the plant is extensively cultivated in South America and in Europe. Stem stout, one to four feet tall, finely hairy, beset with viscid, pedicellate glands. Leaves alternate, entire, varying from broad lanceshape below to linear above, all sticky and strong-scented. Heads numerous, sessile or on short peduncles at the ends of the short branches and in the upper axils; they are about three-fourths of an inch broad, with eight to twelve pale yellow rays and darker disk. 
Both ray and disk florets are fertile; bracts of the involucre in a single series, strongly keeled, and hairy. Disk achenes are oblong, wedge-shaped, and four-angled, those of the rays longer and curved. As soon as ripe they fall readily from the receptacle, and nearly matured plants should never be left on the ground when cut as the seeds ripen on the stalks.

\section{Means of control}

Prevent seed production by close and repeated cutting throughout the growing season.

\section{GALINSOGA}

Galinsdga parvifiòra, Cav.

Introduced. Annual. Propagates by seeds.

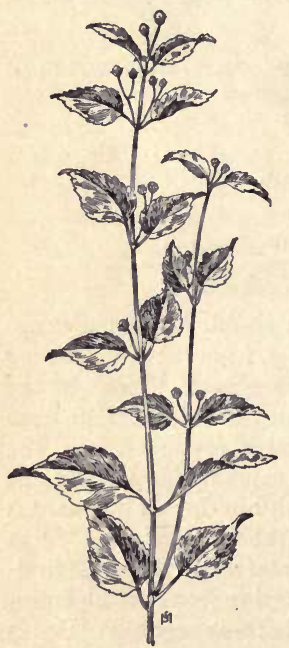

Fic. 333. - Galinsoga ( $G a-$ linsoga parviflora). $\times \frac{1}{4}$.

Time of bloom: June to November. Seed-time: July to December.

Range: Massachusetts to Oregon, south-ward to Georgia and Mexico.

Habitat: Gardens, roadsides, and waste places.

An immigrant from South America which has also crossed the ocean and been reported as troublesome in southern Europe. Stem one to two feet tall, pale green, slender, many-branched and spreading, sparsely clothed with appressed hairs. Ieaves opposite, ovate, thin, three-nerved, scallop-toothed, acute at apex, the lower ones narrowing to slender petioles, the upper ones sessile or nearly so. Heads, hardly a quarterinch broad, solitary on short, slender peduncles, terminal and in the upper axils; rays white, very short, threetoothed, pistillate, fertile; disk-florets yellow, perfect, and fertile; bracts of the involucre smooth, the outer row shorter. Achenes very small, dark, four-sided, wedge-shaped, finely hairy. (Fig. 333.) 
Means of control

Prevent seed production by pulling or hoe-cutting when in first flower. In cultivated ground the weed is destroyed by the tillage of the crop.

\section{SNEEZEWEED}

\section{Helènium autumnàle, L.}

Other English names: Sneezewort, Staggerweed, Swamp Sunflower, False Sunflower, Yellow Star.

Native. Perennial. Propagates by seed.

Time of bloom: August to October.

Seed-time: September to November.

Range: Quebec to Manitoba and the Northwest Territory, southward to Florida, Texas, and Arizona.

Habitat: Wet meadows, swamps, and along streams and ditches.

The pollen from this plant, when inhaled, causes violent sneezing and the powdered flower-heads are used in medicine for that purpose. The weed is poisonous, acrid, and pungently bitter, the flowers especially so. Horses, cattle, and sheep are sometimes killed by it; with milch cows a few mouthfuls are sufficient to taint the dairy products. Animals usually avoid the plant, but it is said that if a little is eaten an abnormal appetite is quickly formed, and then a sufficient quantity is taken to cause convulsions and death.

Stems two to five feet tall, slender, very pale green, angled and winged, branching at the top. Leaves alternate, firm, oblong to elliptic, rather coarsely toothed, pointed at both ends, sessile and decurrent on the stems, forming narrow wings. Heads numerous, often nearly two inches broad, borne at the ends of many short branches at the top of the stem; rays drooping, wedgeshaped, three-toothed at the tip, bright

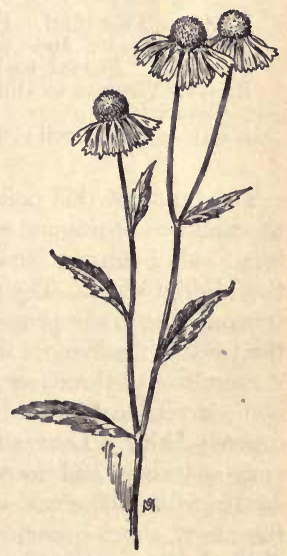

Fig. 334. - Sneezeweed (Helenium autumnale). $\times \frac{1}{8}$. 
golden yellow, pistillate and fertile; disks greenish yellow, hemispherical, the florets perfect and fertile; bracts of the involucre narrow and pointed, hairy, reflexed. Achene slenderly topshaped, ribbed, and hairy, with a pappus of five to eight chaffy, awned scales; these achenes are too often an impurity of grass seeds and are a most obnoxious contamination. (Fig. 334.)

\section{Means of control}

Prevent seed production. Where not so abundant as to make the task impracticable, it pays to hand-pull this noxious plant in order to rid the ground of its perennial roots. Rankly infested grasslands should be put under cultivation for a season. Drainage of the ground is discouraging to the growth of this plant, for it prefers the soil wet.

\section{PURPLE-HEADED SNEEZEWEED}

Helènium nudiflòrum, Nutt.

Native. Perennial. Propagates by seed.

Time of bloom: June to September.

Seed-time: August to November.

Range: Virginia to Illinois and Missouri, southward to Florida and Texas.

Habitat: Moist soil ; wet meadows, sides of streams, and ditches.

The range of this poisonous weed has been greatly widened by the agencies of impure commercial seeds and baled hay; it is now locally abundant in New England and Pennsylvania and through the Middle West. The plant hybridizes with its sister autumnale, transmitting to the progeny its own earlier habit of bloom by which the weed is made more obnoxious.

Stem one to three feet tall, slender, angled, and narrowly winged by decurrent leaf bases, branching near the top, the younger foliage sparsely hairy. Leaves narrow lance-shaped to linear or the lower ones spatulate and toothed, the upper ones entire, sessile, and decurrent on the stem. Heads numerous, clustered at the ends of the many short branches, each about an inch and a half broad; disks bulging to nearly globular form, purplish brown, the florets perfect and fertile; rays pistillate but sterile, drooping, three- 
toothed at tips, yellow, often shading into brown at their bases, sometimes entirely brown, occasionally lacking, hence the name nudiflorum. Seeds oblong, hairy, the pappus of five or more awned scales. (Fig. 335.)

Means of control the same as for the autumn Sneezeweed.

\section{FINE-LEAVED SNEEZEWEED}

Helènium tenufolium, Nutt.

Native. Annual. Propagates by seeds. Time of bloom : Early August to October. Seed-time: September to November.

Range: Virginia to Kansas, southward to Florida and Texas.

Habitat: Prairies ; moist meadows, roadsides, and waste places.

This plant is rapidly extending its range, being locally established as far north as Massachusetts and Ohio; it is considered quite as noxious as the larger, perennial species, several cases having

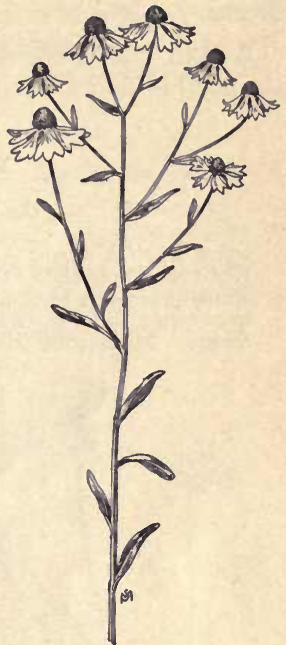

FIG. 335. - Purple-headed Sneezeweed (Helenium nudiflorum.) $\times \frac{1}{4}$. been reported from the Gulf States where it has proved fatal to grazing horses and mules. Neat cattle do not seem to be so dangerously affected, but the weed is often the cause of bitter milk. The bitter, acrid properties are not dissipated by drying and therefore the young plants are very objectionable in meadows, being harvested with the hay and sharply "cutting" its quality.

Stem eight to twenty inches tall, slender, smooth, much branched above, forming a bushy head. Leaves very numerous, smooth, linear, almost thread-like, sessile, often fascicled. Heads many, about an inch broad, with six to ten short, drooping, yellow rays, fanshaped, toothed at the tips, pistillate and fertile; disk yellow, globose, the florets perfect and fertile; bracts of the involucre linear, soon reflexed. Achenes angled and hairy, with a pappus of short, bristle-tipped scales. 
Means of control

Prevent seed production by close cutting or hand-pulling when the plant is in first bloom.

\section{BLANKET FLOWER}

Gaillardia aristata, Pursh.

Other English name: Great-flowered Gaillardia.

Native. Perennial. Propagates by seeds.

Time of bloom: May to September.

Seed-time: June to October.

Range: Minnesota to British Columbia, southward to Colorado, New Mexico, and Texas.

Habitat : Plains and prairies ; meadows and pastures.

This plant is cultivated in eastern flower gardens for its beauty, and frequently escapes to roadsides and fields where it rivals Black-eyed Susan for showiness. Stems one to three feet tall, sometimes branched but usually simple, very slender, clothed with jointed hairs. Leaves rather thick, also finely hairy, the basal ones with petioles; they are exceedingly variable, some being lance-shaped, others spatulate; some deeply cut, even pinnatifid, others entire; some plants have leaves all basal, while others have a few stem leaves which are sessile. Heads large, two to four inches across, the rounded disk of a purplish brown, the tubular florets with fringed lobes and protruding forked styles, also reddish brown, very long

Fig. 336. - Blanket Flower (Gaillardia aristata). $\times \frac{1}{4}$. 
of the involucre lance-shaped, pointed, hairy on both sides, reflexed. Achenes small, brown, top-shaped nutlets, hairy at the base and crowned with a half-dozen or more bristly awns. (Fig. 336. )

\section{Means of control}

No composite flower, however beautiful, should be permitted to give its seeds to the wind's will. In gardens the blossoms should be clipped as they fade, and where the plants "blanket" the fields they should feel the scythe or the mowing-machine blades at sight of the first gay flower. For destruction of the perennial roots the ground requires to be put under cultivation.

\section{FETID MARIGOLD}

Dyssòdia pappdsa, Hitchc.

(Boèbera pappdsa, Rydb.)

Other English names: Yellow Mayweed, False Mayweed, Yellow Dog-fennel, Stinkweed.

Native. Annual. Propagated by seeds.

Time of bloom: July to October.

Seed-time: August to November.

Range: Ontario and Ohio to Minnesota and $\mathrm{Ne}$ braska, southward to Texas, New Mexico, and Arizona.

Habitat: Fields, roadsides, and waste places.

A vile weed, which is gaining ground in the Eastern States, being established in several places where it was brought in western hay, of which the refuse was spread on the fields.

Stem six to eighteen inches tall, erect, smooth, dotted with pellucid glands, much branched, and very leafy. Leaves but an inch or two long, opposite, sessile, pinnately divided into narrow, spatulate, toothed segments, and also dotted with glands which exhale an offensive, fetid odor. Heads numerous, terminal, on short peduncles, dull yellow, but little more than a quarter-inch broad; disk florets perfect and fertile; rays few and short, pistillate; involucre

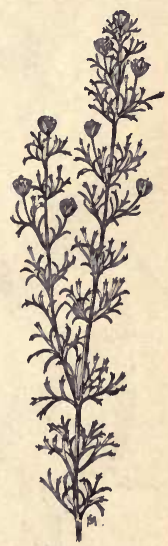

FIG. 337.Fetid Marigold (Dyssodia papposa). $\times \frac{1}{6}$. 
formed of one row of oblong, purplish bracts, united into a cup, with a few short, loose, and spreading ones at the base. Achenes dark, wedge-shaped, covered with fine, upward-pointing bristles; the pappus is a ring of stiff, bristly hairs. (Fig. 337.)

\section{Means of control}

Small areas newly infested should be pulled while in earliest flower, allowing no seed to develop. Ground on which plants have matured should be burned over, in order to destroy the seed on the surface.

\section{YARROW}

Achillèa Millefolium, L.

Other English names: Milfoil, Thousand-leaf, Sanguinary, Bloodwort, Soldier's Woundwort, Nosebleed Weed.

Native. Perennial. Propagates by seeds and by rootstocks.

Time of bloom: June to October.

Seed-time: August to November.

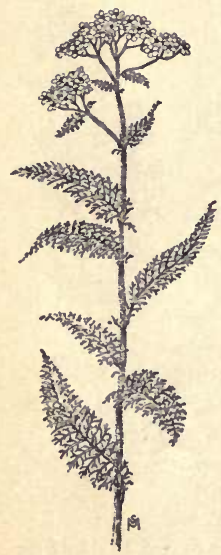

FIG. 338. - Yarrow (Achillea Millefolium). $\times \frac{1}{3}$.

Range: Throughout North America, and in most parts of the world.

Habitat: Meadows, pastures, roadsides, and waste places.

A most hardy weed, thriving in nearly any kind of soil and indifferent to tropic heat or arctic cold; well named for the invulnerable Achilles, who is said to have used the herb for the cure of his Myrmidons wounded at the siege of Troy. However that may be, the plant is still valued medicinally and its dried leaves and flowers bring three to five cents a pound in the drug market.

Stem one to two feet tall, stiffly erect, simple or sometimes forked above, webby-haired or nearly smooth. Leaves alternate, the lower ones sometimes ten inches long, lance-shaped in outline, deep green, twice pinnatifid and the segments finely toothed; stem leaves less divided, narrow and sessile; the foliage is strong-scented, its taste biting and bitter. 
Cattle usually avoid the plant when green, but sometimes eat it with dry fodder, and then it is very damaging to the quality of dairy products. Flowers in dense, flat-topped, stiffly branched, compound corymbs, the heads very small, white or sometimes pink; rays and disk-florets both fertile; bracts of the involucre, imbricated, with scarious margins. Achenes flattened oblong, without pappus. (Fig. 338.)

\section{Means of control}

The rootstocks are horizontal and tough, and cling rather strongly to the parent plant, so that sometimes when the ground is soft one may oust a whole colony at a pull - the young shoots of the first year being mere tufts of plume-like leaves. Prevent seed production by close cutting before the first flowers mature. In cultivated crops the weed is suppressed by the required tillage.

\section{SNEEZEWORT YARROW}

\section{Achillea Ptármica, L.}

Other English names: White Sneezeweed, White Tansy, Wild Pellitory.

Introduced. Perennial. Propagates by seeds and by rootstocks.

Time of bloom: July to September.

Seed-time: August to October.

Range: Newfoundland and Now Brunswick to Michigan, southward to Massachusetts.

Habitat: Moist soil ; low meadows, and waste places.

The range of this weed has increased of recent years, chiefly by the agency of baled hay. Stem slender, one to two feet tall, rather rigid, smooth or only slightly hairy, sometimes branched at the top but usually simple. Leaves alternate, one to three inches long, narrow lance-shaped to linear, pointed, sharply and very finely toothed, sessile and partly clasping, often hairy on the veins

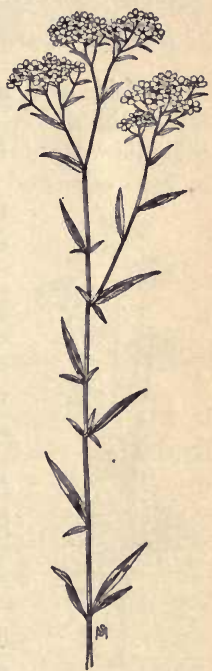

Fig. 339. - Sneezewort Yarrow (Achillea Ptarmica). $\times \frac{1}{2}$. 
beneath. Flowers in loose corymbose clusters, the heads on long, slender pedicels, about a half-inch broad, with six to fifteen white rays, notched at the tips; rays and disk-florets both fertile. Achenes compressed oblong, without pappus.

Means of control the same as for common Yarrow. (Fig. 339.)

\section{MAYWEED}

\section{Ánthemis Cótula, L.}

Other English names: Dog Fennel, Dog Finkle, Dillweed, Fetid Chamomile, Stinking Daisy, White Stinkweed.

Introduced. Annual and winter annual. Propagates by seeds.

Time of bloom: June to October.

Seed-time: July to November.

Range: All over North America except the extreme North. Native of Europe, but widely distributed in Asia, Africa, and Australia.

Habitat: Nearly all soils; invades almost all crops.

In fields and along roadsides, and particularly in barnyards, where the soil is enriched with the constant droppings of cattle, this vile weed thrives; for no grazing animal will eat it because of its rank odor and acrid juices. The modern farmer rides his "self

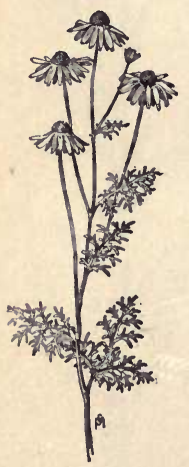

FIG. $340 .-$ Mayweed (Anthemis Cotula). $\times \frac{1}{3}$. binder" through the grain fields and doesn't curse the Mayweeds as did the men who had to "cradle the wheat" and bind it with handtwisted straw withes, and whose hands, arms, and feet became as though scalded from repeated contact with the acrid, glandular foliage of this weed and from its seedy tops sifting into their shoes as they swung the cradle or the scythe. "The Mayweed doth burn and the Thistle doth fret," wrote Thomas Tusser, sympathizing with his harvesters, nearly four hundred years ago; and there are localities in this country where the words are yet applicable.

Stem six to twenty inches in height, smooth below but glandular and somewhat hairy above, much branched, and spreading. Leaves alternate, sessile, pinnate, twice or thrice divided into linear, acute segments. Heads numerous, soli- 
tary, terminal, about an inch broad; rays fifteen to twenty, neutral, white, three-toothed, spreading, becoming reflexed as they wither; disks yellow, hemispheric, growing cone-like with age, the florets tubular and perfect; bracts of the involucre oblong, scarious margined, obtuse, usually somewhat hairy. Achenes oblong, ten-ribbed, roughened with glandular tubercles, and without pappus; they are nearly always found as an impurity in seeds of grass and clover. (Fig. 340.)

\section{Means of control}

The plant is an annual, and, if it were persistently destroyed before any seed had dropped into the soil to vex another year's crop, it must needs disappear. It would pay even to hand-pull it, but prompt cutting would be sufficient. In grain fields the crop may be relieved of much of the crowding growth of the weed by harrowing out the seedlings in the spring.

\section{FIELD OR CORN CHAMOMILE}

\section{Ánthemis arvénsis, $\mathrm{L}$.}

Introduced. Annual or biennial. Propagates by seeds.

Time of bloom: May to August.

Seed-time: June to September.

Range: Nova Scotia to Virginia, and westward to Michigan and Missouri; also on the Pacific Coast.

Habitat: Cultivated fields, meadows, roadsides, and waste places.

Somewhat like the Mayweed, but without its unpleasant odor and acrid juices. It is low, seldom exceeding a foot in height, some of its many branches decumbent, others ascending, very leafy, and finely hairy. Leaves sessile, one to three inches long, pinnate, once or twice divided, much less feathery than the Mayweed. Heads numerous, usually exceeding an inch in width, with ten to twenty white, spreading, two-toothed rays, pistillate and fertile; disk-florets perfect; bracts of the involucre are oblong, obtuse, hairy, with scarious margins. Achenes oblong, obscurely four-angled, crowned only with a minute border for a pappus. In some localities this is a worse weed than its ill-scented relative, 
and its achenes are a common impurity in those of grass and clover.

The same measures should be used for its control as for Mayweed.

\section{YELLOW CHAMOMILE}

\section{Ánthemis tinctòria, L.}

Introduced. Perennial. Propagates by seeds.

Time of bloom: June to September.

Seed-time: July to October.

Range: Atlantic States from Maine to Maryland; locally in some interior states.

Habitat: Fields, roadsides, and waste places.

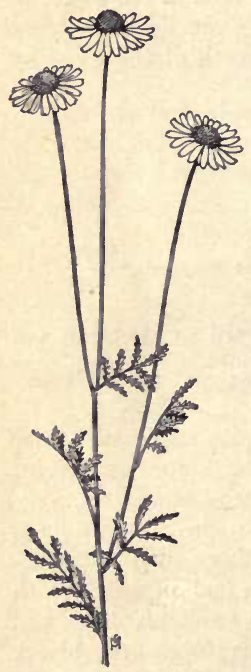

Fro. 341.-Yellow Chamomile (Anthemis tinctoria). $\times \frac{1}{2}$.
An escape from gardens, where it was formerly cultivated for its beauty and for its medicinal qualities, being used as a bitter tonic. It is a persistent weed wherever established, as grazing animals will not touch it and it is left to propagate itself.

Stem one to three feet in height, erect, slender, finely hairy, with a few branches held nearly upright. Leaves also finely hairy, alternate, one to four inches long, pinnate, the oblong segments narrow, pointed, and sharply toothed. Heads terminal, rather few, more than an inch broad, on long, slender peduncles. Both disk-florets and rays are yellow, the latter numbering twenty to thirty, usually twotoothed, pistillate, and fertile; disk-florets perfect and of a darker yellow; bracts of the involucre oblong, obtuse, densely hairy with scarious margins. Achenes fourangled and somewhat flattened, crowned with a narrow border. They are becoming much too common as an impurity of grass and clover seeds. (Fig. 341.) 


\section{Means of control}

Frequent cutting close to the ground, throughout the growing season, will prevent seeding and will starve the perennial roots. New infestations, if areas are not too large, should be promptly hand-pulled as soon as observed.

\section{SCENTLESS CHAMOMILE}

\section{Matricdria inodòra, L.}

Other English name: Corn Mayweed.

Introduced. Annual or winter annual. Propagates by seed.

Time of bloom: June to August.

Seed-time: July to September.

Range: Newfoundland to New Jersey, westward as far as Michigan.

Habitat: Cultivated fields, meadows, roadsides, and waste places.

Not so disagreeable a plant as the illscented Dog Fennel, but a gross feeder and holding ground which should be occupied by better plants. Stem one to two feet in height, smooth or nearly so, very much branched. Leaves alternate, numerous, deep green, sessile, twice or thrice pinnately dissected into linear, almost thread-like, lobes, the rachis somewhat dilated at base. Heads terminal on the many branchlets, about an inch broad, on naked peduncles; rays twenty to thirty, white, spreading, pistillate, and fertile; disk-florets yellow, tubular, perfect, and fertile, their corollas five-toothed; bracts of the involucre green, with brown, scarious margins, obtuse, and spreading. Achenes strongly three-ribbed, tipped with a short, entire-edged or fourtoothed crown.

Means of control the same as for Mayweed. (Fig. 342.)

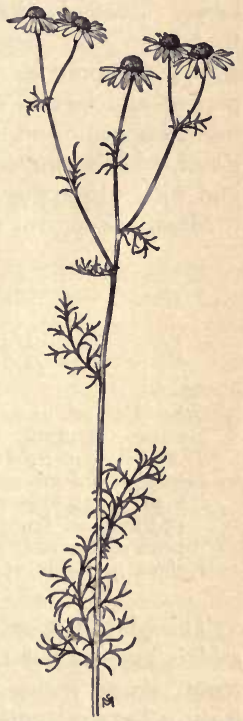

FIG. 342, - Scentless Chamomile (Matricaria inodora). $\times \frac{1}{3}$. 


\section{WILD CHAMOMILE \\ - Matricària Chamomilla, L.}

Other English names: Horse Gowan, German Chamomile.

Introduced. Annual or winter annual. Propagates by seeds.

Time of bloom: June to August.

Seed-time: July to September.

Range: Atlantic States, westward to Ohio.

Habitat: Fields, roadsides, and waste places.

Very like the preceding species, but with rather pleasantly aromatic foliage. Stem smooth, much branched, one to two feet high. Leaves pinnate, twice or thrice divided into many linear lobes. Heads numerous, terminal, about three-fourths of an inch broad, on very slender, naked peduncles; rays ten to twenty, white, drooping as they mature, pistillate, fertile; disk-florets perfect and fertile, yellow, the receptacle at first rather flat but becoming conic and hollow; bracts of the involucre oblong, obtuse, green, with brown, scarious margins. Achenes short, three-ribbed, and without pappus.

Means of control the same as for Mayweed.

\section{PINEAPPLE WEED}

Matricària suavèolens, Buchenau.

(Matricària matricarioides, Porter.)

Other English name: Rayless Chamomile.

Native. Annual. Propagates by seeds.

Time of bloom: May to August.

Seed-time: June to September.

Range: Atlantic States from New Brunswick to Pennsylvania, naturalized from the Pacific Slope where it is native, and common as far east as Wyoming and Montana.

Habitat: Fields, roadsides, and waste places.

This plant not only has found its way East, but has gone abroad and is naturalized as a weed in northern Europe. Stem rather stout, six to eighteen inches tall, smooth, branching, and very leafy. Leaves pinnate, twice or thrice dissected into short, very narrow, and sharply pointed lobes; when bruised they have an odor suggestive of pineapples. Heads very numerous on short 
peduncles, without rays, the disk bluntly ovoid, greenish yellow; bracts of the involucre broadly oval, not quite half the length of the disk, green, with white, scarious margins. Achenes rounded oblong, faintly ribbed, often without a pappus but sometimes having an obscure marginal crown, bearing one or two small, oblique auricles.

Means of control the same as for Mayweed.

\section{WHITE OR OX-EYE DAISY}

Chrysanthemum Leucánthemum, L.

Var. pinnatifidum, Lecoq. \& Lamotte.

Other English names: Whiteweed, Midsummer Daisy, Poverty Weed, Poorland Flower, Moon-penny.

Introduced. Perennial. Propagates by seeds.

Time of bloom: May to October.

Seed-time: June to November.

Range: Nearly throughout North America. Less common in the South and the West.

Habitat: Old fields, meadows, pastures, and waste places.

The seeds of this plant are an impurity of nearly all grass seeds and are distributed with them; fruiting plants are mown with the hay, baled with it, and shipped about the country, pass unharmed through the digestive tracts of the farm animals and are returned to the land in uncomposted stable refuse, carefully spread - no wonder it is such a pervasive weed.

Stems often tufted, one to three feet high, erect, slender, finely grooved, nearly smooth, sometimes forking near the top but usually simple, springing from a short, thick rootstock fringed with fibrous rootlets. Root-leaves in a tufted mat about the base of the stem, spatulate in outline, pinnatifid and irregularly toothed, tapering to petioles; stem-leaves narrowly oblong, sessile and clasping, also cut and toothed. Heads single at the summit of the stalk, about two inches broad, bearing twenty to thirty spreading, white rays, slightly notched at their tips; disk yellow and about a halfinch broad; rays and disk-florets both fertile; involucre very shallow and flat, its bracts with scarious margins and closely imbricated. Achenes grayish black, finely ribbed, without pappus. 


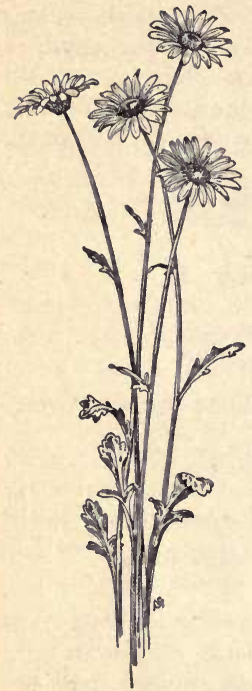

Frg. 343. - White or Ox-eye Daisy (Chrysanthemum Leucanthemum var. pinnatifidum). $\times \frac{1}{4}$.

These will ripen sufficiently to germinate in ten days after the opening of the flowers. (Fig. 343.)

\section{Means of control}

Sow clean seed. Cleanse the Daisy-cursed meadow with a short rotation of other crops. Though perennial, the roots are shallow and are turned out and killed by the plow. Mow infested meadows as soon as the first flowers appear, in order that the seeds may not have time to ripen. Frequently cut and salt the plants of the pasture, which will induce the stock to feed on the leaf-tufts and aid in their destruction. Roadside and waste-land plants should be cut before seed development, or should even be hoed out, for the benefit of adjacent ground.

\section{COSTMARY}

Chrysánthemum Balsámita, L.

Var. tanacetoides, Boiss.

Other English names: Alecost, Balsam Herb, Mint Geranium.

Introduced. Perennial. Propagates by seeds.

Time of bloom: June to September.

Seed-time: July to October.

Range: Nova Seotia and New England, westward to Ontario and Ohio.

Habitat: Roadsides, farmyards, waste places.

An escape from gardens; in some localities it is mistakenly called Lavender, but that is a very different plant. The fragrant leaves were formerly used for flavoring home-brewed ale or beer, but in these days they are occasionally eaten by milch cows and spoil the flavor of milk and butter.

Stems one to three feet tall, much branched, finely hairy. Leaves 
alternate, oblong, obtuse, scallop-toothed, one or two inches in length, many with a pair of small lateral lobes near the base but others without, those of the stem sessile except the lowermost. Heads numerous in open corymbose clusters, some with rays but oftener without; rays, when present, are white, short, and spreading; all the florets are fertile; bracts of the involucre narrow, obtuse, somewhat hairy. Achenes slightly angled with a short cup-like crown for pappus.

Means of control the same as for Tansy.

\section{TANSY}

Tanacètum vulgàre, L.

Other English names: Bitter Buttons, Ginger Plant, Parsley Fern. Introduced. Perennial. Propagates by seeds.

Time of bloom: July to September.

Seed-time: August to October.

Range: Nova Scotia and Ontario to Minnesota, southward to Georgia and Missouri.

Habitat: Roadsides, farmyards, and waste places.

An escape from garden cultivation. The oil distilled from the plant, mixed with that of Fleabane and Pennyroyal and diluted with alcohol, make a "mosquito dope" useful to hunters and fishermen and others who must work where mosquitoes are troublesome. Collectors receive three to five cents a pound for the dried leaves and tops, gathered when in full bloom. (Fig. 344.)

Stem one to three feet high, rather stout, smooth, usually unbranched, except at the flowering top. Leaves alternate, the lower ones sometimes a foot long, deep green, smooth, pinnatifid, the segments narrow, acute, and toothed, the petioles often with toothed margins; upper leaves smaller and less divided. Heads numerous in terminal corymbose clusters, less than a half-inch broad, yellow, the

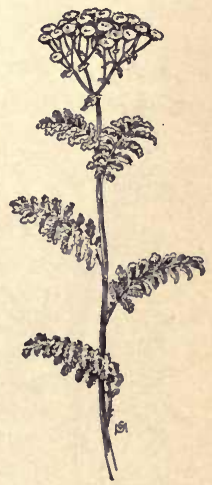

Fig. 344. - Tansy (Tanacetum vulgare). $\times \frac{1}{3}$. 
florets usually all tubular or sometimes with an outer row of imperfectly developed rays; these are pistillate, the central florets perfect, all fertile. Achenes angled or ribbed, with a five-toothed crown for pappus.

\section{Means of control}

Small areas may be grubbed out, or killed with Caustic soda or hot brine. Or the roots may be starved by successive close cutting throughout the growing season.

\section{COMMON MUGWORT}

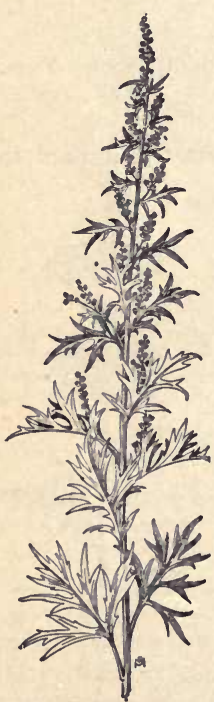

FIg. 345. - Common Mugwort (Artemisia vuloaris). $\times \frac{1}{1}$.
Artemisia vulgàris, L.

Other English names: Felon-herb, Sailor's Tobacco.

Introduced. Perennial. Propagates by seeds. Time of bloom: July to October.

Seed-time: August to November.

Range: Nova Scotia to Ontario and Michigan, southward to New Jersey and Tennessee.

Habitat: Roadsides and waste places; along streams and ditches.

Also called Wormwood, and kept on sale under that name in drug stores. Stem one to three feet tall, smooth or nearly so except the growing branches, which are finely whitewoolly. Leaves alternate, one to four inches long, deeply pinnatifid into narrow oblong or spatulate segments, which are again cut and toothed, the lower ones usually petioled, the upper ones sessile, often with lobes entire; all are smooth and dark green above but covered with fine, white wool beneath. The numerous heads are in spiked panicles, held nearly erect; each head is about one-sixth of an inch broad and only the central florets are fertile; bracts of the involucre dry and scarious. Achenes very small, obovoid, without pappus. (Fig. 345.) 
Means of control

Mugwort has to be grubbed out; or, if the ground is sufficiently soft to relax its hold on the perennial roots, the plants may be hand-pulled. On cultivated ground the weed is destroyed by the required tillage.

\section{BIENNIAL WORMWOOD}

Artemisia biénnis, L.

Other English names: False Tansy, Bitterweed.

Native and introduced. Biennial. Propagates by seed.

Time of bloom: August to October.

Seed-time: September to November.

Range: Nova Scotia to the Northwest Territory, southward to Pennsylvania, Tennessee, and Missouri.

Habitat: Stubble fields, roadsides, and waste places.

Probably the most common of the Wormwoods; frequently a tenant of vacant city lots. Stem one to four feet tall, erect and strict, the branches rather short and held nearly upright. Leaves smooth on both sides, dark green, twice pinnatifid, with oblong to linear, toothed, and pointed segments, the lower with petioles, the upper sessile and with fewer lobes or occasionally quite entire; they are without odor unless bruised. Heads in short, crowded, axillary clusters, erect, sessile, about an eighth of an inch broad, the involucral bracts green with scarious margins, the central flowers only producing seed.

\section{Means of control}

Hoe-cutting or hand-pulling of autumn plants; close cutting of flowering stalks before seed development. Infested stubbles should be given surface cultivation or be mowed before the heads mature.

\section{ANNOAL WORMWOOD}

Artemisia ánnua, $\mathrm{L}$.

Introduced. Annual. Propagates by seeds.

Time of bloom: July to September.

Seed-time: August to October.

Range: Ontario to Tennessee and Kansas.

Habitat: Fields, roadsides, waste places. 


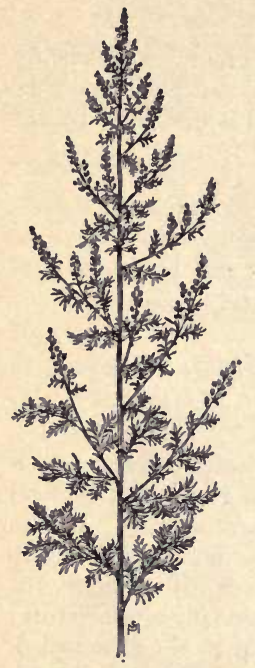

Fig. 346. - Annual Wormwood (Artemisia annua). $\times \frac{1}{6}$.

Nearly as rapid a grower as a ragweed, the stem two to five feet tall, smooth, much branched, and leafy. Leaves alternate, two to six inches long, smooth and green on both sides, very sweet-scented, twice or thrice pinnatifid, the lobes short, obtuse, and narrow; lower leaves with short, slender petioles, upper ones sessile and much smaller, but none entire. Heads very small in loose, open panicles, the florets all fertile; involucre hemispheric, the bracts few, smooth, dry and scarious. (Fig. 346.)

\section{Means of control}

For small areas hand-pulling before the flowers mature. Or close and repeated cutting for the purpose of preventing reproduction.

\section{WORMWOOD OR ABSINTHE}

\section{Artemisia Absinthium, L.}

Introduced. Biennial. Propagates by seeds.

Time of bloom: July to October.

Seed-time: August to November.

Range: Newfoundland and New England to western Ontario and Ohio.

Habitat: Roadsides and waste places.

An escape from gardens, and usually a waste-land weed; but occasionally it gets into hay, causing cattle to reject their fodder - or, if eaten, the consequence is ruined milk and butter, for the extreme bitterness of the plant is proverbial. The herb is used medicinally as a vermifuge, and collectors receive about four cents a pound for its leaves and flowering tops, gathered when in early bloom and dried.

Stem somewhat shrubby, two to four feet high, the new leaves white with fine, silky hair, the older foliage grayish green, soft, 
and thin; the leaves are thrice pinnatifid, the segments finely divided and again cut and lobed; lower ones with slender petioles, but upper ones sessile or nearly so. Flowers in loose compound racemes, often more than a foot in length, the branchlets exceedingly slender and closely strung with nearly globular, nodding heads less than a sixth of an inch in diameter. These small, dried heads are called "seed," though of course they contain a number of very small achenes.

\section{Means of control}

Prevent seed production by frequent close cutting during the - growing season; if this is done, unless the ground is foul with dormant seed, the weed will disappear.

\section{PASTURE SAGE}

Artemisia frigida, Willd.

Other English names: Low Sage-bush, Wormwood Sage, Wild Sage. Native. Perennial. Propagates by seeds.

Time of bloom: July to October.

Seed-time: September to December.

Range: Minnesota to the Saskatchewan and Idaho, southward to Texas and New Mexico.

Habitat: Grasslands.

Closely grazed pastures are sometimes badly overgrown with this weed, for cattle will not eat the bitter foliage and the plant is left to reproduce itself.

Stems tufted, ten to twenty inches tall, smooth, woody at the base, the younger parts silky white with soft hair. Leaves also densely silken-hairy, grayish green, a half-inch to nearly two inches long, three- to five-parted, the segments very narrowly linear; lower leaves have slim petioles, often with a pair of entire or three-cleft divisions near the base; upper ones have fewer segments and are sessile. Heads very numerous in narrow terminal panicles; nearly hemispheric, about an eighth of an inch broad, nodding on short pedicels ; involucral scales rounded oblong, silkyhairy. Only the central florets of the heads are fertile. 


\section{Means of control}

Only by breaking up the sod, and putting the ground under thorough cultivation for a year or two, can it be cleansed of the perennial roots and the dormant seeds of this obnoxious weed. Waste-land plants, the wind-blown seeds of which may infest the country side, should receive the attention of the whole community.

\section{COMMON SAGE-BUSH}

Artemisia tridentàta, Nutt.

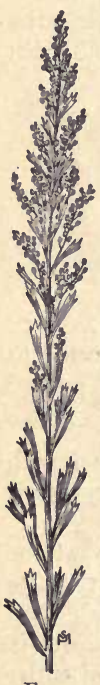

Other English names: Sage-wood, Sage-brush, Mountain Sage.

Native. Perennial. Propagates by seeds.

Time of bloom: July to September.

Seed-time: August to November.

Range: Nebraska to Colorado, Utah, and California, northward to Montana and British Columbia.

Habitat: Dry plains and foothills.

Drought does not seem to affect this plant, and when settled among less sturdy growths it robs them of most of the food and moisture available.

Stems shrubby and branching, one to ten feet tall, covered with silvery gray hair. Leaves a half-inch to but little more than an inch long, narrow, wedgeshaped, sessile, with three to five blunt teeth at the tip, which is the broadest part. Flowers sessile on crowded spikes in the axils and at the ends of the branches, the terminal spikes often dividing into large panicles. Heads only about an eighth of an inch in diameter, the florets all perfect and fertile. When ripe the heads fall entire from the spikes and are blown far and wide, particularly in winter over crusted snows, infesting many a home pasture and meadow with their perennial roots and uneatable, bitter foliage, necessitat-

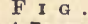

347 . -

Common

Sage-bush (Artemisia tridentata). $\times 1$. ing the breaking-up and cultivation of the ground in order to rid it of their presence. It should interest an entire community to see that waste-land plants are destroyed or at least prevented from developing seed. (Fig. 347.) 


\section{COLTSFOOT}

Tussildago Fárfara, L.

Other English names: Coughwort, Ginger Root, Clayweed, Dovedock, Horsehoof, Foalfoot.

Introduced. Perennial. Propagates by seeds and by rootstocks.

Time of bloom: Early April to June.

Seed-time: May to July.

Range: Nova Scotia to Minnesota, southward to Pennsylvania and Ohio.

Habitat: Moist elay soil; thin pastures, alluvial banks, along brooks and roadsides.

Scapes slender, springing from thick succulent rootstocks and appearing before the leaves, at first but a few inches high, bearing reddish scales that are slightly whitewoolly, and holding erect a single flowerhead about an inch broad, golden yellow; the flowers have the odor of honey and the pollen furnishes bees with early provender. Ray-florets in several rows, pistillate and fertile; disk-florets perfect but sterile, the corolla tubular and fivecleft; after a head has been fertilized the stalk rapidly elongates to a foot or more in height, and the head is so bowed that it is protected from rain by the bellshaped involucre until the achenes have formed, when it is again erected and opens out a ball of downy pappus, whiter and more floss-like than that of the dandelion. Near the end of the flowering season the leaves appear, rising from the rootstocks, nearly round, heart-shaped at base, slightly lobed and toothed, thick, smooth, and dark green above but white-

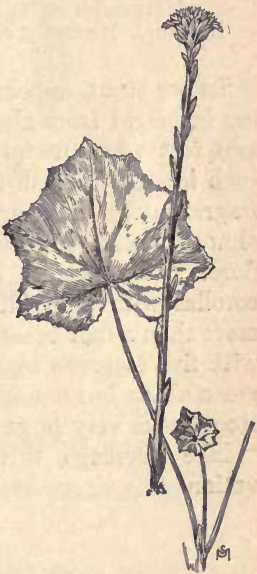

Fig. 348. - Coltsfoot (Tussilago Farfara). $\times \frac{1}{8}$. woolly underneath, with petioles about as long as the blades; they continue to grow all summer, becoming often six or eight inches broad. (Fig. 348.) 


\section{Means of control}

Prevent seed production by cutting the scapes while in bloom. The weed grows only on clay soil and likes it moist ; drainage, liming, manuring, and enriching the ground enables better plants to crowd it out. The horizontal rootstocks grow so near the surface that cultivation turns them out, when they may be readily raked away and removed.

\section{SWEET COLTSFOOT}

\section{Petasites palmàtus, Gray}

Native. Perennial. Propagates by seeds and by rootstocks.

Time of bloom: April to June.

Seed-time: May to July.

Range: Newfoundland to British Columbia and Alaska, southward to Massachusetts, New York, Michigan, and Minnesota.

Habitat: Recently cleared ground, wet meadows, and swamps.

Scapes stout, appearing before the leaves, very scaly, and varying in height from about six inches when in first bloom to nearly two feet when mature. Heads in corymbose terminal clusters, each less than a half-inch broad, pale yellow or cream-color, and fragrant; they are partly diœcious, the fertile plants having heads almost wholly pistillate, with one or more outer rows of ray florets; the perfect but sterile flowers have tubular five-cleft corollas with undivided styles. Leaves finally very large, often more than a foot broad, rounded, palmately and very deeply lobed, with five to seven segments also cut and toothed, glossy and deep green above but densely white-woolly below especially when young. Rootstocks very large and thick.

Like Tussilago, this weed is driven out by drainage and cultivation.

\section{BUTTERFLY DOCK}

\section{Petasites vulgàris, Hill}

Other English names: Butter Dock, Flea Dock, Poison Rhubarb, Oxwort, Pestilence Wort, Umbrella Leaves.

Introduced. Perennial. Propagates by seeds and by rootstocks. Time of bloom: April to May. Seed-time: Late May to June. 
Range: Eastern Massachusetts to eastern Pennsylvania.

Habitat: Moist soil ; cultivated ground, waste places.

In England, whence this plant came, it is a pest of wet meadows and is said to be poisonous; it is to be hoped that its present restricted range in this country may not enlarge. Scapes stout, very scaly, six to eighteen inches tall. Heads in crowded, racemose clusters, each about a half-inch broad, on very short pedicels, pinkish purple, fragrant, the florets all tubular; they are diœecious, the staminate heads being smaller than the fertile ones. Leaves appearing late, often more than a foot broad when mature, rounded heart-shaped, thick, green and smooth above, white-woolly beneath, irregularly but sharply toothed, with stout petioles. (Fig. 349.)

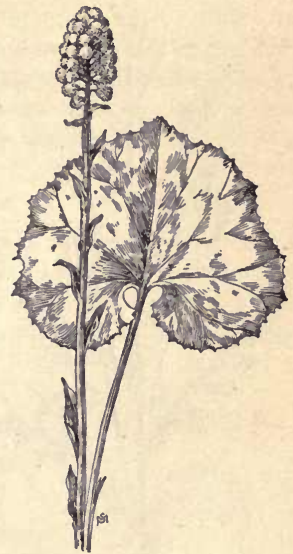

Fra. 349. - Butterfly Dock (Petasites vulgaris). $\times \frac{1}{6}$.

Means of control the same as for Tussilago.

\section{FIREWEED, OR PILEWORT}

Erechtites hieracifòlia, Raf.

Native. Annual. Propagates by seeds.

Time of bloom: July to September.

Seed-time: August to October.

Range: Newfoundland to the Northwest Territory, southward to Florida, Louisiana, and Mexico.

Habitat: Woodland borders and recently cleared land, especially if burned over.

Coarse plants, with a rank odor and juices most nauseous to the taste. It is a medicinal herb for which collectors receive two or three cents a pound, the whole plant being pulled and dried just before bloom, in which process the leaves turn black.

Stem two to eight feet tall, erect, smooth or only slightly hairy, succulent, grooved, usually with ascending branches. Leaves 


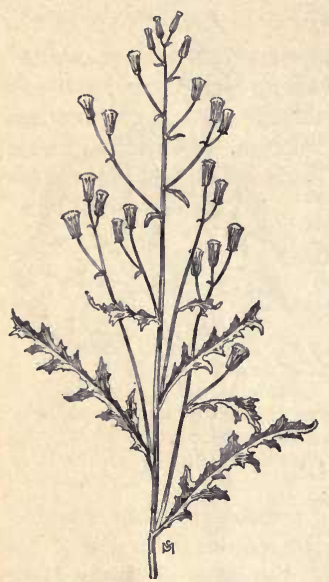

Frg. 350. - Fireweed (Erechtites hieracifolia). $\times \frac{1}{6}$.

lance-shaped, thin; irregularly cut and toothed, the lower ones narrowing to margined petioles, the upper ones sessile, clasping, often auricled at base. Flowers in open terminal panicles, the heads greenish white, the flowers all tubular and fertile, hardly exceeding the nearly cylindric, smooth involucre, which is slightly swollen at the base. Achenes oblong, with very glistening, fine, white pappus. (Fig. 350.)

\section{Means of control}

Prevent seed production by pulling or close cutting before the first flowers mature.

\section{COMMON GROUNDSEL}

Senècio vulgàris, L.

Other English names: Grinsel, Simson, Birdseed, Chicken Weed.

Introduced. Annual. Propagates by seeds.

Time of bloom: April to Oetober.

Seed-time: May to November.

Range: Newfoundland and Hudson Bay to North Carolina, Michigan, and South Dakota. Also on the Pacific Coast.

Habitat: Gardens and cultivated fields, waste places.

In Europe, whence this plant came to us, it is often sown to furnish green food for cage birds and for poultry. In this country it is frequently a great vexation to the truck gardener, for in fertile soil it sometimes appears in such quantities as to smother all other seedlings.

Stem six to fifteen inches high, succulent, hollow, slightly angled, much branched, and leafy to the top. Leaves oblong, pinnatifid, the segments also oblong and toothed; the lower ones taper backward to a petiole, but those of the stem are clasping and some- 
what auricled. Flower-heads yellow, without rays, about a quarter-inch broad, the bracts of the involucre linear, with a few awl-shaped outer ones which are black-tipped. Achenes oblong, finely ribbed, minutely hairy, with a very copious, fine, white pappus, by help of which they are widely wind-sown.

\section{Means of control}

Frequent hoe-cutting while the plants are too young to develop seed. A spray of four-per-cent Copper-sulfate solution will blast buds and temporarily check seed development, but will not harm the smooth foliage, so that the plant recovers and the operation requires to be repeated.

\section{BUTTERWEED}

Senècio glabéllus, Poir. (Senècio lobàtus, Pers.)

Other English name: Cress-leaved Groundsel. Native. Annual. Propagates by seed.

Time of bloom: March to June.

Seed-time: May to July.

Range: North Carolina to southern Illinois and Missouri, southward to Florida, Texas, and New Mexico.

Habitat: Fields, meadows, and waste places.

A rather stout, coarse plant, with furrowed, hollow, and succulent stem, one to three feet tall, sparingly branched. Leaves alternate, three to ten inches long, smooth, fleshy, and tender, and most variable in shape; they are pinnately divided, the segments rounded or oblong or spoon-shaped or pointed, with wavytoothed edges or entire, but usually with terminal segment larger than the others; the basal and lower leaves have slender petioles, but those above are sessile. Flowers in open corymbose clusters, the heads about threefourths of an inch broad, bright yellow, with six to twelve broad, wedge-shaped rays.

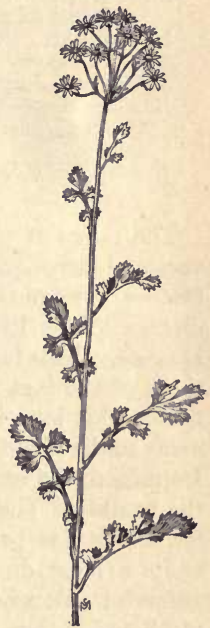

Fig. 351. - Butterweed (Senecio glabellus). $\times \frac{1}{6}$. 
Achenes minutely hairy on the ridges with a long, silky, white pappus, by which the wind is able to distribute them very widely. (Fig. 351.)

\section{Means of control}

Prevent seed production by every means possible. Sheep grazing; frequent and persistent hoe-cutting while young; cultivation of the ground; even hand-pulling for small areas. Being annual, the weed must succumb if not permitted to reproduce itself.

\section{STINKING WILLIE}

Senècio Jacobaèa, L.

Other English names: Common Ragwort, Tansy Ragwort, Staggerwort, St. Jameswort, Cankerweed, Baughlan.

Introduced. Perennial. Propagates by seeds and by rootstocks. Time of bloom: June to November.

Seed-time: July to December.

Range: Newfoundland, Prince Edward Island, Nova Scotia, and Quebec; locally in Ontario, Maine, southern New York, and New Jersey.

Habitat: Fields, meadows, pastures, roadsides, and waste places.

The range of this coarse and dangerous weed is not at present very extensive, and every effort should be made to prevent its further dissemination. When eaten by cattle it causes a fatal disease of the liver (Hepatic cirrhosis), locally known as Pictou Disease, which for many years was supposed to be contagious because of the fact that whole herds were often affected at the same time. But long investigation and a series of careful experiments made under the direction of the Veterinary Director General of the Dominion of Canada have proved that this weed is the cause of the trouble. The Molteno Cattle Disease of South Africa is similar and is due to the same cause. When green, the whole plant emits a most disagreeable, fetid odor, and is disliked by grazing animals; but when dried in hay it is freely eaten by all kinds of stock and is then a serious danger. Plants that are harvested and cured just before coming into bloom are said to be at their most noxious stage. (Fig. 352.) 
The weed springs from rather shallow and fibrous roots, from which a few short, thick rootstocks are extended. Stem two to three feet tall, erect, stiff, grooved, very leafy, and branching at the top. Leaves dark green, deeply twice pinnatifid, the terminal segment largest, particularly of the lower leaves, which are six to eight inches long and petioled; stem-leaves more slender, smaller, and sessile. Flowers in large, many-headed, branching, flat-topped clusters, very showy and handsome. Heads golden yellow, nearly an inch broad, with twelve to fifteen wedge-shaped rays, toothed at their tips. Both rays and disk-florets are fertile. Achenes light yellow, grooved, oblong, those of the disk-florets bristly and straight, those of the rays smooth and curved. Pappus very copious, white, and silky.

\section{Means of control}

All plants in infested meadows should be pulled or grubbed out while in their earliest bloom, before the hay is harvested. Plants in pastures, in waste places, and on roadsides should be closely cut, piled, and burned before any seed has matured to be

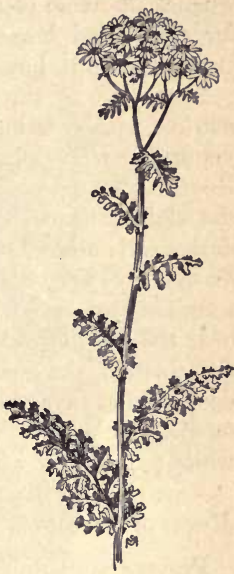

FIG. 352. - Stinking Willie (Senecio Jacobeea). $\times \frac{1}{6}$.

A short rotation of ground of both its cultivated crops would cleanse infested perennial roots and its dormant seeds.

\section{GOLDEN RAGWORT}

Senècio aúreus, L.

Other English names: Squaw Weed, Life Root, False Valerian, Grundy Swallow.

Native. Perennial. Propagates by seeds and by rootstocks.

Time of bloom: May to July.

Seed-time: June to August. 
Range: Newfoundland to Florida, westward to Ontario, Missouri, and Texas.

Habitat: Moist fields and meadows, banks of streams, and swamps.

The slender, creeping rootstocks of this plant are strong-scented, whence its name of False Valerian. It is said to be unwholesome for cattle and horses, but not so much so as Senècio Jacobaèa; sheep feed on it, however, without any apparent harm.

Stems two or three from the same root, very slender, grooved, marked with twisting brown streaks, one to three feet tall. When young the whole plant is webby-haired but soon becomes smooth. Root leaves appear in early April and look somewhat like those of the violet; heart-shaped, rather thick in texture, scallop-toothed, dark green above, purplish red beneath, with long, slim petioles. Stem leaves very different; the lower ones oblong, pinnatifid, with terminal segments large, and with short, margined petioles; those near the top more slender, sessile, and clasping. Flowers in open, flat clusters, the heads nearly an inch broad, with eight to twelve deep golden rays and brownish orange disks, both kinds of florets fertile. Achenes ribbed and smooth, with very copious, silky, white pappus, by which they are borne far on the winds.

\section{Means of control}

Prevent spreading by seed production by cutting while in first bloom. In small areas, rootstocks may be hand-pulled or grubbed out; but drainage and cultivation of the ground are necessary in order to cleanse rankly infested fields and meadows of this weed.

\section{GREAT BURDOCK}

\section{Árctium Láppa, L.}

Other English names: Beggar's Buttons, Cockle Button, Hardock, Hurr-bur.

Introduced. Biennial. Propagates by seeds.

Time of bloom: July to October.

Seed-time: The earlier flowers mature in September, but fruits remain on the stalks all winter if not disseminated nor destroyed. Range: Eastern Canada and New England, southward to Pennsylvania and Ohio: locally in Middle Western States.

Habitat: Fence rows, roadsides, and waste places. 
The presence of one of these huge weeds in flower and fruit should be considered a disgrace to the owner of the soil so occupied, for it must have remained in undisturbed possession of the ground for the necessary second year of growth before reproduction.

The root is enormous; of ten three inches thick, driving straight downward for a foot or more and then branching in all directions, taking strong hold on the soil and grossly robbing it. Stem four to nine feet in height, stout, ridged, rough-hairy, with spreading branches. Leaves broadly oval, the lower ones often more than a foot in length and nearly as wide, rather thin but strongly ribbed and veined, with wavy or slightly ruffled edges which save them from being torn by the wind, light green, woolly and felt-like beneath but darker and smooth above, with deeply furrowed, solid petioles dilated at base to clasp the stem. Heads in crowded axillary clusters, each sometimes more than an inch broad, often on rather long peduncles; florets all tubular and perfect; corollas pink, five-lobed, the ring of anthers purple, stigmas and pollen white; bracts of

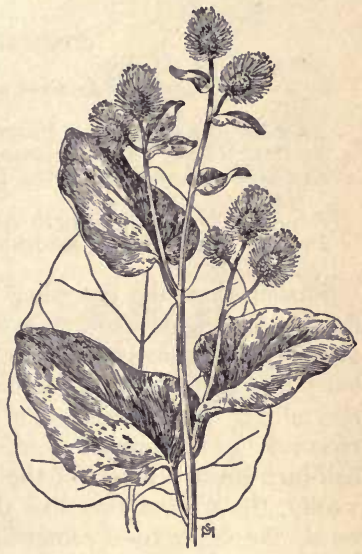

Fig. 353. - Great Burdock (Arctium Lappa). $\times \mathbf{8}$. the involucre in many series, rigid, hooked inwardly at the tip, spreading at differing angles, making the heads nearly globular. Achenes oblong, three-angled, mottled gray and brown, crowned with a short, bristly pappus. Widely distributed in the burs by animals, and on garments of passers-by. (Fig. 353.)

Burdock roots and seeds are used in medicine and the destruction of the weeds may sometimes be made profitable; roots should be collected in autumn of the first year of growth, cleaned, sliced lengthwise, and carefully dried; the price is three to eight cents a pound; ripe seeds bring five to ten cents a pound. 


\section{Means of control}

Destroy the seedlings by hoe-cutting; some will escape and spread sprawling rosettes, which must be deeply cut with spud or hoe; if merely shaved at the top, the food-filled root will immediately crown itself anew, but deep cutting kills. If any are left until the second year, cut the flowering stalks close to the ground before any of the heads are mature.

\section{COMMON BURDOCK}

\section{Árctium minus, Bernh.}

Introduced. Biennial. Propagates by seeds.

Time of bloom: July to November.

Seed-time: September; the later ripened burs persistent on the stalks all winter.

Range: Throughout North America.

Habitat: Fence rows, roadsides, waste places.

Smaller than the preceding species, the stems being three to five feet in height, erect, grooved, and branching. Leaves broadly ovate, obtuse, usually heart-shaped at base, light green and woollyhairy beneath, darker and smooth above, the stout petioles hollow, and not grooved as are those of Great Burdock. Heads numerous, racemose on the branches, sessile or on short peduncles, about a half-inch broad; bracts of the involucre short, smooth or slightly woolly, the hooked tips, like those of Great Burdock, turned inward, the outer rows somewhat spreading, the inner ones erect and shorter than the flowers. Achenes show almost none of the gray and brown mottling characteristic of those of the larger weed. Cows are fond of the plant, but if it is eaten by them in any quantity, the milk takes a bitter flavor.

Means of control the same as for Great Burdock.

\section{COMMON OR BULL THISTLE}

Circium lanceoldtum, Hill

(Cárduus lanceoldtus, L.)

Other English names: Spear Thistle, Plume Thistle, Bur Thistle, Lance-leaved Thistle.

Introduced. Biennial. Propagates by seeds. 
Time of bloom: July to October.

Seed-time: August to November.

Range: Newfoundland to Minnesota and Nebraska, southward to Georgia and Missouri.

Habitat: Pastures, fence rows, roadsides, and waste places.

In order to mature fruit these plants must remain undisturbed until the second year of growth; the first season produces only a deep taproot crowned by a large, tufted, spreading rosette of leaves, three to six or more inches long, lance-shaped, deeply pinnatifid, the lobes tipped with spines, the upper surface deep green and rough-hairy but the under side clothed with brownish, webby wool which disappears as the plants grow older. Stems two to four feet high, stout, branching, leafy to the heads. Leaves decurrent on the stem, the wings extending to the axil of the leaf below, the edges very prickly. Heads large, about two inches high and nearly as broad, mostly solitary at the ends of stem and branches, the bracts of the involucre lance-shaped, long-pointed, all tipped with needle-like spines; florets all tubular, five-lobed, deep purple, fragrant. Achenes lightcolored, oblong, slightly flattened and

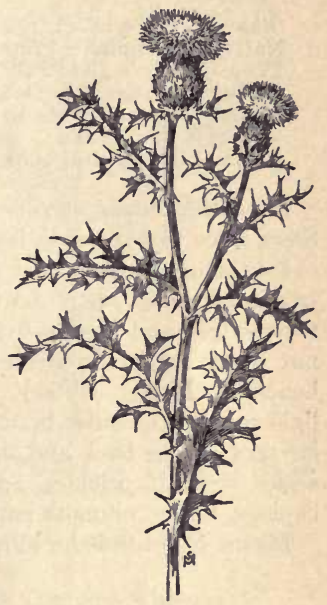

Fig. 354. - Common or Bull Thistle (Circium lanceolatum). $\times \frac{1}{8}$.

curved, with long, plumose, white pappus. (Fig. 354.) Goldfinches are very fond of these seeds and usually build their nests of Thistle-down, a habit which has gained for them the name of "Thistle-birds."

\section{Means of control}

Deep spudding or hoe-cutting of first-year rosettes; flowering stalks should be cut below the crown, before the first flowers mature; 
if cut above the surface of the ground, they will stool and require attention a second time. Cultivation of the ground at once destroys these plants.

\section{TALL THISTLE}

Circium altissimum, Spreng.

(Cárduus altissimus, L.)

Other English names: Roadside Thistle, Horse Thistle.

Native. Biennial. Propagates by seeds.

Time of bloom: Late July to September.

Seed-time: August to Oetober.

Range: Massachusetts to Minnesota and Nebraska, southward to Florida and Texas.

Habitat: Roadsides, borders of fields, waste places.

Root thickened, deep-boring, and winter rosettes very large. Stem three to ten feet in height, branching, downy-hairy. Leaves oblong lance-shaped, the lowermost sometimes pinnatifid into triangular lobes, with short, margined petioles, but those above wavy-edged and prickly-toothed, sessile or somewhat clasping but not decurrent, dark green and rough-hairy above, white-woolly beneath. Heads solitary, terminal, about two inches broad, light purple, the outer bracts of the involucre with a dark, glandular spot on the back and tipped with spreading spines; the inner scales without prickles. Achenes dark brown, numerous, with copious, white, plumose pappus.

Means of control the same as for the Spear Thistle.

\section{PASTURE, OR FRAGRANT, THISTLE}

Circium pùmilum, Spreng.

(Cárduus odoràtus, Porter)

Native. Biennial. Propagates by seeds.

Time of bloom: July to September.

Seed-time: August to October.

Range: Maine to Pennsylvania and Delaware.

Habitat: Pastures, and borders of fields.

Root round, thick, solid, often branching, the autumn tufts of leaves large and spreading. Stem one to three feet tall, stout, hairy, with few branches, very leafy. Leaves oblong lance-shaped, 
sessile or partly clasping, softly hairy, green on both sides, pinnatifid, the lobes short, triangular, very prickly-toothed. Heads purple, pale lilac, or sometimes nearly white, very large, often three inches broad, very sweet-scented; bumblebees are nearly always probing them for nectar, and in the writer's childhood it was a custom of country children to strip away the bracts, pull the florets from the receptacle, and eat the sugary nectaries like taffy; the heads are solitary, terminal,. usually subtended by involucrate clusters of small leaves, the outer bracts of the involucre sometimes slightly glutinous on the back,

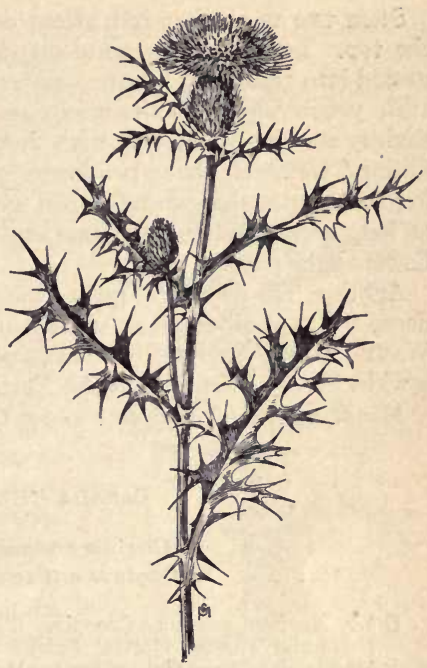

Fig. 355. - Pasture or Fragrant Thistle (Circium pumilum). $\times \frac{1}{1}$. prickly-tipped, the inner ones unarmed and very slender. (Fig. 355.)

Means of control the same as for the Common Thistle.

\section{YELLOW-SPINED THISTLE}

Circium ochrocéntum, Gray

(Cárduus ochrocéntrus, Greene)

Native. Biennial. Propagates by seeds.

Time of bloom: May to September.

Seed-time: July to October.

Range: Nebraska to Nevada, Arizona, and Texas.

Habitat: Plains and prairies. 
Stem two to six feet tall, stout, densely white-woolly, leafy to the top. Leaves oblong lance-shaped in outline but deeply pinnatifid into triangular or lance-shaped segments, armed with long, stiff, yellow spines, white-woolly on the under side, sessile or slightly clasping, the lowest with short, margined petioles. Heads solitary, terminal, about two inches broad, the outer bracts of the involucre lance-shaped and tipped with stout, yellow spines about as long as themselves, the inner ones long-pointed but unarmed; flowers light purple.

Another Thistle of the plains, much resembling this one in its dense white-woolliness but smaller and less fiercely armed, is the Wavy-Leaved Thistle (Circium undulatum, Spreng), which has a wider range, extending to the Northwest Territory.

Means of control the same as for $C$. lanceolatum.

\title{
CANADA THISTLE
}

\author{
Circium arvénse, Scop. \\ (Cárduus arvénsis, Robs.)
}

Other English names: Creeping Thistle, Small-flowered Thistle, Perennial Thistle, Cursed Thistle.

Introduced. Perennial. Propagates by seeds and by rootstocks. Time of bloom: June to August.

Seed-time: July to September.

Range: Newfoundland to the northwest provinces and British Columbia, southward to Virginia and Kansas.

Habitat: Cultivated fields, meadows, pastures, roadsides, and waste places.

In 1896 the United States Department of Agriculture published a bulletin, "Legislation against Weeds," compiling the acts then on the statute-books of the several states and recommending a general state weed law, sufficiently elastic to fit the varying flora, soils, and climate. Therein it is shown that all but three of the states having laws for the suppression of weeds make it an offense for their citizens to permit the Canada Thistle to mature and scatter its seeds. Penalties are also provided in the case of seedsmen who sell grain, grass, or clover seeds contaminated by its presence - but the thistle marches on, bidding defiance in every 
prickle to such attempts at its extermination. The laws are very good but enforcement is neglected. (Fig. 356.)

The jointed, horizontal rootstocks are the most obnoxious part of the plant; round, slender, like tough, white whipcords, lying so deep in the ground as to be always sure of moisture, they creep in every direction for rods even (the writer helped to trace one over eighteen feet long), sending up new plants at short intervals; if broken and dragged about by farm implements, the pieces grow, so that ordinary cultivation but serves to spread the pest. Stem one to four feet tall, erect, slender, grooved, woody, nearly smooth. Leaves three to six inches long, sessile and slightly clasping, deeply and irregularly pinnatifid, the margins loosely crisped, toothed with hard, white, needle-like spines pointing in all

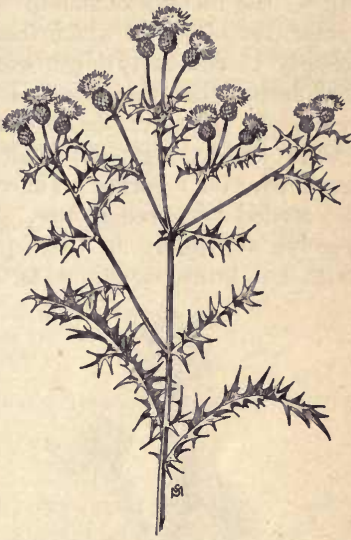

Fig. 356. - Creeping or Canada Thistle (Circium arvense). $\times \frac{1}{6}$. directions. Heads in terminal and axillary clusters, the topmost ones opening first, the bloom proceeding in succession down the stalk. The heads are about a half-inch broad, imperfectly diøcious, the pedicels and bracts without spines, the florets rose-purple, fragrant. Achenes oblong, smooth, with fine, white pappus.

\section{Means of control}

Persistent starvation of the rootstocks by keeping them deprived of the food-assimilating green leaves; this means frequent cutting throughout the growing season for at least two years. In cultivated ground the required tillage keeps the weed in check. In grain fields a spray of Copper sulfate in a solution of fifteen pounds to a barrel of water (fifty-two gallons), applied before the grain begins to head and when the young thistles are not more 
than ten to fifteen inches tall, will so damage the succulent tops that the plants will not recover sufficiently to produce buds before they are again cut with the grain. After harvest new plants sent up by the rootstocks should be cut off with a broad-shared cultivator, the blades of which should be sharp and overlapping sufficiently to cut everything before them. Subsequent fall plowing will insure that the rootstocks get very little sustenance in that year. In the next season a well-tilled and profitable hoed crop should leave the ground clean of thistles and other weeds, and in good trim for a spring grain crop - barley or oats - which should be seeded with red clover. Waysides and waste places should receive attention; in these places the patches are best treated with hot brine, caustic soda, or kerosene, killing all other plant

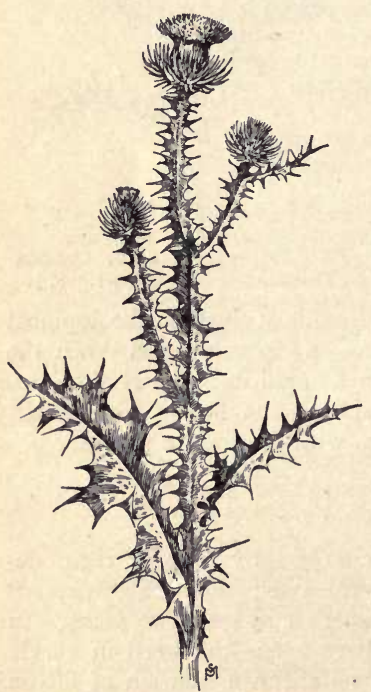

FIG. 357. - Seotch Thistle (Onopordum Acanthium), $\times \frac{1}{3}$. growth as well but ridding the ground at once of the prickly pests.

\section{SCOTCH THISTLE}

Onopórdum Acánthium, L.

Other English names: Cotton Thistle, Downy Thistle, Silver Thistle, Queen Mary's Thistle, Asses' Thistle.

Introduced. Annual or biennial. Propagates by seeds.

Time of bloom: July to September.

Seed-time: August to October.

Range: New Brunswick and Nova Scotia to Ontario, southward to New Jersey and Ohio. Habitat: Roadsides and waste places.

Said to be the heraldic plant of Scotland, but now probably more abundant in its adopted land than on its native heath. Stems three to nine feet tall, erect, stout, branching; the whole plant densely clothed all 
over with silvery white cotton wool. Leaves oblong lanceshaped, thick, irregularly lobed and toothed, decurrent on the stems, the margins and the broad basal wings edged with sharp, yellow-tipped spines. Heads terminal, solitary, large, broader than their height; florets purple; the outer bracts of the involucre narrowly oblong, with slightly roughened edges, and tipped with spreading yellow spines. Achenes faintly ribbed, the pappus brownish and bristly. (Fig. 357.)

Means of control the same as for the Common Thistle.

\section{PURPLE STAR-THISTLE}

Centaúrea Calḉtrapa, L.

Other English names: Caltrops, Maize Thorn.

Introduced. Annual. Propagates by seeds.

Time of bloom: June to September.

Seed-time: August to November.

Range: Atlantic States from Massachusetts to North Carolina; also on the Pacific Coast.

Habitat: Pastures, roadsides, waste places.

A bushy, deep green, leafy plant, one to two feet tall. Leaves only slightly hairy, the lower ones pinnately divided into lanceshaped, irregularly toothed lobes, the petioles often narrowly winged but not decurrent; the upper ones undivided, sessile, slightly clasping, the teeth on all slightly spinulose but not prickly. Heads about an inch broad, sessile or on very short peduncles, terminal, or in the forks, or scattered along the branches; involucre ovoid, and all but its innermost row of bracts tipped with stout, sharp, light yellow, spreading spines, a half-inch to an inch long, each fierce pricker subtended by one to four pairs of harmless little spines at its broadened base. Florets all tubular, the corollas reddish purple, the outer row sterile, the rest perfect and fertile. Achenes brown, flattened, obscurely four-sided, smooth, and without a pappus.

\section{Means of control}

Cutting to the surface of the ground when in first bloom, repeating the operation if the plants recover and put forth new buds. 


\section{ST. BARNABY'S THISTLE}

Centaúrea solstitidlis, L.

Other English name: Yellow Star Thistle.

Introduced. Annual. Propagates by seeds.

Time of bloom: July to September.

Seed-time: Late August to November.

Range: Massachusetts to Ontario and Iowa, southward to the

Carolinas and Arkansas; also common on Pacific Coast.

Habitat: Fields, pastures, roadsides, and waste places.

Seeds of this thistle have been noted by Alfalfa growers as a common impurity in Alfalfa seed, especially of states of the Ohio River Valley. They are so nearly the same weight of alfalfa

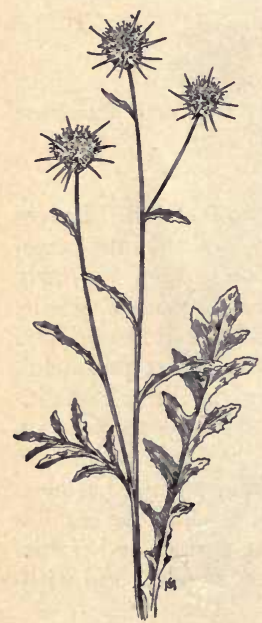

Fig. 358 - St. Barnaby's Thistle (Cenlaurea solstitialis). $\times \frac{1}{6}$. seed as to make removal difficult. When in the soil the seeds have a vitality of about three years, and are a most undesirable acquisition.

Stem stout, rigid, erect, fifteen to thirty inches tall, widely branched, gray with loose woolly hair, and broadly winged by the decurrent bases of the leaves; these are also gray-woolly, the lower ones pinnate with terminal segment large (lyrate), and lateral lobes narrow with wavy or sparsely toothed edges; upper leaves small, entire, nearly linear, but all strongly decurrent. Heads terminal, solitary, more than an inch broad, bright yellow; involucre broadly ovoid or nearly globular, the inner row of its bracts ending in shining, scarious tips; the intermediate row armed with rigid, yellow, divergent spines nearly an inch long, with one or two shorter ones at the base; and the outermost row having short, palmately branched spines. Achenes light-colored, smooth, shining, with soft, white pappus much longer than the achene. (Fig. 358.) 


\section{Means of control}

Prevent seed production, either by cutting while in first bloom or by wholly uprooting. The labor of hand-pulling in alfalfa and grain fields is worth the cost, if expensive seed is saved from contamination and the ground is kept from being fouled for another season.

\section{MALTESE THISTLE}

\section{Centaúrea meliténsis, L.}

Other English names: Napa Thistle, Tocalote.

Introduced. Annual. Propagates by seeds.

Time of bloom: June to September.

Seed-time: July to October.

Range: Atlantic States, mostly in the neighborhood of seaports; also on the Pacific Coast; casual in other places.

Habitat: Fields, pastures, waste places.

As a weed this plant is most common and troublesome on the Pacific Coast, and it is by means of Californian seed grain that it has found its way into many new localities. It is an arduous task to cleanse the smooth, wedge-shaped achenes from such seed, but less strenuous than fighting the growing weeds.

Stem stout, much branched, one to two feet tall. Flower-heads yellow, which cause it to be often confused with St. Barnaby's Thistle; but it differs from the latter in that its hairy covering is roughish instead of being soft and floccose; also the leaves are but slightly decurrent, the lower ones pinnatifid, the upper oncs very narrow and mostly entire. Heads terminal, about a halfinch broad, sometimes in clusters of two or three but often solitary; bracts of the involucre stiff, the inner row terminated with weak, ascending, purplish spines; the intermediate row with short, rigid, divergent spines, about a quarter-inch in length, either simple or with one or two shorter ones at base; and the outer row having very short, palmatifid spines. Achenes light gray, with pappus often in triple rows, the central row longest, the inner and outer ones very short.

The same measures should be used for its control as for St. Barnaby's Thistle. 


\section{BACHELOR'S BUTTON}

\section{Centaúrea Cỳanus, L.}

Other English names: Bluebottle, Blue Bonnets, Ragged Robin, Corn Flower, Hurtsickle.

Introduced. Annual. Propagates by seeds.

Time of bloom: July to September.

Seed-time: August to October.

Range: Locally in many parts of the country; most common in Quebec, western New York, and Virginia.

Habitat: Fields, roadsides, and waste places.

In Europe this plant is a pest of grain fields. In this country it is much cultivated in flower gardens for its beauty, but has escaped in unany localities and, if neglected, may become troublesome.

Stem one to two feet tall, very slender, branched and leafy and softly woolly all over, giving the foliage a grayish green tint; when old it becomes very hard and woody, whence its name of Hurtsickle. Leaves alternate, three to six inches long, those on the upper part of the plant linear and entire, those on the lower part often toothed or pinnatifid. Flower-heads about an inch and a half broad, solitary on long, slender peduncles, usually blue, but may be violet, pink, or white; florets all tubular, those in the center small and slender, perfect, and fertile, those of the outer row much longer, funnel-shaped, showy, and spreading, with deeply notched edges, pistillate but sterile ; involucre ovoid, its bracts imbricated in about four unequal series, of a greenish straw-color with darker tips and margins, or fringed with chaffy teeth. Achenes foursided, somewhat flattened, and tipped with a pappus of rough, rusty brown hairs of unequal length. These seeds have a vitality of several years as shown by the recurrence of seedlings on ground where the plants have been cultivated.

\section{Means of control}

Prevent seed development by cutting or pulling while in early bloom. In this country the weed is seldom abundant in grain fields, but where it does appear many of the seedlings may be raked out with a weeding harrow, without injury to the crop, at the time when the first lower, pinnatifid leaves have grown. 


\title{
BROWN KNAPWEED
}

\author{
Centaúrea Jdcea, L.
}

Other English names: Rayed Knapweed, Brown Centaury. Introduced. Perennial. Propagates by seed.

Time of bloom: June to September.

- Seed-time: Late July to November.

Range: New England States, southward to New Jersey.

Habitat: Fields, pastures, and waste places.

An immigrant from Europe not yet very widely disseminated in this country. Stems, several from the same thick, woody, branching root, erect, stiff, grooved, slender, one to two feet in height, branching near the top. Leaves narrowly lance-shaped, the lower ones sparsely toothed and tapering to a petiole, the upper ones entire and sessile. Heads showy, an inch or more broad, with rosy purple corollas, all tubular but the outer row with enlarged and lengthened lobes, simulating rays; these showy florets are sterile; involucres nearly globose, the bracts closely imbricated, glossy dark brown, the outer row fringed, the middle ones slightly lacerate, the inner ones entire or nearly so. Achenes four-sided and without pappus.

\section{Means of control}

Prevent seeding by cutting while in early bloom, and, if the area infested is small and the plants are not too numerous, grub out or hand-pull the perennial roots when the ground has been softened by rain. Otherwise they may be destroyed by putting the land under cultivation.

\section{BLACK KNAPWEED}

Centaúrea nigra, L.

Other English names: Horse-knobs, Hardheads, Loggerheads, Hurtsickle, Spanish Buttons, Black Centaury.

Introduced. Perennial. Propagates by seeds.

Time of bloom: July to September.

Seed-time: Late August to November.

Range: Newfoundland to Ontario, and southward to New Jersey.

Habitat: Fields, pastures, roadsides, and waste places. 
Considered in Europe a very pernicious grassland weed, because of its large, branching, perennial roots, hard, woody stems, and rough foliage, which cattle will not touch either as green forage or as hay.

Stems one to two feet in height, rough-hairy, grooved, erect, and branching. Leaves also rough-hairy, the lower and basal ones three to six inches in length, spatulate-oblong, sparsely toothed or entire, tapering to long petioles; the upper ones small, lance-shaped, entire, sessile or partly clasping, growing quite up to and subtending the heads. These are a little less than an inch broad, with rosy purple florets, all tubular, perfect, and fertile; involucre globose, the bracts closely imbricated, their appendages very long and edged with stiff hairs like minute combs; the outer and middle rows both thus fringed, the inner one merely lacerate; all black or very dark brown, or the inner row lighter in color than the other two. Achenes four-sided, without pappus or sometimes with a ring of minute scales.

Means of control the same as for the preceding species.

\section{BLESSED THISTLE \\ Cnicus benedictus, L. \\ (Centaúrea benedicta, L.)}

Other English names: Holy Thistle, St. Benedict's Thistle, Our Lady's Thistle, Bitter Thistle, Spotted Thistle.

Introduced. Annual. Propagates by seeds.

Time of bloom: May to August.

Seed-time: June to September.

Range: New Brunswick and Nova Scotia to Pennsylvania, Maryland, and the Southern States; also on the Pacific Coast.

Habitat: Pastures, roadsides, waste places.

The Blessed Thistle is a native of Asia. It is said that returning Crusaders brought the plant into Europe because of its medicinal qualities, and for the same reason it eame with the early settlers to America. It is still the principal ingredient of "bitter tonics," and its leaves and flowering tops, collected in their first bloom and quickly dried, are quoted in the drug market at six to eight cents a pound. (Fig. 359.)

Stem fifteen to thirty inches tall, stout, erect, much branched, 
and softly woolly. Leaves alternate, three to six inches long, lanceshaped in outline but deeply cut and lobed, the margins toothed and very spiny; they are rather thin, net-veined, hairy, the lower ones narrowing to margined petioles, the upper ones sessile and clasping. Heads large, solitary, terminal, closely surrounded by the upper leaves, deep yellow, about two inches broad, the florets all tubular, those in the central part perfect and fertile, those around the margin shorter than the others and sterile; involucre ovoid, its bracts imbricated in several rows, the outer ones ovate and leathery, the inner ones lance-shaped and tipped with long, rigid, pinnately branched, reddish yellow spines. Achenes oblong, ridged, crowned with a double pappus, the inner row of short, fine, white hairs, the outer one of stiff, yellow bristles, about twice as long.

Means of control

Being annual, the persistent prevention of seed development

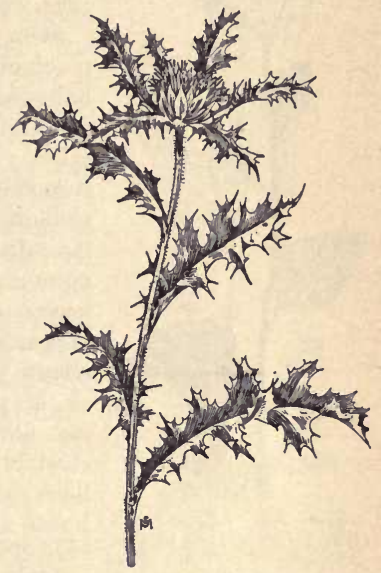

Frg. 359. - Blessed Thistle (Cnicus benedictus). $\times \frac{1}{2}$. will suppress the weed, and, if its leaves and budding flowers can be sold for enough to pay for the labor required, so much the better.

\section{NIPPLEWORT}

Lapsana commùnis, L.

Other English names: Succory Dock, Ballogan.

Introduced. Annual. Propagates by seeds.

Time of bloom: June to September.

Seed-time: July to October.

Range: Quebec and Ontario to Michigan, southward to Pennsylvania and New Jersey; also on the Pacific Coast.

Habitat: Fields, roadsides, and waste places. 


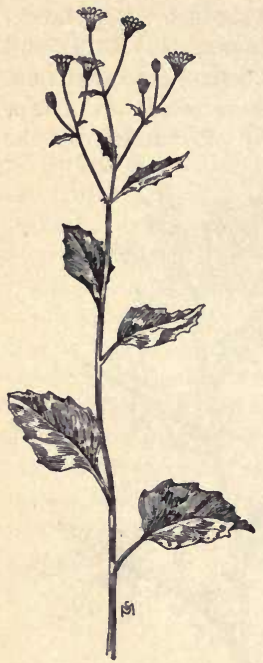

Fig. 360, - Nipplewort (Lapsana communis). $\times \frac{1}{3}$.

Nipplewort is nearly related to Chicory, and, like that plant, is used as a salad in its European home, though not grown for the purpose but instead considered a troublesome weed in cultivated fields. (Fig. 360.)

Stem one to four feet high, slender, and much branched, smooth above but bristlyhairy near the base, all parts of the plant containing a somewhat bitter, milky juice. Lower leaves usually lyrate, the terminal segment being very large with shallow-toothed or wavy edge, but the lateral lobes very small, often mere pointed wings to the petiole; upper leaves sessile and few, usually entire. Heads very numerous, few-flowered, each about a quarter-inch broad, composed all of perfect and fertile golden yellow ray florets, growing in loosely branched clusters on very slender pedicels; involucre cylindric, formed of a row of smooth linear bracts surrounded at base by a very few short outer ones. Achenes very small, pale brown, and without a pappus.

\section{Means of control}

Prevent seed production by cutting closely as soon as the first flowers appear and repeating the treatment as the plants recover and form new buds.

\section{LAMB SUCCORY}

Arnóseris minima, Dumort

Other English names: Hog's Succory, Dwarf Nipplewort.

Introduced. Annual. Propagates by seeds.

Time of bloom: June to August.

Seed-time: July to September.

Range: Maine, Ohio, Michigan.

Habitat: Fields, waste places. 
Not a common plant as yet in this country, and but a few years ago listed as only to be found at one point on the coast, a "fugitive" from Europe. It is small, with a fleshy taproot from which spring several naked stems, three inches to a foot high, sometimes simple but usually branching near the top, full of milky and bitter juices, thickened and hollow just below the heads. Leaves all basal, in a flattened rosette, two to four inches long, spatulate, hairy, coarsely and sharply toothed, tapering to margined petioles. Heads yellow, about a half-inch broad, the bracts of the involucre in one series, equal, thickened, narrow, pointed, and strongly keeled, lengthening after flowering and curving over the achenes, which are ovoid, finely ribbed, and without pappus. (Fig. 361.)

\section{Means of control}

Prevent seed production by close cutting while in early bloom.

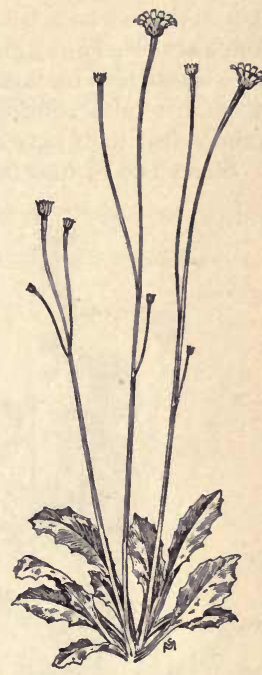

Fig. 361. - Lamb Succory (Arnoseris minima). $\times \frac{1}{3}$.

\section{CHICORY}

Cichòrium Intybus, L.

Other English names: Succory, Blue Sailors, Bunk.

Introduced. Perennial. Propagates by seeds.

Time of bloom: July to October.

Seed-time: August to November.

Range: Nova Scotia to Manitoba, southward to North Carolina, Missouri, and Nebraska.

Habitat: Fields, meadows, pastures, roadsides, city vacant lots.

In this country Chicory is "just a weed," and a very persistent one, but in Europe it is cultivated for profit. The root-leaves are used as forage for cattle and sheep, and are blanched and used as a 
pot herb and as salad; several thousand tons of its thick, fleshy roots are dried and annually exported to the United States for use as a substitute for coffee or as an adulterant, many persons liking the flavor and considering the admixture to be not only more economical than pure coffee but also a more wholesome beverage. Stems two to four feet tall, round, hollow, sparsely hairy, much

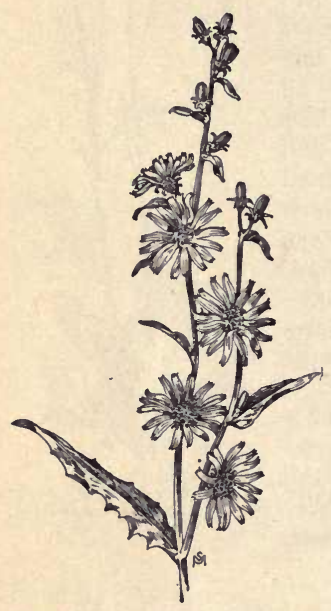

Fra. 362. - Chicory (Cichorium Intybus). $\times \frac{1}{3}$. branched, changing with age from green to purplish red and becoming very hard and woody. Like the two preceding and all the following related species, its juices are milky and somewhat bitter. Root-leaves tufted, spreading on the ground, four to eight inches long, spatulate in outline but pinnatifid, narrowing into margined petioles, the surface rough, the midrib set with stiff hairs on the under side; stem-leaves small, usually entire, clasping and auricled at base. Heads one to four together in sessile clusters on the nearly naked branches ; but one in each cluster is open at one time, only in bright sunshine and is usually closed again by noon; heads an inch or more broad, deep skyblue, the rays five-toothed at the tips; bracts of the involucre green, the inner row erect, the outer one short and spreading. Achenes brown, five-ribbed, crowned with a row of pointed scales; they are a frequent impurity of grass and clover seed. (Fig. 362.)

\section{Means of control}

Deep cutting, below the crown, with spud or hoe will usually kill Chicory. Or it may be grubbed out, or hand-pulled when the ground is sufficiently soft to yield its hold on the long, fleshy taproot. 


\section{DWARF DANDELION}

\section{Krigia virginica, Willd.} (Adopògon caroliniànum, Britton)

Native. Annual. Propagates by seeds.

Time of bloom: April to August.

-Seed-time: May to September.

Range: Maine to Ontario and Minnesota, southward to Florida and Texas.

Habitat: Dry, sandy soil ; fields, meadows, and waste places.

Like a small and delicate Dandelion, with several slender stems from the same root, one or two inches to a foot in height, simple or occasionally branched at the base. Leaves usually all basal, tufted, two to six inches long, spatulate or lance-shaped, irregularly cut and toothed, or sometimes entire, tapering to margined petioles. Heads about a half-inch broad, with yellow, spreading, five-toothed rays; bracts of the involucre linear and thin, becoming reflexed as the achenes ripen and fall. The latter are slenderly topshaped, five-angled, with a pappus of five small, rounded scales encircling an inner row of fine bristles. (Fig. 363.)

Means of control

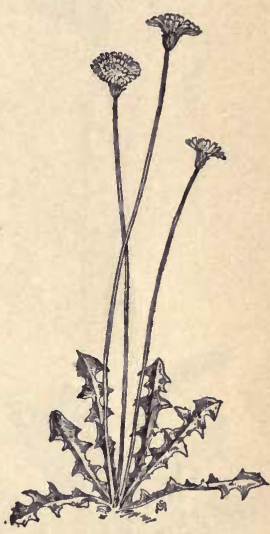

Fig. 363. - Dwarf Dan-

Prevent seed production by cutting delion (Krigia virginica). while in early bloom. Enrich and cul- $\times \frac{1}{3}$. tivate the ground, when better plants will soon supersede the weed.

\section{CYNTHIA}

Krigia amplexicaúlis, Nutt. (Adopdgon virginicum, Kuntze.)

Other English name: Virginia Goatsbeard. Native. Perennial, Propagates by seeds. 
Time of bloom: May to September.

Seed-time: June to October.

Range: Massachusetts to Ontario and Manitoba, southward to Georgia and Kansas.

Habitat: Meadows, open woods, waste places.

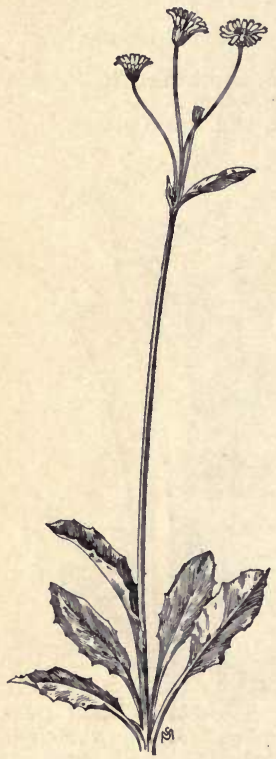

Fig. 364. - Cynthia (Krigia amplexicaulis). $\times \frac{1}{8}$.

The roots of Cynthia are fibrous, clustered, and spreading, the stems one to two feet in height, smooth and naked, except that above the middle there is usually an oblong, clasping leaf - occasionally two, or three - above which may spring one or more branches. Root leaves tufted, smooth, glaucous, three to six inches or more long, with edges toothed or wavy, rarely pinnatifid, the petioles long and winged. Heads solitary, terminating stem and branches, more than an inch broad, with about twenty bright orange-yellow rays, toothed at tips ; involucre of smooth, thin, lanceshaped bracts, all of the same length. Achenes nearly oblong, with a pappus of ten to fifteen oblong, chaffy scales surrounding an inner row of fifteen to twenty delicate bristles. (Fig. 364.)

\section{Means of control}

Meadows where the plant is abundant should be put to a cultivated crop, well tilled, and fertilized, before reseeding.

\section{GOSMORE}

Hypochaèris radicàta, $\mathrm{L}$.

Other English names: Long-rooted Cat's-ear, Flatweed. Introduced. Perennial. Propagates by seeds. Time of bloom: May to October.

Seed-time: June to November. 
Range: Ontario and Massachusetts to southern New Jersey; also on the Pacific Coast. An immigrant from Europe.

Habitat: Gardens, lawns, fields, roadsides, and waste places.

Root very long, thick, and fleshy; from its crown rise several smooth, slender stems, one to two feet tall, usually branched but sometimes simple, naked except for a few scale-like bracts. Leaves all basal, three to ten inches long, spreading flat on the ground in a large tuft or rosette; they are broadly lance-shaped to obovate in outline, deeply cut and lobed, with terminal segment large and lateral ones turned backward (runcinate), covered on both sides with spreading hairs. Heads about an inch broad, yellow, with many slender rays, toothed at their tips, which are inclined to twist together as the blossom withers and recloses. Involucre nearly cylindric, its bracts imbricated in several series, smooth, appressed, pointed, the outer rows successively shorter. Achenes spindle-shaped, ten-ribbed, rough, contracting to a slender beak longer than the body; pappus a row of very plumose bristles. (Fig. 365.)

\section{Means of control}

Where well established the Gos-

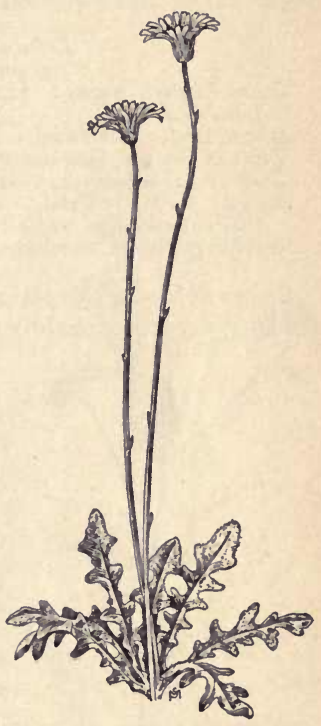

Fig. 365. - Gosmore (Hypocharis radicata). $\times \frac{1}{3}$.

more is nearly as persistent as the Dandelion. In cultivated ground the perennial roots are destroyed by the plow and subsequent tillage of crops. Pigs are very fond of the long, fleshy roots, and badly infested areas may be profitably cleaned out by turning in a few of those animals. In lawns the rosettes may be spudded off, the cut surfaces being treated 
with a liberal pinch of salt or a few drops of carbolic acid. Plants of roadsides and waste places should be grubbed out, or so frequently cut as to prevent seed development and distribution to the damage of adjacent property.

\section{FALL DANDELION}

Leóntodon autumnàlis, $\mathrm{L}$.

Other English names: Autumn Hawkbit, August Flower, Arnica, Lion's-tooth.

Introduced. Perennial. Propagates by seeds and by rootstocks.

Time of bloom: Late June to October.

Seed-time: August to November.

Range: Newfoundland to western Ontario and Michigan, southward to Pennsylvania and Ohio.

Habitat: Fields, meadows, roadsides, and waste places.

Before flowering this plant looks very like the common Dandelion, the long, smooth, or slightly hairy tufted leaves having similar back-

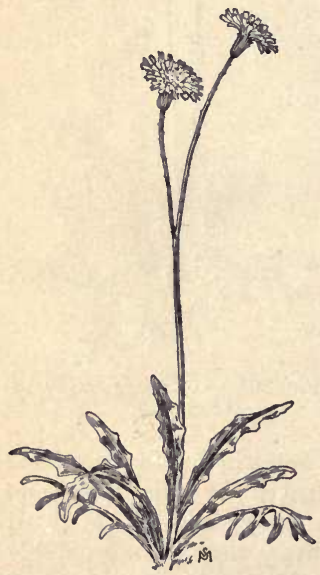

Fig. 366. - Fall Dandelion

(Leontodon autumnalis). $\times \frac{3}{3}$. ward turned, sharp-pointed lobes or "lion's teeth." But instead of a taproot it has short, thick rootstocks, each of which may send up a tuft of leaves and a flowering stalk; so that the weed tends to grow in patches and rapidly chokes out the grass in lawns and meadows.

Stems six inches to two feet tall, smooth, slender, branching, thickened at summit, with small, pointed, scale-like leaves. Heads with many tooth-tipped bright yellow rays, more than an inch broad, growing singly at the ends of the slim, naked branches. Achenes brown, nearly a quarter-inch long, ridged lengthwise, not beaked like the Dandelion, but having a yellowish white pappus of one funnel-shaped row of plumelike bristles. (Fig. 366.) 


\section{Means of control}

The rootstocks are shallow and horizontal in their growth, and plowing the rankly infested pasture or meadow kills them in one season as they decay with the sod. Small areas may be removed by deep hoe-cutting. Flowering stalks should be cut in their first bloom, in order that none of the plumed achenes may be dispersed by the wind.

\section{BRISTLY OX-TONGUE}

\section{Picris echoides, L.}

Other English names: Bugloss Picris, Bitter Bugloss.

Introduced. Annual or biennial. Propagates by seeds.

Time of bloom: July to September.

Seed-time: August to October.

Range: Locally distributed in Nova Scotia and Ontario and near the seaports of the Atlantic States; has reached as far inland as Ohio.

Habitat: Fields, roadsides, and waste places.

The achenes of this plant have been reported as an impurity in alfalfa seeds; it is a very unpleasant weed, rejected by grazing animals because of its bitter juices and prickly-hairy foliage, and it should, if possible, be hindered from extending its range.

Stems fifteen to thirty inches tall, branched, and closely set with stiff, prickly bristles. Lower and basal leaves large, spatulate, irregularly toothed, narrowed to margined petioles; stemleaves much smaller, usually entire, sessile and clasping. Heads yellow, in spreading corymbose panicles, on short peduncles, each about a half-inch broad, the outer bracts of the involucre very large and leaf-like, prickly-hairy, the inner ones membranous, narrow and

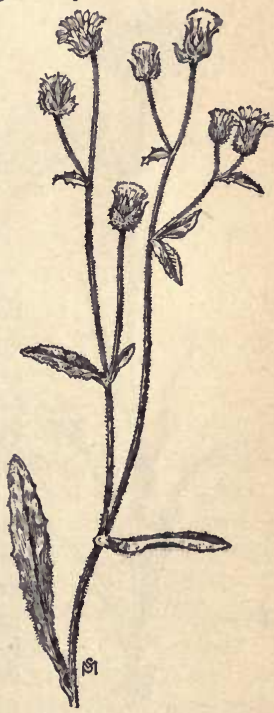

Fig. 367. - Bristly Oxtongue (Picris echoides). $\times \frac{1}{6}$. 
pointed. Achenes reddish brown, long-beaked like those of the Dandelion, with a very plumose pappus to help in their distribution. (Fig. 367.)

Means of control

Deep cutting with hoe or spud while in first flower, making certain that no seed is allowed to mature.

\section{MEADOW SALSIFY}

Tragopògon praténsis, L.

Other English names: Yellow Goat's Beard, Buck's Beard, Morning Sun, Noon-flower, Nap-at-noon, Go-to-bed-at-noon.

Introduced. Biennial or perennial. Propagates by seeds.

Time of bloom: June to September.

Seed-time: July to October.

Range: New Brunswick to Manitoba, southward to New Jersey, Ohio, and Michigan.

Habitat: Fields, meadows, roadsides, and waste places.

This plant springs from a slender, deepboring taproot, somewhat fleshy. Stem one to three feet tall, round, smooth, light green, slender, usually with several branches, held very erect. Leaves alternate, linear, keeled, clasping at base, and with longpointed tips; the lowermost perhaps a foot long, the topmost not exceeding two inches ; at maturity the edges of the leaves become involute and tips curve inward. Grazing animals dislike its bitter, milky juice, and usually leave it unmolested to reproduce itself. . Heads solitary, terminal, golden yellow, nearly two inches broad, the rays five-notched at the tip, with the pointed

Frg. 368. - Meadow Salsify (Tragopogon pratensis). $\times \frac{1}{4}$. bracts of the involucre in a single row, united at base and about as long as the rays; the 
flowers open at sunrise and are closed again by noon. Achenes about a third of an inch in length, rough-ribbed, tipped with a wire-like beak, the pappus a funnel-formed parachute of tawny, plumose bristles with downy interlacing branches. (Fig. 368.)

\section{Means of control}

Destroy by grubbing or hand-pulling when the ground is soft. In view of the fact that its buoyant seeds travel widely and that the plant is perennial if undisturbed, it will pay to take some trouble for its extermination. Land badly infested should be broken up and put under cultivation.

\section{OYSTER PLANT}

\section{Tragopògon porrifolius, $\mathbf{L}$.}

Other English names: Vegetable Oyster, Garden Salsify, Purple Goat's Beard, Joseph's Flower, Noon-plant, Jerusalem Star.

Introduced. Biennial or perennial. Propagates by seeds.

Time of bloom: June to September.

Seed-time: July to October.

Range: Ontario to Minnesota and Nebraska, southward to Georgia ; also naturalized on the Pacific Coast.

Habitat: Fields, meadows, and waste places.

An escape from gardens where it has been cultivated for the fleshy, edible taproot, which, when cooked, has a flavor somewhat like oysters. Larger than the preceding species, with stems two to four feet tall, broader leaves, the peduncles dilated and hollowed for a space of two or three inches below the heads, which are purple, often three inches broad, the long, green points of the involucral bracts extending for about half their length beyond the rays, making an eight- to ten-pointed green star with a purple center, whence the name "Jerusalem Star." Achenes brown, fully a half-inch in length, ridged, and tubercled, the slender beak about an inch long, the tawny, funnel-formed, inter-webbed pappus nearly equal in length. The size and weight of the seeds of both this and the preceding species make them very readily removable when they appear as an impurity among other seeds.

Means of control the same as for the preceding species. 


\section{GUM SUCCORY}

Chondrilla jüncea, $\mathrm{L}$.

Other English names: Skeleton Weed, Naked Weed.

Introduced. Biennial. Propagates by seed.

Time of bloom: Blossoms most abundantly in July and August, but produces scattering flowers until late autumn. Seed-time: August until frost-killed.

Range: Middle Atlantic States and inland to West Virginia. Habitat: Dry fields, roadsides, and waste places.

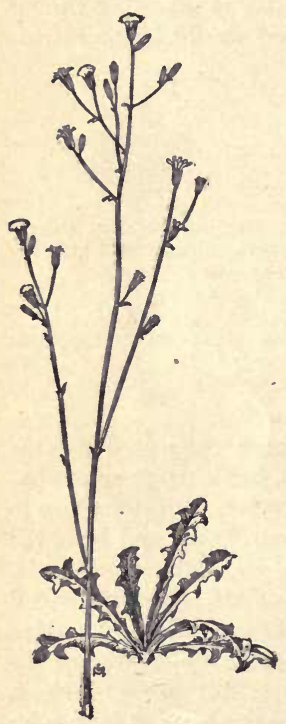

Fic. 369. - Gum Succory (Chondrilla juncea). $\times \frac{1}{4}$.

First-year tufts of the large, pinnatifid root-leaves of this weed resemble those of the Dandelion very much and might be mistaken for them; it has also a similar long, fleshy taproot, But the fruiting stalks, which appear in the second year, are one to three feet high, very slender, round, rigid, bare except for a few scattering stem-leaves so narrow and small as to seem mere awl-like bracts, smooth except that below the many branches the stem bristles with small, fine prickles. Heads yellow, less than a half-inch broad, on short peduncles; they terminate the branches in groups of two or three, and also grow singly and sessile on the sides of the nearly naked branches. Achene nearly black, usually five-ribbed, prickly at the top, with a slender beak about as long as the seed; the pappus attached to it is copious, fine, and shining white. (Fig. 369.)

Means of control

Hoe-cutting or spudding off the crowns of first-year plants; deep cutting of fruiting stems before any seed matures. In cultivated ground the weeds are destroyed by the necessary tillage. 


\section{DANDELION}

Taráxacum officinàle, Weber

Other-English names: Blowball, Cankerwort, Doon-head-clock, Yellow Gowan, Witch's Gowan, Milk Witch.

Introduced. Perennial. Propagates by seeds.

Time of bloom: All months in the year, where the weather is not at freezing point: Most abundant in spring.

Seed-time: Seeds ready for dispersal within two weeks from the unfolding of the flower.

Range: Cosmopolitan.

Habitat: Fields, meadows, lawns, waste places.

Wherever civilized man has established himself and cultivated the ground, he has carried and sown this weed, and, once in the soil, the Dandelion can be depended on to hold it. Drought does not affect it, the root being large, thick, fleshy, driven deeply into the soil, sometimes to a length of twenty inches; and cutting the crowns from the roots will not kill this weed as it does many taprooted plants; indeed, any part of a root will sprout leaves and make a new plant if buried in warm, moist soil. All parts of the plant are protected by bitter, milky juices which animals usually dislike, so that even in pastures it often thrives and reproduces itself unharmed.

Leaves basal, three inches to more than a foot long, blunt lance-shaped in outline but deeply and irregularly lobed and toothed, the divisions usually pointing toward the base, somewhat hairy when young but soon becoming smooth, spreading on the ground in a flat rosette; petioles margined and short. Scapes smooth, hollow, eylindrical, short at first but lengthening with maturity. Flower-heads

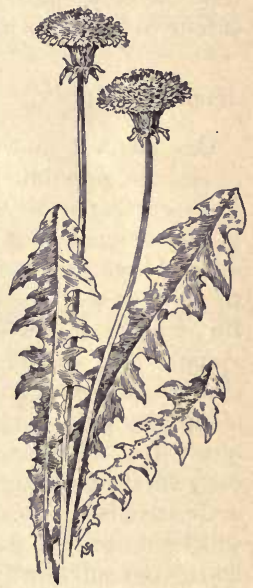

Fra. 370. - Dandelion (Taraxacum officinale). $\times \frac{1}{4}$. often nearly two inches broad, deep golden yellow, opening only in fair weather, and closing and reopening several times before 
the whole colony is fertilized to the center; florets all perfect and fertile, the rays five-toothed at their tips; bracts of the involucre in two series, the outer ones short, spreading, often reflexed at maturity, the inner ones smooth, linear, erect in a single row, long enough to enfold the flowers after their first opening. Achenes brown, oblong, angled, and ridged, set around the top with fine, spinous tubercles, the tip extending in a slender beak, bearing a copious pappus of fine, white hairs. (Fig. 369.)

Young Dandelion plants are excellent salad and pot herbs; the roots are used in medicine and more than a hundred thousand pounds are imported annually, notwithstanding the abundant home-grown product. The time for collection is in autumn when the roots are well stored with sustenance for the next season's growth, at which time the milky juice is thickest and the root most bitter. The price is four to ten cents a pound.

\section{Means of control}

One method, and usually the one practiced in small lawns and often in large public parks, is the diligent, persistent use of spud or knife, cutting below the ground. The plants sprout again, and have to be cut again, but if no leaf-growth is allowed to feed the roots even old ones must finally starve. A pinch of dry salt applied to the root at the time of cutting off the crown, will retard recovery. But winged weeds are constantly "blowing in" to replant the ground, and seedling Dandelions, with taproots still short and slender and leaves finely hairy, may be killed with chemical sprays; old plants with long, well-filled roots and smooth leaves are not much if at all affected. But if lawns and parking are systematically sprayed throughout the growing season with Copper sulfate or Iron sulfate, the grass will not be injured, seedling Dandelions will be destroyed, and the hairy, opening buds of old plants will be injured sufficiently to check development of seeds. Too often it is forgotten that the plants of roadside and waste places must not be neglected, even though growing at some distance, if property-owners expect any degree of success in keeping out the intruder. "Everlastingly keep at it" must be the motto of one who fights this weed. 


\section{RED-SEEDED DANDELION}

Taráxacum erythrospérmum, Andrz.

Introduced. Perennial. Propagates by seeds.

Time of bloom: April to June.

Seed-time: May to July.

Range: Maine to Virginia, westward to Michigan and Illinois.

Habitat: Lawns, grasslands, waste places.

Smaller than the preceding species, the leaves very slender, deeply pinnatifid, the backward-turning lobes very narrow and acute. Flower-heads about an inch broad, sulfur yellow, the outer row of rays purple on the under side; bracts of the involucre glaucous, the outer ones lance-shaped, spreading or ascending, the inner row linear and usually with a small horny appendage just below the tips. Achenes bright brownish red, the upper part very spinulose, the beak less than twice the length of the achene; pappus grayish white, very fine.

Means of control the same as for the Common Dandelion.

\section{FIELD SOW THISTLE}

Sónchus arvénsis, L.

Other English names: Creeping Sow Thistle, Corn Sow Thistle, Milk Thistle, Swine Thistle, Gutweed.

Introduced. Perennial. Propagates by seeds and by rootstocks.

Time of bloom: June to August.

Seed-time: July to September.

Range: Newfoundland and Nova Seotia to Manitoba and the

Dakotas, southward to New Jersey and Illinois.

Habitat: Grain fields, cultivated crops, roadsides, waste places.

A most noxious weed because of the creeping, horizontal rootstocks extending in all directions and putting forth new plants and roots at the joints; these rootstocks are rather thick, yellowish white, and, like all the rest of the plant, filled with a milky and bitter juice. Stems two to four feet tall, stout, smooth, finely grooved, hollow between joints. Leaves pinnatifid, the terminal lobe large, pointed, the lateral lobes turned backward and decreasing in size toward the base; the lower and basal leaves narrowing to margined petioles, the upper ones sessile and clasping by a heart- 
shaped base, all dark green, waxy-smooth, toothed with weak spines. Heads in large corymbose clusters, deep yellow, nearly

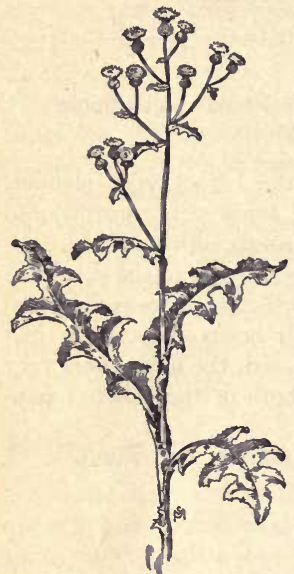

FIg. 371. - Field Sow Thistle

(Sonchus arvensis). $\times \frac{1}{8}$. two inches broad, the long rays fivetoothed, the bracts of the involucre and the pedicels usually set with stiff, glandular hairs, though in some localities a smooth and glaucous variety is common. Achene brown, about an eighth of an inch long, compressed, with wrinkled lengthwise ridges, and tufted with very copious, fine, white pappus. (Fig. 371.)

\section{Means of control}

Short rotations of hoed crops, receiving very frequent, thorough, and late tillage, are necessary in order to clear the ground of this weed. It is not harmed by any spray. Horse cultivation serves only to break and spread the rootstocks. Complete prevention of food-assimilating green growth above ground is the only sure remedy.

\section{COMMON SOW THISTLE}

Sonchus olerd̀ceus, L.

Other English names: Hare's Lettuce, Colewort, Milk Thistle. Introduced. Annual. Propagates by seeds.

Time of bloom: June to September.

Seed-time: July to October.

Range: Throughout North America except the far North.

Habitat: Fields, roadsides, waste places.

In Europe this plant is used as a pot herb, as its specific name, oleraceus, indicates, and is kept succulent by the constant pinching out of its buds. It springs from a white taproot, well fringed with feeding rootlets, the stem one to six feet tall, angled, branching, 
smooth, green, hollow between nodes, filled with milky juice. Leaves lyrate-pinnatifid, the terminal lobe large and triangular, the others narrow and decreasing in size toward the base; the lower and basal leaves petioled, but those on the stem clasping with an auricled and pointed base; the margins toothed with small, weak spines. Heads in crowded cymose panicles, yellow, nearly an inch broad; the involucres are downy while they enclose the buds, but later become smooth. Achenes brown, slightly flattened, with roughened ribs and thickly tufted, white, silken pappus. 372.)

Means of control

Prevent seed development. In gardens and other small areas, hand-pull before the first flowers mature. Stubbles should have surface cultivation after harvest for the purpose of stirring into life such seeds as are on the ground,

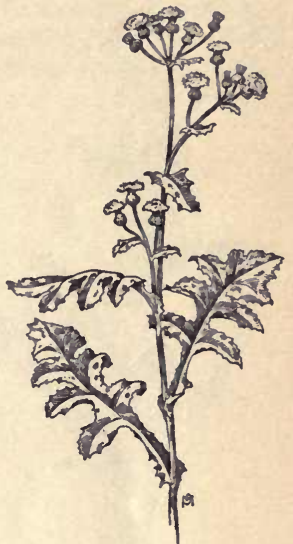

Fig. 372. - Common Sow Thistle (Sonchus oleraceus). $\times \frac{1}{4}$. the seedlings to be turned under at fall plowing. Waste places and roadsides are too often permitted to mature seeds, to the damage of adjacent ground.

\section{SPINY-LEAVED SOW THISTLE}

Sónchus ásper, Hill

Introduced. Annual. Propagates by seeds.

Time of bloom: May to October.

Seed-time: June to November.

Range: All cultivated parts oi the world.

Habitat: Fields, roadsides, waste places.

More prickly than the preceding species; the spines, though weak compared with those of true thistles, can make themselves felt when touched, while those of the Hare's Lettuce are too soft to pene- 


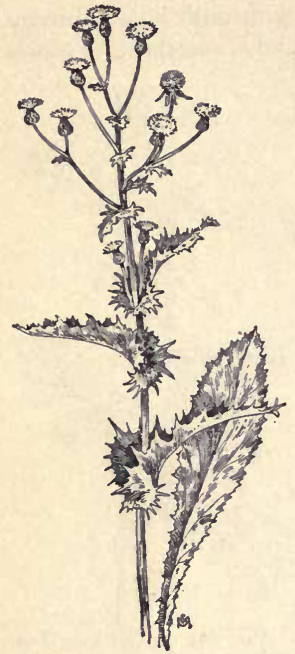

FIg. 373. - Spiny-leaved Sow Thistle (Sonchus asper). $\times \frac{1}{4}$.

\section{Seed-time: August to November.}

trate the skin. Stems one to six feet high, smooth, angled, branching, full of milky sap. Lower leaves sometimes pinnatifid but usually undivided and spatulate, tapering to margined petioles; stem-leaves oblong or lance-shaped, clasping the stem with rounded auricles, the margins prickly-toothed, the surfaces dark green, smooth, and shining. Heads similar to those of the Common Sow Thistle. Achenes oblong, compressed, margined, with smooth ribs. (Fig. 373.)

Means of control the same as for Common Sow Thistle.

\section{PRICKLY LETTUCE}

Lactùca scariola, L. Var. integràta, Gren. \& Godr.

Other English names: Compass Plant, Milk Thistle, English Thistle.

Introduced. Annual and winter annual. Propagates by seeds.

Time of bloom: July to October.

Range: Massachusetts to Georgia and Tennessee, westward to the Missouri River; also in Idaho, Oregon, and Washington. Most abundant in the Ohio Valley and in the states bordering on the Great Lakes.

Habitat: All soils; invades all crops.

A noxious weed that owes its wide range almost entirely to the agency of impure seed. It first appeared in Massachusetts not many years ago, and has since journeyed from ocean to ocean and could probably be found now in every state in the Union. In addition to its robbery of the crop in grain fields, the hardstems dull the reaping knives, and the copious, milky juice makes the weed very troublesome in threshing machines when handling a crop immediately after the reaping, without drying in the shock, as is frequently done in the West. 
Stem erect, with short lateral branches, round, smooth except for a few prickles near the base, sometimes attaining a height of seven feet but usually two to five feet tall; occasionally it has a purplish tinge. Leaves alternate, light green, oblong, variable, often obtuse at tips but sometimes acute, with wavy, prickly-toothed

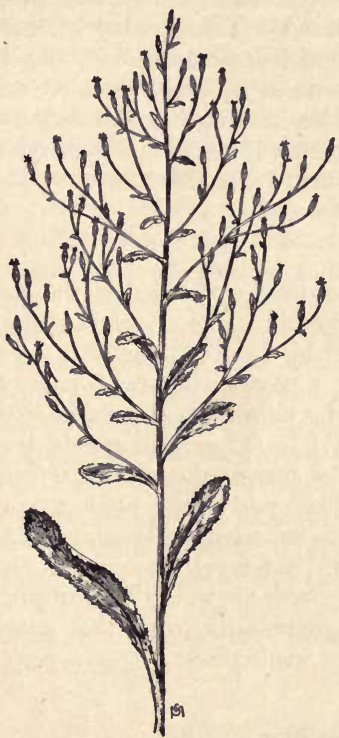

Fig. 374. - Prickly Lettuce (Lactuca scariola, var. integrata). $\times \frac{1}{6}$.

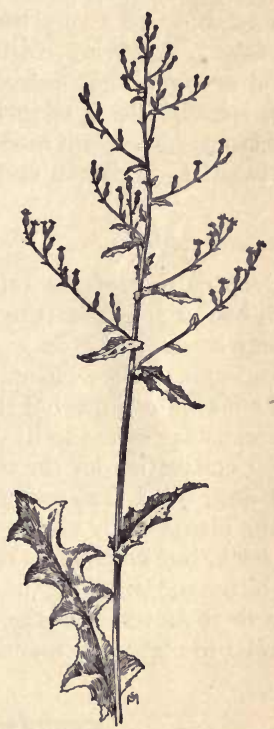

Fig. 375. - True Prickly Lettuce (Lactuca scariola). $\times \frac{1}{6}$.

edges and thick, whitish green midrib, closely set with spines on the under side, sessile, clasping, auricled at base. Leaves of plants growing in the open have a vertical twist at the base which causes their edges to point north and south; plants growing in the shade have not this twist to the leaves. Heads numerous, in a large 
panicle at the summit of the stalk and on short axillary branches; pale yellow, each less than a half-inch broad, on very short pedicels; beginning at the top, they open a few at a time, daily. Achenes brown, ridged lengthwise, with thread-like beak and pappus of fine, white, silken hair. (Fig. 374.)

Not quite so obnoxious nor so common as the variety just described, but still a very bad weed, is the True Prickly Lettuce ( $L$. scariola, L.) differing chiefly in that its prickly ribbed leaves are lobed or pinnatifid, and the smooth or sparsely prickled woody stalk usually taller; the heads are similar but slightly smaller, very numerous. The plant ranges from New England and Pennsylvania westward to Michigan and Missouri. (Fig. 375.)

\section{Means of control}

Deep cutting of the tufted root-leaves, well below the crown, with hoe or spud; cutting of flowering stalks at the beginning of bloom or earlier. In a grain field, hand-pulling of the young flower-stalks before bloom will be a paying operation, as the crop will not be worth much if the weed is allowed to absorb the fertility and moisture of the soil. Rankly infested ground should be put under cultivation for the purpose of stirring dormant seed into life and destroying the seedlings. Sheep and young cattle graze the young plants freely and prove good assistants in keeping the weed in check, but milch cows must not have much of it as the juices are bitter and will taint the milk. Seeds are widely wind-sown, and it is to the interest of the entire community to see that none are allowed to mature in roadsides and waste places.

\section{WILD LETTUCE}

\section{Lactùca canadénsis, L.}

Other English names: Wild Opium, Horseweed, Trumpet Milkweed. Native. Annual and winter annual. Propagates by seeds.

Time of bloom: June to October.

Seed-time: July to November.

Range: Nova Scotia to the Northwest Territory, southward to Georgia, Alabama, Louisiana, and Arkansas.

Habitat: Fields, meadows, roadsides, and waste places. 
In rich, moist soil this weed sometimes attains a height of ten feet, but is more often three to six feet tall. Stem slender, smooth, often glaucous, sometimes of a purplish tinge but most commonly deep green. Lower and bạsal leaves lanceshaped in outline but deeply and irregularly lobed, the terminal segment large and acutely pointed, the lateral ones unequal in number and size, not opposite, and frequently with points turned backward, narrowing to margined petioles; upper leaves much smaller, often entire and sessile. Heads numerous, in a loosely branching terminal panicle and in short axillary clusters; heads yellow, hardly more than a quarter-inch broad, the involucre cylindric, its inner row of bracts linear, the outer ones short and spreading. Achenes oblong-oval, tipped with a slender beak; pappus white, very fine and silky. The plant has a strong, unpleasant odor resembling opium, and, though cattle and sheep eat it readily, it will damage dairy products if milch cows get much of it. (Fig. 376.)

Means of control the same as for Prickly Lettuce.

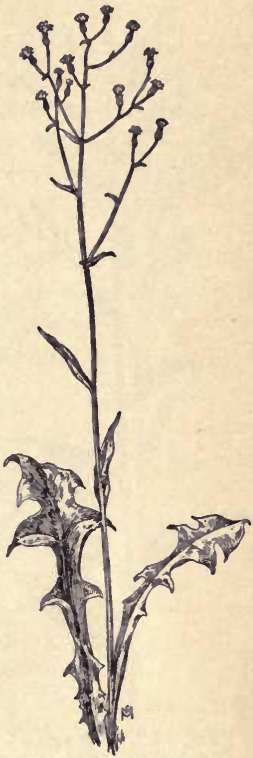

Frg. 376. - Wild Lettuce (Lactuca canadensis). $\times \frac{1}{6}$.

\section{ARROW-LEAVED WILD LETTUCE}

Lactùca sagittifolia, Ellis

Other English names: Devil's Ironweed, Horseweed.

Native. Biennial. Propagates by seeds.

Time of bloom: July to September.

Seed-time: August to November.

Range: New Brunswick and Ontario to Georgia, westward to the Rocky Mountains.

Habitat: Dry, open soil ; fields, meadows, waste places. 


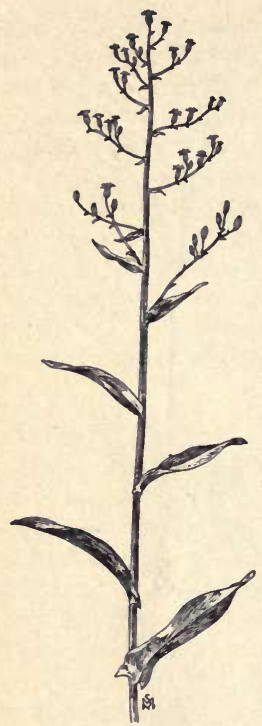

Frg. 377. - Arrow leaved Wild Lettuce (Lactuca sagittifolia). $\times \frac{1}{4}$.

Stem rather stout, smooth, two to six feet high, leafy to the flowering panicle. Leaves oblong-lance-shaped, smooth, somewhat thick, entire or the lower ones with a few shallow teeth, sometimes spinulose on the margins, those of the stem sessile, clasping, and auricled at base. Heads in a long, loosely branched, terminal panicle and in smaller axillary clusters; each about a quarter-inch broad, on slender pedicels, the rays reddish yellow; involucre cylindric, the outer bracts much shorter than the inner ones. Achenes oblong, flattened, shorter than the slender beak. Pappus fine and white. (Fig. 377.)

Means of control the same as for Prickly Lettuce.

\section{BLUE LETTUCE}

Lactùca pulchellla; DC.

Other English names: Showy Lettuce, Large-flowered Blue Lettuce.

Native. Perennial. Propagates by seeds and by rootstocks.

Time of bloom: June to August.

Seed-time: July to September.

Range: Western Ontario to the Northwest Territory and British Columbia, southward to Michigan, Kansas, New Mexico, and California.

Habitat: All crops; most injurious in grain fields and meadows.

A very handsome plant, but one of the most obnoxious weeds of its family and very hard to suppress. Stem slender, round, smooth, two to three feet tall. Leaves exceedingly variable, oblong to lance-shaped in outline, but the lower ones deeply cut or pinnatifid, with segments turned backward and often having margined petioles; upper ones sessile and partly clasping, slightly toothed or entire, becoming linear near the top; all smooth and glaucous. The whole plant, even to its fleshy, light-colored rootstocks, is 
filled with bitter, milky juice. Heads in open racemes, lifted on rather long, scaly-bracted peduncles; they are about an inch broad, with numerous light blue rays, toothed at the tips; bracts of the involucre imbricated in three or four rows, the inner ones lance-shaped, the outer ones shortening to pointed ovate. Achenes flattened club-shaped, with ridged margins and finely grooved sides, tapering to a short, stiff beak tipped with a cup-like disk to which is attached a copious, silky, white pappus which enables the winds to sow the seed very widely. (Fig. 378.)

\section{Means of control}

On the first appearance in any locality, it will pay to hand-pull or dig out the plants before seed production and before the rootstocks have penetrated far into the soil. Established rootstocks should be starved by persistent close cutting of all leaf-growth throughout the growing season. Where the land is badly infested, short rotations of cultivated crops - with very thorough tillage - are necessary if the weed is to be subdued.

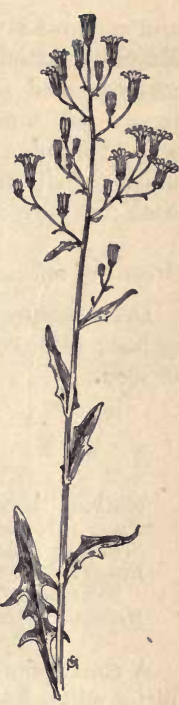

Fig. 378. - Blue Lettuce (Lactuca pulchella). $\times \frac{1}{6}$.

\section{HAIRY-VEINED BLUE LETTUCE}

Lactùca villòsa, Jacq.

Native. Biennial. Propagates by seeds.

Time of bloom: July to September.

Seed-time: August to October.

Range: New York to Illinois and Nebraska, southward to Georgia, Florida, and Kentucky.

Habitat: Meadows, pastures, fence rows, and borders of woods.

Stem two to six feet tall, round and smooth. Leaves oblong to lance-shaped, long-pointed, light green, smooth and glossy above but set with stiff bristly hairs on midrib and veins beneath, sharply and of ten doubly toothed, the lower ones usually lobed at the base 
and narrowed to winged petioles, those on the stem sessile and clasping, sometimes auricled at base. Heads on large, loose, many-headed panicles, with diverging branchlets which usually have a few minute, scaly bracts; each less than a half-inch broad with short blue rays; bracts of the involucre obtuse, the outer row much the shorter. Achenes oblong, small, rather thick, without a beak; pappus silky white.

\section{Means of control}

Deep cutting of autumn tufts of leaves from the roots with spud or hoe; close cutting of all flowering stalks before the development of seed.

\section{TALL BLUE LETTUCE}

Lactùca spicd̀ta, Hitche.

Native. Biennial. Propagates by seeds.

Time of bloom: July to October.

Seed-time: August to November.

Range: Newfoundland to Manitoba, southward to the Carolinas, Tennessee, and Iowa.

Habitat: Meadows, pastures, roadsides, and waste places.

A conspicuous weed, its stem three to twelve feet tall, full of bitter milky juice, stout, round, smooth, very leafy up to the large, rather dense, compound panicle. Leaves six inches to a foot long, two to six inches wide, deeply and irregularly lobed, sharply toothed, smooth above but sometimes slightly hairy on the veins beneath, those on the stem sessile, clasping; and auriculate, the lower ones narrowed to winged petioles. Heads very small, about a quarterinch broad, the rays usually pale blue but sometimes creamcolored. Achenes slightly flattened, very short-beaked, the pappus tawny brown.

Means of control the same as for the preceding species.

\section{RUSH-LIKE LYGODESMIA}

Lygodésmia júncea, D. Don.

Native. Perennial. Propagates by seeds.

Time of bloom: June to August. 
Seed-time: July to September.

Range: Wisconsin to the Plains of the Saskatchewan, southward to Missouri and New Mexico.

Habitat: Prairies; dry fields and meadows.

A troublesome, persistent weed, difficult to suppress, which is appearing locally.in some of the Eastern States, traveling by the agencies of grass seeds or baled hay. Grazing animals reject it when growing because of the copious, bitter, and milky juice; and when dried in hay its stems are too hard and woody to be eaten.

It has a thick, deep-boring, woody root, from which several tufted stems arise, eight to eighteen inches high, erect, stiff, branching, round, and finely grooved. Lower leaves a half-inch to two inches in length, narrowly lance-shaped to linear, the upper ones becoming much smaller, until near the top they are mere awllike scales. Heads erect, solitary and terminal, about a half-inch broad, usually five-flowered, the rays five-toothed at the tips, rosy pink or light purple; involucre about a half-inch high, cylindric, with an inner row of five to eight linear bracts, scarious-margined, united at the base, and surrounded by several very short outer ones. Achenes very slender, nearly a quarter-inch long, round, tapering, truncate at summit, with a copious, light brown pappus by which they are freely wind-distributed.

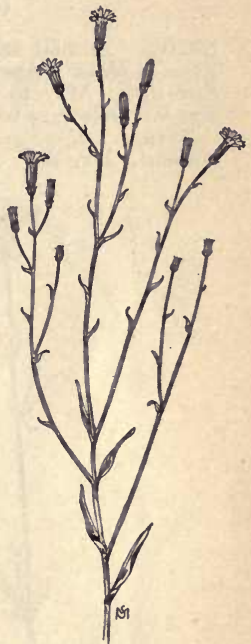

Fig. 379. - Rush-like Lygodesmia (Lygodesmia juncea). $\times \frac{1}{6}$.

(Fig. 379.)

\section{Means of control}

Prevent seed development and distribution by early and repeated cutting. Infested grass lands should be harvested before the first flowers mature, and should later be broken up for a cultivated cleansing crop before reseeding. For newly infested areas the 
labor of hand-pulling is not too great a price to pay in order to save clean ground from being fouled with a growth so pernicious.

\section{FALSE DANDELION}

Pyrrhopáppus caroliniànus, DC.

(Sittlias caroliniàna, Raf.)

Native. Annual or biennial. Propagates by seeds.

Time of bloom: April to July.

Seed-time: May to August.

Range: Delaware to Missouri, southward to Florida, Louisiana, and Texas.

Habitat: Dry soil ; fields, pastures, roadsides, and waste places.

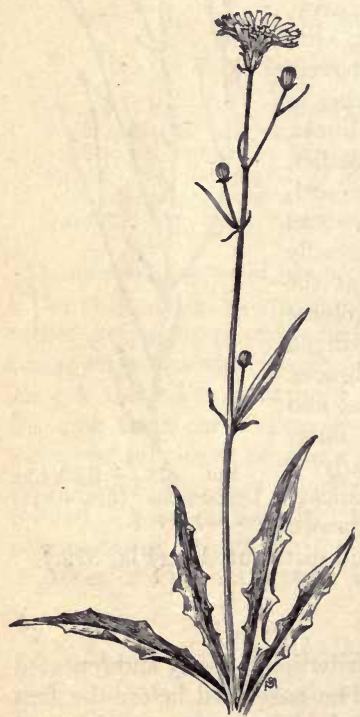

Fis. 380. - False Dandelion (Pyrrhopappus carolinianus). $\times \frac{1}{6}$.
Very like a Dandelion in its appearance but for its branched and leafy stems; these are one to nearly three feet tall, slender, and smooth. Basal leaves oblong to lance-shaped, three to eight inches long, coarsely toothed and lobed, sometimes pinnatifid, narrowing to marginedpetioles ; stem leaves more slender, acute, entire, sessile or partly clasping. Heads solitary at summit of stem and branches, nearly two inches broad, with many deep yellow rays; involucre slightly hairy, its outer bracts spreading, awl-like, and short, subtending the linear, erect, and slightly united inner row. Achenes reddish brown, oblong, five-ribbed, narrowed to a thread-like beak, with a showy, copious pappus of soft rust-red hairs, surrounded at its base by a ring of white down. (Fig. 380.) 


\section{Means of control}

Prevention of seeding by persistent, frequent cutting. In cultivated ground the necessary tillage destroys the weed.

\section{SMOOTH HAWKSBEARD}

Crèpis capillàris, Wallr.

(Crèpis virens, L.)

Introduced. Annual or biennial. Propagates by seeds.

Time of bloom: July to September.

Seed-time: August to October.

Range: Atlantic States from New York southward; also on the Pacific Coast.

Habitat: Fields and waste places.

Hawksbeards are European weeds, not as yet very widely distributed in this country but noted in their range as "becoming frequent." This species has a stem ten to thirty inches tall, smooth, slender, branching at the top into a loose, corymbose flowercluster. Basal leaves somewhat resembling those of a Dandelion, five to eight inches long, lance-shaped to spatulate, pinnatifid or merely coarsely toothed, narrowing to winged petioles; stem leaves much smaller, long-pointed, clasping the stem with an auriculate base, the upper ones usually entire. Heads numerous, on very slender peduncles, about a halfinch broad, gold-yellow; involucre cylindric, of one row of equal bracts. Achenes tapering at both ends, ten-ribbed, smooth, without a beak, the pappus a soft, thick, white aigrette attached to the apex. (Fig. 381.)

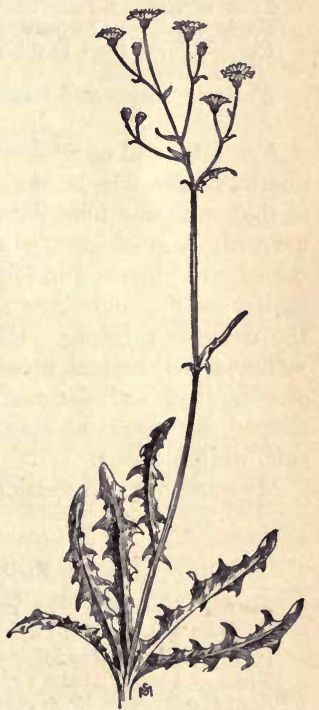

FIg. 381. - Smooth Hawksbeard (Crepis capillaris). $\times\{$. 


\section{Means of control}

Prevent seed development. Crowns of autumn plants should be hoe-cut or spudded from their roots, and flower-stalks should be cut in their first bloom. In cultivated ground the necessary tillage will keep the weed suppressed, but plants along roadsides and in waste places should not be allowed to mature fruit to the injury of neighboring land.

\section{NARROW-LEAVED HAWKSBEARD}

Crèpis tectorum, $\mathrm{L}$.

Introduced. Annual. Propagates by seeds.

Time of bloom: June to August.

Seed-time: July to September.

Range: New York and New Jersey, westward to Ontario, Michigan, and Nebraska.

Habitat: Fields and waste places.

A smaller and more slender plant than the preceding, with stem one to two feet in height, branching from the base, differing also in that stalk and foliage are finely downy. Basal and lower leaves narrowly lance-shaped, with pointed, slim, backward-turning lobes, the edges of leaves and lobes revolute; upper leaves nearly linear, entire, sessile, sometimes slightly auriculate and clasping at base, the margins revolute. Heads numerous, loosely clustered, bright yellow, nearly an inch broad, on slender, hairy peduncles; involucre also downy, with lance-shaped, equal bracts. Achenes spindleshaped, narrowest at apex, with ten roughened ribs and copious, soft, white pappus.

Measures for suppression the same as for Smooth Hawksbeard.

\section{ROUGH HAWKSBEARD}

Crèpis biênnis, L.

Introduced. Biennial. Propagates by seeds.

Time of bloom: June to August.

Seed-time: July to September.

Range: New England to Pennsylvania, westward to Michigan.

Habitat: Fields and waste places. 
Larger than either of the preceding species, two to three feet high, the whole plant usually rough-hairy. Base leaves about six inches in length, oblong to spatulate, lobed or coarsely and very irregularly toothed, narrowing to margined petioles; upper ones much smaller, lance-shaped, and clasping. Heads deep yellow, more than an inch broad, in an open corymbose cluster; involucre about a half-inch high, its principal bracts narrowly lance-shaped, the outer row short, pointed, and spreading. Achenes smooth, slightly tapering to the apex, with thirteen ribs and a spreading pappus of very fine, white bristles.

\section{Means of control}

Hoe-cutting or spudding of first year leaf-crowns from the fleshy root; plants that survive to form fruiting stalks in the second year should be cut close to the ground before the first flowers mature.

\section{SMOOTH WHITE LETTUCE \\ Prenanthes racemòsa, Michx. (Nábalus racemòsus, DC.)}

Native. Perennial. Propagates by seeds.

Time of bloom: August to September.

Seed-time: September to October.

Range: New Brunswick to the Northwest Territory, southward to New York, New Jersey, Missouri, and Colorado.

Habitat: Moist soil; prairies and banks of streams, wet meadows, and marshes.

A plant of very stately appearance, with a stout stalk, two to six feet or more in height, erect, simple, finely ridged, smooth, and glaucous, springing from a thick, tuberous, and very bitter root. Leaves light green, rather thick in texture, smooth, glaucous, the lower ones sometimes oval but usually oblong to obovate, four to eight inches in length, obtuse at apex, tapering to long, margined petioles, the edges with sparse and shallow teeth; upper ones much smaller, long-ovate to lance-shaped, acute, often entire, sessile, and partly clasping. Heads in a long, interrupted, spike-like panicle, the clusters densely crowded, some of the heads nodding but the greater number erect; florets pale purple, eight to fifteen 


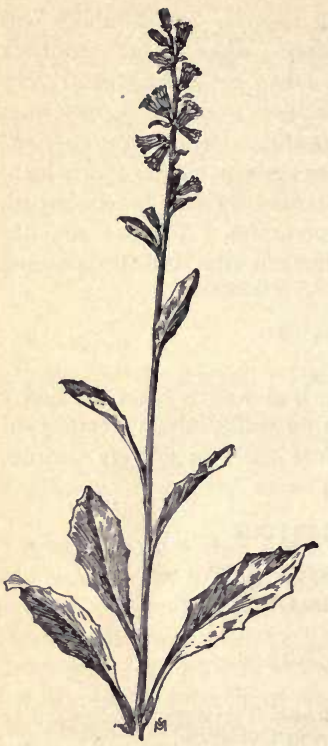

FIG. 382. - Smooth White Lettuce (Prenanthes' racemosa). $\times \frac{1}{6}$. in each head; involucre cylindric, with eight to ten linear bracts in its principal row, with a few short, spreading outer ones. Achenes small, slender, with fine, straw-colored pappus.

\section{Means of control}

Cut flower-stalks close to the ground before the buds unfold, thus preventing seed development and distribution. Drainage and cultivation of the soil are necessary in order to kill the perennial roots.

\section{ROUGH WHITE LETTUCE}

Prenanthes aspera, Michx. (Nabalus asper, T. \& G.)

Native. Perennial. Propagates by seed.

Time of bloom: August to September.

Seed-time: September to October.

Range: Ohio to South Dakota, southward to Kentucky, Kansas, and Louisiana.

Habitat: Dry prairies; fields, pastures, waste places.

Grazing cattle usually leave this weed undisturbed to perfect its fruit, liking neither its rough-hairy foliage nor its bitter juices. Stem stout, simple, ridged, and bristly-hairy, two to four feet tall. Leaves long-oval or broadly lance-shaped, rather thick and firm, rough on both sides, sparsely toothed, obtuse, the basal ones tapering to winged petioles; those on the stem all sessile, the lower ones clasping and obtuse, the uppermost usually entire and acute. Heads numerous, in a long, spike-like panicle, mostly erect on very short pedicels, each about a half-inch broad, with twelve to fifteen cream-colored florets; involucre cylindric, very hairy, its principal 
bracts nearly a half-inch long, linear, with a few short, pointed, spreading ones at base. Achenes oblong, with straw-colored pappus. Means of control should be the same as for Prenanthes serpentaria.

\section{GALL-OF-THE-EARTH}

\section{Prenánthes serpentària, Pursh}

(Nábalus serpentàrius, Hook)

Other English names: Rattlesnake Root, Lion's Foot, Snake Gentian, Drop Flower, Cankerweed.

Native. Perennial. Propagates by seeds.

Time of bloom: August to October.

Seed-time: September to November.

Range: Ontario, New York, and Massachusetts, southward to Florida and Alabama.

Habitat: Fields, pastures, fence rows, open thickets.

The large, tuberous roots of this weed are extremely bitter and once had the reputation of curing rattlesnake bites, whence its specific and common names; stem and leaves partake of the same quality, and, even when good forage is very scarce, grazing cattle will leave it unmolested to bloom and mature seed.

Stem two to four feet tall, erect, smooth, often purplish, not glaucous, branched above, and usually somewhat spreading. Leaves rather thick and firm, the lower ones often six or eight inches long and most variable in shape; pinnatifid or palmately lobed or halberd-form or heart-shaped, usually with wavy edges or coarsely and very irregularly toothed, the petioles winged; upper leaves long-ovate to lance-shaped, often entire. Panicles rather large, loose, fork-branched, upcurved, the heads pendulous, chiefly in terminal clusters but a few in the upper axils ; florets eight to twelve, pale purple or cream-colored; involucre funnel-shaped, the bracts often purplish, usually somewhat bristly, spreading abruptly above the middle. Achenes yellowish brown, with straw-colored pappus.

\section{Means of control}

Prevent seed development and distribution by close cutting while in early bloom. Cultivation of the ground will destroy the tuberous roots. Small areas should be grubbed out. 


\section{MOUSE-EAR HAWKWEED}

Hierd̀cium Pilosélla, L.

Other English names: Felon Herb, Mouse Bloodwort, Ling Gowans. Introduced. Perennial. Propagates by seeds and by stolons.

Time of bloom: June to September.

Seed-time: July to October.

Range: Ontario to Michigan, New York, Pennsylvania, and Ohio. Habitat: Grasslands, lawns and yards, waste places.

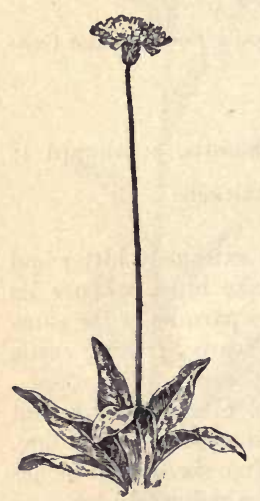

Frg. 383. - Mouse-ear Hawkweed (Hieracium Pilosella). $\times \frac{1}{2}$.

Roots tufted and fibrous, not far below the surface. Stem erect, slender, leafless, bristly-hairy, three to ten inches high. Leaves all basal, only two or three inches long and less than an inch wide, entire, spatulate, narrowing into short petioles, bristly-hairy on both sides, but green above while the hairs on the under side are star-shaped and matted into white wool. Thrust out from among the leaves are several slender, leafy runners, three inches to a foot in length, which take root and form new plants, causing the weed to grow in patches. Heads about an inch broad, solitary, golden yellow; bracts of the involucre in one or two series, linear, pointed, hairy. Achenes oblong, ribbed, the pappus a funnel-form row of fine, tawny bristles. (Fig. 383.)

Means of control the same as for Orange Hawkweed.

\section{ORANGE HAWKWEED}

Hieràcium aurantıacum, $\mathrm{L}$.

Other English names: Devil's Paintbrush, Devil's Weed, Grim the Collier, Red Daisy.

Introduced. Perennial. Propagates by seeds and by stolons.

Time of bloom: Early June to September.

Seed-time: July to October.

Range: Eastern provinces of Canada, New England, and Middle Atlantic States to Ohio; locally farther west.

Habitat: Fields, meadows, pastures, roadsides, waste places. 
One of the most pernicious weeds that have come to us from Europe, the range of which is widening every year. Grazing animals dislike and reject the plant even when dried in hay, for it is densely hairy in every part and its juices are acrid and bitter.

Stem six to eighteen inches tall, unbranched, and without leaves except an occasional short bract, very slender, erect, closely set with short, stiff, black hairs, which, in England, gave the weed its name of Grim the Collier. Leaves basal, clustered in rosette form about the stem, oblong to spatulate, obtuse, dark green, hairy on both sides; this flat, matted growth of leaves chokes out grass or other plants among which the weed is growing. Thrust out from among the leaves are usually several stolons, or runners, with young plants or buds at their tips. Flowerheads in a compact, corymbose cluster, on short, glandular-hairy peduncles, only a few blossoms open at one time, the rest of the bunch being composed of buds in various stages of growth. The heads are about an inch broad when fully open, flaming orange-red, the rays toothed at the tips; bracts of the involucre imbricated in two or three series, lance-shaped, hairy. Achenes oblong, dark brown, ten-ribbed, with pappus a single row of tawny, shining, bristlelike hairs, spread in funnel-form, making parachutes by which the wind distributes

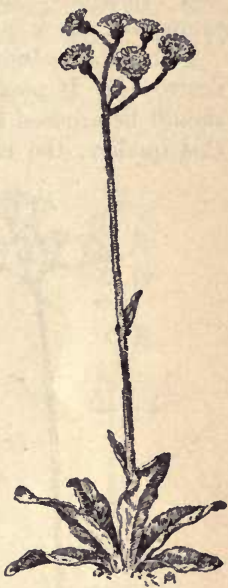

Fig. 384. - Orange Hawkweed (Hieracium aurantiacum). $\times \frac{1}{6}$. them far and wide. (Fig. 384.)

\section{Means of control}

The roots of this weed are fibrous and spreading and near the surface; careful cultivation of the ground, particularly with hoed crops, destroys it. But the plant is often a pest of permanent grass lands where cultivation is not desirable; here the best treatment is a liberal application of dry salt, spread broadcast over the 
patches so thickly as to cover all the plants. In the experiments carried on at the Vermont Agricultural Experiment Station by Professor Jones, it was found that as large a quantity of salt as eighteen pounds to the square rod may be used without serious injury to the grass; indeed the grass soon becomes all the finer when relieved of its crowding competitor, for the weed so smothers and "runs out" the grass that it does much more harm than a temporary check in growth from the salt treatment.

Plants in roadsides and waste places should be looked after and destroyed. If possible, the sentiment of an entire neighborhood should be aroused against Orange Hawkweed, for, with a plant of this quality, the careful farmer is largely at the mercy of any

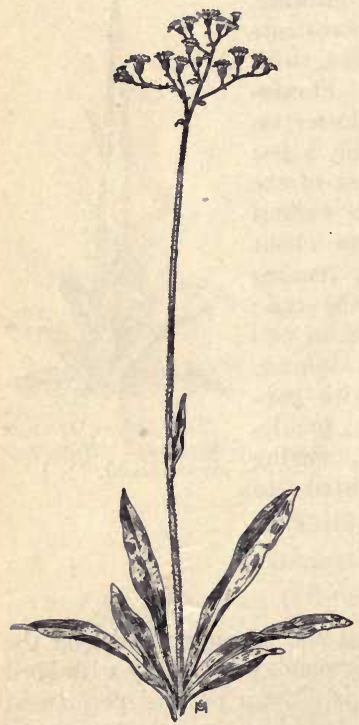

Fig. 385. - Field Hawkweed (Hieracium pratense). $\times \frac{1}{6}$. slovenly cultivator who chooses to be regardless of communal welfare.

\section{FIELD HAWKWEED}

Hierdcium praténse, Tausch.

Other English names: King Devil, Yellow Devil.

Introduced. Perennial. Propagates by seeds and by stolons. Time of bloom: June to August. Seed-time: July to September.

Range: Eastern Quebec to southern New York.

Habitat: Fields, meadows, roadsides, and waste places.

Not many years have passed since this immigrant from Europe landed in this country; its range is not as yet very extensive and it is to be hoped that it may not increase fast or far. Cattle refuse to eat the plant because of its bristly foliage and nauseous, bitter juices.

Stems one to two feet tall, slender, bristly hairy, with two or three 
small leaves near the base, and branching at the top into a loose, open flower-cluster. Basal leaves tufted, narrowly oblong to lance-shaped, tapering backward to margined petioles, light green, entire, bristly hairy on both sides. Stolons few, lacking on many plants. Heads yellow; about three-quarters of an inch broad, on glandular, hairy pedicels; bracts of the involucre nearly linear, pointed, blackish, sticky-hairy. Achenes brown, oblong, with lengthwise ridges; pappus a ring of fine, plumose bristles arranged funnel shape. (Fig. 385.)

Means of control the same as for Orange Hawkweed.

\section{HAIRY HAWKWEED}

\section{Hieràcium Gronòvii, L.}

Native. Perennial. Propagates by seeds. Time of bloom: July to September.

Seed-time: August to October.

Range: Massachusetts to Ontario, Illinois, and Kansas, southward to Georgia and Louisiana.

Habitat: Dry soil ; grasslands, waste places.

Stem very slender, erect, one to three feet tall, hairy, with a few leaves below the middle. Basal and lower leaves two to six inches long, obovate or spatulate, narrowing to short petioles, obtuse, entire or with a few shallow teeth, roughhairy above but covered on the under side with minute, star-shaped hairs. Heads in a narrow panicle, without leafy bracts, each about a half-inch broad, light yellow, on very slender and slightly glandular pedicels; principal bracts of the involucre in one series, nearly linear, acute, with an outer row very much shorter. Achenes spindle-shaped, with a pappus of fine, brown bristles, arranged in funnel form. (Fig. 386.)

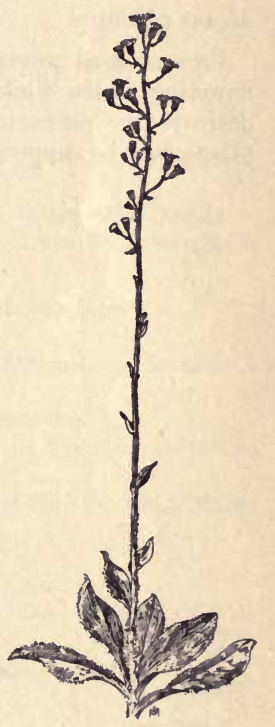

Fra. $386,-$ Hairy Hawkweed (Hieracium Gronovii). $\times\}$. 
Two other species of Hawkweed are becoming abundant in eastern Canada and northern New York and New England. Both promptly named "King Devils" by the farmers whom they victimize. Hieràcium floribúndum, increasing by numerous stolons and also by flowering branches at the base; a smooth and glaucous plant except that the spatulate leaves are bristly on the margins, and sometimes on midrib and veins beneath. Heads in large dense corymbs, yellow, with blackish involucres. Hieràcium florentinum, springing from a short stout rootstock, with smooth, spatulate basal leaves or sometimes sparsely bristly beneath, the scape often nearly two feet tall with manyheaded yellow corymb.

\section{Means of control}

Prevent seed production and distribution by close cutting of flowering stalks while in early bloom. Cultivation of the soil destroys the perennial roots. Like the Orange Hawkweed these plants may be suppressed in grasslands by the use of salt. 


\section{BIBLIOGRAPHY}

Barley, L. H.

Cyclopedia of American Agriculture.

Cyclopedia of American Horticulture.

Farm and Garden Rule Book.

Macmillan Co.

Lessons with Plants.

Manual of Gardening.

BeAL, W. J.

Grasses of North America. Henry Holt \& Co.

Seed Dispersal. Ginn \& Co.

Blatchley, W. S.

The Indiana Weed Book. Nature Publishing Co., Iudianapolis. Brition, N. L., ANd Brown, A.

Illustrated Flora of the Northern United States and Canada. Charles Scribner's Sons.

Chapman, A. W.

Flora of the Southern United States. American Book Co. Clark, G. H., and Fletcher, J.

Farm Weeds of Canada. Department of Agriculture, Canada.

Coulter, John M., revised by Aven Nelson.

New Manual of Botany for the Rocky Mountains.

American Book Co.

Crane, P. B.

Quack-grass Eradication. Webb Publishing Co. St. Paul, Minn.

Darling, Chester A.

Handbook of Wild and Cultivated Flowering Plants.

Mason-Henry Press, Syracuse, N.Y.

Darlington, William.

American Weeds and Useful Plants. Orange Judd Co.

Ewart, Alfred.

Weeds, Poison Plants, and Naturalized Aliens of Victoria.

Government Printing Press, Melbourne, Australia 
Flint, Martha.

The Garden of Simples. Charles Scribner's Sons.

Goodrich, Charles L.

The First Book of Farming. Doubleday, Page \& Co. Gray, Asa.

New Manual of Botany, Seventh Edition.

Field, Forest, and Garden Botany. American Book Co.

JePson, W. L.

Flora of Western Middle California. University of California.

Kerner \& Oliver.

Natural History of Plants. Blackie \& Son, London.

Knight, Alfred E.

The Living Plant. Hutchinson \& Co., London.

KNOBEL, Edward.

Grasses, Sedges, and Rushes of the United States.

Bradlee Whidden, Boston.

Long, Harold C.

Common Weeds of Farm and Garden. Smith, Elder \& Co., London. Lyons, A. B.

Plant Names, Scientific and Popular. Nelson Baker Co., Detroit.

Needham, James G.

Natural History of the Farm. Comstock Publishing Co., Ithaca.

Pammel, L. H.

Manual of Poisonous Plants. Torch Press, Cedar Rapids, Iowa.

Weeds of Farm and Garden. Orange Judd Co.

Parsons, M. E.

Wild Flowers of California. Cunningham, Curtis \& Welch,

San Francisco.

Percival, John.

Agricultural Botany. Henry Holt \& Co.

SARgent, Frederick L.

Plants and their Uses. Henry Holt \& Co.

Scribner, F. Lamson.

American Grasses. Department of Agriculture, Washington. 
Shaw, Thomas.

Weeds and How to Eradicate Them.

Small, John K.

Webb Publishing Co., St. Paul.

Flora of the Southeastern United States.

Spillman, W. J.

Farm Grasses of the United States. Orange Judd Co.

Strasburger, E.

Handbook of Practical Botany. Macmillan Co.

Stevens, George T.

Illustrated Guide to Flowering Plants. Dodd, Mead \& Co.

Walton, George L.

Practical Guide to Wild Flowers and Fruits.

Ward, H. MArshall.

J. B. Lippincott Co.

Grasses. Cambridge University Press, London. Warren, George F.

Elements of Agriculture. Macmillan Co. 



\section{LIST OF PLANTS DISTINCTLY POISONOUS OR}

MECHANICALLY HARMFUL TO ANIMAL LIFE

Aster, Woody

Barley, Wild

Bunch-flower

Buttercup, Bulbous

Meadow

Camas, Death

Cherry, Wild Black

Clover, Rabbit-foot

Cockle, Corn

Cow

Crowfoot, Cursed

Darnel

Dogbane, Spreading

Foxglove, Purple

Hellebore, American

Hemlock, Poison

Water

Hemp, Black Indian

Henbane, Black

Horsetail, Field

Ivy, Poison

Jamestown Weed

Johnson-grass

Larkspur, Dwarf

Field

Purple

Sky-blue

Small

Tall Mountain

Western

Laurel, Narrow-leaved

Lobelia, Great
Xylorhiza Parryi

PAGE

Hordeum jubatum

Melanthium virginicum

Ranunculus bulbosus acris

Zygadenus venenosus

Prunus serotina

Trifolium arvense

429

64

77

157

159

76

217

Agrostemma Githago

Saponaria Vaccaria

Ranunculus sceleratus

Lolium temulentum

A pocynum androscmifolium

Digitalis purpurea

Veratrum viride

Conium maculatum

Cicuta maculata

A pocynum cannabinum

Hyoscyamus niger

Equisetum arvense

Rhus Toxicodendron

Datura Stramonium

Sorghum halepense

229

142

151

154

60

312

382

78

300

301

314

373

20

274

375

22

Delphinium tricorne $\quad 162$

Consolida

bicolor

161

165

azureum

163

Menziesii 166

glaucum 164

trollifolium 167

Kalmia angustifolium $\quad 308$

Lobelia syphilitica 563 
Loco-weed, Stemless Woolly

Lupine, Nebraska

Low

Silvery

Mustard, Wormseed

Nightshade, Bittersweet

Black

Painted Leaf

Parsley, Fool's

Parsnip, Cow

Wild

Pea, Everlasting

Hoary

Meadow

Tuberous Wild

Pear, Prickly

Pimpernel, Scarlet

Pokeberry or Pokeweed

Porcupine-grass

Rattlebox

Sneezeweed

Fine-leaved

Purple-headed

Snow-on-the-Mountain

Sorrel, Field

Spurge, Cypress

Upright Spotted

Stagger-bush

Stinking Willie

Sumac, Poison

Swallow-wort, Black

Thornapple, Purple

Hairy

Tobacco, Indian
Oxytropis Lamberti

Astragalus mollisimus

Lupinus plattensis

pusillus

argenteus

Erysimum cheiranthoides

Solanum Dulcamara

nigrum

Euphorbia heterophylla

Ethusa Cynapium

Heracleum lanatum

Pastinaca sativa

Lathyrus latifolius

Tephrosia virginiana

Lathyrus pratensis

tuberosus

Opuntia Rafinesquii

Anagallus arvensis

Phytolacca decandra

Stipa spartea

Crotalaria sagittalis

Helenium autumnale tenufolium

nudiflorum

Euphorbia marginata

Rumex Acetosella

Euphorbia Cyparissias

Pressli

Lyonia mariana

Senecio Jacobara

Rhus Vernix

Cynanchum nigrum

Datura Tatula

Metel

Lobelia inflata
481

483

482

267

96

272

264

310

506

273

319

376

376

411 


\section{GLOSSARY}

Abortive. Defective or barren.

Achene. A small, dry, hard, one-celled, and one-seeded fruit, with tightly fitting and valveless covering.

Acute. Sharp-pointed.

Alternate (leaves). Not opposite; arranged singly at different heights on the axis.

Annual. A plant which matures fruit in one year.

Anther. The part of a stamen which contains the pollen.

Appressed. Lying flatly and close against.

Ascending. Curving upward or rising obliquely.

Auricle. An ear-shaped lobe or appendage.

Awl-shaped. Tapering from the base to a rigid point.

Awn. A very slender but stiff and bristle-like appendage.

Axil. The angle formed by the junction of a leaf or branch with the stem.

Axillary. Situated in an axil.

Barbed. Tipped with sharp, rigid, and reflexed points.

Beaked. Having a tapering, prolonged tip.

Berry. A simple fruit which is wholly pulpy or fleshy except the outer skin.

Biennial. Of two years' duration.

Blade. The flat, expanded part of a leaf.

Bract. A more or less modified leaf subtending a flower, or a flower cluster, or sometimes borne on a stem.

Bulb. An underground leaf-bud with fleshy scales or coats.

Bulbous. Bearing bulbs.

Calyx. The outer floral envelope.

Canescent. Hoary with fine gray hairs.

Capillary. Hair-like.

Capitate. Shaped like a head.

Capsule. A dry fruit of two or more carpels, opening usually by valves or teeth.

Carpel. A single ovary, or one part of a compound ovary. 
Cell. A cavity of an ovary or of an anther.

Ciliate. Fringed with marginal hairs.

Coma. A tuft of hairs at the end of some seeds.

Comose. Bearing tufted hairs at the apex.

Compound. Composed of similar parts forming one whole.

Compressed. Flattened laterally.

Connate. Similar structures more or less united.

Corm. The swollen, fleshy, and solid base of a stem.

Corolla. The inner floral leaves or petals, which may be distinct or more or less united.

Corymb. A convex or flat-topped flower cluster with pedicels or rays arising from different points on the axis, and with the progression of bloom from the margin inward.

Crenate. Scalloped; having rounded teeth.

Culm. The stem peculiar to grasses and sedges.

Cyme. A convex or flattened flower cluster of which the central flowers first unfold, the progression of bloom being toward the margin.

Deciduous. Not persistent; falling away at the end of the growing period.

Decumbent. Declining but with the end ascending.

Decurrent (leaf). Extending down the stem below the insertion.

Deflexed. Turned abruptly downward.

Dehiscent. Opening regularly by valves, slits, or teeth.

Depressed. Flattened vertically.

Diffuse. Widely or loosely spreading.

Diœcious. Bearing staminate or male flowers on one plant, and fertile or pistillate flowers on another plant.

Disk. In Compositæ, the tubular flowers of the head as distinct from the rays.

Drupe. A fleshy or pulpy fruit having an inner portion of the pericarp hard and bone-like.

Entire. Without divisions, lobes, or teeth.

Exserted. Projecting beyond an envelope, as the stamens from a corolla.

Fascicle. A close bundle or cluster.

Fertile. Bearing fruit or seed.

Filament. The part of a stamen which supports the anther; any thread-like body.

Floret. A small flower, usually one of a head or a dense cluster.

Follicle. A fruit consisting of a single carpel, opening by the ventral or inner suture. 
Fruit. The seed-bearing product of any plant, simple, compound, or aggregated, of whatever form.

Glabrous. Smooth; without hairs.

Gland. A secreting cell or structure.

Glaucous. Covered with a white or bluish-white bloom.

Globose. Nearly spherical.

Glume. One of the two outer chaffy bracts at the base of the spikelet in the grasses.

Habitat. A plant's natural place of growth.

Halberd-shaped. Like an arrow-head but with the basal lobes pointing outward instead of backward.

Herb. A plant with no persistent woody stem above the ground.

Hirsute. Bearing rather coarse, stiff hairs.

Hispid. Set with rigid or bristly hairs.

Imbricated. Overlapping.

Included. Not protruding from the surrounding envelope, as the stamens from the corolla.

Indehiscent. Persistently closed; a fruit covering without an opening. Indigenous. Native to the region of growth.

Inflated. Bladder-like.

Inserted. Attached to or growing out of.

Internode. The portion of a stem between two nodes or joints.

Introduced. Brought from another region to the place of growth.

Involucre. A circle or whorl of bracts subtending a flower eluster, or a head, or a single flower.

Involute. Rolled inward.

Irregular. Showing inequality in size and form of similar parts.

Keeled. Centrally ridged along the back.

Leaflet. A single division of a compound leaf.

Lemma. The lower of the two bracts inclosing the flower in the grasses.

Ligule. The thin projection at the top of the sheath in grasses; the ray flowers in Composites.

Linear. Long and narrow with sides nearly parallel.

Lobe. Any segment of an organ, especially if rounded.

Lyrate. Pinnatifid, with the terminal lobe much larger than the others.

Membranous. Thin, rather soft and more or less translucent.

Moncecious. Bearing stamens and pistils in different flowers but on the same plant.

Naturalized. Not native to the region of growth.

Nectary. An organ or cavity where nectar is secreted.

Nerve. An unbranched vein or a slender rib. 
Neutral. Without stamens or pistils.

Node. The part of a stem or branch at which a leaf or leaves are borne.

Oblong. Longer than broad with sides nearly parallel.

Obovate. Inversely ovate.

Obovoid. Inversely ovoid.

Obtuse. Blunt or rounded at apex.

Ovary. The part of a pistil which contains the seeds.

Ovate. Having an egg-shaped outline with the broader end at the base.

Ovoid. Egg-shaped.

Ovule. The body which after fertilization becomes the seed.

Palea. The upper of the two bracts which inclose the flower in grasses.

Palmate (leaf). With segments radiately diverging.

Panicle. A somewhat loose and irregular compound flower cluster.

Pappus. In Composita the bristles, awns, teeth, or scales which erown the achene.

Parasite. A plant which grows upon other plants and absorbs their juices.

Pedicel. The support of one of the flowers composing a flower eluster. Peduncle. The stalk of a flower cluster or of a single flower.

Perennial. Lasting year after year.

Perfect (flower). Having both stamens and pistils.

Perfoliate. A leaf so clasping the stem as to seem pierced by it.

Perianth. The floral envelope, sepals and petals, regarded collectively.

Persistent. Said of organs which remain attached to their place of growth after growth has ceased.

Petal. One of the divisions of the inner floral envelope or corolla.

Petiole. The footstalk of a leaf.

Pinnate (leaf). Compound, with leaflets arranged along the sides of a common petiole.

Pinnatifid. Pinnately cleft.

Pistil. The seed-bearing organ of a flower, consisting of ovary, stigma, and style, or the latter sometimes lacking.

Pistillate. Having pistils; ordinarily used in the sense of having no stamens.

Pod. Any dry and dehiscent fruit.

Pollen. The fertilizing grains borne in the anthers.

Prickle. A sharp outgrowth from the bark of a stem, or on the surface or stalk of a leaf.

Procumbent. Lying or trailing on the ground but without rooting at the nodes.

Prostrate. Lying flat on the ground. 
Pubescent. Covered with short, soft, and down-like hairs.

Raceme. An elongated simple flower cluster with each flower pedicelled.

Rachis. The axis of a spike or a raceme, or of a compound leaf.

Ray. One of the flower stalks of an umbel; the strap-shaped marginal flowers in the Compositce.

Receptacle. The more or less expanded end of the stem which bears the organs of a flower, or, in the Composit $\alpha$, the collection of flowers in a head.

Recurved. Curved downward or backward.

Reflexed. Bent abruptly downward or backward.

Regular. Having the members of each part alike in form and size.

Revolute. Rolled backward from the margin or apex.

Rib. A primary or prominent vein in a leaf.

Rootstock. An underground, bud-bearing stem.

Scape. A naked or nearly leafless flower-stalk arising directly from the erown of the root.

Scarious. Thin, dry, and membranous, not green.

Segment. One of the divisions of a lobed or cleft leaf, or other organ of a plant.

Sepal. One of the divisions of a calyx.

Serrate. With sharp, forward-pointing teeth.

Sessile. Without a footstalk of any kind.

Sheath. A tubular envelope, as the lower part of the leaf in grasses. Silicle. A short silique.

Silique. The pod peculiar to the Cruciferc.

Simple. Not compound.

Sinuate. Wavy-edged.

Sinus. The eleft or space between two lobes.

Spadix. A flower spike having a fleshy axis.

Spathe. A large bract or a pair of bracts inclosing a spadix or a flower cluster.

Spatulate. Narrowing gradually toward the base from a rounded apex. Spike. An elongated flower cluster with flowers sessile or nearly so upon its axis.

Spine. A sharp and rigid outgrowth from the stem of a plant.

Spur. A tubular or sac-like extension of some part of a flower, usually nectar-bearing.

Stamen. One of the pollen-bearing organs of a flower.

Stem. The main ascending axis of a plant.

Sterile. Unproductive, as a flower without a pistil, or a stamen without an anther. 
Stigma. That part of the pistil through which pollen grains penetrate and effect fertilization.

Stipe. The stalk-like support of a pistil ; the leafstalk of a fern.

Stipule. An appendage at the base of a leafstalk or on each side of its insertion.

Stolon. A runner, or any basal branch which takes root at the nodes. Striate. Marked with lengthwise lines or ridges.

Style. The (usually) slender and elongated part of a pistil connecting the ovary and stigma.

Succulent. Juicy and fleshy.

Suture. The line of splitting or opening of a dehiscent fruit.

Ternate. Arranged in threes.

Tendril. Very slender, coiling organs by which some climbing plants cling to a support.

Tomentose. Densely covered with wool-like hairs.

Truncate. Ending abruptly as if cut off squarely.

Tuber. A short, thickened, underground branch having numerous buds or " eyes."

Umbel. A flower cluster having all the pedicels arising from the same point.

Unisexual. Bearing staminate and pistillate flowers on different. plants.

Utricle. The bladder-like covering of a one-seeded fruit.

Valve. One of the divisions into which a capsule splits.

Vein. Branching threads of fibrous tissue in leaves and other organs.

Viscid. Glutinous or sticky.

Whorl. Arranged in a circle around a stem. 


\section{INDEX}

Names of families and species in Italics; common names in Roman type.

Aaron's Rod, 202

Absinth, 498

Abutilon Avicenna, 276

Theophrasti, 276

Acalypha virginica, 262

Achillea Millefolium, 486

Ptarmica, 487

Acnida tuberculata, 125

Actinomeris alternifolia, 468

Adopogon carolinianum, 527

virginianum, 527

Ethusa Cynapium, 303

Agrimonia gryposepala, 212

hirsuta, 212

mollis, 213

parviflora, 214

Agrimony, Small-flowered, 214

Soft, 213

Tall Hairy, 212

Agropyron repens, 61

Agrostemma Githago, 142

Ajuga reptans, 346

Ale-cost, 494

Ale-hoof, 351

Alfilaria, 258

Alkanet, Bastard, 339

Allelulia, 224

Alliaria officinalis, 190

Allionia hirsuta, 130

linearis, 131

nyctaginea, 129

Allium canadense, 83

vineale, 80

Alopecurus geniculatus, 45

Alsine graminea, 138 media, 139

Alyssum, Hoary, 173

Amaranth, Low, 123

Hairy, 124

Amaranthus albus, 122

blitoides, 123

gracizans, 122
A maranthus retroflexus, 120 spinosus, 124

Ambrosia, 108

Tall, 454

Ambrosia artemisiifolia, 455 psilostachya, 457

trifida, 454

Ampelanus albidus, 319

Amsinckia intermedia, 336

Anagallis arvensis, 311

Andromeda, Maryland, 310

Andropogon halepensis, 22 virginicus, 21

Anemone, Tall, 160

Anemone virginiana, 160

Anemopsis californica, 85

Angle-pod, 319

Antennaria dioica, 443

neglecta, 443

plantaginifolia, 441

Anthemis arvensis, 489 cotula, 488

tinctoria, 490

Antimony, Vegetable, 417

Anychia polygonoides, 134

A pocynum androscemifolium, 312 cannabinum, 314

Apple, Earth, 467

Mad, 375

Mock, 406

of Peru, 372

of Sodom, 365

Wild Balsam, 406

Aragallus spicatus, 241

Arctium Lappa, 508

minus, 510

Arenaria serpyllifolia, 137

Argemone mexicana, 172

Aristida, Few-flowered, 42

Aristida dichotoma, 41

fasciculata, 42

oligantha, 42 
Arnica, 530

Arnoseris minima, 524

Artemisia Absinthium, 498 annua, 497

biennis, 497

frigida, 499

tridentata, 500

vulgaris, 496

Artichoke, Jerusalem, 467

Asclepias incarnata, 316

speciosa, 317

syriaca, 317

tuberosa, 315

Asses' Ears, 337

Aster, Bushy, 428

Early Purple, 435

Hairy Golden, 423

Heart-leaved, 431

Many-flowered, 433

Maryland Golden, 422

New England, 430

Purple-stemmed, 435

Smooth, 431

Tradescant's, 434

White Heath, 432

White Wreath, 433

Willow-leaved, 435

Woody, 429

Aster cordifolius, 432

ericoides, 432

levis, 431

multiflorus, 433

nove-anglia, 430

puniceus, 435

salicifolius, 435

Tradescanti, 434

Astragalus mollisimus, 239

Atriplex patula, 114

Avena fatua, 48

Avens, White, 210

Axyris amarantoides, 119

Bachelor's Button, 520

Backwort, 337

Ballogan, 523

Balm, Field, 351

Stinking, 358

Balsam, Old Field, 443

Sweet White, 443

Balsam-flowers, 234

Balsam Posy, 443

Balsamweed, Clammy, 444
Bamboo, Prickly, 83

Barbarea pracox, 197 verna, 197 vulgaris, 196

Barberry, Common, 168

Barley, Little, 65

Wall, 66

Wild, 64

Basil, Field, 359

Stone, 359

Wild, 359

Baughlan, 506

Bean, Blue, 228

Pink, 254

Small Wild, 254

Trailing Wild, 253

Beard-tongue, Fox-glove, 381

Bedstraw, Rough, 398

Beggar's Buttons, 508

Beggar's Lice, 334

Beggar-tick, Big, 474

Swamp, 475

Beggar-ticks, 334, 473

Behen, 148

Bell-bind, 321

Bell-flower, Clasping, 408

Creeping, 409

Tall, 410

Berberis vulgaris, 168

Berry, Pigeon, 128

Poison, 364

Stubble, 364

Berteroa, Gray, 173

Berteroa incana, 173

Bidens aristosa, 478

bipinnata, 477

cernua, 476

comosa, 475

connata, 475

frondosa, 473

laevis, 476

trichosperma, 478

vulgata, 474

Bindweed, Black, 104

Blue, 363

Bracted, 323

European, 321

Field, 321

Great, 323

Hedge, 105, 323

Knot, 104

Birds as weed destroyers, 10 
Birdseed, 504

Blackberry, Running, 211

Black-brush, 207

Black-eyed Susan, 462

Black Sampson, 463

Bladder Ketmia, 282

Bladder-pod, 411

Blanket-flower, 484

Blanket-leaf, 377

Blite, Strawberry, 110 Mulberry, 110

Blood-leaf, 126

Blood-stanch, 439

Bloodwort, 486 Mouse, 554

Bloom-fell, 237

Blowball, 535

Blue Bonnets, 520

Bluebottle, 520

Blue Curls, 348

Blue Sailors, 525

Blue-top, 367

Bebera papposa, 485

Bahmeria cylindrica, 90

Bœrhaavia erecta, 132

Boltonia asteroides, 428

Boneset, 417

Deerwort, 418

False, 419

Purple, 416

Bouncing Bet, 149

Bracken, 17

Brake, Common, 17

Meadow, 18

Polypod, 18

Turkey-foot, 17

Bramble, Prairie, 216

Trailing, 211

Brassica alba, 186

arvensis, 184

juncea, 185

nigra, 187

sinapistrum, 184

Brauneria purpurea, 463

Brier, Chain, 83

Sand, 365

Saw, 83

Sweet, 214

Bromus hordeaceus, 57 secalinus, 55

tectorum, 58

Broom, Base, 224
Broom, - Continued

Dyer's, 224

Broom-rape, Branched, 387

Clover, 389

Hemp, 387

Lesser, 389

Louisiana, 390

Tobacco, 387

Bruisewort, 337

Buckhorn, 392

Bristly, 394

Gray, 394

Buck's-beard, 532

Buckwheat, Climbing False, 105

Hedge, 105

Wild, 104

Bugbane, 78

Bugle, Brown, 346

Bugleweed, Creeping, 346

Buglewort, 360

Bugloss, Bitter, 531

Small, 338

Viper's, 342

Bugseed, 116

Bulrush, Dark-green, 73

Bunch-flower, Common, 77

Bunk, 535

Bur, Bathurst, 460

Blue, 334

Buffalo, 368

Button, 461

Cockspur, 34

Colorado, 368

Ditch, 461

Dog, 332

Paroquet, 297

Sand, 368

Sheep, 334, 461

Burdock, Common, 510

Great, 508

Prairie, 448

Burseed, 334

Burweed, Hedgehog, 461

Thorny, 460

Yellow, 336

Butter and Eggs, 379

Buttercup, Abortive, 155

Bog, 154

Bulbous, 157

Creeping, 156

Early, 156

Meadow, 159 
Buttercup, - Continued

Tuftod, 156

Butterprint, 276

Buttons, Bitter, 495

Cockle, 508

Spanish, 521

Buttonweed, Rough, 400

Smooth, 399

Cabbage, Hare'sear, 189

Cactus, Ball, 290

Bird's-nest, 291

Globe, 290

Missouri, 291

Nipple, 291

Purple, 290

Russian, 117

Calabazilla, 404

Calamint, 359

Calfkill, 308, 310

Caltrops, 517

Land, 259

Camas, Death, 76

Poison, 76

Camelina microcarpa, 182 sativa, 181

Campanula americana, 410 rapunculoides, 409

Campion, Bladder, 148

Corn, 142

Meadow, 143

Red, 144

White, 145

Cancer Jalap, 128

Candlewick, 377

Cankerwort, 535

Cannabis sativa, 86

Capriola Dactylon, 51

Capsella Bursa-pastoris, 180

Cardamine bulbosa, 197

Carduus altissimus, 512 arvensis, 514

lanceolatus, $\mathbf{5 1 0}$

ochrocentrus, 513

odoratus, 512

Carpetweed, 135

Carrot, Wild, 307

Caseweed, 180

Cassia Chamaerista, 221 marilandica, 218 occidentalis, 220

Catchfly, Forked, 147
Catchfly, - Continued

Hairy, 147

Night-flowering, 147

Sleepy, 146

Catchweed, 397

Cat Fitch, 247

Catgut, 238

Catmint, 350

Catnip, 350

Cat's-ar, Long-rooted, 528

Cat's-foot, 351

Field, 443

Cat's Milk, 272

Celandine, Great, 169

Cenchrus tribuloides, 34

Centaurea benedicta, 522

Calcitrapa, 517

Cyanus, 520

Jacea, 521

melitensis, 519

nigra, 521

solstitialis, 518

Centaury, Black, 521

Brown, 521

Cerastium arvense, 140

vulgatum, 141

Chafeweed, 443

Chamanerion angustifolium, 294

Chamomile, Corn, 489

Fetid, 488

Field, 489

German, 492

Rayless, 492

Scentless, 491

Wild, 492

Yellow, 490

Charlock, 184

Jointed, 183

White, 183

Cheat, 55

Cheeses, 280

Chelidonium majus, 169

Chenopodium album, 112

ambrosioides, 108

Botrys, 110

capitatum, 110

olaucum, 110

hybridum, 112

murale, 114

Cherry, Bladder, 370

Choke, 218

Wild Black, 217 
Chess, 55

Early, 58

Slender, 58

Soft, 57

Chickweed, Common, 139

Common Mouse-ear, 141

Field Mouse-ear, 140

Forked, 134

Germander, 387

Indian, 135

Poison, 311

Red, 311

Whorled, 135

Chicory, 525

Children's Bane, 301

Chinaman's Greens, 120

Chondrilla juncea, 534

Chrysanthemum Balsamita, 494

Leucanthemum, 493

Chrysopsis mariana, 422

villosa, 423

Chufa, 70

Cichorium Intybus, 525

Cicuta maculata, 300

Cinquefoil, Common, 209

Norway, 205

Shrubby, 207

Silvery, 206

Circium altissimum, 512

arvense, 514

lanceolatum, 510

ochrocentrum, 513

pumilum, 512

Clayweed, 501

Cleavers, 397

Cleome, Pink, 199

Cleome serrulata, 199

Climath, 274

Cling Rascal, 397

Clinopodium vulgare, 359

Clotbur, 461

Clover, Black-seeded Hop, 234

Bokhara, 232

Bur, 235

Bush, 245

Cabul, 232

Cat's, 237

Clammy, 198

Devil, 387

Hare-foot, 229

Hart's, 234

Hop, 231
Clover, - Continued

King's, 234

Old Field, 229

Pin, 258

Pussy, 229

Rabbit-foot, 229

Spiny, 460

Stinking, 198, 199

Stone, 229

Tree, 232

Clown's Heal, 357

Cnicus benedictus, 522

Cocash, 435

Cockle, China, 151

Clammy, 147

Corn, 142

Cow, 151

Pink, 151

Purple, 142

Spring, 151

Sticky, 147

White, 145

Cocklebur, 461

Dagger, 460

Spiny, 460

Coffee, Magdad, 220

Negro, 220

Wild, 401

Colewort, 538

Coltsfoot, 501

Sweet, 502

Comfrey, 337

Cone-flower, Long-headed, 464

Prairie, 464

Purple, 463

Conium maculatum, 300

Conringia orientalis, 189

Convolvulus arvensis, 321 sepium, 323

Copper-leaf, 262

Coreopsis lanceolata, 471 tripteris, 472

Corispermum hyssopifolium, 116 nitidum, 116

Corn Flower, 520

Corn Salad, 402

Coronopus didymus, 179

Costmary, 494

Coughwort, 501

Cowbane, Spotted, 300, 301

Cow-bell, 148

Cow-bind, 321 
Cow-cress, 178

Cow-herb, 151

Cow-poison, 164

Cowthwort, 356

Cracca virginiana, 238

Crane's-bill, Small-flowered, 257

Creeping Jack, 200

Crepis biennis, 550

capillaris, 549

virens, 549

Cress, Bastard, 174

Bitter, 197

Bulbous, 197

Carpet, 179

Field, 178

Lesser Wart, 179

Penny, 174

Rocket, 196

St. Barbara's, 196

Spring, 197

Swine, 179

Winter, 196

Crosswort, 417

Crotalaria sagittalis, 222

Croton capitatus, 261

Crowfoot, Celery-leaved, 154

Cursed, 154

Ditch, 154

Early, 156

Small-flowered, 155

Tall, 159

Crownbeard, Golden, 470

Sunflower, 469

Crown-of-the-Field, 142

Crowtoes, 237

Cucumber, One-seeded Bur, 405

Climbing Wild, 406

Four-seeded Bur, 406

Star, 405

Cucurbita fatidissima, 404 perennis, 404

Cudweed, Clammy, 444

Childing, 441

Low, 445

Marsh, 445

Winged, 444

Cuphea, Clammy, 291

Cuphea petiolata, 291

Cuscuta arvensis, 328

Epilinum, 327

Epithymum, 324

Gronovii, 328
Cycloloma atriplicifolium, 106

Cynanchum nigrum, 319

Cynodon Dactylon, 51

Cynoglossum officinale, 332

Cynthia, 527

Cyperus, Baldwin's, 72

Hydra, 68

Straw-colored, 71

Cyperus diandrus, 67

echinatus, 72

esculentus, 70

rotundus, 68

strigosus, 71

Daisy, Blue Spring, 436

Cone-headed, 464

Michaelmas, 434

Midsummer, 493

Ox-eye, 462, 493

Red, 554

Stinking, 458

White, 493

Yellow, 462

Dandelion, 535

Dwarf, 527

Fall, 530

False, 548

Red-seeded, 537

Danthonia spicata, 50

Darkey-heads, 462

Darnel, Bearded, 60

Common, 59

Poison, 60

White, 60

Datura Metel, 376

Stramonium, 375

Tatula, 376

Daucus carota, 307

Death-of-Man, 301

Delphinium azureum, 163

bicolor, 165

carolinianum, 163

Consolida, 161

glaucum, 164

Menziesii, 166

trollifolium, 162, 167

Desmodium canadense, 244 canescens, 243

Devil, Blue, 342

King, 557

Yellow, 556

Devil's Apple, 375 
Devil's Bootjack, 473

Devil's Fig, 172

Devil's Grandmother, 415

Devil's Grass, 61

Devil's Gut, 324

Devil's Hair, 324

Devil's Ironweed, 543

Devil's Milk, 169

Devil's Paintbrush, 554

Devil's Plague, 307

Devil's Shoe-strings, 238

Devil's Trumpet, 375

Devil's Vine, 323

Devil's Weed, 554

Dewberry, 211

Dewtry, 375

Digitalis purpurea, 382

Digitaria humifusa, 27 sanguinalis, 26

Dillweed, 488

Diodia teres, 400

Diplotaxis muralis, 188

Dipsacus sylvestris, 403

Dock, Bitter, 94

Broad-leaved, 94

Butter, 502

Butterfly, 502

Curled, 91

Dove, 501

Elf, 446

Flea, 502

Narrow-leaved, 91

Patience, 90

Prairie, 448

Round, 280

Sour, 94

Succory, 523

Velvet, 377, 446

Willow-leaved, 93

Yellow, 91

Dodder, Clover, 324

Common, 328

Field, 328

Flax, 327

Onion, 328

Wild, 328

Dogbane, Spreading, 312

Dog Fennel, 488

Yellow, 485

Dog Finkle, 488

Dog's Tongue, 332

Doon-head-clock, 535
Drop-flower, 553

Drop-seed, Indian, 47

Mexican, 43

Duck-retter, 78

Duckweed, 152

Duscle, 364

Dyssodia papposa, 485

Earth-gall, 78

Echinochloa crus-galli, 30

Echinocystis lobata, 406

Echinospermum Lappula, 334

Echium vulgare, 342

Elecampane, 446

Elephantopus tomentosus, 415

Elephant's Foot, Woolly, 415

Eleusine indica, 53

Ellisia Nyctelea, 330

Enslenia albida, 319

Epilobium angustifolium, 294

Equisetum arvense, 20

Eragrostis major, 54

megastachya, 54

pilosa, 54

Erechtites hieracifolia, 503

Erigeron annuus, 438

canadensis, 439

philadelphicus, 437

pulchellus, 436

ramosus, 439

Erodium cicutarium, 258 moschatum, 258

Erysimum cheiranthoides, 195

Eupatorium ageratoides, 418 colestinum, 419

perfoliatum, 417

purpureum, 416

urticafolium, 418

Euphorbia corollata, 268

Cyparissias, 272

dentata, 269

Esula, 271

Helioscopia, 272

heterophylla, 270

hirsuta, 265

maculata, 266

marginata, 267

nutans, 264

Preslii, 264

serpyllifolia, 263

Euthamia graminifolia, 426

Evening Primrose, 295 
Everlasting, Clammy, 444

Common, 443

Early, 441

Fragrant, 443

Many-headed, 443

Mouse-ear, 441

Plantain-leaved, 441

Spring, 441

'Sweet, 443

Eye-bright, 264

Farewell Summer, 434

Fat Hen, 112

Felonwort, 169, 363

Feltwort, 377

Fern, Fagle, 17

Parsley, 495

Sensitive, 18

Upland, 17

Feverwort, 401, 417

Figwort, Maryland, 380

Filaree, 258

Fireball, 107

Fireweed, 294, 336, 503

Five-finger, Common, 209

Tall, 205

Flat-top, 412

Flax, False, 181

Wild, 181

Fleabane, Canada, 439

Daisy, 438

Lowground, 437

Philadelphia, 437

Flicker-tail, 64

Flower, August, 530

Blister, 159

Butter, 159

Chester, 207

Cuckoo, 143

Fall, 433

Joseph's, 533

Mist, 419

Flower-of-an-Hour, 282

Flower, Poorland, 493

Snake, 342

Fluellin, 383

Foalfoot, 501

Fool's Cicely, 303

Fool's Parsley, 303

Forget-me-not, Bur, 334

Yellow, 336

Four o'clock, Wild, 129
Foxglove, Purple, 362

Foxtail, Bent, 45

Bristly, 33

Green, 33

Marsh, 45

Water, 45

Yellow, 31

Franseria discolor, 458 tomentosa, 459

Franseria, White-leaved, 458

Woolly, 459

Frœlichia floridana, 127

Gaertheria discolor, 458 tomentosa, 459

Gaillardia aristata, 484

Galeopsis Tetrahit, 354

Galingale, Low, 67

Yellow, 70

Galinsoga parviflora, 480

Galium A parine, 397 asprellum, 398

Gall-of-the-Earth, 553

Garget, 128

Garlic, Crow, 80 Field, 80

Hedge, 190

Meadow, 83

Wild, 80, 174

Gaura, Biennial, 297

Gaura biennis, 297 villosa, 298

Gaura, Woolly, 298

Genista tinctoria, 224

Gentian, Horse, 401 Snake, 553

Geranium, Feather, 110 Mint, 494

Geranium pusillum, 257

Geranium, Turnpike, 110

Germander, American, 347

Geum album, 210 canadense, 210

Gifola germanica, 441

Gilia squarrosa, 329

Gilia, Sticky, 329

Gill-ale, 351

Gill-over-the-ground, 351

Gipsy Combs, 403

Girasole, 467

Glycyrrhiza lepidota, 242

Gnaphalium decurrens, 444 
Gnaphalium obtusifolium, 443 polycephalum, 443 uliginosum, 445

Goat's-beard, Purple, 533

Virginia, 527

Yellow, 532

Goat's Rue, 238

Goldcup, 159

Golden Jerusalem, 462

Golden Moss, 200

Goldenrod, Bushy, 426

Canada, 425

Field, 423

Fragrant, 426

Gray, 423

Hard-leaved, 426

Hoary, 424

Low, 423

Narrow-leaved, 426

Soft, 424

Stiff, 426

Tall, 425

Gold of Pleasure, 181

Gonolobus lovis, 319

Good-night-at-noon, 282

Gooseberry, Dwarf Cape, 370

Goosefoot, Maple-leaved, 112

Nettle-leaved, 114

Oak-leaved, 110

White, 112

Gosmore, 528

Go-to-bed-at-noon, 532

Gourd, Missouri, 404

Wild, 404

Gowan, Horse, 492

Ling, 554

Witch's, 535

Yellow, 535

Grass, Aleppo, 22

Annual Ray, 60

Auger-seed, 39

Barley, 66

Barnyard, 30

Bear, 34

Bermuda, 51

Bonnet, 50

Bottle, 33

Bur, 34

Canary, 37

Candy, 54

Cockspur, 30

Coco, 68
Grass, - Continued

Couch, 61

Crab, 26, 53

Crow-foot, 53

Dog, 61

Dog's-tooth, 51

Downy Brome, 58

Drop-seed, 44

Egyptian, 22

Faitour's, 271

False Guinea, 22

Finger, 26

German Knot, 133

Goose, 53, 208, 397

Grip, 397

Hairy Spear, 54

Hedgehog, 34

Holy, 37

Indian Rush, 47

Johnson, 22

Knot, 97

Knot-root, 43

Mat, 97

Means, 22

Milk, 402

Mystery, 76

Needle, 34, 40, 42

Nut, 68

Old Witch, 28

Perennial Rye, 57

Pigeon, 31

Pin, 258

Pine, 20

Poison Rye, 60

Porcupine, 39

Poverty, 41, 50

Pungent Meadow, 54

Pussy, 31

Quack, 61

Quack Salver's,272

Quitch, 61

Ray, 59

Rib, 392

Rice Cut, 35

Ripple, 392

Sand, 42

Scratch, 397

Scurvy, 197

Scutch, 51, 61

Sedge, 21

Seneca, 37

Sheathed Rush, 46 


\section{Grass, - Continued}

Slender Meadow, 54

Small Crab, 27

Small Rush, 47

Smut, 47

Snake, 20, 54

Sour, 95, 255

Sprouting Panic, 29

Stink, 54

Summer, 31

Sweet, 37

Switch, 30

Syrian, 22

Tickle, 28, 64

Tine, 247

Tongue, 176

Tufted Spear, 54

Tumbleweed, 28

Twitch, 61

Vanilla, 37

Virginia Beard, 21

Wart, 272

Weather, 39

Wheat, 61

Wildcat, 50

Wild Oat, 50

Willard's Brome, 55

Wire, 44, 50, 53, 74

Wood, 43

Yard, 53

Yellow Nut, 70

Graymile, 340

Grim-the-Collier, 554

Grindelia lanceolata, 421 squarrosa, 420

Grinsel,'504

Gromwell, Common, 340

Corn, 339

Field, 339

Gray, 341

Ground Bur-nut, 259

Ground-cherry, Low Hairy, 370

Mexican, 369

Prairie, 371

Virginia, 371

Ground-hele, 383

Groundsel, Common, 504

Cress-leaved, 505

Grundy Swallow, 507

Gumbo, 283

Gum-plant, Broad-leaved, 420

Narrow-leaved, 421
Gum-weed, 420

Gut-weed, 537

Hardhack, 204

Yellow, 207

Hardheads, 521

Hardock, 508

Harvest Lice, 475

Hawkbit, Autumn, 530

Hawksbeard, Narrow-leaved, 550

Rough, 550

Smooth, 549

Hawkweed, Field, 556

Hairy, 557

Mouse-ear, 554

Orange, 554

Heal-all, 352, 380

Heart-of-the-Earth, 352

Heartweed, 102

Hedeoma pulegioides, 358

Hedge-burs, 397

Hedge Taper, 377

Helenium autumnale, 481 nudiflorum, 482

tenufolium, 483

Helianthus annuus, 465 scaberrimus, 466

tuberosus, 467

Heliotrope, Indian, 331

Heliotropium indicum, 331

Hellbind, 324

Hellebore, American, 78

False, 78

Green, 78

Swamp, 78

Hellroot, 389

Hemlock, Deadly, 300

Poison, 300

Water, 301

Hemp, 86

American, 314

Bastard, 354

Black Indian, 315

Water, 125

Wild, 354,454

Henbane, Black, 373

Henbit, 355

Heracleum lanatum, 306

Herb, Balsam, 494

Barbara's, 196

Carpenter's, 346, 352

Felon, 496, 554 
Herb, - Continued

Fuller's, 149

Healing, 337

Holy, 343

Sherard, 396

Viper's, 342

Herba Impia, 441

Herb-bane, 389

Herb-of-St. Bennet, 300

Herb-of-St. John, 284

Herb-of-the-Cross, 343

Heron's-bill, 258

Herrick, 184

Hibiscus esculentus, 283

Trionum, 282

Hieracium aurantiacum, 554

florentinum, 558

floribundum, 558

Gronovii, 557

Pilosella, 554

pratense, 557

Hierochloa odorata, 37

Highwater Shrub, 451

Hoarwort, 441

Hock-heal, 352

Hog's Bean, 373

Hogweed, 132

Hogwort, 261

Honeybloom, 312

Honeylotus, 232

Honeysuckle, Ground, 237

Hordeum jubatum, 64

murinam, 66

pusillum, 65

Horehound, 349

Ditch, 360

Virginia, 360

Water, 360

Horse Cane, 454

Horse Elder, 446

Horse Gowan, 492

Horse Nettle, 365

Horse Sorrel, 95

Horse Thyme, 359

Horse-heal, 446

Horse-hoof, 501

Horse-knobs, 521

Horsetail, Field, 20

Horseweed, 439, 454, 543

Houndsbene, 349

Hound's Berry, 364

Hound's Tongue, 332
Hurr-bur, 508

Hurtsickle, 520

Hyoscyamus niger, 373

Hypericum mutilum, 285

perforatum, 284

prolificum, 285

Hypocharis radicata, 528

Hyssop, Wild, 344

Impudent Lawyer, 379

Indian cup, 449

Indian Eleusine, 53

Indian Fig, 288

Indian Physic, 314

Indian Poke, 78

Ink Berry, 128

Inula Helenium, 446

Ipecac, Milk, 312

Wild, 401

Ipomae pandurata, 320

Iresine paniculata, 126

Ironweed, Illinois, 414

Tall, 412

Western, 413

Winged, 468

Yellow, 468

Isnardia palustris, 293

Itchweed, 78

Iva axillaris, 453

ciliata, 450

xanthifolia, 451

Ivray, 60

Ivy, Ground, 351

Poison, 274

Three-leaved, 274

Jack-by-the-hedge, 190

Jacob's Staff, 377

Jatropha stimulosa, 260

Jerusalem, Golden, 462

Jerusalem Oak, 110

Jerusalem Star, 533

Joe-Pye Weed, 416

Juba's Bush, 126

Juncus effusus, 75

tenuis, 74

Jute, American, 276

Kale, Field, 184

Kalmia angustifolia, 308

Kedluck, 184

Kill-wart, 169 
Kingcup, 159

King Devil, 556

Kinghead, 454

Klinkweed, 189

Knapweed, Black, 521

Brown, 521

Rayed, 521

Knawel, 133

Kneiffia fruticosa, 296

Knight's Spur, 161

Knit-back, 337

Knotgrass, German, 133

Knotweed, 98

Biting, 101

Bushy, 98

Erect, 98

Prostrate, 97

Spotted, 102

Kochia scoparia, 107

Krigia amplexicaulus, 527 virginica, 527

Kuhnia eupatorioides, 419

Lactuca canadensis, 542 pulchellus, 544 sagittifolia, 543

scariola, 540

spicata, 546

villosa, 545

Lady-by-the-gate, 149

Lady-fingers, 382

Lady's Thumb, 102

Lambkill, 308

Lamb's Lettuce, 402

Lamb's Quarters, 112

Lamium amplexicaule, 355

Lappula echinata, 334

floribunda, 335

virginica, 334

Lapsana communis, 523

Larkheel, 161

Larkspur, Azure-flowered, 163

Carolina, 163

Dwarf, 162

Field, 161

Large, 164

Purple, 165

Sky-blue, 163

Small, 166

Smooth, 164

Tall Mountain, 164

Western, 167
Lathyrus latifolius, 250

pratensis, 252

tuberosus, 250

Laurel, Dwarf, 308

Narrow-leaved, 308

Sheep, 308

Leersia oryzoides, 35

Legouzia perfoliata, 408

Leontodon autumnalis, 530

Leonurus Cardiaca, 356

Lepachys columnaris, 464

Lepidium apetalum, 178 campestre, 178

virginicum, 176

Lespedeza violacia, 245

Lettuce, Arrow-leaved, 543

Blue, 544

'Hairy-veined, 545

Hare's, 538

Prickly, 540

Rough White, 552

Showy, 544

Smooth White, 551

Tall Blue, 546

Wild, 542

Lily, Hedge, 323

Jamestown, 375

Linaria vulgaris, 379

Lion's-ear, 356

Lion's-foot, 553

Lion's-tail, 356

Lion's-tooth, 530

Liquorice, Wild, 242

Lithospermum arvense, 339 canescens, 341

officinale, 340

Littlegood, 272

Littlewale, 340

Live-forever, 201, 202

Live-long, 202

Lobelia, Great, 410

Lobelia inflata, 411 syphilitica, 410

Loco, Purple, 239

Stemless, 241

Stemmed, 239

Texas, 239

Loco-vetch, Colorado, 241

Loco-weed, White, 241

Woolly, 239

Loggerheads, 521

Lolium perenne, 59 
Lolium temulentum, 60

London Pride, 149

Loosestrife, Clammy, 291 False, 293

Lotus corniculatus, 237

Ludvigia alternifolia, 292 palustris, 293

Lupine, Low, 229

Nebraska, 226

Silvery, 228

Wild, 225

Lupinus argenteus, 228 perennis, 225

plattensis, 226 pusillus, 229

Lychnis alba, 145 dioica, 144

Lychnis, Evening, 145

Lychnis Flos-cuculi, 143 Githago, 142 vespertina, 145

Lycopsis arvensis, 388

Lycopus virginicus, 360

Lygodesmia juncea, 546

Lygodesmia, Rush-like, 546

Lyonia mariana, 310

Macrocalyx Nyctelea, 330

Madder, Blue Field, 396

Madia sativa, 479

Madnep, 305

Mallow, Common, 280

Dwarf, 280

Indian, 276

Musk, 281

Red False, 277

Running, 280

Thistle, 278

Venice, 282

Malva moschata, 281 rotundifolia, 280

Malvastrum coccineum, 277

Mamillaria missouriensis, 291 vivipara, 290

Man-of-the-Earth, 320

Mare's-tail, 439

Marigold, Bưr, 473

Fetid, $485^{\circ}$

Nodding Bur, 476

Markweed, 274

Marrube, 349

Marrubium vulgare, 349
Marsh Elder, Burweed, 451

Rough, 450

Small-flowered, 453

Marvel, 349

Masterwort, 306

Matricaria Chamomilla, 492 inodora, 491

Matricaria matricarioides, 492 suaveolens, 492

Matweed, Spotted, 266

Maul, 280

May-pop, 287

Mayweed, 488

Corn, 491

False, 485

Yellow, 485

Meadow Queen, 203

Meadow-sweet, 203

Willow-leaved, 204

Woolly, 204

Mecha-Meck, 320

Medicago denticulata, 235

hispida, 235

lupulina, 234

Medick, Black, 234

Hop, 234

Toothed, 235

Winter, 235

Meibomia canadensis, 244 canescens, 243

Melanthium virginicum, $\mathbf{7 7}$

Melilot, White, 232

Yellow, 234

Melilotus alba, 232

officinalis, 234

Mentha piperita, 361 spicata, 362

Mercury, Black, 274

Scotch, 382

Three-seeded, 262

Micrampelis lobata, 406

Milfoil, 486

Milk, Mouse, 272

Wolf's, 272

Milkweed, Climbing, 319

Common, 317

Orange, 315

Poison, 268

Showy, 317

Swamp, 316

Trumpet, 542 
Milkweed, - Continued

Wandering, 312

White-flowered, 268

Milk Witch, 535

Millet, Arabian, 22

Evergreen, 22

Morocco, 22

Polish, 26

Wild, 31

Mint, Brandy, 361

Garden, 362

Lamb, 361, 362

Mackerel, 362

Our Lady's, 362

Pepper, 361

Spear, 362

Squaw, 358

Mollugo verticillata, 135

Moon-penny, 493

Morning Glory, Small-flowered, 321

Morning Sun, 532

Moss, Golden, 200

Mother's Hearts, 180

Motherwort, 356

Mouse-ear, 445

Mugwort, Common, 496

Muhlenbergia diffusa, 44

mexicana, 43

Schreberi, 44

Mullein, Common, 377

Moth, 378

Mustard, Ball, 182

Black, 187

Garlic, 190

Gray Tansy, 194

Green Tansy, 194

Hare's-ear, 189

Hedge, 191

Indian, 185

Mithridate, 178

Stinking, 174

Treacle, 195

Tumbling, 192

White, 186

Wild, 184

Wormseed, 195

Myzorrhiza ludoviciana, 390

Nabalus asper, 552

racemosus, 551

serpentarius, 553

Nap-at-noon, 532
Navarretia squarrosa, 329

Neckweed, 385

Needle-and-thread, 40

Needles, Spanish, 477

Nepeta cataria, 250

hederacea, 251

Neslia paniculata, 182

Nettle, Bee, 354, 355

Blind, 355

Bull, 260, 365

Dead, 355, 357

Dog, 354

False, 90

Great, 88

Hedge, 357

Horse, 365

Slender, 87

Spurge, 260

Stinging, 88, 354

Western, 89

White Horse, 367

Nicandra Physalodes, 373

Niggerhead, 462

Nightshade, Beaked, 368

Bitter-sweet, 363

Black, 364

Common, 364

Deadly, 364

Fetid, 373

Prickly, 367

Silver-leaved, 367

Woody, 363

Nimble Kate, 405

Nimble Will, 44

Nipplewort, 523

Dwarf, 524

None-such, 234

Noon-flower, 532

Nyctelea, 330

Oats, Wild, 48

Enothera biennis, 295 fruticosa, 296

Okra, 283

Old Fog, 50

Old Maid's Bonnets, 225

Old Maid's Pink, 149

Old Man's Hands, 288

Onagra biennis, 295

Onion, Wild, 80

Onoclea sensibilis, 18

Onopordum Acanthium, 516 
Opium, Wild, 542

Opuntia fragilis, 287 humifusa, 288

Rafinesque, 288

Orache, Spreading, 114

Orobanche ludoviciana, 390 minor, 389 ramosa, 387

Orpine, Biting, 200 Common, 202

Owl's Crown, 441

Oxalis corniculata, 256 stricta, 255

Ox-tongue, Bristly, 531

Oxwort, 502

Oะybaphus hirsutus, 130 linearis, 131 nyctagineus, 129

Oxytropis Lamberti, 241

Oyster, Vegetable, 533

Painted Leaf, 270

Panicum capillare, 28 crus-galli, 30

dichotomiflorum, 29

proliferum, 29

virgatum, 30

Papaver dubium, 171 Rhoeas, 170

Parsley, Dog's, 303

False, 303

Fool's, 303

Spotted, 300

Parsnip, Cow, 306

Field, 305

Meadow, 304

Wild, 305

Woolly, 306

Parsonia petiolata, 291

Passiflora incarnata, 287

Passion-flower, 287 .

Passion-vine, 287

Pastinaca sativa, 305

Paul's Betony, 360, 383

Pea, 222, 225

Blue, 228, 229

Everlasting, 250

Hoary, 238

Large-flowered Sensitive, 221

Meadow, 252

Partridge, 221

Tuberous Wild, 250
Pea, - Continued

Turkey, 238

Peas, Cat, 247

Craw, 252

Mouse, 252

Pellitory, Wild, 487

Pennyroyal, American, 358

Bastard, 358

Mock, 358

Pentstemon lovigatus, 381

Pepper, Bird's, 176

Poor Man's, 178

Wall, 200

Peppergrass, Common, 176

Field, 178

Green-flowered, 178

Peppermint, 361

Persicary, Glandular, 100 Peach-leaved, 102

Petasites palmatus, 502 vulgatus, 502

Phalaris canariensis, 37

Physalis ixocarpa, 369 lanceolata, 371

pubescens, 370

virginiana, 371

Phytolacca decandra, 128

Pick-purse, 136

Picris, Bugloss, 531

Picris echoides, 531

Pieris mariana, 310

Pigweed, Matted, 123

Prostrate, 123

Redroot, 120

Rough, 120

Russian, 119

Smooth, 112

Tumbling, 122

White, 122

Winged, 106

Pilewort, 380, 503

Pimpernel, Scarlet, 311

Pine, Meadow, 20

Pinetop, 20

Pink, Hedge, 149

Meadow, 143

Mullein, 142

Plant, Compass, 447, 540

Cruel, 270

Cup, 449

Enchanter's, 343

Fever, 295 
Plant, - Continued

Ginger, 495

Mosquito, 358

Oyster, 533

Paint, 341

Pearl, 340

Polar, 447

Purse, 202

Rosin, 448

Shirt-button, 280

Shoofly, 282

Sweating, 417

Umbrella, 129

Yellow Locust, 218

Plantago arenaria, 396

aristata, 394

lanceolata, 392

major, 391

media, 394

Rugelli, 392

Plantain, Birdseed, 391

Black, 392

Broad-leaved, 391

Common, 391

Dooryard, 391

Hoвry, 394

Large-bracted, 394

Narrow-leaved, 392

Pale, 392

Red-stem, 392

Robin's, 436

Rugel's, 392

Sandwort, 396

White, 441

Whorled, 396

Woolly, 394

Plume-seed, 419

Poinsettia heterophylla, 270

Poison, Beaver, 301

Dog, 303

Sheep, 308

Poison Ash, 273

Poison Creeper, 274

Poison Dogwood, 273

Poison Elder, 273

Poison Ivy, 274

Poison Oak, 274

Poison Rhubarb, 502

Poison Sego, 76

Poison Stinkweed, 300

Poison Sumac, 273

Poisonweed, 311
Pokeberry, 128

Poke, Virginia, 128

Pokeweed, 128

Polanisia graveolens, 198

Polygonum aviculare, 97

convolvulus, 104

emersum, 99

erectum, 98

Hydropiper, 101

hydropiperoides, 102

Muhlenbergii, 99

pennsylvanicum, 100

Persicaria, 102

ramosissimum, 98

scandens, 105

Poorland Flower, 493

Poor-man's Weather-glass, 311

Poor Robin, 436

Pop-dock, 382

Poppy, Bubble, 148

Corn, 170

Field, 170

Long Smooth-fruited, 171

Mexican, 172

Prickly, 172

Thistle, 172

Portulaca oleracea, 152

Portulaca, Wild, 152

Potato, Canada, 467

Hog's, 76

Potentilla Anserina, 208

argentea, 206

canadensis, 209

fruticosa, 207

monspeliensis, 205

Prenanthes aspera, 552

racemosa, 551

serpentaria, 553

Prickly Pear, 287

Brittle, 288

Pricket, 200

Primrose, Day, 296

Evening, 295

Field, 295

Perennial, 296

Tree, 295

Prunella vulgaris, 352

Prunus serotina, 217

virginiana, 218

Pteris aquilina, 17

Puccoon, Hoary, 341

Pudding-bags, 202 
Pumpkin, Fetid Wild, 404

Purplehead, 100

Purse, Shepherd's, 180

Purslane, 152

Ditch, 293

Milk, 266

Water, 293

Winter, 385

Pusley, 152

Pussy-toes, 441

Pyrrhopappus carolinianus, 548

Quaker Lady, 203

Queen Anne's Lace, 307

Queen-of-the-meadow, 416

Rabbit-ears, 189

Radish, Wild, 183

Ragged Cup, 449

Ragged Robin, 143, 520

Ragweed, Bur, 458

Common, 455

False, 451

Giant, 454

Great, 454

Perennial, 457

Ragwort, Common, 506

Golden, 507

Tansy, 506

Ranstead, 379

Ranunculus abortivus, 155

acris, 159

bulbosus, 157

fascicularis, 156

repens, 156

sceleratus, 154

Raphanus Raphanistrum, 183

Ratibida columnaris, 464

Rattlebox, 222, 292

Rattleweed, White, 241

Redroot, 339

Redshanks, 102

Redstalk, 435

Redstem, 291

Redweed, 128, 170

Rhus radicans, 274

Toxicodendron, 274

Vernix, 273

Ribwort, 392

- Gray, 394

Rocket, Sand, 188

Yellow, 196
Root, Amy, 314

Bitter, 312

Bowman's, 314

Choctaw, 314

Devil's, 389

Dropsy, 314

Emetic, 411

Gag, 411

Ginger, 501

Gravel, 416

Insane, 373

Kidney, 416

Life, 507

Musquash, 301

Orange, 315

Pleurisy, 315

Rattlesnake, 553

Slippery, 337

White, 315

Rosa arkansana, 216

eglanteria, 214

rubiginosa, 214

Rose, Canker, 170

Corn, 142

Cotton, 441

Prairie, 216

Running Brier, 216

Rosemary, White, 432

Rose Petty, 436

Rotation of crops, 5

Rubus procumbens, 211 villosus, 211

Rudbeckia hirta, 462

Ruddy-stem, 435

Rumex Acetosa, 94 Acetosella, 95

crispus, 91

mexicanus, 93

obtusifolia, 94

Patientia, 90

Rush, Bog, 75

Club, 73

Common, 75

Field, 74

Green Foxtail, 20

Meadow, 73

Slender, 74

Soft, 75

Yard, 74

Rutland Beauty, 323

Sage-of-Bethlehem, 362 
Sage, Mountain, 500 Pasture, 499

Wild, 499

Wood, 347

Wormwood, 499

Sage-brush, 500

Sage-bush, 500

Low, 499

Sage-wood, 500

St. Jameswort, 506

St. John's-wort, 284

Dwarf, 286

Shrubby, 285

Salsify, Garden, 533

Meadow, 532

Salsola Kali, 117

Sandbur, 34

Sandspur, 34

Sandweed, 136

Sandwort, 396 Thyme-leaved, 137

Sanguinary, 486

Sanicle, 299, 418

Sanicula canadensis, 299 marilandica, 300

Saponaria officinalis, 149 Vaccaria, 151

Sarsaparilla, False, 83

Satureja vulgaris, 359

Sauce-alone, 190

Savastana odorata, 27

Scabious, Sweet, 438

Scabish, Meadow, 435

Scabwort, 446

Scirpus atrovirens, 73

Scleranthus annuus, 133

Scoke, 128

Scourwort, 149

Scrophularia leporella, 381 marilandica, 380

Scrub-bush, 432

Sedge, Broom, 21

Coco, 68

Nut, 68

Sedum acre, 200

purpureum, 202

stoloniferum, 201

Telepheum, 202

Seed-box, 292

Self-heal, 352

Senebiera didyma, 179

Senecio aureus, 507
Senecio Jacobcea, 506

glabellus, 505

lobatus, 505

vulgaris, 504

Senna, American, 218

Coffee, 220

Wild, 218

Setaria glauca, 31

verticillata, 33

viridis, 33

Sheepbur, Western, 335

Sheepfoot, 237

Sheepkill, 310

Sheep Poison, 255

Shepherd's Clock, 311

Shepherd's Purse, 180

Sherardia arvensis, 396

Sicklewort, 346, 352

Sicyos angulatus, 405

Sida acuta, 279

spinosa, 278

stipulata, 279

Sida, Spiny, 278

Prickly, 278

Silene antirrhina, 146

dichotoma, 147

inflata, 148

latifolia, 148

noctiflora, 147

Silphium laciniatum, 447

perforatum, 449

terebinthinaceum, 448

Simpler's Joy, 343, 344

Simson, 504

Sinapis alba, 186 nigra, 187

Sisymbrium altissimum, 192 incisum, 194

officinale, 191

Sitilics caroliniana, 548

Skellick, 184

Skevish, 437

Skunk-tail, 64

Smartweed, Common, 101

Pennsylvania, 100

Spotted, 102

Swamp, 99

Smilax glauca, 83

Snakeroot, Black, 299

White, 418

Snapdragon, Wild, 379

Sneezeweed, 481 
Sneezeweed, Fine-leaved, 483 Purple-headed, 482 White, 487

Sneezewort, 481

Snow-on-the-mountain, 267

Soapwort, 149

Solanum carolinense, 365 Dulcamara, 363 elocagnifolium, 367

Solanum nigrum, 364 rostratum, 368

Solidago canadensis, 425 graminifolia, 426 mollis, 424 nemoralis, 423 rigida, 426

Sonchus arvensis, 537 asper, 539 oleraceus, 538

Sorghum halepense, 22

Sorrel, Field, 95

Garden, 94

Horse, 95

Lady's, 256

Redtop, 95

Sheep, 95, 255

Tall, 94

Sowbane, 114

Sow Thistle, Common, 538

Corn, 537

Creeping, 537

Field, 537

Spiny-leaved, 539

Spatling, 148

Spearmint, 362

Speckled John, 284

Specularia perfoliata, 408

Speedwell, Common, 383

Corn, 386

Field, 387

Garden, 387

Purslane, 385

Thyme-leaved, 385

Upland, 383

Spergula arvensis, 136

Spermacoce glabra, 399

Spinach, Strawberry, 110

Spircea latifolia, 203

salicifolia, 204

tomentosa, 204

Sporobolus indicus, 47 neglectus, 47
Sporobolus vaginiflorus, 46

Spurge, Creeping, 266

Cypress, 272

Flowering, 268

Hairy, 265

Leafy, 271

Pasture, 264

Spotted, 266

Stubble, 264

Sun, 272

Thyme-leaved, 263

Toothed, 269

Upright Spotted, 264

Various-leaved, 270

White-margined, 267

Spurry, 136

Spurwort, 396

Squirrel-tail, 64

Stachys palustris, 357

Stagger Bush, 310

Stagger Weed, 162

Staggerwort, 506

Stammerwort, 455

Star Thistle, Purple, 517

Yellow, 518

Starwort, 139

Grassy, 138

Yellow, 446

Steeple-bush, 204

Stellaria graminea, 138

- media, 139

Stickseed, European, 334

Large-flowered, 335

Many-flowered, 336

Purple-stemmed, 375

Virginia, 334

Western, 335

Sticktight, 473

Sticky-stem, 291

Stinkweed, 488

Stinking Willie, 506

Stipa comata, 40

spartea 39

Stipa, Western, 40

Stitchwort, Grass-leaved, 138

Lesser, 138

Stonecrop, Mossy, 200

Stork's-bill, 258

Strophostyles helvola, 253

pauciflora, 254

umbellata, 254

Succory, 525 
Succory, Gum, 534

Hog's, 524

Lamb, 524

Sumac, Poison, 273

Swamp, 273

Sundial, 225

Sundrops, 296

Sunflower, Brook, 476

Common, 465

False, 451, 481

Red, 463

Stiff, 466

Swamp, 481

Tickseed, 478

Tuberous, 467

Swallow-wort, 169,315

Black, 319

White, 319

Sweet Betty, 149

Sweet-brier, 214

Sweet-clover, White, 232 Yellow, 234

Sweethearts, 397

Sweetpea, Tuberous, 250 Wild, 238

Sweetroot, 242

Sweet William, Wild, 149

Swine's-bane, 114

Symphytum oficinale, 337

Syntherisma sanguinalis, 26 linearis, 27

Tanacetum vulgare, 495

Tank, 305

Tansy, 495

False, 497

Goose, 208

White, 487

Wild, 455

Taraxacum erythrospermum, 537 officinale, 536

Tare, 246

Hairy, 249

Tar-fitch, 252

Tarweed, 291, 479

Yellow, 336

Tea, Jerusalem, 108

Jesuit, 108

Mexican, 108

Spanish, 108

Teasel, 403

Tephrosia virginiana, 238
Tetterwort, 169

Teucrium canadense, 347

Thaspium aureum, 304

Thimbleweed, 160

Thistle, Asses', 516

Bitter, 522

Blessèd, 522

Blue, 342

Bull, 365, 512

Bur, 510

Canada, 514

Card, 403

Common, 510

Cotton, 516

Creeping, 514

Cursed, 514

Downy, 516

English, 540

Fragrant, 512

Holy, 522

Horse, 512

Lance-leaved, 510

Maltese, 519

Mexican, 368

Milk, 537, 538, 540

Napa, 519

Our Lady's, 522

Pasture, 512

Perennial, 514

Plume, 512

Queen Mary's, 516

Roadside, 512

Russian, 117

St. Barnaby's, 518

St. Benedict's, 522

Scotch, 516

Silver, 516

Spear, 510

Spotted, 522

Swine, 537

Tall, 512

Texas, 368

Tumbling, 117

Water, 403

Yellow-spined, 513

Thlaspi arvense, 174

Thorn, Maize, 517

Thornapple, 375

Hairy, 376

Purple, 376

Thoroughwort, 417

Thousand-leaf, 486 
Thunderwood, 273

Ticks, Seed, 243 Wool, 243

Tickseed, Lance-leaved, 471 Tall, 472

Tick-trefoil, Hoary, 243

Showy, 244

Timothy, False, 45

Tiniaria scandens, 105

Tithymal, 271

Titters, 247

Toadflax, 379

Tobacco, Indian, 411

Ladies', 441

Sailor's, 496

Wild, 411

Tocalote, 519

Tomatillo, 369

Tomato, Husk, 370

Strawberry, 369

Tragopogon porrifolius, 533 pratensis, 532

Tread-softly, 260, 365

Trefoil, Bird's-foot, 237

Yellow, 234

Tribulus terrestris, 259

Trichostema dichotomum, 348

Trifolium agrarium, 231

arvense, 229

procumbens, 231

Triosteum perfoliatum, 401

Trompillo, 367

Tumbleweed, 122

Russian, 117

Turkey-strip, 50

Tussilago Farfara, 501

Umbrella Leaves, 502

Umbrella-wort, Hairy, 130

Heart-leaved, 129

Narrow-leaved, 131

Urtica dioica, 88

gracilis, 87

holosericea, 89

Valerian, False, 507

Valerianella Locusta, 402 radiata, 402

Velvet-leaf, 276

Venus's Looking-glass, 408

Veratrum viride, 78

Verbascum Blattaria, 378
Verbascum Thapsus, 377

Verbena bracteosa, 345

hastata, 344

officinalis, 343

stricta, 346

urticoefolia, 343

Verbesina alternifolia, 468

encelioides, 470

helianthoides, 469

Vernonia altissima, 412

fasciculata, 413

gigantea, 412

illincensis, 414

maxima, 412

Veronica agrestis, 387

officinalis, 383

peregrina, 385

serpyllifolia, 385

Vervain, Blue, 344

European, 343

Hoary, 346

Large-bracted, 345

Mullein-leaved, 346

Nettle-leaved, 346

White, 343

Woolly, 346

Vetch, Bird, 247

Blue, 247

Common, 246

Cow, 247

Hairy, 249

Pebble, 246

Spring, 246

Tufted, 247

Winter, 249

Vetchling, Yellow, 253

Vicia Cracca, 247

sativa, 246

villosa, 249

Vincetoxicum nigrum, 319

Vine, Love, 324

Sand, 319

Wild Sweet Potato, 320

Wartwort, 445

Water-pepper, 101

Mild, 102

Waxballs, 262

Waybent, 66

Waybread, 391

Weed, Ague, 417

Asthma, 411 
Weed, - Continued

Basil, 359

Bird, 139

Bird's Nest, 307

Bitter, 439, 455, 497

Blue, 342

Blue Wax, 291

Bugle, 360

Bur, 334

Butter, 505

Butterfly, 315

Canker, 506, 553

Carrot, 455

Chicken, 504

Choke, 389

Clammy, 198

Cotton, 317

Crazy, 239

Crown, 454

Dagger, 460

Door, 97

Downy, 441

Dyer's, 423

Dyer's Green, 224

Fever, 416

Flat, 528

Flax, 379

French, 174

Frost, 432

Hair, 324

Halfbreed, 451

Heart, 102

Hog, 132, 439

Horse, 439, 454, 543

Jamestown or Jimson, 375

Mark, 274

Meal, 112

Muskrat, 301

Naked, 534

Neck, 385

Nosebleed, 586

Pepper, 329

Pigeon, 339

Pilot, 449

Pin, 258

Pineapple, 492

Pitchfork, 473

Poverty, 433, 493

Prairie, 207

Prickly Careless, 124

Pride, 439

Puke, 411

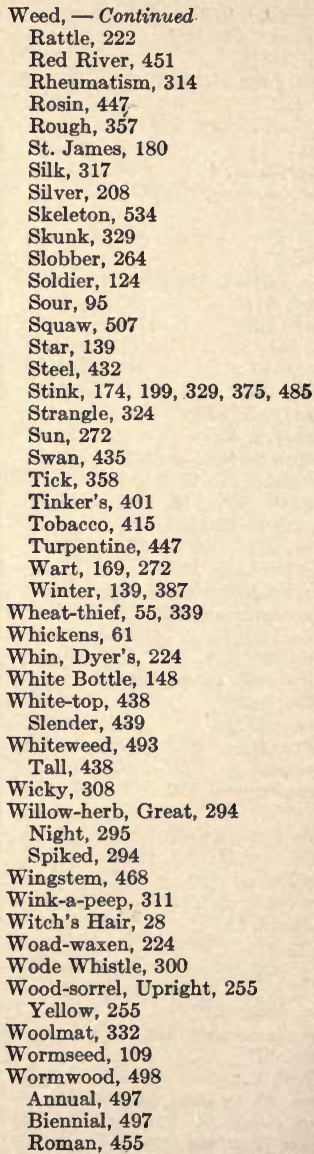


Woundwort, Marsh, 357 Soldier's, 486

Xanthium canadense, 461 spinosum, 460

$X$ anthoxalis corniculata, 256 stricta, 255

Ximenesia encelioides, 470

Xylorhiza Parryi, 439
Yarrow, 486

Sneezewort, 489

Yellow-seed, 178

Yellow Star, 481

Yellowweed, Creeping, 426

Tall, 425

Yerba Mansa, 85

Zygadenus venenosus, 76 

$T^{H E}$ following pages contain advertisements of a few of the Macmillan books on kindred subjects. 



\section{Manual of Fruit Insects}

\section{By M. V. SLINGERLAND ANd C. R. CROSBY}

Illustrated. Decorated cloth, $12 \mathrm{mo}, \$ 2.00$

A practical account of the principal insects which attack fruits, including the enemies of the apple, pear, peach, plum, bush fruits, grapes, strawberries, and cranberries. The life history of each insect is given, its injuries described and recommendations made as to the means of control, primarily from the standpoint of the commercial grower. A chapter on insecticides details the more important facts relating to their composition, preparation, and use. The book is illustrated with more than four hundred pictures, largely reproductions of photographs made by Professor Slingerland.

\section{Manual of Weeds}

\section{By ADA E. GEORGIA}

of the New York State College of Agriculture at Cornell University

\section{Illustrated. Cloth, I2mo, $\$ 2.00$}

Every separate species of weed known to occur in the United States or Canada is described, and its range and habitat stated. The crops which each species particularly infests and the means of controlling each species are also discussed. Between 300 and 400 original illustrations, made directly from the plants, greatly enhance the practical value of this book, which will be of service both as a text for college students and as a reference book for farmers and horticulturists.

\section{Manual of Fruit Growing}

\section{By Professor L. H. BAILEY}

New edition. Cloth, ramo

Since the original publication of this book, in 1897 , it has gone through many editions. The progress of fruit growing in the meantime has been very marked and it has been necessary to rewrite completely the work. The present issue of it brings the accounts of the new practices and discoveries as they relate to fruit growing up to date. All of the text and practically all of the illustrations are new.

\section{THE MACMILLAN COMPANY Publishers 64-66 Fifth Avenue New York}




\title{
Manual of Farm Animals
}

A Practical Guide to the Choosing. Breeding, and Keep of Horses, Cattle, Sheep, and Swine.

\section{BY MERRITT W. HARPER}

Assistant Professor of Animal Husbandry in the New York State College of Agriculture at Cornell University

Illustrated, decorated cloth, $12 m 0,545$ pp., index, $\$ 2.00$

postage extra

"The work is invaluable as a practical guide in raising farm animals."

- Morning Telegram.

"A book deserving of close study as well as being handy for reference, and should be in the possession of every farmer interested in stock." - Rural World.

\section{Manual of Gardening}

A Practical Guide to the Making of Home Grounds and the Growing of Flow. ers, Fruits, and Vegetables for Home Use.

\author{
By L. H. BAILEY \\ Illustrated, cloth, 12mo, 544 pages, $\$ 2.00$ \\ postage extra
}

This new work is a combination and revision of the main parts of two other books by the saine author, "Garden-Making " and "Practical Garden Book," together with much new material and the result of the experience of ten added years. Among the persons who collaborated in the preparation of the other two books, and whose contributions have been freely used in this one, are C. E. Hunn, a gardener of long experience; Professor Ernest Walker, reared as a commercial florist; Professor L. R. Taft, and Professor F. A. Waugh, well known for their studies and writings on horticultural subjects.

\section{The Farm and Garden Rule Book}

A Standard Work Revised and Enlarged.

$$
\begin{aligned}
& \text { By L. H. BAILEY } \\
& \text { Illustrated, cloth, 12mo, } \$ 2.00
\end{aligned}
$$

postage extra

When Professor Bailey's "Horticulturist's Rule Book" was published nearly twenty-five years ago, the volume became a standard agricultural work running through sixteen editions. Taking this book as a basis, the author has now made a wholly new book, extending it to cover the field of general farming, stock-raising, dairying, poultry-rearing, horticulture, gardening, forestry, and the like. It is essentially a small cyclopedia of ready rules and references, packed full from cover to cover of condensed, meaty information and precepts on almost every leading subject connected with country life.

\section{THE MACMILLAN COMPANY

Publishers 64-66 Fifth Avenue New York




\title{
NEW VOLUMES IN
}

\section{The Rural Text-Book Series}

Edited by L. H. Bailey

\section{Forage Plants and their Culture}

\author{
By Professor C. V. PIPER
}

Of the United States Department of Agriculture

Cloth, I2mo

A clear and concise account of the present knowledge of forage cropping in North America, intended primarily as a text-book for the use of agricultural college students. The author presents the subject in such a way as to make the student realize the shortcomings of the present knowledge on the subject, as well as the progress which has been definitely accomplished. All the plants and crops which are used for forage and for hay are described, and their botanical characteristics and means of cultivation are carefully discussed. The grasses, alfalfa, the clovers, the millets, and the various fodder crops are all treated.

\section{Small Grains}

\section{By M. A. CARLETON}

Cerealist of the United States Department of Agriculture

Cloth, I2mo

The cereal grains and buckwheat are described carefully. Their methods of cultivation and of handling and marketing are thoroughly discussed. Among the grains thus treated are wheat, oats, rye, barley, and the minor crops. This book will prove an admirable complement to Montgomery's "The Corn Crops." Both these books are intended primarily for use as texts in college courses, and may very well be used in conjunction in the general course on grain crops. These books also are of distinct interest and value to the farmer.

\section{THE MACMILLAN COMPANY

Publishers 64-66 Fifth Avenue New York




\title{
The Principles of Irrigation Practice
}

\author{
By JOHN A. WIDTSOE
}

President of the Utah Agricultural College

Illustrated, Cloth, 12mo, $\$ 1.75$

Although much of the writing on irrigation has been from the engineering point of view, this book is written distinctly from the point of view of practical farming. President Widtsoe has drawn not only upon his own intimate knowledge of conditions in an irrigated country, but also upon all the available literature on the application of water to land for irrigating purposes. The effect of water on the soil, the losses by seepage and evaporation, the service that water renders to the plants, and the practical means of employing water for the growing of the different crops are all discussed clearly and thoroughly.

\section{Field Crops}

\section{By GEORGE LIVINGSTON}

Assistant Professor of Agronomy, Ohio State University

Illustrated, Cloth, I2mo, $\$ 1.40$

This text is intended to meet the needs of agricultural high schools and of brief courses in Field Crops in the colleges. Based on actual experiment, it points out the "better way" of raising field crops; of selecting the field; of preparing the soil; of sowing the seed; of cultivating the plant ; of harvesting the crop. It is to be fully illustrated with reproductions from photographs of unusual excellence.

\section{THE MACMILLAN COMPANY Publishers 64-66 Fifth Avonue New York}




\section{The Principles and Practice of Live-Stock Judging \\ BY CARL WARREN GAY}

Professor of Animal Industry in the University of Pennsylvania

Illustrated, Cloth, ramo

Part I introduces the principles upon which the practice of judging is founded; Part II applies to the practice of judging, definition, and procedure - the features of animal form to be considered, the means of making observations and practice judging by the score card, demonstrations, comparative and competitive judging. The balance of the work is devoted to special judging, one part being given to each of the following : horses, cattle, sheep, swine, the judging of breeding animals and live stock shows. The volume is profusely illustrated, typical representatives of the types and breeds being shown in untouched photographs of animals to which championship honors have been awarded.

\section{Agricultural Grasses}

\section{By A. S. HITCHCOCK}

Agrostologist, United States Department of Agriculture

Illustrated, Cloth, I2mo

This book covers the two great branches of grass knowledge as it relates to teaching in the college - the economic value of grasses, and the identification of the main economic species and groups.

The part devoted to systematic agrostology, or the part that gives a description of the different kinds, goes carefully into the morphology of leaf and flower and stem, provides a discussion of ecology and accounts of all the different genera that are economically important, and ends with a general discussion of nomenclature as applied to grasses.

\section{THE MACMILLAN COMPANY}

Publishers

64-66 Fifth Avenue
Now York 


\title{
INJURIOUS INSECTS HOW TO RECOGNIZE AND CONTROL THEM
}

\author{
By WALTER C. O'KANE
}

Entomologist of the New Hampshire Experiment Station, and Professor of Economic Entomology in New Hampshire College

\section{Decorated Cloth. 414 pages. Over 600 Photographic Illustrations $\$ 2.00$ postpaid, \$2.17}

Written out of a large scientific knowledge, but in a popular style, this book discusses concisely and yet fully the characteristics, life histories, and means of control of our common injurious insects.

The illustrations are from photographs throughout. The idea of the author has been to picture graphically the injurious stages and the work of the various pests, so that they may easily be recognized, independently from the text. More than 135 of the illustrations are photomicrographs.

All of the common injurious forms are described, including the pests of orchard, garden, field crops, domestic animals, and the household.

The arrangement of species is original and unique. In each division the pests are grouped according to the place where found at work and the characteristics. Prompt identification is thus made easy.

Other valuable features of the volume are:

Complete directions for the preparation and use of insecticides. Spray formulæ, repellents, and fumigants described in detail.

Descriptions and photographs of spray machinery and accessories.

An illustrated discussion of the structure of insects. How they live: their habits, senses, and manner of growth. others.

Insects as carriers of disease. The typhoid fly, the malarial mosquitoes, and

The classification of insects, including illustrated descriptions of the various important groups into which insects are divided.

An account of the means by which insects are dispersed.

The natural enemies of insects. How they are held in check by parasites, by fungous and bacterial diseases, and by birds and other larger animals.

How farm practice assists in insect control, showing the influence of plowing, cultivating, destruction of weeds, and the like.

A complete bibliography, giving an authoritative reference for each species treated in the book.

\section{THE MACMILLAN COMPANY \\ Publishers \\ 64-66 Fifth Avenue \\ New York}



This book is DUE on the last date stamped below

MAR 251929

MAR 1 \& 1932

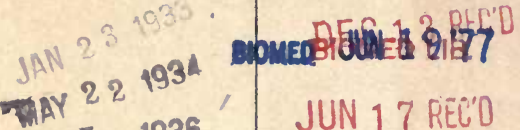
MAY 51936

I JUN 41937

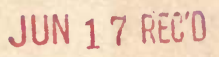

JAN 23 19AP BLOMED UB.

DEC 021984

DEC 519501

JUN 41962

JUL 301968

Form L-9-15m-11,'27 


\section{UNIVERSITY OF CALIFORNIA LIBRARY}

\section{Los Angeles}

This book is DUE on the last date stamped below.

ivtiv 171988

\section{UNTVERSTTY OF CALIFORNLO}


